Camila de Freitas Almeida

\author{
Identificação e estudo de genes \\ diferencialmente expressos em modelos \\ murinos de distrofia muscular
}

Identification and study of differentially

expressed genes in mouse models for

muscular dystrophy

São Paulo

2014 
Camila de Freitas Almeida

\title{
Identificação e estudo de genes \\ diferencialmente expressos em modelos \\ murinos de distrofia muscular
}

\section{Identification and study of differentially expressed genes in mouse models for muscular dystrophy}

\begin{abstract}
Dissertação apresentada ao Instituto de Biociências da Universidade de São Paulo, para a obtenção de Título de Mestre em Ciências, na Área de Genética.
\end{abstract}

Orientadora: Dra. Mariz Vainzof

São Paulo

2014 


\section{Ficha Catalográfica}

\section{Almeida, Camila de Freitas}

Identificação e estudo de genes diferencialmente expressos em modelos murinos de distrofia muscular

237p.

Dissertação (Mestrado) - Instituto de Biociências da Universidade de São Paulo. Departamento de Genética e Biologia Evolutiva.

1. Distrofias musculares 2. Modelos murinos 3. Expressão gênica global I. Universidade de São Paulo. Instituto de Biociências. Departamento de Genética e Biologia Evolutiva.

\section{Comissão Julgadora:}

$\operatorname{Prof}(a) \cdot \operatorname{Dr}(a)$

$$
\text { Prof(a). Dr(a). }
$$

Prof(a). Dr.(a). Mariz Vainzof

Orientador(a) 


\section{Dedicatória}

A todos que possibilitam e confiam na ciência 


\section{Epígrafe}

A ideia de que somente é belo o que é jovem e novo envenena nossas relações com o passado e com o nosso próprio futuro. A ideia de que somente é belo o que é jovem e novo nos impede de compreender as nossas raízes e as maiores obras de nossa cultura e das outras culturas. A ideia de que somente é belo o que é jovem e novo nos faz recear o que está à nossa frente e não entendemos, e leva muita gente a fugir da realidade. 


\section{Agradecimentos}

À minha mãe e ao meu pai, que mesmo com tudo contando contra, deram-me a oportunidade de estudar além do que eles poderiam imaginar. Sem o esforço, dedicação e cuidado deles, eu sequer poderia ter sonhado em ingressar nesta universidade. $\mathrm{O}$ apoio deles foi e ainda é a condição essencial para eu ter chegado até aqui.

Meus sinceros agradecimentos à minha orientadora Mariz Vainzof, que me recebeu de braços abertos em sua equipe há seis anos, por toda a confiança depositada em mim e por todas as oportunidades proporcionadas ao longo desses anos. E claro, pela orientação na elaboração, execução e finalização deste projeto, mesmo com todas as dificuldades impostas pela vida acadêmica burocrática... Como ela mesma diz: ela não deixa a peteca cair!

À Lydia, sempre tão gentil e atenciosa, foi quem me recebeu no primeiro dia de laboratório e me ensinou os primeiros passos da biologia molecular.

Aos meus colegas: Leticia, Paula, Poliana, Priscila, Stephanie, André, Aurea, Renata, Antônio, Marina, Daniel, Marta, e tantos outros que passaram por aqui durante esses anos, sem os quais o laboratório simplesmente não existiria!

Poli, muito obrigada por me contar todos os segredos dos seus camundongos mais amados! Espero que meu trabalho seja apenas o primeiro fruto do seu grande empenho. E por me ensinar tantas coisas científicas e não científicas. O seu apoio (só faltou ligar para a Dilma!) foi crucial nesses últimos meses tão complicados.

Lê, você é a minha grande parceira nesse laboratório, minha cúmplice, em quem sempre encontro apoio e que me trata com muito carinho. Nós somos, definitivamente, as "bicho-ruim" do lab!

Paula, muito obrigada por me ensinar os segredos dos microarrays e ter sempre um bom comentário a fazer, que dá aquela luz! O seu raciocínio lógico e rápido são fundamentais no laboratório, aprendo muito com você.

Pri, muito obrigada pela ajuda na identificação de inúmeros camundongos e ter me livrado das mordidas dos bichinhos!

Agradeço também aos colegas de outros laboratórios: Simone, por ajudar com os experimentos de microarray; Lucas e Gerson, com a ajuda nas análises; ao Marcelo Boareto, do Instituto de Física, pela disponibilidade e paciência para me ensinar truques do pacote $\mathrm{R}$ e estatística; e aos alunos da professora Mayana, que estão sempre por perto. 
Agradeço aos meus colegas de graduação, especialmente ao Adriano, que foi quem me trouxe para esse laboratório e com quem passei momentos muito bons nos anos da graduação, nos quais nos víamos "todos os dias, o dia inteiro"; mesmo estando longe, sei que posso sempre contar com a sua amizade!

Ao meu namorado Wesley, que é antes de tudo um grande amigo, sempre presente, com quem pude dividir todas as angústias e alegrias dessa fase. Obrigada por todo apoio, por sempre me incentivar, não deixar que eu desanimasse. Pela compreensão por tantos compromissos desfeitos por conta das horas extras, finais de semana e feriados no lab. Está sempre disposto a ajudar, não mede esforços para realizar um pedido meu; mesmo sendo de uma área completamente diferente da Biologia, leu essa dissertação ponto por ponto, deu sua opinião, me ajudou com as figuras, corrigiu. Esse trabalho tem o seu dedo também!

Agradeço também à Heloísa e Rose, que facilitam muito o nosso trabalho, cuidando do biotério. À Vanessa e Wagner, sempre prestativos e eficientes nas questões administrativas. E a todos os funcionários do CEGH.

Não poderia deixar de agradecer aos camundongos, que são o cerne deste trabalho.

Agradeço às agências FAPESP, CNPq e Capes pelo financiamento deste projeto. 


\section{Lista de siglas}

BMD: distrofia muscular de Becker

cDNA: DNA codificante

CMD: distrofia muscular congênita

DAVID: Database for Annotation,Visualization and Integrate Discovery

DGA: distrofina-glicoproteínas associadas

DMD: distrofia muscular de Duchenne

EDL: músculo extensor longo dos dedos

EOM: músculo extraocular

FDR: descoberta de falso-positivo

GDE: genes diferencialmente expressos

GO: Gene Ontology

IPA: Ingenuity Pathway Analysis

KEGG: Kyoto Encyclopedia of Genes and Genomes

MeV: Multiexperiment Viewer

MRF: fator de regulação miogênica

mRNA: RNA mensageiro

nNOS: óxido nítrico sintase neuronal

NO: óxido nítrico

PCR: reação da polimerase em cadeia

RMA: Robust Multichip Average

SAM: Significance Analysis of Microarray

TA: tibial anterior

UV: ultravioleta 


\section{Lista de figuras}

Figura 1 - Etapas da diferenciação miogênica. Extraído de Almeida C F, Ayub-Guerrieri D,Vainzof M. Myogenic differentiation of ES cells for therapies in neuromuscular diseases: progress to date. In: Kallos MS, editor. Embryonic stem cells - differentiation and pluripotent alternatives. 2011. p. 227-242.

Figura 2 - Miogênese no tecido adulto. Extraído de Almeida C F, Ayub-Guerrieri D,Vainzof M. Myogenic differentiation of ES cells for therapies in neuromuscular diseases: progress to date. In: Kallos MS, editor. Embryonic stem cells - differentiation and pluripotent alternatives. 2011. p. 227-242.

Figura 3 - Organização do músculo esquelético. Modificado de http://imgarcade.com/1/cardiactissue-diagram/

Figura 4 - Complexo distrofina-glicoproteínas associadas. Extraído de Kay E Davies \& Kristen J Nowak Nature Reviews Molecular Cell Biology 7, 762-773 (October 2006).

Figura 5 - Animais duplo-mutantes em diferentes idades, comparados com o $\mathrm{Dmd}^{m d x}$...............31

Figura 6 - Resumo dos procedimentos com o GeneChip $($ Mouse Gene 1.0 ST Array ...............42

Figura 7 - Géis de agarose $2 \%$ corado com brometo de etídio (a - e). Amostras de RNA; é possível visualizar as bandas do RNA ribossômico $28 \mathrm{~S}$ e $18 \mathrm{~S}$. A banda de contaminação de DNA fica acima da banda $28 \mathrm{~S}$

Figura 8 - Eletroferogramas e respectivos RIN das 60 amostras do estudo. Amostras com RIN igual ou superior a 7 são de boa qualidade

Figura 9 - Gel de agarose 1\% corado com brometo de etídeo mostrando a fragmentação de algumas amostras

Figura 10 - Imagens das lâminas dos microarranjos. Estão ilustradas uma amostra de cada idade e linhagem para exemplificação

Figura 11 - Controle de hibridização do oligo B2. O nome do chip deve ser formado completamente.

Figura 12 - Valores de bgrd_mean (vermelho) e pm_mean (azul). Amostras de 21 dias. Em todos os casos o valor de pm_mean é superior ao de bgrd_mean Figura 13 - Valores de bgrd_mean (vermelho) e pm_mean (azul). Amostras de 3 meses. Em todos os casos o valor de pm_mean é superior ao de bgrd_mean

Figura 14 - Valores de bgrd_mean (vermelho) e pm_mean (azul). Amostras de 6 meses. Em todos os casos o valor de pm_mean é superior ao de bgrd_mean Figura 15 - Valores de pos_vs_neg_auc das amostras de 21 dias. Todas as amostras apresentam valores entre 0,89 e 0,91

Figura 16 - Valores de pos_vs_neg_auc das amostras de 3 meses. Todas as amostras apresentam valores entre 0,89 e 0,92 
Figura 17 - Valores de pos_vs_neg_auc das amostras de 6 meses. Todas as amostras

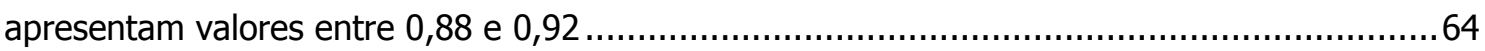

Figura 18 - Controles de hibridização bac_spike das amostras de 21 dias ..............................65

Figura 19 - Controles de hibridização bac_spike das amostras de 3 meses .............................65

Figura 20 - Controles de hibridização bac_spike das amostras de 6 meses .............................65

Figura 21 - Controles de RNA poly-A. Amostras de 21 dias ...................................................6 66

Figura 22 - Controles de RNA poly-A. Amostras de 3 meses .................................................66

Figura 23 - Controles de RNA poly-A. Amostras de 6 meses ...............................................6

Figura 24 - Histograma de intensidade de sinal das amostras de 21 dias, com padrão próximo à

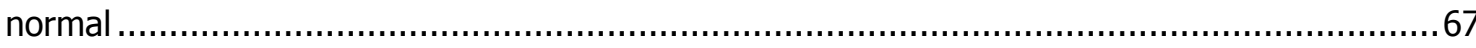

Figura 25 - Histograma de intensidade de sinal das amostras de 3 meses, com padrão próximo à normal

Figura 26 - Histograma de intensidade de sinal das amostras de 6 meses, com padrão próximo à normal 68

Figura 27 - Gráficos com intensidade dos agrupamentos de sondas antes (A) e depois (B) da normalização. Amostras de 21 dias .....

Figura 28 - Gráficos com intensidade dos agrupamentos de sondas antes (A) e depois (B) da normalização. Amostras de 3 meses

Figura 29 - Gráficos com intensidade dos agrupamentos de sondas antes (A) e depois (B) da normalização. Amostras de 6 meses

Figura 30 - Análise $D m d^{m d x}$ vs C57BL 21 dias. Gráfico gerado após a análise estatística SAM; 75 genes identificados 71

Figura 31 - Análise Large ${ }^{m y d-/}$ vs C57BL 21 dias. Gráfico gerados após a análise estatística SAM; 142 genes identificados.

Figura 32 - Análise $D m d^{m d x} / L a r g e^{m y d-/-}$ vs C57BL 21 dias. Gráfico gerado após a análise estatística SAM; 106 genes identificados .71

Figura 33 - Análise $D m d^{m d x} / \operatorname{Large}^{m y d-/}$ vs $D m d^{m d x} 21$ dias. Gráfico gerado após a análise estatística SAM; 185 genes identificados

Figura 34 - Análise $D m d^{m d x} / L a r g e^{m y d-/}$ vs $L a r g e^{m y d-/-} 21$ dias. Gráfico gerado após a análise estatística SAM; 36 genes identificados

Figura 35 - Análise $D m d^{m d x}$ vs C57BL 3 meses. Gráfico gerados após a análise estatística SAM;

225 genes identificados

Erro! Indicador não definido.

Figura 36 - Análise Large ${ }^{m y d-/}$ vs C57BL 3 meses. Gráfico gerado após a análise estatística SAM; 200 genes identificados. .72

Figura 37 - Análise $D m d^{m d x} / L a r g e^{m y d-/-}$ vs C57BL 3 meses. Gráfico gerado após a análise estatística SAM; 350 genes identificados

Figura 38 - Análise $D m d^{m d x} / L a r g e^{m y d-/}$ vs $D m d^{m d x} 3$ meses. Gráfico gerado após a análise estatística SAM; 58 genes identificados 
Figura 39 - Análise $D m d^{m d x} / \operatorname{Larg} e^{m y d-/-}$ vs $L a r g e^{m y d-/} 3$ meses. Gráfico gerado após a análise estatística SAM; 22 genes identificados

Figura 40 - Análise $D m d^{m d x}$ vs C57BL 6 meses. Gráfico gerados após a análise estatística SAM;

508 genes identificados

Figura 41 - Análise Large ${ }^{m y d-/}$ vs C57BL 6 meses. Gráfico gerado após a análise estatística SAM;

291 genes identificados.

Figura 42 - Análise $D m d^{m d x} /$ Large $^{m y d-/}$ vs C57BL 3 meses. Gráfico gerado após a análise estatística SAM; 344 genes identificados

Figura 43 - Análise $D m d^{m d x} / L a r g e^{m y d-/}$ vs $D m d^{m d x} 6$ meses. Gráfico gerado após a análise estatística SAM; 44 genes identificados

Figura 44 - Análise $D m d^{m d x} / \operatorname{Larg}^{m y d-/-}$ vs $L a r g e^{m y d-/} 6$ meses. Gráfico gerado após a análise estatística SAM; 39 genes identificados

Figura 45 - Totais de genes diferencialmente expressos após a anotação ................................75

Figura 46 - Número de genes diferencialmente expressos no tecido muscular ......................... 76

Figura 47 - Diagrama de Venn reunindo todos os genes diferencialmente expressos nas três idades de cada linhagem. No centro estão os genes compartilhados por todas as linhagens e idades

Figura 48 - A: diagrama de Venn reunindo os genes diferencialmente expressos nas três linhagens com 21 dias. No centro estão os 63 genes compartilhados por todas as linhagens nessa idade. B: genes comuns a cada uma das idades; na área hachurada estão destacados os 17 genes com expressão diferencial em todas as linhagens somente na idade de 21 dias .......79 Figura 49 - A: diagrama de Venn reunindo os genes diferencialmente expressos nas três linhagens com 3 meses. No centro estão os 88 genes compartilhados por todas as linhagens nessa idade. B: genes comuns a cada uma das idades; na área hachurada estão destacados os 11 genes com expressão diferencial em todas as linhagens somente na idade de 3 meses......80 Figura 50 - A: diagrama de Venn reunindo os genes diferencialmente expressos nas três linhagens com 6 meses. No centro estão os 127 genes compartilhados por todas as linhagens nessa idade. B: genes comuns a cada uma das idades; na área hachurada estão destacados os 55 genes com expressão diferencial em todas as linhagens somente na idade de 6 meses.......81 Figura 51 - Categorias de funções biológicas enriquecidas nos animais de 21 dias. A, C e E: distribuição de todas as categorias. B, D e F: distribuição das categorias sem contar as funções do sistema imune e inflamação.

Figura 52 - Categorias de funções biológicas enriquecidas nos animais de três meses. A, C e E: distribuição de todas as categorias. B, D e F: distribuição das categorias sem contar as funções do sistema imune e inflamação.

Figura 53 - Categorias de funções biológicas enriquecidas nos animais de seis meses. A, C e E: distribuição de todas as categorias. B, D e F: distribuição das categorias sem contar as funções do sistema imune e inflamação. 
Figura 54 - Diagrama de Venn com o número de genes difencialmente expressos nas três idades da linhagem $D m d^{m d x}$.....

Figura 55 - Diagrama de Venn com o número de genes difencialmente expressos nas três idades da linhagem Large myd- $^{\text {- }}$

Figura 56 - Diagrama de Venn com o número de genes difencialmente expressos nas três idades da linhagem $D m d^{m d x} /$ Large $e^{m y d--}$

Figura 57 - Rede mais significativa do camundongo $D m d^{m d x}$ com 21 dias. Score: 61; 33 genes selecionados. Categorias envolvidas: Ciclo celular; Organização celular; Replicação, recombinação e reparo de DNA

Figura 58 - Rede mais significativa do camundongo $D m d^{m d x}$ com 3 meses. Score: 29; 12 genes selecionados. Categorias envolvidas: Sinalização e interação célula-célula; Desenvolvimento e função do sistema hematológico; Tráfico de células imunes

Figura 59 - Rede mais significativa do camundongo $D m d^{m d x}$ com 6 meses. Score: 37; 18 genes selecionados. Categorias envolvidas: Metabolismo de lipídio; Transporte molecular; Bioquímica de moléculas pequenas.

Figura 60 - Rede mais significativa do camundongo Large ${ }^{m y d-/}$ com 21 dias. Score: 7; 3 genes selecionados. Categorias envolvidas: Morfologia tecidual; Desenvolvimento celular; Desenvolvimento e função do sistema hematológico 101

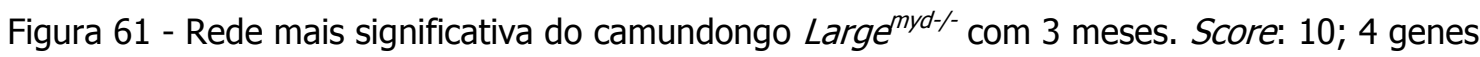
selecionados. Categorias envolvidas: Desenvolvimento e função do tecido conectivo; Morfologia tecidual; Morte e sobrevivência celular 102

Figura 62 - Rede mais significativa do camundongo Large ${ }^{\text {myd-/- }}$ com 6 meses. Score: 62; 26 genes selecionados. Categorias envolvidas: Doença metabólica; Resposta inflamatória; Doenças do tecido conectivo

Figura 63 - Rede mais significativa do camundongo $D m d^{m d x} / L a r g e^{m y d-/-}$ com 21 dias. Score: 15; 4 genes selecionados. Categorias envolvidas: Sobrevivência e morte celular; Desenvolvimento celular; Morfologia de tumores

Figura 64 - Rede mais significativa do camundongo $D m d^{m d x} / \operatorname{Large}^{m y d-/}$ com 3 meses. Score: 31; 72 genes selecionados. Categorias envolvidas: Movimento celular; Desenvolvimento embrionário; Desenvolvimento e função do sistema nervoso 105 Figura 65 - Rede mais significativa do camundongo $D m d^{m d x} /$ Large $^{m y d-/-}$ com 6 meses. Score: 32; 14 genes selecionados. Categorias envolvidas: Desenvolvimento embrionário; Desenvolvimento e função do sistema nervoso, Desenvolvimento do órgão 106 Figura 66 - Diagrama de Venn reunindo todos os genes diferencialmente expressos nas três idades de cada linhagem. No centro estão os genes compartilhados por todas as linhagens e idades. Em destaque o único gene com expressão diferencial apenas na linhagem $D m d^{m d x} /$ Large $e^{m y d-/}$ 107 
Figura 67 - Rede mais significativa do camundongo $D m d^{m d x} / L a r g e^{m y d-/-}$ com 21 dias. Score: 45; 21 genes selecionados. Categorias envolvidas: Movimento celular; Desenvolvimento e função do sistema hematológico; Tráfego de células imunes

Figura 68 - Segunda rede mais significativa do camundongo $D m d^{m d x} / L a r g e^{m y d--}$ com 21 dias.

Score: 33; 17 genes selecionados. Categorias envolvidas: Doença do desenvolvimento; Doença hereditária; Doenças esqueléticas e musculares

Figura 69 - Rede mais significativa do camundongo $D m d^{m d x} /$ Large ${ }^{m y d-/-}$ com 3 meses. Score: 47;

27 genes selecionados. Categorias envolvidas: Doença cardiovascular; Doença neurológica;

Doença hereditária

Figura 70 - Segunda rede mais significativa do camundongo $D m d^{m d x} /$ Large $e^{m y d-/}$ com 3 meses.

Score: 40; 24 genes selecionados. Categorias envolvidas: Desenvolvimento e função do sistema hematológico; Resposta inflamatória; Morfologia tecidual 115

Figura 71 - Rede mais significativa do camundongo $D m d^{m d x} /$ Large ${ }^{m y d-/-}$ com 6 meses. Score: 50; 29 genes selecionados. Categorias envolvidas: Resposta inflamatória; Movimento celular; Tráfego de células imunes.

Figura 72 - Segunda rede mais significativa do camundongo $D m d^{m d x} / \operatorname{Larg}^{m y d-/-}$ com 6 meses.

Score: 41; 24 genes selecionados. Categorias envolvidas: Desenvolvimento e função do sistema hematológico; Morfologia tecidual; Desenvolvimento celular............................................117

Figura 73 - Quantificações relativas dos gens estudados nas amostras de 21 dias ................ 118

Figura 74 - Quantificações relativas dos genes estudados nas amostras de 3 meses .............. 118

Figura 75 - Quantificações relativas dos genes estudados nas amostras de 6 meses ..............119

Figura 76 - Histologia do músculo gastrocnêmio dos animais $D m d^{m d x}$ e $\operatorname{Larg} e^{m y d-/}$. Coloração de hematoxilina-eosina; aumento $10 \mathrm{X}$ 


\section{Lista de tabelas}

Tabela 1 - Reagentes da reação da primeira fita de cDNA …............................................... 43

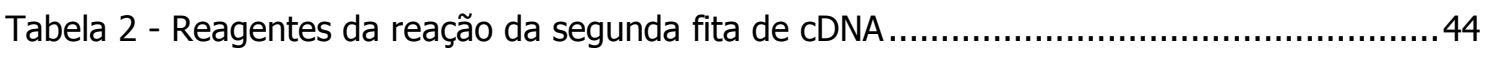

Tabela 3 - Reagentes da reação de cRNA ..................................................................4 44

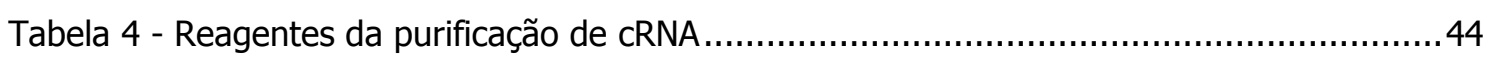

Tabela 5 - Reagentes da reação do segundo ciclo de cDNA …...........................................45

Tabela 6 - Reagentes da purificação de cDNA.............................................................. 46

Tabela 7 - Reagentes da reação de fragmentação do ss-cDNA .........................................47

Tabela 8 - Reagentes de marcação do cDNA …........................................................ 47

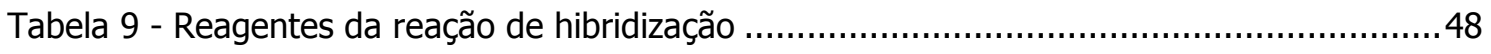

Tabela 10 - Amostras usadas na validação dos genes por PCR em tempo real ........................50

Tabela 11 - Genes escolhidos para a validação e respectivos pares de primers........................50

Tabela 12 - Reagentes e condições da reação de PCR em tempo real ...................................51

Tabela 13 - Identificação das amostras utilizadas; quantificação do RNA e razão $A_{260} / A_{280} \ldots . . . .52$

Tabela 14 - Quantificação do cRNA das amostras do grupo de animais com 21 dias ...............58

Tabela 15 - Quantificação do cRNA das amostras do grupo de animais com 3 meses..............59

Tabela 16 - Quantificação do cRNA das amostras do grupo de animais com 6 meses..............59

Tabela 17 - Quantificação do cDNA das amostras do grupo de animais com 21 dias ...............59

Tabela 18 - Quantificação do cDNA das amostras do grupo de animais com 3 meses...............60

Tabela 19 - Quantificação do cDNA das amostras do grupo de animais com 6 meses...............60

Tabela 20 - Totais de genes diferencialmente expressos em cada comparação e idade ...........74

Tabela 21 - Totais de genes diferencialmente expressos após a anotação. Em vermelho, os genes superexpressos; em verde, os genes subexpressos .............................................. 74

Tabela 22 - Número de genes diferencialmente expressos com expressão no tecido muscular.

Em vermelho, os genes superexpressos; em verde, os genes subexpressos ........................... 76

Tabela 23 - Proporção de genes do tecido muscular em relação ao total de genes....................76

Tabela 24 - 31 genes com expressão diferencial em todas as linhagens e idades.....................78

Tabela 25 - 17 genes com expressão diferencial em todas as linhagens somente na idade de 21 dias

Tabela 26 - 11 genes com expressão diferencial em todas as linhagens somente na idade de 3 meses.

Tabela 27 - 55 genes com expressão diferencial em todas as linhagens somente na idade de 6 meses.

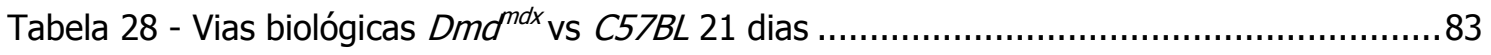

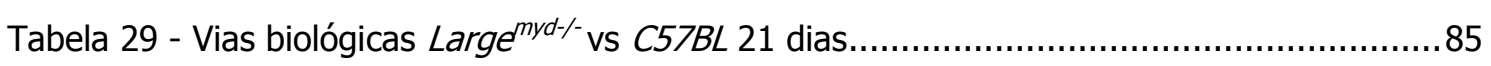

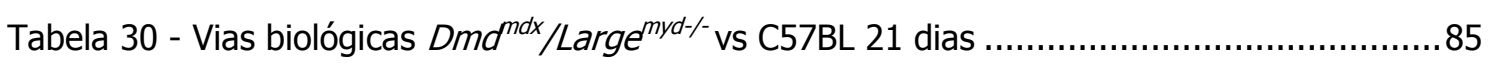

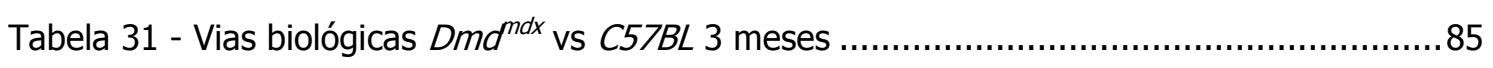

Tabela 32 - Vias biológicas Large $e^{m y d-1}$ vs C57BL 3 meses.................................................. 86 
Tabela 33 - Vias biológicas C57BL vs $D m d^{m d x} / \operatorname{Larg}^{m y d}-/-3$ meses....................................... 86

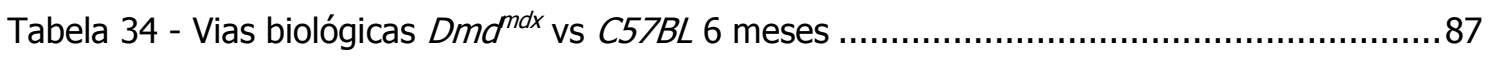

Tabela 35 - Vias biológicas Large $e^{m y d-/}$ vs C57BL 6 meses.................................................. 88

Tabela 36 - Vias biológicas $D m d^{m d x} /$ Large $^{m y d-1-}$ vs C57BL 6 meses .......................................89

Tabela 37 - Número de genes diferencialmente expressos nas comparações do duplo-mutante

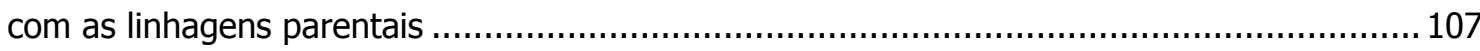

Tabela 38 - Comparações do duplo-mutante com as linhagens parentais. Totais de genes diferencialmente expressos após a anotação. Em vermelho, os genes superexpressos; em

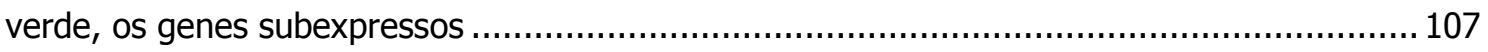

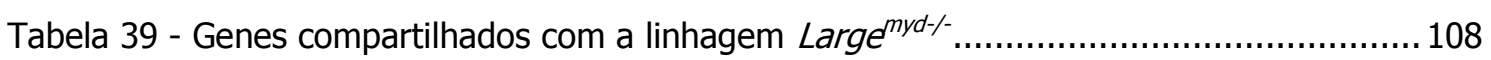

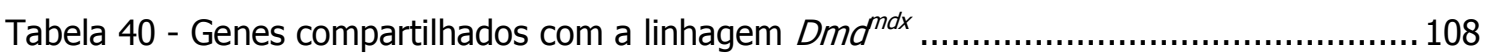

Tabela 41 - Categorias biológicas enriquecidas na linhagem $D m d^{m d x} / L a r g e^{m y d-/-}$ com 21 dias de idade. 97 genes diferencialmente expressos foram utilizados nessa análise 109 Tabela 42 - Categorias biológicas enriquecidas na linhagem Dmd $d^{m d x} / L a r g e^{m y d-1}$ com 3 meses de idade. 280 genes diferencialmente expressos foram utilizados nessa análise 110 Tabela 43 - Categorias biológicas enriquecidas na linhagem $D m d^{m d x} / L a r g e^{m y d-}$ com 6 meses de idade. 283 genes diferencialmente expressos foram utilizados nessa análise 110 Tabela 44 - Principais redes gênicas formadas com os genes diferencialmente expressos no $D m d^{m d x} /$ Large end-/- $^{m}$ com 21 dias

Tabela 45 - Principais redes gênicas formadas com os genes diferencialmente expressos no $D m d^{m d x} /$ Large $^{m y d-/-}$ com 3 meses.

Tabela 46 - Principais redes gênicas formadas com os genes diferencialmente expressos no $D_{m d^{m d x}} /$ Large $^{m y d-/-}$ com 6 meses.

Tabela 47 - Resumo dos trabalhos publicados sobre a expressão gênica global do $D m d^{m d x} \ldots 122$ 


\section{Sumário}

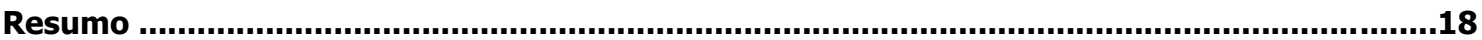

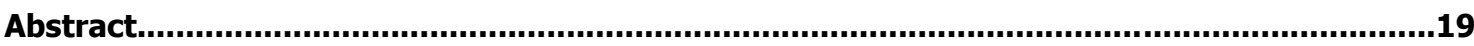

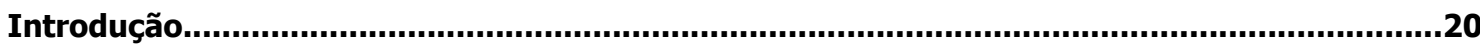

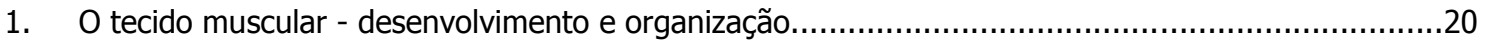

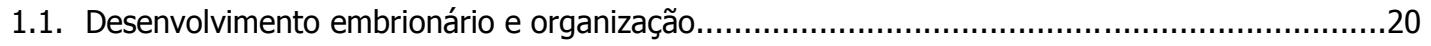

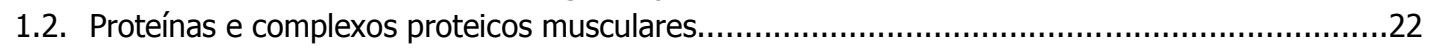

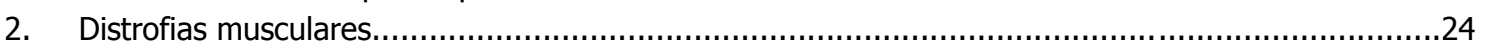

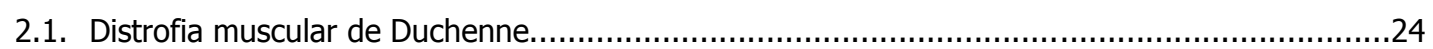

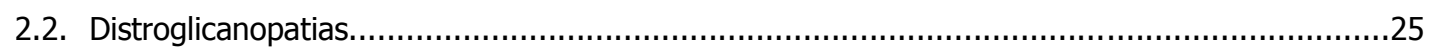

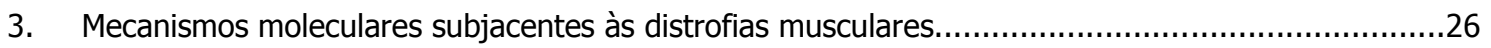

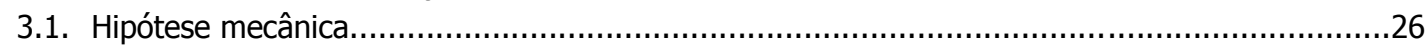

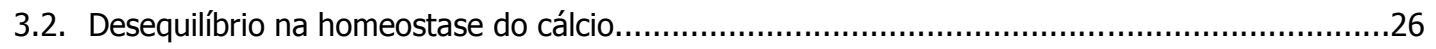

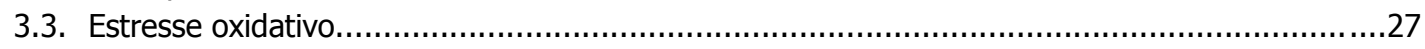

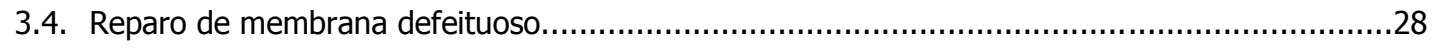

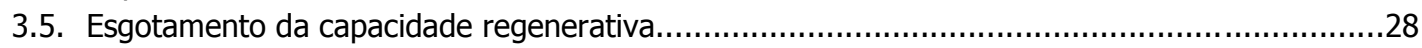

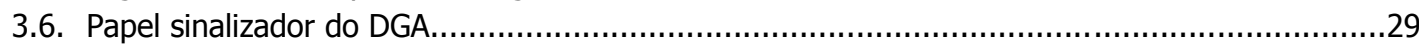

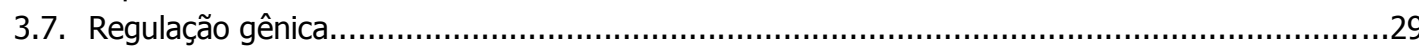

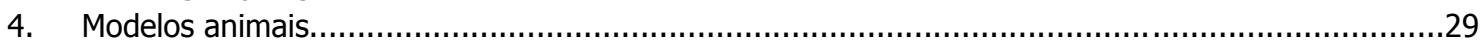

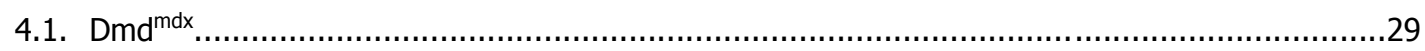

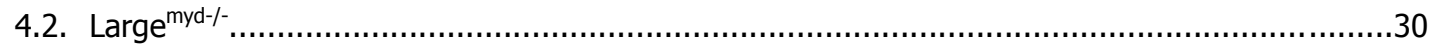

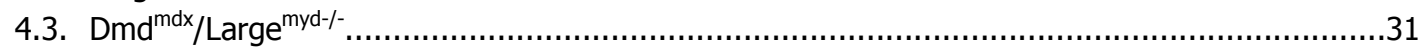

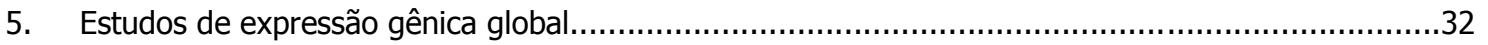

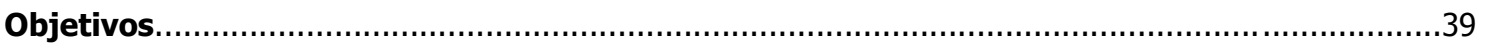

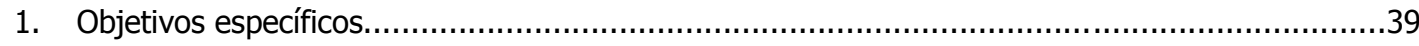

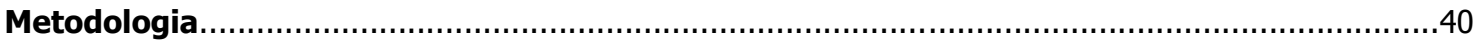

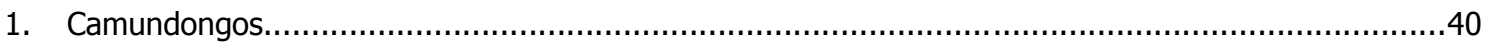

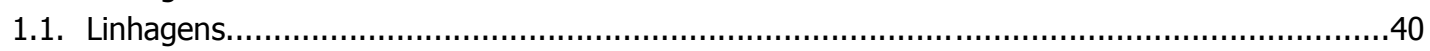

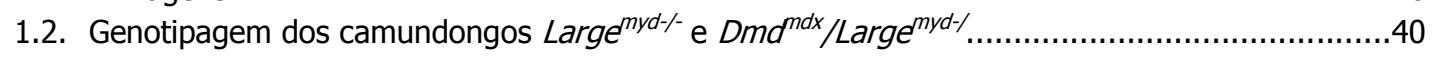

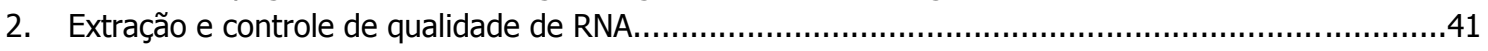

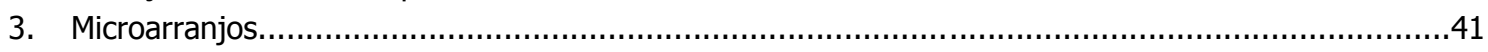

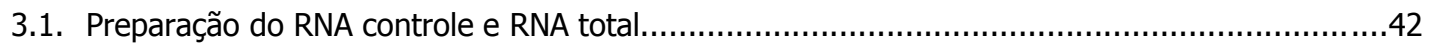

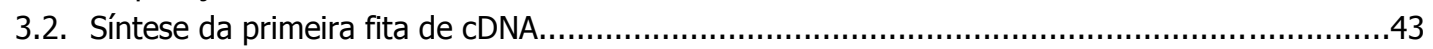

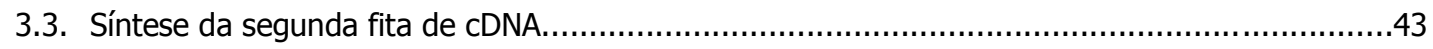

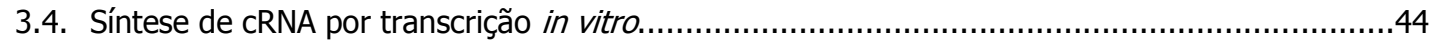

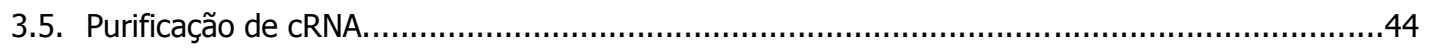

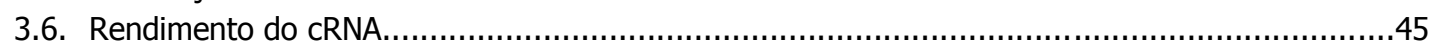

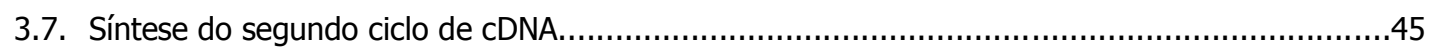

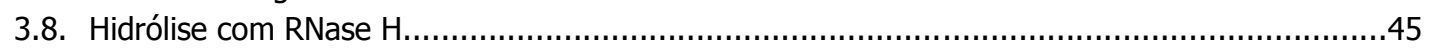

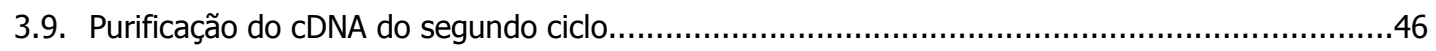

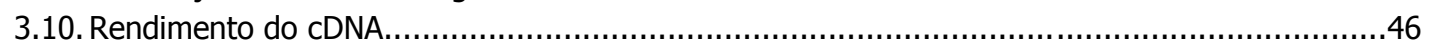

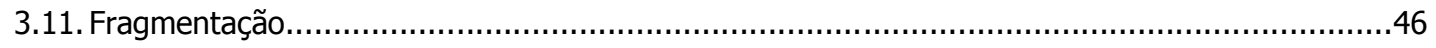

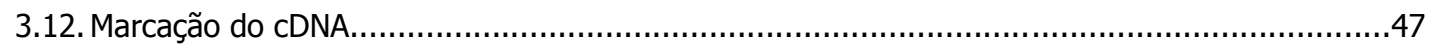

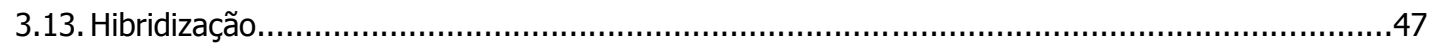

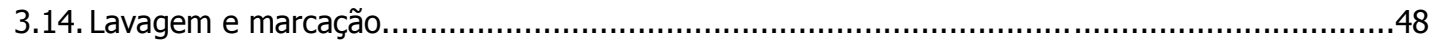

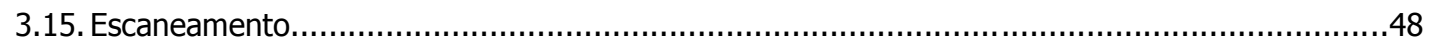

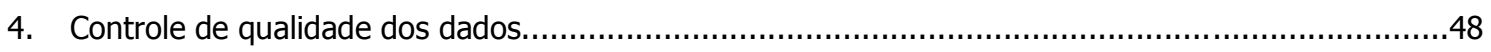

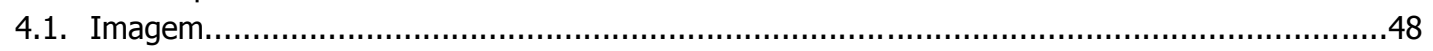

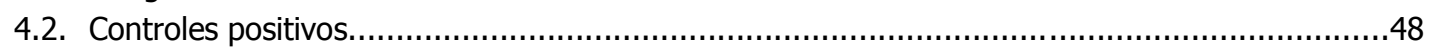

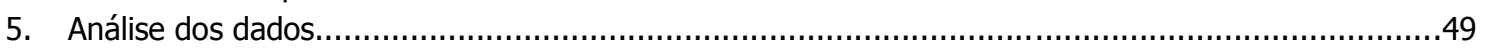

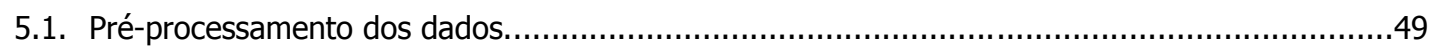

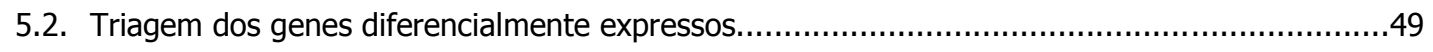

5.3. Análise funcional dos genes diferencialmente expressos...............................................49

6. Validação dos dados por PCR em tempo real - quantificação relativa...............................................50 
Resultados.

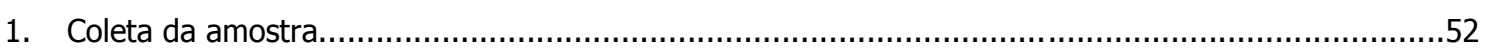

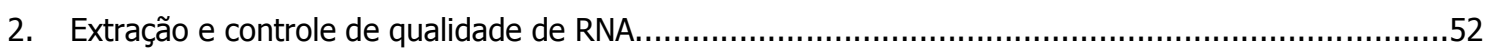

3. Controle de qualidade dos microarranjos e pré-análise.......................................................58

3.1. Síntese de cRNA e cDNA, fragmentação e hibridização..............................................58

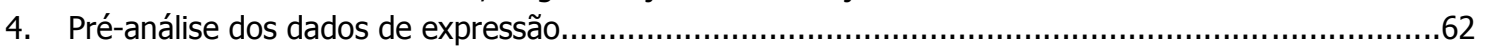

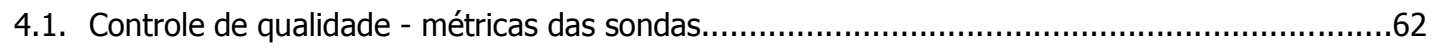

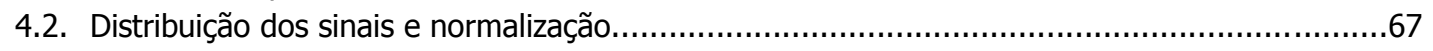

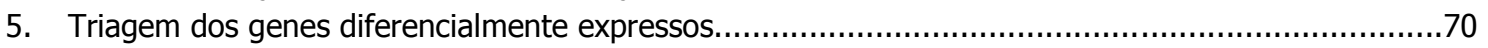

5.1. Número total de genes diferencialmente expressos....................................................70

5.2. Classificação dos genes quanto ao aumento ou redução da expressão (em relação ao

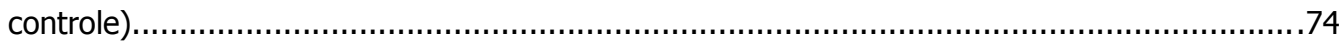

5.3. Genes diferencialmente expressos - análise de genes de tecido muscular...........................75

6. Caracterização do processo distrófico.........................................................................77

6.1. Genes diferencialmente expressos em todos os modelos distróficos e em todas as idades........77

6.2. Genes diferencialmente expressos em cada idade - Efeito da idade.....................................79

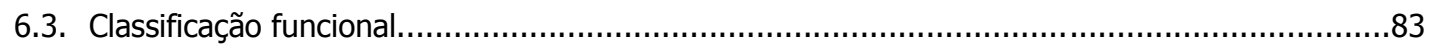

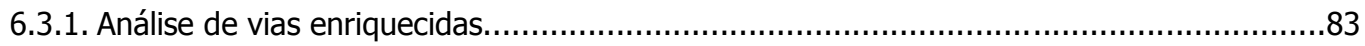

6.3.2. Anotação funcional dos genes de acordo com o Gene Ontology.................................90

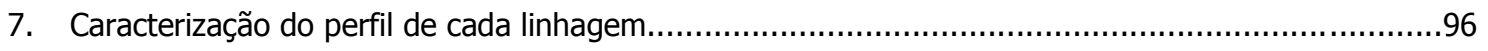

7.1. Análise do número de genes diferencialmente expressos - evolução de cada linhagem...........96

7.2. Redes gênicas - genes exclusivos de cada linhagem...............................................97

8. Caracterização da linhagem $D m d^{m d x} / \operatorname{Large}^{m y d-/-}$ - Comparação com suas linhagens parentais..........107

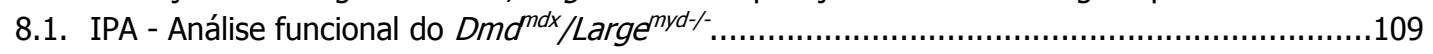

8.2. Redes funcionais com todos os genes................................................................111

9. Validação do perfil de expressão por PCR em tempo real quantitativo......................................118

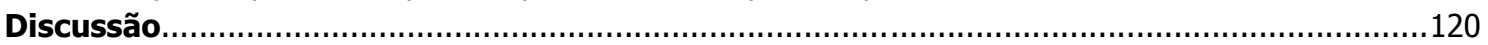

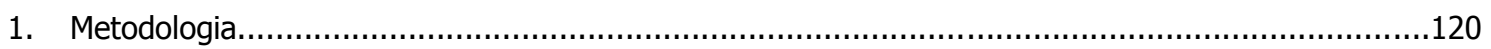

1.1. Coleta da amostra; extração e controle de qualidade de RNA .......................................120

1.2. Controle de qualidade dos microarranjos e pré-análise................................................121

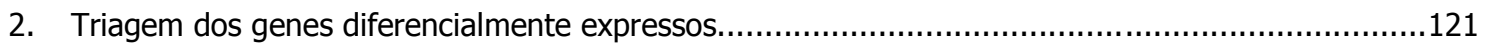

2.1. Número total de genes diferencialmente expressos.............................................121

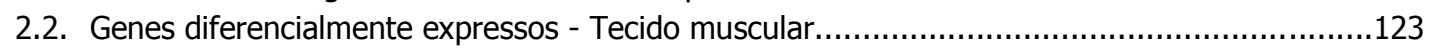

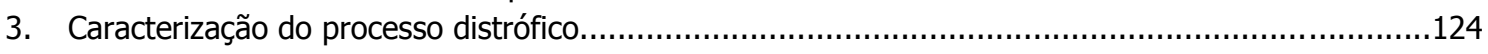

3.1. GDEs comuns em todas as linhagens distróficas........................................................124

3.2. Genes diferencialmente expressos em cada idade - Efeito da idade.................................129

3.3. Classificação funcional dos genes diferencialmente expressos.........................................131

3.3.1. Enriquecimento de vias biológicas - KEGG Pathways.......................................131

3.3.2. Enriquecimento de funções biológicas........................................................131

4. Caracterização do perfil de cada linhagem..................................................................139

4.1. Análise do número de genes diferencialmente expressos - efeito da idade na evolução de cada linhagem.

4.2. Redes gênicas - o que está diferente em cada linhagem em relação às demais, na mesma idade?.

139

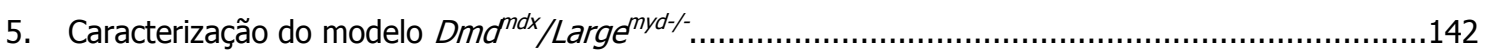

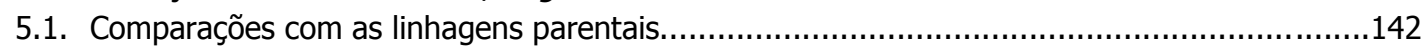

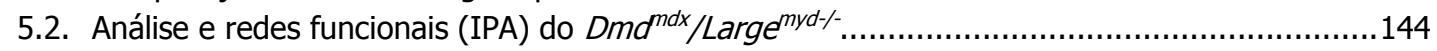

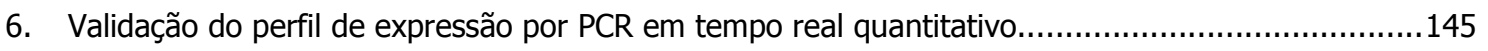

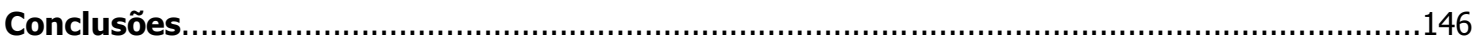

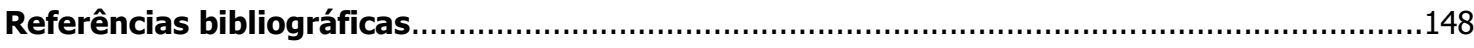

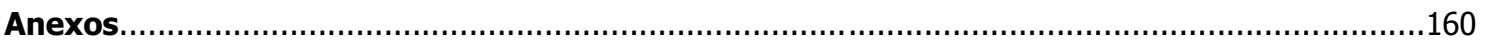




\section{Resumo}

As distrofias musculares formam um grupo amplo e heterogêneo de doenças genéticas, caracterizado basicamente pela degeneração e fraqueza muscular progressivas. Ao longo das últimas décadas muitos estudos vêm sendo realizados para a identificação dos genes envolvidos nessas doenças. Entretanto, apesar da identificação da mutação responsável pela grande maioria das formas descritas, os processos moleculares subjacentes ao defeito genético primário são muito complexos e ainda precisam ser melhor compreendidos. E a compreensão dos mecanismos de cada uma das formas é muito importante para o desenvolvimento adequado de terapias.

A avaliação da expressão gênica global por microarranjos de DNA é uma ferramenta bastante poderosa, capaz de produzir uma grande quantidade de dados, delineando o panorama geral do estado do transcriptoma de um determinado tecido ou célula. Assim, os objetivos desse trabalho foram estudar os perfis de expressão do músculo de três linhagens de camundongos modelos de formas distintas de distrofia muscular $\left(D m d^{m d x}, \operatorname{Larg} e^{m y d-/}\right.$ e $\left.D m d^{m d x} / \operatorname{Larg} e^{m y d-/}\right)$ em diferentes fases da progressão da doença (21 dias, três meses e seis meses de idade), com o intuito de caracterizar o processo distrófico e como o perfil de expressão varia com a progressão da idade e a depender da mutação genética.

Em cada um dos modelos e idades estudados identificamos um grande número de genes diferencialmente expressos (GDEs), refletindo a complexidade dessas doenças. A análise dos processos e vias biológicas nas quais esses genes estão envolvidos mostrou o forte envolvimento de componentes do sistema imunológico e inflamação, e também de genes relacionados com os processos de degeneração/regeneração e remodelamento da matriz extracelular. De modo geral, as funções biológicas alteradas são bem semelhantes entre as linhagens, sugerindo que apesar de as mutações serem em genes distintos, com funções diferentes, os processos moleculares que são afetados em decorrência dessas mutações são praticamente os mesmos. As maiores diferenças foram vistas na idade de 21 dias, especialmente na linhagem $D m d^{m d x}$ que apresentou uma grande quantidade de GDEs, dos quais grande parte relacionada com a maior capacidade regenerativa dessa linhagem e, assim, são genes que podem explicar o porquê desses animais apresentarem um fenótipo benigno em relação aos pacientes humanos.

A caracterização do modelo duplo-mutante $D m d^{m d x} /$ Large $e^{m y d-/}$ mostrou que a junção das duas mutações não ocasiona alterações no transcriptoma distintas das observadas nas linhagens parentais, sendo que o perfil do duplo-mutante é mais próximo ao de seu parental $L a r g e^{m y d-/}$, não apresentando a mesma capacidade regenerativa que o $D m d^{m d x}$. 
The muscular dystrophies form a large and heterogeneous group of genetic diseases, characterized mainly by progressive muscular degeneration and weakness. In the last decades, many studies have been carried on in order to identify the involved genes in these disorders. However, despite the identification of responsible mutations of the majority of the described forms, the underlying molecular processes to the primary mutation are very complex and are not fully understood. And to understand the mechanisms of each form is of major importance to the development of therapies.

Global gene expression profiling by DNA microarrays is a powerful tool, able to yield a huge quantity of data, outlining the general landscape of the transcriptome of a given tissue or cell. In this sense, the objectives of this work were to study the expression profile of the muscles from three mice lineages, models for different forms of muscular dystrophy $\left(D m d^{m d x}, \operatorname{Larg}^{m y d-/-}\right.$ and $\left.D m d^{m d x} / \operatorname{Larg}^{m y d-/}\right)$ in different phases of disease progression (21day-old, three-month-old and six-month-old), in order to characterize the dystrophic process and how the expression profile changes according to aging and depending on the genetic mutation.

In each model and age studied we identified a substantial number of differentially expressed genes (DEGs), reflecting the diseases' complexity. The analysis of the biological processes and pathways in which these genes are implicated showed a strong involvement of immune system and inflammation components, and also genes related to degeneration/regeneration and extracellular matrix remodeling processes. Altogether, the altered biologic functions are very similar in lineages, suggesting that although mutations are in different genes, with diverse functions, the affected molecular processes due to these mutations are basically the same. The most notable differences were seen on 21day-old, especially on $D m d^{m d x}$ lineage that showed a great quantity of DEGs, many of which are related to the better regenerative capacity this lineage exhibits and, thus, they are genes that could explain why these animals manifest a mild phenotype in comparison to human patients.

The characterization of the double mutant $D m d^{m d x} / L a r g e^{m y d-/}$ showed that the union of both mutations does not bring on alterations on the transcriptome different from those seen in the parental lineages, with the double mutant profile closer to its parental $\operatorname{Larg}^{m y d-/}$, not bearing the same regenerative capacity that $D m d^{m d x}$. 


\section{Introdução}

As afecções neuromusculares humanas constituem um grupo heterogêneo de doenças genéticas caracterizadas por degeneração muscular progressiva, levando ao desenvolvimento de fraqueza muscular e perda de capacidade motora. Na última década, foram identificadas mutações em vários genes, que resultam na deficiência ou perda de função de diversas proteínas musculares de importância significativa para o bom funcionamento do músculo. A fraqueza muscular observada nos pacientes resulta do desequilíbrio entre ciclos de degeneração e regeneração. O rompimento das miofibrilas do sarcolema leva à ativação de células mononucleadas inflamatórias e de células-satélite, que induzem a regeneração muscular, porém com capacidade limitada que se esgota ao longo de um processo contínuo de degeneração do músculo.

Portanto, analisar a função de genes diferencialmente expressos no fenótipo distrófico em camundongos modelos para diferentes formas de distrofias musculares, em diferentes fases da progressão da doença, pode contribuir para um melhor entendimento dos processos patológicos nesses animais.

\section{O tecido muscular - desenvolvimento e organização}

O músculo esquelético é um órgão altamente organizado e especializado, responsável pela locomoção e geração de energia nos organismos multicelulares.

\subsection{Desenvolvimento embrionário e organização}

O desenvolvimento do músculo esquelético pode ser dividido nos seguintes estágios principais: determinação do destino celular (formação de mioblastos); proliferação de mioblastos; alinhamento e fusão de mioblastos; formação de miotubos; maturação dos miotubos e formação da fibra muscular. Cada etapa é especificamente regulada por fatores moleculares, de modo bastante ordenado (Parker, Seale e Rudnicki, 2003).

Os mioblastos têm sua origem nos somitos do embrião, que são condensações transitórias de mesoderme paraxial em cada lado do tubo neural e da notocorda (Buckingham, 2001; 2006). Os fatores de regulação miogênica (MRFs) - MyoD, Myf5, miogenina e Myf6 - têm um papel bem definido na coordenação do desenvolvimento e diferenciação da musculatura esquelética, ligando-se a uma sequência consenso encontrada nos promotores de muitos genes específicos do músculo (Brand-Saberi e Christ, 1999). Uma vez que o fator de transcrição Pax3, junto com os fatores MyoD e Myf5 determinaram a identidade e proliferação dos mioblastos, estes se fundem e se diferenciam para formar os miotubos (células multinucleadas imaturas) e as miofibras 
(células musculares completamente diferenciadas), sob a ação dos fatores miogenina e Myf6 (Parker, Seale e Rudnicki, 2003) (Figura 1).

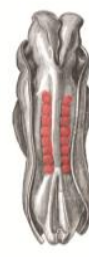

Somites

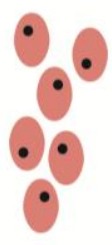

Myoblasts

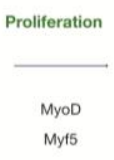

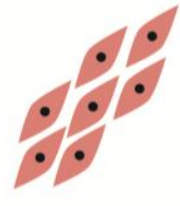

Myocytes

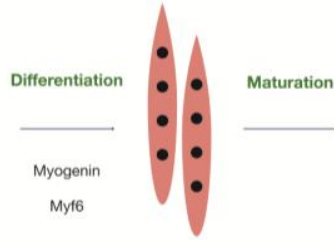

Myotubes

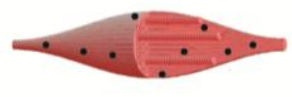

Muscle

Figura 1 - Etapas da diferenciação miogênica. Extraído de Almeida C F, Ayub-Guerrieri D,Vainzof M. Myogenic differentiation of ES cells for therapies in neuromuscular diseases: progress to date. In:

Kallos MS, editor. Embryonic stem cells - differentiation and pluripotent alternatives. 2011. p. 227-242.

Quando sofre algum dano, o processo da miogênese também ocorre no músculo adulto. A regeneração ocorre pela ativação e diferenciação de células-tronco musculares, principalmente as células-satélite, que estão localizadas entre a lâmina basal e o sarcolema, em estado quiescente. Essas células são necessárias para o crescimento, a manutenção e a regeneração do músculo adulto. A diferenciação das células-satélite para a formação e/ou reparo de novas miofibras é regulada de maneira muito semelhante ao que ocorre nos estágios embrionários, também pela ação dos MRFs. Entretanto, existem algumas diferenças, como a necessidade da expressão de Pax7 nas células-satélite, que não é observada na embriogênese (Wang e Rudnicki, 2012) (Figura 2).

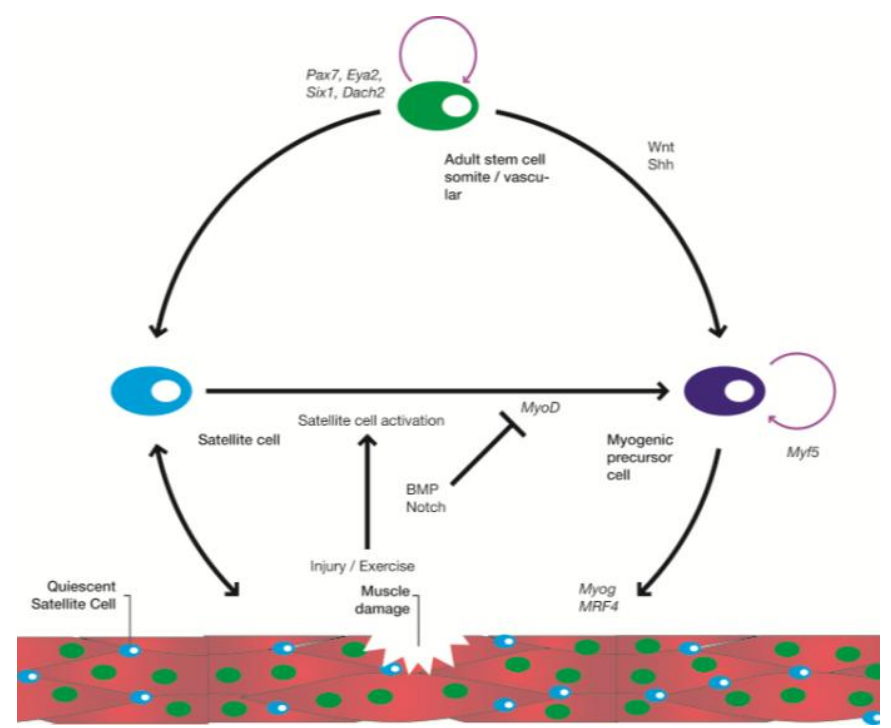

Figura 2 - Miogênese no tecido adulto. Extraído de Almeida C F, Ayub-Guerrieri D,Vainzof M. Myogenic differentiation of ES cells for therapies in neuromuscular diseases: progress to date. In: Kallos MS, editor. Embryonic stem cells - differentiation and pluripotent alternatives. 2011. p. 227-242.

A fusão e diferenciação dos mioblastos formam a miofibra, uma estrutura tubular, alongada e multinucleada. O músculo esquelético adulto é constituído por feixes de miofibras (ou fibras musculares), que contêm uma série de filamentos proteicos, as 
miofibrilas. Tais filamentos são formados por proteínas contráteis, que formam o sarcômero, a unidade contrátil do músculo. O sarcômero é um segmento da miofibrila, delimitado por duas linhas $Z$ (onde se ancoram os filamentos de actina, e as proteínas titina e nebulina), contendo uma banda A (sobreposição de actina e miosina), que separa duas semibandas I, formadas apenas por actina. Na banda $\mathrm{H}$ há apenas miosina (Junqueira e Carneiro, 2009; (Clark et al., 2002) (Figura 3).

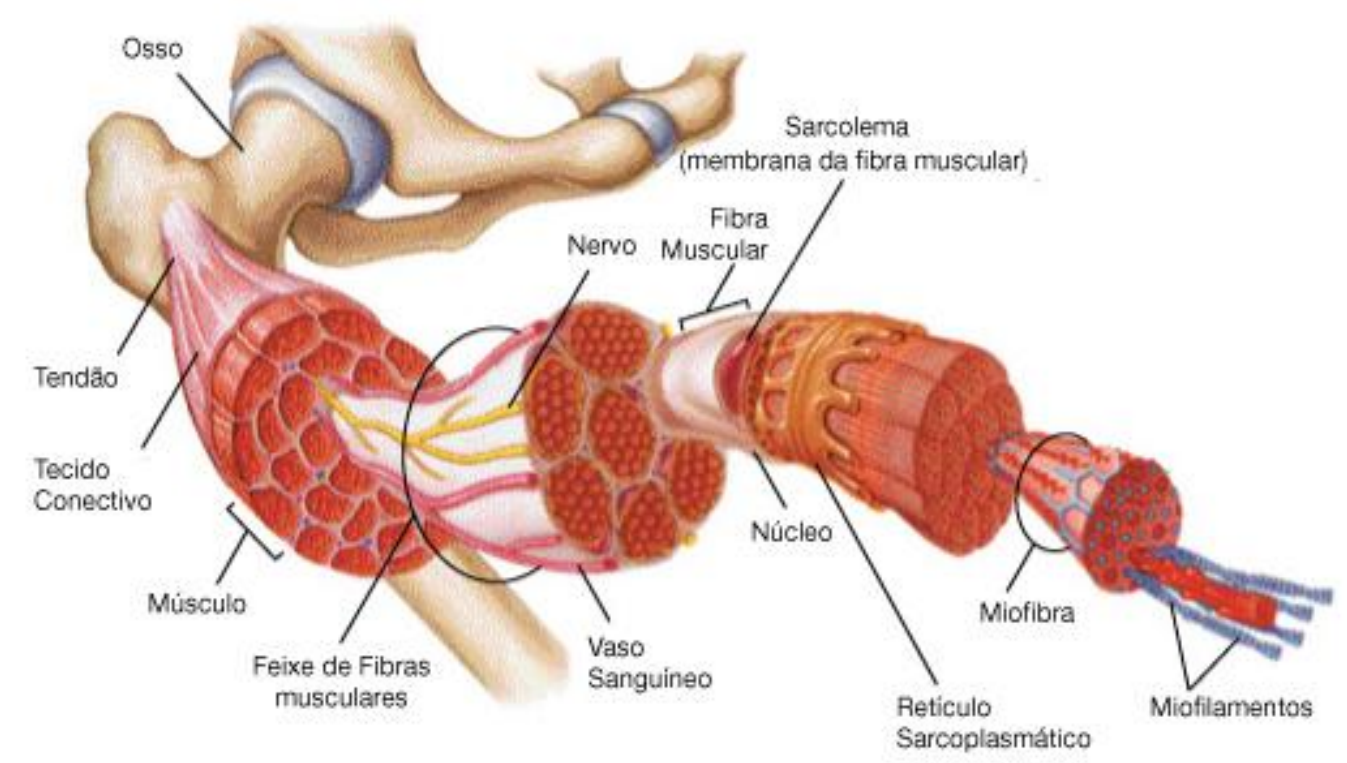

Figura 3 - Organização do músculo esquelético. Modificado de http://imgarcade.com/1/cardiactissue-diagram/

As miofibrilas estão envolvidas pela rede do retículo sarcoplasmático, que desempenha as funções de transporte e armazenamento, regulando o fluxo de íons cálcio, necessários para a contração muscular. No momento da contração muscular, ocorre uma mudança conformacional na miosina que desliza sobre os filamentos de actina, levando ao encurtamento do sarcômero, devido à sobreposição dos filamentos contráteis, bem como da fibra muscular inteira (Junqueira e Carneiro, 2009).

\subsection{Proteínas e complexos proteicos musculares}

A membrana da célula muscular possui uma série de proteínas que fazem a conexão entre o citoesqueleto de actina e a matriz extracelular (Ervasti e Campbell, 1993). Essa ligação fornece estabilidade à fibra e também permite a transmissão de força durante a contração muscular. Todas essas proteínas constituem o complexo distrofinaglicoproteínas associadas (DGA) (Figura 4). 


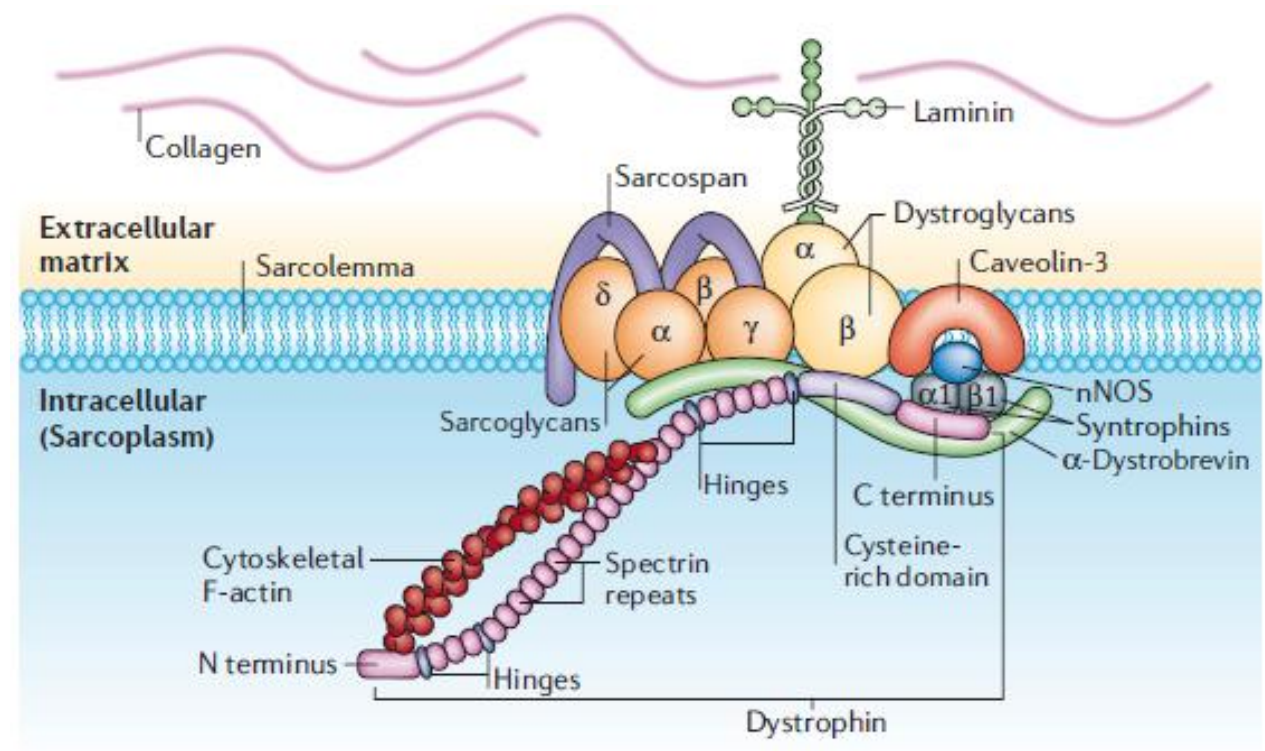

Figura 4 - Complexo distrofina-glicoproteínas associadas. Extraído de Kay E Davies \& Kristen J Nowak Nature Reviews Molecular Cell Biology 7, 762-773 (October 2006)

Esse complexo é composto pelo complexo distroglicano, formado pela proteína $\beta$ distroglicana que ancora uma proteína extracelular altamente glicosilada, a-distroglicana (Ibraghimov-Beskrovnaya et al., 1992; Yoshida et al., 1994), além de outras proteínas descritas mais adiante. Dentro do complexo DGA, a a-distroglicana se conecta a proteínas da matriz extracelular, incluindo a laminina 211, enquanto que o domínio intracelular da $\beta$ distroglicana interage com a distrofina (Suzuki et al., 1992; Ervasti e Campbell, 1993; Gee et al., 1993). Assim, o complexo distroglicano é central na ligação entre o citoesqueleto intracelular e a matriz extracelular, o que é importante para proteger a miofibra do estresse mecânico da contração muscular.

Além da ligação com a distrofina e a laminina, foi recentemente mostrado que o complexo distroglicano também interage com outras proteínas fora do complexo DGA, o que implica em mais funções deste subcomplexo no músculo e no mecanismo de doenças (Johnson et al., 2013).

No citoplasma, a proteína distrofina se liga aos filamentos de actina por seu domínio N-terminal (Way et al., 1992); o seu domínio C-terminal está ligado à proteína integrante de membrana $\beta$-distroglicana e às proteínas distrobrevina, sintrofina e à enzima óxido nítrico sintase (nNOS) (Campbell e Kahl, 1989; Suzuki et al., 1992; Sadoulet-Puccio, Rajala e Kunkel, 1997).

Na membrana do músculo esquelético o complexo de sarcoglicanas é composto por quatro membros (a-, $\beta$-, $\gamma^{-}$e $\delta$-sarcoglicana) e tem importância para a estabilização da membrana, uma vez que mutações nos genes dessas proteínas são a causa de algumas 
formas de distrofia muscular de cinturas (Vainzof e Zatz, 2003; Allikian e Mcnally, 2007). $\mathrm{Na}$ ausência de apenas uma sarcoglicana, há uma perda secundária das demais; na deficiência de distrofina também ocorre a perda secundária de todo o complexo de sarcoglicanas (Vainzof e Zatz, 2003).

O rompimento da conexão citoplasma-membrana-matriz e/ou a perda de alguma das proteínas do complexo torna o sarcolema instável, aumentando a suscetibilidade da fibra muscular à morte celular, o principal evento das distrofias musculares.

\section{Distrofias musculares}

O termo distrofia muscular abrange um grupo clínica, genética e bioquimicamente heterogêneo de doenças hereditárias caracterizadas pela degeneração muscular progressiva e fraqueza muscular (Emery, 2002; Flanigan, 2012). Histologicamente, a maioria das distrofias tem em comum degeneração das fibras musculares com a posterior substituição do tecido muscular por fibrose e tecido adiposo.

A classificação dessas doenças tem sido feita, historicamente, de acordo com os principais aspectos clínicos e a idade de início de manifestação. Há ainda a subclassificação de grupos heterogêneos (por exemplo, as distrofias musculares de cinturas e as distrofias musculares congênitas). Entretanto, os avanços na identificação das mutações causadoras e na compreensão dos mecanismos patológicos têm mostrado que a classificação nem sempre pode ser feita baseando-se apenas nos aspectos clínicos; fenótipos semelhantes são frequentemente associados a mutações em diferentes genes, mas que compartilham funções similares. Atualmente, mais de 50 formas já foram descritas, porém algumas ainda não foram associadas a um gene específico (Mercuri e Muntoni, 2013).

As mutações causadoras das distrofias musculares ocorrem em um amplo conjunto de proteínas, sejam elas estruturais ou enzimas que fazem modificações pós-traducionais nessas proteínas; a localização dessas proteínas também é variável: matriz extracelular, sarcolema, sarcoplasma e membrana nuclear. Essas mutações comprometem a integridade da célula muscular levando ao desgaste progressivo da musculatura, acompanhado de uma série de consequências deteriorantes, incluindo a morte prematura (Rahimov e Kunkel, 2013).

\subsection{Distrofia muscular de Duchenne}

A distrofia muscular de Duchenne (DMD) é a forma mais comum dentre as distrofias musculares, e afeta aproximadamente um a cada 3500 meninos nascidos vivos. Foi descrita pela primeira vez pelo médico inglês Edward Meryon, em 1851, mas a doença 
só foi realmente reconhecida pela comunidade médica quando o médico francês Guillaume Duchenne fez uma descrição mais detalhada e profunda da patologia (Emery, 2002).

Essa forma de distrofia muscular é devida a mutações no gene $D M D$ localizado no braço curto do cromossomo X, que codifica a proteína distrofina de 427 kD (Hoffman, Brown e Kunkel, 1987; Koenig, Monaco e Kunkel, 1988). A distrofina é uma proteína intracelular com formato de bastão, localizada na região subsarcolemal. Pela sua porção Nterminal a distrofina se liga aos filamentos de actina do citoesqueleto; o domínio C-terminal interage com várias proteínas, formando o complexo distrofina-glicoproteínas-associadas (Ervasti et al., 1990; Yoshida e Ozawa, 1990).

Os sintomas costumam aparecer entre os três e cinco anos de idade. Clinicamente, os pacientes com DMD apresentam atraso para começar a andar, fraqueza progressiva acompanhada de dificuldades para correr, subir escadas e pular, quedas frequentes e hipertrofia de panturrilha acentuada. A perda da ambulação ocorre por volta dos 10 anos de idade e a morte geralmente antes do final da segunda década de vida devido a problemas respiratórios e cardíacos (Vainzof e Zatz, 2003).

\subsection{Distroglicanopatias}

A glicosilação da proteína a-distroglicana, membro importante do DGA, é crucial para a sua ligação com a laminina e a fosforilação da $\beta$-distroglicana regula a sua associação a ligantes intracelulares (Moore e Winder, 2012). A integridade dessa conexão é mantida e regulada por modificações pós-traducionais na distroglicana, o que tem efeitos tanto dentro quanto fora da célula.

A glicosilação anormal da proteína a-distroglicana caracteriza um grupo de distrofia muscular denominado distroglicanopatias, geralmente com padrão de herança autossômico recessivo e grande variabilidade clínica (Moore e Hewitt, 2009). Essas doenças têm em comum a hipoglicosilação da a-distroglicana o que leva a diminuição da ligação com a laminina e uma redução da função do eixo laminina-distroglicana (Muntoni et al., 2002).

A glicosilação da a-distroglicana é feita por diversas enzimas. Mutações nos genes das glicosiltransferases POMT1 (Beltrán-Valero De Bernabé et al., 2002), POMT2 (Van Reeuwijk et al., 2005), POMGnT1 (Yoshida et al., 2001), FCMD (Toda e Kobayashi, 1999), FKRP (Brockington et al., 2001), LARGE (Longman et al., 2003) dentre outros, são responsáveis por um amplo espectro de fenótipos clínicos, de menor ou maior gravidade, incluindo a síndrome de Walker-Warburg, a muscle-eye-brain disease, a distrofia muscular de Fukuyama, formas de distrofias musculares congênitas e a distrofias musculares de cintura tipo 2. 


\section{Mecanismos moleculares e celulares subjacentes às distrofias musculares}

As distrofias musculares são doenças monogênicas, entretanto a patologia resultante é complexa, podendo afetar outros órgãos além dos músculos, o que sugere um rompimento muito mais amplo da homeostase do que poderia ser predito pelo defeito em um único gene. Assim, torna-se importante o estudo dos mecanismos moleculares e celulares subjacentes ao defeito primário, e que são desencadeados devido ao processo de degeneração muscular.

Nas patologias causadas pela deficiência de distrofina, esses mecanismos são mais bem explorados e estudados, porém ainda não são completamente compreendidos. Para os defeitos de glicosilação há menos estudos ainda.

Há diversas hipóteses envolvidas no mecanismo de degeneração muscular e algumas serão apresentadas a seguir.

\subsection{Hipótese mecânica}

Uma característica clássica das distrofias musculares é a elevação do nível plasmático da enzima creatina quinase muscular, o que sugere que há uma maior permeabilidade da membrana, permitindo o extravasamento dessa enzima da fibra muscular para a corrente sanguínea. Além disso, diversos estudos já demonstraram uma maior permeabilidade do sarcolema do músculo distrófico pela absorção de corantes, como o Evans Blue (Matsuda, Nishikawa e Tanaka, 1995).

A hipótese mais recorrente para explicar a degeneração nas distrofias musculares atribui às mutações em genes de proteínas com função estrutural, como a distrofina, a falha no músculo que afetaria a estabilidade mecânica da fibra e de sua membrana (Petrof et al., 1993). A perda da conexão entre o citoesqueleto, a membrana e a matriz deixa a membrana mais frágil, o que exacerbaria o dano provocado normalmente pela contração muscular, dando início a uma série de eventos que culminam na morte celular (Wallace e Mcnally, 2009; Gumerson e Michele, 2011).

Entretanto, também é possível que as mutações alterem a homeostase do músculo em repouso ou ainda interfiram na habilidade do músculo de se adaptar e se recuperar após um ciclo normal de dano.

\subsection{Desequilíbrio na homeostase do cálcio}

Aumento no nível de cálcio intracelular em músculos distróficos já é um fato conhecido e bem documentado (Mallouk, Jacquemond e Allard, 2000). Porém, os mecanismos responsáveis por esse aumento ainda não são bem esclarecidos. Os estudos 
mais iniciais apontavam que o cálcio entraria na célula através de pequenas lesões na membrana (Turner et al., 1988), hipótese compatível com as observações de que o sarcolema do músculo é mais frágil e suscetível a rupturas. Outros estudos sugerem que canais de cálcio estariam mais ativos nessa condição (Allen e Whitehead, 2011).

Outros trabalhos indicam que o excesso de cálcio viria do próprio retículo sarcoplasmático, por alterações nos canais RyR1 como consequência de mudanças na sinalização do óxido nítrico (Bellinger et al., 2009).

A despeito do mecanismo pelo qual ocorre, a comprovada elevação da concentração intracelular de cálcio pode resultar em danos celulares diversos que podem estar subjacentes aos efeitos observados no músculo distrófico. Acredita-se que níveis aumentados de cálcio prejudiquem a capacidade da célula de manter os níveis fisiológicos desse íon, levando à ativação de proteases dependentes de cálcio, como as calpaínas que clivam proteínas das miofibrilas (Alderton e Steinhardt, 2000).

O excesso de cálcio também afeta as mitocôndrias, aumentando a sua permeabilidade, o que pode desencadear em apoptose mediada pela mitocôndria, com liberação do citocromo c e ativação de caspases (Orrenius, Zhivotovsky e Nicotera, 2003).

\subsection{Estresse oxidativo}

A enzima óxido nítrico sintase neuronal (nNOS) está ligada à proteína sintrofina no complexo distrofina-glicoproteínas (DGA), porém, na ausência de distrofina essa enzima é deslocada para o citoplasma, reduzindo a produção do radical livre óxido nítrico (NO). 0 óxido nítrico é uma molécula bastante versátil que participa de uma série de processos no músculo e em outros tecidos: inflamação, proteólise, morte celular, formação e função de sinapses, metabolismo, função cardíaca e vasodilatação. Além disso, o NO está relacionado com a diminuição da produção de espécies reativas de oxigênio prejudiciais à célula. Dessa forma, é possível fazer uma relação direta das funções do NO com diversas consequências da distrofia muscular: inflamação, desgaste muscular, morte celular, deficiências na memória e aprendizado, cardiomiopatia, defeitos metabólicos, disfunção sináptica, e defeitos vasculares (Tidball e Wehling-Henricks, 2007).

Outro efeito do cálcio na mitocôndria é a produção de espécies reativas de oxigênio, que vão atuar na via do NF-KB, que sinaliza para a via do TNF-a, para a ubiquitinização de proteínas e para a inflamação, contribuindo para o agravamento da degeneração muscular (Allen e Whitehead, 2011). 


\subsection{Reparo de membrana defeituoso}

A membrana da célula de um músculo normal sofre constantemente com lesões devido à contração, mas, ao mesmo tempo, ela é capaz de repará-las por meio de um complexo sistema de reparo, mediado por uma série de proteínas. Entretanto, em alguns casos esse sistema pode estar prejudicado, como ocorre quando há mutações nos genes das proteínas disferlina, calpaína 3 e caveolina.

O modelo de reparo de membranas proposto sugere que um complexo formado pela disferlina e outras proteínas seja ativado por íons cálcio e recrute vesículas membranosas e as deposite no local da ruptura da membrana (Wallace e Mcnally, 2009; Rahimov e Kunkel, 2013).

Assim, a degeneração muscular não ocorreria pela desestruturação do complexo DGA, mas sim pela ineficiência em reparar a membrana danificada (Rahimov e Kunkel, 2013), mantendo as lesões abertas, permitindo um maior influxo de cálcio para dentro da célula, que em última instância desencadeia na degeneração muscular.

\subsection{Esgotamento da capacidade regenerativa}

Quando um dano à miofibra tem maiores proporções, de forma que o sistema de reparo de membrana não seja capaz de promover a recuperação adequada da célula, ocorre a ativação das células-satélite, as células-tronco do tecido muscular. Contudo, nas distrofias musculares, o músculo não é capaz de se regenerar continuamente, visto que o resultado final dessas doenças é a perda de fibras musculares e substituição por outros tecidos, o que sugere que a regeneração pelas células-satélites não consegue superar as taxas de degeneração.

Algumas explicações são propostas a fim de se esclarecer essa regeneração ineficiente. A primeira delas trata da senescência precoce das células-satélite, devido aos repetidos ciclos de divisão e à ativação constante, o que levaria a um esgotamento do estoque dessas células. Em apoio a esta hipótese, já foi observado uma menor quantidade de células-satélite (Heslop, Morgan e Partridge, 2000) e encurtamento de telômeros (Decary et al., 2000) em músculos distróficos, apesar de haver estudos contraditórios (Kottlors e Kirschner, 2010).

A segunda hipótese trata da capacidade de diferenciação e fusão das célulassatélites, uma vez que elas também possuem a mutação causadora da doença, o que de alguma forma pode reduzir a sua eficiência em regenerar adequadamente o tecido, como já foi observado no camundongo Large $e^{m y d-/-}$ (Ross et al., 2012). A produção reduzida de óxido nítrico também foi associada a alterações na proliferação e diferenciação das célulassatélite (Anderson, 2000). 
Por fim, o próprio microambiente distrófico, caracterizado por excesso de fibrose, dificultaria a migração, fusão e diferenciação apropriada das células-satélite.

\subsection{Papel sinalizador do complexo DGA}

Além do papel estrutural, associa-se ao complexo DGA uma função sinalizadora, especialmente relacionada com vias de sobrevivência celular. Diversas moléculas sinalizadoras já foram encontradas associadas com o complexo DGA, como a CaM kinase II, envolvida na via do PI3K de aumento de sobrevivência celular, dentre outras.

Os componentes do complexo DGA servem como pontos de ancoragem para complexos sinalizadores, em adição à função mecânica de estabilização da membrana. Consequentemente, a desestabilização e perda de componentes do complexo tem impacto em diversas vias de sinalização necessárias para a manutenção da célula. Isso explica, em partes, a maior suscetibilidade à morte de miofibras na distrofia muscular (Rando, 2001).

\subsection{Regulação gênica}

Algumas formas de distrofia são causadas por mutações em genes de proteínas nucleares, intimamente relacionadas com a cromatina. Isso teria implicações na expressão de uma série de genes, envolvidos em diversos processos, o que acarretaria em defeitos na apoptose e diferenciação muscular (Wallace e Mcnally, 2009).

\section{Modelos animais}

$\mathrm{Na}$ natureza já foram identificados diversos modelos animais, de diferentes espécies, para as mais variadas doenças humanas, incluindo as distrofias musculares. Além disso, também novos modelos podem ser desenvolvidos por manipulação genética. Esses animais servem como valiosas ferramentas para estudos genéticos, clínicos e histopatológicos, contribuindo para a melhor compreensão das patologias humanas e para testes terapêuticos.

\section{1. $D m d^{m d x}$}

O camundongo $D m d^{m d x}$, modelo natural para distrofia muscular de Duchenne, é o mais bem estudado e utilizado. Esse camundongo foi descrito pela primeira vez em 1984; ele apresenta deficiência total de distrofina devido a uma mutação de ponto no éxon 23 do gene Dmd, que resulta em um códon de parada prematuro (Bulfield et al., 1984; Sicinski et al., 1989). 
Assim como os pacientes humanos, o músculo do camundongo $D m d^{m d x}$ tem características distróficas, como degeneração, necrose e substituição por fibrose. Entretanto, diferentemente dos humanos, os camundongos mutantes apresentam sinais clínicos moderados, tem uma taxa de regeneração muscular significativa, conseguem se reproduzir e tem expectativa de vida normal, de aproximadamente dois anos (Dangain e Vrbova, 1984).

No músculo do camundongo $D m d^{m d x}$, apesar da deficiência de distrofina, é possível observar uma pequena porcentagem de miofibras distrofina-positivas, chamadas de fibras revertentes, vistas também em pacientes com DMD (Hoffman et al., 1990; Danko, Chapman e Wolff, 1992). A presença de fibras revertentes não tem nenhum efeito no fenótipo clínico e os mecanismos de formação dessas fibras são pouco compreendidos. Recentemente, foi publicado um estudo que reforça a hipótese de que eventos epigenéticos envolvendo mecanismo de splicing recuperariam o quadro de leitura em algumas células-satélite; as fibras revertentes posteriores surgiriam por expansão clonal dessas primeiras fibras revertentes (Pigozzo et al., 2013).

Dessa forma, o camundongo $D m d^{m d x}$ é um bom modelo genético e bioquímico, mas não é adequado em triagens terapêuticas. Por isso, a análise histológica do músculo diafragma, o mais afetado nesse animal, é mais frequentemente utilizada para a avaliação da evolução da doença, já que ele reproduz melhor as características degenerativas da distrofia muscular (Stedman et al., 1991).

\section{2. $L a r g e^{m y d-/-}$}

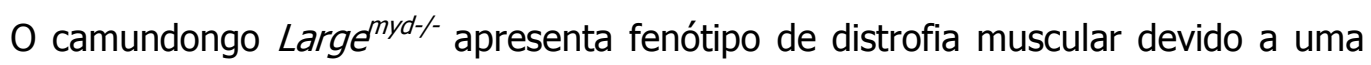
mutação no gene Large murino, herdada de forma autossômica recessiva; ele foi descrito pela primeira vez na década de 1970 (Lane, Beamer e Myers, 1976). Os animais homozigotos têm a marcha alterada, apresentam postura anormal quando suspensos pela cauda, são menores em comparação aos seus irmãos normais e têm expectativa de vida de aproximadamente 39 semanas. A concentração de creatina quinase é elevada e a histologia é típica de uma miopatia progressiva com variação no tamanho das fibras e focos de necrose e de regeneração (Grewal et al., 2001; Reed et al., 2004). Além das alterações no músculo esquelético, esse animal apresenta alterações cardíacas e defeitos no desenvolvimento do sistema nervoso central (Holzfeind et al., 2002).

A mutação causativa do fenótipo do $L a r g e^{m y d}$ é uma deleção de 379 pares de bases, correspondente aos éxons 5-7, no gene Large. Esta deleção causa uma mudança no quadro de leitura do mRNA, resultando em um códon de parada prematuro e, consequentemente, na perda dos domínios catalíticos da proteína (Grewal et al., 2001; 
Grewal e Hewitt, 2002). O gene Large codifica a enzima like-glycosy/transferase (LARGE), responsável por uma das etapas da glicosilação da proteína a-distroglicana (Hewitt, 2012; Inamori et al., 2012). Por isso, esse camundongo é utilizado como modelo para as distroglicanopatias.

\section{3. $D m d^{m d x} /$ Large $e^{m y d-/-}$}

Como o camundongo $D m d^{m d x}$ apresenta um fenótipo brando de distrofia muscular, diversos duplo-mutantes com background $D m d^{m d x}$ têm sido desenvolvidos, a fim de se obter animais com associação de duas proteínas alteradas e com fenótipo mais grave.

Com o objetivo de avaliar os efeitos da hipoglicosilação na modulação do fenótipo distrófico e de estimar o impacto da ausência simultânea de distrofina e a enzima LARGE na formação do complexo DGA, foi desenvolvido em nosso laboratório, por cruzamentos mendelianos, um camundongo duplo-mutante para essas duas proteínas (Martins et al., 2013).

Este novo modelo murino é viável, mas apresenta significativo atraso no crescimento e desenvolvimento, além de infertilidade por incapacidade de realizar a cópula. A taxa de mortalidade no período perinatal é elevada - apenas cerca de $15 \%$ dos animais afetados sobrevivem além das primeiras 24 horas. Esse animal mostra fraqueza muscular progressiva, mais grave que a observada nas linhagens parentais, com expectativa de vida reduzida, de no máximo 24 semanas (Martins et al., 2013) (Figura 5).

1 dia

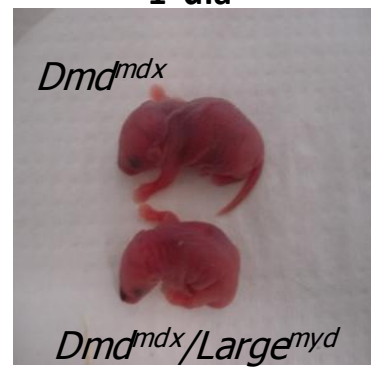

7 dias

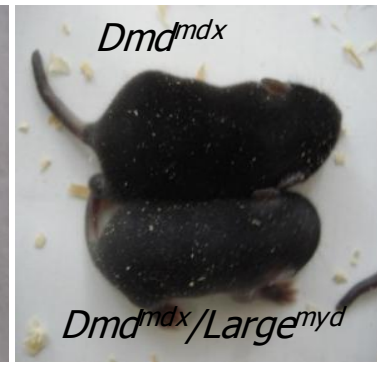

14 dias

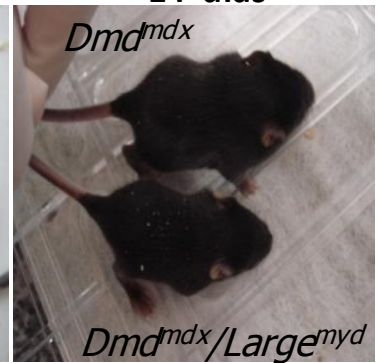

30 dias

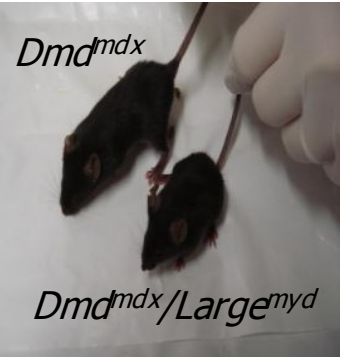

Figura 5 - Animais duplo-mutantes em diferentes idades, comparados com o $D m d^{m d x}$

Na análise histológica dos músculos do $D m d^{m d x} / \operatorname{Larg} e^{m y d-/}$, observa-se um padrão de degeneração similar ao visto no camundongo $\operatorname{Larg} e^{m y d-/}$; entretanto, nas idades de 21 dias e 180 dias, o duplo-mutante apresenta degeneração mais severa, incluindo aumento do endomísio e do perimísio, maior variação no tamanho da fibra, e uma proporção maior de núcleos centrais e fibras fendidas. Assim como o camundongo $D m d^{m d x}$, o duplo-mutante também apresenta fibras revertentes, o que significa que a presença da mutação no gene Large não interfere na produção das mesmas. Além disso, o duplo também tem deficiência 
secundária das sarcoglicanas, mostrando que há desestabilização no complexo DGA, o que

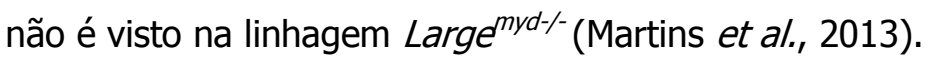

O camundongo $D m d^{m d x} / \operatorname{Larg}^{m y d-/}$ é o primeiro animal que combina ambos os defeitos genéticos de DMD e distroglicanopatias e oferece um significativo potencial para estudos sobre os mecanismos de desestabilização do complexo DGA. Além disso, esse modelo tem utilidade em estudos de terapia celular, pela facilidade de rastreamento de células seja por análise de DNA ou de proteínas (Martins et al., 2013).

\section{Estudos de expressão gênica global}

Apesar do conhecimento dos defeitos genéticos primários das distrofias musculares, a patologia molecular que leva a degeneração muscular ainda necessita de maiores estudos. A análise em larga escala da expressão gênica permite acessar as vias moleculares que estejam alteradas no músculo distrófico. Neste sentido, o uso de microarranjos de DNA oferece uma ferramenta poderosa para a análise global da expressão gênica (Haslett e Kunkel, 2002). Com os avanços nas áreas da genômica e da proteômica, o desenvolvimento das abordagens terapêuticas está sendo cada vez mais baseado na compreensão da sinalização celular para se identificar alvos moleculares ligados à fisiopatologia. Estudar as vias de sinalização que possam estar perturbadas devido à falta de distrofina ou outros componentes do complexo pode ajudar a revelar prováveis pontos de intervenção terapêutica ou a identificação de biomarcadores da doença.

Microarranjos de DNA são lâminas formadas por micropontos de ácidos nucleicos ordenados e de alta densidade, cuja tecnologia permite a análise de expressão gênica simultânea e em larga escala, e tem sido empregada extensivamente no estudo molecular de patologias. Esta ferramenta possibilita uma compreensão global das diversas vias gênicas envolvidas tanto em doenças multigênicas como em doenças mendelianas, complementando os estudos clínicos e histológicos.

Os trabalhos publicados diferem em escala e na abordagem experimental e analítica, mas são concordantes na conclusão de que as vias moleculares encontradas refletem as características patológicas vistas na histologia. De modo geral, em todos os trabalhos, a maioria dos genes superexpressos é composta por genes ligados à resposta imune e à formação de matriz extracelular, o que condiz e corrobora os achados histológicos. O perfil de expressão gênica global, por microarranjo e outras técnicas, já foi estudado em pacientes com DMD (Chen et al., 2000; Bakay et al., 2002; Haslett et al., 2002; Goetsch et al., 2003; Haslett et al., 2003; Noguchi et al., 2003), e em camundongos Dmd ${ }^{m d x}$ (Tkatchenko et al., 2000; Boer et al., 2002; Porter et al., 2002; Rouger et al., 
2002; Tseng et al., 2002; Porter, Merriam, Khanna, et al., 2003; Porter, Merriam, Leahy, et al., 2003; Porter et al., 2004; Turk et al., 2005; Baban e Davies, 2008; Marotta et al., 2009).

Alguns estudos anteriores ao uso da análise de genes diferencialmente expressos por microarranjos moleculares, já sugeriam resultados muito interessantes. Tkatchenko e colaboradores analisaram a expressão gênica nos músculos posteriores e do diafragma do camundongo $D m d^{m d x}$. Foram identificados 93 genes diferencialmente expressos entre 0 animal normal e o afetado. Os genes foram divididos em grupos, de acordo com a função descrita: metabolismo energético, crescimento (H19 e Igf2), diferenciação celular (NF-KB), homeostase de cálcio (Ryr1), degradação proteica, organização celular, biogênese, matriz extracelular (genes dos colágenos I, III e V), inflamação, ativação de macrófagos e genes desconhecidos. A expressão diferencial desses genes tem correlação com diversas observações já feitas nos camundongos, como a elevação do nível de cálcio intracelular e a formação de fibrose.

Dentre esses genes, destacou-se um grupo de genes codificando enzimas envolvidas no metabolismo energético, proliferação e diferenciação celular, e equilíbrio de cálcio cuja expressão foi claramente diferente entre o diafragma e os músculos posteriores do $D m d^{m d x}$, indicando que esses aspectos da função muscular possam estar comprometidos no diafragma do $D m d^{m d x}$ (Tkatchenko et al., 2000).

Posteriormente, estes mesmos autores identificaram sete genes com expressão alterada em pacientes com DMD com um arranjo de cDNA: a proteína sarcomérica titina, dois genes mitocondriais, um fator de transcrição muscular e três genes ainda desconhecidos. A superexpressão dos genes mitocondriais foi associada à redução na atividade de enzimas mitocondriais observada em pacientes com DMD, o que significaria uma tentativa de compensação para manter o equilíbrio das proteínas mitocondriais. A hipoexpressão do gene da titina está relacionada com a desorganização do sarcômero e a fragilidade das miofibras desses pacientes (Tkatchenko et al., 2001).

Em outro trabalho realizado por Chen e colaboradores foi encontrada, no músculo de pacientes com deficiência de distrofina e a-sarcoglicana, alta expressão de genes do desenvolvimento, o que poderia ser atribuído ao processo de regeneração, mas a expressão desses genes não estava limitada às fibras em regeneração, indicando uma diferenciação incompleta. A hipoexpressão de genes da função mitocondrial e metabolismo energético apontam para uma crise metabólica generalizada e disfunção mitocondrial, provavelmente devido ao influxo constante de cálcio (Chen et al., 2000).

Porter et al. (2002) identificaram 242 genes expressos diferencialmente nos músculos gastrocnêmio e soleus de camundongos $D m d^{m d x}$ com oito semanas de idade. Esses genes foram agrupados em categorias diretamente relevantes para a patogênese da 
distrofia muscular: inflamação (30\% dos genes), deposição de matriz extracelular (9\%), proteólise (7\%), regeneração muscular $(7 \%)$ e metabolismo energético (2\%). A superexpressão de 22 genes de matriz extracelular contrasta com o grau limitado de fibrose no animal $D m d^{m d x}$, sugerindo a existência de algum mecanismo pós-transcricional compensador ou protetor nesses animais. O fato de $30 \%$ dos genes diferencialmente expressos serem implicados na resposta inflamatória indica uma reação inflamatória persistente no músculo do $D m d^{m d x}$ (Porter et al., 2002).

Com o chip HG-U95Av2 da Affymetrix, foi confirmada a expressão diferencial de 42 genes do trabalho de Chen et al. (2000), e ainda foram identificados 63 genes não reportados previamente no músculo de pacientes com DMD. Como nos trabalhos anteriores, foi visto que há mais genes hiperexpressos em relação aos hipoexpressos, o que é atribuído ao aumento da renovação proteica e também a expressão contínua de genes de desenvolvimento muscular, devido ao processo de regeneração. Mais uma vez, genes relacionados com a resposta imune e a matriz extracelular apresentaram superexpressão, refletindo as características histopatológicas (infiltração de células inflamatórias e fibrose) dos músculos dos pacientes estudados (Haslett et al., 2002).

Para complementar e expandir os dados obtidos no trabalho anterior, os mesmos autores estudaram o perfil de expressão gênica de pacientes com DMD utilizando outro conjunto de microarranjos com maior cobertura do genoma. Foram encontrados mais 51 genes e 124 ESTs diferencialmente expressos, confirmando o padrão de expressão encontrado anteriormente. Dos 144 genes identificados como diferencialmente expressos nos dois estudos, 46 são genes que codificam proteínas envolvidas em sinalização. Isso sugere que vias de sinalização estão alteradas no músculo dos pacientes $\mathrm{DMD}$, reforçando o papel sinalizador do complexo DGA (Haslett et al., 2003).

A análise do perfil de expressão global dos músculos dos membros posteriores de camundongos $D m d^{m d x}$ com 13 e 15 semanas de idade (fase de estabilização da regeneração muscular), usando os microarranjos U74Av2 da Affymetrix, revelou apenas 58 genes diferencialmente expressos (Boer et al., 2002), em contraste com os 242 genes diferencialmente expressos na idade de oito semanas. Essa diferença se deve, provavelmente, ao fato de a fase mais ativa de regeneração já ter passado nos animais mais velhos. A maioria desses genes está implicada na regeneração muscular, resposta imune e proteólise. Entretanto, a inflamação, nessas idades, não é tão pronunciada quanto em animais mais jovens, como encontrado em Porter et al. (2002). Uma crise metabólica generalizada, como reportado para pacientes com DMD (Chen et al., 2000), está ausente nesses animais.

O diafragma dos animais $D m d^{m d x}$ apresenta um processo de degeneração mais significativo do que ocorre nos músculos dos membros posteriores. Desta forma, o músculo 
diafragma do camundongo $D m d^{m d x}$ é mais semelhante histologicamente, em termos de degeneração muscular, ao músculo esquelético dos pacientes DMD.

Assim sendo, Rouger et al. (2002) estudaram a expressão gênica de camundongos controle e $D m d^{m d x}$ em 12 idades diferentes, comparando os músculos posteriores e o diafragma, usando um microarranjo de cDNA personalizado. Dentre os 1082 genes estudados, 112 apresentaram expressão diferencial e foram divididos em grupos funcionais: 10 de defesa celular; 17 de sinalização; 19 de estrutura e mobilidade celular; 16 de expressão gênica/proteica; 19 de metabolismo; os 20 genes restantes não se encaixam em nenhuma categoria ou eram desconhecidos. Comparando os genes encontrados no $D m d^{m d x}$ com os genes encontrados no transcriptoma de pacientes DMD, os autores concluem que a deficiência de distrofina inicia cascatas patológicas semelhantes nas duas espécies, apesar de terem encontrado muitas diferenças entre os perfis de expressão de humanos e camundongos. Com isso, os autores concluem que nenhum desses músculos do camundongo corresponde inteiramente à patologia nos humanos (Rouger et al., 2002).

Confrontando a expressão dos músculos dos membros posteriores e o diafragma, 34 genes apresentaram diferenças, com destaque para genes envolvidos na estrutura/organização de miofibras e no metabolismo energético e função mitocondrial, que podem ser os principais responsáveis pelas diferenças histológicas observadas. Portanto, a deficiência de distrofina causa perturbações diferentes nos transcriptomas desses músculos (Rouger et al., 2002).

A análise do perfil de expressão gênica do músculo gastrocnêmio de camundongos $D m d^{m d x}$ com 16 semanas de idade (fase de estabilização da regeneração) revelou 137 genes diferencialmente expressos. Essa lista de genes foi comparada com dados obtidos em humanos (Chen et al., 2000) e foi observado que há superexpressão de genes reguladores da polimerização da actina, cujos filamentos são comprometidos na ausência de distrofina, apenas nos camundongos, tornando esses genes candidatos a protetores contra danos nos filamentos de actina desses animais. O aumento na expressão de uma protease (mast cell chymase) envolvida na degradação de matriz extracelular também pode estar relacionado com o fenótipo mais brando do $D m d^{m d x}$ (Tseng et al., 2002).

O estudo do transcriptoma de pacientes com DMD de Bakay e colaboradores destacou vias relacionadas com o IGF, incluindo inibidores do IGF, o que pode explicar a hipertrofia observada nos pacientes; e também a indução de genes cardíacos, devido a uma série de fatores, como a infiltração de macrófagos, ativação das células-satélite, aumento de fibras lentas, e mudanças na homeostase das miofibras (Bakay et al., 2002).

Em estudo mais recente realizado por outro grupo utilizando um microarranjo de cDNA composto por 3500 genes expressos no músculo esquelético, foram encontrados 420 
genes diferencialmente expressos em pacientes com DMD. Mais uma vez, grande parte desses genes tem relação com a resposta imune, o sarcômero, a matriz extracelular e o crescimento celular. Genes ligados ao desenvolvimento estão superexpressos, enquanto que genes relacionados à homeostase do músculo estão subexpressos, o que reflete eventos celulares como necrose e regeneração (Noguchi et al., 2003).

Nas distrofias musculares, alguns músculos apresentam mais sinais de degeneração que outros. Na distrofia muscular de Duchenne, por exemplo, há comprometimento dos músculos dos membros e do diafragma, enquanto o músculo extraocular (EOM) é preservado. O padrão de expressão gênica do EOM de camundongos $D m d^{m d x}$ mostra que apenas sete genes apresentam expressão diferenciada, o que significa que a ausência de distrofina não provoca uma resposta exacerbada em nível transcricional nesse músculo. Sugere-se, portanto, que a proteção a este músculo venha de suas próprias diferenças constitutivas, que fornecem proteção contra danos devido à contração, em vez de adaptações moleculares (Porter, Merriam, Khanna, et al., 2003).

A natureza heterogênea da distrofia muscular de Duchenne, como o período de latência entre o nascimento e a manifestação de sintomas, a preservação de certos músculos, e diferenças na severidade entre as espécies, sugere que apenas a deficiência de distrofina é insuficiente para causar distrofia muscular. A avaliação temporal dos perfis de expressão do diafragma de camundongos revelou por volta de 700 transcritos diferencialmente expressos, com distribuição funcional semelhante à vista nos músculos dos membros posteriores. Porém, $50 \%$ dos transcritos aparecem nos dois grupos musculares, o que é consistente com a hipótese de que há uma divergência nos mecanismos em resposta à ausência de distrofina, a depender do músculo, mas as diferenças são atribuídas mais ao nível de variação da expressão, do que à natureza dos genes. Assim, a alteração de alguns transcritos pode tanto elevar (diafragma) ou diminuir (músculo extraocular) a sensibilidade do músculo à distrofia muscular (Porter et al., 2004).

$\mathrm{Na}$ tentativa de compreender por que cada músculo responde de maneira diferente à ausência de distrofina, Haslett e colaboradores estudaram os perfis de expressão gênica, em camundongos com deficiência de distrofina, dos músculos gastrocnêmio, quadríceps, sóleo, tibial anterior (TA), extensor dos dígitos (EDL) e diafragma individualmente. A análise mostrou que o gastrocnêmio, quadríceps, TA e EDL têm perfis similares. O sóleo e o diafragma diferem consideravelmente dos demais, mas são mais semelhantes entre si. As diferenças observadas não devem ser atribuídas apenas à proporção dos tipos de fibra que formam cada músculo; estudos mais detalhados são necessários para explicá-las (Haslett et al., 2005).

A variabilidade no grau de severidade também é presente entre as diferentes formas de distrofia muscular. Com o objetivo de identificar os diferentes eventos 
moleculares responsáveis pelas distrofias musculares, foi feita a comparação dos perfis de expressão gênica de camundongos com deficiência de distrofina, sarcoglicanas, disferlina, sarcospan comparativamente a camundongos selvagens. Foi possível discernir dois grupos: o primeiro formado pelos animais com o fenótipo distrófico grave (distrofinopatia e sarcoglicanopatia), e o segundo, por animais com fenótipo brando ou não afetados (deficientes de disferlina e sarcospan, e selvagens). Em resumo, genes envolvidos na resposta inflamatória e organização estrutural estão significativamente hiper-regulados, enquanto genes de metabolismo estão hiporregulados (Turk et al., 2006).

Para caracterizar melhor os processos moleculares envolvidos na regeneração muscular, Turk e colaboradores estudaram a regeneração de camundongos $D m d^{m d x}$ em nove tempos diferentes, entre uma e 20 semanas de idade. 166 genes diferencialmente expressos foram analisados mais detalhadamente, e a maioria desses genes tem o pico de expressão na idade de oito semanas, quando a regeneração atinge seu ponto máximo. A partir dessa análise foi visto que as vias do Notch-Delta, Bmp15 e Neuregulin estão ativadas e envolvidas na ativação, proliferação e diferenciação de células-satélite, diferentemente do que é visto em humanos. Assim, os autores propõem que a ativação dessas vias contribui para o maior sucesso regenerativo nos camundongos, o que poderia ser uma estratégia terapêutica interessante para humanos (Turk et al., 2005).

A proteína utrofina é homóloga à distrofina; por isso, acredita-se, que na ausência de distrofina, a superexpressão da utrofina possa trazer benefícios funcionais. O perfil de expressão de camundongos deficientes para distrofina, mas que superexpressam utrofina é bastante semelhante ao de camundongos selvagens. Logo, a superexpressão de utrofina pode ser uma terapia promissora para a deficiência de distrofina (Baban e Davies, 2008).

A tecnologia de microarranjos evolui rapidamente, com o surgimento de chips e programas computacionais de análise com coberturas mais completas dos genomas, permitindo análises cada vez mais complexas e refinadas, tornando necessária a repetição e reavaliação dos perfis de expressão gênica obtidos anteriormente.

A comparação do perfil de expressão de camundongos $D m d^{m d x}$ no decorrer da evolução da doença, utilizando um microarranjo com cobertura total do genoma murino, mostrou que há uma forte indução de genes ligados à adesão celular, matriz extracelular, proteólise, estrutura muscular e regeneração, em relação a animais normais. Foi visto também que o $D m d^{m d x}$ mantém a expressão de alguns genes que geralmente são suprimidos após o nascimento; e a natureza desses genes diferencialmente expressos provavelmente revela um mecanismo de resposta para reforçar a conexão entre o citoesqueleto e a matriz extracelular, na tentativa de proteger a fibra muscular contra os danos da contração muscular (Marotta et al., 2009). 
Pelo estudo de expressão gênica por microarranjo de músculos de pacientes com distrofia muscular de Duchenne e indivíduos idosos, Baron e colaboradores verificaram que há uma grande semelhança no perfil de expressão gênica entre esses dois grupos, sendo que a maioria dos genes coexpressos nos dois grupos está relacionada à resposta imunológica, à formação de fibrose e ao metabolismo mitocondrial. Isso sugere que processos patológicos distintos podem compartilhar um mesmo perfil gênico, com o envolvimento das mesmas cascatas de regulação. Além disso, os autores validaram seus resultados através de meta-análises, valendo-se de bancos de dados de microarranjos públicos (Baron et al., 2011).

Com o avanço das pesquisas genômicas em larga escala, diversas ferramentas de bioinformática vem sendo desenvolvidas para auxiliar na análise e interpretação do número gigantesco de dados gerados.

Kotelnikova e colaboradores desenvolveram uma nova forma de análise, baseada em redes de regulação proteína-proteína extraídas da literatura, que permite a identificação de reguladores, como fatores de transcrição, que também apresentem expressão diferencial. Assim, essa abordagem conecta genes diferencialmente expressos às principais vias implicadas e aos principais reguladores de expressão. Os autores aplicaram essa abordagem aos dados de perfis de expressão gênica de distrofia muscular de Duchenne e identificaram um conjunto de potenciais reguladores e biomarcadores da progressão e gravidade de DMD. Tais biomarcadores podem ser muito úteis em tratamentos e triagens clínicas, sendo usados para monitorar a eficiência de drogas e a escolha das doses corretas (Kotelnikova et al., 2012).

Com esses trabalhos podemos perceber o quão importante e delicada é a análise dos dados de expressão gênica global. A realização de meta-análises se torna cada vez mais interessante, tanto para fins de comparação com dados depositados em bancos públicos, quanto para fins de validação dos resultados obtidos. Além disso, é importante estar atento aos novos métodos de análise que surgem constantemente.

Portanto, a partir dos trabalhos avaliados, torna-se clara a importância da análise de transcriptomas para a melhor compreensão de mecanismos fisiopatológicos complexos. Por serem estudos de larga escala e de natureza exploratória, eles fornecem uma grande quantidade de dados, abrindo caminho para novas abordagens de pesquisa. 


\section{Objetivos}

Dado o contexto apresentado na seção anterior, os objetivos do presente trabalho consistem em analisar o perfil de expressão gênica do tecido muscular de camundongos modelos de distrofias musculares - $D m d^{m d x}, \operatorname{Large}^{m y d}$ e $D m d^{m d x} / \operatorname{Larg}^{m y d-\text { em diferentes }}$ fases da progressão da doença, para identificar e analisar a função de genes diferencialmente expressos no fenótipo distrófico, contribuindo para um melhor entendimento dos processos patológicos nesses animais.

\section{Objetivos específicos}

- Análise da expressão gênica no tecido muscular de modelos animais portadores de mutações em diferentes genes musculares

- Triagem de genes diferencialmente expressos

- Correlacionar o perfil de expressão com:

- O processo distrófico

- A evolução da doença

- Cada tipo de distrofia

- Análise da função dos genes diferentemente expressos

- Análise das vias em que estes genes estão envolvidos

- Validação do padrão de expressão gênica obtido por PCR em tempo real 


\section{Metodologia}

\section{Camundongos}

Os camundongos foram mantidos em biotério climatizado, com temperatura e iluminação controladas, em gaiolas com água e ração à vontade. O sacrifício dos animais foi realizado por exposição à $\mathrm{CO}_{2}$.

\subsection{Linhagens}

Foram utilizadas as linhagens $D m d^{m d x}$, Large $^{m y d-1-}, D m d^{m d x} /$ Large $e^{m y d-1}$ e C57Black6 (camundongo selvagem). As linhagens $D m d^{m d x}$ e $L a r g e^{m y d-/}$ são linhagens comerciais e são mantidas no biotério do Centro de Estudos do Genoma Humano há alguns anos. Os camundongos $D m d^{m d x} / \operatorname{Larg}^{m y d-/}$ foram gerados nesse mesmo biotério, pelo cruzamento das duas linhagens anteriores.

Dos animais utilizados nesse trabalho foram coletados os músculos quadríceps, diafragma e da parte inferior das patas posteriores; apenas esses últimos foram utilizados para os estudos de transcriptoma.

\subsection{Genotipagem dos camundongos Large $e^{m y-/-}$ e $D m d^{m d x} / L a r g e^{m y d-/-}$}

A mutação myd é mantida em heterozigose nas linhagens $\operatorname{Large}^{\text {myd-- }} \mathrm{e}$ $D m d^{m d x} /$ Large $^{m y d-/}$, por isso os filhotes heterozigotos e homozigotos para a mutação são identificados por genotipagem.

Um segmento da cauda dos animais foi utilizado para a extração de DNA, que foi feita com solução de extração e proteinase $K$ (Invitrogen, no catálogo 25530-049). A genotipagem é feita por PCR (Polymerase Chain Reaction), utilizando dois pares de primers. GT4F (5'-GGCCGTGTTCCATAAGTTCAA-3') e GT4R (5'GGCATACGCCTCTGTGAAAAC-3') reconhecem um produto de $162 \mathrm{pb}$ apenas quando há o alelo selvagem; MydF3 (5'-ATCTCAGCTCCAAAGGGTGAAG-3') e MydR2 (5'GCCAATGTAAAATGAGGGGAAA-3') amplificam um produto de 421pb somente no alelo com a mutação (Browning et al., 2005).

A amplificação por PCR foi feita em um volume de $25 \mu \mathrm{l}$, contendo $20 \mu \mathrm{M}$ de cada primer, 40ng de DNA, e 0,5 unidades de Taq DNA Polymerase Recombinant (GE Healthcare, no catálogo 27079805). Como os dois pares de primers possuem a mesma temperatura de annealing, a reação foi feita em duplex; as condições de reação foram as seguintes: um período de pré-incubação de 2 minutos a $96^{\circ} \mathrm{C}$ para a completa desnaturação do DNA, seguido por 35 ciclos de $96^{\circ} \mathrm{C}$ por 30 segundos, $59^{\circ} \mathrm{C}$ por 30 
segundos e $72^{\circ} \mathrm{C}$ por 30 segundos. Os produtos da reação foram separados em gel de agarose $3 \%$, corado com solução de brometo de etídio.

\section{Extração e controle de qualidade de RNA}

Os músculos foram macerados com cadinho e pistilo, imersos em nitrogênio líquido para evitar o descongelamento do tecido.

A extração de RNA do tecido pulverizado foi feita com o RNeasy Microarray Tissue Mini Kit (Quiagen, no catálogo 73304) que foi desenvolvido para a purificação de RNA para a análise de microarranjos. A lise do tecido é feita com o QIAzol Lysis Reagent, uma solução de fenol e tiocianato. Após a adição de clorofórmio, o tecido homogeneizado é separado em uma fase orgânica e inorgânica por centrifugação. A fase aquosa superior é coletada, e é adicionado etanol para condições adequadas de ligação à membrana de sílica. A solução é transferida para uma coluna com a membrana, aonde o RNA se liga, e os contaminantes, como fenol, são removidos. Por fim, o RNA é eluído em água livre de RNase e armazenado a $-70^{\circ} \mathrm{C}$.

A quantificação do RNA obtido é feita no espectrofotômetro NanoDrop ${ }^{\circledR}$, em $260 \mathrm{~nm}$. A pureza foi avaliada pela razão $A_{260} / A_{280}$. Foram utilizadas as amostras que apresentaram concentração igual ou maior que $100 \mathrm{ng} / \mu \mathrm{l}$ e razão $A_{260} / A_{280}$ entre 1,7 e 2,1. A integridade do RNA foi avaliada em gel de agarose $1 \%$.

A integridade também foi avaliada no aparelho Agilent 2100 Bioanalyzer, utilizando o kit Agilent RNA 6000 Nano (Agilent, no catálogo 5067-1511). Esse kit contém chips que possuem um conjunto de microcanais interconectados que são usados para a separação de fragmentos de ácidos nucléicos baseada nos seus tamanhos, por eletroforese. 0 ensaio calcula o número de integridade do RNA (RIN - RNA integrity number), que varia entre $1 \mathrm{e}$ 10, sendo que 1 significa que o material está degradado, e 10 significa que o material está perfeito, sem nenhum sinal de degradação. Os resultados são visualizados no programa 2100 Expert (Agilent).

\section{Microarranjos}

Com o objetivo de minimizar a variação entre amostras causada por diferenças sutis nos procedimentos, optou-se por utilizar sempre o mesmo método de extração de RNA, a mesma quantidade de RNA inicial, o mesmo termociclador e o mesmo ponto de parada em todos os experimentos.

Para a preparação das amostras para a análise do transcriptoma completo foi utilizado o kit Ambion $^{\circledR}$ WT Expression (Invitrogen, $n^{\circ}$ catálogo 4411974). A partir do RNA 
total, é gerado o cDNA para a fragmentação e marcação utilizando o kit GeneChip ${ }^{\circledR} W T$ Terminal Labeling. O kit Ambion ${ }^{\circledR}$ WT Expression utiliza um método de iniciação (priming) por transcrição reversa que se liga especialmente ao RNA não ribossômico, incluindo o mRNA com ou sem poly-A. As sequências de primers fornecem uma cobertura completa e imparcial do transcriptoma, reduzindo a hibridação com rRNA.

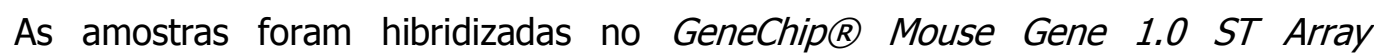
(Affymetrix, no catálogo 901171), que cobre um total de 26.166 transcritos e contém 770.317 sondas.

As etapas do protocolo completo estão resumidas na figura 6.

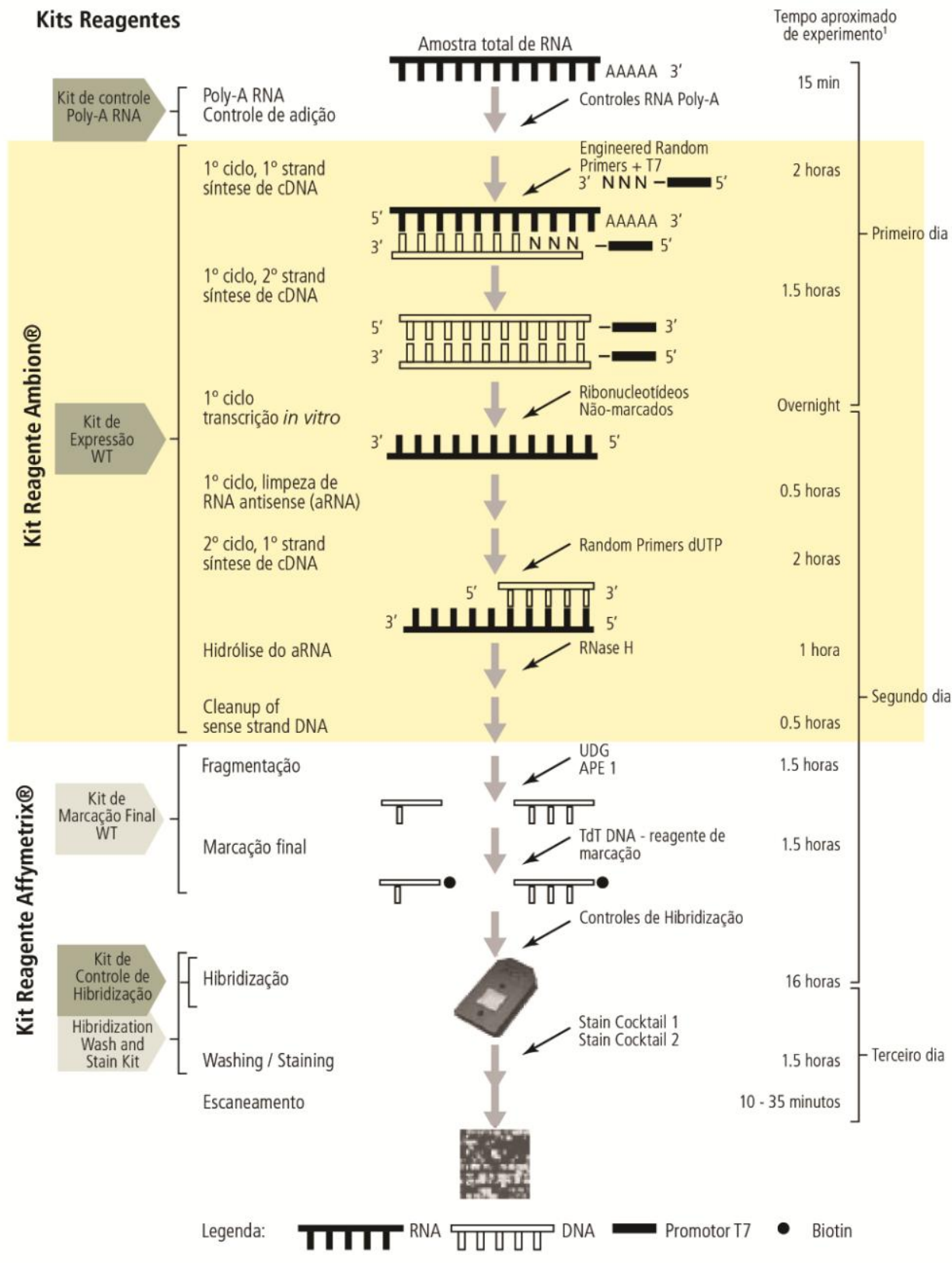

Figura 6 - Resumo dos procedimentos com o GeneChip® Mouse Gene 1.0 ST Array 


\subsection{Preparação do RNA controle e RNA total}

Uma amostra de RNA controle é fornecida pelo kit (RNA total de células HeLa). São preparados $2 \mu$ lde RNA controle em $40 \mu l$ de água livre de nucleases.

De acordo com a recomendação do fabricante, a quantidade de RNA total a ser utilizada no experimento deve ser entre 50ng e 500ng; optou-se por sempre iniciar os experimentos com 250ng de RNA total das amostras.

Os controles poly-A (lys, phe, thr, e dap) (Affymetrix ${ }^{\circledR}$ GeneChip ${ }^{\circledR}$ Poly-A RNA Control Kit, no catálogo 900433) foram desenhados para serem os controles exógenos que monitoram o processo de marcação. O GeneChip ${ }^{\circledR}$ de eucariotos contém conjuntos de sondas para vários genes da bactéria B. subtilis que estão ausentes nos eucariotos (lys, phe, thr, e dap). A cada amostra de RNA total foram adicionados $2 \mu$ de poly-A diluído. Os controles são amplificados e marcados junto com o RNA das amostras. O exame da intensidade de hibridização desses controles no chip ajuda a monitorar o processo de marcação independentemente da qualidade das amostras.

\subsection{Síntese da primeira fita de cDNA}

Nesse procedimento de transcrição reversa, o RNA total é ligado a primers contendo uma sequência do promotor T7. A reação sintetiza um cDNA de fita simples contendo a sequência do promotor T7.

Para essa reação são utilizados os reagentes listados na Tabela 1, que são adicionados a $5 \mu$ l de amostra ( $3 \mu$ l de RNA total mais $2 \mu$ l de controle poly-A):

\section{Tabela 1 - Reagentes da reação da primeira fita de cDNA}

\begin{tabular}{lc}
\hline First-strand master mix & Volume (1 reação) $\boldsymbol{\mu L}$ \\
\hline First-strand Buffer Mix & 4 \\
First-strand Enzyme Mix & 1 \\
Volume total & 5 \\
\hline
\end{tabular}

A reação é incubada por 1 hora a $25^{\circ} \mathrm{C}, 1$ hora a $42^{\circ} \mathrm{C}$, e por fim por pelo menos 2 minutos a $4^{\circ} \mathrm{C}$.

\subsection{Síntese da segunda fita de cDNA}

Nessa etapa, o cDNA de fita simples é convertido em cDNA de dupla-fita, que funciona como molde para a transcrição. Essa reação utiliza a DNA polimerase para sintetizar a segunda fita de cDNA e RNase H para degradar o RNA (Tabela 2). 
Tabela 2 - Reagentes da reação da segunda fita de cDNA

\begin{tabular}{lc}
\hline Second-Strand Master Mix & Volume (1 reação) $\boldsymbol{\mu L}$ \\
\hline Nuclease free water & 32,5 \\
Second-strand Buffer Mix & 12,5 \\
Second-strand Enzyme Mix & 5 \\
Volume total & 50 \\
\hline
\end{tabular}

Aos $10 \mu \mathrm{L}$ de cDNA da etapa anterior são adicionados $50 \mu \mathrm{L}$ do Second-Strand Master Mix. A reação é incubada por uma hora a $16^{\circ} \mathrm{C}, 10$ minutos a $65^{\circ} \mathrm{C}$ e por no mínimo 2 minutos a $4^{\circ} \mathrm{C}$.

\subsection{Síntese de CRNA por transcrição in vitro}

Nesse procedimento, cRNA antissenso é sintetizado e amplificado por transcrição in vitro do cDNA produzindo no passo anterior, utilizando a T7 RNA polimerase.

Tabela 3 - Reagentes da reação de cRNA

\begin{tabular}{lc}
\hline IVT master mix & Volume (1 reação) $\mathbf{\mu L}$ \\
\hline IVT Buffer Mix & 24 \\
IVT Enzyme Mix & 6 \\
Volume total & 30 \\
\hline
\end{tabular}

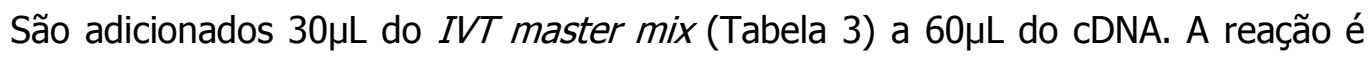
incubada a $40^{\circ} \mathrm{C}$ durante 16 horas, e depois overnight a $4^{\circ} \mathrm{C}$.

\subsection{Purificação de $c R N A$}

Esse procedimento tem como objetivo remover enzimas, sais, fosfatos inorgânicos, e nucleotídeos não incorporados para aumentar a estabilidade do cRNA produzido, utilizando esferas magnéticas que capturam o cRNA.

Tabela 4 - Reagentes da purificação de cRNA

\begin{tabular}{lc}
\hline \multicolumn{1}{c}{ CRNA binding mix } & Volume (1 reação) $\boldsymbol{\mu L}$ \\
\hline Nucleic acid binding beads & 10 \\
Nucleic acid binding buffer concentrate & 50 \\
Volume total & 60 \\
\hline
\end{tabular}


A cada amostra de cRNA $(90 \mu \mathrm{L}$ ) são adicionados $60 \mu \mathrm{L}$ de $C R N A$ binding mix (Tabela 4); em seguida, essa mistura é transferida para um poço de uma placa com fundo em formato de $\mathrm{U}$ e adiciona-se $60 \mu \mathrm{L}$ de isopropanol $100 \%$. As esferas magnéticas são capturadas com o auxílio de uma placa magnética e lavadas duas vezes com $100 \mu \mathrm{L}$ de Nucleic Acid Wash Solution. Por fim, o cRNA é liberado das esferas e eluído em $40 \mu \mathrm{L}$ de Elution Solution.

\subsection{Rendimento do $C R N A$}

O rendimento de cRNA depende da quantidade e qualidade do RNA poly-A no RNA total inicial. O cRNA purificado é quantificado pela absorbância de raios UV em 260nm, utilizando o espectrofotômetro NanoDrop ${ }^{\circledR}$. Para o prosseguimento do experimento, devese preparar $455 \mathrm{ng} / \mu \mathrm{L}$ de cRNA, que é equivalente a $10 \mu \mathrm{g}$ de cRNA em $22 \mu \mathrm{L}$.

\subsection{Síntese do segundo ciclo de CDNA}

Nessa etapa, cDNA fita-senso é sintetizado pela transcrição reversa do cRNA utilizando-se primers randômicos. A fita senso de cDNA contém dUTP em proporção relativa a dTTP.

Primeiro, adiciona-se $2 \mu \mathrm{L}$ de Random Primers a $22 \mu \mathrm{L}$ de cRNA (10 $\mu \mathrm{g})$ e incuba por 5 minutos a $70^{\circ} \mathrm{C}, 5$ minutos a $25^{\circ} \mathrm{C}$ e por 2 minutos a $4^{\circ} \mathrm{C}$. Em seguida, prepara-se o $2 n d$ Cycle Master Mix (Tabela 5).

Tabela 5 - Reagentes da reação do segundo ciclo de cDNA

\begin{tabular}{lc}
\hline 2nd-Cycle Master mix & Volume (1 reação) $\boldsymbol{\mu L}$ \\
\hline 2nd-Cycle Buffer Mix & 8 \\
2nd-Cycle Enzyme Mix & 8 \\
Volume total & 16 \\
\hline
\end{tabular}

Adiciona-se $16 \mu \mathrm{L}$ desse mix aos $24 \mu \mathrm{L}$ de cRNA; a reação é incubada por 10 minutos a $25^{\circ} \mathrm{C}, 90$ minutos a $42^{\circ} \mathrm{C}, 10$ minutos a $70^{\circ} \mathrm{C}$ e por pelo menos 2 minutos a $4^{\circ} \mathrm{C}$.

\subsection{Hidrólise com RNase $H$}

Nessa etapa, a enzima RNase $\mathrm{H}$ degrada o molde de CRNA, deixando apenas $\mathrm{O}$ cDNA de fita simples. Para isso, são adicionados $2 \mu \mathrm{L}$ de RNase $\mathrm{H}$ ao cDNA do segundo ciclo produzido anteriormente e incuba-se a $37^{\circ} \mathrm{C}$ por 45 minutos, a $95^{\circ} \mathrm{C}$ por 5 minutos, e por último a $4^{\circ} \mathrm{C}$ por no mínimo 2 minutos. 


\subsection{Purificação do CDNA do segundo ciclo}

Após sua síntese, o cDNA deve ser purificado para a remoção de enzimas, sais e dNTPs não incorporados. Esse processo prepara o cDNA para a fragmentação e a marcação. O procedimento é semelhante ao de purificação do cRNA.

Primeiro, adiciona-se $18 \mu \mathrm{L}$ de água livre de nucleases aos $42 \mu \mathrm{L}$ de cDNA e $60 \mu \mathrm{L}$ do cDNA Binding Mix (Tabela 6).

\section{Tabela 6 - Reagentes da purificação de CDNA}

\begin{tabular}{lc}
\hline \multicolumn{1}{c}{ cDNA binding mix } & Volume (1 reação) $\boldsymbol{\mu L}$ \\
\hline Nucleic acid binding beads & 10 \\
Nucleic acid binding buffer concentrate & 50 \\
Volume total & 60 \\
\hline
\end{tabular}

Essa mistura é transferida para um poço de uma placa com fundo em formato de $\mathrm{U}$ e são adicionados $120 \mu \mathrm{L}$ de etanol $100 \%$ a cada amostra. As esferas magnéticas são capturadas com o auxílio de uma placa magnética e lavadas duas vezes com $100 \mu \mathrm{L}$ de Nucleic Acid Wash Solution. Por fim, o cDNA é liberado das esferas e eluído em $30 \mu \mathrm{L}$ de Elution Solution.

\subsection{Rendimento do CDNA}

A partir de $10 \mu \mathrm{g}$ de cRNA espera-se um rendimento de 6 a $9 \mu \mathrm{g}$ de cDNA. O cDNA purificado é quantificado pela absorbância de raios UV em 260nm, utilizando o espectrofotômetro NanoDrop ${ }^{\circledR}$.

\subsection{Fragmentação}

A fragmentação do cDNA é feita com o kit GeneChip ${ }^{\circledR}$ WT Terminal Labeling. $O$ cDNA é tratado com as enzimas uracil DNA glycosylase (UDG) e apurinic/apyrimidinic endonuclease 1 (APE1) que reconhecem especificamente os resíduos de dUTP e cortam a fita de cDNA. Para a reação de fragmentação são necessários 5,5 $\mathrm{g}$ de cDNA, diluídos em $31,2 \mu l$ de água livre de nucleases. Os reagentes do Fragmentation Master Mix estão na Tabela 7. 
Tabela 7 - Reagentes da reação de fragmentação do ss-cDNA

\begin{tabular}{|c|c|}
\hline Fragmentation master mix & Volume (1 reação) $\mu \mathrm{L}$ \\
\hline RNase-free Water & 10 \\
\hline 10X cDNA Fragmentation Buffer & 4,8 \\
\hline UDG, $10 U / \mu l$ & 1 \\
\hline APE $1,1000 U / \mu l$ & 1 \\
\hline Volume total & 16,8 \\
\hline
\end{tabular}

Então, são adicionados 16,8 $\mu \mathrm{l}$ de Fragmentation Master Mix ao cDNA; a reação é incubada durante 60 minutos a $37^{\circ} \mathrm{C}$, por 2 minutos a $93^{\circ} \mathrm{C}$ e por ao menos 2 minutos a $4^{\circ} \mathrm{C}$. Ao término da reação, $45 \mu \mathrm{l}$ do produto são transferidos para um tubo novo, os $3 \mu \mathrm{l}$ restantes são aplicados em gel de agarose $1 \%$ para checagem da fragmentação.

\subsection{Marcação do CDNA}

O cDNA fragmentado é marcado pela enzima terminal deoxynucleotidyl transferase (TdT) com o reagente de marcação (Affymetrix ${ }^{\circledR}$ DNA Labeling Reagent) que está covalentemente ligado à biotina.

Os reagentes utilizados estão na Tabela 8.

Tabela 8 - Reagentes de marcação do cDNA

\begin{tabular}{lc}
\hline \multicolumn{1}{c}{ Labeling master mix } & Volume (1 reação) $\mathbf{\mu L}$ \\
\hline $5 X$ TdT Buffer & 12 \\
TdT & 2 \\
DNA Labeling Reagent, 5mM & 1 \\
Volume total & 15 \\
\hline
\end{tabular}

A reação é incubada a $37^{\circ} \mathrm{C}$ por 60 minutos, a $70^{\circ} \mathrm{C}$ por 10 minutos e a $4^{\circ} \mathrm{C}$ por pelo menos 2 minutos.

\subsection{Hibridização}

Nessa etapa, as amostras são preparadas para a aplicação nos chips, é utilizado o GeneChip $^{\circledR}$ Hybridization, Wash and Stain Kit. Para cada amostra $(27 \mu \mathrm{l})$ são adicionados $73 \mu \mathrm{l}$ do Hybridization Master Mix (Tabela 9). 
Tabela 9 - Reagentes da reação de hibridização

\begin{tabular}{lc}
\hline \multicolumn{1}{c}{ Hybridization master mix } & Volume (1 reação) $\boldsymbol{\mu L}$ \\
\hline Control Oligonucleotide B2 (3nM) & 1,7 \\
20X Eukaryotic Hybridization Controls & 5 \\
2X Hybridization Mix & 50 \\
DMSO & 7 \\
Nuclease-free water & 9,3 \\
Volume total & 73 \\
\hline
\end{tabular}

A reação é incubada a $99^{\circ} \mathrm{C}$ por 5 minutos e a $45^{\circ} \mathrm{C}$ por 5 minutos. Em seguida, $80 \mu l$ da amostra são injetados no septo do chip. Os chips são então colocados no forno de hibridização Hybrydization Oven 640 , na temperatura de $45^{\circ} \mathrm{C}$, com rotação de $60 \mathrm{rpm}$, durante 17 horas.

\subsection{Lavagem e marcação}

Após a hibridização, os chips passam por um processo de lavagem no equipamento Fluidcs Station 450/250. Os chips também são marcados com anticorpos.

\subsection{Escaneamento}

A leitura da intensidade de fluorescência dos chips é feita no equipamento Affymetrix $^{\circledR}$ GeneChip ${ }^{\circledR}$ Scanner 3000, operado pelo programa Affymetrix ${ }^{\circledR}$ GeneChip Command Console (AGCC).

\section{Controle de qualidade dos dados}

\subsection{Imagem}

O escaneamento dos chips fornece uma imagem que deve ser inspecionada para a presença de artefatos, como bolhas e manchas. Também são verificadas as bordas da imagem para se observar a hibridização do oligo B2, que serve como um controle positivo da hibridização e é usado pelo software para posicionar uma grade de alinhamento sobre a imagem.

\subsection{Controles positivos}

Os controles poly-A adicionados no início das reações são utilizados para monitorar o processo de marcação das amostras. Todos os controles devem estar presentes com valores crescentes de sinal na ordem $l y s$, phe, thre dap. 
Os controles de hibridização bioB, bioC e bioD representam genes da via de síntese da biotina na E. coli. O controle cre é um gene do bacteriófago P1. Esses controles são usados para avaliar a eficiência da hibridização e devem estar presentes, com valores de sinal crescentes.

\section{Análise dos dados}

\subsection{Pré-processamento dos dados}

Os dados foram normalizados com o algoritmo RMA (Robust Multichip Analysis), no programa Expression Console ${ }^{T M}$ (Affymetrix). Esse método aumenta a sensibilidade a pequenas mudanças entre as amostras controle e experimentais e minimiza a variância entre os experimentos. O RMA consiste de três etapas: o ajuste do background; a normalização do quantil e a sumarização. Como é uma abordagem multichip, todos os arrays a serem comparados devem ser incluídos juntos na sumarização.

\subsection{Triagem dos genes diferencialmente expressos}

A seleção dos genes com expressão diferencial foi feita no programa MeV, utilizando o algoritmo SAM. O SAM (Tusher, Tibshirani e Chu, 2001) é utilizado para selecionar genes significantes baseando-se na expressão diferencial entre conjuntos de amostras. Ele é útil quando não existe uma hipótese a priori de que alguns genes terão níveis de expressão médios significativamente diferentes entre os conjuntos de amostras.

O teste gera um gráfico dos valores observados versus esperados (baseado nos dados permutados) e também dá uma estimativa da taxa de falsas descobertas (FDR False Discovery Rate), que é a proporção de genes que podem ter sidos identificados por acaso como significantes. O FDR é ajustado pelo parâmetro delta.

\subsection{Análise funcional dos genes diferencialmente expressos}

Para o estudo dos genes selecionados foi utilizado o programa IPA (Ingenuity $®$ Systems, www.ingenuity.com) que indica as funções e as possíveis relações entre os genes, baseando-se em dados da literatura, utilizando os parâmetros padrão: 35 moléculas por rede, 25 redes por análise e apenas relações diretas.

As listas de genes também foram avaliadas quanto ao enriquecimento de vias biológicas, utilizando o programa Expander (EXPression ANalyzer and DisplayER http://acgt.cs.tau.ac.il/expander/) que fornece ferramentas para essas análises. Para isso, os genes foram agrupados com o algoritmo Click e foi utilizado o KEGG Pathways (Kyoto Encyclopedia of Genes and Genomes). 
A análise de enriquecimento de funções do Gene Ontology (GO) foi feita com a ferramenta DAVID (Database for Annotation, Visualization and Integrate Discovery, http://david.abcc.ncifcrf.gov/).

\section{Validação dos dados por PCR em tempo real - quantificação relativa}

Foram selecionados onze genes com expressão diferencial para a validação dos resultados do microaranjo de DNA. As mesmas amostras de RNA foram utilizadas para a síntese de cDNA, de acordo com o protocolo da enzima MMLV (Invitrogen); foram escolhidas três amostras de cada linhagem e idade, dentro das cinco disponíveis (Tabela 10).

Tabela 10 - Amostras usadas na validação dos genes por PCR em tempo real

\begin{tabular}{|c|c|c|}
\hline 21 dias & 3 meses & 6 meses \\
\hline C57BL 1B & C57BL 20 & $C 57 B L 6$ \\
\hline C57BL 1D & C57BL 46 & $C 57 B L 8$ \\
\hline C57BL 1E & C57BL 47 & C57BL 49 \\
\hline$D m d^{m d x} 1 \mathrm{~B}$ & $D m d^{m d x} 8$ & $D m d^{m d x} 2$ \\
\hline$D m d^{m d x} 1 C$ & $D m d^{m d x} 28$ & $D m d^{m d x} 35$ \\
\hline$D m d^{m d x} 1 \mathrm{E}$ & $D m d^{m d x} 29$ & $D m d^{m d x} 36$ \\
\hline Large $e^{m y d-1-} 39 \mathrm{E}$ & $\operatorname{Large}^{m y d--}$ 22D & $\operatorname{Large}^{m y d-/-} 15$ \\
\hline $\operatorname{Large}^{m y d-/-} 40 \mathrm{E}$ & $\operatorname{Large}^{m y d-/-}$ 63D & $\operatorname{Large}^{m y d-/-} 18$ \\
\hline $\operatorname{Large}^{m y d-/-}$ 73D & $\operatorname{Large}^{m y d-/-}$ 64D & $\operatorname{Large}^{m y d-1-} \mathrm{PL} 2 \mathrm{~B}$ \\
\hline Dmd ${ }^{m d x} /$ Large $^{m y d-1-33 G}$ & $D^{m} d^{m d x} /$ Large $^{m y d-1-} 31 \mathrm{~F}$ & $\operatorname{Dmd}^{m d x} /$ Large $^{m y d-/-} 12 \mathrm{E}$ \\
\hline \multirow[t]{2}{*}{$D m d^{m d x} / \operatorname{Large}^{m y d-1-} 41 \mathrm{~B}$} & $\mathrm{Dmd}^{m d x} /$ Large $^{m y d-/-} 69 \mathrm{C}$ & $D m d^{m d x} / \operatorname{Large}^{m y d-/-} 31 \mathrm{E}$ \\
\hline & $\operatorname{Dmd}^{m d x} /$ Large $^{m y d-/-94 \mathrm{E}}$ & $\mathrm{Dmd}^{m d x} /$ Large $^{m y d-/} 50$ \\
\hline
\end{tabular}

A Tabela 11 mostra os genes e as sequências dos primers utilizadas.

Tabela 11 - Genes escolhidos para a validação e respectivos pares de primers

\begin{tabular}{llll}
\hline Gene & Primer Forward (5'-3') & Primer Reverse (5'-3') & Amplicon \\
\hline Ankrd1 & TGCGATGAGTATAAACGGACG & GTGGATTCAAGCATATCTCGGAA & $119 \mathrm{pb}$ \\
Gpnmb & AGAAATGGAGCTTTGTCTACGTC & CTTCGAGATGGGAATGTATGCC & $170 \mathrm{pb}$ \\
Large & CACCTGTACTTCCTGCACTACGA & CAGATGGCCTCCAGCATCTG & $108 \mathrm{pb}$ \\
Mmp14 & CAGTATGGCTACCTACCTCCAG & GCCTTGCCTGTCACTTGTAAA & $119 \mathrm{pb}$ \\
Mstn & AACCTTCCCAGGACCAGGAG & CATCGCAGTCAAGCCCAAAG & $101 \mathrm{pb}$ \\
Mup1 & TGTGTCCATGCAGAAGAAGC & CAAGACATGGATTTGCTCCA & $156 \mathrm{pb}$ \\
Myog & CAGTACATTGAGCGCCTACAG & GGACCGAACTCCAGTGCA & $164 \mathrm{pb}$ \\
Nos1 & CTGGTGAAGGAACGGGTCAG & CCGATCATTGACGGCGAGAAT & $120 \mathrm{pb}$ \\
Ostn & CTGGAGATTGGCAAGTACACAC & CGCAGGAGCTTAGCCGAAA & $144 \mathrm{pb}$ \\
Pttg1 & TCTGATCCGCTGTACTCTCCT & AGGCGGCAATTCAACATCCA & $60 \mathrm{pb}$ \\
Tnnt2 & CAGAGGAGGCCAACGTAGAAG & CTCCATCGGGGATCTTGGGT & $138 \mathrm{pb}$ \\
\hline
\end{tabular}


A partir das mesmas amostras de RNA usadas no experimento de microarranjo de DNA, foi sintetizado cDNA de acordo com o protocolo da enzima MMLV (Invitrogen). A reação de PCR quantitativo foi baseada no protocolo descrito por Gosselin (Gosselin et al., 2004). Na tabela 12 estão os reagentes e as condições da reação.

Tabela 12 - Reagentes e condições da reação de PCR em tempo real

\begin{tabular}{|c|c|c|c|c|c|}
\hline & Volume & \multicolumn{4}{|c|}{ Perfil de ciclagem térmica } \\
\hline $\mathrm{H}_{2} \mathrm{O}$ DEPC & $6,5 \mu \mathrm{l}$ & Etapa & Repetições & Temperatura & Tempo \\
\hline \multirow{2}{*}{$\begin{array}{l}\text { FastStart Universal } \\
\text { SYBR Green Master }\end{array}$} & \multirow[t]{2}{*}{$12,5 \mu \mathrm{l}$} & 1 & 1 & $50^{\circ} \mathrm{C}$ & $2 \mathrm{~min}$ \\
\hline & & 2 & 1 & $95^{\circ} \mathrm{C}$ & $10 \mathrm{~min}$ \\
\hline $\begin{array}{l}\text { Primer F }(600 n M) \\
\text { Primer R }(600 n M)\end{array}$ & $2,5 \mu l$ & \multirow{2}{*}{3} & \multirow{2}{*}{40} & $95^{\circ} \mathrm{C}$ & $15 \mathrm{~s}$ \\
\hline cDNA & $\begin{array}{ll}2,5 \mu \mathrm{l} \\
1,0 \mu \mathrm{l}\end{array}$ & & & $60^{\circ} \mathrm{C}$ & $1 \mathrm{~min}$ \\
\hline Total & $25 \mu l$ & & & & \\
\hline
\end{tabular}

Para a quantificação relativa, deve ser feita uma curva-padrão para cada gene alvo, para o cálculo da eficiência da reação, determinando-se o limiar do sinal de fluorescência necessário para a determinação do valor de Ct (ciclo aonde é feita a medida da fluorescência). Esse limiar deve ser acima da linha de flurescência basal e baixo o suficiente, de modo que esteja na região de crescimento exponencial. O Ct depende do número inicial de cópias da amostra e da eficiência da amplificação do PCR. Optou-se que o próprio programa do termociclador Real-Time 7500 Fast (Applied Biosystems) localize o limiar, cujo valor ideal está na região onde a eficiência de amplificação é próxima de $100 \%$.

Em seguida, é calculado o $\Delta \mathrm{Ct}$, que é diferença entre a média das triplicatas do $\mathrm{Ct}$ do gene alvo e a média das triplicatas do $\mathrm{Ct}$ do gene endógeno: $\Delta \mathrm{Ct}=\mathrm{Ct}$ (amostra) - $\mathrm{Ct}$ (controle endógeno). Então, é calculado o $\Delta \Delta \mathrm{Ct}$, que é a diferença entre as médias dos $\Delta \mathrm{Ct}$ de uma amostra do gene alvo e de uma amostra calibradora: $\Delta \Delta \mathrm{Ct}=$ média $\Delta \mathrm{Ct}$ (amostra alvo) - média $\Delta C$ t (amostra calibradora). O $\Delta \Delta$ Ct é utilizado para calcular o valor da expressão: $2^{-\Delta \Delta C t}$. Esse valor final fornece o nível de expressão de cada gene em reação à expressão da amostra calibradora. O programa do equipamento mostra os resultados em escala logarítmica, onde casa incremento corresponde a uma diferença de 10 vezes na expressão gênica. 


\section{Resultados}

\section{Coleta da amostra}

Foram obtidos cinco animais machos de cada linhagem e cada idade estudadas, totalizando 60 animais.

Para a obtenção dos 15 animais duplo-mutantes ( $D m d^{m d x} / L a r g e^{m y d-/}$ ) foram formados mais de 30 casais heterozigotos, que produziram um total de 485 filhotes. Esses animais foram genotipados e identificamos 46 animais duplo-afetados, sendo 35 machos e 11 fêmeas. A sobrevivência dos filhotes duplo-mutantes é reduzida, com a ocorrência de muitos casos de canibalismo e morte antes do desmame (por volta de 21 dias). Na tese de doutorado de Machado (2010) é relatado que por volta de $84 \%$ dos animais duplomutantes morrem no período perinatal. Dos 35 machos, apenas 18 animais ultrapassaram a idade de 21 dias.

\section{Extração e controle de qualidade de RNA}

As primeiras tentativas de extração de RNA foram feitas com o kit Nucleo Spin RNA II (Macherey-Nagel), porém esse método não foi eficiente, pois o rendimento do RNA foi muito baixo. Então, a extração de RNA foi feita com o kit RNeasy Microarray Tissue Mini (Qiagen). A tabela 13 lista as amostras e suas respectivas concentrações e a razão $A_{260} / A_{280}$, obtidas pela quantificação no espectrofotômetro NanoDrop.

Tabela 13 - Identificação das amostras utilizadas; quantificação do RNA e razão $A_{260} / A_{280}$

\begin{tabular}{|c|c|c|}
\hline Animal & Quantificação (ng/ $\mu \mathrm{L})$ & Razão $A_{260} / A_{280}$ \\
\hline \multicolumn{3}{|l|}{21 dias } \\
\hline C57BL 1A & 204,42 & 2,03 \\
\hline C57BL 1B & 253,62 & 2,03 \\
\hline C57BL 1C & 137,35 & 2,02 \\
\hline C57BL 1D & 532,32 & 2,07 \\
\hline C57BL $1 \mathrm{E}$ & 556,71 & 2,10 \\
\hline$D m d^{m d x} 1 \mathrm{~A}$ & 418,27 & 1,86 \\
\hline$D m d^{m d x} 1 \mathrm{~B}$ & 460,76 & 1,78 \\
\hline$D m d^{m d x} 1 C$ & 428,97 & 1,78 \\
\hline$D m d^{m d x} 1 \mathrm{D}$ & 408,39 & 2,05 \\
\hline$D m d^{m d x} 1 \mathrm{E}$ & 956,44 & 2,08 \\
\hline Large $e^{m y d-/-} 39 \mathrm{E}$ & 528,87 & 2,26 \\
\hline Large $e^{m y d-/} 40 \mathrm{E}$ & 442,56 & 2,03 \\
\hline Large $e^{m y d-/-}$ 73D & 313,15 & 1,75 \\
\hline $\operatorname{Large}^{m y d-/-}$ 76D & 297,75 & 1,75 \\
\hline $\operatorname{Large}^{m y d-/-} 84 \mathrm{D}$ & 265,58 & 1,73 \\
\hline$D m d^{m d x} / \operatorname{Larg}^{m y d-\gamma} 1 \mathrm{C}$ & 144,25 & 1,74 \\
\hline $\mathrm{Dmd}^{m d x} / \operatorname{Large}^{m y d-/-} 11 \mathrm{C}$ & 228,48 & 2,05 \\
\hline
\end{tabular}




\begin{tabular}{|c|c|c|}
\hline $\operatorname{Dmd}^{m d x} / \operatorname{Large}^{m y d-/-} 32 \mathrm{G}$ & 213,93 & 2,04 \\
\hline$D_{m d^{m d x}} /$ Large $^{m y d-/-} 33 \mathrm{G}$ & 283,75 & 2,02 \\
\hline$D m d^{m d x} / \operatorname{Large}^{m y d-/-} 41 \mathrm{~B}$ & 374,82 & 1,80 \\
\hline \multicolumn{3}{|l|}{3 meses } \\
\hline C57BL 20 & 436,94 & 1,98 \\
\hline C57BL 23 & 381,86 & 2,04 \\
\hline C57BL 25 & 272,22 & 2,01 \\
\hline C57BL 46 & 853,80 & 1,89 \\
\hline C57BL 47 & 734,95 & 1,97 \\
\hline$D m d^{m d x} 8$ & 828,22 & 2,07 \\
\hline$D m d^{m d x} 9$ & 613,66 & 1,82 \\
\hline$D m d^{m d x} 10$ & 503,69 & 1,78 \\
\hline$D m d^{m d x} 28$ & 965,43 & 2,07 \\
\hline$D m d^{m d x} 29$ & 992,20 & 1,96 \\
\hline Large $e^{m y d-/-} 22 \mathrm{D}$ & 1522,62 & 1,93 \\
\hline Large $e^{m y d-/-}$ 27D & 950,24 & 1,90 \\
\hline $\operatorname{Large}^{m y d-/-}$ 63D & 1853,19 & 1,98 \\
\hline $\operatorname{Large}^{m y d-/-}$ 64D & 1338,70 & 1,97 \\
\hline $\operatorname{Large}^{m y d--} 118$ & 622,47 & 1,81 \\
\hline $\operatorname{Dmd}^{m d x} / \operatorname{Large}^{m y d-/-} 31 \mathrm{~F}$ & 1373,03 & 1,98 \\
\hline Dmd ${ }^{m d x} /$ Large $e^{m y d-/-} 55 C$ & 651,78 & 1,92 \\
\hline$D m d^{m d x} / \operatorname{Large}^{m y d-/-} 58 \mathrm{C}$ & 780,79 & 1,83 \\
\hline $\mathrm{Dmd}^{m d x} / \operatorname{Larg}^{m y d-1-} 69 \mathrm{C}$ & 920,30 & 1,87 \\
\hline$D m d^{m d x} / \operatorname{Large}^{m y d-/-94 \mathrm{E}}$ & 946,36 & 2,00 \\
\hline \multicolumn{3}{|l|}{6 meses } \\
\hline C57BL 5 & 293,86 & 1,72 \\
\hline C57BL 6 & 488,23 & 2,08 \\
\hline C57BL 7 & 274,52 & 2,03 \\
\hline C57BL 8 & 488,37 & 2,08 \\
\hline C57BL 49 & 397,35 & 2,04 \\
\hline$D m d^{m d x} 1$ & 175,62 & 2,01 \\
\hline$D m d^{m d x} 2$ & 1018,54 & 1,92 \\
\hline$D m d^{m d x} 3$ & 507,04 & 1,73 \\
\hline$D m d^{m d x} 35$ & 1296,28 & 2,06 \\
\hline$D m d^{m d x} 36$ & 614,51 & 2,08 \\
\hline $\operatorname{Large}^{m y d-/-} 15$ & 776,96 & 2,07 \\
\hline $\operatorname{Large}^{m y d-/-} 18$ & 600,97 & 2,05 \\
\hline $\operatorname{Large}^{m y d-1-} \mathrm{PL} 2 \mathrm{~A}$ & 346,52 & 2,00 \\
\hline $\operatorname{Large}^{m y d-1-} \mathrm{PL} 2 \mathrm{~B}$ & 446,26 & 2,01 \\
\hline $\operatorname{Large}^{m y d-1-} \mathrm{PL} 2 \mathrm{C}$ & 433,69 & 2,02 \\
\hline$D m d^{m d x} / \operatorname{Large}^{m y d-/-} 12 \mathrm{E}$ & 879,92 & 2,05 \\
\hline$D_{m d^{m d x}} / \operatorname{Large}^{m y d-/-} 31 \mathrm{E}$ & 900,64 & 2,04 \\
\hline$D m d^{m d x} / \operatorname{Large}^{m y d-1-49}$ & 461,76 & 2,00 \\
\hline$D m d^{m d x} / \operatorname{Large}^{m y d-1-} 50$ & 470,83 & 1,84 \\
\hline $\operatorname{Dmd}^{m d x} / \operatorname{Large}^{m y d-1-} 51$ & 428,36 & 2,09 \\
\hline
\end{tabular}


Todas as amostras produziram quantidades adequadas de RNA total, acima de 130 $\mathrm{ng} / \mu \mathrm{L}$, e a razão $A_{260} / A_{280}$ também está dentro do esperado, entre 1,7 e 2,1 . Na avaliação da integridade do RNA por gel de agarose foi possível visualizar as bandas de RNA ribossômico $28 \mathrm{~S}$ e $18 \mathrm{~S}$ (Figura 7); e também que, durante a extração, algumas amostras apresentaram contaminação com DNA genômico. Essas amostras foram tratadas com DNase e repurificadas por precipitação com etanol, e a eliminação da contaminação foi satisfatória.
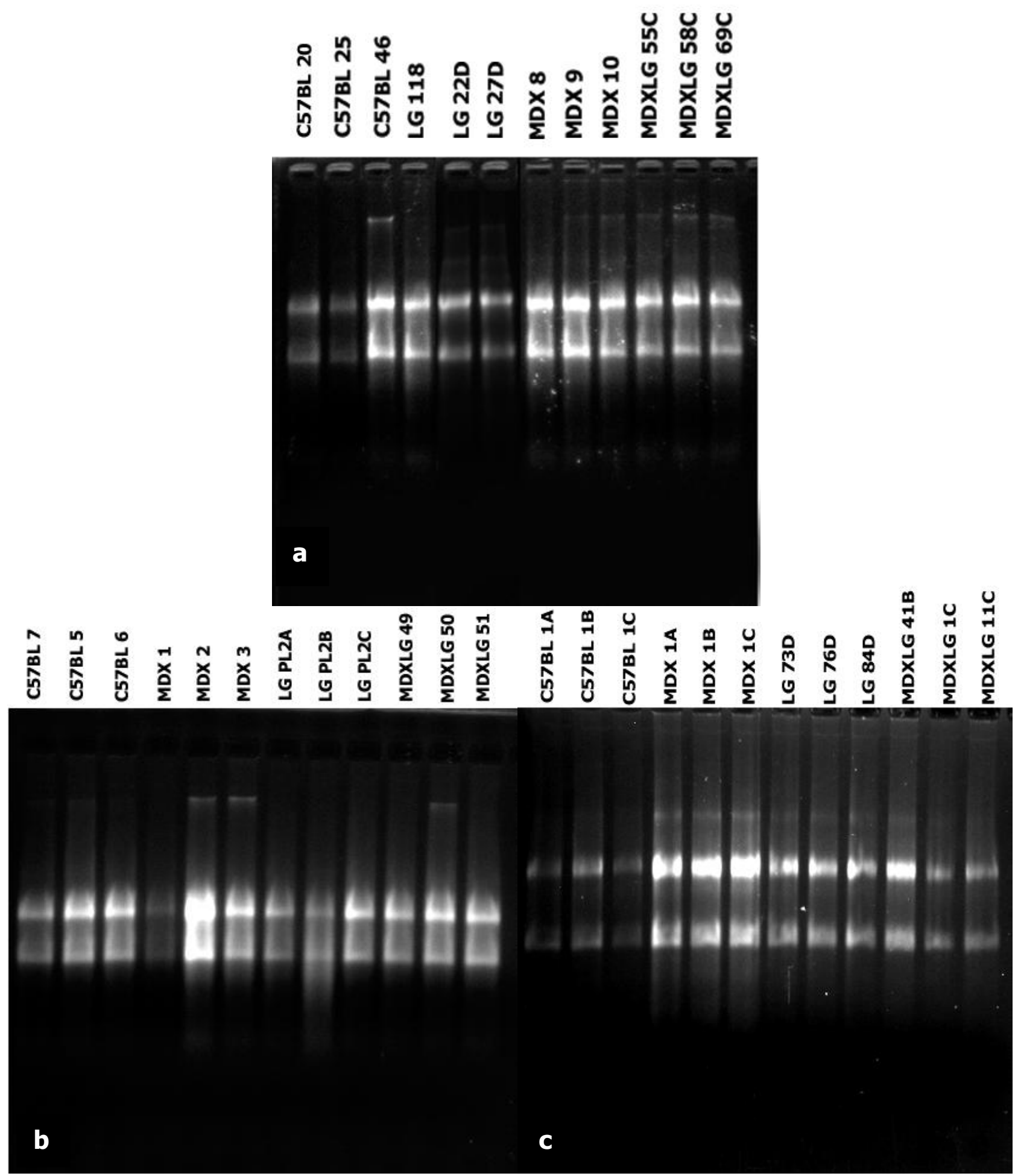


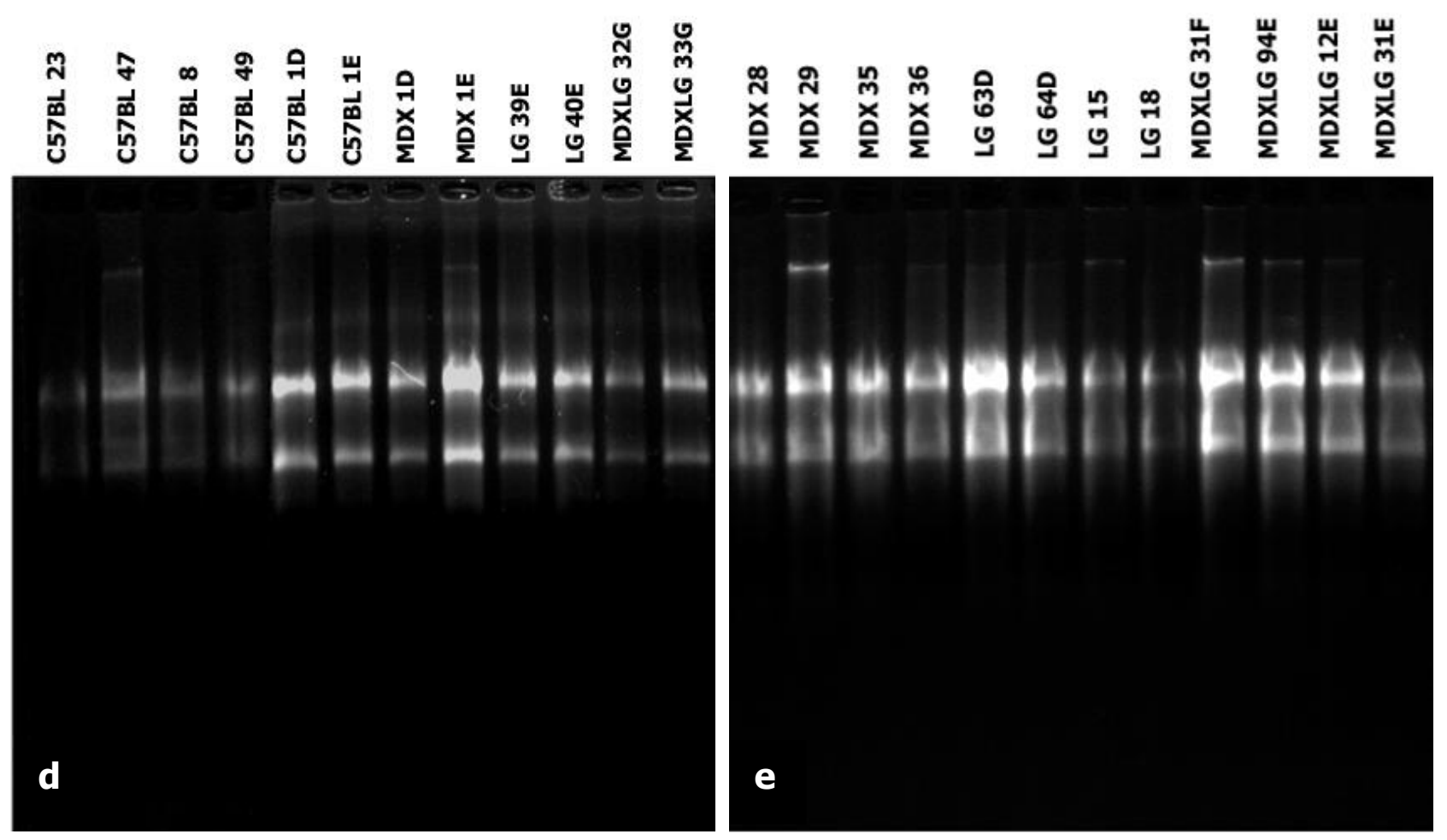

Figura 7 - Géis de agarose $2 \%$ corado com brometo de etídio (a - e). Amostras de RNA; é possível visualizar as bandas do RNA ribossômico $28 \mathrm{~S}$ e 18S. A banda de contaminação de DNA fica acima da banda $28 \mathrm{~S}$

As amostras também foram avaliadas no equipamento BioAnalyzer (Applied Biosystems). Os eletroferogramas com os respectivos RIN (RNA integrity number) de todas as sessenta amostras estão na figura 8. Amostras com RIN igual ou superior a 7 são consideradas de boa qualidade. 

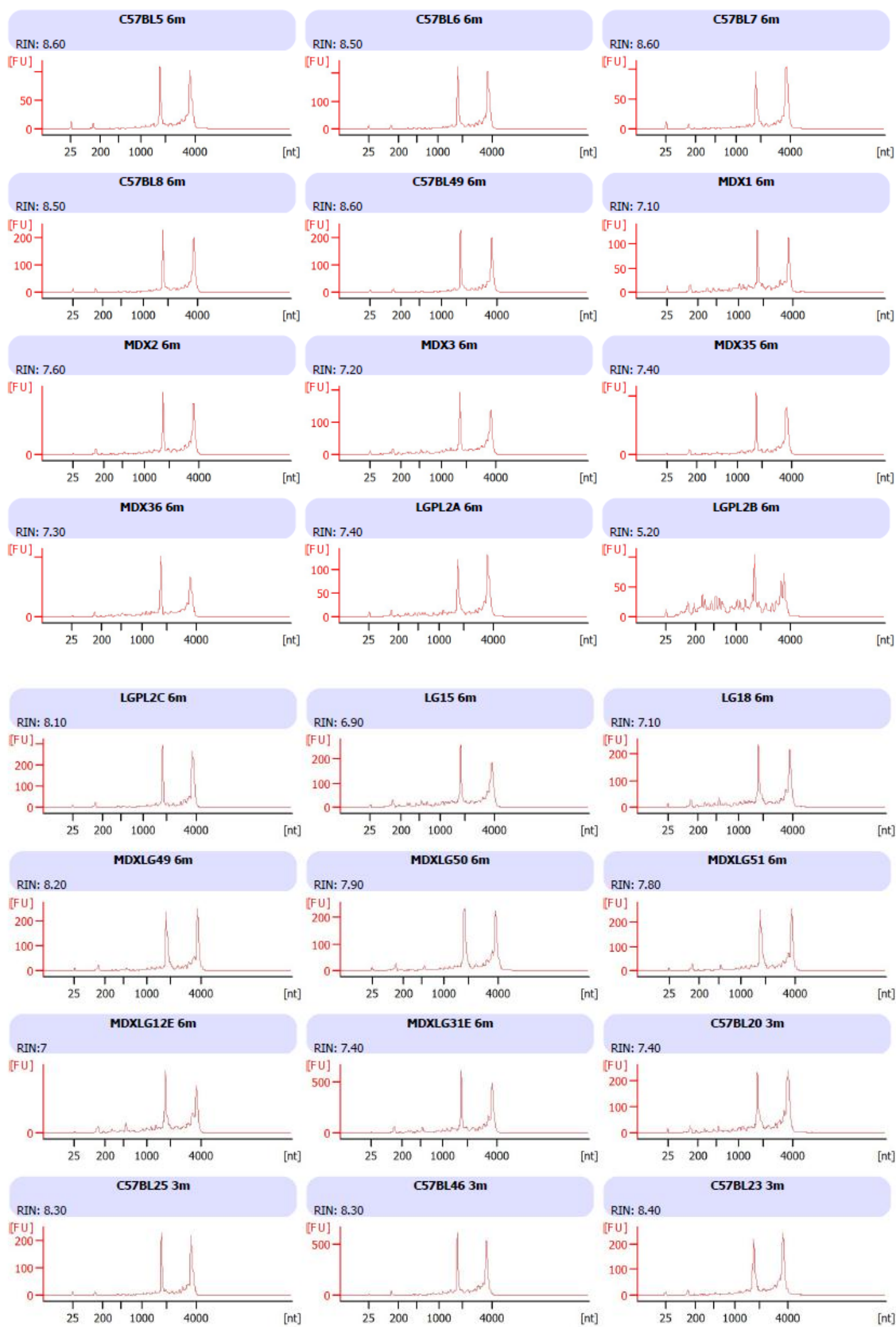

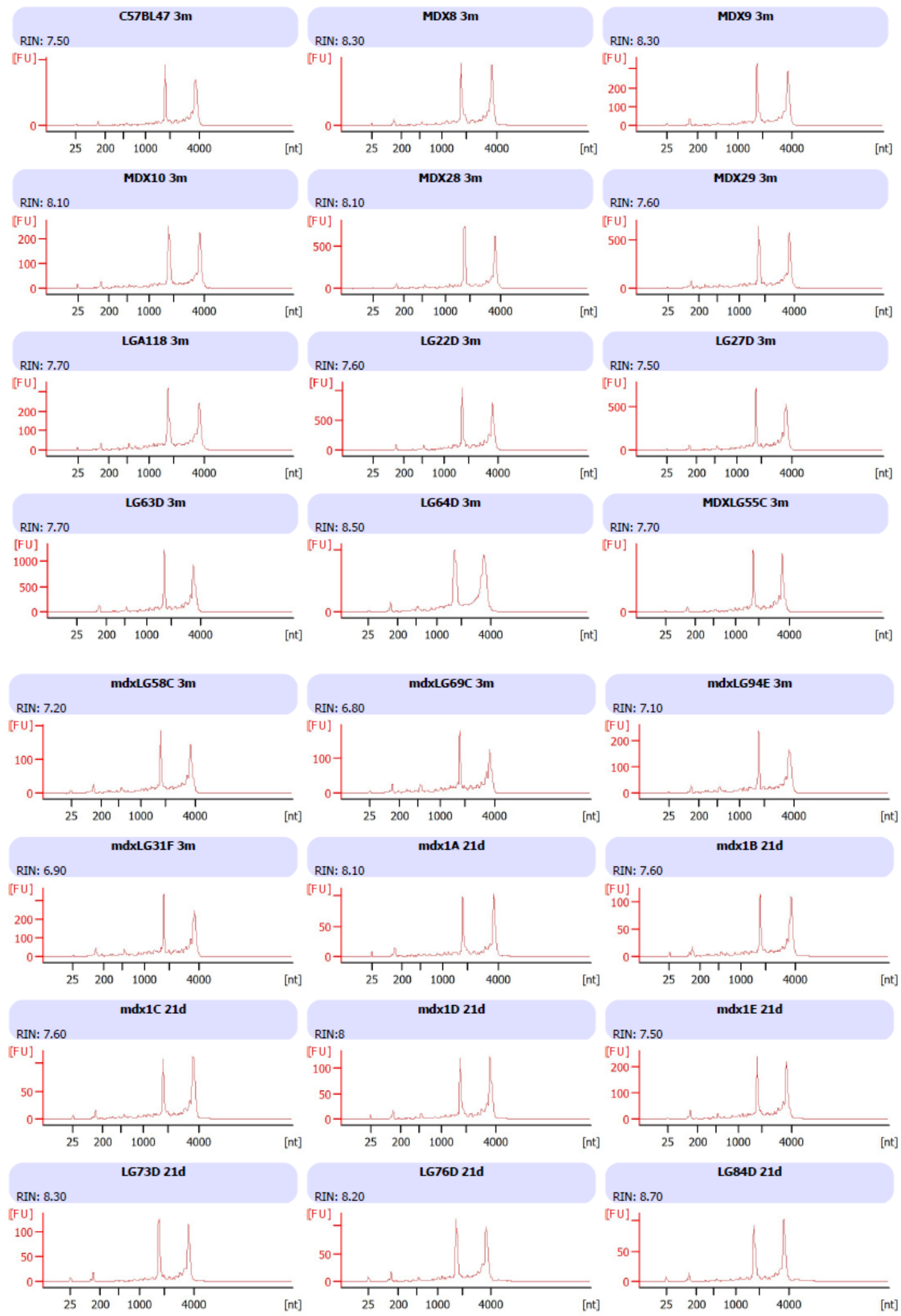

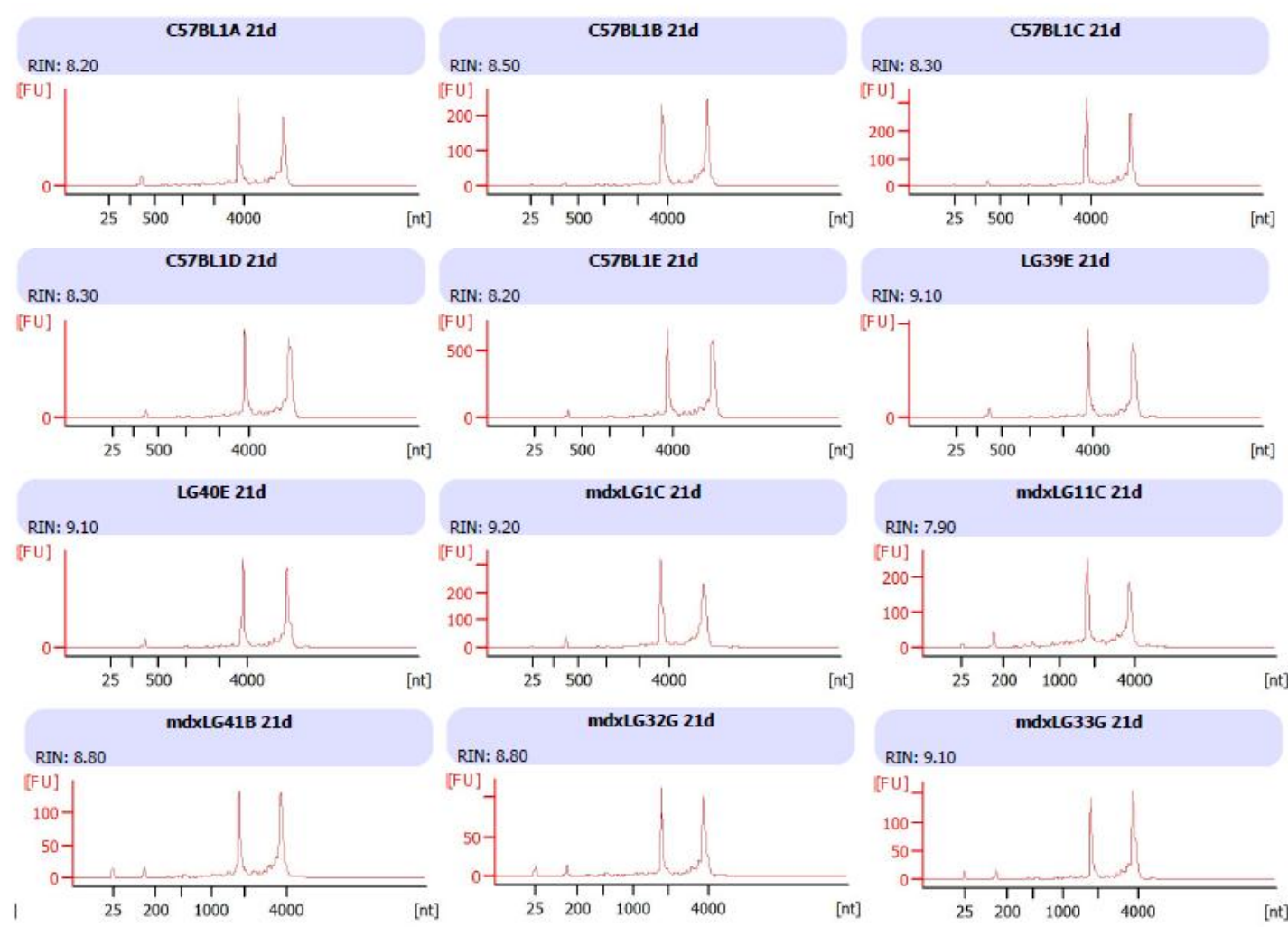

Figura 8 - Eletroferogramas e respectivos RIN das 60 amostras do estudo. Amostras com RIN igual ou superior a 7 são de boa qualidade

\section{Controle de qualidade dos microarranjos e pré-análise}

\subsection{Síntese de CRNA e CDNA, fragmentação e hibridização}

As sessenta amostras de RNA foram diluídas para a reação de síntese da primeira e segunda fita de CDNA, seguida da síntese de cRNA por transcrição in vitro, e purificação do CRNA produzido. O cRNA foi então quantificado e todas as amostras apresentaram o rendimento necessário para o prosseguimento do protocolo, que é de $455 \mathrm{ng} / \mu \mathrm{L}$ (Tabelas 14 a 16$)$.

Tabela 14 - Quantificação do cRNA das amostras do grupo de animais com 21 dias

\begin{tabular}{|c|c|c|c|}
\hline Amostra & $\mathrm{ng} / \mu \mathrm{L}$ & Amostra & $\mathrm{ng} / \mu \mathrm{L}$ \\
\hline C57BL 1A & 1023,31 & $\operatorname{Large}^{m y d-1-} 39 \mathrm{E}$ & 3148,90 \\
\hline$C 57 B L 1 B$ & 579,90 & $\operatorname{Large}^{m y d-/-} 40 \mathrm{E}$ & 3452,22 \\
\hline C57BL 1C & 1001,48 & $\operatorname{Large}^{m y d-/-} 73 \mathrm{D}$ & 1723,73 \\
\hline$C 57 B L 1 D$ & 1256,98 & Large $e^{m y d-1-} 76 \mathrm{D}$ & 1803,17 \\
\hline C57BL 1E & 1385,82 & $\operatorname{Large}^{m y d-/-} 84 \mathrm{D}$ & 1317,70 \\
\hline$D m d^{m d x} 1 \mathrm{~A}$ & 1620,39 & $\operatorname{Dmd}^{m d x} / \operatorname{Larg}^{m y d-1} 1 \mathrm{C}$ & 2258,62 \\
\hline$D m d^{m d x} 1 \mathrm{~B}$ & 1133,48 & $D m d^{m d x} /$ Large $^{m y d-/} 11 C$ & 1870,35 \\
\hline$D m d^{m d x} 1 \mathrm{C}$ & 1196,54 & $D m d^{m d x} / \operatorname{Larg}^{m y d-/-} 32 \mathrm{G}$ & 2492,78 \\
\hline$D m d^{m d x} 1 \mathrm{D}$ & 2245,91 & $D m d^{m d x} / \operatorname{Larg}^{m y d-/-} 33 \mathrm{G}$ & 2443,67 \\
\hline$D m d^{n d x} 1 \mathrm{E}$ & 2213,17 & $D m d^{m d x} / \operatorname{Larg}^{m y d-/-} 41 \mathrm{~B}$ & 1768,11 \\
\hline
\end{tabular}


Tabela 15 - Quantificação do cRNA das amostras do grupo de animais com 3 meses

\begin{tabular}{|c|c|c|c|}
\hline Amostra & $\mathrm{ng} / \boldsymbol{\mu L}$ & Amostra & $\mathrm{ng} / \mu \mathrm{L}$ \\
\hline C57BL 20 & 3111,45 & Large $e^{m y d-1-} 22 \mathrm{D}$ & 3705,29 \\
\hline C57BL 23 & 3680,65 & Large ${ }^{m y d-/-}$ 27D & 3814,16 \\
\hline C57BL 25 & 1201,69 & Large ${ }^{m y d-1-}$ 63D & 3607,16 \\
\hline C57BL 46 & 1166,66 & Large $e^{m y d-1-}$ 64D & 3684,95 \\
\hline C57BL 47 & 3396,19 & Large $e^{m y d-/-} 118$ & 2588,93 \\
\hline$D m d^{m d x} 8$ & 2688,91 & $D m d^{m d x} / \operatorname{Larg}^{m y d-/-} 31 \mathrm{~F}$ & 1664,27 \\
\hline$D m d^{m d x} 9$ & 3672,99 & $\mathrm{Dmd}^{m d x} / \mathrm{Large}^{m y d-/-} 55 \mathrm{C}$ & 3275,85 \\
\hline$D m d^{m d x} 10$ & 3477,20 & $D m d^{m d x} / L^{2} a r g e^{m y d-/-} 58 \mathrm{C}$ & 3134,49 \\
\hline$D m d^{m d x} 28$ & 3733,00 & $D m d^{m d x} / \operatorname{Larg}^{m y d-/-} 69 \mathrm{C}$ & 1812,62 \\
\hline$D m d^{m d x} 29$ & 3736,18 & $D m d^{m d x} /$ Large $^{m y d-/-}$ 94E & 3311,52 \\
\hline
\end{tabular}

Tabela 16 - Quantificação do cRNA das amostras do grupo de animais com 6 meses

\begin{tabular}{|c|c|c|c|}
\hline Amostra & $\mathrm{ng} / \boldsymbol{\mu L}$ & Amostra & $\mathrm{ng} / \mu \mathrm{L}$ \\
\hline C57BL 5 & 3384,54 & $\operatorname{Large}^{m y d---} 15$ & 3472,57 \\
\hline C57BL 6 & 3877,59 & $\operatorname{Large}^{m y d-1-} 18$ & 3755,06 \\
\hline C57BL 7 & 889,21 & Large $e^{m y d-/-} \mathrm{PL} 2 \mathrm{~A}$ & 1730,83 \\
\hline C57BL 8 & 1509,53 & $\operatorname{Larg}^{m y d-/-} \mathrm{PL} 2 \mathrm{~B}$ & 1909,27 \\
\hline C57BL 49 & 1360,25 & $\operatorname{Large}^{m y d--_{-}} \mathrm{PL} 2 \mathrm{C}$ & 1754,23 \\
\hline$D m d^{m d x} 1$ & 995,21 & $D m d^{m d x} / \operatorname{Large}^{m y d-/-} 12 \mathrm{E}$ & 3467,50 \\
\hline$D m d^{m d x} 2$ & 783,26 & $D m d^{m d x} / \operatorname{Larg}^{m y d-/-} 31 \mathrm{E}$ & 3488,50 \\
\hline$D m d^{m d x} 3$ & 859,47 & $D m d^{m d x} / \operatorname{Larg} e^{m y d-l-49}$ & 2695,19 \\
\hline$D m d^{m d x} 35$ & 886,72 & $D m d^{m d x} / \operatorname{Larg}^{m y d-/-} 50$ & 1027,46 \\
\hline$D m d^{m d x} 36$ & 1224,28 & $D m d^{m d x} / \operatorname{Larg}^{m y d-/-} 51$ & 1320,69 \\
\hline
\end{tabular}

Em seguida, foi feita a segunda síntese de cDNA, a hidrólise e purificação do cDNA. 0 rendimento de cDNA deve ser de no mínimo $220 \mathrm{ng} / \mu \mathrm{L}$. Todas as amostras atenderam a esse critério (Tabelas 17 a 19) e foram diluídas e fragmentadas.

Tabela 17 - Quantificação do cDNA das amostras do grupo de animais com 21 dias

\begin{tabular}{|c|c|c|c|}
\hline Amostra & $\mathrm{ng} / \mu \mathrm{L}$ & Amostra & $\mathrm{ng} / \mu \mathrm{L}$ \\
\hline C57BL 1A & 434,93 & $\operatorname{Large}^{m y d-/-} 39 \mathrm{E}$ & 428,59 \\
\hline$C 57 B L 1 B$ & 412,25 & Large $e^{m y d-1-} 40 \mathrm{E}$ & 394,79 \\
\hline C57BL 1C & 396,76 & Large ${ }^{m y d-/-}$ 73D & 374,54 \\
\hline C57BL 1D & 412,22 & Large $e^{m y d-/} 76 \mathrm{D}$ & 407,29 \\
\hline C57BL 1E & 396,53 & Large $e^{m y d-/-} 84 \mathrm{D}$ & 372,56 \\
\hline$D m d^{m d x} 1 \mathrm{~A}$ & 393,43 & $\operatorname{Dmd}^{m d x} / \operatorname{Larg}^{m y d-1-} 1 \mathrm{C}$ & 402,95 \\
\hline$D m d^{m d x} 1 \mathrm{~B}$ & 366,39 & $D m d^{m d x} / L_{a r g} e^{m y d-/-} 11 \mathrm{C}$ & 384,71 \\
\hline$D m d^{m d x} 1 C$ & 375,39 & $D m d^{m d x} / \operatorname{Larg}^{m y d-/-} 32 \mathrm{G}$ & 344,56 \\
\hline$D m d^{m d x} 1 \mathrm{D}$ & 414,47 & Dmd ${ }^{m d x} /$ Large $^{m y d-/-} 33 G$ & 380,07 \\
\hline$D m d^{m d x} 1 \mathrm{E}$ & 400,69 & $\operatorname{Dmd}^{m d x} /$ Large $^{m y d-1-}$ 41B & 339,33 \\
\hline
\end{tabular}


Tabela 18 - Quantificação do cDNA das amostras do grupo de animais com 3 meses

\begin{tabular}{|c|c|c|c|}
\hline Amostra & $\mathrm{ng} / \mu \mathrm{L}$ & Amostra & $\mathrm{ng} / \mu \mathrm{L}$ \\
\hline C57BL 20 & 453,75 & $\operatorname{Large}^{m y d-1-} 22 \mathrm{D}$ & 456,82 \\
\hline C57BL 23 & 474,42 & $\operatorname{Large}^{m y d-/-}$ 27D & 469,00 \\
\hline C57BL 25 & 365,50 & $\operatorname{Large}^{m y d-/-}$ 63D & 450,97 \\
\hline$C 57 B L 46$ & 415,15 & $\operatorname{Larg}^{m y d-/-}$ 64D & 433,84 \\
\hline C57BL 47 & 454,12 & $\operatorname{Larg}^{m y d-/-} 118$ & 407,85 \\
\hline$D m d^{m d x} 8$ & 416,17 & $D m d^{m d x} / \operatorname{Large}^{m y d-/-} 31 \mathrm{~F}$ & 387,56 \\
\hline$D m d^{m d x} 9$ & 477,51 & $D m d^{m d x} / \operatorname{Large}^{m y d-/-} 55 \mathrm{C}$ & 446,64 \\
\hline$D m d^{m d x} 10$ & 446,49 & $D m d^{m d x} / \operatorname{Large}^{m y d-/-58 C}$ & 440,99 \\
\hline$D m d^{m d x} 28$ & 463,57 & $D m d^{m d x} / \operatorname{Larg}^{m y d-/-} 69 C$ & 378,53 \\
\hline$D m d^{m d x} 29$ & 473,68 & $D m d^{m d x} / \operatorname{Large}^{m y d-/}$ 94E & 438,05 \\
\hline
\end{tabular}

Tabela 19 - Quantificação do cDNA das amostras do grupo de animais com 6 meses

\begin{tabular}{|c|c|c|c|}
\hline Amostra & $\mathrm{ng} / \mu \mathrm{L}$ & Amostra & $\mathrm{ng} / \mu \mathrm{L}$ \\
\hline C57BL 5 & 451,37 & $\operatorname{Larg}^{\text {myd-/- }} 15$ & 413,11 \\
\hline C57BL 6 & 479,29 & $\operatorname{Larg}^{\text {myd-/- }} 18$ & 407,49 \\
\hline$C 57 B L 7$ & 385,51 & $\operatorname{Large}^{m y d-1-} \mathrm{PL} 2 \mathrm{~A}$ & 412,85 \\
\hline$C 57 B L 8$ & 402,88 & $\operatorname{Large}^{m y d-/-} \mathrm{PL} 2 \mathrm{~B}$ & 404,39 \\
\hline C57BL 49 & 412,18 & $\operatorname{Large}^{m y d-1-} \mathrm{PL} 2 \mathrm{C}$ & 430,55 \\
\hline$D m d^{n d x} 1$ & 384,46 & $\operatorname{Dmd}^{m d x} /$ Large $^{m y d-/-} 12 \mathrm{E}$ & 454,85 \\
\hline$D m d^{m d x} 2$ & 383,15 & $D m d^{m d x} / \operatorname{Larg}^{m y d-/-} 31 \mathrm{E}$ & 386,06 \\
\hline$D m d^{m d x} 3$ & 406,87 & $D m d^{m d x} / \operatorname{Larg}^{m y d-1-} 49$ & 399,15 \\
\hline$D m d^{m d x} 35$ & 384,67 & $D m d^{m d x} / \operatorname{Larg}^{m y d-1-} 50$ & 309,08 \\
\hline$D m d^{m d x} 36$ & 447,74 & $D m d^{m d x} / \operatorname{Larg}^{m y d-/} 51$ & 388,17 \\
\hline
\end{tabular}

Parte do produto da fragmentação foi aplicada em gel de agarose $1 \%$ para se avaliar se a reação ocorreu de forma adequada, pela presença de um arrasto no gel (exemplo na Figura 9).

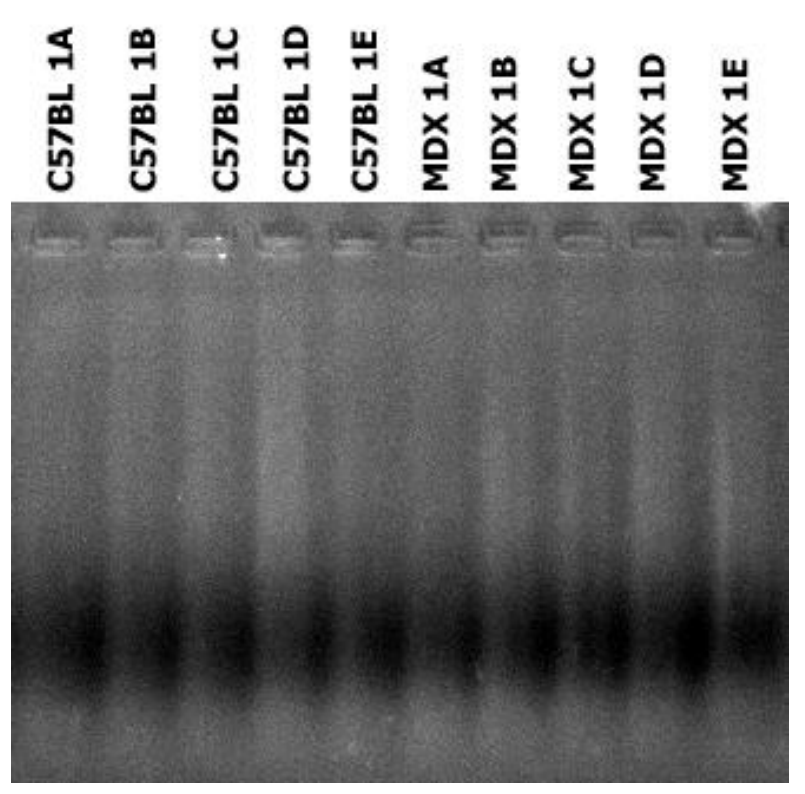

Figura 9 - Gel de agarose 1\% corado com brometo de etídeo mostrando a fragmentação de algumas amostras 
Por fim, as amostras fragmentadas foram marcadas e hibridizadas nos chips por 16 horas, que foram lavados e escaneados. As imagens das lâminas foram inspecionadas para se verificar a presença de bolhas, manchas e artefatos, que prejudicam a leitura correta dos dados (exemplo Figura 10). Além disso, foi checada a hibridização do oligo B2 em alguns pontos da lâmina, como o local onde está escrito o nome da lâmina (Figura 11). Todos as lâminas atenderam a esses critérios.

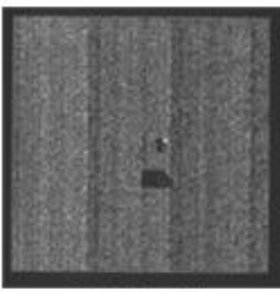

C57BL 1A

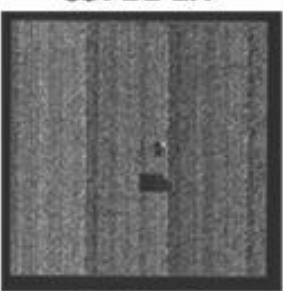

C57BL 20

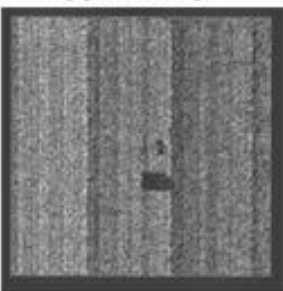

C57BL 5

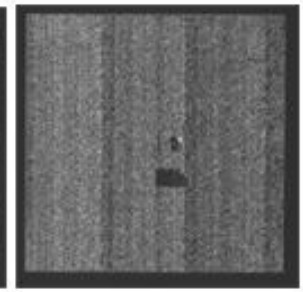

MDX 1A

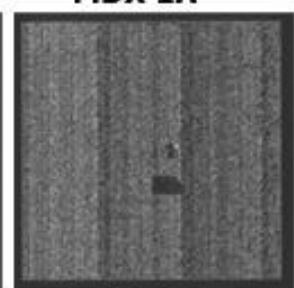

MDX 8

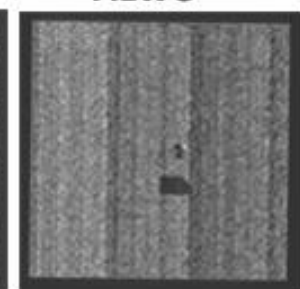

MDX 2

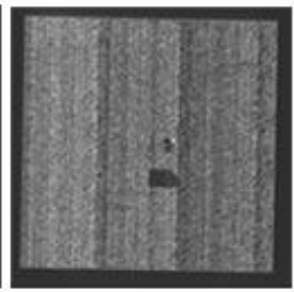

LG 39E

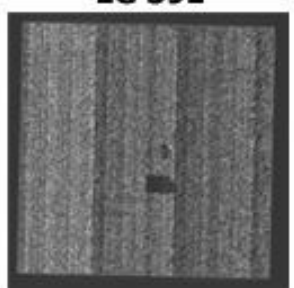

LG 22D

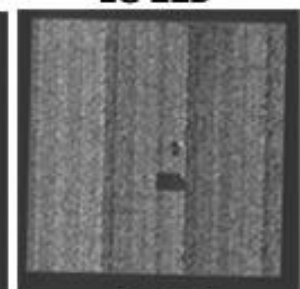

LG PL2B

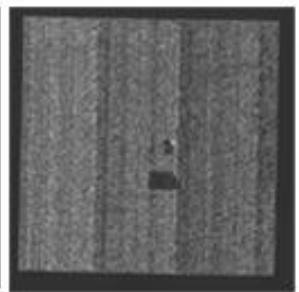

MDXLG1C

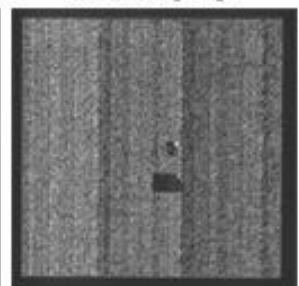

MDXLG 69C

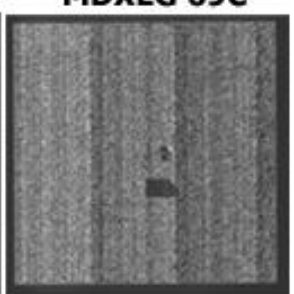

MDXLG 12E

Figura 10 - Imagens das lâminas dos microarranjos. Estão ilustradas uma amostra de cada idade e linhagem para exemplificação

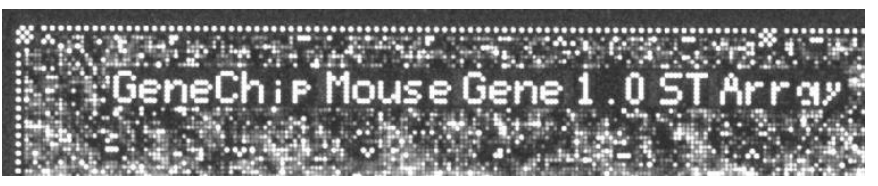

Figura 11 - Controle de hibridização do oligo B2. O nome do chip deve ser formado completamente 


\section{Pré-análise dos dados de expressão}

\subsection{Controle de qualidade - métricas das sondas}

Os dados obtidos a partir do escaneamento das lâminas foram analisados no programa Expression Console ${ }^{T M}$ (Affymetrix) para verificação de uma série de parâmetros da qualidade das reações.

O primeiro deles é o pm_mean que é a média de intensidade bruta de todas as sondas do microarranjo antes de qualquer transformação das intensidades. Esse valor é usado para determinar se algum chip está muito escuro ou muito brilhante; e ele também está relacionado com outro valor, o bgrd_mean, que é a média da intensidade bruta das sondas utilizada para calcular o background antes da transformação das intensidades. Dados de boa qualidade devem apresentar valores de pm-mean superiores aos de bgrd_mean. Todas as amostras em estudo atendem a esse critério (figuras 12 a 14).
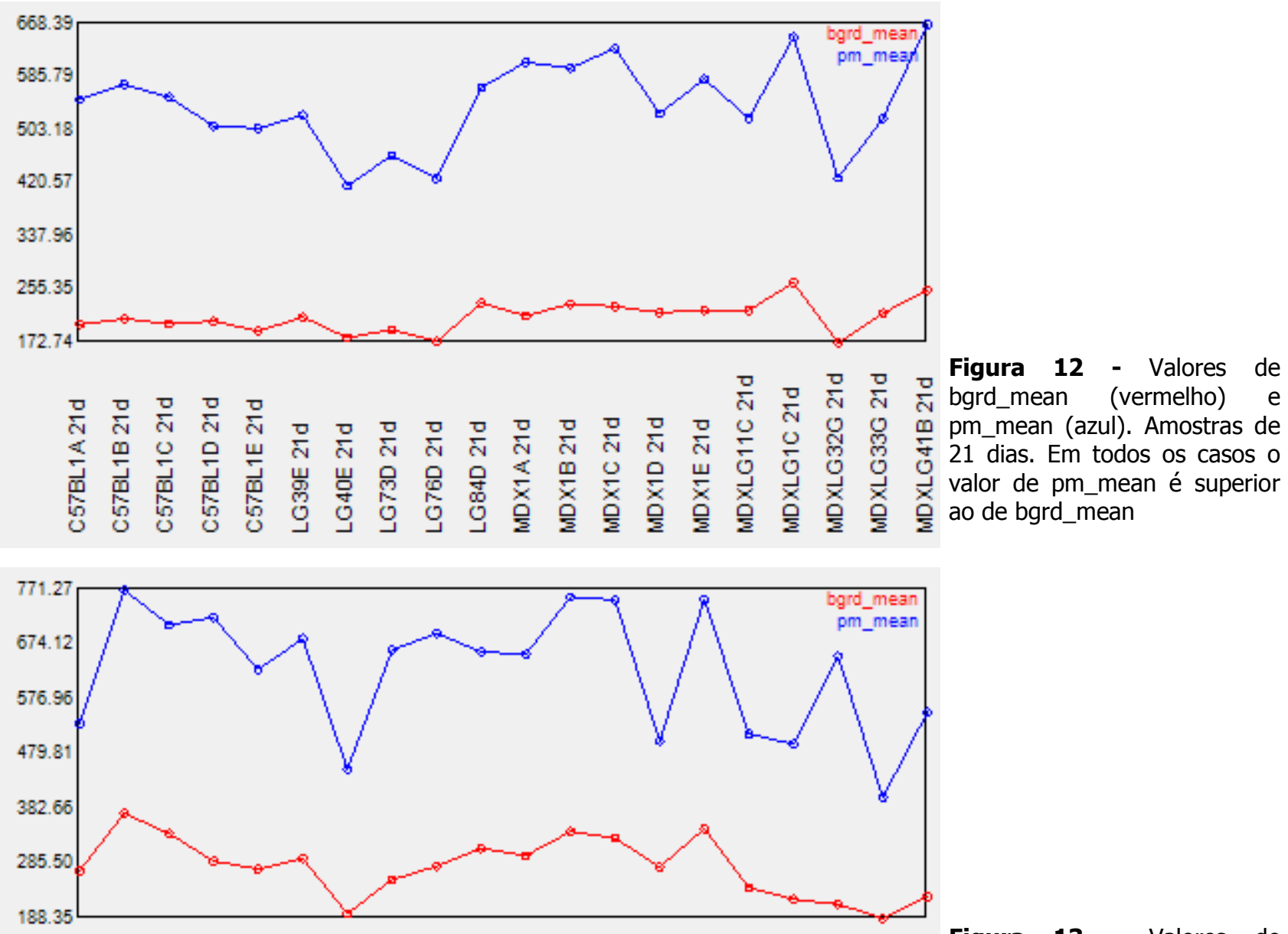

Figura 13 - Valores de bgrd_mean (vermelho) e pm_mean (azul). Amostras de 3 meses. Em todos os casos o valor de pm_mean é superior ao de bgrd_mean 


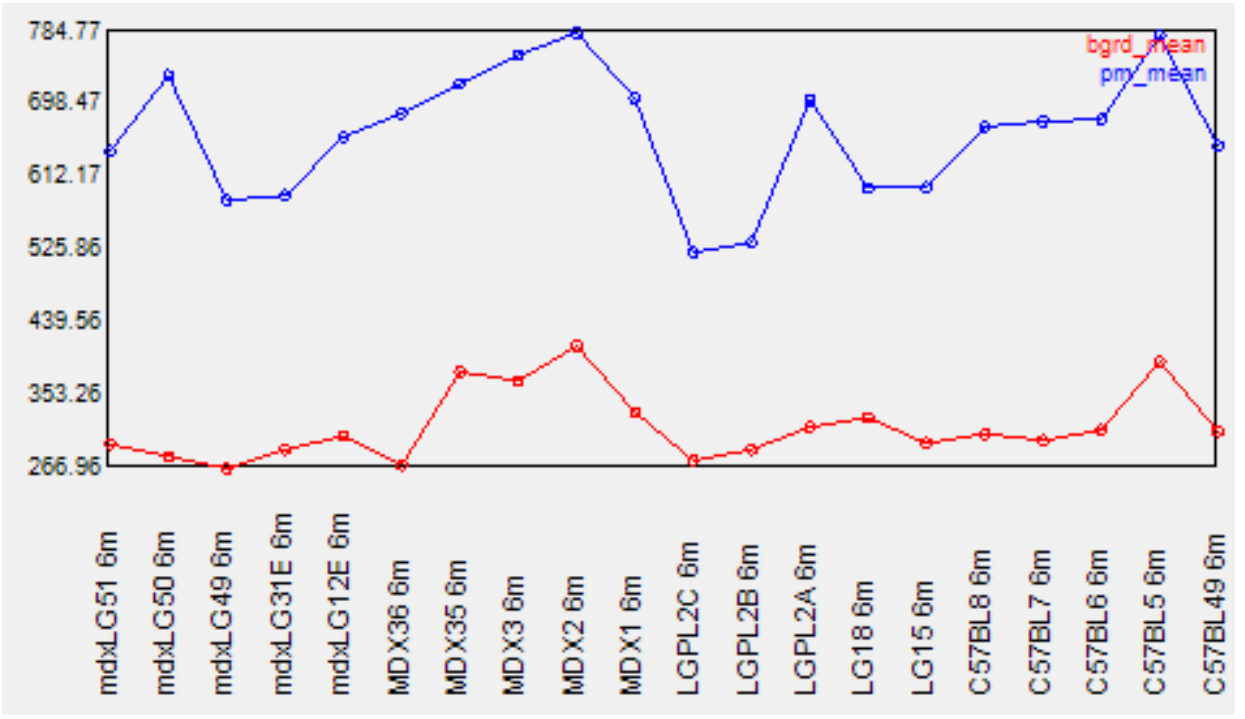

Figura 14 - Valores de bgrd_mean (vermelho) e pm_mean (azul). Amostras de 6 meses. Em todos os casos o valor de pm_mean é superior ao de bgrd_mean

O valor pos_vs_neg_auc é baseado nos resultados da sumarização do conjunto de sondas. Esse valor é uma comparação entre os sinais dos controles positivos (medida de positivos verdadeiros) e negativos (medida de falsos positivos), onde 1 indica uma separação perfeita entre os controles, e 0,5 indica não separação (valores entre 0,8 e 0,9 são os mais comuns). Essa medida é sensível à qualidade do RNA. Todas as amostras apresentam valores dentro desse limite, assim confirmamos a qualidade dos RNAs utilizados (Figuras 15 a 17).

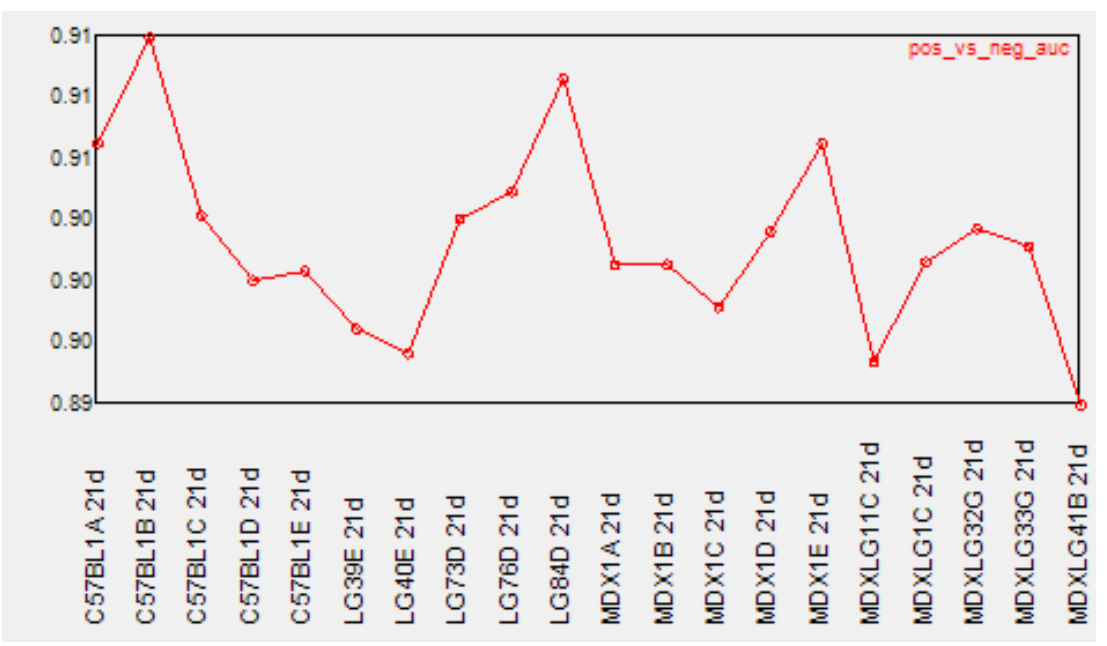

Figura 15 - Valores de pos_vs_neg_auc das amostras de 21 dias. Todas as amostras apresentam valores entre 0,89 e 0,91 


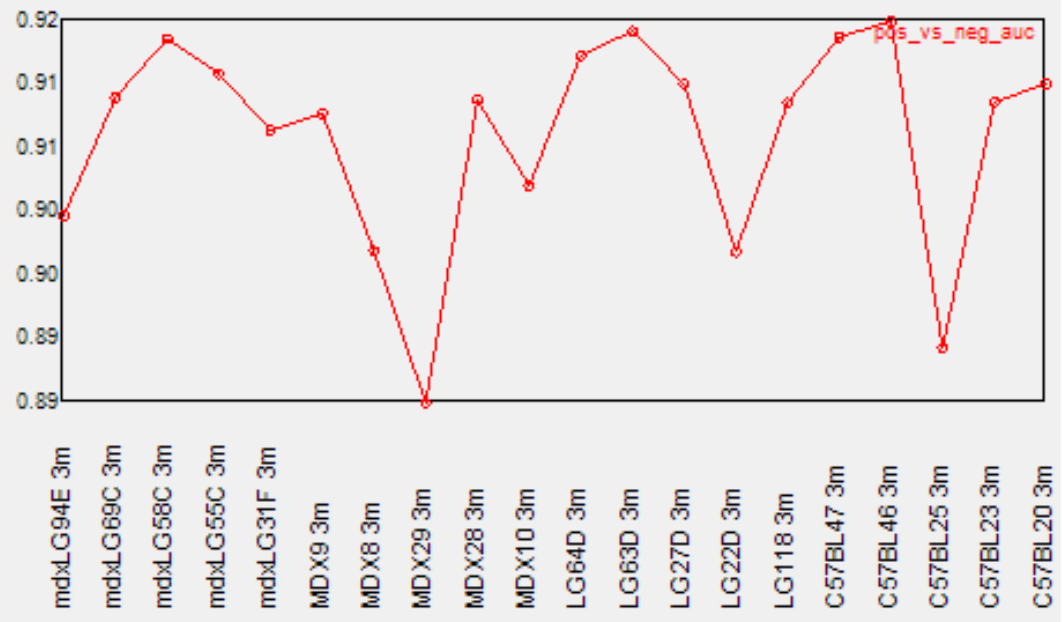

Figura 16 - Valores de pos_vs_neg_auc das amostras de 3 meses. Todas as amostras apresentam valores entre 0,89 e 0,92

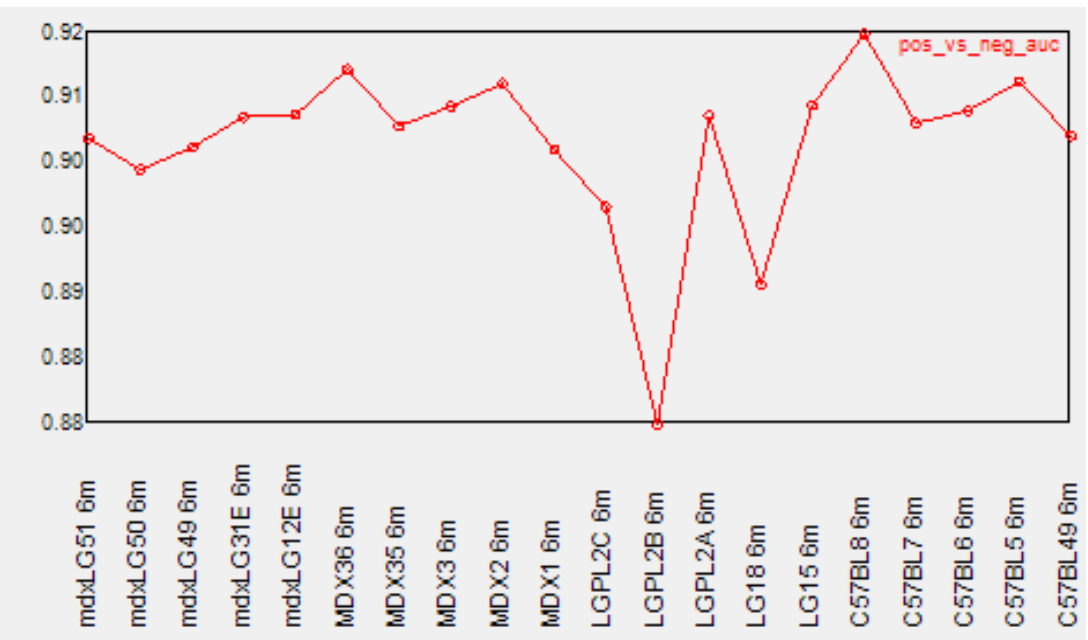

Figura 17 - Valores de pos_vs_neg_auc das amostras de 6 meses. Todas as amostras apresentam valores entre 0,88 e 0,92

O conjunto de controles de hibridização bac_spike são sondas que hibridizam com os controles exógenos bacterianos e servem para identificar problemas na hibridização. Eles devem estar sempre presentes e com valores crescentes, de acordo com as suas concentrações relativas: BioB 1,5 pM; BioC 5 pM; BioD 25 pM e Cre 100 pM. Os valores desses controles das amostras em estudo estão dentro do esperado e representados nos gráficos das figuras a seguir (Figuras 18 a 20). 

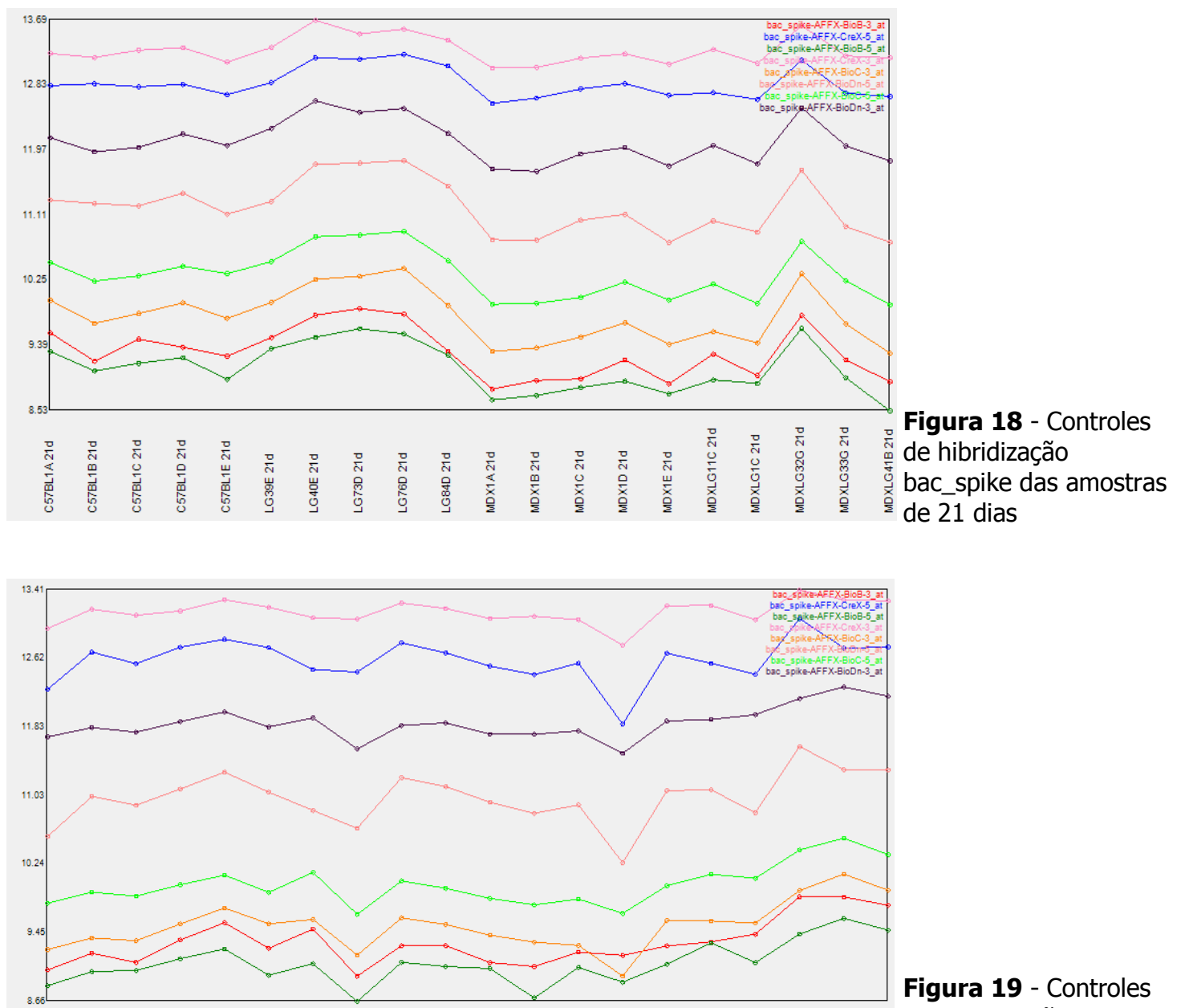

Figura 19 - Controles

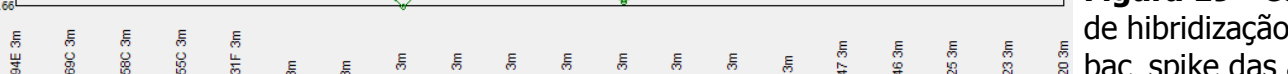
bac_spike das amostras de 3 meses

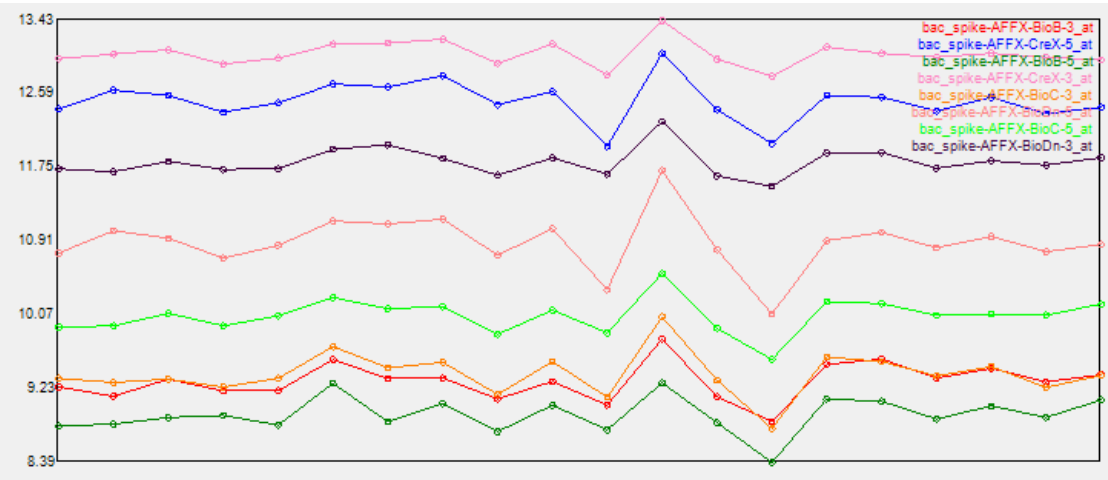

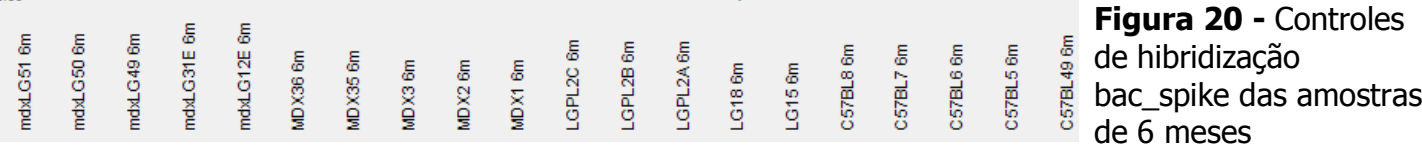

Os RNAs exógenos poliadenilados Lys, Phe, Dap e Thr (polya_spike) servem para identificar problemas nas reações e devem estar presentes com valores crescentes na seguinte ordem: Lys, Phe, Dap e Thr. Os gráficos das figuras seguintes (Figuras 21 a 23) mostram esses valores, que estão de acordo com o esperado. 


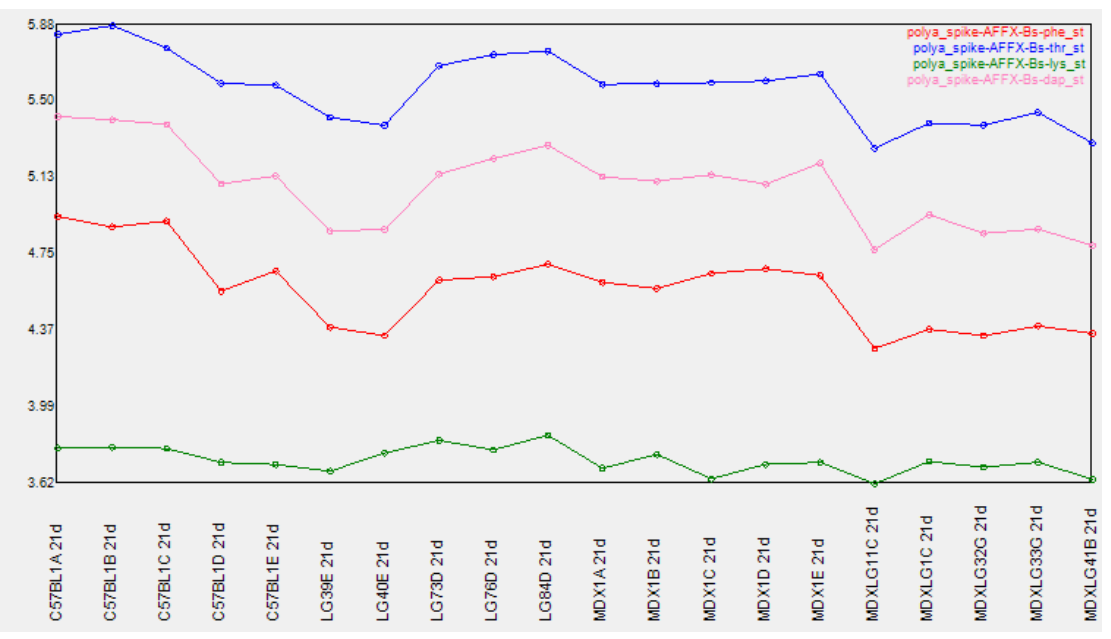

Figura 21 - Controles de RNA poly-A. Amostras de 21 dias

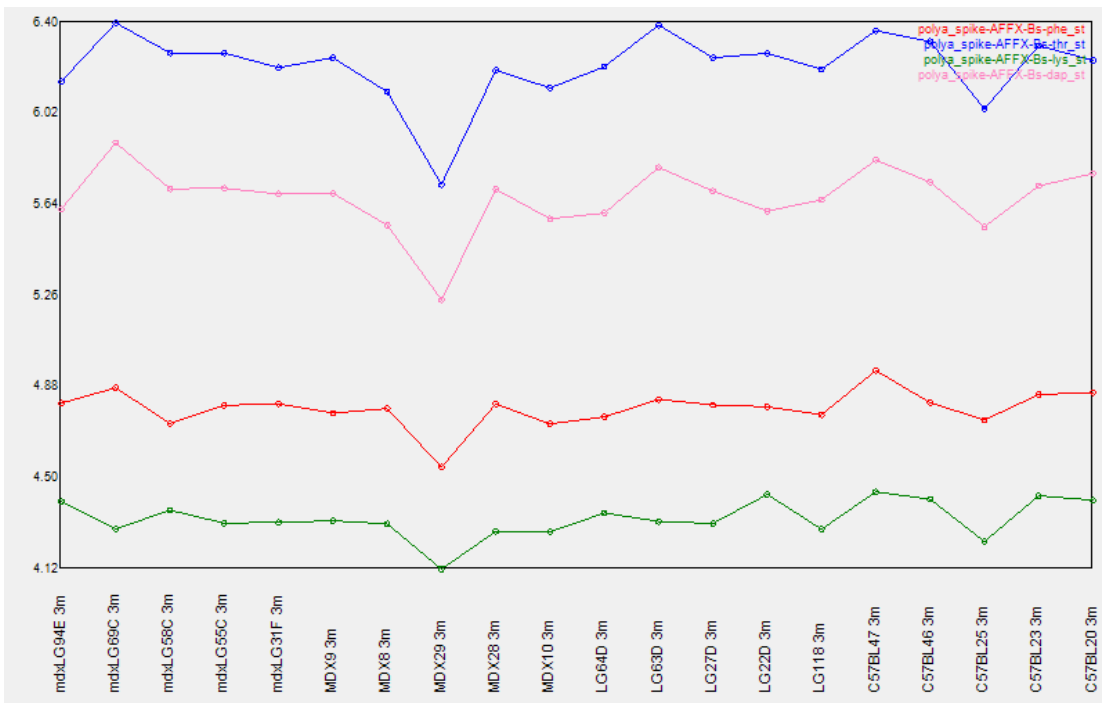

Figura 22 - Controles de RNA poly-A. Amostras de 3 meses

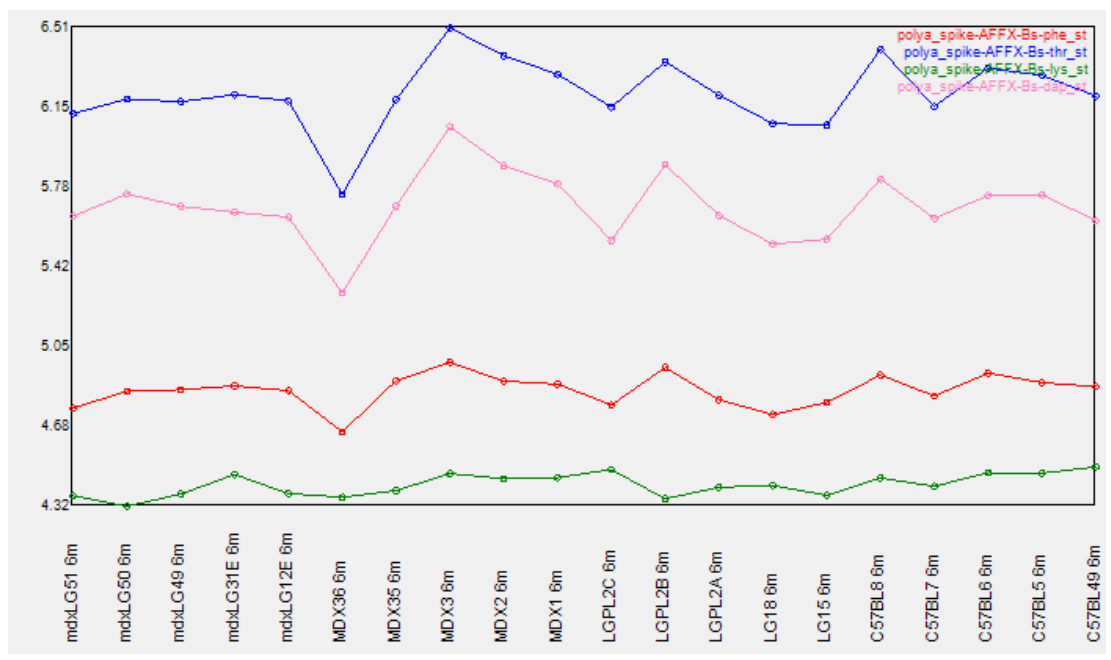

Figura 23 - Controles de RNA poly-A. Amostras de 6 meses 


\subsection{Distribuição dos sinais e normalização}

O histograma de sinal mostra o padrão de distribuição dos sinais de intensidade e o padrão da curva formado pelos mesmos, servindo para identificar outliers. É esperado que a curva seja normal. As amostras apresentam um padrão de distribuição bem próximo à normal (Figuras 24 a 26).

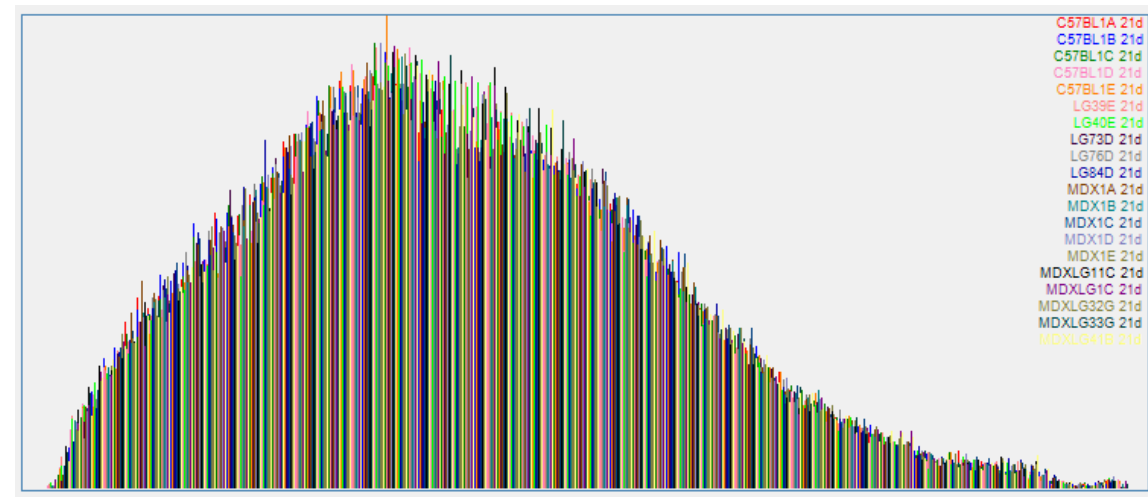

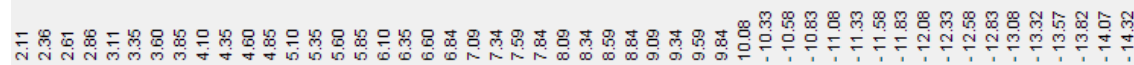

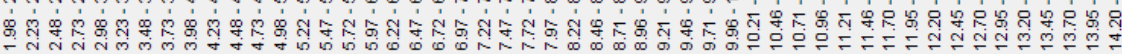

Figura 24 - Histograma de intensidade de sinal das amostras de 21 dias, com padrão próximo à normal

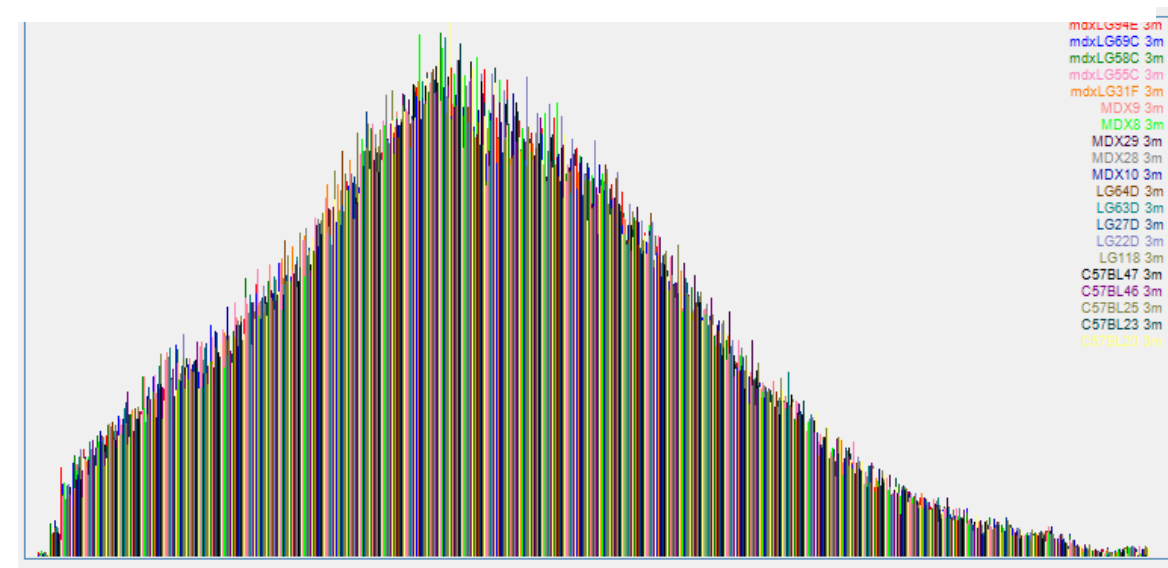

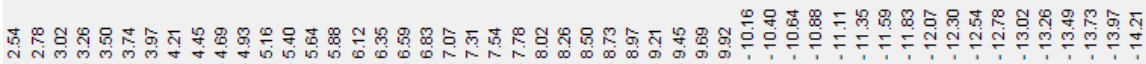

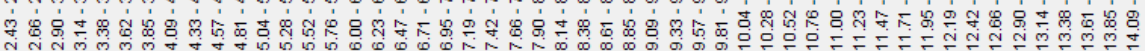

Figura 25 - Histograma de intensidade de sinal das amostras de 3 meses, com padrão próximo à normal 


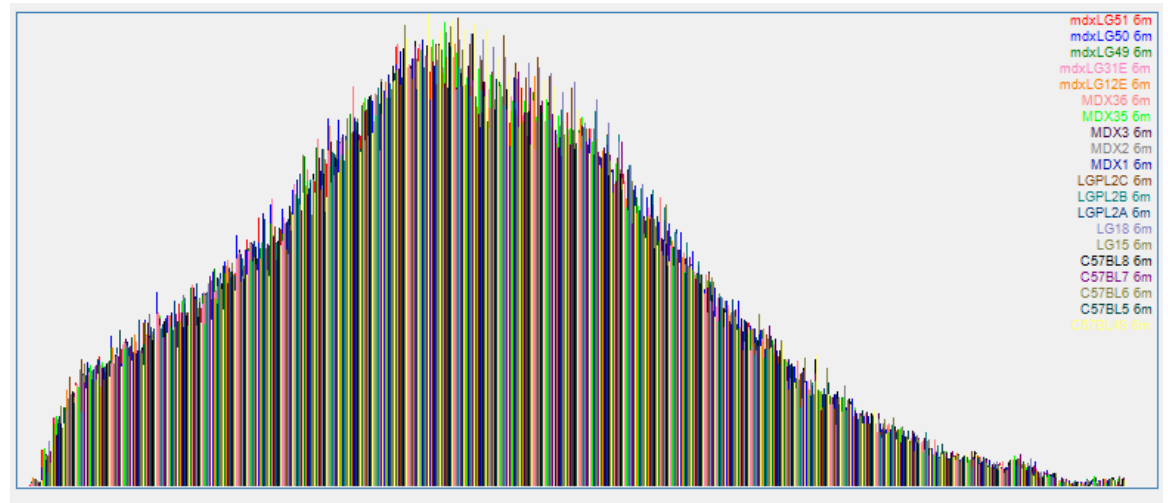

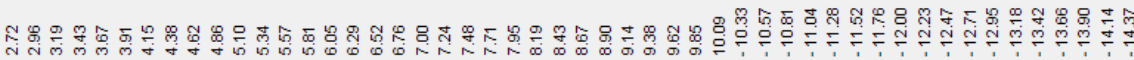

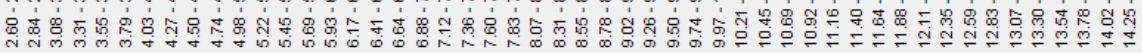

Figura 26 - Histograma de intensidade de sinal das amostras de 6 meses, com padrão próximo à normal

A normalização dos dados faz a correção dos erros originados por diferenças técnicas e de intensidade de fluorescência dos fluoróforos. Para isso, foi utilizado o algoritmo RMA. Após a normalização, as médias dos box plots dos sinais de intensidade relativos devem ser zero ou próximas à zero, assim pode-se identificar outliers.

Os gráficos a seguir mostram os dados antes e depois da normalização, que corrigiu os dados de todos os 60 chips adequadamente (Figuras 27 a 29).

A

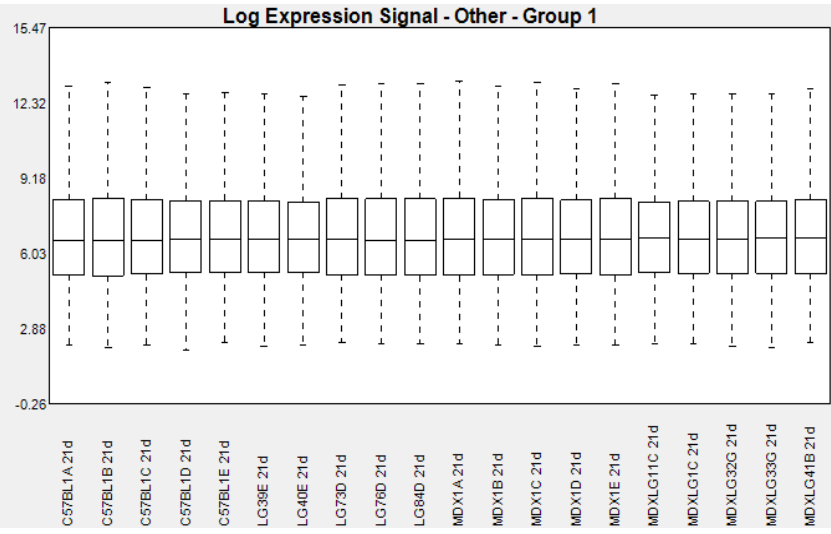

B

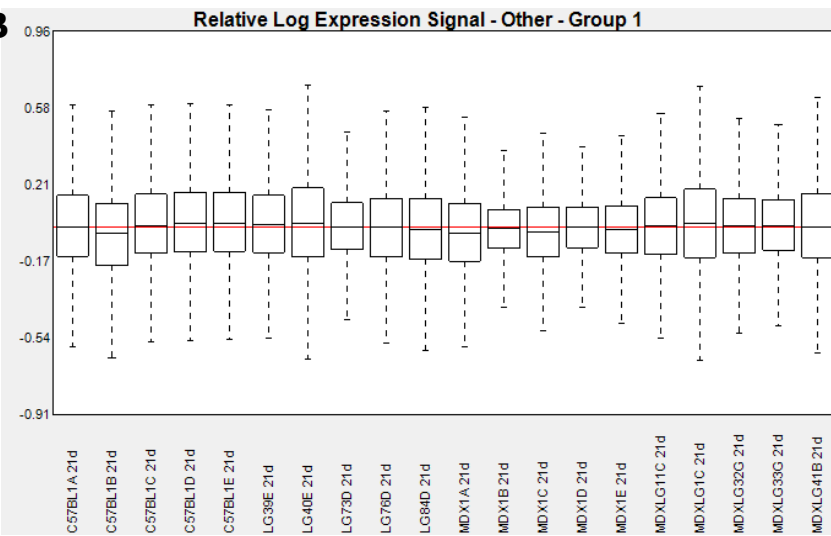

Figura 27 - Gráficos com intensidade dos agrupamentos de sondas antes (A) e depois (B) da normalização. Amostras de 21 dias 
A

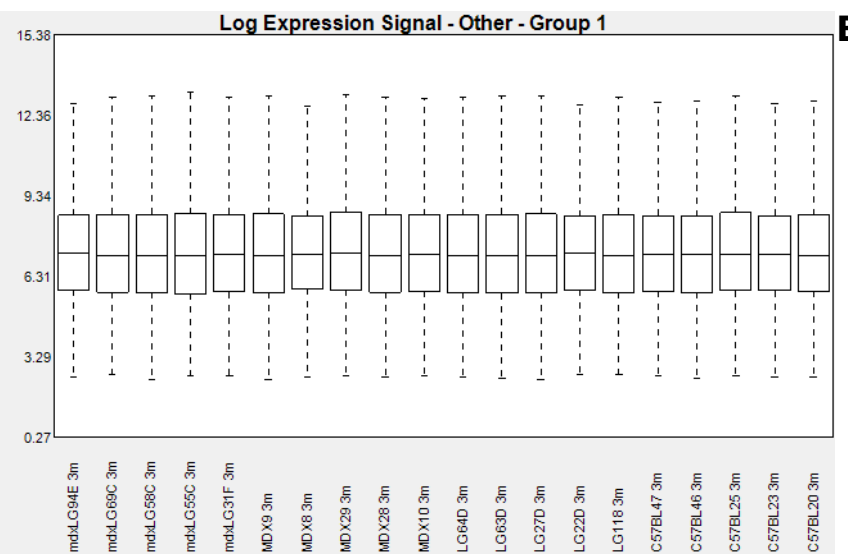

B

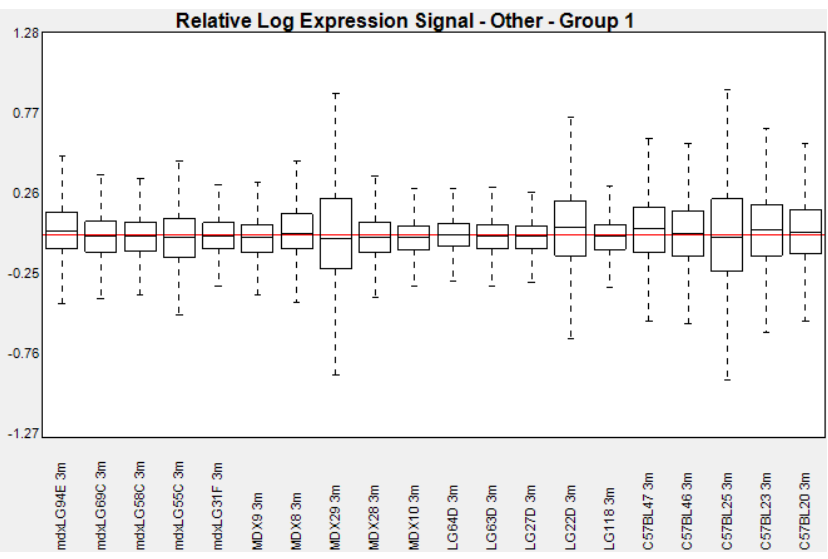

Figura 28 - Gráficos com intensidade dos agrupamentos de sondas antes (A) e depois (B) da normalização. Amostras de 3 meses

A

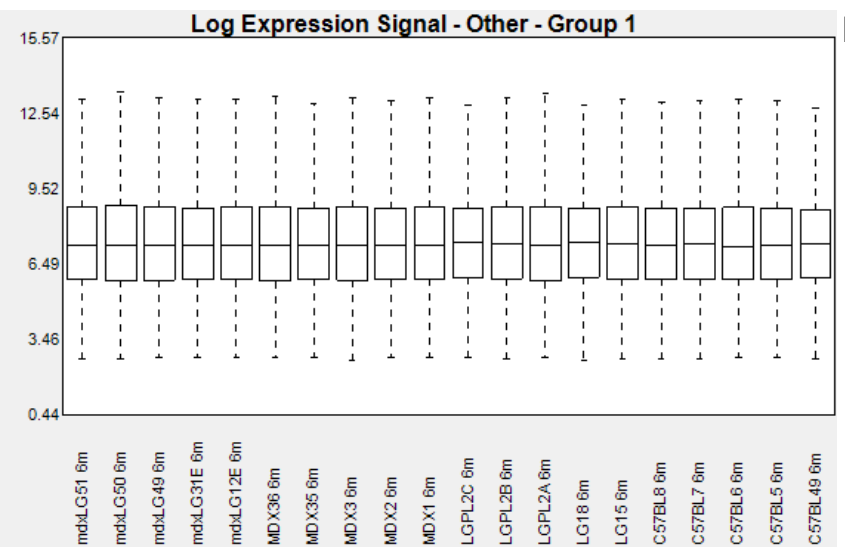

B

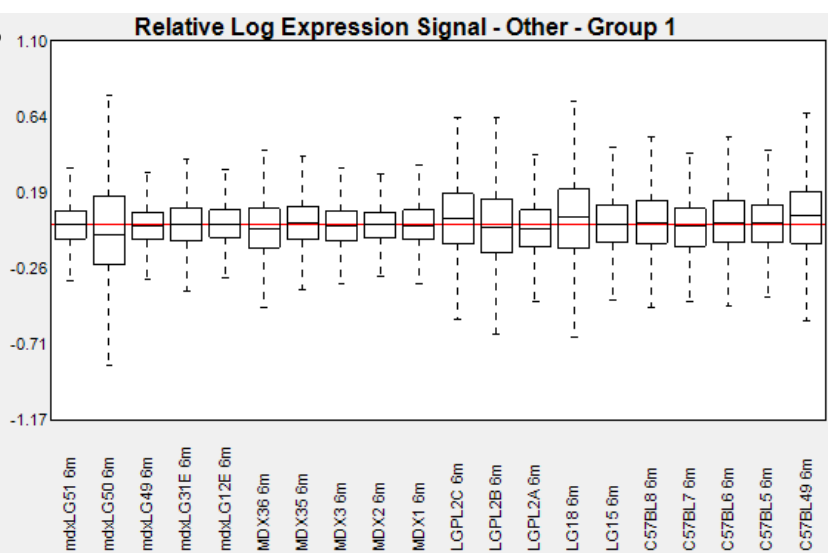

Figura 29 - Gráficos com intensidade dos agrupamentos de sondas antes (A) e depois (B) da normalização. Amostras de 6 meses 


\section{Triagem dos genes diferencialmente expressos}

\subsection{Número total de genes diferencialmente expressos}

Para a seleção dos genes diferencialmente expressos foram feitas diversas combinações entre os grupos dentro de cada uma das idades.

Inicialmente, foram comparadas cada uma das linhagens, com o controle normal:

$D m d^{m d x} \times C 57 B L$

Large $e^{m y d-1} \times C 57 B L$

$D m d^{m d x} / L a r g e^{m y d--} \times C 57 B L$

Posteriormente, a linhagem $D m d^{m d x} / \operatorname{Larg} e^{m y d--}$ foi comparada com cada uma das linhagens parentais:

$$
\begin{aligned}
& D m d^{m d x} / \operatorname{Larg}^{m y d-\gamma} \times \operatorname{Dmd}^{m d x} \\
& D m d^{m d x} / \operatorname{Larg}^{m y d-\gamma} \times \operatorname{Larg}^{m y d-1-}
\end{aligned}
$$

Para cada combinação foi feita uma nova normalização usando o algoritmo RMA no programa Expression Console ${ }^{T M}$. Os dados normalizados foram tratados no programa MeV. Primeiro os dados passaram por um filtro de variância para a remoção dos genes que não apresentaram variação entre as amostras. Este filtro faz uma classificação dos genes baseada no desvio padrão, mantendo apenas $50 \%$ dos genes com maior variação. Assim, dos 35556 genes presentes no microarranjo, foram mantidos 17778 genes.

Para a triagem dos genes diferencialmente expressos, o método estatístico escolhido foi o SAM (Significance Analysis for Microarrays), que é um teste para a análise de microarranjos amplamente utilizado. Foram feitas análises de duas classes não pareadas (cada classe é formada por cinco microarranjos de cada linhagem), com 5000 permutações e mediana do número de genes falso-positivos igual a zero. Os gráficos gerados estão nas figuras a seguir (Figuras 30 a 44). 


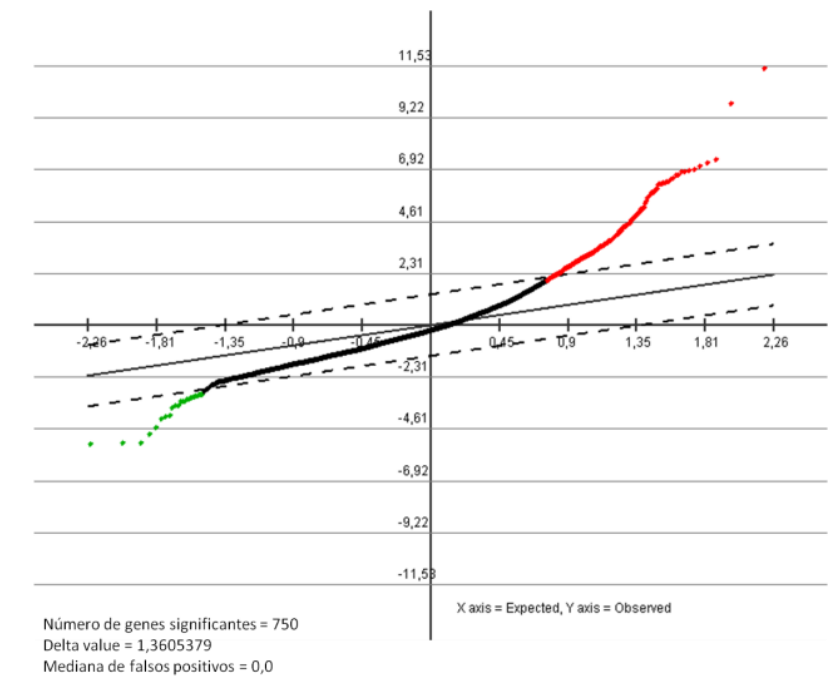

Figura 30 - Análise $D m d^{m d x}$ vs C57BL 21 dias. Gráfico gerado após a análise estatística SAM; 75 genes identificados

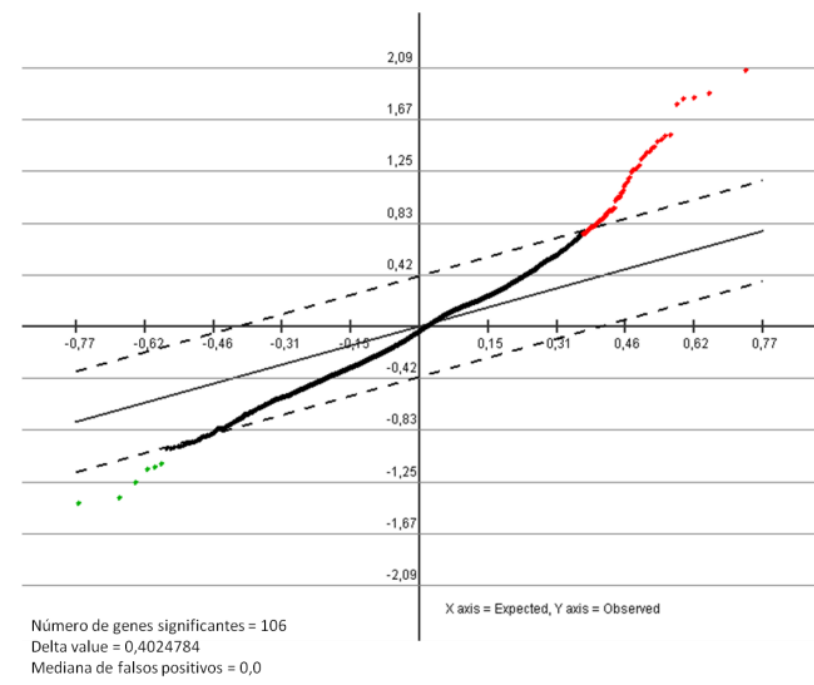

Figura 32 - Análise $D m d^{m d x} /$ Large $^{m y d-/}$ vs C57BL 21 dias. Gráfico gerado após a análise estatística SAM; 106 genes identificados

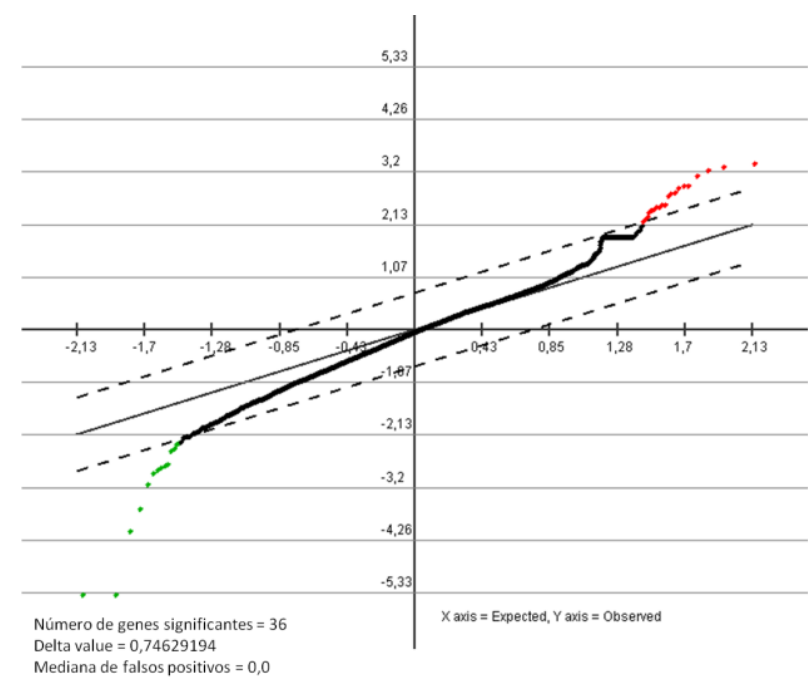

Figura 34 - Análise $D m d^{m d x} / \operatorname{Larg}^{m y d-/-}$ vs $\operatorname{Larg}^{m y d-/-} 21$ dias. Gráfico gerado após a análise estatística SAM; 36 genes identificados

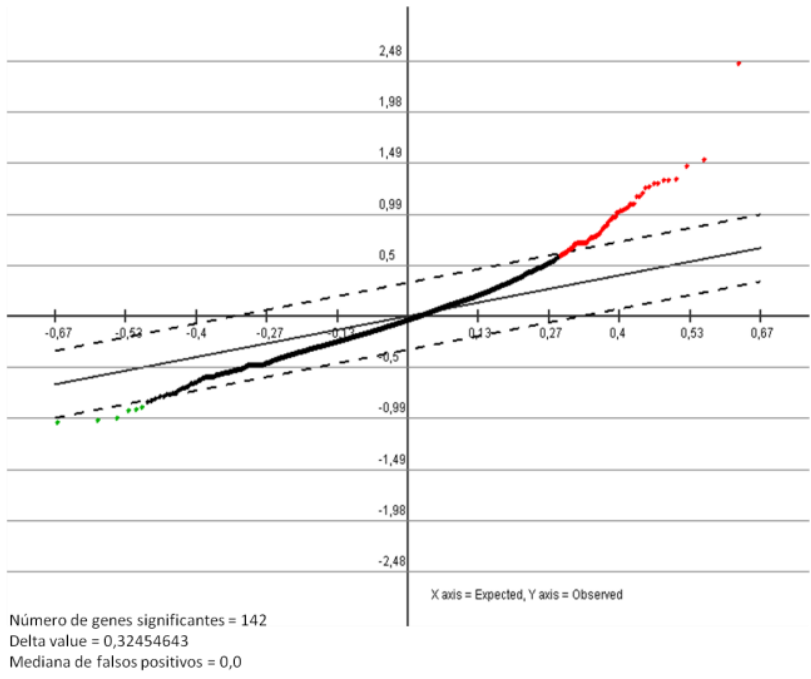

Figura 31 - Análise Large $e^{m y d-/}$ vs C57BL 21 dias. Gráfico gerados após a análise estatística SAM; 142 genes identificados

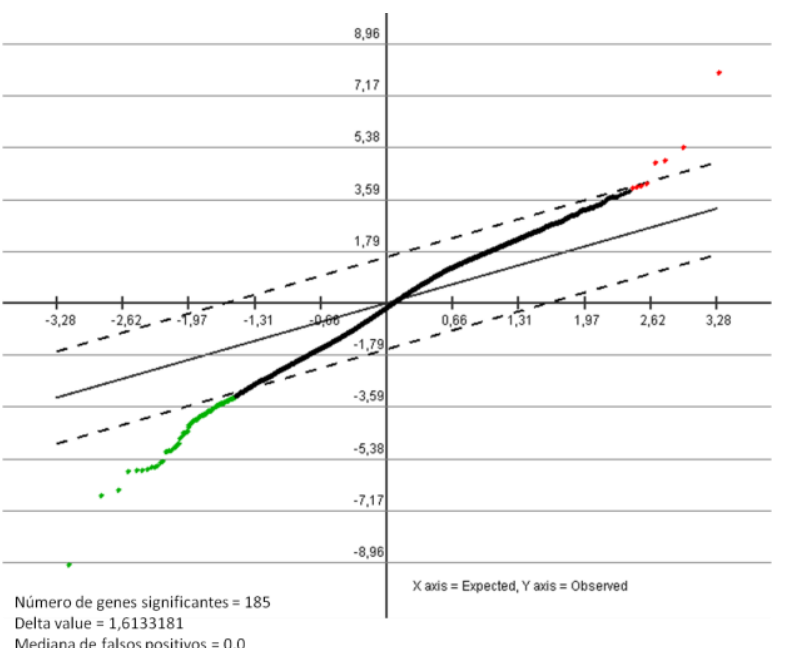

Mediana de falsos positivos $=0,0$

Figura 33 - Análise $D m d^{m d x} / \operatorname{Larg}^{m y d-/-}$ vs $D m d^{m d x} 21$ dias. Gráfico gerado após a análise estatística SAM; 185 genes identificados

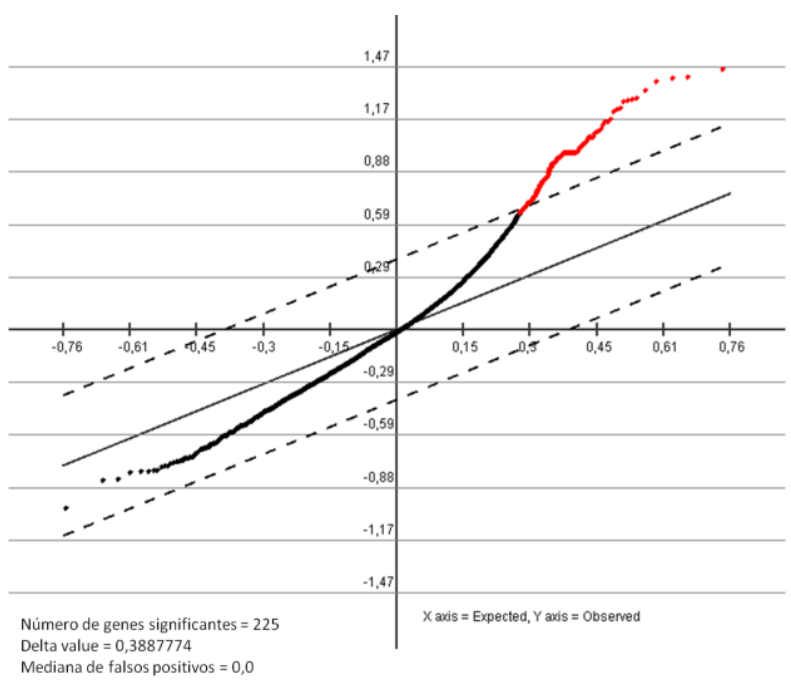

Figura 35 - Análise $D m d^{m d x}$ vs C57BL 3 meses. Gráfico gerados após a análise estatística SAM; 225 genes identificados 


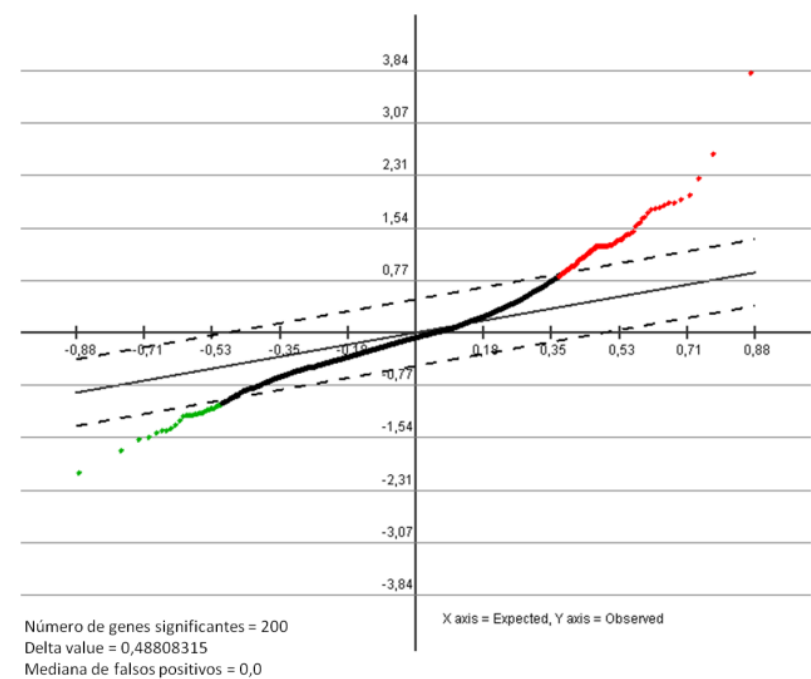

Figura 36 - Análise Large $e^{m y d-/}$ vs C57BL 3 meses. Gráfico gerado após a análise estatística SAM; 200 genes identificados

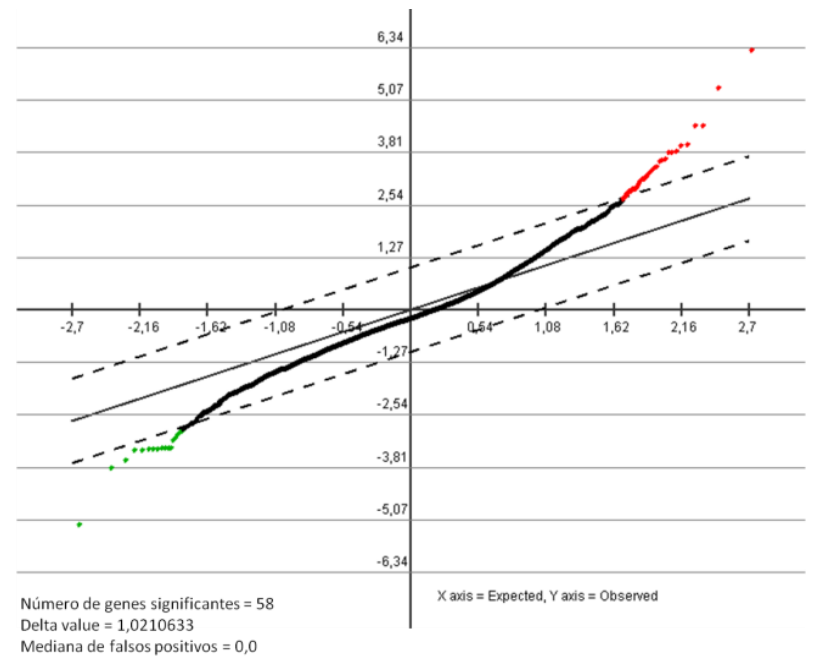

Figura 38 - Análise $D m d^{m d x} / \operatorname{Larg}^{m y d-/}$ vs $D m d^{m d x} 3$ meses. Gráfico gerado após a análise estatística SAM; 58 genes identificados

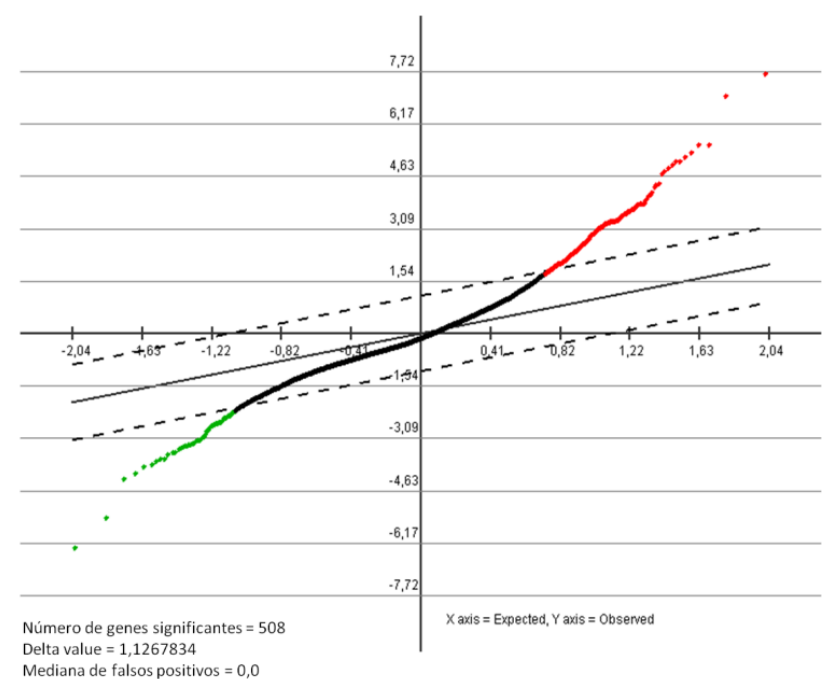

Figura 40 - Análise $D m d^{m d x}$ vs C57BL 6 meses. Gráfico gerados após a análise estatística SAM; 508 genes identificados

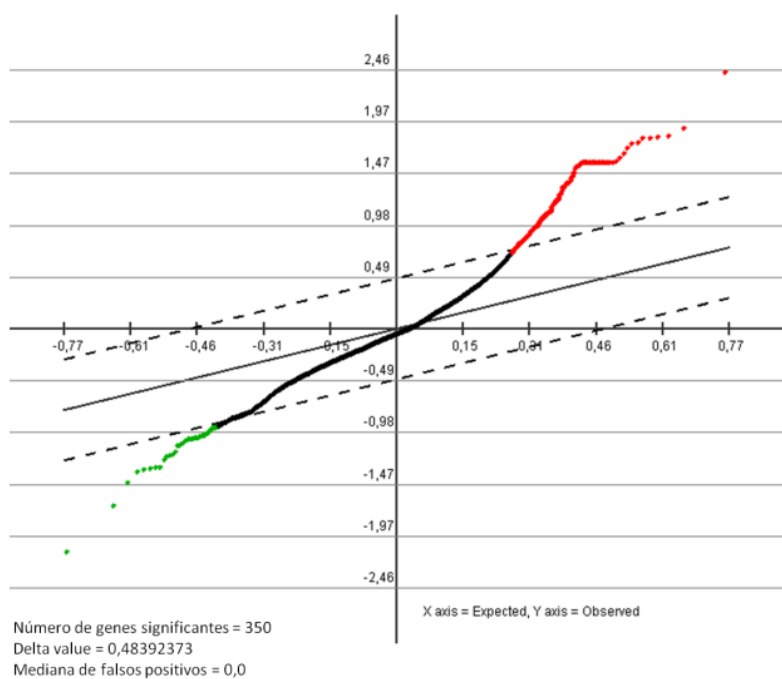

Figura 37 - Análise $D m d^{m d x} / \operatorname{Larg}^{m y d-/}$ vs C57BL 3 meses. Gráfico gerado após a análise estatística SAM; 350 genes identificados

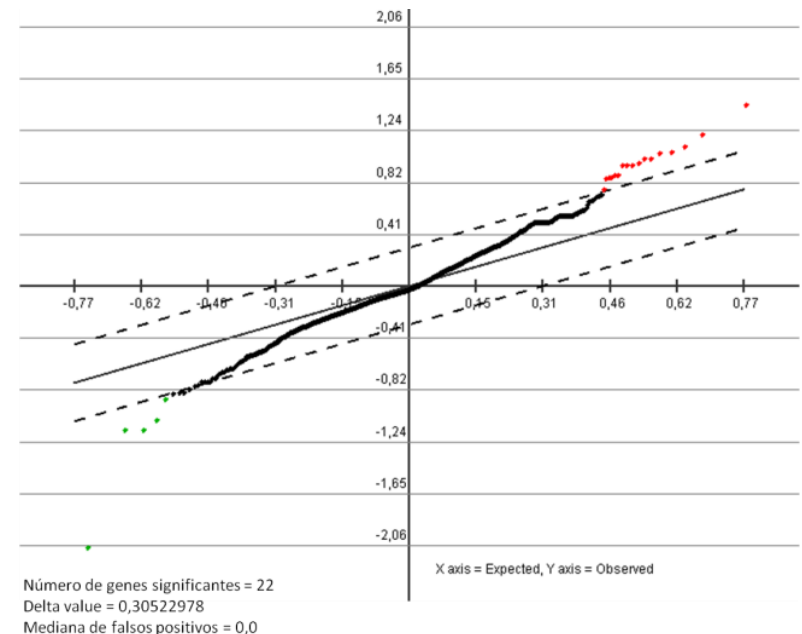

Figura 39 - Análise $D m d^{m d x} / \operatorname{Larg}^{m y d-/}$ vs $\operatorname{Larg}^{m y d-/} 3$ meses. Gráfico gerado após a análise estatística SAM; 22 genes identificados

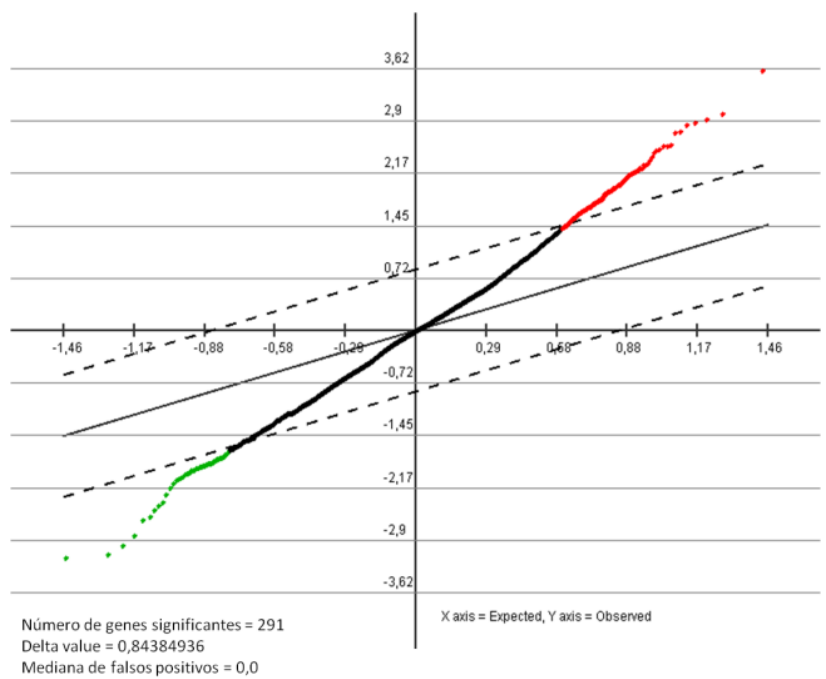

Figura 41 - Análise Large $e^{m y d-/}$ vs C57BL 6 meses. Gráfico gerado após a análise estatística SAM; 291 genes identificados 


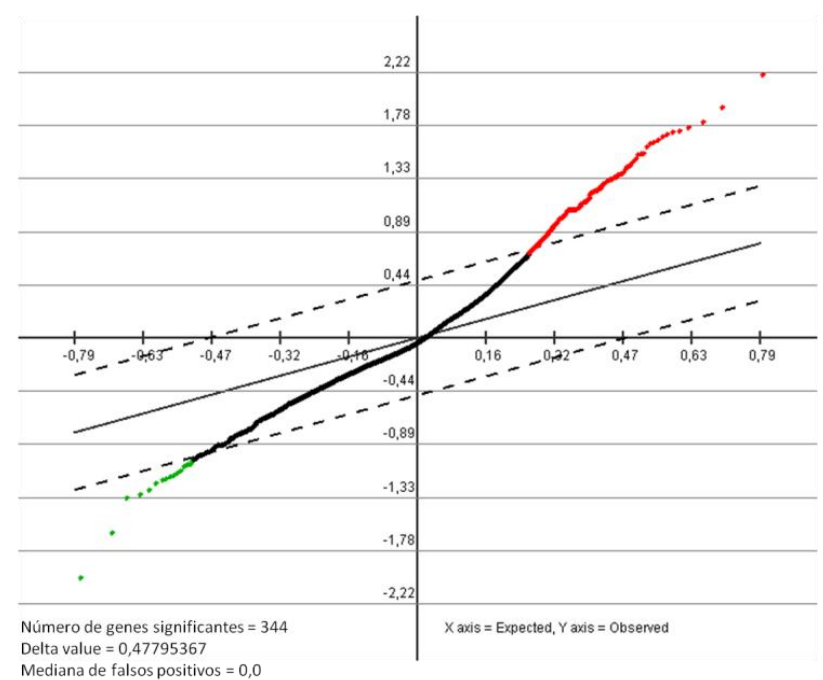

Figura 42 - Análise $D m d^{m d x} / L a r g e^{m y d-/}$ vs C57BL 3 meses. Gráfico gerado após a análise estatística SAM; 344 genes identificados

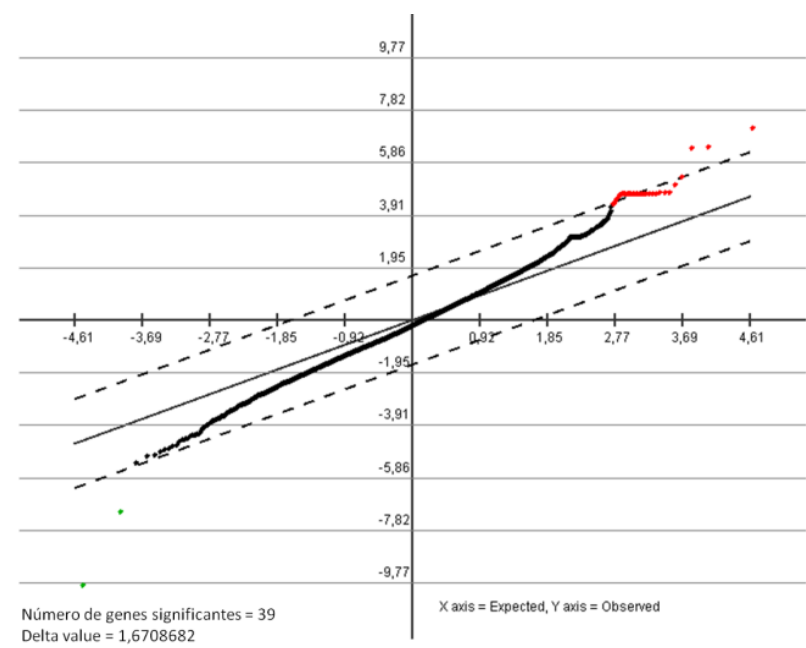

Delta value $=1,6708682$

Figura 44 - Análise $D m d^{m d x} / \operatorname{Larg}^{m y d-/-}$ vs $\operatorname{Large}^{m y d-/-} 6$ meses. Gráfico gerado após a análise estatística SAM; 39 genes identificados

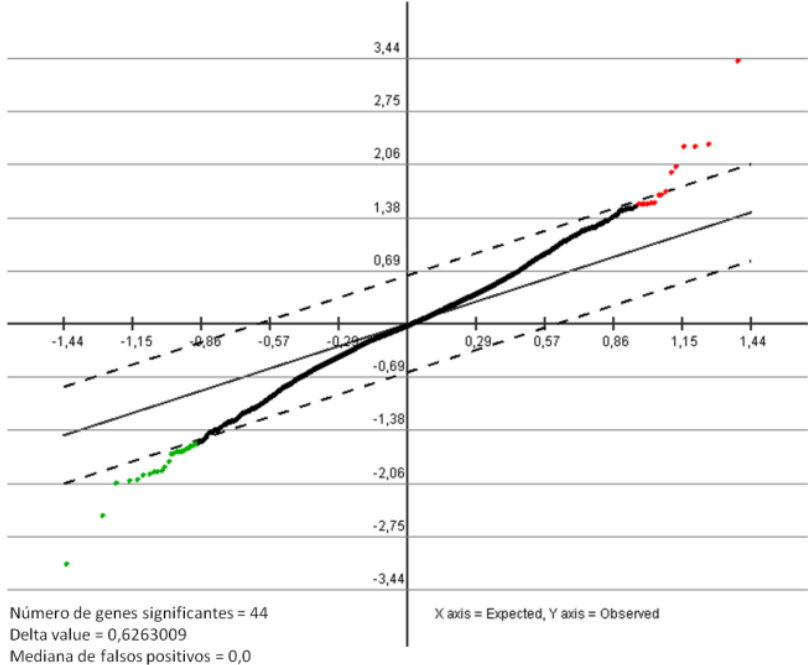

Figura 43 - Análise $D m d^{m d x} / \operatorname{Large}^{m y d-/}$ vs $D m d^{m d x} 6$ meses. Gráfico gerado após a análise estatística SAM; 44 genes identificados 
Na tabela abaixo (Tabela 20) estão reunidos os números de genes diferencialmente expressos (probes selecionadas pelo SAM) nas comparações com o controle, antes da anotação dos genes. As listas completas estão no Anexo A.

Tabela 20 - Totais de genes diferencialmente expressos em cada comparação e idade

\begin{tabular}{|c|c|c|c|}
\hline Comparações & 21 dias & 3 meses & 6 meses \\
\hline$D m d^{m d x} \times C 57 B L$ & 750 & 225 & 508 \\
\hline $\operatorname{Large}^{m y d-/-} \times C 57 B L$ & 142 & 200 & 291 \\
\hline$D m d^{m d x} /$ Large $^{m y d-/-} \times C 57 B L$ & 106 & 350 & 344 \\
\hline$D m d^{m d x} / \operatorname{Large}^{m y d-/-} x \operatorname{Dmd}^{m d x}$ & 185 & 58 & 44 \\
\hline$D m d^{m d x} /$ Large $e^{m y d-/-} x \operatorname{Larg}^{m y d-/-}$ & 36 & 22 & 39 \\
\hline
\end{tabular}

\subsection{Classificação dos genes quanto ao aumento ou redução da expressão (em relação ao controle)}

As listas de genes (com os respectivos valores de fold change em escala log2) de todos os pares foram então analisadas no programa IPA (Ingenuity Pathway Analysis Ingenuity ${ }^{\circledR}$ Systems, www.ingenuity.com), que faz a anotação dos genes conhecidos e análises funcionais, baseadas na literatura. Assim, genes repetidos, com função desconhecida ou apenas predita são eliminados das listas, reduzindo o número total de genes (Tabela 21 e Figura 45).

Tabela 21 - Totais de genes diferencialmente expressos após a anotação. Em vermelho, os genes superexpressos; em verde, os genes subexpressos

\begin{tabular}{|c|c|c|c|c|c|c|c|c|c|c|}
\hline Comparações & \multicolumn{3}{|c|}{21 dias } & \multicolumn{3}{|c|}{3 meses } & \multicolumn{3}{|c|}{6 meses } & Total* \\
\hline$D m d^{m d x} \times C 57 B L$ & 个651 & $\downarrow 18$ & 669 & 个209 & $\downarrow 0$ & 209 & 个399 & $\downarrow 69$ & 468 & 577 \\
\hline $\operatorname{Large}^{m y d-1-} \times C 57 B L$ & 个124 & 4 & 128 & 157 & 26 & 183 & 213 & 64 & 277 & 343 \\
\hline$D m d^{m d x} / L a r g e^{m y d-1-} \times C 57 B L$ & 个97 & $\downarrow 6$ & 103 & 个281 & $\downarrow 39$ & 320 & 个299 & $\downarrow 17$ & 316 & 376 \\
\hline
\end{tabular}

* Total de cada linhagem, excluindo-se os genes com fold change menores que $+/-1,0$.

Diagramas das figuras 54,55 e 56. 


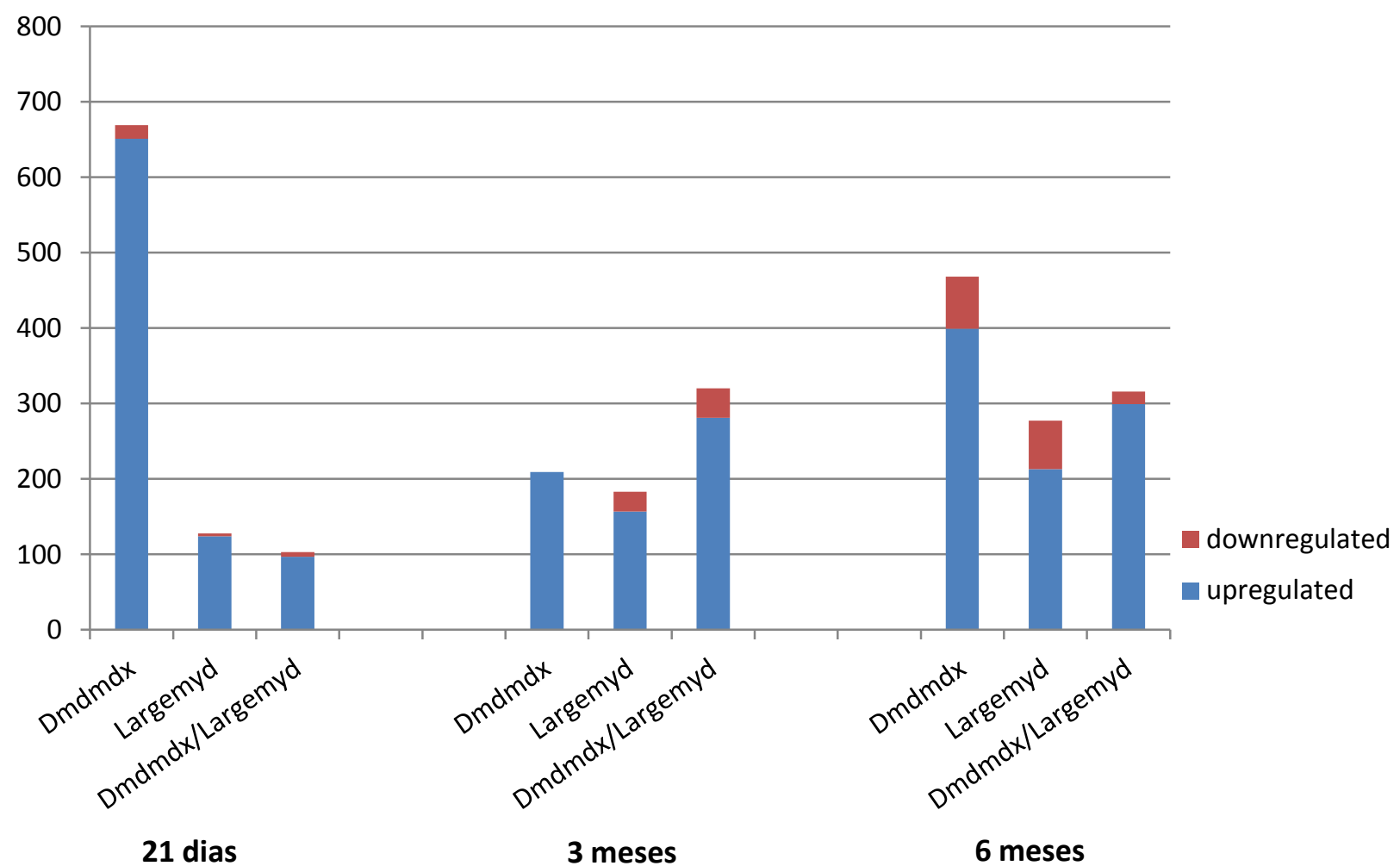

Figura 45 - Totais de genes diferencialmente expressos após a anotação

Em todas as comparações o número de genes superexpressos é bem maior que o número de genes subexpressos.

É notável que a linhagem $D m d^{m d x}$ com 21 dias apresente um número total de genes muito maior que as demais linhagens. Aos três meses de idade, o camundongo $D m d^{m d x}$ não apresentou nenhum gene subexpresso.

$\mathrm{Na}$ idade de 21 dias, a quantidade de genes diferencialmente expressos difere muito entre as linhagens: é muito maior nos animais com fenótipo mais brando ( $D m d^{m d x}$ 669 genes) do que naqueles com o fenótipo mais grave ( $D m d^{m d x} / \operatorname{Larg}^{m y d-\gamma}-103$ genes). Já nas idades de três e seis meses, as três linhagens apresentam quantidades de genes desregulados em quantidades mais próximas.

Nas linhagens $L a r g e^{m y d-/}$ e $D m d^{m d x} / L a r g e^{m y d-/}$ observa-se um aumento tanto do número total de genes como do número de genes superexpressos, com o avanço da idade.

\subsection{Genes diferencialmente expressos - análise de genes de tecido muscular}

Para aprofundar mais a análise, os dados foram submetidos a um filtro, determinando apenas genes com atividade já descrita no músculo esquelético, o que reduz o número de genes (Tabela 22 e Figura 46). 
Tabela 22 - Número de genes diferencialmente expressos com expressão no tecido muscular. Em vermelho, os genes superexpressos; em verde, os genes subexpressos

\begin{tabular}{lcccccccccc}
\hline Comparações & \multicolumn{3}{c}{ 21 dias } & \multicolumn{3}{c}{ 3 meses } & \multicolumn{3}{c}{6 meses } \\
\hline Dmd $^{m d x} \times C 57 B L$ & $\uparrow 190$ & $\downarrow 5$ & 195 & $\uparrow 70$ & $\downarrow 0$ & 70 & $\uparrow 107$ & $\downarrow 28$ & 135 \\
Large $^{m y d--} \times C 57 B L$ & $\uparrow 36$ & $\downarrow 3$ & 39 & $\uparrow 60$ & $\downarrow 13$ & 73 & $\uparrow 103$ & $\downarrow 46$ & 149 \\
Dmd $^{m d x} / L_{\text {Large }}^{m y d--}$ & $x$ C57BL & $\uparrow 27$ & $\downarrow 4$ & 31 & $\uparrow 116$ & $\downarrow 18$ & 134 & $\uparrow 130$ & $\downarrow 14$ & 144 \\
\hline
\end{tabular}

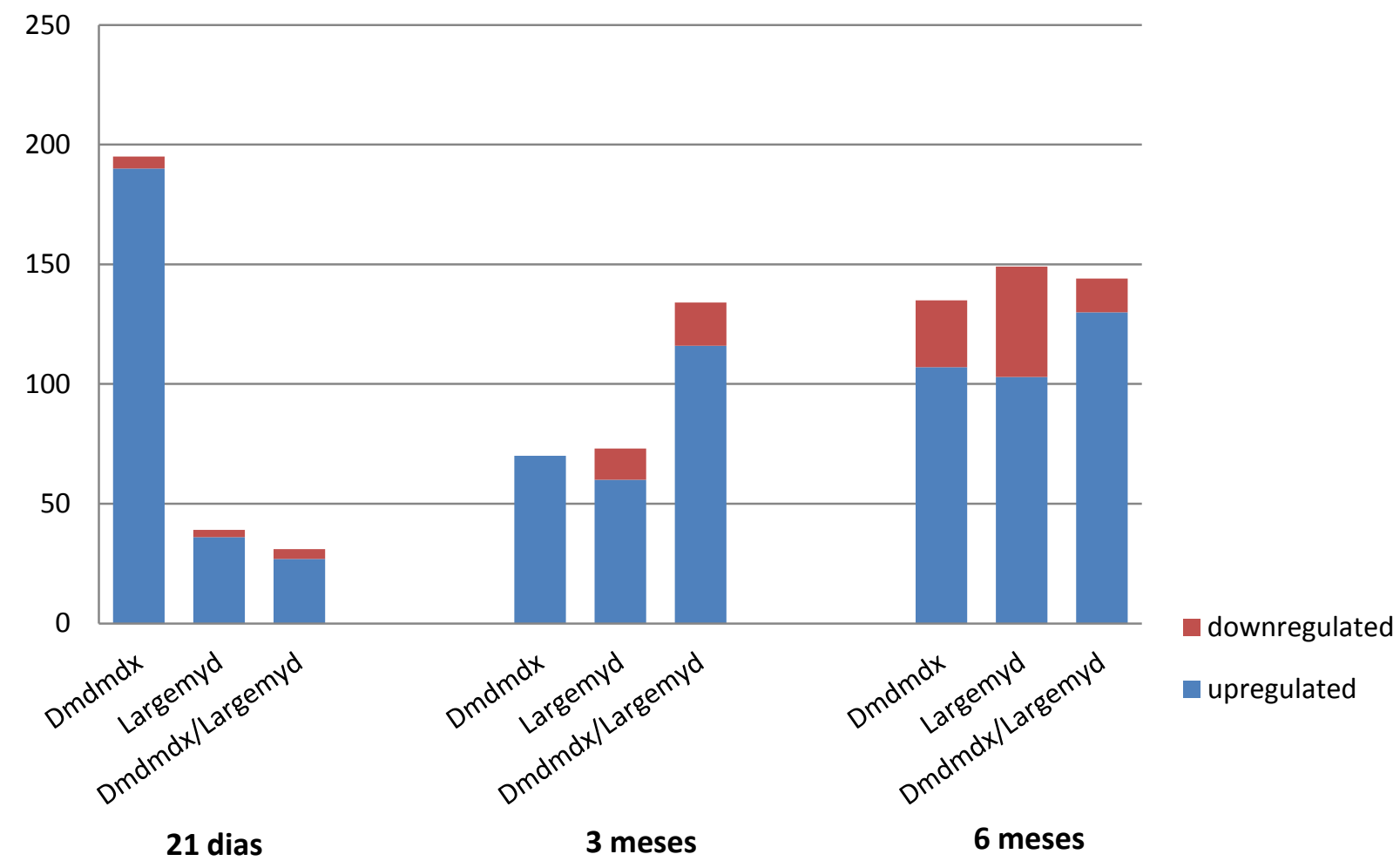

Figura 46 - Número de genes diferencialmente expressos no tecido muscular

A proporção desses genes selecionados em relação ao total de genes não filtrados foi calculada e está na tabela a seguir:

Tabela 23 - Proporção de genes do tecido muscular em relação ao total de genes

\begin{tabular}{|c|c|c|c|}
\hline Comparações & 21 dias & 3 meses & 6 meses \\
\hline$D m d^{m d x} \times C 57 B L$ & $29 \%$ & $33 \%$ & $29 \%$ \\
\hline $\operatorname{Large}^{m y d-/-} \times C 57 B L$ & $30 \%$ & $40 \%$ & $54 \%$ \\
\hline$D m d^{m d x} / L_{\text {Large }}^{m y d-/-} \times C 57 B L$ & $30 \%$ & $42 \%$ & $46 \%$ \\
\hline
\end{tabular}




\section{Caracterização do processo distrófico}

\subsection{Genes diferencialmente expressos em todos os modelos distróficos e em todas as idades}

As listas de genes diferencialmente expressos de todas as linhagens e idades foram sobrepostas, de forma que fosse possível identificar o conjunto de genes com padrão de expressão constante em relação à idade e/ou linhagem. A tabela 24 mostra o total de genes que tem expressão diferencial em todas as linhagens (comparadas com o controle) e em todas as idades (centro do diagrama ${ }^{1}$ da Figura 47); todos estão superexpressos.

Os diagramas de Venn mostram os genes diferencialmente expressos unicamente em cada uma das linhagens e os genes que são comuns a duas ou a três linhagens simultaneamente. $\mathrm{Na}$ interseção dos conjuntos estão os genes característicos do processo distrófico. As moléculas únicas em cada uma das linhagens seriam as candidatas às especificidades das linhagens.

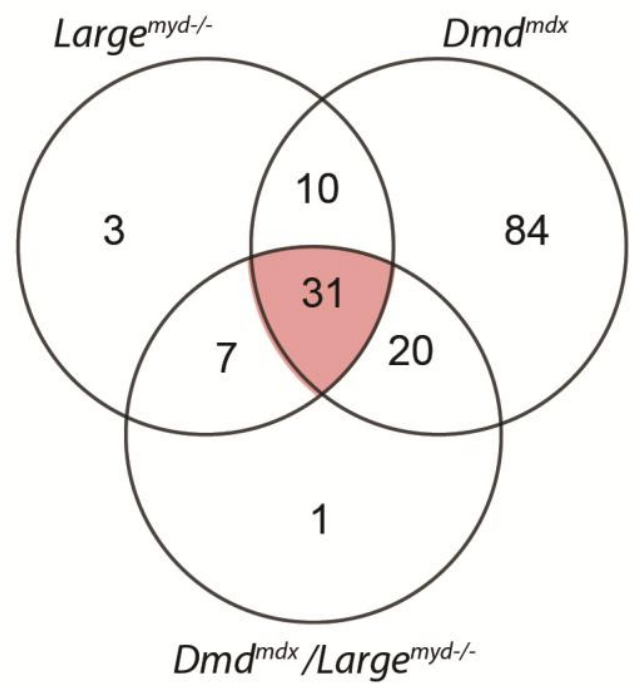

Figura 47 - Diagrama de Venn reunindo todos os genes diferencialmente expressos nas três idades de cada linhagem. No centro estão os genes compartilhados por todas as linhagens e idades

\footnotetext{
1 Observação: na construção dos diagramas de Venn e demais análises feitas no programa IPA são consideradas apenas os genes com valores de fold change maiores que $+1-1,0$. Como exemplo, para a linhagem Dmd ${ }^{\text {mdx }}$ de 21 dias (Figura 54), os iniciais 669 genes foram reduzidos para 491 $(268+14+145+64)$.
} 
Tabela 24 - 31 genes com expressão diferencial em todas as linhagens e idades

\begin{tabular}{ll}
\hline Símbolo & Entrez Gene Name \\
\hline ANKRD1 & ankyrin repeat domain 1 (cardiac muscle) \\
C1QB & complement component 1, q subcomponent, B chain \\
C3AR1 & complement component 3a receptor 1 \\
CcI6 & chemokine (C-C motif) ligand 6 \\
CCL7 & chemokine (C-C motif) ligand 7 \\
CcI9 & chemokine (C-C motif) ligand 9 \\
CD68 & CD68 molecule \\
CTSS & cathepsin S \\
DPEP2 & dipeptidase 2 \\
Gp49a/Lilrb4 & leukocyte immunoglobulin-like receptor, subfamily B, member 4 \\
GPNMB & glycoprotein (transmembrane) nmb \\
LGALS3 & lectin, galactoside-binding, soluble, 3 \\
LGMN & legumain \\
\hline MMP12 & matrix metallopeptidase 12 (macrophage elastase) \\
MPEG1 & macrophage expressed 1 \\
MS4A7 & membrane-spanning 4-domains, subfamily A, member 7 \\
MS4A4A & membrane-spanning 4-domains, subfamily A, member 4A \\
MS4A6A & membrane-spanning 4-domains, subfamily A, member 6A \\
MS4a6c & membrane-spanning 4-domains, subfamily A, member 6C \\
MSR1 & macrophage scavenger receptor 1 \\
MT1H & metallothionein 1H \\
MYH3 & myosin, heavy chain 3, skeletal muscle, embryonic \\
MYL4 & myosin, light chain 4, alkali; atrial, embryonic \\
PCBD1 & pterin-4 alpha-carbinolamine dehydratase/dimerization cofactor of hepatocyte nuclear \\
& factor 1 alpha \\
\hline S100A4 & S100 calcium binding protein A4 \\
SERPINA3 & serpin peptidase inhibitor, clade A (alpha-1 antiproteinase, antitrypsin), member 3 \\
TIMP1 & TIMP metallopeptidase inhibitor 1 \\
TMEM8C & transmembrane protein 8C \\
TNNT2 & troponin T type 2 (cardiac) \\
TUBB6 & tubulin, beta 6 class V \\
Wfdc17 & WAP four-disulfide core domain 17 \\
\hline & \\
\hline
\end{tabular}




\subsection{Genes diferencialmente expressos em cada idade - Efeito da idade}

Nos diagramas das Figuras 48, 49 e 50 estão representados os genes que são compartilhados por todas as linhagens em cada uma das idades estudadas. As áreas coloridas mostram os genes compartilhados especificamente em cada idade e em seguida os genes particulares (áreas hachuradas) são listados nas tabelas 25 a 27.

\section{1 dias}

A

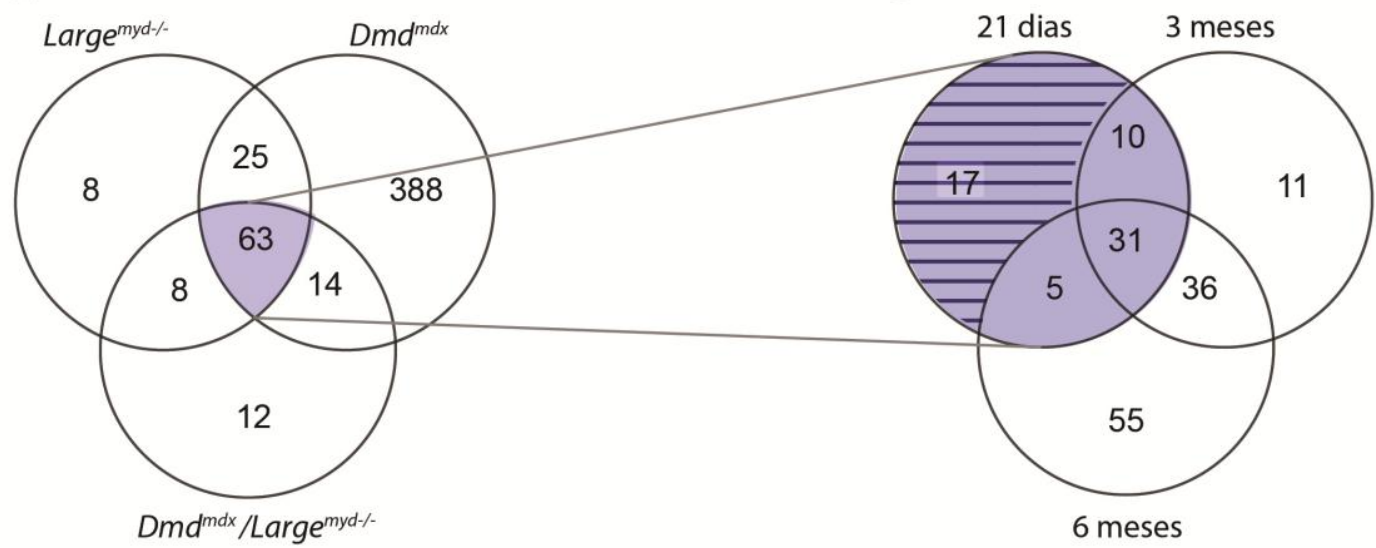

Figura 48 - A: diagrama de Venn reunindo os genes diferencialmente expressos nas três linhagens com 21 dias. No centro estão os 63 genes compartilhados por todas as linhagens nessa idade. B: genes comuns a cada uma das idades; na área hachurada estão destacados os 17 genes com expressão diferencial em todas as linhagens somente na idade de 21 dias

Tabela 25 - 17 genes com expressão diferencial em todas as linhagens somente na idade de 21 dias

\begin{tabular}{ll}
\hline Símbolo & Entrez Gene Name \\
\hline AKR1E2 & aldo-keto reductase family 1, member E2 \\
\hline BAIAP2L1 & BAI1-associated protein 2-like 1 \\
CCNA2 & cyclin A2 \\
Ccnb1/Gm5593 & cyclin B1 \\
CDKN1A & cyclin-dependent kinase inhibitor 1A (p21, Cip1) \\
CLEC4D & C-type lectin domain family 4, member D \\
CYBB & cytochrome b-245, beta polypeptide \\
FCER1G & Fc fragment of IgE, high affinity I, receptor for; gamma polypeptide \\
IGSF6 & immunoglobulin superfamily, member 6 \\
ITGAM & integrin, alpha M (complement component 3 receptor 3 subunit) \\
Milr1 & mast cell immunoglobulin like receptor 1 \\
MYH8 & myosin, heavy chain 8, skeletal muscle, perinatal \\
PLEK & pleckstrin \\
PRG4 & proteoglycan 4 \\
R3HDML & R3H domain containing-like \\
SPP1 & secreted phosphoprotein 1 \\
VSIG4 & V-set and immunoglobulin domain containing 4 \\
\hline *Todos SuperexpresSOS
\end{tabular}

*Todos superexpressos 


\section{3 meses}

A

B

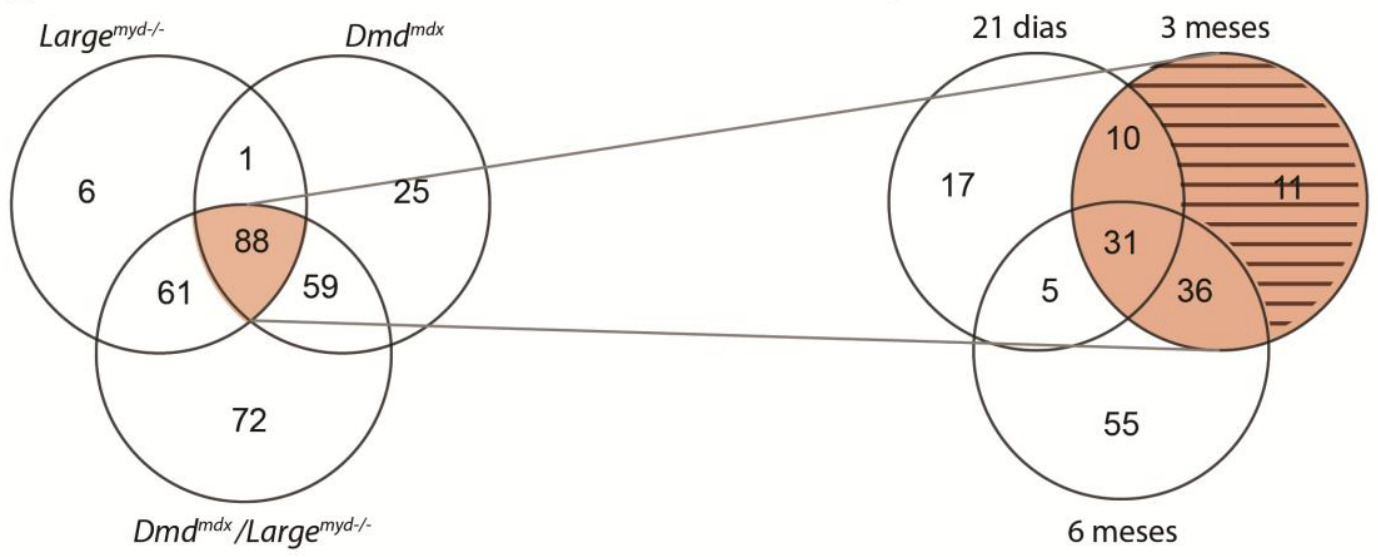

Figura 49 - A: diagrama de Venn reunindo os genes diferencialmente expressos nas três linhagens com 3 meses. No centro estão os 88 genes compartilhados por todas as linhagens nessa idade. B: genes comuns a cada uma das idades; na área hachurada estão destacados os 11 genes com expressão diferencial em todas as linhagens somente na idade de 3 meses

Tabela 26 - 11 genes com expressão diferencial em todas as linhagens somente na idade de 3 meses

\begin{tabular}{ll}
\hline Símbolo & Entrez Gene Name \\
\hline 5430435G22Rik & RIKEN CDNA 5430435G22 gene \\
CAPN6 & calpain 6 \\
\hline CCDC141 & coiled-coil domain containing 141 \\
CLEC7A & C-type lectin domain family 7, member A \\
DCLK1 & doublecortin-like kinase 1 \\
FABP5 & fatty acid binding protein 5 (psoriasis-associated) \\
PEG3 & paternally expressed 3 \\
RGS1 & regulator of G-protein signaling 1 \\
SLC11A1 & solute carrier family 11 (proton-coupled divalent metal ion transporter), member 1 \\
Snord116 & small nucleolar RNA, C/D box 116 \\
TUBB2B & tubulin, beta 2B class IIb \\
\hline *Todos superexpressos
\end{tabular}




\section{6 meses}

A

B

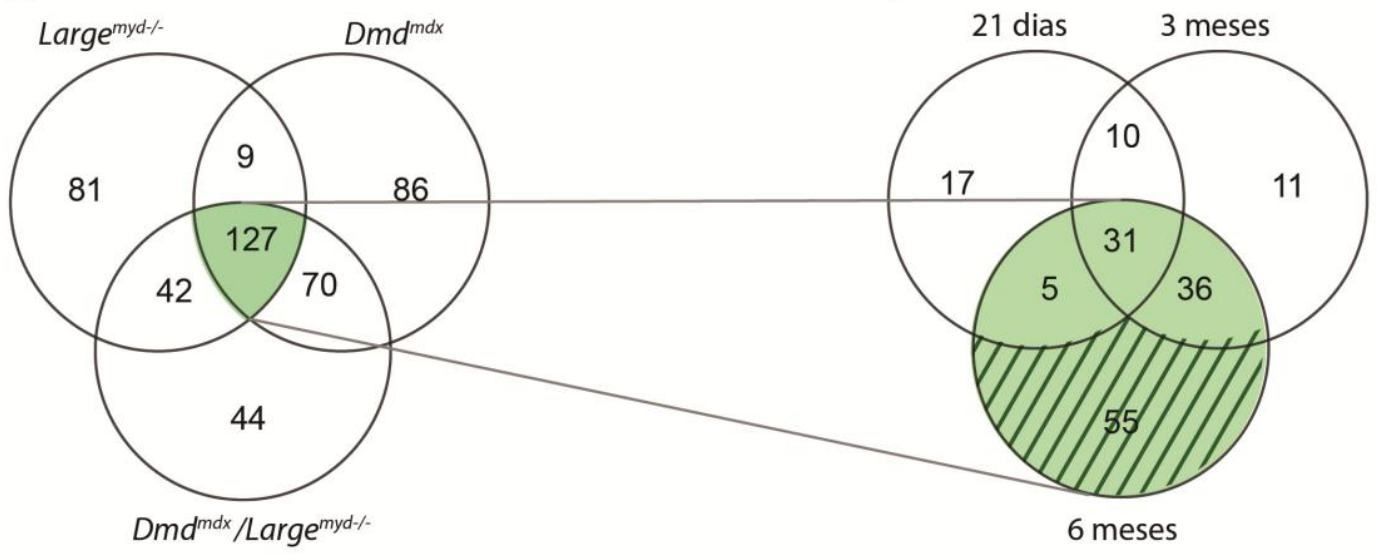

Figura 50 - A: diagrama de Venn reunindo os genes diferencialmente expressos nas três linhagens com 6 meses. No centro estão os 127 genes compartilhados por todas as linhagens nessa idade. B: genes comuns a cada uma das idades; na área hachurada estão destacados os 55 genes com expressão diferencial em todas as linhagens somente na idade de 6 meses

Tabela 27 - 55 genes com expressão diferencial em todas as linhagens somente na idade de 6 meses

\begin{tabular}{|c|c|}
\hline Símbolo & Entrez Gene Name \\
\hline ANPEP & alanyl (membrane) aminopeptidase \\
\hline ANXA4 & annexin A4 \\
\hline ASB2 & ankyrin repeat and SOCS box containing 2 \\
\hline ASB4 & ankyrin repeat and SOCS box containing 4 \\
\hline C14orf37 & chromosome 14 open reading frame 37 \\
\hline CAPG & capping protein (actin filament), gelsolin-like \\
\hline CD48 & CD48 molecule \\
\hline CD53 & CD53 molecule \\
\hline CD300LD & CD300 molecule-like family member $d$ \\
\hline CFB & complement factor B \\
\hline CILP & cartilage intermediate layer protein, nucleotide pyrophosphohydrolase \\
\hline Clec4a1 & C-type lectin domain family 4 , member a1 \\
\hline COL3A1 & collagen, type III, alpha 1 \\
\hline COL6A3 & collagen, type VI, alpha 3 \\
\hline COL8A1 & collagen, type VIII, alpha 1 \\
\hline CSF1R & colony stimulating factor 1 receptor \\
\hline CSF2RB & $\begin{array}{l}\text { colony stimulating factor } 2 \text { receptor, beta, low-affinity (granulocyte- } \\
\text { macrophage) }\end{array}$ \\
\hline CTSH & cathepsin $\mathrm{H}$ \\
\hline CYP4F22 & cytochrome P450, family 4, subfamily F, polypeptide 22 \\
\hline CYTH4 & cytohesin 4 \\
\hline DAB2 & Dab, mitogen-responsive phosphoprotein, homolog 2 (Drosophila) \\
\hline EMB & embigin \\
\hline FBLN7 & fibulin 7 \\
\hline Fcrls & Fc receptor-like S, scavenger receptor \\
\hline GRN & granulin \\
\hline HGF & hepatocyte growth factor (hepapoietin A; scatter factor) \\
\hline HLA-DQB1 & major histocompatibility complex, class II, DQ beta 1 \\
\hline HLA-DRB1 & major histocompatibility complex, class II, DR beta 1 \\
\hline
\end{tabular}




\begin{tabular}{|c|c|}
\hline HPSE & heparanase \\
\hline HS3ST5 & heparan sulfate (glucosamine) 3-O-sulfotransferase 5 \\
\hline $\begin{array}{l}\text { Ifi2 } 204 \text { (includes } \\
\text { others) }\end{array}$ & interferon activated gene 204 \\
\hline LAYN & layilin \\
\hline LCP1 & lymphocyte cytosolic protein 1 (L-plastin) \\
\hline LOX & lysyl oxidase \\
\hline METTL11B & methyltransferase like $11 \mathrm{~B}$ \\
\hline MRC1 & mannose receptor, C type 1 \\
\hline Ms4a6b & membrane-spanning 4-domains, subfamily $\mathrm{A}$, member $6 \mathrm{~B}$ \\
\hline MSTN & myostatin \\
\hline MT1E & metallothionein $1 \mathrm{E}$ \\
\hline MY05A & myosin VA (heavy chain 12 , myoxin) \\
\hline NCKAP1L & NCK-associated protein 1-like \\
\hline Nxpe5 & neurexophilin and PC-esterase domain family, member 5 \\
\hline OSTN & osteocrin \\
\hline PDPN & podoplanin \\
\hline PLD4 & phospholipase $\mathrm{D}$ family, member 4 \\
\hline PLTP & phospholipid transfer protein \\
\hline PLXNB2 & plexin B2 \\
\hline PTPRC & protein tyrosine phosphatase, receptor type, C \\
\hline RGS10 & regulator of G-protein signaling 10 \\
\hline SFRP1 & secreted frizzled-related protein 1 \\
\hline SLC9A9 & $\begin{array}{l}\text { solute carrier family } 9 \text {, subfamily A (NHE9, cation proton antiporter 9), member } \\
9\end{array}$ \\
\hline STAB1 & stabilin 1 \\
\hline TLR1 & toll-like receptor 1 \\
\hline TMEM176B & transmembrane protein 176B \\
\hline UNC93B1 & unc-93 homolog B1 (C. elegans) \\
\hline
\end{tabular}




\subsection{Classificação funcional}

Genes coexpressos tem maior probabilidade de participarem de um mesmo processo biológico e serem regulados por um mesmo promotor (Allocco, Kohane e Butte, 2004); assim, o agrupamento desses genes e a análise das funções por eles desempenhadas são úteis na identificação das funções e processos biológicos que estão desregulados no tecido estudado.

\subsubsection{Análise de vias enriquecidas}

Os genes diferencialmente expressos, em relação ao animal controle, foram avaliados quanto às vias biológicas que pudessem estar enriquecidas. Essa análise foi feita no programa Expander, utilizando-se o total de genes, com a ferramenta que identifica as vias biológicas do banco de dados Kegg Pathways mais significantes.

\section{Animais jovens - 21 dias}

A análise dos 669 genes diferencialmente expressos nos animais $D m d^{m d x}$ com 21 dias de idade mostraram o enriquecimento majoritário de vias relacionadas com o sistema imunológico (Tabela 28). Destacam-se também as vias "Cell cycle", "p53 signaling pathway" e "DNA replication", o que indica que há a ativação da proliferação celular.

A via "Lysosome" foi a mais significativa de todas, o que pode ter relação com a degradação proteica devido à degeneração do tecido.

Tabela 28 - Vias biológicas $D m d^{m d x}$ vs C57BL 21 dias

\begin{tabular}{|c|c|c|c|c|}
\hline Enriquecido com & \#genes & $\begin{array}{l}\text { p-value } \\
\text { bruto }\end{array}$ & $\begin{array}{l}\text { p-value } \\
\text { corrigido }\end{array}$ & Lista de genes \\
\hline Lysosome & 26 & $4.44 \mathrm{E}-19$ & $5.55 \mathrm{E}-17$ & $\begin{array}{l}\text { [Ctsb, Hexb, Hexa, Ctsc, Ctsh, Galns, } \\
\text { Pla2g15, Galc, Ctss, Cd63, Asah1, Ctsz, } \\
\text { Laptm5, Glb1, Lgmn, Tcirg1, Lipa, } \\
\text { Slc11a1, Gusb, Cd68, Ppt1, Psap, } \\
\text { Man2b1, Gla, Atp6v0d2, Fuca1] }\end{array}$ \\
\hline Chemokine signaling pathway & 25 & $2.99 \mathrm{E}-13$ & $6.21 \mathrm{E}-11$ & $\begin{array}{l}\text { [Pik3r5, Arrb2, Cxcl10, Ccr5, Ccr3, Ccr2, } \\
\text { Dock2, Cx3cr1, Vav1, Pf4, Ccl3, Ccl2, } \\
\text { Ppbp, Ncf1, Ccr1, Ccl9, Ccl8, Pik3cg, } \\
\text { Cxcl9, Fgr, Hck, Ccl7, Cxcl16, Prkcd, } \\
\text { Ccl6] }\end{array}$ \\
\hline $\begin{array}{l}\text { Cytokine-cytokine receptor } \\
\text { interaction }\end{array}$ & 27 & 7.94E-12 & 2.03E-09 & $\begin{array}{l}\text { [Csf1r, II13ra1, Csf3r, Pdgfc, Tnfrsf1b, } \\
\text { Cx3cr1, Ccl3, Ccl2, Ppbp, Ccr1, Ccl9, } \\
\text { Ccl8, Ccl7, Cxcl16, Ccl6, Csf2ra, Cxcl10, } \\
\text { Ccr5, Ccr3, Ccr2, Csf2rb, Pf4, Hgf, ॥7r, } \\
\text { Cxc19, ॥110ra, Tnfrsf11a] }\end{array}$ \\
\hline
\end{tabular}




\begin{tabular}{|c|c|c|c|c|}
\hline Systemic lupus erythematosus & 21 & $2.69 \mathrm{E}-11$ & 4.95E-09 & $\begin{array}{l}\text { [Hist1h2ab, Hist1h3a, Fcgr2b, } \\
\text { Hist1h2bb, Hist1h2af, C1qa, C1qb, } \\
\text { Hist1h3g, Hist2h3b, Hist2h2bb, } \\
\text { Hist1h2ap, H2-Ab1, C1qc, H2-Aa, } \\
\text { Hist2h3c1, H2-Eb1, Fcgr4, Hist1h2ak, } \\
\text { Fcgr1, Fcgr3, Hist1h2an] }\end{array}$ \\
\hline $\begin{array}{l}\text { Toll-like receptor signaling } \\
\text { pathway }\end{array}$ & 15 & 5.35E-09 & $5.67 \mathrm{E}-07$ & $\begin{array}{l}\text { [Pik3r5, Cxcl10, Cd14, Irf5, Irf7, Tlr1, } \\
\text { Myd88, Tlr6, Tlr7, Tlr8, Ccl3, Pik3cg, } \\
\text { Cxcl9, Ticam2, Spp1] }\end{array}$ \\
\hline Other glycan degradation & 7 & $2.35 \mathrm{E}-08$ & $4.22 \mathrm{E}-07$ & $\begin{array}{l}\text { [Hexb, Hexa, Man2b2, Man2b1, Fuca2, } \\
\text { Fuca1, Glb1] }\end{array}$ \\
\hline Cell cycle & 16 & $2.72 \mathrm{E}-08$ & $3.81 \mathrm{E}-06$ & $\begin{array}{l}\text { [Ccne1, Cdk1, Mad2l1, Plk1, Cdkn1a, } \\
\text { Cdk6, Ccnb1, Ccna2, Mcm4, Ccnb2, } \\
\text { Mcm6, Bub1b, Pcna, Bub1, Chek1, } \\
\text { Dbf4] }\end{array}$ \\
\hline $\begin{array}{l}\text { Complement and coagulation } \\
\text { cascades }\end{array}$ & 12 & $8.70 \mathrm{E}-08$ & $6.70 \mathrm{E}-06$ & $\begin{array}{l}\text { [Pros1, C3ar1, Serpine1, C5ar1, F10, F5, } \\
\text { C1qc, C1qa, C1qb, F7, F13a1, Cfb] }\end{array}$ \\
\hline p53 signaling pathway & 11 & $3.12 \mathrm{E}-07$ & $2.43 \mathrm{E}-05$ & $\begin{array}{l}\text { [Ccne1, Cdk1, Serpine1, Thbs1, Casp3, } \\
\text { Rrm2, Chek1, Cdkn1a, Cdk6, Ccnb1, } \\
\text { Ccnb2] }\end{array}$ \\
\hline Hematopoietic cell lineage & 12 & $3.14 \mathrm{E}-07$ & $2.77 \mathrm{E}-05$ & $\begin{array}{l}\text { [Csf2ra, Csf1r, Csf3r, Cd14, Itga4, II7r, } \\
\text { H2-Eb1, Cd44, Itgam, Fcgr1, Cd33, } \\
\text { Anpep] }\end{array}$ \\
\hline $\begin{array}{l}\text { Natural killer cell mediated } \\
\text { cytotoxicity }\end{array}$ & 14 & 8.67E-07 & $1.15 \mathrm{E}-04$ & $\begin{array}{l}\text { [Pik3r5, Casp3, Sh2d1b1, H2-D1, } \\
\text { Sh3bp2, Vav1, Cd48, Fcer1g, Tyrobp, } \\
\text { Lcp2, Fcgr4, Itgb2, Pik3cg, Fcgr3] }\end{array}$ \\
\hline $\begin{array}{l}\text { Fc gamma R-mediated } \\
\text { phagocytosis }\end{array}$ & 12 & 1.09E-06 & $1.16 \mathrm{E}-04$ & $\begin{array}{l}\text { [Fcgr2b, Pik3r5, Ppap2c, Ncf1, Ptprc, } \\
\text { Dock2, Pik3cg, Fcgr1, Inpp5d, Vav1, } \\
\text { Hck, Prkcd] }\end{array}$ \\
\hline Sphingolipid metabolism & 8 & 2.19E-06 & $9.87 \mathrm{E}-05$ & $\begin{array}{l}\text { [Acer3, B4galt6, Ppap2c, Asah1, Sgpl1, } \\
\text { Gla, Galc, Glb1] }\end{array}$ \\
\hline Metabolic pathways & 49 & $6.29 \mathrm{E}-06$ & 0.0079 & $\begin{array}{l}\text { [Aldh1a2, Sat1, Pole2, Hexb, Prim1, } \\
\text { Hexa, Galns, Gatm, Akr1e1, Rrm2, Gda, } \\
\text { Alox15, Galc, Eno1, Arg1, Gnpda1, Bst1, } \\
\text { Tyms, Cbr2, Asah1, Sgpl1, Anpep, } \\
\text { Atp6v1a, Pgd, Glb1, B4galt6, Hk3, } \\
\text { Tcirg1, G6pdx, Ppap2c, Cyp4f18, } \\
\text { Bcl2a1b, P4ha3, Pla2g7, Tbxas1, Ada, } \\
\text { Aldh9a1, Akr1b8, Hpgds, Psat1, Gusb, } \\
\text { Hsd17b12, Asns, Pgam1, Hpse, } \\
\text { Aldh3b1, Ppt1, Ugt1a9, Atp6v0d2] }\end{array}$ \\
\hline Cell adhesion molecules (CAMs) & 14 & $6.31 \mathrm{E}-06$ & 0.00107 & $\begin{array}{l}\text { [Ncam1, H2-Ab1, Itga4, Ptprc, Vcan, H2- } \\
\text { Aa, Alcam, H2-D1, H2-Eb1, Itgb2, Cdh2, } \\
\text { Selplg, Itgam, Siglec1] }\end{array}$ \\
\hline Glycosaminoglycan degradation & 6 & 8.19E-06 & $2.05 \mathrm{E}-04$ & [Hexb, Gusb, Hexa, Hpse, Galns, Glb1] \\
\hline $\begin{array}{l}\text { Amino sugar and nucleotide } \\
\text { sugar metabolism }\end{array}$ & 7 & $4.60 \mathrm{E}-05$ & 0.00212 & $\begin{array}{l}\text { [Hk3, Gnpda1, Npl, Hexb, Hexa, Renbp, } \\
\text { Nagk] }\end{array}$ \\
\hline DNA replication & 6 & $1.05 \mathrm{E}-04$ & 0.004 & $\begin{array}{l}\text { [Dna2, Pole2, Prim1, Pcna, Mcm4, } \\
\text { Mcm6] }\end{array}$ \\
\hline $\begin{array}{l}\text { Leukocyte transendothelial } \\
\text { migration }\end{array}$ & 10 & $3.11 \mathrm{E}-04$ & 0.0388 & $\begin{array}{l}\text { [Pik3r5, Ncf2, Ncf1, Itga4, Itgb2, Pik3cg, } \\
\text { Itgam, Cyba, Vav1, Cybb] }\end{array}$ \\
\hline B cell receptor signaling pathway & 8 & $3.21 \mathrm{E}-04$ & 0.028 & $\begin{array}{l}\text { [Fcgr2b, Pik3r5, Btk, Pik3cg, Pik3ap1, } \\
\text { Inpp5d, Vav1, Lilrb3] }\end{array}$ \\
\hline Fc epsilon RI signaling pathway & 8 & $4.16 \mathrm{E}-04$ & 0.0362 & $\begin{array}{l}\text { [Pik3r5, Fcer1g, Btk, Lcp2, Pik3cg, } \\
\text { Inpp5d, Vav1, Prkcd] }\end{array}$ \\
\hline
\end{tabular}




\begin{tabular}{|c|c|c|c|c|}
\hline ECM-receptor interaction & 8 & $4.52 \mathrm{E}-04$ & 0.0389 & $\begin{array}{l}\text { [Hmmr, Thbs1, Fn1, Npnt, Itga4, Cd44, } \\
\text { Tnc, Spp1] }\end{array}$ \\
\hline Primary immunodeficiency & 5 & 0.00109 & 0.0427 & [Dclre1c, Ptprc, Btk, Ada, II7r] \\
\hline
\end{tabular}

As linhagens Large $e^{m y d-/-}(128 \mathrm{GDEs})$ e $D m d^{m d x} / \operatorname{Larg}^{m y d-/}$ (103 GDEs) também apresentam enriquecimento de vias do sistema imunológico (Tabelas 29 e 30).

Tabela 29 - Vias biológicas Large $e^{m y d-/-}$ vs C57BL 21 dias

\begin{tabular}{|c|c|c|c|c|}
\hline Enriquecido com & \#genes & $\begin{array}{l}\text { p-value } \\
\text { bruto }\end{array}$ & $\begin{array}{l}\text { p-value } \\
\text { corrigido }\end{array}$ & Lista de genes \\
\hline $\begin{array}{l}\text { Cytokine-cytokine receptor } \\
\text { interaction }\end{array}$ & 8 & $3.98 \mathrm{E}-06$ & 0.00101 & $\begin{array}{l}{[\mathrm{Ccl} 3, \mathrm{Ccl} 2, \mathrm{Cxcl} 10, \mathrm{Ccl} 9, \mathrm{II} 7 \mathrm{r}, \mathrm{Ccl} 8, \mathrm{Ccl} 7,} \\
\mathrm{Ccl} 6]\end{array}$ \\
\hline Chemokine signaling pathway & 7 & $5.44 \mathrm{E}-06$ & 0.00113 & $\begin{array}{l}{[\mathrm{Ccl} 3, \mathrm{Ccl} 2, \mathrm{Cxcl} 10, \mathrm{Ccl} 9, \mathrm{Ccl} 8, \mathrm{Ccl} 7,} \\
\mathrm{Ccl} 6]\end{array}$ \\
\hline $\begin{array}{l}\text { Antigen processing and } \\
\text { presentation }\end{array}$ & 4 & $3.81 \mathrm{E}-04$ & 0.04 & [Lgmn, Ctss, H2-Aa] \\
\hline Asthma & 3 & 1.09E-04 & 0.00394 & [Fcer1g, H2-Aa] \\
\hline
\end{tabular}

Tabela 30 - Vias biológicas Dmd ${ }^{m d x} /$ Large $^{m y d-/-}$ vs C57BL 21 dias

\begin{tabular}{lcccl}
\hline Enriquecido com & \#genes & $\begin{array}{l}\text { p-value } \\
\text { bruto }\end{array}$ & $\begin{array}{l}\text { p-value } \\
\text { corrigido }\end{array}$ & Lista de genes \\
\hline $\begin{array}{l}\text { Chemokine signaling pathway } \\
\text { Cytokine-cytokine receptor }\end{array}$ & 7 & $1.84 \mathrm{E}-06$ & $3.80 \mathrm{E}-04$ & $\begin{array}{l}\text { [Ccl3, Ccl2, Ccr1, Ccl9, Cxcl13, Ccl7, } \\
\mathrm{Ccl} 6]\end{array}$ \\
$\begin{array}{l}\text { interaction } \\
\begin{array}{l}\text { Complement and coagulation } \\
\text { cascades }\end{array}\end{array}$ & 7 & $1.34 \mathrm{E}-05$ & 0.00341 & $\begin{array}{l}\mathrm{Ccl} 3, \mathrm{Ccl} 2, \mathrm{Ccr} 1, \mathrm{Ccl} 9, \mathrm{Cxcl13}, \mathrm{Ccl} 7, \\
\mathrm{Ccl} 6]\end{array}$ \\
\hline
\end{tabular}

\section{Animais adultos - 3 meses}

Aos três meses de idade (209 GDEs), as vias biológicas encontradas no $D m d^{m d x}$ são praticamente as mesmas da idade anterior, porém as vias correlacionadas com a proliferação celular já não aparecem mais (Tabela 31).

Tabela 31 - Vias biológicas $D m d^{m d x}$ vs C57BL 3 meses

\begin{tabular}{|c|c|c|c|c|}
\hline Enriquecido com & \#genes & $\begin{array}{l}\text { p-value } \\
\text { bruto }\end{array}$ & $\begin{array}{l}\text { p-value } \\
\text { corrigido }\end{array}$ & Lista de genes \\
\hline Chemokine signaling pathway & 7 & $6.33 \mathrm{E}-08$ & $1.33 \mathrm{E}-05$ & $\begin{array}{l}{[\mathrm{Ccl} 3, \mathrm{Ccl} 2, \mathrm{Ccr} 5, \mathrm{Ccl} 9, \mathrm{Ccl} 8, \mathrm{Cxcl} 16,} \\
\mathrm{Ccl} 7]\end{array}$ \\
\hline Lysosome & 7 & $1.30 \mathrm{E}-07$ & $1.66 \mathrm{E}-05$ & $\begin{array}{l}\text { [Ctss, Hexb, Lipa, Ctsh, Cd68, Laptm5, } \\
\text { Atp6v0d2] }\end{array}$ \\
\hline $\begin{array}{l}\text { Cytokine-cytokine receptor } \\
\text { interaction }\end{array}$ & 7 & 4.94E-07 & $1.28 \mathrm{E}-04$ & $\begin{array}{l}{[\mathrm{Ccl} 3, \mathrm{Ccl} 2, \mathrm{Ccr} 5, \mathrm{Ccl} 9, \mathrm{Ccl} 8, \mathrm{Cxcl} 16,} \\
\mathrm{Ccl} 7]\end{array}$ \\
\hline $\begin{array}{l}\text { Antigen processing and } \\
\text { presentation }\end{array}$ & 6 & $6.36 \mathrm{E}-07$ & $6.87 \mathrm{E}-05$ & $\begin{array}{l}\text { [Ifi30, Ctss, H2-Ab1, H2-Aa, H2-Eb1, } \\
\text { Cd74] }\end{array}$ \\
\hline Asthma & 4 & $1.41 \mathrm{E}-06$ & 5.51E-05 & [H2-Ab1, Fcer1g, H2-Aa, H2-Eb1] \\
\hline
\end{tabular}




\begin{tabular}{|c|c|c|c|c|}
\hline Systemic lupus erythematosus & 6 & $1.30 \mathrm{E}-05$ & 0.00242 & $\begin{array}{l}\text { [Fcgr2b, H2-Ab1, H2-Aa, H2-Eb1, Fcgr4, } \\
\text { Fcgr3] }\end{array}$ \\
\hline $\begin{array}{l}\text { Complement and coagulation } \\
\text { cascades }\end{array}$ & 4 & $1.43 \mathrm{E}-05$ & 0.00113 & [C3ar1, C1qc, C1qa, C1qb] \\
\hline $\begin{array}{l}\text { Cytokine-cytokine receptor } \\
\text { interaction }\end{array}$ & 7 & $1.90 \mathrm{E}-05$ & 0.00491 & $\begin{array}{l}\text { [Csf1r, II13ra1, Hgf, Ccr2, II7r, II10ra, } \\
\text { Ccl6] }\end{array}$ \\
\hline Prion diseases & 3 & $4.41 \mathrm{E}-05$ & 0.00185 & [C1qc, C1qa, C1qb] \\
\hline $\begin{array}{l}\text { Natural killer cell mediated } \\
\text { cytotoxicity }\end{array}$ & 5 & $6.96 \mathrm{E}-05$ & 0.0094 & [Fcer1g, Tyrobp, Fcgr4, Cd48, Fcgr3] \\
\hline $\begin{array}{l}\text { Leukocyte transendothelial } \\
\text { migration }\end{array}$ & 3 & $8.77 \mathrm{E}-05$ & 0.0111 & [Itgb2, Itgam, Cybb] \\
\hline Cell adhesion molecules (CAMs) & 5 & $1.52 \mathrm{E}-04$ & 0.0261 & $\begin{array}{l}\text { [H2-Ab1, H2-Aa, Alcam, H2-Eb1, } \\
\text { Siglec1] }\end{array}$ \\
\hline Cell adhesion molecules (CAMs) & 3 & $1.74 \mathrm{E}-04$ & 0.0297 & [Ptprc, Itgb2, Itgam] \\
\hline Systemic lupus erythematosus & 4 & $2.30 \mathrm{E}-04$ & 0.0429 & [C1qc, C1qa, C1qb, Fcgr1] \\
\hline $\begin{array}{l}\text { Toll-like receptor signaling } \\
\text { pathway }\end{array}$ & 4 & $3.61 \mathrm{E}-04$ & 0.039 & {$[\mathrm{~T}|r 1, \mathrm{~T}| \mathrm{r} 7, \mathrm{~T} \mid \mathrm{r} 8, \mathrm{Spp} 1]$} \\
\hline Steroid biosynthesis & 2 & 0.00146 & 0.0306 & [Lipa, Soat1] \\
\hline
\end{tabular}

O enriquecimento de vias do sistema imunológico se mantém nas linhagens $\operatorname{Larg}^{m y d-/}$ (183 GDEs) e $D m d^{m d x} / \operatorname{Larg}^{m y d-/}$ (320 GDEs) aos três meses de idade, com a adição da via "Lysosome" (Tabelas 32 e 33).

Tabela 32 - Vias biológicas Large $e^{m y d-/-}$ vs C57BL 3 meses

\begin{tabular}{|c|c|c|c|c|}
\hline Enriquecido com & \#genes & $\begin{array}{l}\text { p-value } \\
\text { bruto }\end{array}$ & $\begin{array}{l}\text { p-value } \\
\text { corrigido }\end{array}$ & Lista de genes \\
\hline Lysosome & 8 & $9.08 \mathrm{E}-08$ & $1.13 \mathrm{E}-05$ & $\begin{array}{l}\text { [Lgmn, Ctss, Lipa, Cd68, Ctsz, Laptm5, } \\
\text { Atp6v0d2, Slc11a1] }\end{array}$ \\
\hline $\begin{array}{l}\text { Cytokine-cytokine receptor } \\
\text { interaction }\end{array}$ & 10 & $3.05 \mathrm{E}-07$ & $7.82 \mathrm{E}-05$ & $\begin{array}{l}{[\mathrm{Ccl} 3, \mathrm{Ccl} 2,\|13 \mathrm{ra1}, \mathrm{Ccr} 5, \mathrm{Ccl} 9,\| 17 \mathrm{r}, \mathrm{Ccl} 8,} \\
\mathrm{Cxcl} 16, \mathrm{Ccl} 7, \mathrm{Ccl} 6]\end{array}$ \\
\hline Chemokine signaling pathway & 8 & 2.69E-06 & $5.60 \mathrm{E}-04$ & $\begin{array}{l}{[\mathrm{Ccl} 3, \mathrm{Ccl} 2, \mathrm{Ccr} 5, \mathrm{Ccl} 9, \mathrm{Ccl} 8, \mathrm{Cxcl} 16,} \\
\mathrm{Ccl} 7, \mathrm{Ccl} 6]\end{array}$ \\
\hline $\begin{array}{l}\text { Antigen processing and } \\
\text { presentation }\end{array}$ & 6 & $5.08 \mathrm{E}-06$ & $5.39 \mathrm{E}-04$ & [Lgmn, Ifi30, Ctss, H2-Aa, Cd74] \\
\hline Prion diseases & 4 & $2.32 \mathrm{E}-05$ & $9.30 \mathrm{E}-04$ & [Ncam1, C1qc, C1qa, C1qb] \\
\hline $\begin{array}{l}\text { Complement and coagulation } \\
\text { cascades }\end{array}$ & 5 & $3.05 \mathrm{E}-05$ & 0.00235 & [C3ar1, C1qc, C1qa, C1qb, Cfb] \\
\hline
\end{tabular}

Tabela 33 - Vias biológicas C57BL vs Dmd $^{m d x} /$ Large $^{m y d-/ / 3}$ meses

\begin{tabular}{|c|c|c|c|c|}
\hline Enriquecido com & \#genes & $\begin{array}{l}\text { p-value } \\
\text { bruto }\end{array}$ & $\begin{array}{l}\text { p-value } \\
\text { corrigido }\end{array}$ & Lista de genes \\
\hline $\begin{array}{l}\text { Cytokine-cytokine receptor } \\
\text { interaction }\end{array}$ & 18 & $1.11 \mathrm{E}-11$ & $2.84 \mathrm{E}-09$ & $\begin{array}{l}\text { [Csf1r, II13ra1, Ccr5, Ccr2, Csf2rb, } \\
\text { Tnfrsf1b, Ccl3, Hgf, Ccl2, II7r, Ccl9, Ccl8, } \\
\text { Cxcl9, II10ra, Cxcl16, Ccl7, Ccl6, } \\
\text { Csf2rb2] }\end{array}$ \\
\hline Lysosome & 13 & $4.51 \mathrm{E}-11$ & 5.64E-09 & $\begin{array}{l}\text { [Lgmn, Hexb, Lipa, Ctsh, Slc11a1, Ctss, } \\
\text { Gusb, Cd68, Man2b1, Ctsz, Laptm5, Gla, } \\
\text { Atp6v0d2] }\end{array}$ \\
\hline
\end{tabular}




\begin{tabular}{|c|c|c|c|c|}
\hline Systemic lupus erythematosus & 12 & $1.56 \mathrm{E}-08$ & 2.87E-06 & $\begin{array}{l}\text { [Fcgr2b, , H2-Ab1, C1qc, H2-Aa, C1qa, } \\
\text { H2-Eb1, C1qb, C1ra, Fcgr4, Fcgr1, Fcgr3] }\end{array}$ \\
\hline $\begin{array}{l}\text { Complement and coagulation } \\
\text { cascades }\end{array}$ & 8 & $3.86 \mathrm{E}-07$ & 2.97E-05 & $\begin{array}{l}\text { [Pros1, C3ar1, C5ar1, C1qc, C1qa, C1qb, } \\
\text { C1ra, Cfb] }\end{array}$ \\
\hline $\begin{array}{l}\text { Antigen processing and } \\
\text { presentation }\end{array}$ & 8 & $1.72 \mathrm{E}-06$ & $1.82 \mathrm{E}-04$ & $\begin{array}{l}\text { [Lgmn, Ifi30, Ctss, H2-Ab1, H2-Aa, H2- } \\
\text { Eb1, Cd74] }\end{array}$ \\
\hline Asthma & 5 & 2.60E-06 & $9.61 \mathrm{E}-05$ & [H2-Ab1, Fcer1g, H2-Aa, H2-Eb1] \\
\hline Chemokine signaling pathway & 10 & $6.12 \mathrm{E}-06$ & 0.00127 & $\begin{array}{l}{[\mathrm{Ccl} 3, \mathrm{Ccl} 2, \mathrm{Ccr} 5, \mathrm{Ccr} 2, \mathrm{Ccl} 9, \mathrm{Ccl} 8, \mathrm{Cxcl} 9,} \\
\mathrm{Cxcl} 16, \mathrm{Ccl} 7, \mathrm{Ccl} 6]\end{array}$ \\
\hline Hematopoietic cell lineage & 6 & 1.13E-04 & 0.00994 & [Csf1r, II7r, H2-Eb1, Fcgr1, Anpep] \\
\hline Prion diseases & 4 & 2.69E-04 & 0.0108 & [Ncam1, C1qc, C1qa, C1qb] \\
\hline Glycosaminoglycan degradation & 3 & 0.00112 & 0.0279 & [Hexb, Gusb, Hpse] \\
\hline
\end{tabular}

\section{Animais adultos - 6 meses}

Aos seis meses de idade (468 GDEs), as vias biológicas encontradas no $D m d^{m d x}$ são praticamente as mesmas da idade de três meses, variando apenas a ordem de significância de algumas vias (Tabela 34).

Tabela 34 - Vias biológicas $D m d^{m d x}$ vs C57BL 6 meses

\begin{tabular}{|c|c|c|c|c|}
\hline Enriquecido com & \#genes & $\begin{array}{l}\text { p-value } \\
\text { bruto }\end{array}$ & $\begin{array}{l}\text { p-value } \\
\text { corrigido }\end{array}$ & Lista de genes \\
\hline Lysosome & 19 & 8.99E-16 & $1.12 \mathrm{E}-13$ & $\begin{array}{l}\text { [Lgmn, Tcirg1, Hexb, Lipa, Ctsb, Ctsc, } \\
\text { Ctsh, Slc11a1, Ctss, Gusb, Cd63, Asah1, } \\
\text { Cd68, Ppt1, Ctsz, Laptm5, Gla, } \\
\text { Atp6v0d2, Fuca1] }\end{array}$ \\
\hline $\begin{array}{l}\text { Cytokine-cytokine receptor } \\
\text { interaction }\end{array}$ & 20 & $9.49 E-11$ & $2.43 \mathrm{E}-08$ & $\begin{array}{l}\text { [Csf1r, Il13ra1, Ccr5, Ccr2, Csf2rb, } \\
\text { Tnfrsf1b, Cx3cr1, Egfr, Ccl3, Hgf, Ccl2, } \\
\text { II7r, Ccl9, Ccl8, II10ra, Cxcl16, Il10rb, } \\
\text { Ccl7, Tgfb1, Ccl6] }\end{array}$ \\
\hline $\begin{array}{l}\text { Antigen processing and } \\
\text { presentation }\end{array}$ & 10 & $3.17 E-07$ & $3.36 \mathrm{E}-05$ & $\begin{array}{l}\text { [Lgmn, Ifi30, Ctss, Ctsb, H2-DMa, H2- } \\
\text { Ab1, Pdia3, H2-Aa, H2-Eb1, Cd74] }\end{array}$ \\
\hline Systemic lupus erythematosus & 12 & $8.60 \mathrm{E}-07$ & $1.58 \mathrm{E}-04$ & $\begin{array}{l}\text { [Fcgr2b, H2-DMa, H2-Ab1, C1qc, H2-Aa, } \\
\text { C1qa, H2-Eb1, C1qb, Fcgr4, Fcgr1, Cd80, } \\
\text { Fcgr3] }\end{array}$ \\
\hline Chemokine signaling pathway & 12 & $5.01 \mathrm{E}-06$ & 0.00104 & $\begin{array}{l}{[\mathrm{Ccl} 3, \mathrm{Ccl} 2, \mathrm{Ccr} 5, \mathrm{Ccr} 2, \text { Dock2, Ccl9, }} \\
\text { Ccl8, Cx3cr1, Pak1, Cxcl16, Ccl7, Ccl6] }\end{array}$ \\
\hline $\begin{array}{l}\text { Complement and coagulation } \\
\text { cascades }\end{array}$ & 8 & $6.11 \mathrm{E}-06$ & 4.70E-04 & $\begin{array}{l}\text { [C3ar1, C5ar1, C1qc, Plau, C1qa, C1qb, } \\
\text { F13a1, Cfb] }\end{array}$ \\
\hline Asthma & 5 & $1.57 \mathrm{E}-05$ & $5.82 \mathrm{E}-04$ & $\begin{array}{l}\text { [H2-DMa, H2-Ab1, Fcer1g, H2-Aa, H2- } \\
\text { Eb1] }\end{array}$ \\
\hline $\begin{array}{l}\text { Fc gamma R-mediated } \\
\text { phagocytosis }\end{array}$ & 8 & $3.25 \mathrm{E}-05$ & 0.00348 & $\begin{array}{l}\text { [Fcgr2b, Marcks, Ptprc, Dock2, Pak1, } \\
\text { Fcgr1, Inpp5d, Arpc1b] }\end{array}$ \\
\hline Propanoate metabolism & 3 & 3.39E-05 & 0.00112 & [Acss2, Ldhb, Acss1] \\
\hline $\begin{array}{l}\text { Toll-like receptor signaling } \\
\text { pathway }\end{array}$ & 8 & $5.08 \mathrm{E}-05$ & 0.00538 & $\begin{array}{l}\text { [Ccl3, Cd14, Irf7, TIr1, TIr7, Cd80, TIr8, } \\
\text { Tlr9] }\end{array}$ \\
\hline Pyruvate metabolism & 3 & $8.76 \mathrm{E}-05$ & 0.00394 & [Acss2, Ldhb, Acss1] \\
\hline Hematopoietic cell lineage & 7 & $1.16 \mathrm{E}-04$ & 0.0102 & $\begin{array}{l}\text { [Csf1r, Cd14, II7r, H2-Eb1, Cd44, Fcgr1, } \\
\text { Anpep] }\end{array}$ \\
\hline
\end{tabular}




\begin{tabular}{lccrl}
\hline Cell adhesion molecules (CAMs) & 9 & $1.64 \mathrm{E}-04$ & 0.0277 & $\begin{array}{l}\text { [H2-DMa, H2-Ab1, Ptprc, Vcan, H2-Aa, } \\
\text { Alcam, H2-Eb1, Siglec1, Cd80] }\end{array}$ \\
$\begin{array}{l}\text { Sphingolipid metabolism } \\
\begin{array}{l}\text { Natural killer cell mediated } \\
\text { cytotoxicity }\end{array}\end{array}$ & 5 & $1.66 \mathrm{E}-04$ & 0.00747 & [Acer3, B4galt6, Asah1, Sgpl1, Gla] \\
$\begin{array}{l}\text { Glycolysis / Gluconeogenesis } \\
\text { [Fcer1g, Sh2d1b1, Tyrobp, Fcgr4, Pak1, }\end{array}$ & $2.70 \mathrm{E}-04$ & 0.0359 & $\begin{array}{l}\text { Sh3bp2, Cd48, Fcgr3] } \\
\text { [Acss2, Ldhb, Acss1] }\end{array}$ \\
\hline
\end{tabular}

Nas linhagens Large $e^{m y d-/}(277 \mathrm{GDEs})$ e $D m d^{m d x} /$ Large $^{m y d-/}(316 \mathrm{GDEs})$, as vias enriquecidas também são bem semelhantes ao visto aos três meses de idade, continuando o prevalecimento de vias do sistema imunológico (Tabelas 35 e 36).

Tabela 35 - Vias biológicas Large $e^{m y d-/-}$ vs C57BL 6 meses

\begin{tabular}{|c|c|c|c|c|}
\hline Enriquecido com & \#genes & $\begin{array}{l}\text { p-value } \\
\text { bruto }\end{array}$ & $\begin{array}{l}\text { p-value } \\
\text { corrigido }\end{array}$ & Listas de genes \\
\hline Systemic lupus erythematosus & 15 & $5.89 \mathrm{E}-13$ & $1.08 \mathrm{E}-10$ & $\begin{array}{l}\text { [Fcgr2b, C3, C4b, C1qa, Cd86, C1ra, C1s, } \\
\text { C1qb, Cd80, H2-Ab1, C1qc, H2-DMb2, } \\
\text { H2-Aa, H2-Eb1] }\end{array}$ \\
\hline $\begin{array}{l}\text { Cytokine-cytokine receptor } \\
\text { interaction }\end{array}$ & 17 & $4.60 \mathrm{E}-12$ & $1.18 \mathrm{E}-09$ & $\begin{array}{l}\text { [Csf1r, II13ra1, Ccr5, Csf2rb, \|11r1, II2rg, } \\
\text { Hgf, ॥17r, Ccl9, Ccl8, Ccl5, Cxcl13, Cxcl16, } \\
\text { Ccl7, Ccl6, Csf2rb2] }\end{array}$ \\
\hline $\begin{array}{l}\text { Complement and coagulation } \\
\text { cascades }\end{array}$ & 11 & 8.97E-12 & $6.91 \mathrm{E}-10$ & $\begin{array}{l}\text { [Cfh, C3ar1, Cfd, C1qc, C3, C4b, C1qa, } \\
\text { C1qb, C1s, C1ra, Cfb] }\end{array}$ \\
\hline Cell adhesion molecules (CAMs) & 11 & $1.68 \mathrm{E}-08$ & $2.84 \mathrm{E}-06$ & $\begin{array}{l}\text { [Selp, H2-Ab1, H2-DMb2, Ptprc, H2-Aa, } \\
\text { Cd86, H2-Eb1, Siglec1, Cd80, Glycam1] }\end{array}$ \\
\hline $\begin{array}{l}\text { Antigen processing and } \\
\text { presentation }\end{array}$ & 9 & $2.58 \mathrm{E}-08$ & $2.73 \mathrm{E}-06$ & $\begin{array}{l}\text { [Lgmn, Ifi30, Ctss, H2-Ab1, H2-DMb2, } \\
\text { H2-Aa, H2-Eb1, Cd74] }\end{array}$ \\
\hline Graft-versus-host disease & 7 & $1.64 \mathrm{E}-07$ & $1.18 \mathrm{E}-05$ & $\begin{array}{l}\text { [H2-Ab1, H2-DMb2, H2-Aa, Cd86, H2- } \\
\text { Eb1, Cd80] }\end{array}$ \\
\hline Allograft rejection & 7 & $1.64 \mathrm{E}-07$ & $1.18 \mathrm{E}-05$ & $\begin{array}{l}\text { [H2-Ab1, H2-DMb2, H2-Aa, Cd86, H2- } \\
\text { Eb1, Cd80] }\end{array}$ \\
\hline Hematopoietic cell lineage & 8 & $2.10 \mathrm{E}-07$ & $1.85 \mathrm{E}-05$ & $\begin{array}{l}\text { [Csf1r, Cd14, II7r, H2-Eb1, IIr1, Anpep, } \\
\text { Cd3g] }\end{array}$ \\
\hline Type I diabetes mellitus & 7 & $3.02 \mathrm{E}-07$ & $2.33 \mathrm{E}-05$ & $\begin{array}{l}\text { [H2-Ab1, H2-DMb2, H2-Aa, Cd86, H2- } \\
\text { Eb1, Cd80] }\end{array}$ \\
\hline Autoimmune thyroid disease & 7 & $8.81 \mathrm{E}-07$ & $7.76 \mathrm{E}-05$ & $\begin{array}{l}\text { [H2-Ab1, H2-DMb2, H2-Aa, Cd86, H2- } \\
\text { Eb1, Cd80] }\end{array}$ \\
\hline Asthma & 5 & 9.91E-07 & 3.67E-05 & [H2-Ab1, H2-DMb2, H2-Aa, H2-Eb1] \\
\hline Chemokine signaling pathway & 10 & $1.06 \mathrm{E}-06$ & $2.20 \mathrm{E}-04$ & $\begin{array}{l}\text { [Ccr5, Dock2, Ccl9, Ccl8, Ccl5, Cxcl13, } \\
\text { Cxcl16, Ccl7, Ccl6] }\end{array}$ \\
\hline Prion diseases & 5 & $5.70 \mathrm{E}-06$ & $2.28 \mathrm{E}-04$ & [Egr1, C1qc, C1qa, C1qb, Ccl5] \\
\hline $\begin{array}{l}\text { Toll-like receptor signaling } \\
\text { pathway }\end{array}$ & 7 & $9.76 \mathrm{E}-06$ & 0.00103 & [Cd14, TIr1, Cd86, Ccl5, TIr7, Cd80, T/r8] \\
\hline Lysosome & 6 & $2.29 \mathrm{E}-04$ & 0.0287 & [Lgmn, Ctss, Lipa, Ctsh, Cd68, Laptm5] \\
\hline
\end{tabular}


Tabela 36 - Vias biológicas Dmd ${ }^{m d x} /$ Large $^{m y d-/-}$ vs C57BL 6 meses

\begin{tabular}{|c|c|c|c|c|}
\hline Enriquecido com & \#genes & $\begin{array}{l}\text { p-value } \\
\text { bruto }\end{array}$ & $\begin{array}{l}\text { p-value } \\
\text { corrigido }\end{array}$ & Lista de genes \\
\hline $\begin{array}{l}\text { Cytokine-cytokine receptor } \\
\text { interaction }\end{array}$ & 22 & $7.54 \mathrm{E}-15$ & $1.93 \mathrm{E}-12$ & $\begin{array}{l}\text { [Csf1r, Il13ra1, Ccr5, Ccr2, Csf2rb, } \\
\text { Tnfrsf1b, Egfr, II1r1, Pf4, Ccl3, Hgf, Ccl2, } \\
\text { Osmr, Ccl9, II7r, Ccl8, Cxcl14, II10ra, } \\
\text { Cxcl16, Ccl7, Csf2rb2, Ccl6] }\end{array}$ \\
\hline $\begin{array}{l}\text { Complement and coagulation } \\
\text { cascades }\end{array}$ & 14 & $2.38 \mathrm{E}-14$ & $1.83 \mathrm{E}-12$ & $\begin{array}{l}\text { [Pros1, Cfh, C7, C5ar1, C4b, C1qa, C1ra, } \\
\text { C1s, C1qb, F13a1, C3ar1, Serpine1, } \\
\text { C1qc, Cfb] }\end{array}$ \\
\hline Systemic lupus erythematosus & 15 & $4.51 \mathrm{E}-11$ & 8.30E-09 & $\begin{array}{l}\text { [Fcgr2b, C7, C4b, C1qa, C1qb, C1ra, C1s, } \\
\text { Cd80, H2-Ab1, C1qc, H2-Aa, H2-Eb1, } \\
\text { Fcgr4, Fcgr1, Fcgr3] }\end{array}$ \\
\hline Hematopoietic cell lineage & 9 & 1.69E-07 & $1.49 \mathrm{E}-05$ & $\begin{array}{l}\text { [Csf1r, Cd14, II7r, H2-Eb1, Cd44, Itgam, } \\
\text { Fcgr1, II1r1, Anpep] }\end{array}$ \\
\hline Chemokine signaling pathway & 11 & $2.32 \mathrm{E}-06$ & 4.83E-04 & $\begin{array}{l}{[\mathrm{Pf} 4, \mathrm{Ccl} 3, \mathrm{Ccl} 2, \mathrm{Ccr} 5, \mathrm{Ccr} 2, \mathrm{Ccl} 9, \mathrm{Ccl} 8,} \\
\mathrm{Cxcl} 14, \mathrm{Cxcl} 16, \mathrm{Ccl} 7, \mathrm{Ccl} 6]\end{array}$ \\
\hline Lysosome & 9 & $2.65 \mathrm{E}-06$ & $3.32 \mathrm{E}-04$ & $\begin{array}{l}\text { [Lgmn, Ctss, Lipa, Ctsh, Cd68, Ctsk, } \\
\text { Laptm5, Atp6v0d2, Slc11a1] }\end{array}$ \\
\hline Cell adhesion molecules (CAMs) & 9 & $2.15 E-05$ & 0.00363 & $\begin{array}{l}\text { [Ncam1, H2-Ab1, Ptprc, Vcan, H2-Aa, } \\
\text { H2-Eb1, Itgb2, Itgam, Cd80] }\end{array}$ \\
\hline Prion diseases & 5 & $2.46 \mathrm{E}-05$ & $9.83 E-04$ & [Ncam1, C7, C1qc, C1qa, C1qb] \\
\hline $\begin{array}{l}\text { Antigen processing and } \\
\text { presentation }\end{array}$ & 7 & $3.69 \mathrm{E}-05$ & 0.00391 & $\begin{array}{l}\text { [Lgmn, Ifi30, Ctss, H2-Ab1, H2-Aa, H2- } \\
\text { Eb1, Cd74] }\end{array}$ \\
\hline $\begin{array}{l}\text { Toll-like receptor signaling } \\
\text { pathway }\end{array}$ & 7 & $6.76 \mathrm{E}-05$ & 0.00716 & {$[\mathrm{Ccl} 3, \mathrm{Cd} 14, \mathrm{~T}|r 1, \mathrm{Tlr} 4, \mathrm{Tlr} 7, \mathrm{Cd} 80, \mathrm{~T}| \mathrm{r} 8]$} \\
\hline Asthma & 4 & $1.05 \mathrm{E}-04$ & 0.00389 & [H2-Ab1, Fcer1g, H2-Aa, H2-Eb1] \\
\hline
\end{tabular}




\subsubsection{Anotação funcional dos genes de acordo com o Gene Ontology}

As tabelas no Anexo B mostram as funções (Gene Ontology - $G O$ ) enriquecidas nas listas de genes diferencialmente expressos. Foram selecionadas apenas as funções com FDR $<20$, p-value $<0,05$. Por conta da redundância e proximidade de muitos termos, foi feito um agrupamento manual das mesmas em categorias mais amplas para sabermos como elas se distribuem; e pela grande representação de funções relacionadas com a resposta imunológica, as demais funções foram separadas em gráficos diferentes para melhor visualização (Figuras 51, 52 e 53).

\section{Animais jovens - $\mathbf{2 1}$ dias}

No animal $D m d^{m d x}$ com 21 dias de idade foram identificadas 221 funções enriquecidas, das quais $55 \%$ remetem diretamente a mecanismos do sistema imune e inflamação (Figura 51 A), e 27\% são relacionadas ao ciclo celular, síntese de DNA e morte celular. Quando se exclui as funções do sistema imune/inflamação, nota-se que as funções mais enriquecidas são as do ciclo celular e metabolismo (Figura $51 \mathrm{~B}$ ).

No animal Large $e^{\text {myd-- }}$ com 21 dias de idade foram encontradas 62 funções enriquecidas. Destas, $82 \%$ têm relação com funções características do sistema imune e inflamação; 10\% representam funções da matriz extracelular (ECM) e adesão (Figura 51 C). Pelo gráfico da Figura 51 D, vemos que, as funções da ECM e adesão perfazem $55 \%$ do total quando são excluídas as funções imunológicas.

Assim como suas linhagens parentais, a linhagem $D m d^{m d x} / L a r g e^{m y d-/}$ também mostra a presença majoritária de funções do sistema imune/inflamação: das 60 funções identificadas, $72 \%$ são dessa categoria. Destacam-se também os $13 \%$ de funções de atividade enzimática/proteólise (Figura $51 \mathrm{E}$ ).

Removendo os $72 \%$ de resposta imunológica, ficam destacadas as categorias de atividade enzimática/proteólise, matriz extracelular e adesão e fagocitose (Figura $51 \mathrm{~F}$ ). 


\section{Animais com 21 dias}

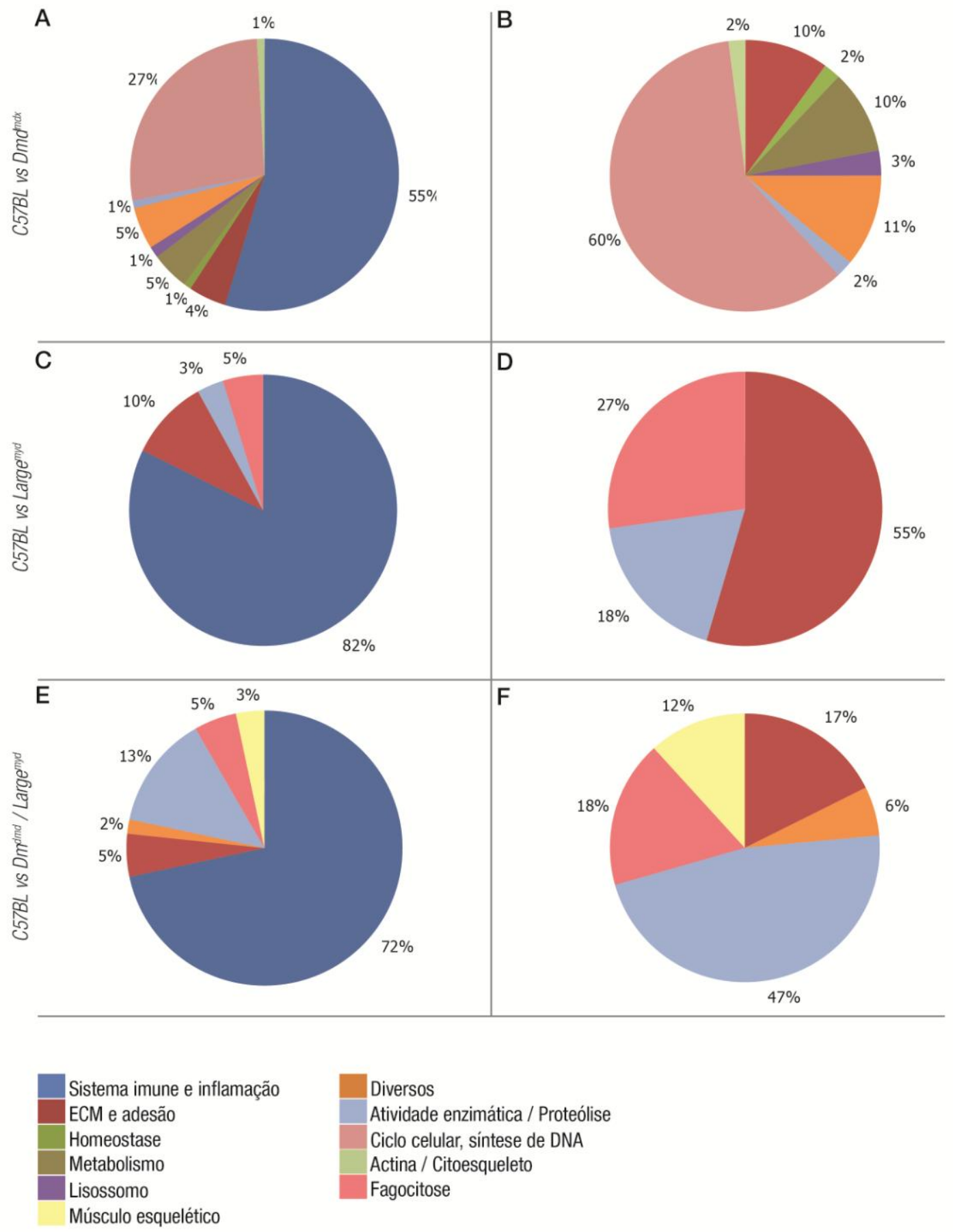

Figura 51 - Categorias de funções biológicas enriquecidas nos animais de 21 dias. A, C e E: distribuição de todas as categorias. B, D e F: distribuição das categorias sem contar as funções do sistema imune e inflamação 


\section{Idade de 3 meses}

Aos três meses de idade, a linhagem $D m d^{m d x}$ apresentou uma predominância maior das funções da categoria sistema imune/inflamação (Figura $52 \mathrm{~A}$ ). No gráfico da figura 52 $B$ vemos que as funções de ciclo celular reduzem drasticamente e as de ECM e adesão ganham destaque.

Na linhagem Large $e^{m y d-/}$ com três meses de idade, o enriquecimento das funções do sistema imune e inflamação reduz de $82 \%$ para 56\% (Figura 52 C); e há aumento da representação das funções de matriz extracelular e adesão (Figura 52 D).

A resposta imune representa $71 \%$ do total das funções enriquecidas no animal duplo-mutante com três meses de idade, de forma semelhante à idade de 21 dias (Figura 52 E). A categoria atividade enzimática/proteólise perde parte de sua representação, caindo de $47 \%$ para $17 \%$ quando analisamos a distribuição das categorias excluindo a de sistema imune e inflamação (Figura 52 F). 


\section{Animais com 3 meses}

A
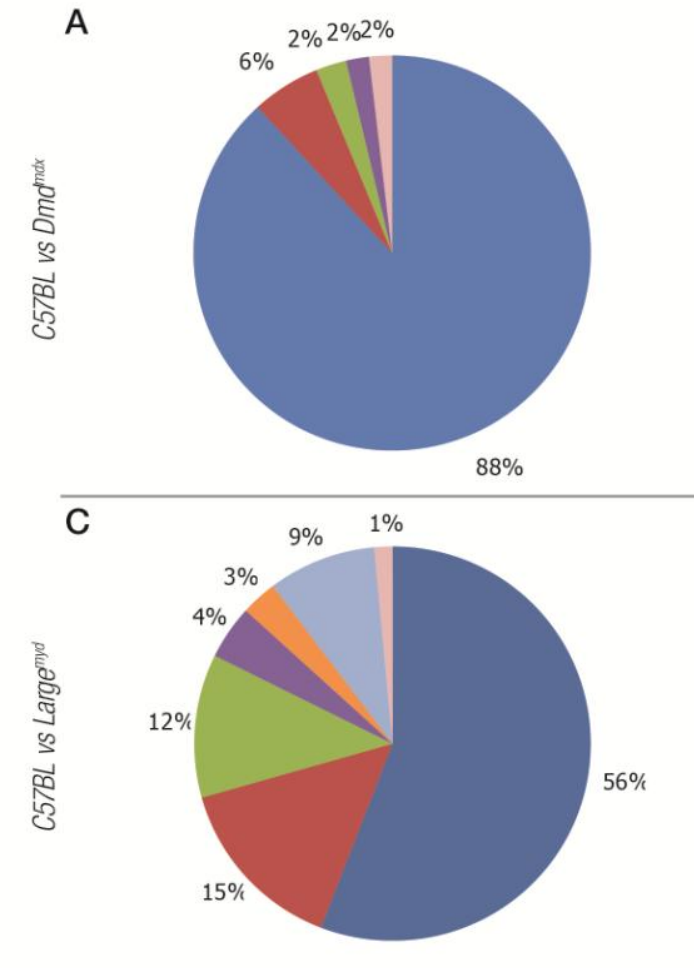

\section{$\bar{E}$}

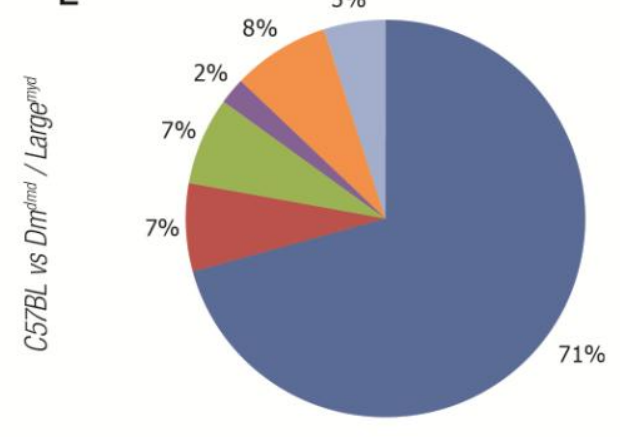

B

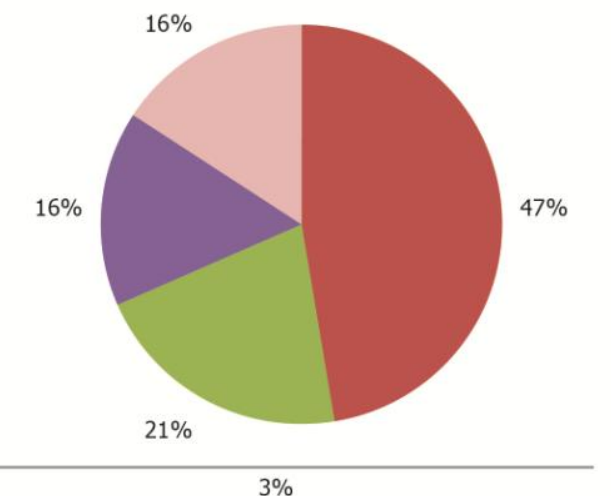

D

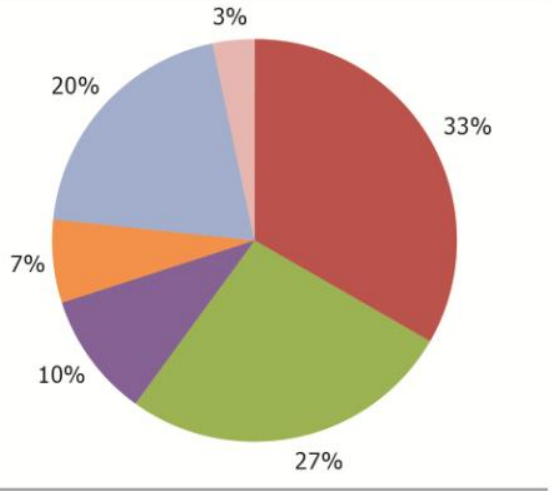

F

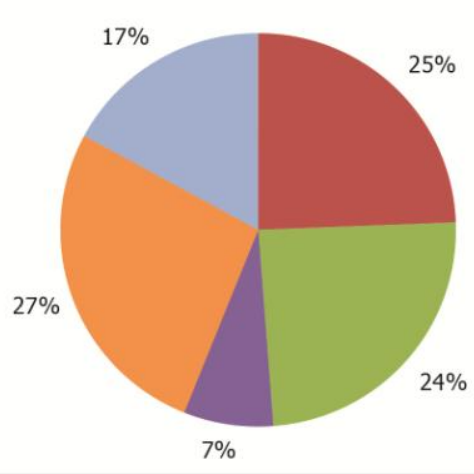

Sistema imune e inflamação ECM e adesão

Homeostase

Metabolismo

Lisossomo

Músculo esquelético
Diversos

Atividade enzimática / Proteólise

Ciclo celular, síntese de DNA

Actina / Citoesqueleto

Fagocitose

Figura 52 - Categorias de funções biológicas enriquecidas nos animais de três meses. A, C e E: distribuição de todas as categorias. B, D e F: distribuição das categorias sem contar as funções do sistema imune e inflamação 


\section{Idade de 6 meses}

Aos seis meses de idade, no camundongo $D m d^{n d x}$ continuam prevalecendo as funções do sistema imunológico (Figura 53 A). Dentre as demais categorias funcionais, vemos que a de ECM e adesão diminui em relação à idade de três meses (Figura 53 B).

$\mathrm{Na}$ linhagem Large $^{m y d-/}$ com seis meses de idade, a categoria sistema imune e inflamação tem maior representação que aos três meses, mas ainda é um pouco menor que aos 21 dias (Figura $53 \mathrm{C}$ ). Dentre as demais categorias, a de ECM e adesão e atividade enzimática/proteólise permanecem iguais ao visto aos três meses, ao passo que a de metabolismo aumenta de 6\% para 23\% (Figura $53 \mathrm{D}$ ).

Aos seis meses, no camundongo $D m d^{m d x} / L a r g e^{m y d-/}$, as funções envolvidas com a resposta imunológica atingem o maior percentual de representação, com 84\% das 161 funções identificadas na análise computacional (Figura $53 \mathrm{E}$ ). Na análise das demais categorias, a de atividade enzimática aumenta um pouco em comparação à idade de três meses, mas é menor ao visto aos 21 dias (Figura $53 \mathrm{~F}$ ). 


\section{Animais com 6 meses}

A

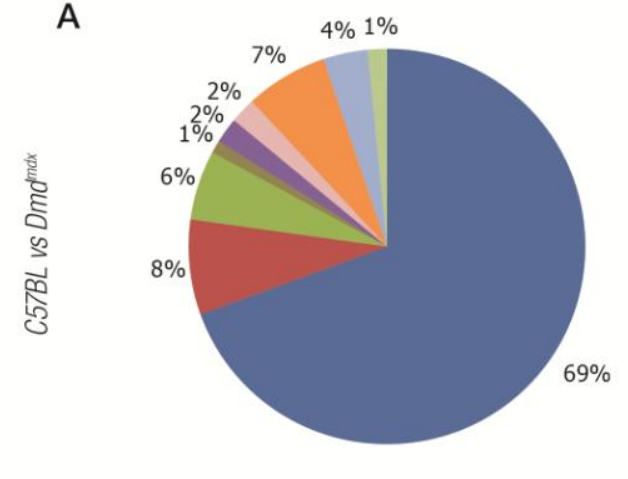

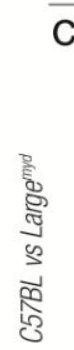

C
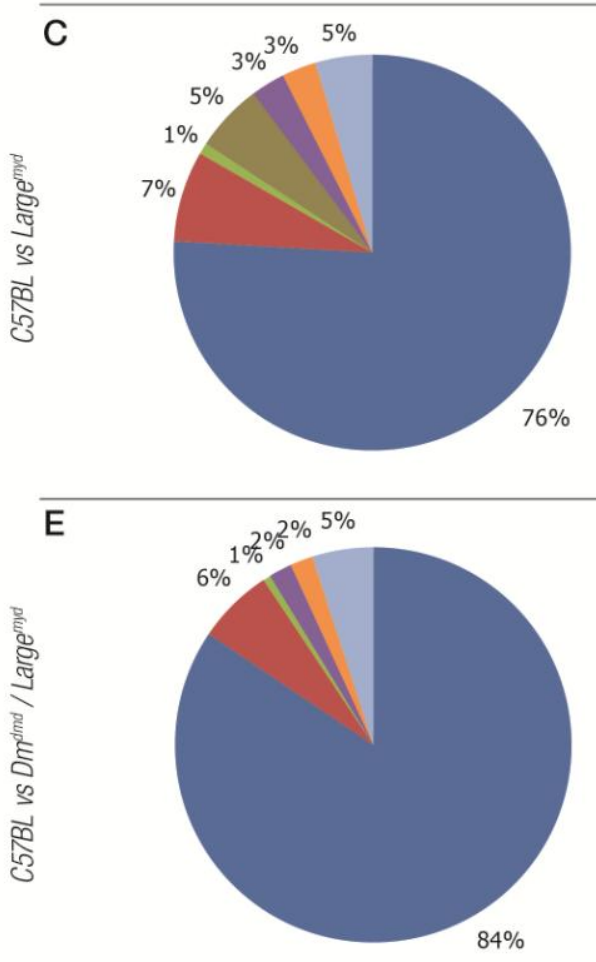

B

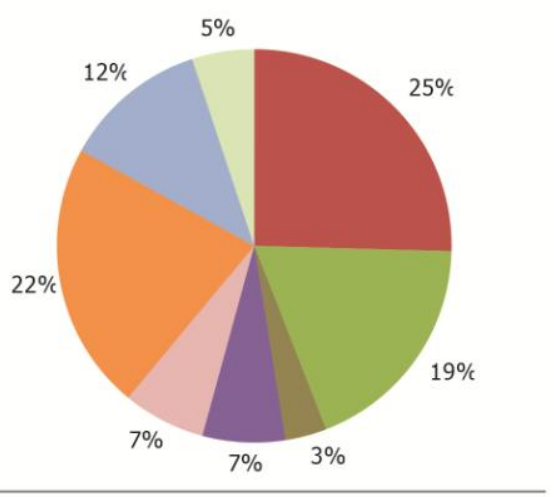

D

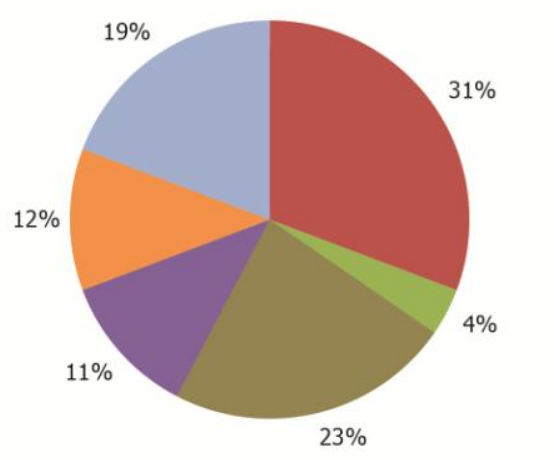

F

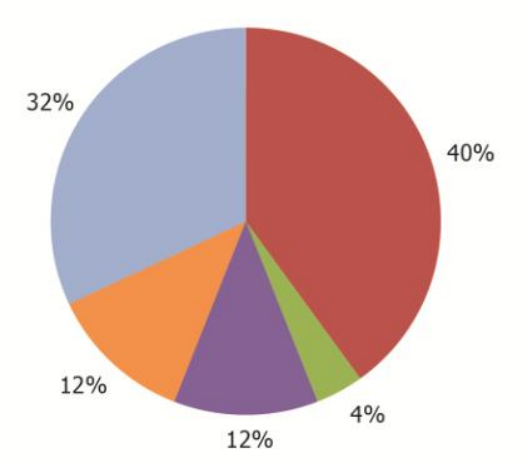

Sistema imune e inflamação

ECM e adesão

Homeostase

Metabolismo

Lisossomo

Músculo esquelético
Diversos

Atividade enzimática / Proteólise

Ciclo celular, sintese de DNA

Actina / Citoesqueleto

Fagocitose

Figura 53 - Categorias de funções biológicas enriquecidas nos animais de seis meses. A, C e E: distribuição de todas as categorias. B, D e F: distribuição das categorias sem contar as funções do sistema imune e inflamação 


\section{Caracterização do perfil de cada linhagem}

7.1. Análise do número de genes diferencialmente expressos - evolução de cada linhagem

As listas de genes diferencialmente expressos obtidas para as três idades de cada linhagem foram sobrepostas para sabermos quantos genes estão sempre alterados em cada linhagem e especificamente nas idades. Os resultados estão ilustrados nos diagramas de Venn das figuras a seguir. A análise do $D m d^{m d x} / L a r g e^{m y d-\gamma}$ está mais detalhada em seguida.

Na linhagem $D m d^{m d x}$, observamos uma redução dos genes específicos da linhagem com o avanço da idade (268 - 3 - 72) (Figura 54), enquanto no Large $e^{\text {myd-- }}(27-35$ - 156) (Figura 55) e $D m d^{m d x} /$ Large $^{m y d-/}$ (22-63-66) aumenta (Figura 56).

\section{$D m d^{m d x}$}

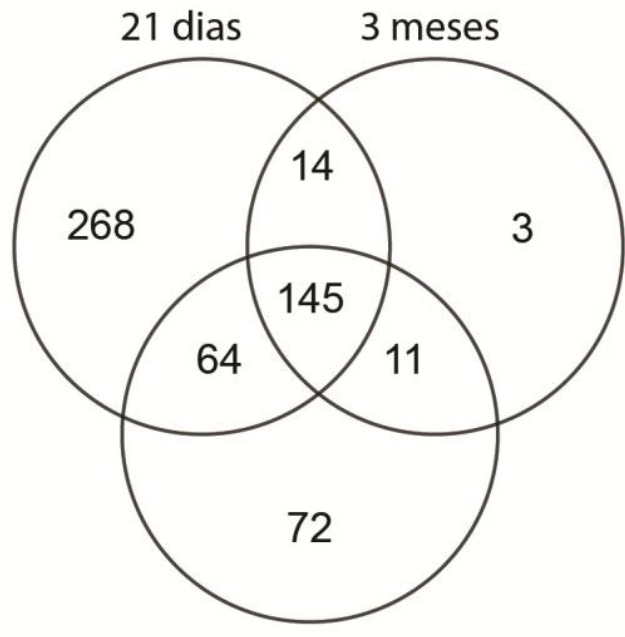

6 meses

\section{$\operatorname{Large}^{\text {myd-l- }}$}

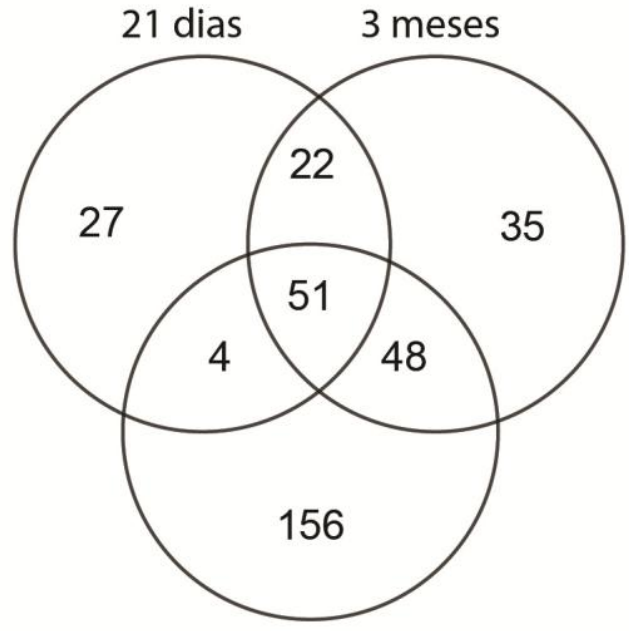

6 meses
Figura 54 - Diagrama de Venn com o número de genes difencialmente expressos nas três idades da linhagem $D m d^{m d x}$
Figura 55 - Diagrama de Venn com o número de genes difencialmente expressos nas três idades da linhagem Large $^{\text {myd-/- }}$ 
$D m d^{m d x} / \operatorname{Large}^{m y d-/-}$

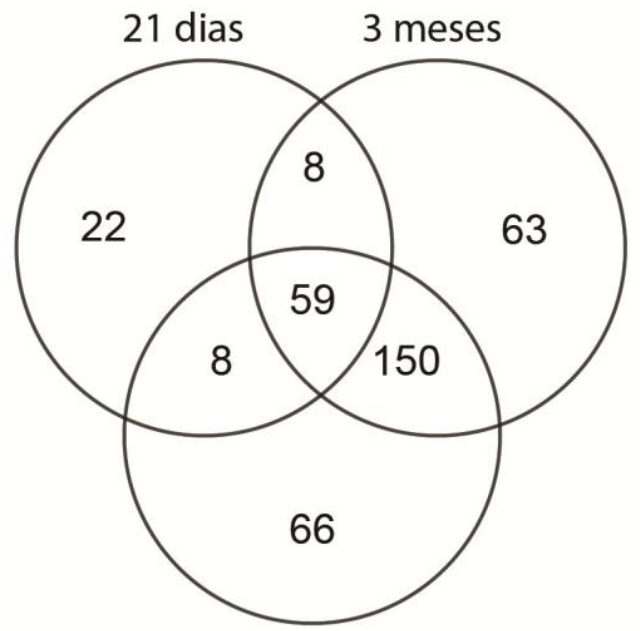

6 meses
Figura 56 - Diagrama de Venn com o número de genes difencialmente expressos nas três idades da linhagem $D m d^{m d x} /$ Large $^{m y d-/-}$

\subsection{Redes gênicas - genes exclusivos de cada linhagem}

Os genes particulares de cada linhagem (partes externas dos diagramas A da seção 6.2) foram analisados quanto às possíveis interações que eles possam ter entre si e com outros genes com a ajuda do programa IPA. Apresentamos as redes que tiveram maior significância.

A intensidade de cor das moléculas indica o grau de aumento (vermelho) ou diminuição (verde) de expressão. As moléculas sem cor não foram identificadas como diferencialmente expressas nos experimentos, mas foram adicionadas pelo programa com base em bancos de dados, indicando que elas são relevantes no contexto da rede construída. 


\section{$D \boldsymbol{m}^{m d x}$}

Com os 388 genes que estão com expressão diferencial apenas nos animais $D m d^{m d x}$ com 21 dias (diagrama A da Figura 48) foi possível gerar 25 redes significantes. Apresentamos a que obteve o maior score e que envolve o maior número de genes (Figura 57).

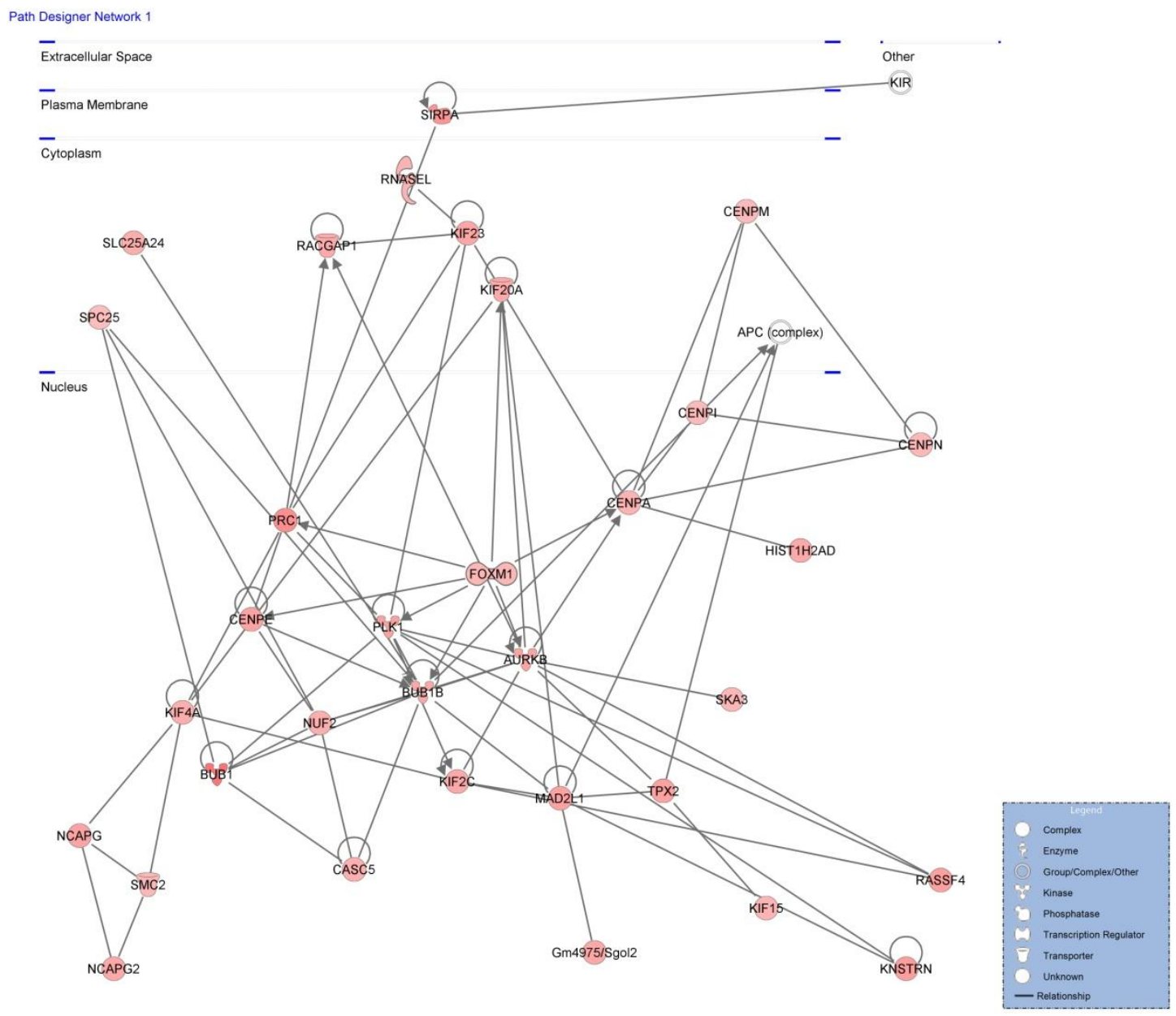

Figura 57 - Rede mais significativa do camundongo $D m d^{m d x}$ com 21 dias. Score: 61; 33 genes selecionados. Categorias envolvidas: Ciclo celular; Organização celular; Replicação, recombinação e reparo de DNA 
Os 25 genes do $D m d^{m d x}$ formaram cinco redes; na figura 58 está a principal rede construída, que integra 12 genes.

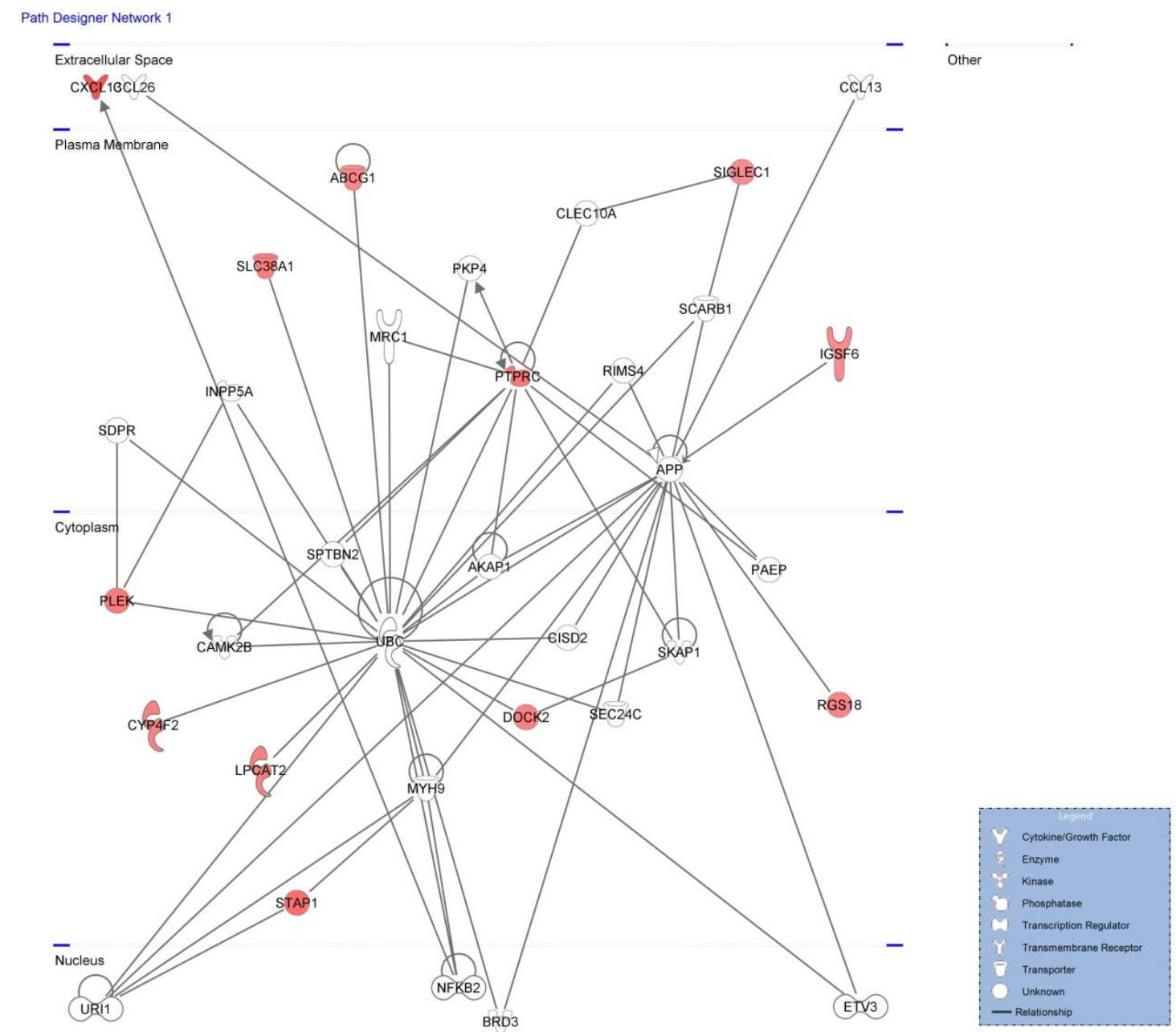

Figura 58 - Rede mais significativa do camundongo $D m d^{m d x}$ com 3 meses. Score: 29; 12 genes selecionados. Categorias envolvidas: Sinalização e interação célula-célula; Desenvolvimento e função do sistema hematológico; Tráfico de células imunes 
Para os 86 genes diferencialmente expressos no $D m d^{m d x}$ com seis meses, a análise retornou seis redes; a com maior score está na Figura 59.

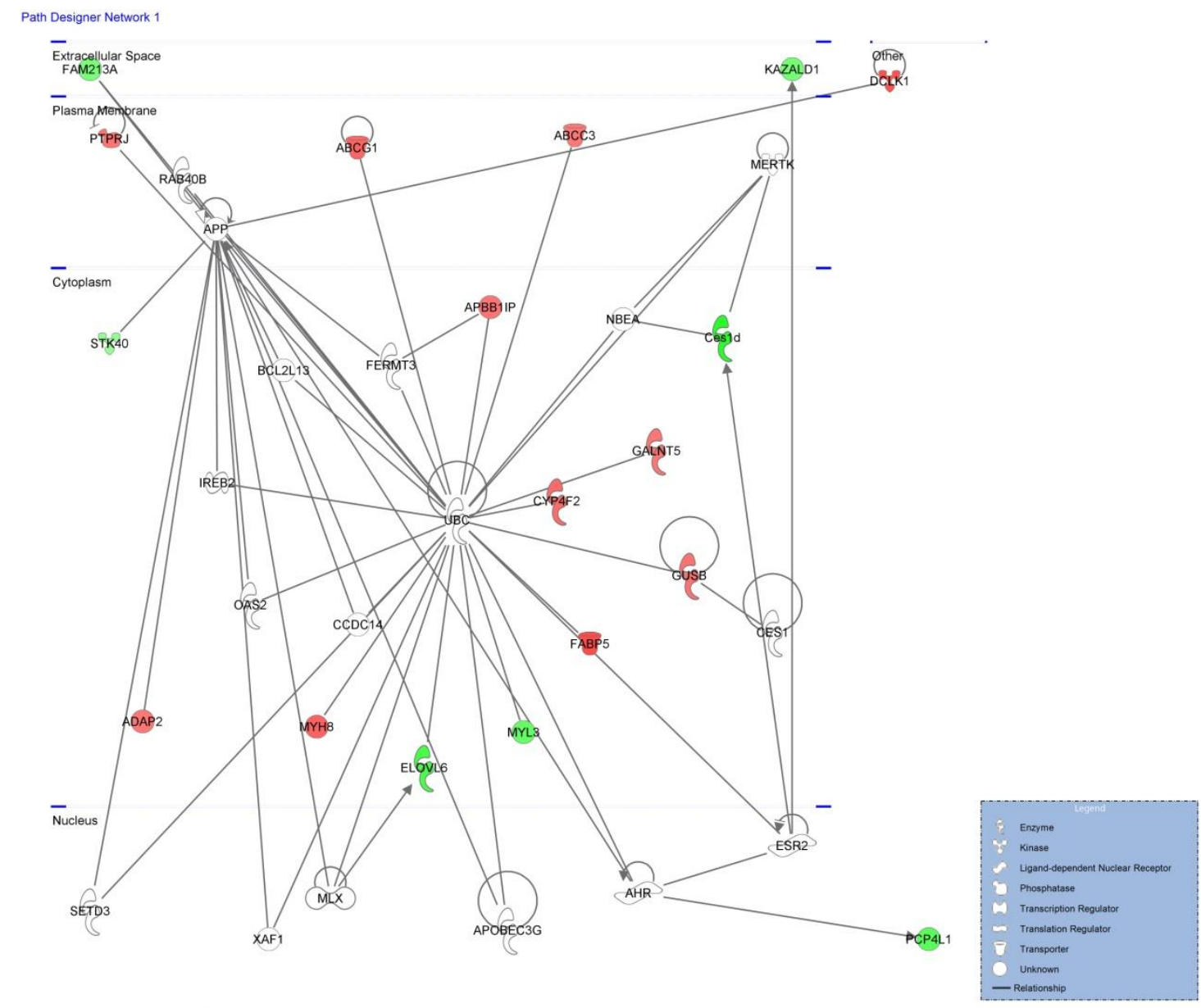

Figura 59 - Rede mais significativa do camundongo $D m^{m d x}$ com 6 meses. Score: 37; 18 genes selecionados. Categorias envolvidas: Metabolismo de lipídio; Transporte molecular; Bioquímica de moléculas pequenas 


\section{Large $^{m y d-/-}$}

Com os oito genes do Large $^{m y d}$ (diagrama A da figura 48), o programa conseguiu formar quatro redes; a figura 60 mostra a rede mais significante que integra três genes.

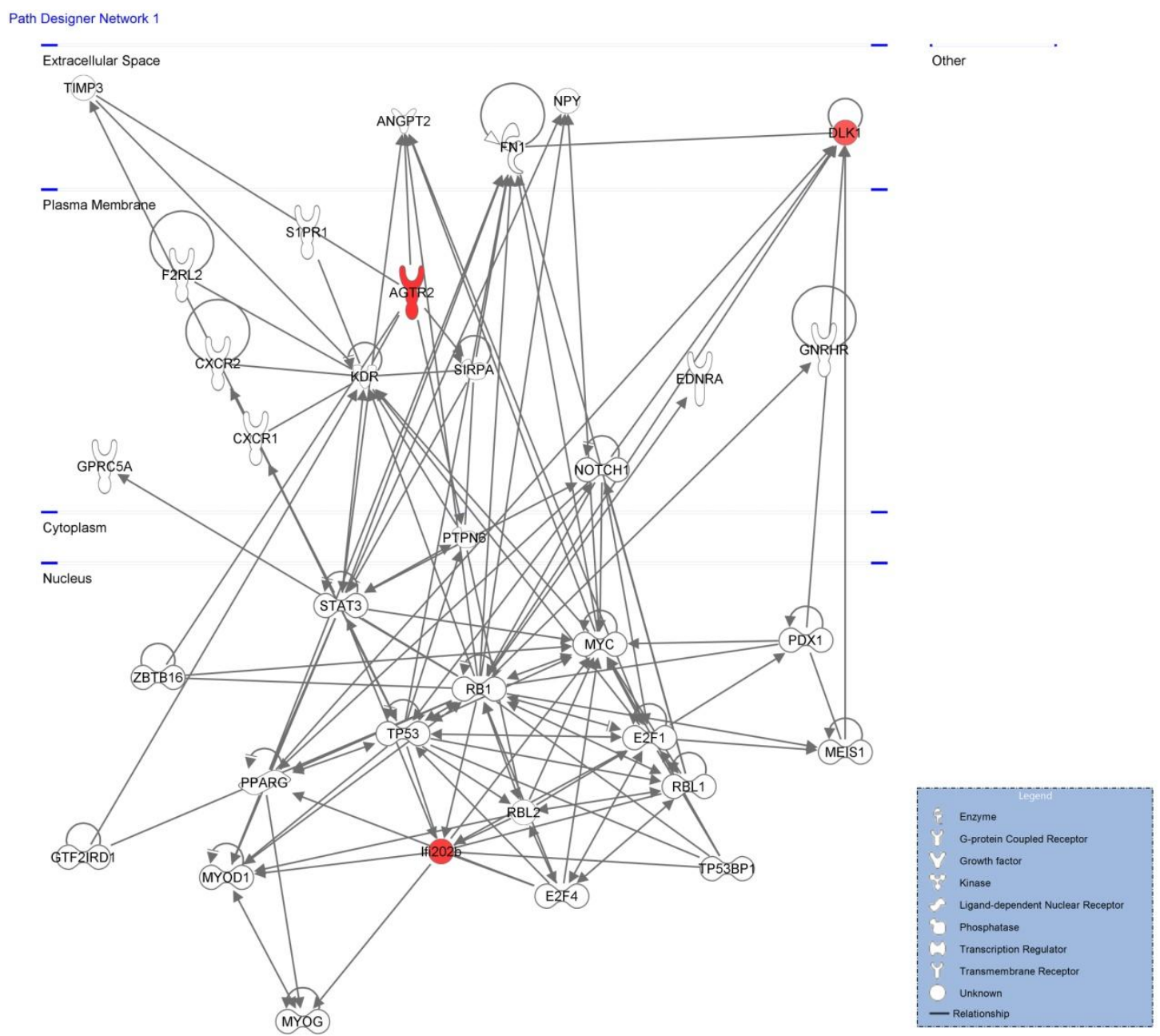

Figura 60 - Rede mais significativa do camundongo Large $e^{\text {myd } /}$ com 21 dias. Score: 7; 3 genes selecionados. Categorias envolvidas: Morfologia tecidual; Desenvolvimento celular; Desenvolvimento e função do sistema hematológico 
Com a análise dos seis genes do $L a r g e^{m y d-/-}$ foram formadas três redes; a que tem o maior score está na Figura 61.

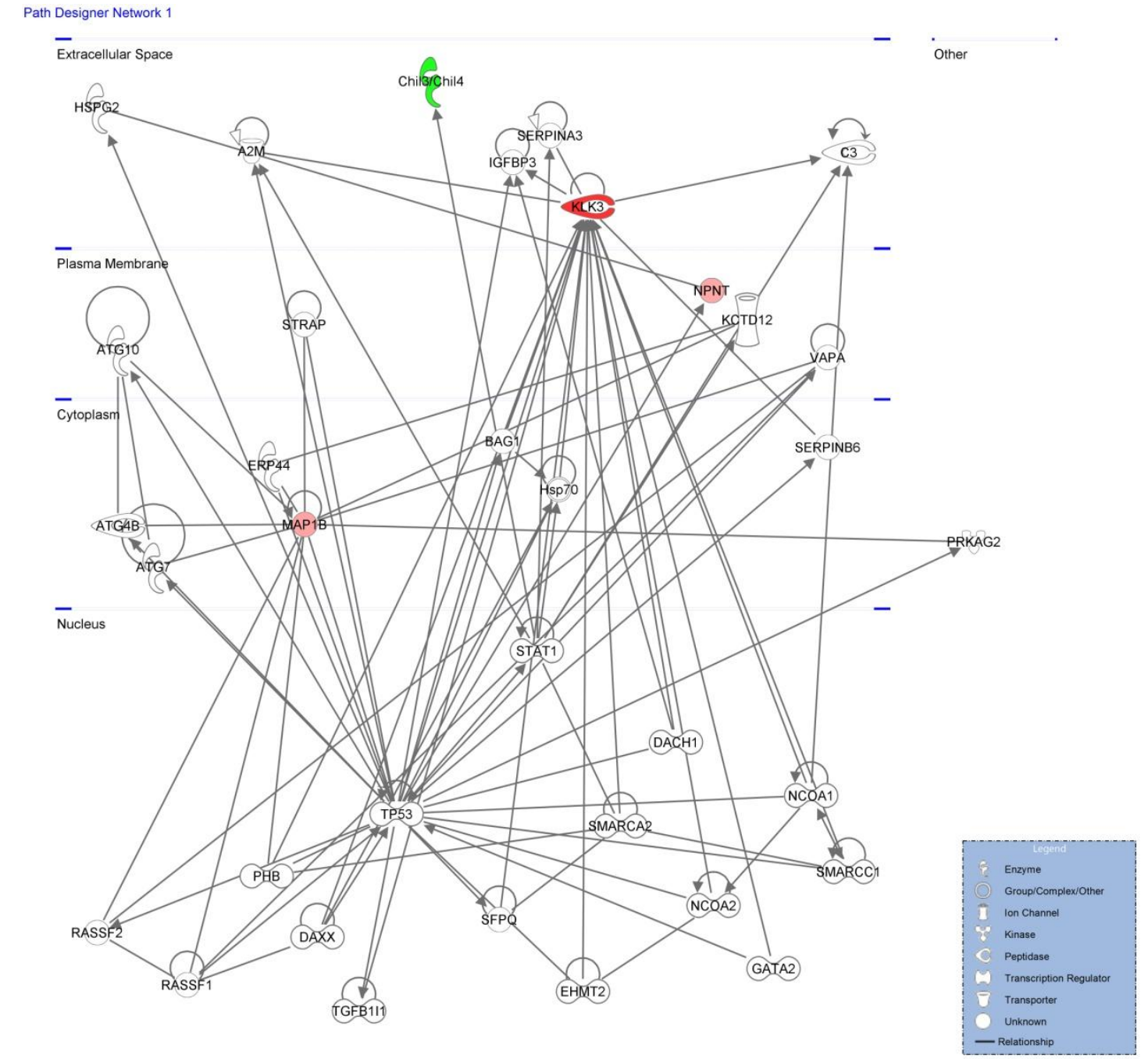

Figura 61 - Rede mais significativa do camundongo Large $e^{m y d-}$ com 3 meses. Score: 10; 4 genes selecionados. Categorias envolvidas: Desenvolvimento e função do tecido conectivo; Morfologia tecidual; Morte e sobrevivência celular 
A Figura 62 mostra a rede mais significante (total de oito redes) formada com a análise dos 81 genes do Large $^{\text {myd-/- }}$ com seis meses de idade (diagrama 1, Figura 50).

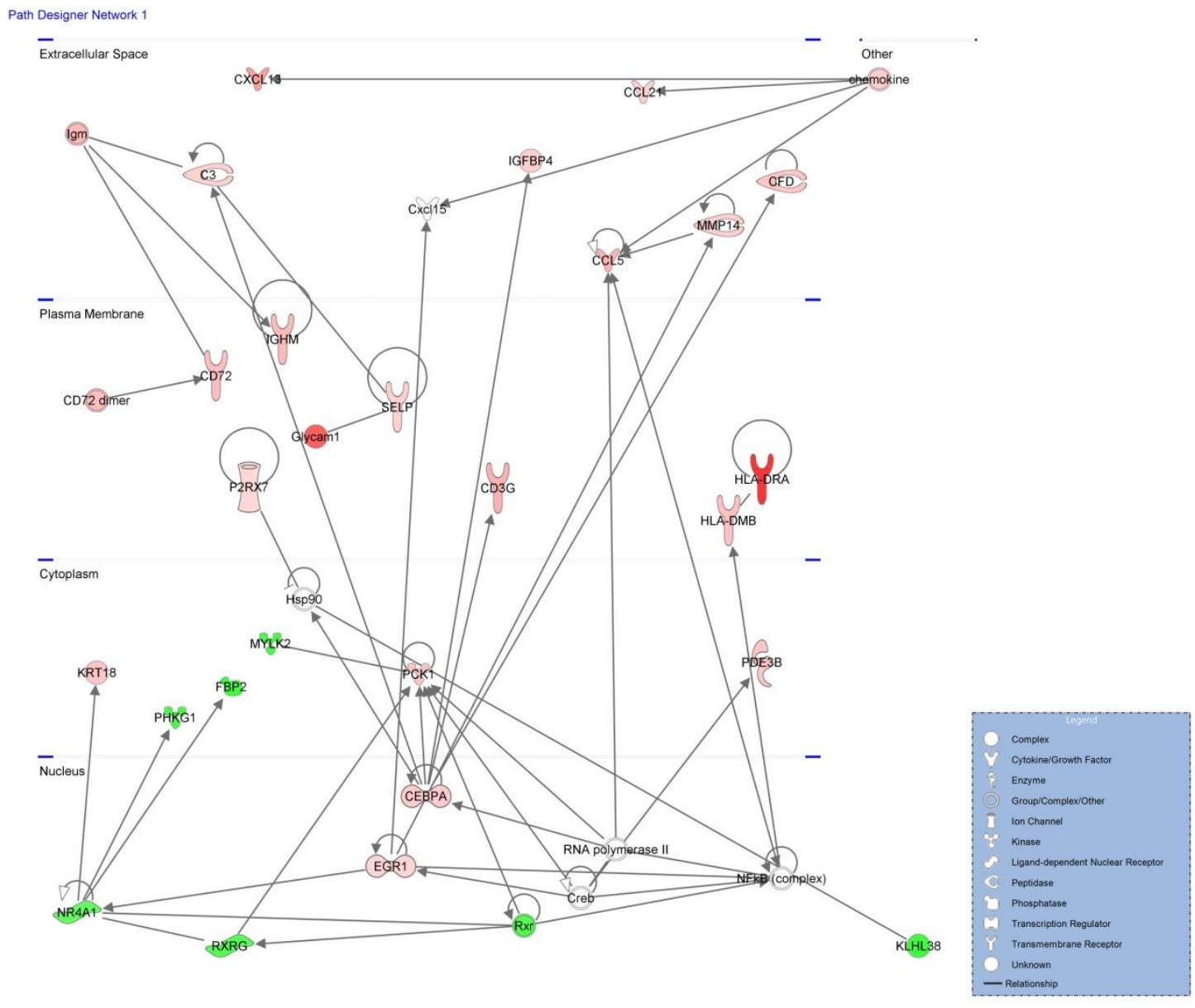

Figura 62 - Rede mais significativa do camundongo Large $e^{m y d--}$ com 6 meses. Score: 62; 26 genes selecionados. Categorias envolvidas: Doença metabólica; Resposta inflamatória; Doenças do tecido conectivo 


\section{$\operatorname{Dmd}^{m d x} / \operatorname{Large}^{m y d-/-}$}

$\mathrm{Na}$ Figura 63, ilustramos a rede mais significante (total de quatro redes) que foi gerada a partir da análise dos 12 genes do duplo-mutante de 21 dias (diagrama A da figura 48).

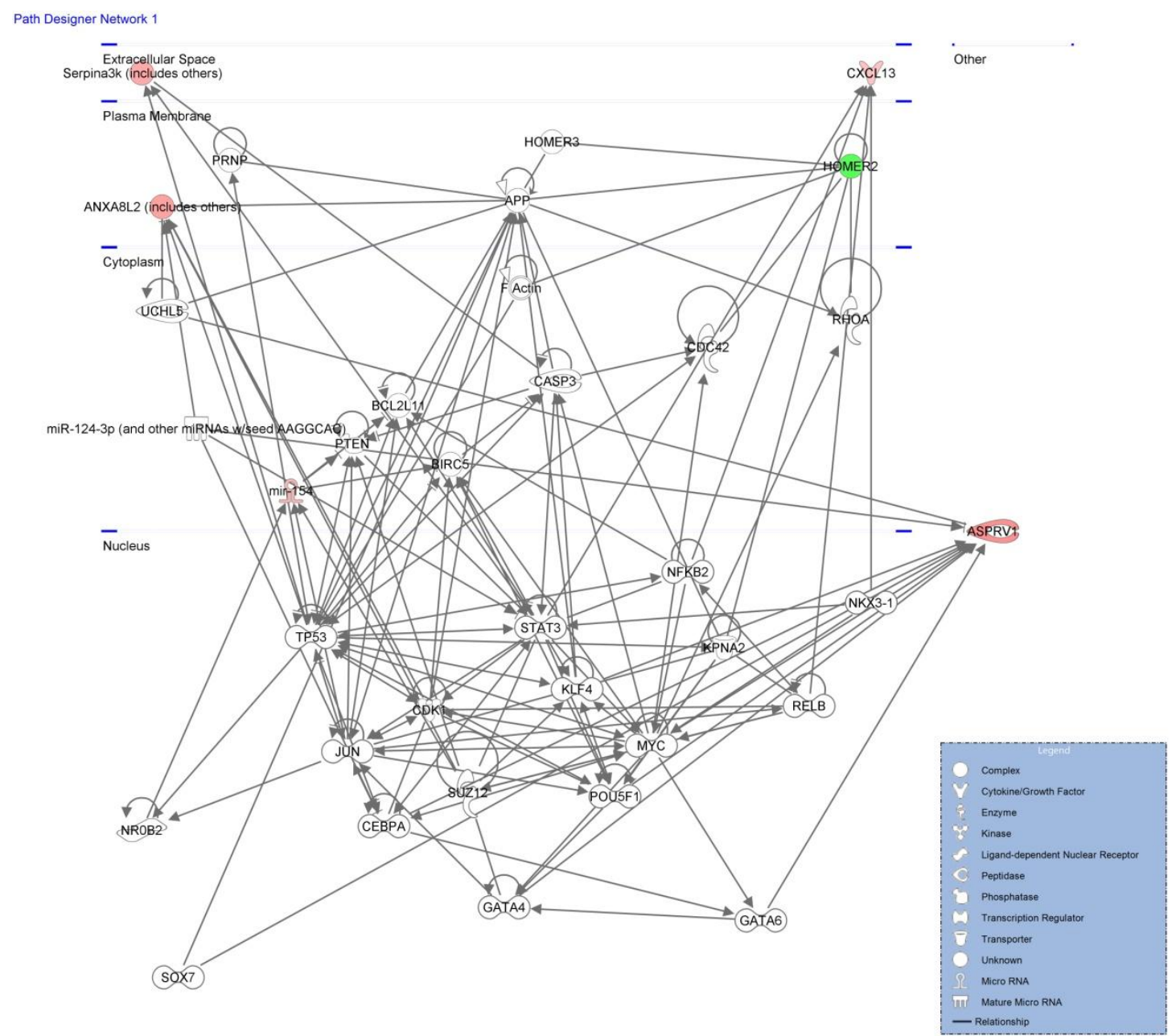

Figura 63 - Rede mais significativa do camundongo $D m d^{m d x} /$ Large $e^{m y d-/}$ com 21 dias. Score: 15; 4 genes selecionados. Categorias envolvidas: Sobrevivência e morte celular; Desenvolvimento celular; Morfologia de tumores 
Já com a análise dos 72 genes específicos do duplo-mutante com três meses de idade, oito redes foram geradas e a mais significante está ilustrada na Figura 64.

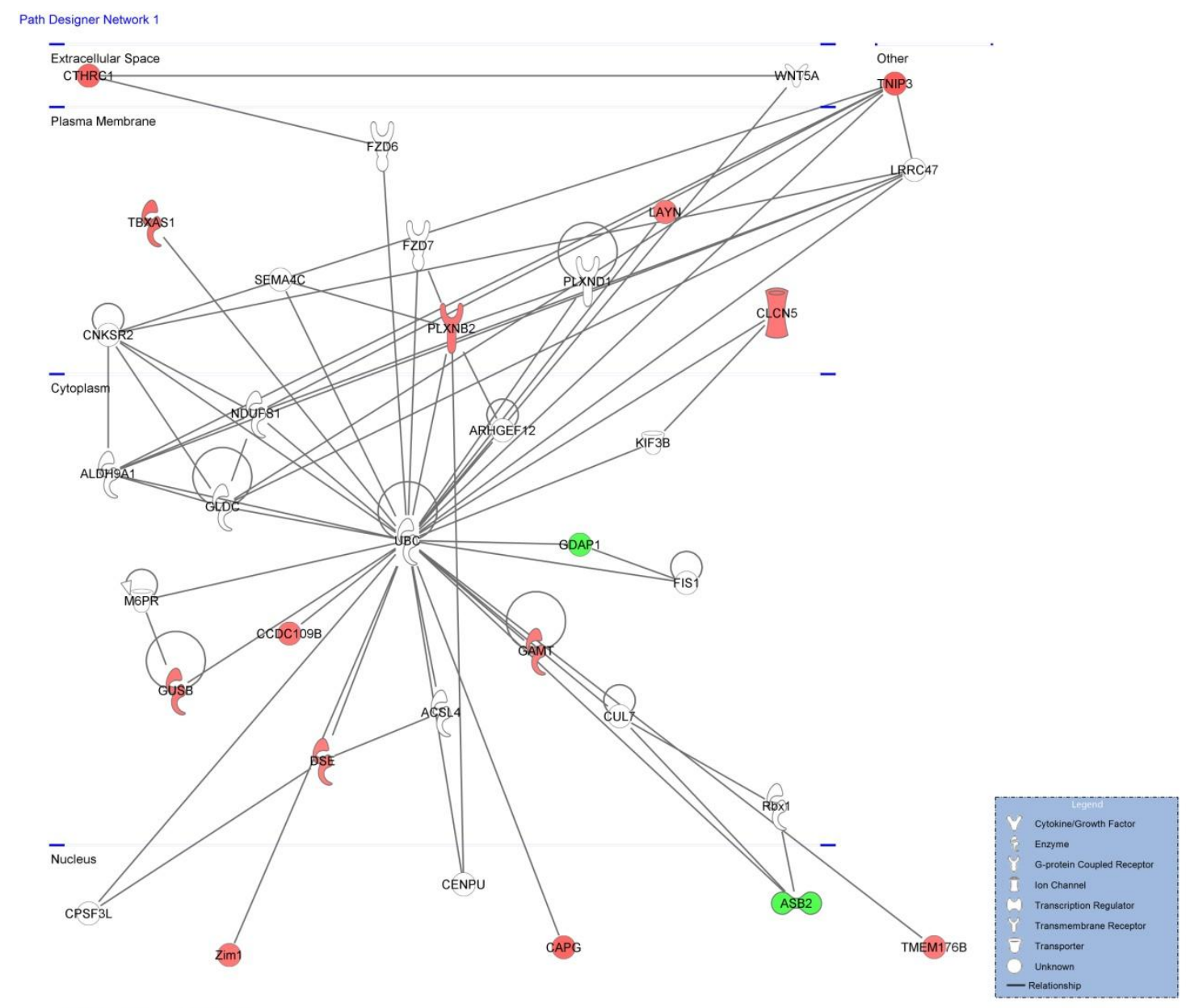

Figura 64 - Rede mais significativa do camundongo Dmd ${ }^{m d x} /$ Large ${ }^{m y d-/}$ com 3 meses. Score: $31 ; 72$ genes selecionados. Categorias envolvidas: Movimento celular; Desenvolvimento embrionário; Desenvolvimento e função do sistema nervoso 
Por fim, a análise com os 44 genes do duplo-mutante com seis meses (diagrama A, Figura 50) gerou quatro redes; a mais significante está na Figura 65.

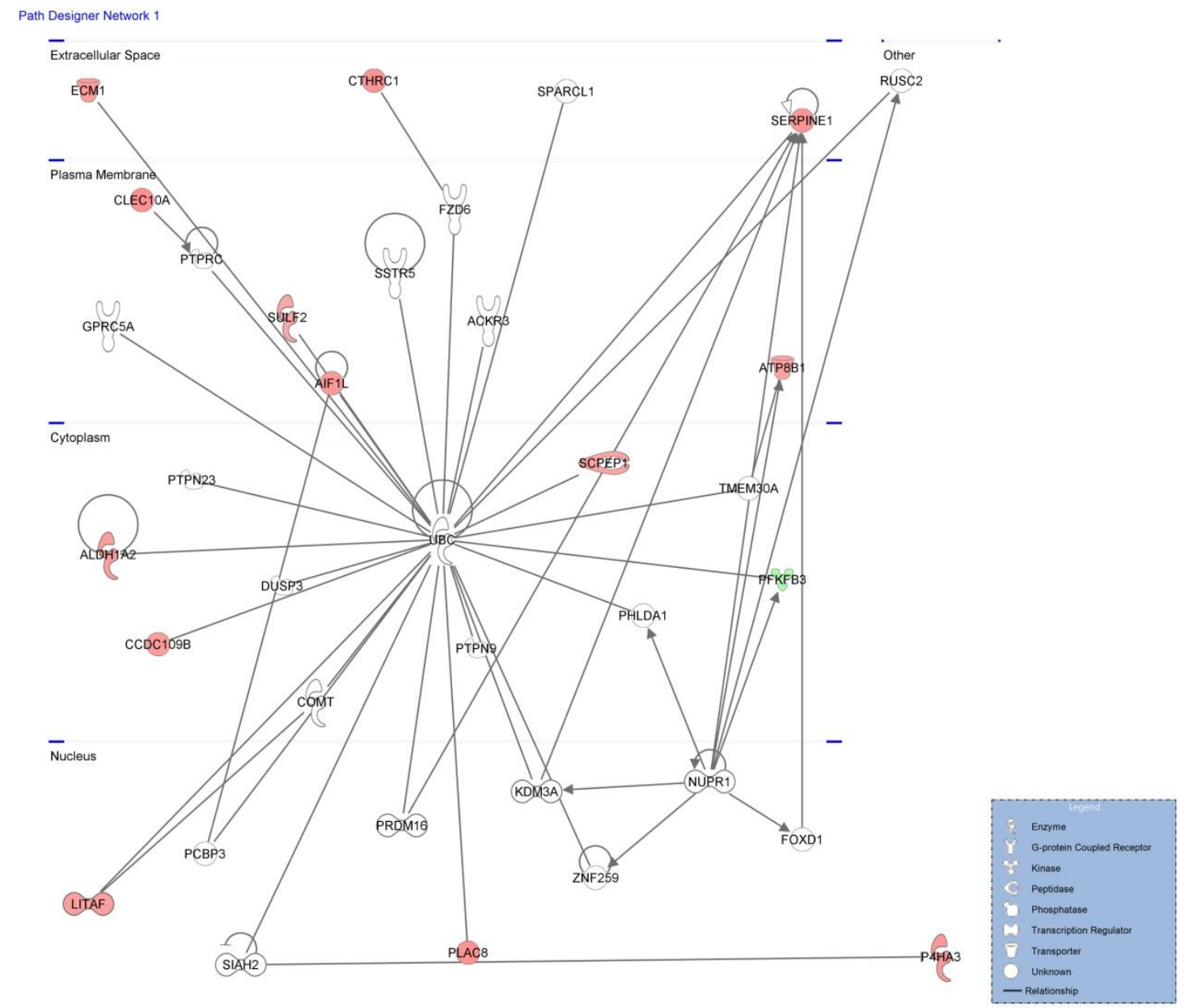

Figura 65 - Rede mais significativa do camundongo $D m d^{m d x} / L a r g e^{m y d-/}$ com 6 meses. Score: 32; 14 genes selecionados. Categorias envolvidas: Desenvolvimento embrionário; Desenvolvimento e função do sistema nervoso, Desenvolvimento do órgão 


\section{Caracterização da linhagem Dmd ${ }^{m d x} / \operatorname{Large}^{m y d-/-}$ Comparação com suas linhagens parentais}

Na tabela abaixo estão os totais de genes diferencialmente expressos no duplomutante antes da anotação:

Tabela 37 - Número de genes diferencialmente expressos nas comparações do duplo-mutante com as linhagens parentais

\begin{tabular}{lccc}
\hline Comparações & 21 dias & 3 meses & 6 meses \\
\hline Dmd $^{\text {mdx }} /$ Large ${ }^{\text {myd-/- }} \times$ Dmd $^{\text {mdx }}$ & 185 & 58 & 44 \\
Dmd $^{\text {mdx }} /$ Large $^{\text {myd-/- }} \times$ Large $^{\text {myd-/- }}$ & 36 & 22 & 39 \\
\hline
\end{tabular}

Nesta tabela estão os totais de genes após a anotação, indicando quantos genes estão super e subexpressos.

Tabela 38 - Comparações do duplo-mutante com as linhagens parentais. Totais de genes diferencialmente expressos após a anotação. Em vermelho, os genes superexpressos; em verde, os genes subexpressos

\begin{tabular}{|c|c|c|c|c|c|c|c|c|c|}
\hline \multirow{2}{*}{$\begin{array}{l}\text { Comparações } \\
m d^{m d x} / \operatorname{Larg} e^{m y d-1-} \times D m d^{m d x}\end{array}$} & \multicolumn{3}{|c|}{21 dias } & \multicolumn{3}{|c|}{3 meses } & \multicolumn{3}{|c|}{6 meses } \\
\hline & $\uparrow 6$ & $\downarrow 124$ & 130 & 个38 & $\downarrow 15$ & 53 & 个11 & $\downarrow 25$ & 36 \\
\hline$D m d^{m d x} / \operatorname{Larg}^{m y d-1-} \times \operatorname{Larg}^{m y d-1}$ & $\uparrow 8$ & $\downarrow 8$ & 16 & 个9 & $\downarrow 3$ & 12 & 个32 & $\downarrow 1$ & 33 \\
\hline
\end{tabular}

No diagrama da figura 66, estão as listas de genes comuns de cada linhagem em todas as idades. Do total de 59 GDEs no duplo, 31 genes são os comuns a todas as linhagens (centro) descritos na tabela 24. Sete genes são compartilhados com a linhagem Large $^{m y d-/}$ (Tabela 39), e 20 genes com $D m d^{m d x}$ (Tabela X). Em destaque, está o único gene que tem expressão aumentada apenas na linhagem $D m d^{m d x} / \operatorname{Larg}^{m y d-\gamma}$ nas três idades. Esse gene é o Lilrb3.

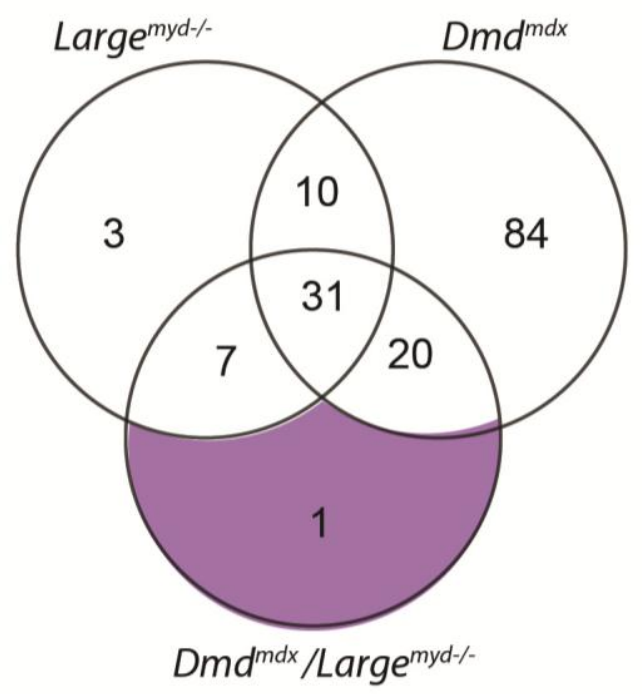

Figura 66 - Diagrama de Venn reunindo todos os genes diferencialmente expressos nas três idades de cada linhagem. No centro estão os genes compartilhados por todas as linhagens e idades. Em destaque o único gene com expressão diferencial apenas na linhagem $D m d^{m d x} / \operatorname{Larg}^{m y d-/}$ 
Tabela 39 - Genes compartilhados com a linhagem Large myd-/- $^{\text {- }}$

\begin{tabular}{ll}
\hline Símbolo & Entrez Gene Name \\
\hline BAIAP2L1 & BAI1-associated protein 2-like 1 \\
\hline HAL & histidine ammonia-lyase \\
\hline LARGE & like-glycosyltransferase \\
MMP19 & matrix metallopeptidase 19 \\
\hline MT1E & metallothionein 1E \\
\hline PRUNE2 & prune homolog 2 (Drosophila) \\
\hline VSIG4 & V-set and immunoglobulin domain containing 4 \\
\hline
\end{tabular}

Tabela 40 - Genes compartilhados com a linhagem Dmd ${ }^{m d x}$

\begin{tabular}{ll}
\hline Símbolo & Entrez Gene Name \\
\hline ADAM8 & ADAM metallopeptidase domain 8 \\
\hline ATP6V0D2 & ATPase, H+ transporting, lysosomal 38kDa, V0 subunit d2 \\
\hline C5AR1 & complement component 5a receptor 1 \\
\hline CCI2 & chemokine (C-C motif) ligand 2 \\
\hline CCL3L1/CCL3L3 & chemokine (C-C motif) ligand 3-like 1 \\
\hline CD84 & CD84 molecule \\
\hline CYBB & cytochrome b-245, beta polypeptide \\
\hline EMB & embigin \\
\hline FCER1G & Fc fragment of IgE, high affinity I, receptor for; gamma polypeptide \\
\hline FCGR2B & Fc fragment of IgG, low affinity IIb, receptor (CD32) \\
\hline FCGR3A & Fc fragment of IgG, low affinity IIIa, receptor (CD16a) \\
\hline GAL & galanin/GMAP prepropeptide \\
\hline Ifi204 (includes others) & interferon activated gene 204 \\
\hline Lyz1/Lyz2 & lysozyme 2 \\
\hline Milr1 & mast cell immunoglobulin like receptor 1 \\
\hline PRG4 & proteoglycan 4 \\
\hline RUNX1 & runt-related transcription factor 1 \\
\hline TIr13 & toll-like receptor 13 \\
\hline TREM2 & triggering receptor expressed on myeloid cells 2 \\
\hline TYROBP & TYRO protein tyrosine kinase binding protein \\
\hline
\end{tabular}




\subsection{IPA - Análise funcional do Dmd ${ }^{m d x} / \operatorname{Large}^{m y d-/-}$}

Para explorar mais os dados obtidos com os estudos do duplo-mutante, os genes diferencialmente expressos em cada idade do duplo-mutante (diagrama 56) foram avaliados no programa IPA, que além de gerar redes gênicas, também fornecer uma análise funcional, categorizando as principais funções encontradas dentre os genes fornecidos, servindo para corroborar os achados nas análises de enriquecimento apresentadas anteriormente. As tabelas 41, 42 e 43 mostram o que foi encontrado nas análises com os genes do duplo-mutante, nas três idades.

Tabela 41 - Categorias biológicas enriquecidas na linhagem Dmd mdx $^{\prime}$ Large $e^{m y d-/-}$ com 21 dias de idade. 97 genes diferencialmente expressos foram utilizados nessa análise

\begin{tabular}{llc}
\hline Categorias & p-value & \# Moléculas \\
\hline Diseases and disorders & & 38 \\
\hline Endocrine System Disorders & $1,05 \mathrm{E}-21-1,13 \mathrm{E}-03$ & 43 \\
Gastrointestinal Disease & $1,05 \mathrm{E}-21-1,05 \mathrm{E}-03$ & 40 \\
\hline Metabolic Disease & $1,05 \mathrm{E}-21-2,23 \mathrm{E}-05$ & 52 \\
\hline Immunological Disease & $1,79 \mathrm{E}-21-6,60 \mathrm{E}-04$ & 51 \\
\hline Inflammatory Response & $2,47 \mathrm{E}-19-1,09 \mathrm{E}-03$ & \\
Molecular and Cellular Functions & & 42 \\
Cellular Movement & $1,36 \mathrm{E}-21-1,08 \mathrm{E}-03$ & 44 \\
Cell-to-Cell Signaling and Interaction & $3,11 \mathrm{E}-15-1,14 \mathrm{E}-03$ & 38 \\
\hline Cellular Function and Maintenance & $4,11 \mathrm{E}-15-1,11 \mathrm{E}-03$ & 41 \\
\hline Cell Death and Survival & $3,31 \mathrm{E}-12-1,08 \mathrm{E}-03$ & 35 \\
\hline Molecular Transport & $4,53 \mathrm{E}-10-1,14 \mathrm{E}-03$ & \\
Physiological System Development and Function & & 40 \\
Immune Cell Trafficking & $1,36 \mathrm{E}-21-9,79 \mathrm{E}-04$ & 51 \\
\hline Hematological System Development and Function & $1,67 \mathrm{E}-21-8,91 \mathrm{E}-04$ & 42 \\
\hline Tissue Morphology & $2,47 \mathrm{E}-19-1,11 \mathrm{E}-03$ & 19 \\
\hline Humoral Immune Response & $7,32 \mathrm{E}-10-6,07 \mathrm{E}-04$ & 25 \\
\hline Connective Tissue Development and Function & $2,67 \mathrm{E}-09-5,45 \mathrm{E}-04$ & \\
\hline
\end{tabular}


Tabela 42 - Categorias biológicas enriquecidas na linhagem $D m d^{m d x} /$ Large $^{m y d-/-}$ com 3 meses de idade. $\mathbf{2 8 0}$ genes diferencialmente expressos foram utilizados nessa análise

\begin{tabular}{llc}
\hline Categorias & p-value & \# Moléculas \\
\hline Diseases and disorders & & \\
Inflammatory Response & $4,35 \mathrm{E}-35-2,25 \mathrm{E}-05$ & 135 \\
Immunological Disease & $3,72 \mathrm{E}-34-8,12 \mathrm{E}-06$ & 111 \\
\hline Endocrine System Disorders & $6,29 \mathrm{E}-34-1,39 \mathrm{E}-05$ & 84 \\
Gastrointestinal Disease & $6,29 \mathrm{E}-34-2,25 \mathrm{E}-05$ & 92 \\
\hline Metabolic Disease & $6,29 \mathrm{E}-34-1,09 \mathrm{E}-05$ & 82 \\
Molecular and Cellular Functions & & \\
Cellular Movement & $6,33 \mathrm{E}-35-2,06 \mathrm{E}-05$ & 109 \\
Cell-to-Cell Signaling and Interaction & $1,53 \mathrm{E}-31-2,03 \mathrm{E}-05$ & 117 \\
Cellular Function and Maintenance & $4,27 \mathrm{E}-27-1,35 \mathrm{E}-05$ & 112 \\
Cellular Development & $1,17 \mathrm{E}-21-1,12 \mathrm{E}-05$ & 124 \\
Cellular Growth and Proliferation & $1,17 \mathrm{E}-21-1,89 \mathrm{E}-05$ & 141 \\
Physiological System Development and Function & & \\
Immune Cell Trafficking & $6,33 \mathrm{E}-35-1,94 \mathrm{E}-05$ & 103 \\
\hline Hematological System Development and Function & $5,65 \mathrm{E}-33-2,11 \mathrm{E}-05$ & 136 \\
\hline Tissue Morphology & $2,44 \mathrm{E}-31-2,11 \mathrm{E}-05$ & 119 \\
\hline Tissue Development & $3,42 \mathrm{E}-25-2,06 \mathrm{E}-05$ & 116 \\
\hline Humoral Immune Response & $9,90 \mathrm{E}-21-4,79 \mathrm{E}-06$ & 51 \\
\hline
\end{tabular}

Tabela 43 - Categorias biológicas enriquecidas na linhagem Dmd ${ }^{m d x} /$ Large $^{m y d-/-}$ com 6 meses de idade. $\mathbf{2 8 3}$ genes diferencialmente expressos foram utilizados nessa análise

\begin{tabular}{llc}
\hline Categorias & p-value & \# Moléculas \\
\hline Diseases and disorders & & \\
\hline Immunological Disease & $1,98 \mathrm{E}-42-1,91 \mathrm{E}-06$ & 122 \\
Endocrine System Disorders & $4,10 \mathrm{E}-41-1,35 \mathrm{E}-09$ & 106 \\
\hline Gastrointestinal Disease & $4,10 \mathrm{E}-41-1,38 \mathrm{E}-06$ & 112 \\
Metabolic Disease & $4,10 \mathrm{E}-41-6,78 \mathrm{E}-07$ & 104 \\
\hline Inflammatory Response & $1,55 \mathrm{E}-39-1,86 \mathrm{E}-06$ & 139 \\
Molecular and Cellular Functions & & \\
Cellular Movement & $3,36 \mathrm{E}-38-1,86 \mathrm{E}-06$ & 114 \\
Cell-to-Cell Signaling and Interaction & $2,66 \mathrm{E}-36-1,38 \mathrm{E}-06$ & 121 \\
\hline Cellular Function and Maintenance & $1,68 \mathrm{E}-31-8,97 \mathrm{E}-07$ & 116 \\
Cellular Development & $1,34 \mathrm{E}-27-1,82 \mathrm{E}-06$ & 124 \\
\hline Cellular Growth and Proliferation & $1,34 \mathrm{E}-27-1,82 \mathrm{E}-06$ & 139 \\
Physiological System Development and Function & & \\
Immune Cell Trafficking & $3,36 \mathrm{E}-38-1,86 \mathrm{E}-06$ & 108 \\
\hline Hematological System Development and Function & $2,04 \mathrm{E}-35-1,86 \mathrm{E}-06$ & 142 \\
\hline Tissue Morphology & $1,18 \mathrm{E}-32-5,51 \mathrm{E}-07$ & 113 \\
\hline Tissue Development & $4,33 \mathrm{E}-24-1,18 \mathrm{E}-06$ & 123 \\
\hline Humoral Immune Response & $1,45 \mathrm{E}-22-5,51 \mathrm{E}-07$ & 54 \\
\hline
\end{tabular}




\subsection{Redes funcionais com todos os genes}

Além das redes apresentadas anteriormente, também foram feitas análises no programa IPA com o total de genes diferencialmente expressos nos animais duplomutantes, mostrando as interações entre eles.

Estão apresentadas as cinco redes com maior significância e número de moléculas envolvidas, e ilustradas apenas as duas principais.

Tabela 44 - Principais redes gênicas formadas com os genes diferencialmente expressos no $D_{m d^{m d x}} /$ Large $^{m y d-/}$ com 21 dias

\begin{tabular}{llcc}
\hline & Top Networks & Score & \# moléculas \\
\hline $\mathbf{1}$ & $\begin{array}{l}\text { Cellular Movement, Hematological System Development } \\
\text { and Function, Immune Cell Trafficking }\end{array}$ & 45 & 21 \\
$\mathbf{2}$ & $\begin{array}{l}\text { Developmental Disorder, Hereditary Disorder, Skeletal and } \\
\text { Muscular Disorders }\end{array}$ & 33 & 17 \\
$\mathbf{3}$ & $\begin{array}{l}\text { Cell-To-Cell Signaling and Interaction, Inflammatory } \\
\text { Response, Antimicrobial Response }\end{array}$ & 27 & 14 \\
$\mathbf{4}$ & $\begin{array}{l}\text { Cellular Movement, Hematological System Development } \\
\text { and Function, Immune Cell Trafficking }\end{array}$ & 24 & 13 \\
$\mathbf{5}$ & $\begin{array}{l}\text { Cell-To-Cell Signaling and Interaction, Nervous System } \\
\text { Development and Function, Behavior }\end{array}$ & 21 & 12 \\
\hline
\end{tabular}



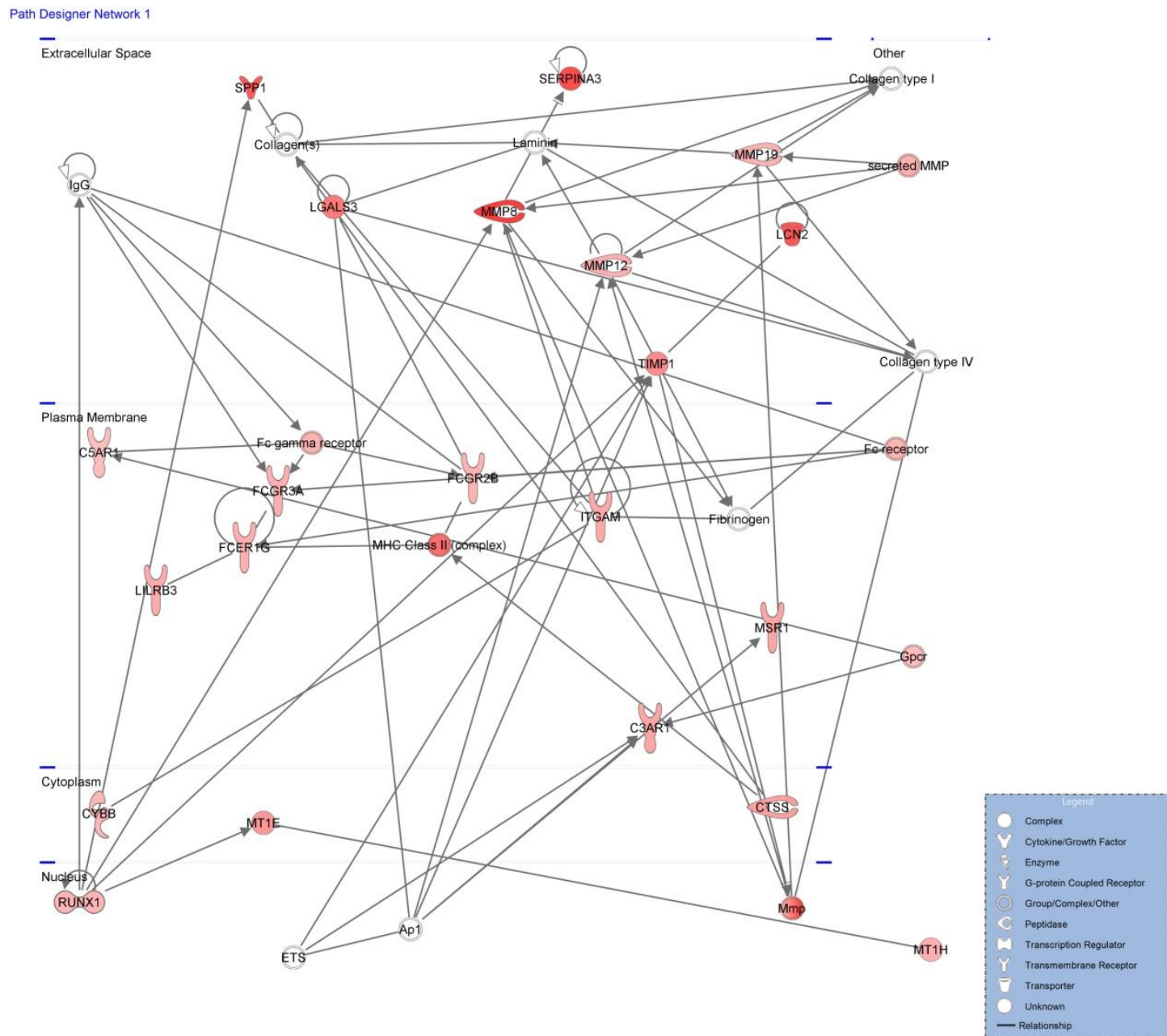

Figura 67 - Rede mais significativa do camundongo $D m d^{m d x} /$ Large $e^{m y d-/}$ com 21 dias. Score: 45; 21 genes selecionados. Categorias envolvidas: Movimento celular; Desenvolvimento e função do sistema hematológico; Tráfego de células imunes 


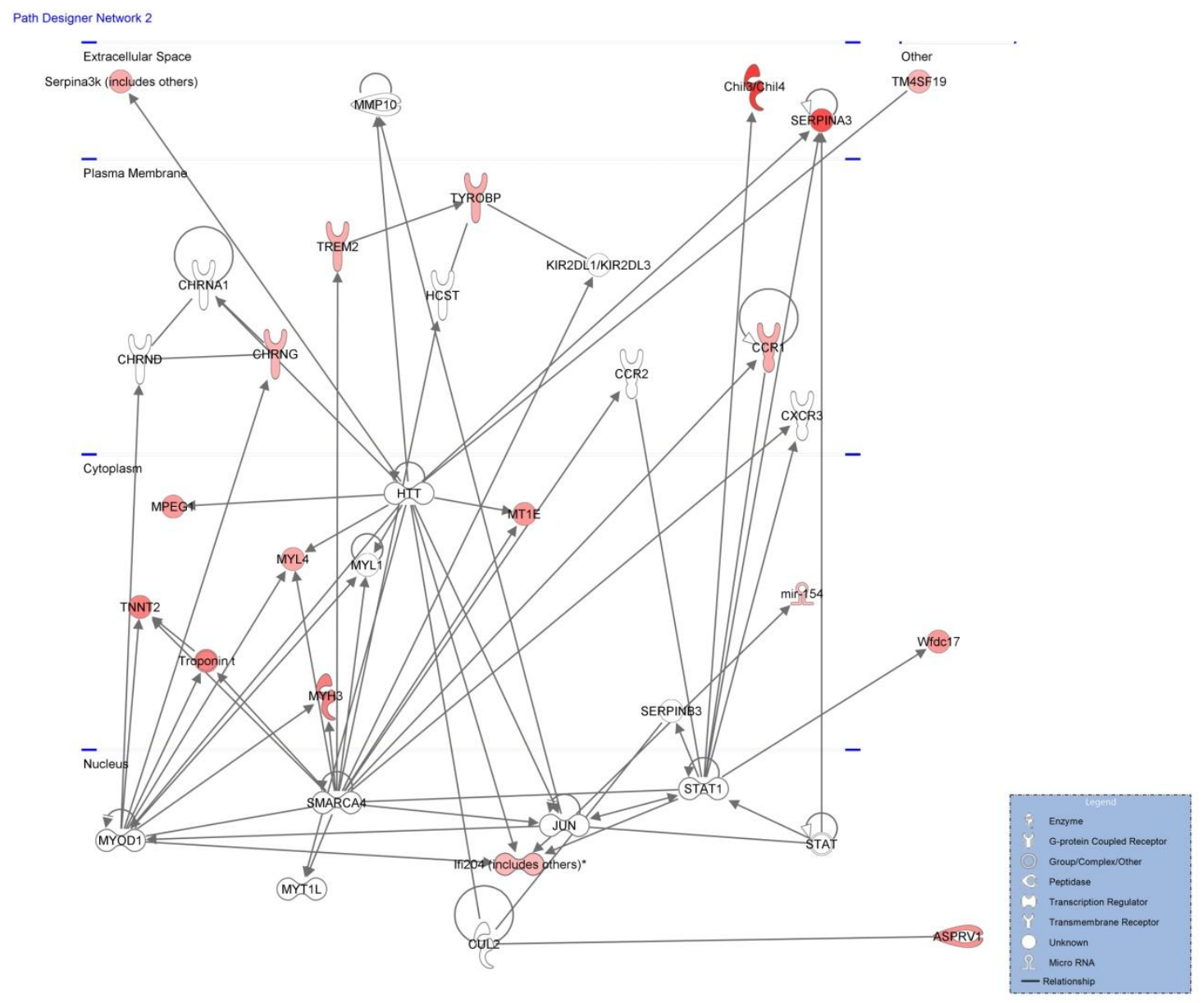

Figura 68 - Segunda rede mais significativa do camundongo $D m d^{m d x} /$ Large $^{m y d-/-}$ com 21 dias. Score: 33; 17 genes selecionados. Categorias envolvidas: Doença do desenvolvimento; Doença hereditária; Doenças esqueléticas e musculares

Tabela 45 - Principais redes gênicas formadas com os genes diferencialmente expressos no Dmd $^{m d x} /$ Large $^{m y d-/-}$ com 3 meses

\section{Top Networks}

1 Cardiovascular Disease, Neurological Disease, Hereditary Disorder

2 Hematological System Development And Function, Inflammatory Response, Tissue Morphology

3 Endocrine System Disorders, Gastrointestinal Disease, Immunological Disease

4 Humoral Immune Response, Protein Synthesis, Developmental Disorder

5 Connective Tissue Disorders, Organismal Injury and Abnormalities, Immunological Disease
Score \# moléculas

$47 \quad 27$

40

24

39




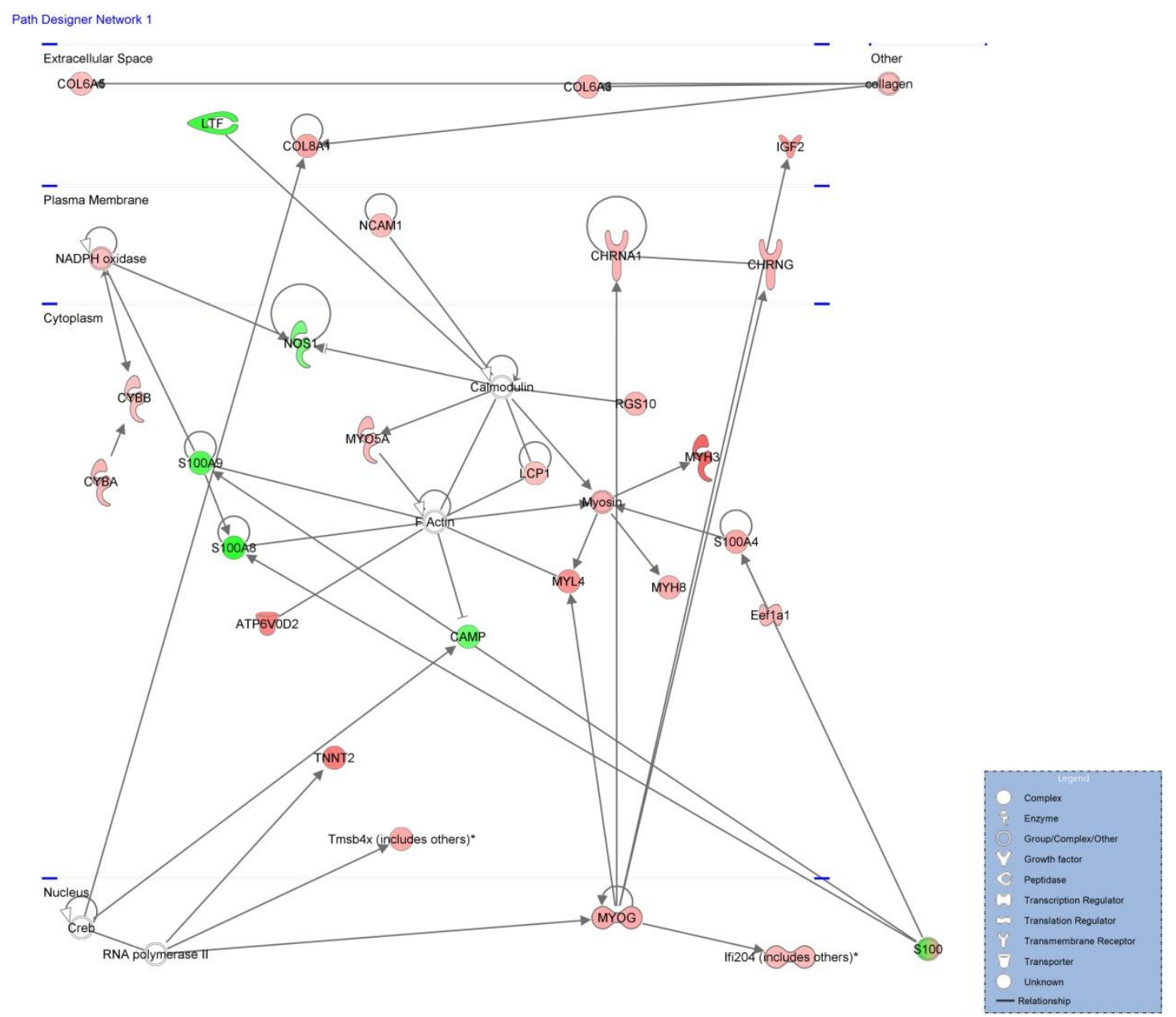

Figura 69 - Rede mais significativa do camundongo $D m d^{m d x} / L a r g e^{m y d-/-}$ com 3 meses. Score: 47; 27 genes selecionados. Categorias envolvidas: Doença cardiovascular; Doença neurológica; Doença hereditária 


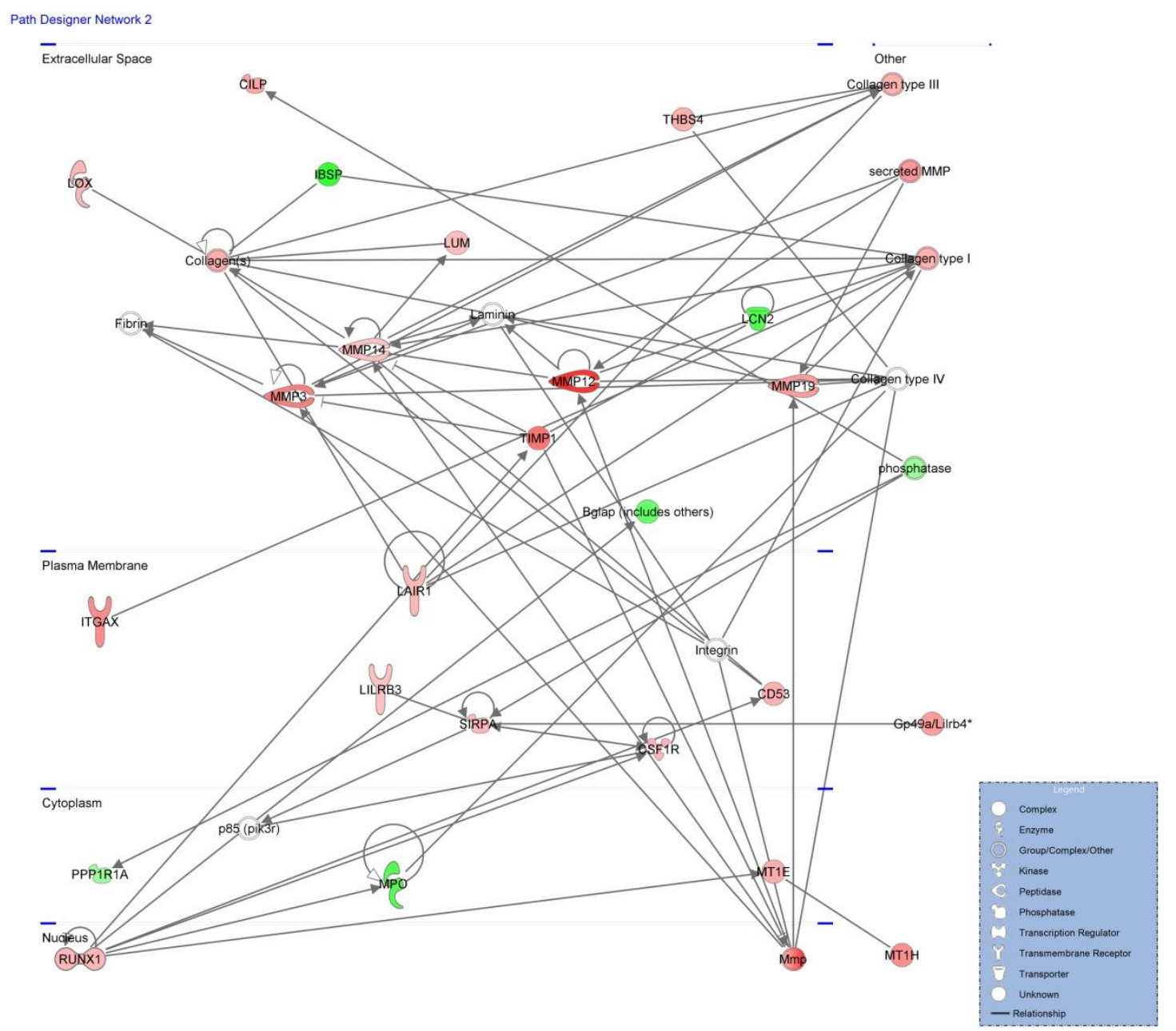

Figura 70 - Segunda rede mais significativa do camundongo Dmd ${ }^{m d x} / L_{a r g} e^{m y d-/}$ com 3 meses. Score: 40; 24 genes selecionados. Categorias envolvidas: Desenvolvimento e função do sistema hematológico; Resposta inflamatória; Morfologia tecidual

Tabela 46 - Principais redes gênicas formadas com os genes diferencialmente expressos no Dmd $^{m d x} /$ Large $^{m y d-/-}$ com 6 meses

\begin{tabular}{clcc}
\hline & Top Networks & Score & \# moléculas \\
\hline $\mathbf{1}$ & $\begin{array}{l}\text { Inflammatory Response, Cellular Movement, Immune Cell } \\
\text { Trafficking }\end{array}$ & 50 & 29 \\
$\mathbf{2}$ & $\begin{array}{l}\text { Hematological System Development And Function, Tissue } \\
\text { Morphology, Cellular Development }\end{array}$ & 41 & 24 \\
$\mathbf{3}$ & $\begin{array}{l}\text { Cell Death And Survival, Cellular Assembly and Organization, } \\
\text { Cellular Compromise }\end{array}$ & 36 & 22 \\
$\mathbf{4}$ & $\begin{array}{l}\text { Developmental Disorder, Hereditary Disorder, Immunological } \\
\text { Disease }\end{array}$ & 31 & 20 \\
$\mathbf{5}$ & $\begin{array}{l}\text { Cellular Function and Maintenance, Hematological System } \\
\text { Development And Function, Infectious Disease }\end{array}$ & 30 & 19 \\
\hline
\end{tabular}




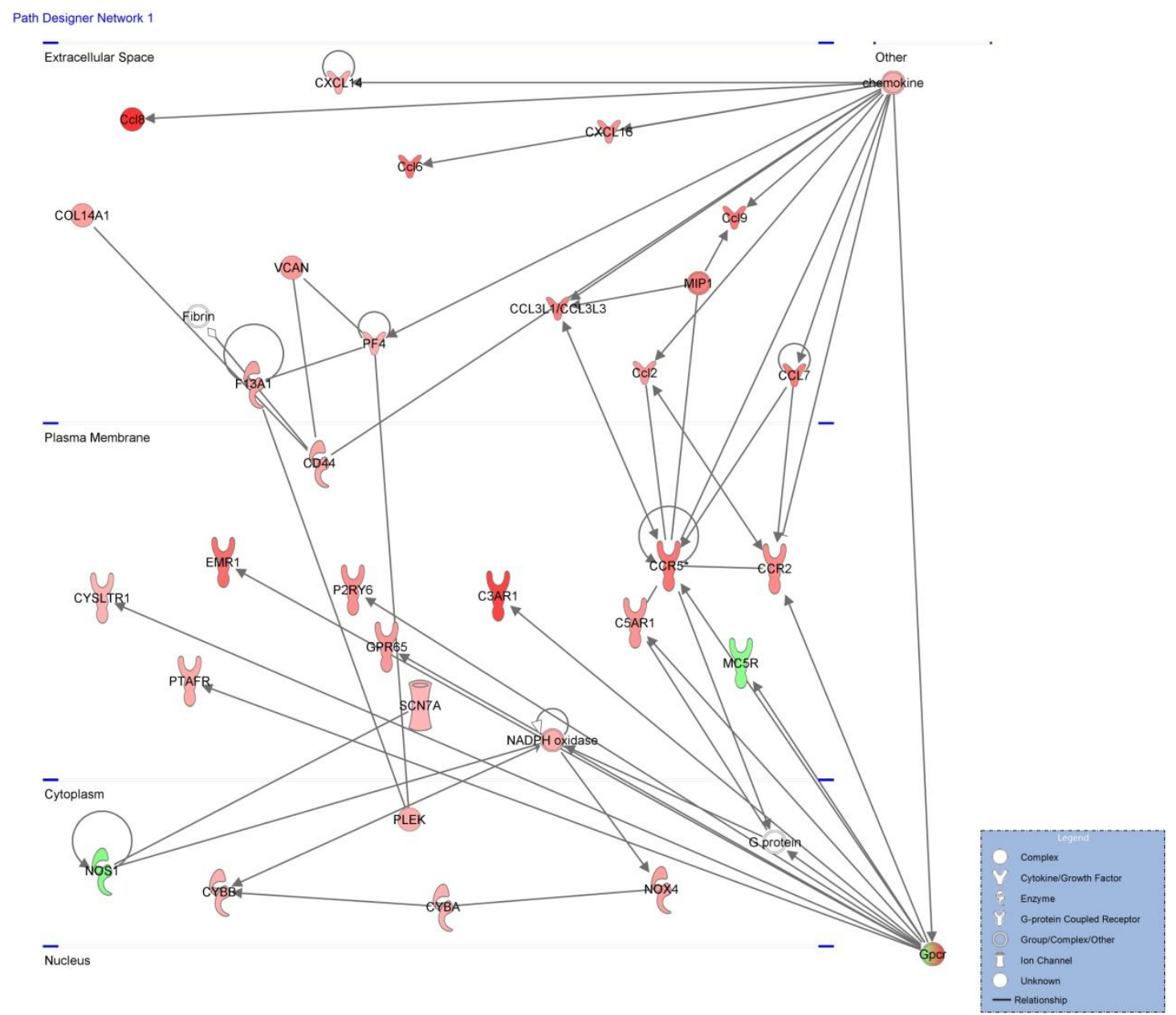

Figura 71 - Rede mais significativa do camundongo $D m d^{m d x} / L a r g e^{m y d-/}$ com 6 meses. Score: 50; 29 genes selecionados. Categorias envolvidas: Resposta inflamatória; Movimento celular; Tráfego de células imunes 


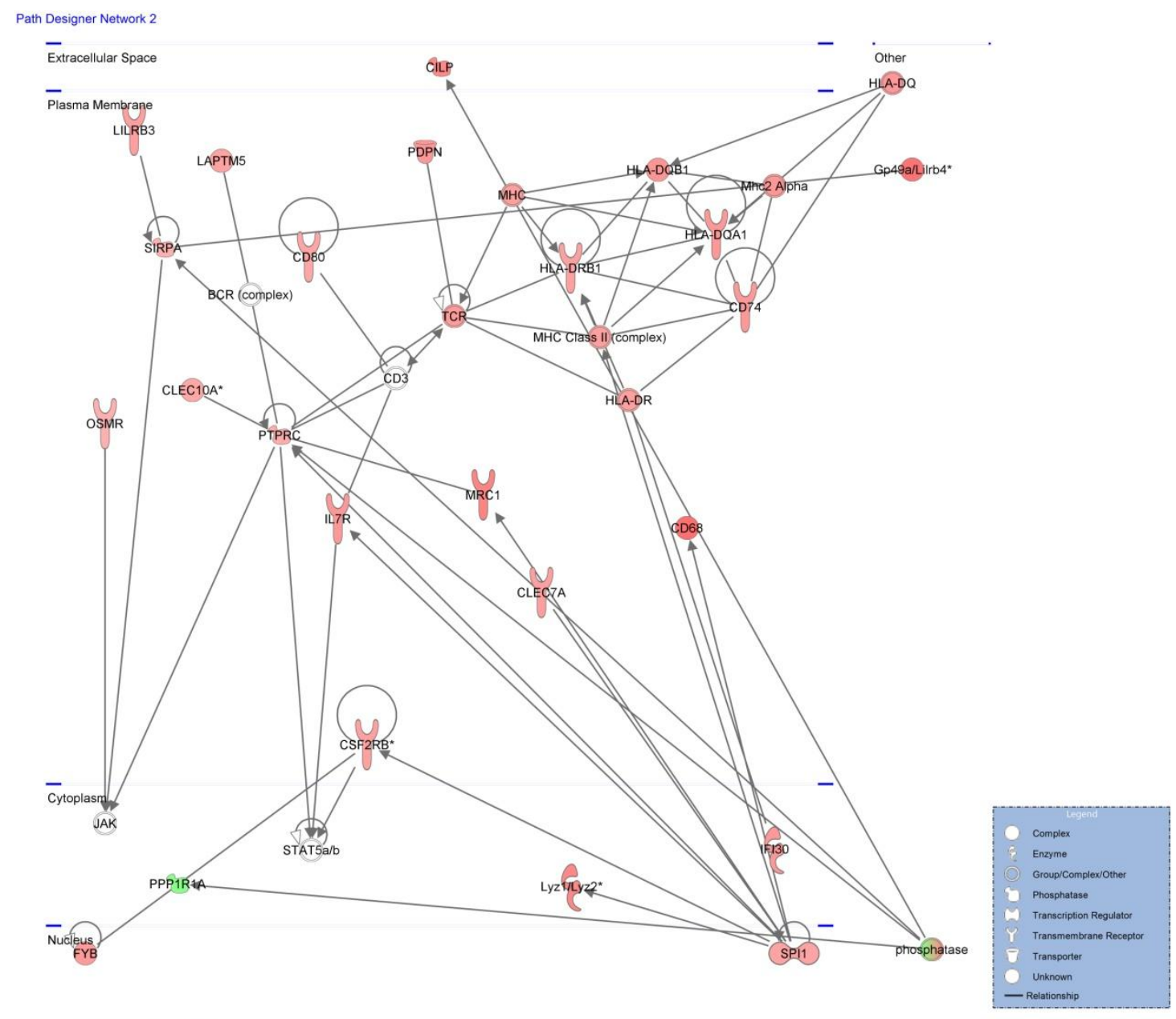

Figura 72 - Segunda rede mais significativa do camundongo $D m d^{m d x} / L a r g e^{m y d-/}$ com 6 meses. Score: 41; 24 genes selecionados. Categorias envolvidas: Desenvolvimento e função do sistema hematológico; Morfologia tecidual; Desenvolvimento celular 


\section{Validação do perfil de expressão por PCR em tempo real quantitativo}

Doze genes que apresentaram expressão alterada nos microarranjos foram avaliados por PCR em tempo real quantitativo para a confirmação do perfil de expressão. São eles: Ankrd1, Gpnmb, Large, Mmp14, Mstn, Mup1, Myog, Nos1, Ostn, Pttg1, Tnnt2. A análise foi feita em três animais de cada linhagem de cada idade.

As quantificações relativas da expressão dos genes estão apresentadas nos gráficos seguintes.

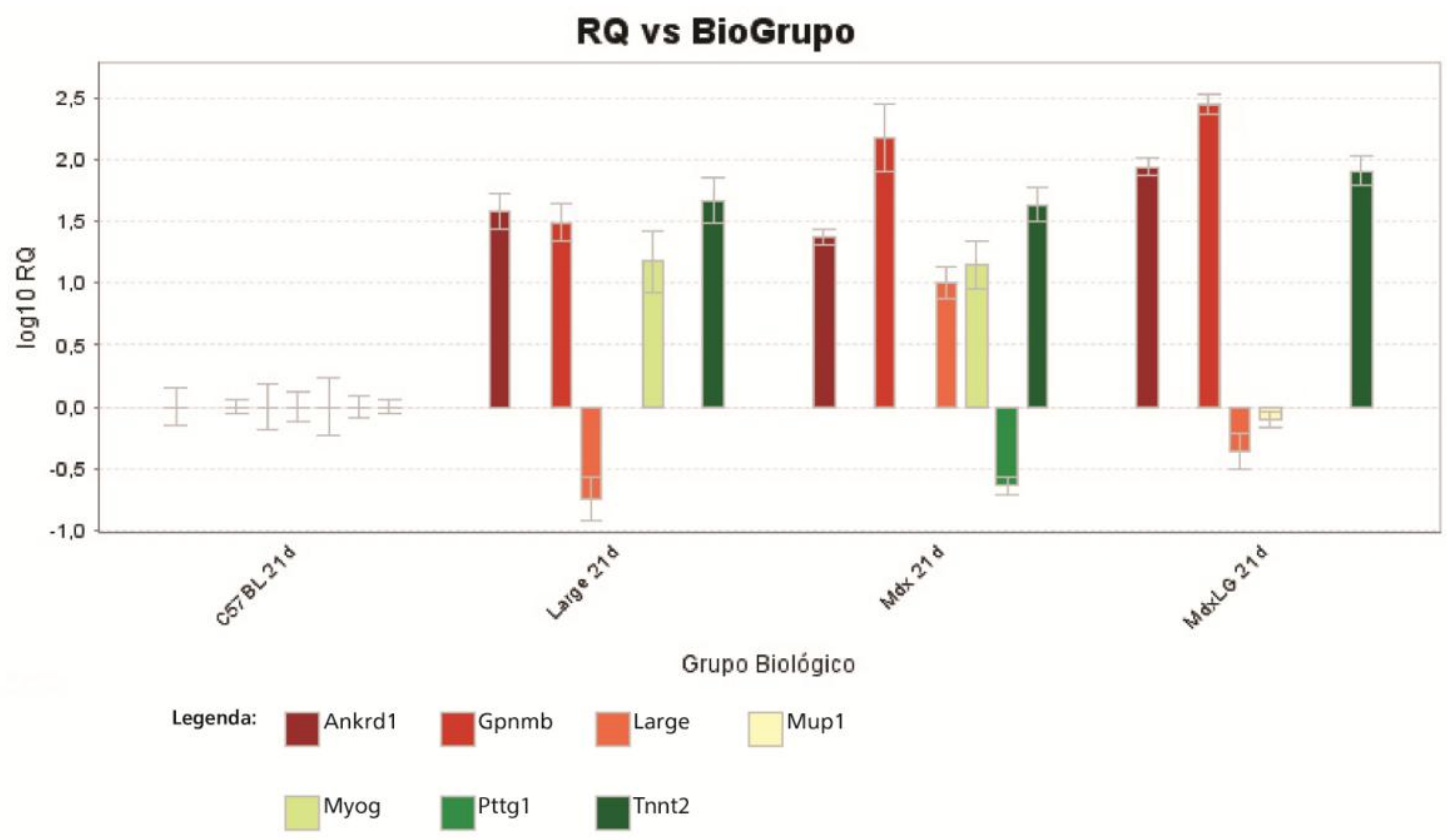

Figura 73 - Quantificações relativas dos gens estudados nas amostras de 21 dias

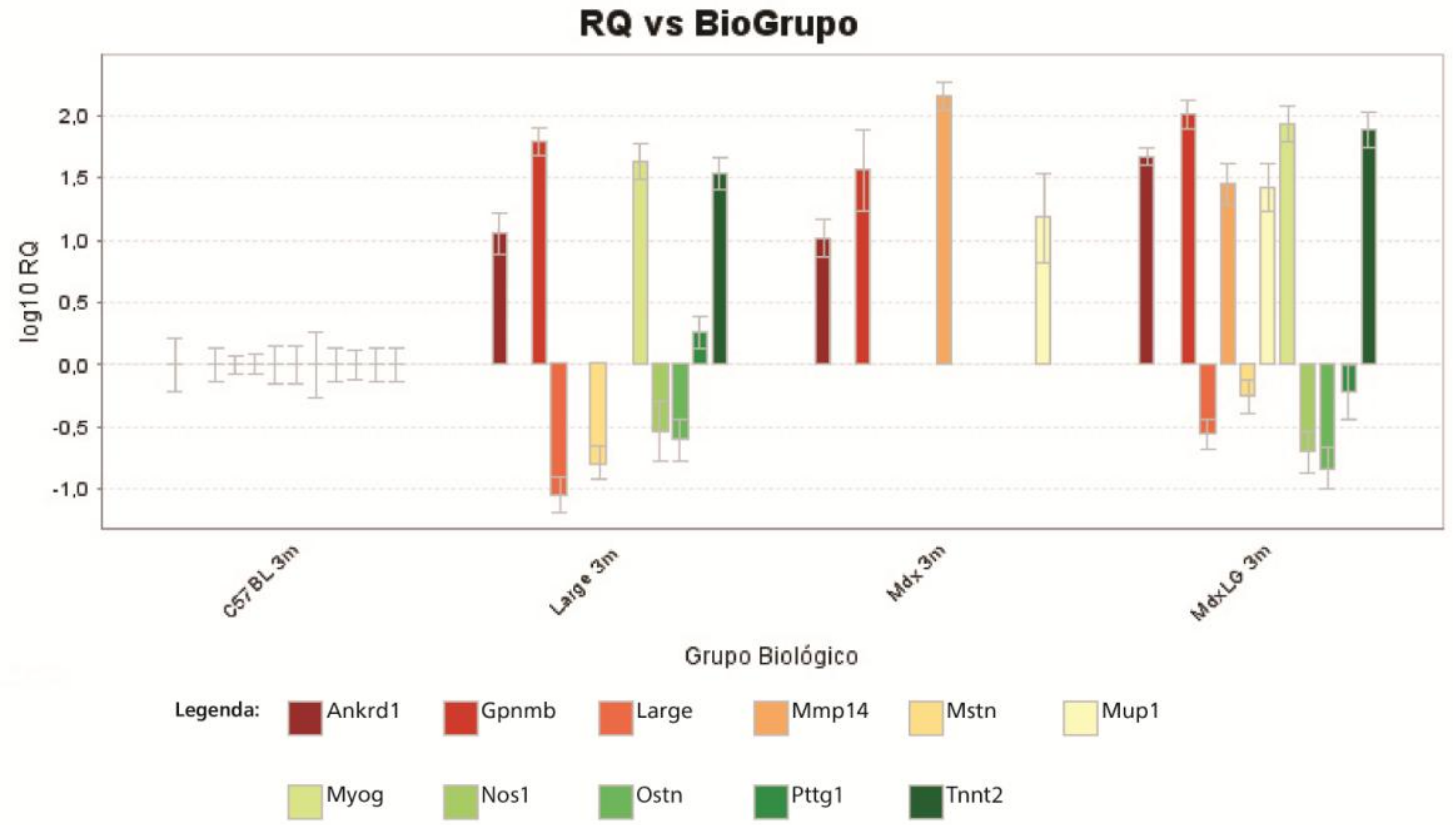

Figura 74 - Quantificações relativas dos genes estudados nas amostras de 3 meses 


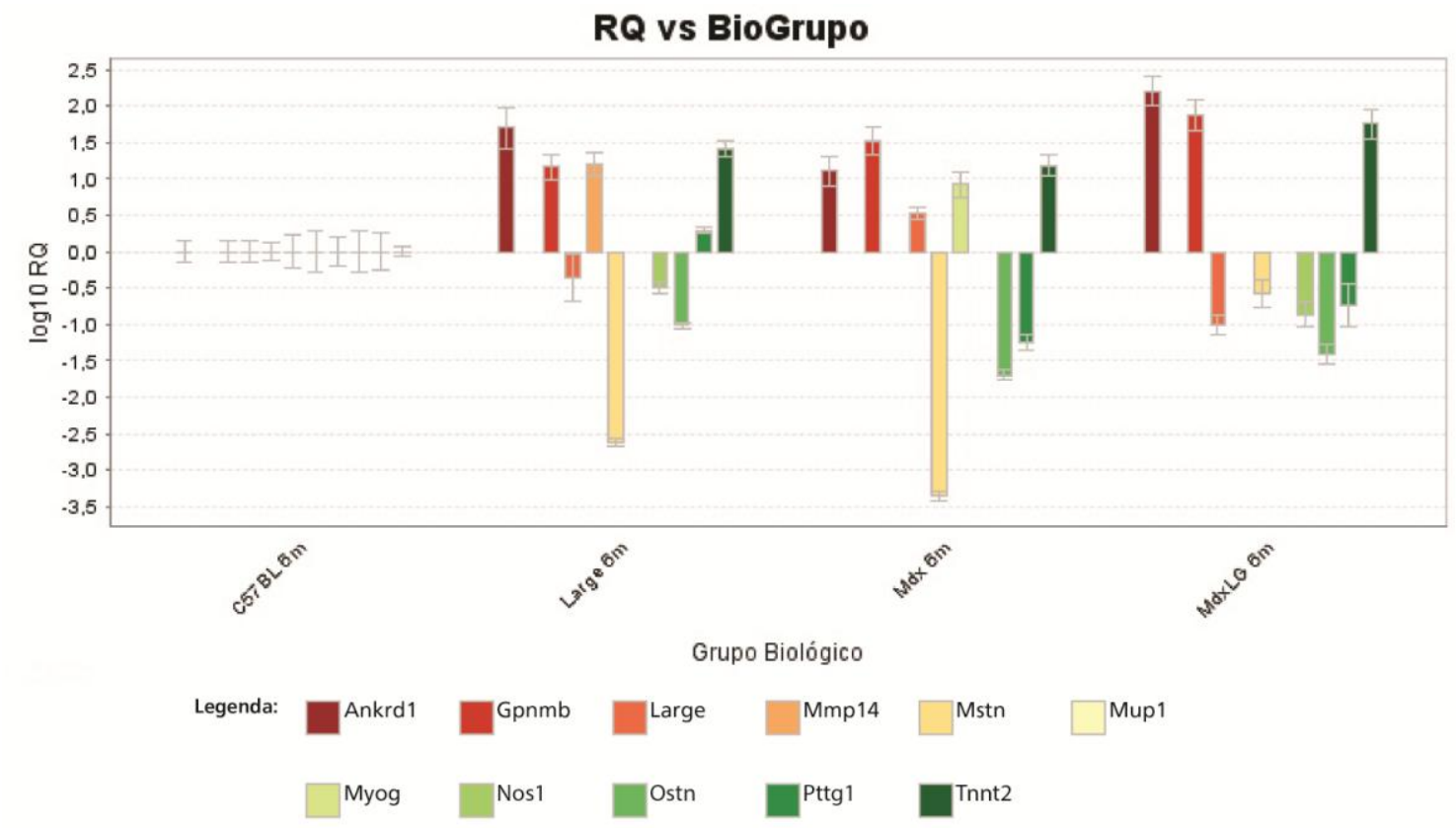

Figura 75 - Quantificações relativas dos genes estudados nas amostras de 6 meses 


\section{Discussão}

O estudo do perfil de expressão do tecido muscular dos camundongos modelo de distrofias musculares forneceu uma grande quantidade de dados valiosos para a compreensão dos mecanismos que são ativados nessas doenças. Com esses dados pudemos responder a algumas questões e especular a respeito das implicações que as alterações nos valores de expressão de alguns genes, mas mais importante que isso, abrimos novos e interessantes caminhos para serem investigados futuramente.

\section{Metodologia}

\subsection{Coleta da amostra; extração e controle de qualidade de RNA}

As colônias dos animais C57BL, Dmd ${ }^{m d x}$ e $L a r g e^{m y d-/}$ são mantidas no biotério do Centro de Pesquisas do Genoma Humano e Células-tronco há muitos anos e os camundongos necessários para os experimentos desse trabalho foram obtidos através de cruzamentos programados.

A colônia da linhagem $D m d^{m d x} / L a r g e^{m y d--}$ é mantida em heterozigose, a dupla mutação não causa perda pré-natal, e assim os animais homozigotos para a mutação no gene Large nascem na proporção de 25\% (Martins et al., 2013). O ponto crítico desses animais é a sobrevivência, visto que alguns morrem logo nas primeiras 24 horas de vida e outros antes ou no período próximo à idade do desmame, realizado por volta de 21 dias após o nascimento. Assim, para a obtenção de um conjunto mínimo de animais é necessário o emprego de esforços maiores na manutenção da colônia, incluindo um número elevado de casais em reprodução e maior atenção ao nascimento das ninhadas e manejo dos animais duplo-mutantes, que são mais delicados em relação a outros camundongos distróficos.

Em geral, a coleta de material para extração de DNA para a genotipagem de camundongos é feita no desmame, mas como esses animais tem a sobrevivência reduzida, a genotipagem foi feita quando os filhotes completavam 15 dias. Mesmo assim, nem todos os animais duplo-afetados chegam a ser genotipados, o que explica os 9,5\% de animais identificados (46 dentre os 485 filhotes genotipados). E mesmo após a fase do desmame, são poucos os animais que atingem a vida adulta: dos 35 machos obtidos, 18 (51\%) atingiram a idade adulta.

Estudos de transcriptoma requerem dados de qualidade e confiáveis, além de serem ensaios de alto custo financeiro. Por essas razões, a qualidade do RNA a ser utilizado é muito importante para a produção de dados confiáveis. 
A extração de RNA dos músculos foi satisfatória, oferecendo produtos dentro da concentração e qualidade necessárias, de acordo com os parâmetros utilizados. Mesmo as amostras em que foi necessário o tratamento com DNase e posterior purificação, mantiveram a qualidade requerida.

\subsection{Controle de qualidade dos microarranjos e pré-análise}

Ao longo das diversas etapas de preparação das amostras para a hibridização nas lâminas de microarranjos há alguns pontos de controle de qualidade das reações, que são determinantes para o prosseguimento do protocolo. O primeiro ponto é o rendimento de cRNA, que deve ser acima de $455 \mathrm{ng} / \mu \mathrm{l}$; o segundo é o rendimento do cDNA, com rendimento mínimo de $220 \mathrm{ng} / \mu \mathrm{l}$ e o último é o controle em gel de agarose para verificação da reação de fragmentação. Todos esses critérios foram atendidos satisfatoriamente. A hibridização também ocorreu de modo adequado e não foi necessário excluir nenhuma lâmina da análise pela presença de artefatos.

O pré-processamento feito com o algoritmo RMA fornece parâmetros para a avaliação da qualidade dos dados gerados. Todos os parâmetros analisados estão dentro dos valores estabelecidos, refletindo a boa qualidade dos RNAs usados, oferecendo segurança para o prosseguimento das análises.

\section{Triagem dos genes diferencialmente expressos}

\subsection{Número total de genes diferencialmente expressos}

A análise do perfil de expressão gênica global dos músculos posteriores da pata dos camundongos estudados foi capaz de revelar um grande número de genes que se comportam de maneira distinta na presença de um defeito genético, confirmando que, apesar de serem doenças monogênicas, os efeitos das mutações são muito mais amplos e complexos.

As comparações entre os controles normais e os animais distróficos apresentam o maior número de genes com expressão diferencial do que as feitas entre o duplo-mutante e as linhagens parentais.

É notável também que o processo de distrófico envolve em sua maioria um aumento da expressão de muitos genes; apenas poucos genes tiveram valores reduzidos de expressão. Mais genes super do que hipoexpressos pode ser um reflexo da alta produção de proteínas, por conta da regeneração, e também da forte ativação do sistema imunológico.

Dos modelos estudados neste trabalho, na literatura há apenas trabalhos sobre a expressão global no camundongo $D m d^{m d x}$; o estudo da expressão gênica do músculo do 
Large $e^{m y d-/}$ é inédito, bem como do duplo-mutante $D m d^{m d x} / L a r g e^{m y d-/}$, que foi desenvolvido e descrito recentemente em nosso laboratório.

A quantidade de genes diferencialmente expressos no camundongo $D m d^{m d x}$ descrita nos trabalhos publicados até o presente varia bastante (Tabela 47). Isso se deve às diferenças nos desenhos experimentais: as idades, os músculos, os microarranjos e os testes estatísticos.

Tabela 47 - Resumo dos trabalhos publicados sobre a expressão gênica global do $\mathbf{D m d}^{m d x}$

\begin{tabular}{|c|c|c|c|c|}
\hline Artigo & Microarranjo & Músculo & Idade & \# genes \\
\hline $\begin{array}{l}\text { Marotta et al, } \\
2009\end{array}$ & $\begin{array}{lr}\text { MOE } \quad 430 & 2.0 \\
\text { Affymetrix } & \end{array}$ & $\begin{array}{l}\text { Gastrocnêmio } \\
\text { medial }\end{array}$ & $\begin{array}{l}3 \text { semanas; } \\
1,5 \text { mês; } 3 \\
\text { meses }\end{array}$ & $\begin{array}{l}206 \text { (total) } \\
117 \text { (3 meses) }\end{array}$ \\
\hline $\begin{array}{l}\text { Haslett et al, } \\
2005\end{array}$ & $\begin{array}{l}\text { MG-U74Av2 } \\
\text { Affymetrix }\end{array}$ & $\begin{array}{l}\text { Diafragma, } \\
\text { EDL, } \\
\text { gastrocnêmio, } \\
\text { quadríceps, } \\
\text { soleus e TA }\end{array}$ & 8 semanas & $\begin{array}{l}373 \text { (músculos das } \\
\text { patas) }\end{array}$ \\
\hline $\begin{array}{l}\text { Turk et al, } \\
2005 b\end{array}$ & $\begin{array}{l}\text { Sigma-Genosys } \\
\text { mouse } 7.5 \mathrm{k}\end{array}$ & Quadríceps & $\begin{array}{l}8 \text { semanas } \\
\text { (incluía outras } \\
\text { linhagens) }\end{array}$ & $\begin{array}{l}2171 \text { genes (todas as } \\
\text { linhagens) }\end{array}$ \\
\hline $\begin{array}{l}\text { Turk et al, } \\
2005\end{array}$ & $\begin{array}{l}\text { Sigma-Genosys } \\
\text { mouse } 7.5 \mathrm{k}\end{array}$ & $\begin{array}{l}\text { Posteriores das } \\
\text { patas }\end{array}$ & $\begin{array}{l}1,2.5,4,6,8, \\
10,12,14 \text { e } \\
20 \text { semanas }\end{array}$ & $\begin{array}{l}1735 \text { (todas as idades) } \\
2.5 \text { semanas: } 400 \\
4 \text { semanas: } \sim 250 \\
12 \text { semanas: }>800 \\
20 \text { semanas: } 600\end{array}$ \\
\hline $\begin{array}{l}\text { Porter et al, } \\
2003\end{array}$ & $\begin{array}{l}\text { MG-U74Av2 } \\
\text { Affymetrix }\end{array}$ & $\begin{array}{l}\text { Gastrocnêmio e } \\
\text { soleus }\end{array}$ & $\begin{array}{l}7,14,23,28 \\
56 \text { e } 112 \text { dias }\end{array}$ & 719 (todas as idades) \\
\hline $\begin{array}{l}\text { Porter et al, } \\
2002\end{array}$ & $\begin{array}{l}\text { MG-U74Av } \\
\text { Affymetrix }\end{array}$ & $\begin{array}{l}\text { Gastrocnêmio e } \\
\text { soleus }\end{array}$ & 8 semanas & 242 \\
\hline $\begin{array}{l}\text { Rouger et al, } \\
2002\end{array}$ & Customizado & $\begin{array}{l}\text { Posteriores das } \\
\text { patas }\end{array}$ & $\begin{array}{l}1,2,3,4,5,7, \\
9,12,16,24, \\
36 \text { e } 52 \\
\text { semanas }\end{array}$ & 67 \\
\hline $\begin{array}{l}\text { Boer et al, } \\
2002\end{array}$ & $\begin{array}{l}\text { MG-U74Av2 } \\
\text { Affymetrix }\end{array}$ & Gastrocnêmio & $\begin{array}{l}13 \mathrm{e} \\
\text { semanas }\end{array}$ & 58 \\
\hline $\begin{array}{l}\text { Tseng et al, } \\
2002\end{array}$ & $\begin{array}{l}\text { MG-U74Av2 } \\
\text { Affymetrix }\end{array}$ & Gastrocnêmio & 16 semanas & 137 \\
\hline $\begin{array}{l}\text { Tkatchenko et } \\
\text { al, } 2000\end{array}$ & Customizado & $\begin{array}{l}\text { Posteriores das } \\
\text { patas }\end{array}$ & 3 meses & 51 \\
\hline
\end{tabular}

Por essas razões, é difícil encontrar uma correspondência exata entre o número de GDEs aqui encontrados e os reportados na literatura.

A primeira análise comparativa dos genes diferentemente expressos revelou um grande número de genes no modelo $D m d^{m d x}$, bem maior que o visto nas outras duas linhagens na mesma idade de 21 dias. A doença no $D m d^{m d x}$ começa a se manifestar aos 21 dias de idade, o que pode explicar a grande quantidade de genes desregulados, diferentemente dos outros dois camundongos, que já manifestam a doença desde o nascimento. Já na idade adulta, o número de genes com expressão diferencial no $D m d^{m d x}$ é 
mais próxima à observada nos dois outros modelos, o que pode ser um reflexo da estabilização da doença.

$O$ aumento na quantidade de genes conforme o envelhecimento dos modelos Large $e^{m y d-/}$ e $D m d^{m d x} / L a r g e^{m y d-/}$ sugere que nos processos distróficos mais graves, como os observados nestes modelos, a intensa transformação do músculo com a progressão, envolve um aumento de expressão de muitos outros genes.

Os músculos dos camundongos $D m d^{m d x}$ e $L a r g e^{m y d-\text { - }}$ apresentam diferenças marcantes quanto ao grau de degeneração e capacidade de regeneração. Na Figura 76, temos a histologia do músculo gastrocnêmio dos animais $D m d^{m d x}(\mathrm{~A})$ e $\operatorname{Larg} \mathrm{e}^{m y d-/}$ (B) com três meses de idade. Podemos observar o maior comprometimento do músculo do

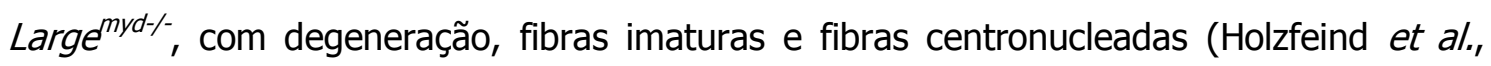
2002); já no $D m d^{m d x}$ o comprometimento é menor, o músculo está mais preservado e regenerado, com fibras centronucleadas (Briguet et al., 2004).
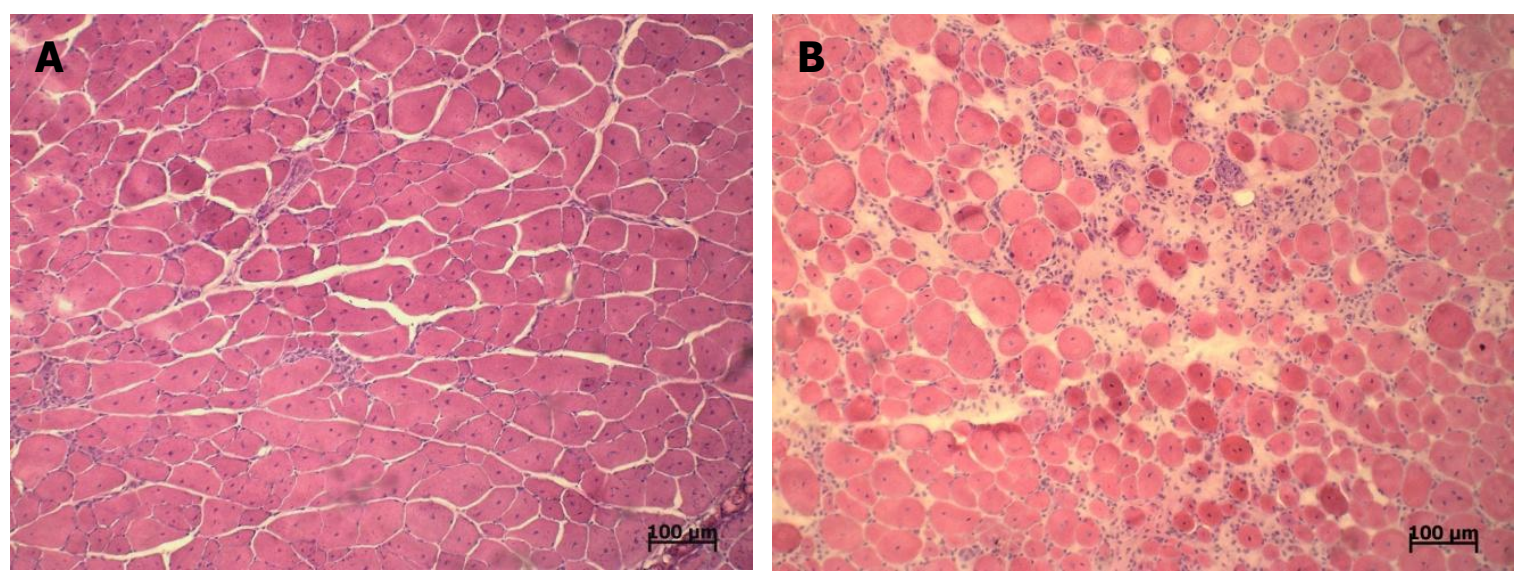

Figura 76 - Histologia do músculo gastrocnêmio dos animais $D m d^{m d x}$ e $L a r g e^{m y d--}$. Coloração de hematoxilina-eosina; aumento $10 \mathrm{X}$

\subsection{Genes diferencialmente expressos - Tecido muscular}

O filtro para os genes com atividade descrita no músculo esquelético mostrou que por volta de $40 \%$ (nas comparações com o animal controle) dos genes se encaixam nesse critério. Isso é uma indicação da heterogeneidade do órgão, que evidentemente além das células musculares, possui diversos tipos celulares associados. Assim sendo, as mudanças na expressão de grande parte dos genes estão ocorrendo em outros componentes do músculo, mostrando que o defeito genético, que primariamente afeta as células musculares, é capaz de perturbar e influenciar os demais tipos celulares.

Interessantemente, no $D m d^{m d x}$ a proporção de genes musculares, ao redor de $30 \%$, se manteve constante em todas as idades. Por outro lado, no modelo $\operatorname{Large}^{m y d-/} \mathrm{e}$ $D m d^{m d x} /$ Large $^{m y d-1}$ o valor inicial de $30 \%$ de genes musculares aumentou com a idade, sugerindo que nos estágios mais adiantados da doença, mais componentes musculares 
estão envolvidos. Isso é um fato curioso, pois com o avanço da idade a proporção do tecido muscular é menor, devido à substituição por tecido conjuntivo; assim, esperaríamos que mais genes desse tecido estivessem desregulados.

Neste grupo de GDE, também se observou mais genes superexpressos, do que subexpressos, sendo estes últimos mais elevados nos animais mais velhos.

\section{Caracterização do Processo Distrófico}

\subsection{GDEs comuns em todas as linhagens distróficas}

Os genes que são comuns a todas as linhagens e idades podem ser considerados genes marcadores de distrofia muscular, isto é, são genes que vão apresentar expressão diferencial independentemente do defeito genético primário causador da forma de distrofia e do grau de evolução da doença.

Dentre os 31 genes diferentemente expressos em todas as linhagens e todas as idades serão discutidos aqueles com alguma relação com o funcionamento muscular já descrita na literatura.

\section{Ankrd1}

O gene Ankrd1 codifica a proteína CARP, que se associa às proteínas titina e calpaína 3, dentre outras, provendo estabilidade ao sarcômero (Laure et al., 2010), e está envolvida em uma via mecanosinalizadora que conecta a resposta ao estresse miofibrilar à expressão gênica do músculo. Além disso, ela exerce um papel importante na regulação da transcrição de genes como Ttn (titina) e $M y O D$, na formação da miofibrila, na cardiogênese e na miogênese (Kojic, Radojkovic e Faulkner, 2011). A expressão de Ankrd1 é predominantemente cardíaca (Baumeister, Arber e Caroni, 1997), mas também está fortemente induzida no músculo esquelético humano fetal, o que indica que CARP tem um papel importante no músculo esquelético também.

De fato, na biópsia muscular de indivíduos com DMD foi detectada alta expressão de CARP, confinada a pequenas miofibras em regeneração, que expressam miosina de cadeia pesada (MHC) embrionária, sugerindo que CARP possa ser usada como um marcador de regeneração nessa doença. Em pacientes com CMD foram encontradas mais miofibras positivas para CARP do que em DMD, porém, a expressão não está limitada a fibras em regeneração, sendo detectada em miofibras expressando MHC embrionária e naquelas expressando MHC adulta. Isso sugere que o estágio de diferenciação das miofibras CARP-positivas em DMD e CMD podem ser diferentes (Nakada et al., 2003).

Modelos temporários ou definitivos de atrofia muscular e camundongos modelo de distrofias musculares apresentam expressão persistente de CARP, servindo então como um 
marcador de lesão muscular. A expressão de Ankrd1 aumenta também a expressão de Cdkn1a (inibidor da proliferação celular) em mioblastos em proliferação e em miotubos diferenciados, o que pode implicar na redução da proliferação celular e/ou inibição da apoptose, impedindo o remodelamento tecidual. Entretanto, ainda é duvidoso se a maior expressão CARP significa que ela participa da degeneração ou se é uma tentativa de resistência. $\mathrm{O}$ fato de estar superexpressa em todos os modelos e em todas as idades, incluindo os animais gravemente afetados com três meses sugere um envolvimento significativo no processo de degeneração. Portanto, se a superexpressão de CARP for realmente prejudicial ao músculo esquelético, a sua inibição poderia ser um importante ponto de intervenção terapêutica (Laure et al., 2009).

A partir disso concluímos que a indução da expressão de $A n k r d 1$ em todas as linhagens estudadas pode ser um indicador da degeneração muscular, e ao mesmo tempo um reflexo da regeneração nesses músculos. Assim, mais estudos são necessários para um melhor entendimento do papel dessa proteína na distrofia muscular.

\section{Mmp12}

A fibrose é uma importante característica das distrofias musculares, sendo possível até traçar uma correlação entre a extensão da fibrose e progressão do quadro clínico.

As metaloproteinases de matriz são importantes reguladores da matriz extracelular, coordenando a inflamação, a deposição de matriz e a reorganização do tecido (Tallant, Marrero e Gomis-Rüth, 2010). Na literatura não foram encontrados trabalhos que relacionem a proteína MMP12 (macrophage elastase) com distrofias musculares ou o músculo esquelético, mas já foi vista a expressão diferencial em camundongos $D m d^{m d x}$ (Boer et al., 2002).

O gene Mmp12 é principalmente expresso por macrófagos que secretam uma variedade de metaloproteinases que atuam no remodelamento da matriz extracelular associado a processos inflamatórios, facilitando a migração dos próprios macrófagos. Macrófagos que não expressam Mmp12 são incapazes de realizar a proteólise da matriz extracelular e invadir tecidos (Shipley et al., 1996).

$\mathrm{Na}$ infecção por parasitas, há indução da expressão de $M m p 12$ no fígado e no pulmão, agindo como um potente promotor da inflamação e fibrose. Em camundongos deficientes em Mmp12 e infectados com parasitas foram observados aumentos na expressão de $M m p 2$ e $M m p 13$, sugerindo que $M m p 12$ promoveria a fibrose limitando a expressão de Mmps específicas da degradação da ECM; também observada redução da fibrose induzida por IL-13 (Madala et al., 2010).

Em camundongos modelo de inflamação foi demonstrado que MMP12 faz também a proteólise de quimiocinas, além da atividade de degradação de matriz já bem 
caracterizada. Inicialmente, MMP12 tem um papel pró-inflamatório no recrutamento de células polimorfonucleadas (PMN); mais tardiamente, MMP12 exerce um papel antiinflamatório que anula o influxo de PMNs e macrófagos. Assim, MMP12 está envolvida na regulação da atividade celular inflamatória independentemente de qualquer atividade degradativa (Dean et al., 2008).

Extrapolando as informações obtidas nesses trabalhos, podemos propor dois cenários para a indução da expressão de Mmp12 nos camundongos distróficos. 0 primeiro seria a atividade constante de macrófagos no músculo desses animais, promovendo a inflamação e a fibrose; o segundo seria uma tentativa de redução da inflamação, pela degradação de quimiocinas e redução da atração de mais células inflamatórias. De toda forma, ambos os processos estariam presentes desde os estágios iniciais, até os mais adiantados e em todas as formas de distrofias.

\section{Timp1}

Todas as linhagens estudadas também apresentaram expressão aumentada de Timp1, que codifica para a enzima inibidora de metaloproteinase-1. TIMP1 inibe MMP14, MMP9, MMP2, MMP1, MMP16, MMP19, MMP24, MMP3 e MMP8, e peptidases da família Adam.

A indução do mRNA de Timp1 já foi reportada nos músculos de pacientes com DMD. O aumento na atividade de Timp1 sugere a redução da atividade de Mmp1 e consequente diminuição da remoção de ECM, aumentando a fibrose (Von Moers et al., 2005).

A análise da expressão e localização de TIMP1 foi feita em biópsias de pacientes com DMD, BMD e CMD, e nos camundongos $D m d^{m d x}$ e $d y / d y$ (modelo com deficiência de laminina). Timp1 está distribuída no citoplasma, sarcolema e núcleo de fibras em regeneração, e algumas vezes também está fortemente expressas em fibras não regenerativas. Foi vista uma localização muito próxima com Tgf- $\beta$ no citoplasma e núcleo de fibras regenerativas, sugerindo uma relação entre essas duas proteínas. TIMP1 também foi localizada em fibroblastos ativos e em macrófagos (Sun et al., 2010).

As consequências da expressão aumentada de Timp1 podem incluir a inibição de Mmps, resultando no acúmulo de ECM e na inibição da angiogênese de células endoteliais intramusculares, resultando na redução da irrigação sanguínea para fibras em regeneração. Mas também pode haver um efeito autócrino nas fibras em regeneração para produzir miofibras fundidas, uma vez que TIMP1 já foi relacionada com a diferenciação miogênica (Sun et al., 2010).

A superexpressão de $M m p 9$, cujo inibidor é TIMP1, melhora a migração de células miogênicas e a sua inibição reduz a capacidade migratória (Morgan et al., 2010). Assim, o 
aumento da expressão de Timp1 nos camundongos estudados pode ter duas consequências principais, diretamente relacionadas com o processo distrófico: aumentar a fibrose e atrapalhar a regeneração, dificultando a migração de células pela inibição de Mmp9.

\section{Myh3}

Myh3 tem a função de converter a energia química do ATP em energia mecânica. É um gene expresso predominantemente no músculo esquelético e é indispensável no desenvolvimento e na regeneração muscular (Feghali e Leinwand, 1989; Karsch-Mizrachi et al., 1989). A expressão de $M y h 3$ foi vista em mioblastos mononucleados em proliferação e também em miotubos multinucleados e maduros, em cultura de células humanas (AbdulHussein, Van Der Ven e Tajsharghi, 2012). Logo, a superexpressão de Myh3 nos animais distróficos pode ser tanto um marcador de células em regeneração, como de células imaturas resultantes da própria regeneração.

\section{Myl4}

My/4 também é relacionado ao processo de formação de miotubos, sendo transcrito no músculo esquelético no início da diferenciação muscular (Catala et al., 1995), portanto é um marcador de regeneração.

Nos animais estudados, o gene Myl4 apresenta expressão aumentada com valores entre 2,1 e 2,5 nas idades de 21 dias e três meses, mas valores entre 1,2 e 1,9 nos camundongos com seis meses, sugerindo que na idade mais avançada ainda há regeneração muscular, porém um pouco menos ativa que nos animais mais jovens.

\section{Tnnt2}

Outro gene expresso no início da regeneração é Tnnt2 e que também já foi encontrado com expressão aumentada em pacientes com DMD, sendo associado à regeneração ativa no músculo distrófico (Noguchi et al., 2003).

\section{Tubb6}

Tubb6 é o gene de umas da beta-tubulinas que formam os microtúbulos, estruturas importantes em processos como mitose e transporte intracelular. 


\section{Catepsina $\mathbf{S}$}

Catepsina S é uma protease localizada no lisossomo, que cliva proteínas antigênicas para a apresentação por moléculas MHC-II. Ela também pode atuar como uma elastase em macrófagos.

A expressão alterada de Ctss já foi vista em análises do transcriptoma do $D m d^{m d x} \mathrm{e}$ foi proposto que, junto com a superexpressão de componentes do sistema elástico elastina, Lox e Mfap2, a catepsina pode modular a produção de elastinas e a sua deposição no músculo desse animal. Isso indicaria um provável mecanismo de resposta, que reforçaria a ligação entre a matriz extracelular e o citoesqueleto, protegendo as fibras musculares contra danos da contração muscular (Marotta et al., 2009).

Assim, a expressão aumentada de Ctss nos animais distróficos pode resultar no maior processamento de antígenos para apresentação dos mesmos para linfócitos T, e também na degradação de matriz extracelular.

\section{Lgmn}

Lgmn codifica também uma protease lisossômica com papel no processamento de antígenos para apresentação por moléculas MHC-II e no metabolismo de vitamina D. Tumores que superexpressam $L g m n$ têm maior capacidade migratória e de invasão, sendo um ativador de MMP2 (Liu et al., 2003).

\section{Dpep2}

DPEP2 é uma protease envolvida no metabolismo do ácido araquidônico; há poucas informações na literatura.

\section{S100a4}

Proteínas da família S100 regulam diversos processos como a progressão no ciclo celular e a diferenciação. Em tumores, a superexpressão de $S 100 A 4$ eleva a expressão de MMP13, favorecendo a migração celular e a angiogênese (Wang et al., 2012), bem como a expressão e a atividade proteolítica de MMP9 (Zhang et al., 2011).

\section{Gpnmb}

A expressão elevada de Gpnmb (osteoactivina) em camundongos distróficos (Turk et al., 2006) e pacientes com DMD (An et al., 2013) já foi descrita em trabalhos anteriores. Osteoactivina tem sido implicada na diferenciação e funcionamento de vários tipos celulares (Singh et al., 2010). Estudos em músculo esquelético atrofiado por denervação mostraram que a denervação induz a expressão de osteoactivina no sarcolema, levando à 
expressão de MMP3 e MMP9 por fibroblastos infiltrados no tecido, sugerindo um papel importante na regulação da degeneração/regeneração da matriz extracelular (Ogawa et al., 2005).

MMP3 regula o crescimento e desenvolvimento de tecidos pela degradação seletiva de complexos ligantes de proteína IGF1/IGF1 (Fowlkes et al., 2004). MMP9 está envolvida na migração e formação de miotubos (Lewis et al., 2000).

A denervação do músculo por um longo prazo causa uma degeneração severa e fibrose, mas a superexpressão de Gpnmb protege o músculo contra esses efeitos, havendo a expressão de genes associados à degeneração/regeneração e redução da expressão de genes antifibrose (Furochi et al., 2007).

\section{Ms4a7, Ms4a4a, Ms4a6a, Ms4a6c}

Os genes Ms4a7, Ms4a4a, Ms4a6a, Ms4a6c são expressos por linfócitos, mas ainda não têm função estabelecida. Na literatura há poucas informações sobre o gene $W f d c 17$ que também parece estar envolvido na resposta imunológica.

Portanto, parte dos genes aqui discutidos tem envolvimento com regeneração e remodelamento da matriz extracelular, em todos os processos distróficos e em todas as idades. Dos restantes, alguns ainda não têm sua função identificada, e os que participam das vias de sistema imune serão discutidos adiante.

\subsection{Genes diferencialmente expressos em cada idade - Efeito da idade}

Quando analisamos quais são os genes compartilhados por todas as linhagens especificamente em cada idade (seção 6.2), podemos avaliar a extensão da alteração na expressão gênica e quais são os genes que poderiam caracterizar as mudanças que ocorrem com o avanço da idade na presença do processo distrófico.

De modo geral, o total de GDEs compartilhados pelas três linhagens aumenta progressivamente com a idade: 63 genes em 21 dias, 88 genes aos três meses e 127 genes aos seis meses (diagrama B das Figuras 48, 49 e 50). Muitos genes são diferencialmente expressos em mais de uma idade. Para verificar o efeito da idade no processo distrófico, avaliamos os GDEs comuns especificamente expressos em cada idade.

Na tabela 25 temos os 17 genes que são expressos nas três linhagens distróficas na idade de 21 dias. Destes genes destacamos alguns.

Ccna2, Ccnb1/Gm5593 e Cdkn1A são genes envolvidos em funções do ciclo celular, sugerindo um aumento da divisão celular. Myh8 codifica a miosina de cadeia pesada 
perinatal, o que mostra a imaturidade do músculo desses animais, ou a presença de fibras novas em regeneração.

O genótipo do gene SPP1 em pacientes com DMD é utilizado como marcador de prognóstico da doença (Pegoraro et al., 2011). A proteína codificada por este gene, osteopontina ou fosfoproteína secretada 1 , é secretada por mioblastos e estimula a proliferação dos mesmos (Uaesoontrachoon et al., 2008) e já foi descrita como um dos componentes da inflamação no músculo distrófico (Haslett et al., 2002; Porter et al., 2002). Recentemente, foi demonstrado que o aumento da expressão de osteopontina é induzido após uma lesão, indicando que ela promove a inflamação muscular, a necrose e a regeneração, tornando-a um fator importante da remodelação muscular (Uaesoontrachoon et al., 2013). Assim, o aumento da expressão de Spp1 nos camundongos aqui estudados tem relação direta com a intensa degeneração e subsequente regeneração que os músculos deles sofrem nessa idade. Vale lembrar que Spp1 também está superexpresso no $D m d^{m d x}$ com três meses de idade.

A tabela 26 lista os 11 genes característicos dos três meses de idade, dos quais o gene Capn6 chama mais a atenção. CAPN6 é expresso predominantemente nos músculos embrionários e na placenta, estando envolvido na regulação da dinâmica dos microtúbulos e na reorganização da actina de células em cultura. Em um trabalho recente, foi gerado um camundongo com deficiência de Capn6 no músculo esquelético. A análise do desenvolvimento desse animal mostrou que a deficiência de Capn6 promoveu o desenvolvimento do músculo esquelético embrionário. Os mioblastos deficientes em Capn6 também apresentaram melhor diferenciação muscular em relação às células controle. Além disso, foi visto que CAPN6 é expressa no músculo em regeneração de camundongos lesionados, mas a expressão de marcadores de regeneração foi maior nos camundongos com deficiência de Capn6, que exibiram uma regeneração mais avançada que os animais controle. Todos esses dados apontam que a perda da expressão da proteína calpaína 6 promove a diferenciação muscular tanto no desenvolvimento quanto na regeneração, logo, CAPN6 age como um supressor da diferenciação e crescimento do músculo esquelético, modulando funções basais como a divisão celular (Tonami et al., 2013).

Nos animais com três meses de idade, a expressão de Capn6 está aumentada, o que pode ter implicações na modulação da regeneração muscular nessa fase da doença.

A tabela 27 mostra os 55 genes com expressão alterada especificamente aos seis meses de idade nas três idades. Destacamos os genes de colágeno Col3a1, Col6a3 e Col8a1, com expressão aumentada, refletindo a formação de fibrose.

O gene Mstn, da proteína miostatina que é um supressor do crescimento muscular (Lee, 2004), está subexpresso em todas as linhagens com seis meses de idade. Os animais $\operatorname{Larg}^{m y d-/}$ e $D m d^{m d x} / \operatorname{Larg}^{m y d-/}$ com três meses também apresentaram redução na 
expressão de Mstn. Assim, a redução da expressão de miostatina pode ser uma tentativa de facilitar a regeneração nos animais adultos.

\subsection{Classificação funcional dos genes diferencialmente expressos}

Com o intuito de entender o significado biológico das mudanças observadas no padrão de expressão dos genes, analisamos os genes diferencialmente expressos nos camundongos modelo estudados usando ferramentas de bioinformática que fornecem informações sobre as vias biológicas (Kegg Pathways) e a classificação ontológica (Gene Ontology), identificando os termos significativamente enriquecidos. Esse modo de análise agrupa os genes, dando uma visão mais panorâmica e generalista do estado em que se encontram os processos biológicos da condição estudada.

Os termos enriquecidos foram encontrados apenas com os genes superexpressos, os genes subexpressos não tiveram resultados significantes; assim, as vias e funções apresentadas estão ativadas no músculo dos camundongos estudados.

\subsubsection{Enriquecimento de vias biológicas - KEGG Pathways}

As vias biológicas que estão enriquecidas são majoritariamente vias do sistema imunológico, principalmente as vias de sinalização de quimiocinas e de interação de citocinas com seus receptores, que aparecem ativadas em todas as linhagens, em todas as idades.

É interessante também o enriquecimento da via "Lisossomo" no camundongo $D m d^{m d x} 21$ dias, e nas três linhagens com três e seis meses de idade. A maior atividade dessa via pode ser devido ao processo de degeneração, que aumenta as taxas de digestão celular.

As vias "Ciclo celular", "Sinalização do p53" e "Replicação de DNA" também aparecem apenas no $D m d^{m d x}$ com 21 dias de idade, indicando que nessa fase, o músculo desses animais está passando por uma fase mais intensa de proliferação celular, o que está diretamente relacionado com a regeneração muscular.

De forma geral, as vias biológicas que estão alteradas nos animais distróficos são as mesmas, independentemente do estágio de progressão da doença ou da mutação primária.

\subsubsection{Enriquecimento de funções biológicas}

Os termos GO (Anexo B) encontrados na análise bioinformática foram agrupados manualmente em categorias mais generalistas, pois muitos termos são redundantes e correlacionados entre si. E como a representação da categoria "Sistema imune e 
inflamação" foi sempre superior a 50\% do total, optamos por ver a distribuição das demais separadamente, para melhor visualização das categorias que se destacam mais em cada linhagem além da resposta imunológica.

O papel do sistema imune nas distrofias musculares será discutido mais adiante.

Na linhagem $D m d^{m d x}$ com 21 dias de idade é notável a grande proporção de funções relacionadas com o ciclo celular ( $27 \%$ na análise com todas as categorias e $60 \%$ na análise eliminando a categoria sistema imune e inflamação). Essa categoria aparece muito pouco nas outras linhagens e idades. Assim, aprofundamento da sua avaliação é interessante, uma vez que essas funções podem ajudar a explicar o fenótipo desse animal, que apesar de ter ausência total de distrofina não manifesta a doença na mesma proporção que os humanos afetados. Além disso, os genes envolvidos nessas funções poderiam ser os genes protetores desse camundongo e, consequentemente, genes possivelmente terapêuticos.

Nessa idade, é sabido que o músculo desse camundongo começa a apresentar os primeiros sinais da doença caracterizada por intensa degeneração muscular (Pastoret e Sebille, 1995; Reed e Bloch, 2005). Consequentemente, há a ativação do processo regenerativo, que inclui a ativação e proliferação de novas células, que aqui no estudo do transcriptoma, está representado pelo aumento na expressão de genes do ciclo celular.

Comparando os gráficos de pizza (Figura 51, partes A e B) do camundongo $D m d^{m d x}$ de 21 dias com as duas outras linhagens da mesma idade, há uma evidente redução da participação das vias de ciclo celular e aumento de atividades de ECM e adesão, bem como de fagócitos e atividade enzimática nos modelos mais gravemente afetados nesta idade.

Nas idades de três e seis meses, é bem evidente que os perfis são mais homogêneos entre si na análise comparativa das três linhagens. Desta forma, as maiores diferenças com a idade ocorrem no modelo $D m d^{m d x}$.

Curiosamente, o animal $D m d^{m d x} / \operatorname{Larg}^{m y d-/}$ não apresentou nenhuma função de divisão celular enriquecida, ou seja, a linhagem duplo-mutante não recebeu do $D m d^{m d x}$ essa característica tão marcante. Isso implica que esses animais, nessa idade, não estão conseguindo ativar de forma satisfatória o mecanismo de regeneração, o que pode explicar o maior comprometimento do tecido observado nos estudos histológicos, como a substituição por tecido conjuntivo (Martins et al., 2013).

Outra categoria de funções biológicas que parece não ser transmitida para o duplomutante é a de matriz extracelular e adesão. Com 21 dias de idade, do total das 62 funções biológicas encontradas, $10 \%$ são da categoria ECM e adesão no $\operatorname{Larg}^{\text {myd-/} \text {; no }}$ $D m d^{m d x} / L_{a r g} e^{m y d-/}$ o percentual é de $5 \%$ do total de 60 funções. Porém, de modo geral, 0 perfil do duplo-mutante é mais semelhante ao seu parental $L a r g e^{m y d-/-}$ que ao $D m d^{m d x}$. 
A segunda categoria mais representada no $D m d^{m d x} / L a r g e^{m y d-/}$ é a de atividade enzimática/proteólise. Dos genes que se encaixaram nessas funções alguns são Mmp19, Mmp12, Mmp8 e Timp1, envolvidos na degradação de componentes da matriz extracelular, logo o aumento da expressão desses genes é uma resposta à deposição de tecido fibroso que já está se formando no músculo. Entretanto, na idade seguinte a proteólise está menos ativa, voltando a aumentar aos seis meses.

Os demais genes são Wfdc17, Serpine1, Serpina3, Serpina3k, Lgmn, Ctss, Cdkn1A, Stfa2/Stfa211, R3hdm/, Asprv1, Adam8 e Dpep2. Stfa2/Stfa2/1 codifica um inibidor de endopeptidase e foi o gene com maior valor de fold change no $D m d^{m d x} / L_{a r g} e^{m y d-/}$ com 21 dias $(+4,8)$; na literatura não há muitas informações sobre suas funções. $R 3 h d m /$ também é um inibidor da atividade de peptidase, mas pouco se sabe sobre seu papel; o mesmo vale para a peptidase ASPRV1.

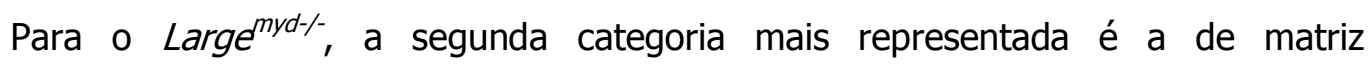
extracelular e adesão. Considerando que mutação no gene Large afeta a ligação de uma proteína que interage com o meio extracelular, é esperado que outros componentes da ECM sejam mais afetados.

\section{Sistema imune e inflamação}

Em todas as análises feitas, as funções com maior enriquecimento foram as de sistema imune e inflamação, sempre representando mais $55 \%$ das funções biológicas anotadas no Gene Ontology, isso pode ser até certo ponto, um indicador da gravidade dos tipos de distrofia muscular estudados: quanto mais severa a doença, maior expressão de genes da resposta imunológica. De fato, nas idades de 21 dias e seis meses, as duas linhagens com fenótipos mais severos, Large $e^{m y d-/-}$ e $D m d^{m d x} / L a r g e^{m y d-/-}$ estão com mais $70 \%$ das funções ligadas a processos imunológicos.

Essa representação marcante de genes envolvidos na imunidade e inflamação já foi reportada em trabalhos anteriores. No estudo do perfil de expressão do músculo gastrocnêmio medial, de camundongos $D m d^{m d x}$ com diferentes idades, a maior parte dos genes com expressão induzida pertence à resposta imune e inflamação (Marotta et al., 2009). Porter et al. (2002) encontrou 242 genes com expressão diferencial no gastrocnêmio do $D m d^{m d x}$, dos quais $29,8 \%$ foram classificados como genes de inflamação, determinando uma resposta inflamatória crônica. O mesmo é relatado por Haslett et al. (2005), Turk et al. (2005), Porter et al. (2004), e outros.

Em contrapartida, a proporção que os genes da imunidade e inflamação ocupa nos dados aqui obtidos é superior aos dados já publicados, atingindo até $88 \%$ das funções biológicas enriquecidas. 
O processo inflamatório no músculo distrófico fundamenta um dos tratamentos mais usados para a DMD, que consiste no uso de glicocorticoides. Porém, os efeitos colaterais dos esteroides são prejudiciais; assim, a caracterização minuciosa dos fatores envolvidos na resposta imune nessas doenças é útil para o desenvolvimento de estratégias mais específicas para a redução da inflamação e seus efeitos que exacerbam a perda da função muscular, levando em consideração que a resposta imune produz tanto fatores negativos quanto positivos para músculo.

A deficiência de distrofina é a causa primária da distrofia muscular de Duchenne, porém não é o fator determinante para o desenvolvimento da doença (Rando, 2001). Mecanismos secundários, como a inflamação e ativação do sistema imunológico, têm uma participação substancial na fisiopatologia, modulando a manifestação das características da doença.

O sistema imune exerce um papel essencial no desenrolar da distrofia muscular e está fortemente correlacionado com a severidade da doença. O dano produzido nas miofibras decorrente da contração muscular gera um ciclo de necrose e regeneração celular. As miofibras necróticas são atacadas por macrófagos, linfócitos $T$, linfócitos $B$ e células dendríticas. Ocorre também a liberação de moléculas solúveis e de adesão, que regulam essa resposta inflamatória, resultando em fibrose e, consequentemente, na disfunção da contração muscular.

As citocinas compreendem uma ampla família de pequenas proteínas importantes para a sinalização celular, incluindo os interferons, interleucinas, fatores de necrose tumoral, fatores transformadores de crescimento e quimiocinas. Essas citocinas estão todas relacionadas com a resposta inflamatória, que está especialmente ativada nas distrofias musculares, com ações pró e anti-inflamatórias.

As citocinas mais presentes nas distrofias musculares são as quimiocinas, que coordenam a ativação e direcionam a migração de leucócitos em direção ao tecido lesionado. As quimiocinas são originadas tanto por células do sistema imune, como pelas próprias células musculares, o que contribui para a perpetuação da inflamação crônica. As quimiocinas estão subdivididas em quatro famílias de acordo com a sua estrutura primária: $C, \mathrm{CC}, \mathrm{CXC}$ e $\mathrm{CX}_{3} \mathrm{C}$, com seus ligantes e respectivos receptores. As quimiocinas da classe CXC atraem rapidamente os leucócitos na fase inicial da inflamação (Tidball e Villalta, 2010).

A inflamação aguda é uma resposta ao dano tecidual ou infecção caracterizada pela produção de fatores inflamatórios, que recrutam temporariamente leucócitos polimorfonucleados, e em seguida há o acúmulo de macrófagos (Nathan, 2006). 
Depois do influxo inicial de leucócitos PMN, a fase seguinte da inflamação é comandada pelas quimiocinas CC, que recrutam subgrupos específicos de leucócitos, como macrófagos fagocitários (Mcquibban et al., 2002).

Em DMD, algumas quimiocinas têm um efeito protetor por contribuírem na regulação da regeneração. As propriedades proliferativas da sinalização de CXCL1/2/3 por meio do receptor CXCR2 foram descrita em tecidos humanos. A expressão de CXCL1/2/3 está induzida nas fibras musculares em regeneração de pacientes com DMD, e fibras musculares necróticas são positivas para o receptor CXCR2 (De Paepe et al., 2012).

Em oposição, as quimiocinas podem ter efeitos tóxicos, pró-inflamatórios. Em pacientes com DMD, macrófagos M1 expressam diversas quimiocinas: CXCL8, CCL2 e CCL5. CCL2 tem como alvo linfócitos $T$, que então podem estimular a inflamação, amplificando o processo (De Paepe et al., 2012).

O trabalho de Porter e colaboradores (2003) é o estudo mais completo encontrado na literatura sobre a expressão de quimiocinas no $D m d^{m d x}$. No músculo do $D m d^{m d x}$ a expressão de $C C L s(C C l 2, C C l 5, C C l 6, C C l 7, C C l 8$ e CCl9) e CCRs (CCr2, CCr1 e CCr5) específicas para o recrutamento de macrófagos e linfócitos T está aumentada, o que pode funcionar como regulação positiva da resposta inflamatória na distrofia muscular; e essas quimiocinas são produzidas tanto por células mononucleadas quanto pelas próprias fibras musculares (Porter, Guo, et al., 2003).

Além da capacidade de atrair leucócitos, quimiocinas da classe CC podem atuar diretamente nas células musculares, ativando a proliferação dos mioblastos no músculo lesado. Tanto macrófagos quanto células musculares expressam o receptor CCR2 (receptor de CCL2, CCL7 e CCL8) e a sinalização por meio desse receptor está envolvida na regeneração muscular após lesões, tanto que a deficiência de CCR2 resulta em atraso no processo regenerativo, acompanhado de inflamação prolongada, aumento no acúmulo de gordura e fibrose em camundongos (Warren et al., 2005). CCL2, CCL3 e CCL4 são capazes de estimular mioblastos a entrarem na fase $S$ do ciclo celular pela indução da via MAPK (Yahiaoui et al., 2008).

Assim, a CCL2 tem importância tanto na promoção da inflamação, quanto na regeneração muscular. A superexpressão de $C C / 2$ foi identificada em todas as linhagens distróficas, e em todas as idades, com exceção da linhagem Large $^{\text {myd }}$ com seis meses de idade. $\mathrm{O}$ gene do receptor $C \mathrm{Cr} 2$ também está superexpresso nos animais com aumento na expressão de CCl2, exceto nos camundongos $L a r g e^{m y d-/} 21$ dias, Dmd ${ }^{m d x} / L_{a r g} e^{m y d-/} 21$ dias e $L a r g e^{m y d-1-} 3$ meses. Os genes $C C / 5$ e $C c / 8$ relatados no trabalho de Porter e colaboradores também apresentaram expressão elevada, com adição de Ccl3L1 e Ccl21 (este último apenas em $\operatorname{Large}^{\text {myd-/}} 6$ meses). Os receptores das demais quimiocinas encontradas 
também estão com expressão elevada ( C cr1, C Cr3 e C Cr5), indicando que a sinalização dessas moléculas possa estar realmente ativada.

Todas as linhagens estudadas têm expressão ativada dos genes das quimiocinas Cc16, Ccl7 e Cc19. Ccl6 é expresso por eosinófilos e também por macrófagos depois que eles se movem para o tecido, atraindo mais monócitos. Foi sugerido que Ccl6 possa ser permanentemente ativo na manutenção da inflamação promovida por macrófagos, que são inicialmente atraídos por MCP-1 (CC/2) (Wu, Prystowsky e Orlofsky, 1999). Tal sugestão se aplica ao observado aqui, já que todas as linhagens superexpressam Ccl6, independentemente da idade.

CCI7 atrai eosinófilos e células dendríticas; CC/9 tem expressão ubíqua e recruta linfócitos T CD4 ${ }^{+}$e $\mathrm{CD}^{+}$(Porter, Guo, et al., 2003).

Em resumo, as quimiocinas CC são moléculas que podem regular as subpopulações de macrófagos (tratadas mais abaixo) e outros leucócitos dentro do músculo lesionado, bem como a persistência da inflamação e a eficácia do remodelamento do tecido.

Nas análises de enriquecimento de vias (Kegg) feitas nas comparações com os animais controle, as vias "Cytokine-cytokine receptor interaction" e "Chemokine signaling pathway" estão presentes em todas as linhagens distróficas, nas três idades. Isso é uma indicação de que o recrutamento de células inflamatórias mediado por quimiocinas ocorre o tempo todo, e não de forma restrita à idade de dois meses como já foi proposto (Porter, Guo, et al., 2003).

Nesse trabalho também não foi encontrada expressão alterada de quimiocinas da classe CXC, exceto CXCL14. Isso não era esperado, pois CXCLs atraem neutrófilos e células NK, células ativas no início da doença. Em contrapartida, encontramos a superexpressão de CXCl10, CXCl13 e CXCl14, mas não de receptores CXCR.

Não encontramos estudos sobre a expressão de quimiocinas nas distrofias musculares congênitas; na linhagem Large ${ }^{\text {myd-/- }}$ e no duplo-mutante encontramos que os genes dessas proteínas estão induzidos, assim, podemos dizer que a atração de células inflamatórias pela ação dessas citocinas é um fator em comum ao processo distrófico em geral, incluindo tanto as distrofinopatias, como as de defeito de glicosilação.

No músculo normal, um dano agudo provoca a resposta imune inata de forma bem característica, na qual a invasão de neutrófilos é seguida pela invasão de populações de macrófagos dos tipos M1 e M2. No entanto, no músculo cronicamente sujeito a injúrias, a inflamação é dominada pela infiltração de células mieloides, como ocorre na distrofia muscular de Duchenne, distrofia muscular congênita e distrofia muscular de cinturas 2B. Macrófagos, mastócitos, neutrófilos, eosinófilos e linfócitos T citotóxicos, todos contribuem para a patogênese dessas condições miopáticas, mas é sabido que apenas macrófagos, e talvez eosinófilos, contribuem para a regeneração muscular (Tidball e Villalta, 2010). 
Tanto em pacientes com DMD, quanto no camundongo $D m d^{m d x}$ o início da manifestação da doença coincide com o início da inflamação muscular, sugerindo um papel regulatório das células inflamatórias. Camundongos $D m d^{m d x}$ que tiveram seus macrófagos removidos antes do início da doença tiveram uma grande redução nos sinais histopatológicos (Wehling, Spencer e Tidball, 2001).

O curso da inflamação nos estágios iniciais da distrofia no $D m d^{m d x}$ compartilha algumas semelhanças com a resposta imune inata que ocorre a injúrias agudas no músculo saudável. A população inicial de células que invade o músculo distrófico é composta por neutrófilos e macrófagos M1, que são capazes de remover restos celulares produzidos pela lesão oxidativa e de produzir citocinas capazes de promover a fase proliferativa da miogênese (Tidball e Villalta, 2010).

Diferentemente do que ocorre no tecido saudável, o influxo de macrófagos M1 é acompanhado pela invasão concomitante de macrófagos M2a, que normalmente ocorre em estágios mais tardios da inflamação. Como macrófagos M1 produzem NO, que aumenta a lesão muscular, e macrófagos M2 são capazes de reduzir a produção de NO, a entrada simultânea dessas duas populações seria importante para minimizar os efeitos prejudiciais causados pelos macrófagos M1. No $D m d^{m d x}$ a transição da fase de intensa necrose para a fase com menor necrose e regeneração é acompanhada pela transição na população de macrófagos M1 e M2a para uma população de macrófagos M2c, prevalentes no músculo em regeneração (Villalta et al., 2009).

Os genes Cd68, Mpeg1 e Msr1 são expressos por macrófagos e estão superexpressos em todas as linhagens e idades de camundongos estudados neste trabalho. Cd68 é típico de macrófagos M1.

A autoimunidade pode surgir quando proteínas intracelulares são liberadas em excesso na corrente sanguínea e consequentemente estimulam a resposta imune, o como já foi visto em tecidos amplamente lesionados, e o mesmo acontece constantemente no músculo distrófico com o rompimento celular devido à atividade muscular. Logo, essas proteínas livres podem ser capturadas por células apresentadoras de antígenos, que ativam linfócitos $\mathrm{T}$, levando ao agravamento da patologia pela destruição de células próprias.

A autorreatividade de linfócitos $T$ requer a apresentação dos antígenos por moléculas MHC de classe I ou II de células apresentadoras de antígenos. O músculo saudável não expressa MHC classe I, nem MHC classe II (Mcdouall, Dunn e Dubowitz, 1989), mas algumas fibras do músculo deficiente em distrofina expressa MHC classe I (Emslie-Smith, Arahata e Engel, 1989). Dessa forma, até mesmo as próprias células musculares podem atuar como apresentadoras de antígenos, pois já foi visto que o músculo adulto tem em sua superfície moléculas coestimulatórias para a ativação de 
células T (Behrens et al., 1998). As células musculares não expressam MHC classe II, mas há a expressão dessas moléculas por outros tipos celulares presentes no órgão.

A depleção de linfócitos $\mathrm{T} \mathrm{CD}^{+}$e $\mathrm{CD} 8^{+}$também reduz a patologia (Spencer et al., 2001). Camundongos $D m d^{m d x}$ cruzados com camundongos deficientes em linfócitos $B$ e $T$ têm fibrose reduzida, sugerindo que a contribuição de linfócitos para a patologia provenha da estimulação da fibrose, que dificulta a regeneração (Farini et al., 2007).

As distrofias musculares permanecem sem tratamento, mas diversas estratégias de tratamento estão em estudo, incluindo a terapia gênica com vetores contendo minidistrofina. Entretanto, os resultados obtidos até o momento indicam que essas terapias ativam a imunidade mediada por células T que atacam a distrofina exógena. Isso mostra o quão importante é o monitoramento da resposta imune nos experimentos de terapias que objetivam o aumento do número de fibras musculares expressando distrofina (Flanigan et al., 2013).

Outro componente do sistema imunológico que pode contribuir negativamente para a patologia das distrofias musculares é o sistema complemento, composto por proteínas circulantes que se ligam aos antígenos, atraindo neutrófilos e monócitos e formam complexos na membrana da célula ser destruída, facilitando a sua lise.

O envolvimento do sistema complemento com a distrofia muscular está mais caracterizado nas disferlinopatias. A deficiência de disferlina aumenta a expressão de fatores do sistema complemento; a remoção do gene $C 3$ melhora os aspectos musculares do camundongo modelo dessa doença, mostrando a forte contribuição do sistema complemento no desenvolvimento da patologia (Han et al., 2010). Camundongos deficientes em disferlina e linfócitos apresentam melhora na regeneração muscular, com redução na quantidade de macrófagos e deposição de proteínas do complemento (Farini et al., 2012).

Dessa forma, a ativação de proteínas do sistema complemento constitui mais um mecanismo pelo qual o sistema imune agrava a lesão no músculo distrófico. Todos os animais estudados apresentaram maior expressão dos genes C1qb e C3ar1 que são do sistema complemento. 


\section{Caracterização do perfil de cada linhagem}

4.1. Análise do número de genes diferencialmente expressos - efeito da idade na evolução de cada linhagem

Os diagramas das figuras 54, 55 e 56 (seção 7.1) reúnem o total de genes diferencialmente expressos de todas as linhagens em relação ao controle, mostrando quantos genes estão sempre alterados (centro dos diagramas) e aqueles que estão desregulados especificamente em uma determinada idade (partes externas dos diagramas).

A linhagem $D m d^{m d x}$ é a que apresenta o maior número de genes desregulados (577 genes no total), sendo a idade de 21 dias com maior parte do total. A partir desses números podemos concluir que a fase juvenil é que causa a maior perturbação no transcriptoma, seguida de uma estabilização na idade adulta. Os números encontrados neste trabalho são superiores aos já reportados na literatura, mas que seguem essa mesma tendência de haver mais genes afetados nos estágios mais iniciais e menos genes conforme a doença se estabiliza, como consequência da deficiência de distrofina neste modelo.

A linhagem $\operatorname{Larg} e^{\text {myd-- }}$ tem no total 343 genes diferencialmente expressos; com o número de genes específicos de cada idade aumentando progressivamente. Ao contrário do que é visto no $D m d^{m d x}$, é aos seis meses que ocorre a maior alteração no transcriptoma, fase na qual o camundongo Large ${ }^{\text {myd-- }}$ está bem debilitado.

A linhagem $D m d^{m d x} / \operatorname{Larg}^{m y d-\gamma}$ em uma quantidade semelhante de genes que o Large ${ }^{\text {myd- }}$ (376 genes no total), e também com aumento progressivo com o avanço da idade. Contudo, o maior número de genes está nas idades de três e seis meses. Assim, nessa linhagem as maiores alterações se encontram na fase adulta, sendo que as idades de três e seis meses têm boa parte dos genes compartilhados entre si (150 genes).

Comparando as três linhagens, fica evidente que o perfil de expressão do $D m d^{m d x}$ segue um padrão distinto dos outros dois modelos: mais genes são alterados e as alterações se concentram mais no estágio inicial da doença.

\subsection{Redes gênicas - o que está diferente em cada linhagem em relação às demais, na mesma idade?}

As funções e doenças que foram atribuídas às redes gênicas pelo programa não diferem muito entre as linhagens, e nem do que foi visto com as análises mais gerais. Logo, podemos entender que apesar de haver diferenças nos genes que são diferentemente expressos especificamente nas linhagens, esses genes atuam em processos 
similares, valendo-se de caminhos sutilmente distintos, mas que provocam as mesmas consequências: degeneração e regeneração.

\section{$D \boldsymbol{m}^{m d x}$}

\section{1 dias}

A principal rede formada para essa linhagem mostra as relações entre 33 genes, que exercem funções relacionadas com o ciclo celular. Isso reitera o que encontramos na classificação funcional de todos os genes diferencialmente expressos, confirmando a relevância biológica dessas vias nos camundongos $D m d^{m d x}$ jovens. E também é uma evidência de que o processo de regeneração está fortemente ativo, diferentemente dos outros modelos. Assim, estudos mais aprofundados desses genes são necessários.

\section{3 meses}

A rede da figura 58 mostra a interação de alguns dos genes que estão particularmente expressos de forma diferencial no $D m d^{m d x}$ aos três meses. Essa rede está mais implicada com a resposta imunológica, o que é concordante com as outras análises funcionais.

\section{6 meses}

A rede da figura 59 integrou genes que participam do metabolismo de lipídios, transporte molecular, e bioquímica de pequenas moléculas. Recentemente, o estudo do transcriptoma de músculos em processo de regeneração após lesão com glicerol e cardiotoxina, revelou que o comprometimento adipogênico é uma marca da regeneração muscular, o que pode levar ao acúmulo anormal de adipócitos (Lukjanenko et al., 2013). A substituição de fibras musculares por tecido adiposo, durante o processo distrófico também é bem descrito (Pastoret e Sebille, 1995).

\section{Large $^{m y d-/-}$}

\section{1 dias}

A rede da figura 60 mostra as interações que três dos oito genes especificamente expressos no Large $^{m y d-/}$ têm com outros genes. O gene Ifizo2b ativa os genes Myog e Myod1, dois fatores de transcrição diretamente envolvidos na diferenciação muscular. Entretanto a superexpressão de Ifi202b em mioblastos inibe a expressão de Myod, interferindo na sua atividade e, consequentemente, inibe a indução da diferenciação de mioblastos (Datta et al., 1998). Assim sendo, é possível que nessa fase, por conta da superexpressão de Ifi202b, a diferenciação muscular no $\operatorname{Larg}^{\text {myd-/- }}$ seja menos eficiente. 
Agtr2 é expresso pelas células satélite. Recentemente foi descoberto que a sinalização da angiotensina-2 impede a regeneração muscular por suprimir a função das células satélite (Yoshida et al., 2013). Dessa forma, o aumento da expressão do receptor Agtr2 poderia estar, de forma indireta, dificultando a regeneração, assim como Ifi202b.

\section{3 meses}

A rede formada com os genes do Large $e^{m y d-/}$ com três meses está implicada na morfologia tecidual, sobrevivência e morte celular, e desenvolvimento e função do tecido conectivo, que tem bastante importância nessa linhagem, que apresenta bastante deposição de tecido fibroso em substituição à perda de tecido muscular. Os quatro genes dessa rede (Chil3/Chil4, Klk3, Map1b e Npnt) ainda não foram relacionados com a distrofia muscular.

\section{6 meses}

Os genes agrupados na rede mais significante formada com os 81 genes do Large $e^{\text {myd- }}$ atuam em doenças metabólicas e do tecido conectivo, e na resposta inflamatória. Mesmo a inflamação sendo um aspecto compartilhado pelas diferentes formas de distrofia muscular, o camundongo Large $^{\text {myd-/- }}$ tem outros genes com expressão diferencial com essa função; em outras palavras, além das vias inflamatórias comuns ao processo distrófico, nessa linhagem há a participação de outros componentes correlacionados.

\section{Dmd $d^{m d x} /$ Large $e^{m y d-/-}$}

\section{1 dias}

A rede gênica mais significante proposta pela análise computacional para os 12 genes com expressão diferencial apenas no duplo-mutante com 21 dias de idade está correlacionada com a morte e sobrevivência celular, e o desenvolvimento celular. Não encontramos na literatura informações sobre o papel de Anxa8, que possam ter relação com o músculo esquelético.

Camundongos deficientes em Homer1, um regulador da sensibilidade de canais TRP (receptor transiente de potencial) exibem miopatia, caracterizada por redução na geração de força, refletindo em dano muscular por aumento do influxo de cálcio (Stiber et al., 2008). A isoforma Homer2, está hipoexpressa no duplo-mutante e poderia estar envolvida em um mecanismo similar, e já foi reportado que a sua superexpressão aumenta a diferenciação de miotubos (Stiber et al., 2005). Logo, é possível que a subexpressão de Homer2 pode contribuir para o fenótipo mais grave do duplo-mutante. 


\section{3 meses}

O nó no centro da rede da figura $\mathrm{X}, \mathrm{UBC}$ (ubiquitina $\mathrm{C}$ ) chama a atenção porque a proteólise controlada via a degradação mediada por ubiquitinas é crucial para o desenvolvimento e manutenção do músculo. O gene $A s b 2$ está conectado com UBC nesta rede; é sabido que $A s b 2$ está envolvido na diferenciação muscular, pois marca a proteína FLNb (envolvida no remodelamento da actina, evento importante para a diferenciação muscular) para a destruição, e está com expressão induzida em mioblastos em diferenciação, no mesmo momento em ocorre a expressão de miogenina. Foi visto também que a inativação de $A s b 2$ por RNA de interferência atrasa a formação dos miotubos (Bello et al., 2009).

Com base nessas informações e dado que Asb2 está subexpresso no $D m d^{m d x} /$ Large $^{m y d-\text {, }}$ é possível que a regeneração no músculo desses animais esteja comprometida e não ocorra de forma eficiente, contribuindo ainda mais para a degradação do tecido.

\section{6 meses}

É interessante que aos seis meses de idade a linhagem $D m d^{m d x} / L a r g e^{m y d-/}$ tenha a expressão aumentada de genes de desenvolvimento embrionário; talvez isso seja o reflexo de uma tentativa de regeneração do tecido, mas que permanece apenas no nível transcricional, já que nessa fase o animal está muito comprometido e no final de sua vida.

\section{Caracterização do modelo Dmd ${ }^{m d x} / \operatorname{Large}^{m y d-/-}$}

\subsection{Comparações com as linhagens parentais}

O pequeno número de genes desregulados no $D m d^{m d x} / L a r g e^{m y d-/}$ em comparação com as linhagens parentais indica a proximidade entre eles, e que a junção das duas linhagens leva a uma perturbação pequena na transcrição de novos genes. A maior diferença está na comparação do $D m d^{m d x} / L a r g e^{m y d-/}$ com o $D m d^{m d x}$, (tabela 22) com 130 genes, sendo 124 subexpressos, dos quais apenas 41 estão superexpressos no $D m d^{m d x}$, ou seja, no duplo-mutante alguns genes assumem um comportamento distinto do que ocorre na linhagem parental. Seria esperado que a grande maioria desses genes fosse aqueles que estão envolvidos com a proliferação celular (e superexpressos) no $D m d^{m d x}$, mas a maior parte desses genes está implicada em vias do sistema imunológico. Isso sugere que a resposta imune no duplo-mutante seja menos intensa que no $D m d^{m d x}$.

Quatro estão envolvidos na regulação positiva da proliferação celular: Clec11a, CD28, Derl2 e I/15; e dois com o ciclo celular: Haus8 e Gadd45gip1. Esses genes merecem ser estudados com mais atenção. Dos 41 genes listamos também os seguintes: Mup1, 
Ifi204, Retnla, Slamf7,Cyp4f2, Fcrls, Oas1 que apresentam valores de fold change maiores que $-1,5$.

Ifi204 produz uma proteína que tem seus níveis aumentados durante a fusão de mioblastos sob a ação do fator de transcrição MyoD. A superexpressão de Ifizo4 acelera a fusão de mioblastos (Liu et al., 2000), pois diminui o nível das proteínas Id, conhecidas por inibirem a diferenciação muscular via bloqueio de $M y o D$, dentre outras proteínas miogênicas (Liu et al., 2002). Com base nessas informações podemos dizer que no $D m d^{m d x} /$ Large $^{m y d-/}$ a subexpressão de Ifi204 (em relação ao $D m d^{m d x}$ ) está dificultando a diferenciação miogênica, ao contrário do $D m d^{m d x}$ que está superexpressando esse mesmo gene e apresenta um melhor potencial de regeneração.

Não encontramos informações na literatura para discutir o papel dos demais genes, mas eles podem ser candidatos para explicar as diferenças fenotípicas vistas nessas duas linhagens.

A sobreposição das listas de genes com expressão diferencial em cada uma das idades estudadas no duplo-mutante mostrou que essa linhagem tem 59 genes que se mantêm alterados na linhagem, independentemente da idade. Destes 59, 31 são os genes comuns ao processo distrófico, restando os 28 genes que estão nas tabelas 39 e 40, dos quais sete estão presentes na linhagem $L a r g e^{m y d-/}$ e 20 na $D m d^{m d x}$, restando apenas um gene que está sempre superexpresso somente no $D m d^{m d x} / \operatorname{Large}^{m y d-/}$. Mais uma vez, a junção das duas linhagens não leva a perturbação da transcrição gênica no animal gerado, sem alteração de vias diferentes daquelas já alteradas nos parentais. Entretanto, o que ocorre não é apenas uma soma dos genes alterados em cada linhagem, pois o número de GDEs no duplo-mutante é inferior à soma simples dos GDEs no $D m d^{m d x}$ e no Large $^{m y d-}$. Assim, apenas parte dos genes com expressão diferencial nas linhagens parentais também terão expressão alterada no duplo-mutante.

Mesmo assim, quando comparamos as vias KEGG obtidas para as linhagens $\operatorname{Larg}^{m y d-/}$ e $D m d^{m d x} / \operatorname{Larg}^{m y d-/}$ vemos que as duas têm listas bastante semelhantes, e vias que estão ativadas no $D m d^{m d x}$ não estão ativadas no duplo-mutante. Assim, o perfil de expressão do $D m d^{m d x} / \operatorname{Larg}^{m y d-/}$ é mais próximo do parental $L a r g e^{m y d-/}$.

\section{Genes "herdados" do Large myd-/- $^{\text {- }}$}

Seis genes que estão superexpressos no $\operatorname{Large}^{\text {myd- }}$ também estão no $D m d^{m d x} /$ Large $^{m y d-/}$, além do gene Large, que está subexpresso. Destes podemos destacar Mmp19, que degrada uma série de componentes da matriz extracelular, incluindo colágeno tipo IV, fibronectina e laminina (Stracke et al., 2000). 


\section{Genes "herdados" do Dmd"}

Na tabela 40 estão os 20 genes que apresentam expressão diferencial no $D m d^{m d x} \mathrm{e}$ também no $D m d^{m d x} /$ Large $e^{m y d-1}$.

O gene Atp6v0d2 codifica uma subunidade de uma ATPase vacuolar, importante para a acidificação do meio extracelular na reabsorção óssea (Wu, Xu e Li, 2009), mas não há trabalhos na literatura que a associem a alguma função no músculo esquelético.

Dos demais genes, alguns foram discutidos anteriormente e para os demais não encontramos informações que ajudem a relacioná-los com o fenótipo distrófico.

\section{Gene exclusivamente alterado no modelo do duplo mutante}

O único gene que apresentou expressão diferencial apenas no $D m d^{m d x} / L a r g e^{m y d-/-~}$ em todas as idades foi Lilrb3, que codifica um receptor expresso em células imunes, nas quais ele se liga a moléculas MHC classe I e transduz um sinal negativo que inibe 0 estímulo de uma resposta imune. Acredita-se que ele controle as respostas inflamatórias e a citotoxicidade, limitando a autorreatividade (Anderson e Allen, 2009). Na literatura não há informações que ajudem a relacionar o aumento da expressão de Lilrb3 com o fenótipo mais grave do duplo-mutante.

\subsection{Análise e redes funcionais (IPA) do $D m d^{m d x} / \operatorname{Large}^{m y d-/-}$}

A análise funcional feita no programa IPA mostrou os processos biológicos mais afetados no duplo-mutante (Tabelas 42 a 44 e Figuras 67 a 72); as mesmas categorias foram encontradas em todas as idades, variando apenas a ordem de significância entre elas. Esses dados reiteram o que foi observado com as outras análises, e mostram que os processos alterados nesse animal são os mesmos, independentemente da idade. O que varia entre as idades é quantidade de moléculas envolvidas nos processos, com mais genes participando das vias conforme o animal envelhece.

A seguir, serão discutidos alguns pontos das redes gênicas formadas com todos os genes diferencialmente expressos no $D m d^{m d x} / \operatorname{Large}^{m y d-/}$.

Nas redes das Figuras 67 e 70 (rede 1, 21 dias e rede 2, 3 meses) destacam-se genes da degradação de colágeno, as metaloproteinases Mmp12 (discutida anteriormente), Mmp19, Mmp3, Mmp14 e Mmp8, mostrando que há ao menos uma tentativa de se reduzir a quantidade de tecido fibroso que é depositada no músculo.

Na rede 2 dos 21 dias (Figura 68), os genes mir154, Chrng, Tnnt2, Myh3, Ccr1 e Tyrobp estão diretamente envolvidos com doenças musculares. O mir154 está 
superexpresso na distrofia muscular de Duchenne e em algumas formas de distrofia muscular de cinturas (Eisenberg et al., 2007).

Os genes (rede 1, 3 meses) (Figura 69) Cyba, Cybb, Ltf, Col6a3, Igf2, Ncam1, Chrna1, Chrng, Nos1, S100a9, S100a8, Atp6v0d2, Rgs10, Myh3, Myh8, Myl4, Tnnt2, Tmsb4x e Myog estão todos envolvidos no desenvolvimento muscular e em doenças musculares, de acordo com as análises do programa.

As duas redes da análise do animal com seis meses mostram a interação de genes da resposta imunológica.

\section{Validação do perfil de expressão por PCR em tempo real quantitativo}

A quantidade de genes identificados como diferencialmente expressos é muito extensa e é provável que alguns genes não estejam realmente com expressão alterada, assim a validação por PCR em tempo real quantitativo é um procedimento padrão.

Todos os genes testados apresentaram a mesma tendência de expressão, confirmando a reprodutibilidade e confiabilidade dos experimentos com os microarranjos. 


\section{Conclusões}

\section{O que caracteriza o processo distrófico?}

Os resultados de todas as análises funcionais apontam para uma forte participação de genes e vias do sistema imunológico na patologia das distrofias musculares, a despeito da mutação primária ou estágio de evolução da doença.

O conjunto de 31 genes compartilhados por todos os animais estudados revelam pontos importantes do processo distrófico como um todo. O primeiro ponto é a importância da ativação via de sinalização de quimiocinas, que atuam em duas frentes distintas: a promoção da inflamação e o estímulo à regeneração. Parte desses genes também está diretamente relacionada com outros componentes da resposta imunológica.

Os demais genes têm mais participação na regulação do equilíbrio entre os processos de degeneração/regeneração e modulação da matriz extracelular.

\section{Quais são as mudanças com a evolução da doença?}

Para as linhagens em geral, a quantidade de genes de uma idade para a outra aumenta: 63 genes aos 21dias, 88 aos três meses e 127 aos seis meses. Aos 21 dias destacamos a participação de genes do ciclo celular, de fibras imaturas e degeneração.

Aos três meses, é interessante a atuação do gene Capn6, modulando o desenvolvimento muscular. Aos seis meses, destacam-se os genes de colágeno, relacionados com a deposição de matriz extracelular em substituição à perda do tecido muscular; e também a subexpressão de Mstn indicando a ativação de mecanismos que possam favorecer o aumento do tecido muscular.

Na fase juvenil, para as linhagens $L a r g e^{m y d-/}$ e $D m d^{m d x} / L a r g e^{m y d-/-}$ a contribuição do sistema imune e inflamação é o fator principal. Para o $D m d^{m d x}$, a proliferação celular tem um papel mais significativo. $O$ estudo aprofundamento dos genes envolvidos nessa função é interessante e necessário, pois eles são candidatos a serem os genes responsáveis pelo fenótipo menos grave dessa linhagem.

Na fase adulta, para o $L a r g e^{m y d--}$ e $D m d^{m d x} / L a r g e^{m y d-/}$, a resposta imune reduz um pouco a sua representação, porém ainda é majoritária. O perfil do $D m d^{m d x}$ já parece mais semelhante às outras duas linhagens. 


\section{O que diferencia cada linhagem? Como é a evolução de cada linhagem?}

Em relação às funções e vias biológicas que são afetadas, as linhagens pouco se diferenciam, exceto a linhagem $D m d^{m d x}$ com 21 dias. De forma geral, apesar da mutação primária em cada camundongo ser distinta, as vias e processos biológicos que desencadeiam na distrofia muscular são muito semelhantes; as diferenças se concentram mais em quais genes são afetados.

Quanto ao número de genes afetados, novamente na idade de 21 dias que estão as maiores diferenças: o $D m d^{m d x}$ tem muito mais genes especificamente alterados apenas nele. Nas idades seguintes, a quantidade de genes específicos reduz consideravelmente.

Para a linhagem $L a r g e^{m y d-\text {, }}$ na idade de 21 dias há poucos genes que estão exclusivamente expressos nela, sugerindo que a doença está sendo regulada mais por genes gerais do processo distrófico. Aos três meses essa tendência é semelhante, mas é importante ressaltar que 61 genes são partilhados com o duplo-mutante, assim, podemos dizer que nessa idade o $\operatorname{Larg}^{m y d-\text { já }}$ passa a se diferenciar mais em relação ao $D m d^{m d x}$. Aos seis meses, ocorre um grande incremento na quantidade de genes específicos no

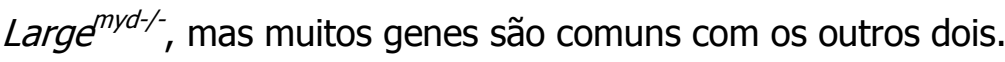

\section{O que o duplo mutante tem de diferente?}

O $\mathrm{Dmd}^{m d x} /$ Large $\mathrm{myd-/}^{m}$ carrega um pouco de cada uma de suas linhagens parentais, havendo mais semelhanças do que diferenças. Analisando a linhagem como um todo, podemos concluir que a maior parte de suas características se deve aos genes que estão regulando a fisiopatologia da distrofia muscular em todas as linhagens; sendo que grande parte dos genes que aparecem desregulados no parental $D m d^{m d x}$ não apresentam o mesmo comportamento no duplo-mutante. Pela quantidade de genes alterados e pelas

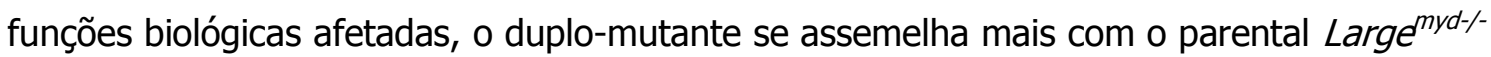
sugerindo que a hipoglicosilação não traz maiores consequências quando associada ao defeito estrutural na distrofina. Em resumo, o duplo-mutante, apresenta poucas diferenças em relação ao $L_{a r g} e^{m y d-/}$ e não apresenta as características peculiares ao $D m d^{m d x}$, principalmente no início do desenvolvimento da doença. 


\section{Referências bibliográficas}

ABDUL-HUSSEIN, S.; VAN DER VEN, P. F.; TAJSHARGHI, H. Expression profiles of muscle disease-associated genes and their isoforms during differentiation of cultured human skeletal muscle cells. BMC Musculoskelet Disord, v. 13, p. 262, 2012. ISSN 1471-2474. Disponível em: < http://www.ncbi.nlm.nih.gov/pubmed/23273262 >.

ALDERTON, J. M.; STEINHARDT, R. A. How calcium influx through calcium leak channels is responsible for the elevated levels of calcium-dependent proteolysis in dystrophic myotubes. Trends Cardiovasc Med, v. 10, n. 6, p. 268-72, Aug 2000. ISSN 1050-1738. Disponível em: < http://www.ncbi.nlm.nih.gov/pubmed/11282306 >.

ALLEN, D. G.; WHITEHEAD, N. P. Duchenne muscular dystrophy--what causes the increased membrane permeability in skeletal muscle? Int J Biochem Cell Biol, v. 43, n. 3, p. 290-4, Mar 2011. ISSN 1878-5875. Disponível em: < http://www.ncbi.nlm.nih.gov/pubmed/21084059 >.

ALLIKIAN, M. J.; MCNALLY, E. M. Processing and assembly of the dystrophin glycoprotein complex. Traffic, v. 8, n. 3, p. 177-83, Mar 2007. ISSN 1398-9219. Disponível em: < http://www.ncbi.nlm.nih.gov/pubmed/17274800 >.

ALLOCCO, D. J.; KOHANE, I. S.; BUTTE, A. J. Quantifying the relationship between coexpression, co-regulation and gene function. BMC Bioinformatics, v. 5, p. 18, Feb 2004. ISSN 1471-2105. Disponível em: < http://www.ncbi.nlm.nih.gov/pubmed/15053845 >.

AN, H. B. et al. Partial least squares based identification of Duchenne muscular dystrophy specific genes. J Zhejiang Univ Sci B, v. 14, n. 11, p. 973-82, Nov 2013. ISSN 1862-1783. Disponível em: < http://www.ncbi.nlm.nih.gov/pubmed/24190443 >.

ANDERSON, J. E. A role for nitric oxide in muscle repair: nitric oxide-mediated activation of muscle satellite cells. Mol Biol Cell, v. 11, n. 5, p. 1859-74, May 2000. ISSN 1059-1524. Disponível em: < http://www.ncbi.nlm.nih.gov/pubmed/10793157 >.

ANDERSON, K. J.; ALLEN, R. L. Regulation of T-cell immunity by leucocyte immunoglobulin-like receptors: innate immune receptors for self on antigen-presenting cells. Immunology, v. 127, n. 1 , p. 8-17, May 2009. ISSN 1365-2567. Disponível em: < http://www.ncbi.nlm.nih.gov/pubmed/19368561 >.

BABAN, D.; DAVIES, K. E. Microarray analysis of mdx mice expressing high levels of utrophin: therapeutic implications for dystrophin deficiency. Neuromuscul Disord, v. 18, n. 3, p. 23947, Mar 2008. ISSN 0960-8966. Disponível em: < http://www.ncbi.nlm.nih.gov/pubmed/18343112 >.

BAKAY, M. et al. A web-accessible complete transcriptome of normal human and DMD muscle. Neuromuscul Disord, v. 12 Suppl 1, p. S125-41, Oct 2002. ISSN 0960-8966. Disponível em: < http://www.ncbi.nlm.nih.gov/pubmed/12206807 >.

BARON, D. et al. Immune response and mitochondrial metabolism are commonly deregulated in DMD and aging skeletal muscle. PLoS One, v. 6, n. 11, p. e26952, 2011. ISSN 1932-6203. Disponível em: < http://www.ncbi.nlm.nih.gov/pubmed/22096509 >.

BAUMEISTER, A.; ARBER, S.; CARONI, P. Accumulation of muscle ankyrin repeat protein transcript reveals local activation of primary myotube endcompartments during muscle morphogenesis. J Cell Biol, v. 139, n. 5, p. 1231-42, Dec 1997. ISSN 0021-9525. Disponível em: < http://www.ncbi.nlm.nih.gov/pubmed/9382869 >.

BEHRENS, L. et al. Human muscle cells express a functional costimulatory molecule distinct from B7.1 (CD80) and B7.2 (CD86) in vitro and in inflammatory lesions. J Immunol, v. 161, n. 
11, p. 5943-51, Dec 1998. ISSN 0022-1767. Disponível em: < http://www.ncbi.nlm.nih.gov/pubmed/9834075 >.

BELLINGER, A. M. et al. Hypernitrosylated ryanodine receptor calcium release channels are leaky in dystrophic muscle. Nat Med, v. 15, n. 3, p. 325-30, Mar 2009. ISSN 1546-170X. Disponível em: < http://www.ncbi.nlm.nih.gov/pubmed/19198614 >.

BELLO, N. F. et al. The E3 ubiquitin ligase specificity subunit ASB2beta is a novel regulator of muscle differentiation that targets filamin B to proteasomal degradation. Cell Death Differ, v. 16, n. 6, p. 921-32, Jun 2009. ISSN 1476-5403. Disponível em: < http://www.ncbi.nlm.nih.gov/pubmed/19300455 >.

BELTRÁN-VALERO DE BERNABÉ, D. et al. Mutations in the O-mannosyltransferase gene POMT1 give rise to the severe neuronal migration disorder Walker-Warburg syndrome. Am J Hum Genet, v. 71, n. 5, p. 1033-43, Nov 2002. ISSN 0002-9297. Disponível em: < http://www.ncbi.nlm.nih.gov/pubmed/12369018 >.

BOER, J. M. et al. Expression profiling in stably regenerating skeletal muscle of dystrophindeficient mdx mice. Neuromuscul Disord, v. 12 Suppl 1, p. S118-24, Oct 2002. ISSN 09608966. Disponível em: < http://www.ncbi.nlm.nih.gov/pubmed/12206806 >.

BRAND-SABERI, B.; CHRIST, B. Genetic and epigenetic control of muscle development in vertebrates. Cell Tissue Res, v. 296, n. 1, p. 199-212, Apr 1999. ISSN 0302-766X. Disponível em: < http://www.ncbi.nlm.nih.gov/pubmed/10199980 >.

BRIGUET, A. et al. Histological parameters for the quantitative assessment of muscular dystrophy in the mdx-mouse. Neuromuscul Disord, v. 14, n. 10, p. 675-82, Oct 2004. ISSN 0960-8966. Disponível em: < http://www.ncbi.nlm.nih.gov/pubmed/15351425 >.

BROCKINGTON, M. et al. Mutations in the fukutin-related protein gene (FKRP) cause a form of congenital muscular dystrophy with secondary laminin alpha2 deficiency and abnormal glycosylation of alpha-dystroglycan. Am J Hum Genet, v. 69, n. 6, p. 1198-209, Dec 2001. ISSN 0002-9297. Disponível em: < http://www.ncbi.nlm.nih.gov/pubmed/11592034 >.

BROWNING, C. A. et al. A rapid PCR method for genotyping the Large(myd) mouse, a model of glycosylation-deficient congenital muscular dystrophy. Neuromuscul Disord, v. 15, n. 5, p. 331-5, May 2005. ISSN 0960-8966. Disponível em: < http://www.ncbi.nlm.nih.gov/pubmed/15833424 >.

BUCKINGHAM, M. Skeletal muscle formation in vertebrates. Curr Opin Genet Dev, v. 11, n. 4, p. 440-8, Aug 2001. ISSN 0959-437X. Disponível em: < http://www.ncbi.nlm.nih.gov/pubmed/11448631 >.

Myogenic progenitor cells and skeletal myogenesis in vertebrates. Curr Opin Genet Dev, v. 16, n. 5, p. 525-32, Oct 2006. ISSN 0959-437X. Disponível em: < http://www.ncbi.nlm.nih.gov/pubmed/16930987 >.

BULFIELD, G. et al. X chromosome-linked muscular dystrophy ( $\mathrm{mdx}$ ) in the mouse. Proc Natl Acad Sci U S A, v. 81, n. 4, p. 1189-92, Feb 1984. ISSN 0027-8424. Disponível em: < http://www.ncbi.nlm.nih.gov/pubmed/6583703 >.

CAMPBELL, K. P.; KAHL, S. D. Association of dystrophin and an integral membrane glycoprotein. Nature, v. 338, n. 6212, p. 259-62, Mar 1989. ISSN 0028-0836. Disponível em: < http://www.ncbi.nlm.nih.gov/pubmed/2493582 >.

CATALA, $F$. et al. A skeletal muscle-specific enhancer regulated by factors binding to $E$ and CArG boxes is present in the promoter of the mouse myosin light-chain $1 \mathrm{~A}$ gene. Mol Cell Biol, 
v. 15, n. 8, p. 4585-96, Aug 1995. ISSN 0270-7306. Disponível em: < http://www.ncbi.nlm.nih.gov/pubmed/7623850 >.

CHEN, Y. W. et al. Expression profiling in the muscular dystrophies: identification of novel aspects of molecular pathophysiology. J Cell Biol, v. 151, n. 6, p. 1321-36, Dec 2000. ISSN 0021-9525. Disponível em: < http://www.ncbi.nlm.nih.gov/pubmed/11121445 >.

CLARK, K. A. et al. Striated muscle cytoarchitecture: an intricate web of form and function. Annu Rev Cell Dev Biol, v. 18, p. 637-706, 2002. ISSN 1081-0706. Disponível em: < http://www.ncbi.nlm.nih.gov/pubmed/12142273 >.

DANGAIN, J.; VRBOVA, G. Muscle development in mdx mutant mice. Muscle Nerve, v. 7, n. 9, p. 700-4, 1984 Nov-Dec 1984. ISSN 0148-639X. Disponível em: < http://www.ncbi.nlm.nih.gov/pubmed/6543918 >.

DANKO, I.; CHAPMAN, V.; WOLFF, J. A. The frequency of revertants in mdx mouse genetic models for Duchenne muscular dystrophy. Pediatr Res, v. 32, n. 1, p. 128-31, Jul 1992. ISSN 0031-3998. Disponível em: < http://www.ncbi.nlm.nih.gov/pubmed/1635838 >.

DATTA, B. et al. Increase in p202 expression during skeletal muscle differentiation: inhibition of MyoD protein expression and activity by p202. Mol Cell Biol, v. 18, n. 2, p. 1074-83, Feb 1998. ISSN 0270-7306. Disponível em: < http://www.ncbi.nlm.nih.gov/pubmed/9448005 >.

DE PAEPE, B. et al. Upregulation of chemokines and their receptors in Duchenne muscular dystrophy: potential for attenuation of myofiber necrosis. Muscle Nerve, v. 46, n. 6, p. 91725, Dec 2012. ISSN 1097-4598. Disponível em: < http://www.ncbi.nlm.nih.gov/pubmed/23225384 >.

DEAN, R. A. et al. Macrophage-specific metalloelastase (MMP-12) truncates and inactivates ELR+ CXC chemokines and generates CCL2, $-7,-8$, and -13 antagonists: potential role of the macrophage in terminating polymorphonuclear leukocyte influx. Blood, v. 112, n. 8, p. 345564, Oct 2008. ISSN 1528-0020. Disponível em: < http://www.ncbi.nlm.nih.gov/pubmed/18660381 >.

DECARY, S. et al. Shorter telomeres in dystrophic muscle consistent with extensive regeneration in young children. Neuromuscul Disord, v. 10, n. 2, p. 113-20, Feb 2000. ISSN 0960-8966. Disponível em: < http://www.ncbi.nlm.nih.gov/pubmed/10714586 >.

EISENBERG, I. et al. Distinctive patterns of microRNA expression in primary muscular disorders. Proc Natl Acad Sci U S A, v. 104, n. 43, p. 17016-21, Oct 2007. ISSN 0027-8424. Disponível em: < http://www.ncbi.nlm.nih.gov/pubmed/17942673 >.

EMERY, A. E. The muscular dystrophies. Lancet, v. 359, n. 9307, p. 687-95, Feb 2002. ISSN 0140-6736. Disponível em: < http://www.ncbi.nlm.nih.gov/pubmed/11879882 >.

EMSLIE-SMITH, A. M.; ARAHATA, K.; ENGEL, A. G. Major histocompatibility complex class I antigen expression, immunolocalization of interferon subtypes, and T cell-mediated cytotoxicity in myopathies. Hum Pathol, v. 20, n. 3, p. 224-31, Mar 1989. ISSN 0046-8177. Disponível em: < http://www.ncbi.nlm.nih.gov/pubmed/2470663 >.

ERVASTI, J. M.; CAMPBELL, K. P. A role for the dystrophin-glycoprotein complex as a transmembrane linker between laminin and actin. J Cell Biol, v. 122, n. 4, p. 809-23, Aug 1993. ISSN 0021-9525. Disponível em: < http://www.ncbi.nlm.nih.gov/pubmed/8349731 >.

ERVASTI, J. M. et al. Deficiency of a glycoprotein component of the dystrophin complex in dystrophic muscle. Nature, v. 345, n. 6273, p. 315-9, May 1990. ISSN 0028-0836. Disponível em: < http://www.ncbi.nlm.nih.gov/pubmed/2188135 >. 
FARINI, A. et al. T and B lymphocyte depletion has a marked effect on the fibrosis of dystrophic skeletal muscles in the scid/mdx mouse. J Pathol, v. 213, n. 2, p. 229-38, Oct 2007. ISSN 0022-3417. Disponível em: < http://www.ncbi.nlm.nih.gov/pubmed/17668421 >.

. Absence of $T$ and $B$ lymphocytes modulates dystrophic features in dysferlin deficient animal model. Exp Cell Res, v. 318, n. 10, p. 1160-74, Jun 2012. ISSN 1090-2422. Disponível em: < http://www.ncbi.nlm.nih.gov/pubmed/22465227 >.

FEGHALI, R.; LEINWAND, L. A. Molecular genetic characterization of a developmentally regulated human perinatal myosin heavy chain. J Cell Biol, v. 108, n. 5, p. 1791-7, May 1989. ISSN 0021-9525. Disponível em: < http://www.ncbi.nlm.nih.gov/pubmed/2715179 >.

FLANIGAN, K. M. The muscular dystrophies. Semin Neurol, v. 32, n. 3, p. 255-63, Jul 2012. ISSN 1098-9021. Disponível em: < http://www.ncbi.nlm.nih.gov/pubmed/23117950 >.

FLANIGAN, K. M. et al. Anti-dystrophin T cell responses in Duchenne muscular dystrophy: prevalence and a glucocorticoid treatment effect. Hum Gene Ther, v. 24, n. 9, p. 797-806, Sep 2013. ISSN 1557-7422. Disponível em: < http://www.ncbi.nlm.nih.gov/pubmed/24010700 $>$.

FOWLKES, J. L. et al. Regulation of insulin-like growth factor (IGF)-I action by matrix metalloproteinase-3 involves selective disruption of IGF-I/IGF-binding protein-3 complexes. Endocrinology, v. 145, n. 2, p. 620-6, Feb 2004. ISSN 0013-7227. Disponível em: < http://www.ncbi.nlm.nih.gov/pubmed/14605000 >.

FUROCHI, $\mathrm{H}$. et al. Overexpression of osteoactivin protects skeletal muscle from severe degeneration caused by long-term denervation in mice. J Med Invest, v. 54, n. 3-4, p. 248-54, Aug 2007. ISSN 1343-1420. Disponível em: < http://www.ncbi.nlm.nih.gov/pubmed/17878673 $>$.

GEE, S. H. et al. Laminin-binding protein 120 from brain is closely related to the dystrophinassociated glycoprotein, dystroglycan, and binds with high affinity to the major heparin binding domain of laminin. J Biol Chem, v. 268, n. 20, p. 14972-80, Jul 1993. ISSN 0021-9258. Disponível em: < http://www.ncbi.nlm.nih.gov/pubmed/8325873 >.

GOETSCH, S. C. et al. Transcriptional profiling and regulation of the extracellular matrix during muscle regeneration. Physiol Genomics, v. 14, n. 3, p. 261-71, Aug 2003. ISSN 1531-2267. Disponível em: < http://www.ncbi.nlm.nih.gov/pubmed/12799472 >.

GOSSELIN, L. E. et al. Localization and early time course of TGF-beta 1 mRNA expression in dystrophic muscle. Muscle Nerve, v. 30, n. 5, p. 645-53, Nov 2004. ISSN 0148-639X. Disponível em: < http://www.ncbi.nlm.nih.gov/pubmed/15389721 >.

GREWAL, P. K.; HEWITT, J. E. Mutation of Large, which encodes a putative glycosyltransferase, in an animal model of muscular dystrophy. Biochim Biophys Acta, v. 1573, n. 3, p. 216-24, Dec 2002. ISSN 0006-3002. Disponível em: < http://www.ncbi.nlm.nih.gov/pubmed/12417403 $>$.

GREWAL, P. K. et al. Mutant glycosyltransferase and altered glycosylation of alphadystroglycan in the myodystrophy mouse. Nat Genet, v. 28, n. 2, p. 151-4, Jun 2001. ISSN 1061-4036. Disponível em: < http://www.ncbi.nlm.nih.gov/pubmed/11381262 >.

GUMERSON, J. D.; MICHELE, D. E. The dystrophin-glycoprotein complex in the prevention of muscle damage. J Biomed Biotechnol, v. 2011, p. 210797, 2011. ISSN 1110-7251. Disponível em: < http://www.ncbi.nlm.nih.gov/pubmed/22007139 >. 
HAN, R. et al. Genetic ablation of complement C3 attenuates muscle pathology in dysferlindeficient mice. J Clin Invest, v. 120, n. 12, p. 4366-74, Dec 2010. ISSN 1558-8238. Disponível em: < http://www.ncbi.nlm.nih.gov/pubmed/21060153 >.

HASLETT, J. N. et al. The influence of muscle type and dystrophin deficiency on murine expression profiles. Mamm Genome, v. 16, n. 10, p. 739-48, Oct 2005. ISSN 0938-8990. Disponível em: < http://www.ncbi.nlm.nih.gov/pubmed/16261416 >.

HASLETT, J. N.; KUNKEL, L. M. Microarray analysis of normal and dystrophic skeletal muscle. Int J Dev Neurosci, v. 20, n. 3-5, p. 359-65, 2002 Jun-Aug 2002. ISSN 0736-5748. Disponível em: < http://www.ncbi.nlm.nih.gov/pubmed/12175874 >.

HASLETT, J. N. et al. Gene expression comparison of biopsies from Duchenne muscular dystrophy (DMD) and normal skeletal muscle. Proc Natl Acad Sci U S A, v. 99, n. 23, p. 15000-5, Nov 2002. ISSN 0027-8424. Disponível em: < http://www.ncbi.nlm.nih.gov/pubmed/12415109 >.

Gene expression profiling of Duchenne muscular dystrophy skeletal muscle. Neurogenetics, v. 4, n. 4, p. 163-71, Aug 2003. ISSN 1364-6745. Disponível em: < http://www.ncbi.nlm.nih.gov/pubmed/12698323 >.

HESLOP, L.; MORGAN, J. E.; PARTRIDGE, T. A. Evidence for a myogenic stem cell that is exhausted in dystrophic muscle. J Cell Sci, v. 113 ( Pt 12), p. 2299-308, Jun 2000. ISSN 00219533. Disponível em: < http://www.ncbi.nlm.nih.gov/pubmed/10825301 >.

HEWITT, J. E. LARGE enzyme activity deciphered: a new therapeutic target for muscular dystrophies. Genome Med, v. 4, n. 3, p. 23, Mar 2012. ISSN 1756-994X. Disponível em: < http://www.ncbi.nlm.nih.gov/pubmed/22458537 >.

HOFFMAN, E. P.; BROWN, R. H.; KUNKEL, L. M. Dystrophin: the protein product of the Duchenne muscular dystrophy locus. Cell, v. 51, n. 6, p. 919-28, Dec 1987. ISSN 0092-8674. Disponível em: < http://www.ncbi.nlm.nih.gov/pubmed/3319190 >.

HOFFMAN, E. P. et al. Somatic reversion/suppression of the mouse mdx phenotype in vivo. J Neurol Sci, v. 99, n. 1, p. 9-25, Oct 1990. ISSN 0022-510X. Disponível em: < http://www.ncbi.nlm.nih.gov/pubmed/2250176 >.

HOLZFEIND, P. J. et al. Skeletal, cardiac and tongue muscle pathology, defective retinal transmission, and neuronal migration defects in the Large(myd) mouse defines a natural model for glycosylation-deficient muscle - eye - brain disorders. Hum Mol Genet, v. 11, n. 21, p. 2673-87, Oct 2002. ISSN 0964-6906. Disponível em: < http://www.ncbi.nlm.nih.gov/pubmed/12354792 >.

IBRAGHIMOV-BESKROVNAYA, $O$. et al. Primary structure of dystrophin-associated glycoproteins linking dystrophin to the extracellular matrix. Nature, v. 355, n. 6362, p. 696702, Feb 1992. ISSN 0028-0836. Disponível em: < http://www.ncbi.nlm.nih.gov/pubmed/1741056 >.

INAMORI, K. et al. Dystroglycan function requires xylosyl- and glucuronyltransferase activities of LARGE. Science, v. 335, n. 6064, p. 93-6, Jan 2012. ISSN 1095-9203. Disponível em: < http://www.ncbi.nlm.nih.gov/pubmed/22223806 >.

JOHNSON, E. K. et al. Identification of new dystroglycan complexes in skeletal muscle. PLoS One, v. 8, n. 8, p. e73224, 2013. ISSN 1932-6203. Disponível em: < http://www.ncbi.nlm.nih.gov/pubmed/23951345 >. 
KARSCH-MIZRACHI, I. et al. Expression and DNA sequence analysis of a human embryonic skeletal muscle myosin heavy chain gene. Nucleic Acids Res, v. 17, n. 15, p. 6167-79, Aug 1989. ISSN 0305-1048. Disponível em: < http://www.ncbi.nlm.nih.gov/pubmed/2771643 >.

KOENIG, M.; MONACO, A. P.; KUNKEL, L. M. The complete sequence of dystrophin predicts a rod-shaped cytoskeletal protein. Cell, v. 53, n. 2, p. 219-28, Apr 1988. ISSN 0092-8674. Disponível em: < http://www.ncbi.nlm.nih.gov/pubmed/3282674 >.

KOJIC, S.; RADOJKOVIC, D.; FAULKNER, G. Muscle ankyrin repeat proteins: their role in striated muscle function in health and disease. Crit Rev Clin Lab Sci, v. 48, n. 5-6, p. 269-94, 2011 Sep-Dec 2011. ISSN 1549-781X. Disponível em: < http://www.ncbi.nlm.nih.gov/pubmed/22185618 >.

KOTELNIKOVA, E. et al. Novel approach to meta-analysis of microarray datasets reveals muscle remodeling-related drug targets and biomarkers in Duchenne muscular dystrophy. PLoS Comput Biol, v. 8, n. 2, p. e1002365, Feb 2012. ISSN 1553-7358. Disponível em: < http://www.ncbi.nlm.nih.gov/pubmed/22319435 >.

KOTTLORS, M.; KIRSCHNER, J. Elevated satellite cell number in Duchenne muscular dystrophy. Cell Tissue Res, v. 340, n. 3, p. 541-8, Jun 2010. ISSN 1432-0878. Disponível em: < http://www.ncbi.nlm.nih.gov/pubmed/20467789 >.

LANE, P. W.; BEAMER, T. C.; MYERS, D. D. Myodystrophy, a new myopathy on chromosome 8 of the mouse. J Hered, v. 67, n. 3, p. 135-8, 1976 May-Jun 1976. ISSN 0022-1503. Disponível em: < http://www.ncbi.nlm.nih.gov/pubmed/939913 >.

LAURE, L. et al. A new pathway encompassing calpain 3 and its newly identified substrate cardiac ankyrin repeat protein is involved in the regulation of the nuclear factor-kB pathway in skeletal muscle. FEBS J, v. 277, n. 20, p. 4322-37, Oct 2010. ISSN 1742-4658. Disponível em: < http://www.ncbi.nlm.nih.gov/pubmed/20860623 >.

Cardiac ankyrin repeat protein is a marker of skeletal muscle pathological remodelling. FEBS J, v. 276, n. 3, p. 669-84, Feb 2009. ISSN 1742-4658. Disponível em: < http://www.ncbi.nlm.nih.gov/pubmed/19143834 >.

LEE, S. J. Regulation of muscle mass by myostatin. Annu Rev Cell Dev Biol, v. 20, p. 61-86, 2004. ISSN 1081-0706. Disponível em: < http://www.ncbi.nlm.nih.gov/pubmed/15473835 >.

LEWIS, M. P. et al. Gelatinase-B (matrix metalloproteinase-9; MMP-9) secretion is involved in the migratory phase of human and murine muscle cell cultures. J Muscle Res Cell Motil, v. 21, n. 3, p. 223-33, Apr 2000. ISSN 0142-4319. Disponível em: < http://www.ncbi.nlm.nih.gov/pubmed/10952170 >.

LIU, C. et al. Overexpression of legumain in tumors is significant for invasion/metastasis and a candidate enzymatic target for prodrug therapy. Cancer Res, v. 63, n. 11, p. 2957-64, Jun 2003. ISSN 0008-5472. Disponível em: < http://www.ncbi.nlm.nih.gov/pubmed/12782603 >.

MyoD-dependent induction during myoblast differentiation of p204, a protein also inducible by interferon. Mol Cell Biol, v. 20, n. 18, p. 7024-36, Sep 2000. ISSN 0270-7306. Disponível em: < http://www.ncbi.nlm.nih.gov/pubmed/10958697 >.

LIU, C. J. et al. The MyoD-inducible p204 protein overcomes the inhibition of myoblast differentiation by Id proteins. Mol Cell Biol, v. 22, n. 9, p. 2893-905, May 2002. ISSN 02707306. Disponível em: < http://www.ncbi.nlm.nih.gov/pubmed/11940648 >.

LONGMAN, C. et al. Mutations in the human LARGE gene cause MDC1D, a novel form of congenital muscular dystrophy with severe mental retardation and abnormal glycosylation of 
alpha-dystroglycan. Hum Mol Genet, v. 12, n. 21, p. 2853-61, Nov 2003. ISSN 0964-6906. Disponível em: < http://www.ncbi.nlm.nih.gov/pubmed/12966029 >.

LUKJANENKO, L. et al. Genomic profiling reveals that transient adipogenic activation is a hallmark of mouse models of skeletal muscle regeneration. PLoS One, v. 8, n. 8, p. e71084, 2013. ISSN 1932-6203. Disponível em: < http://www.ncbi.nlm.nih.gov/pubmed/23976982 >.

MADALA, S. K. et al. Matrix metalloproteinase 12-deficiency augments extracellular matrix degrading metalloproteinases and attenuates IL-13-dependent fibrosis. J Immunol, v. 184, n. 7, p. 3955-63, Apr 2010. ISSN 1550-6606. Disponível em: < http://www.ncbi.nlm.nih.gov/pubmed/20181883 >.

MALLOUK, N.; JACQUEMOND, V.; ALLARD, B. Elevated subsarcolemmal Ca2+ in mdx mouse skeletal muscle fibers detected with Ca2+-activated K+ channels. Proc Natl Acad Sci U S A, v. 97, n. 9, p. 4950-5, Apr 2000. ISSN 0027-8424. Disponível em: < http://www.ncbi.nlm.nih.gov/pubmed/10781103 >.

MAROTTA, $M$. et al. Muscle genome-wide expression profiling during disease evolution in $\mathrm{mdx}$ mice. Physiol Genomics, v. 37, n. 2, p. 119-32, Apr 2009. ISSN 1531-2267. Disponível em: < http://www.ncbi.nlm.nih.gov/pubmed/19223608 >.

MARTINS, P. C. et al. Dmdmdx/Largemyd: a new mouse model of neuromuscular diseases useful for studying physiopathological mechanisms and testing therapies. Dis Model Mech, v. 6, n. 5, p. 1167-74, 2013 Sep-Oct 2013. ISSN 1754-8411. Disponível em: < http://www.ncbi.nlm.nih.gov/pubmed/23798567 >.

MATSUDA, R.; NISHIKAWA, A.; TANAKA, $\mathrm{H}$. Visualization of dystrophic muscle fibers in mdx mouse by vital staining with Evans blue: evidence of apoptosis in dystrophin-deficient muscle. J Biochem, v. 118, n. 5, p. 959-64, Nov 1995. ISSN 0021-924X. Disponível em: < http://www.ncbi.nlm.nih.gov/pubmed/8749313 >.

MCDOUALL, R. M.; DUNN, M. J.; DUBOWITZ, V. Expression of class I and class II MHC antigens in neuromuscular diseases. J Neurol Sci, v. 89, n. 2-3, p. 213-26, Feb 1989. ISSN 0022-510X. Disponível em: < http://www.ncbi.nlm.nih.gov/pubmed/2926449 >.

MCQUIBBAN, G. A. et al. Matrix metalloproteinase processing of monocyte chemoattractant proteins generates CC chemokine receptor antagonists with anti-inflammatory properties in vivo. Blood, v. 100, n. 4, p. 1160-7, Aug 2002. ISSN 0006-4971. Disponível em: < http://www.ncbi.nlm.nih.gov/pubmed/12149192 >.

MERCURI, E.; MUNTONI, F. Muscular dystrophies. Lancet, v. 381, n. 9869, p. 845-60, Mar 2013. ISSN 1474-547X. Disponível em: < http://www.ncbi.nlm.nih.gov/pubmed/23465426 >.

MOORE, C. J.; HEWITT, J. E. Dystroglycan glycosylation and muscular dystrophy. Glycoconj J, v. 26, n. 3, p. 349-57, Apr 2009. ISSN 1573-4986. Disponível em: < http://www.ncbi.nlm.nih.gov/pubmed/18773291 >.

MOORE, C. J.; WINDER, S. J. The inside and out of dystroglycan post-translational modification. Neuromuscul Disord, v. 22, n. 11, p. 959-65, Nov 2012. ISSN 1873-2364. Disponível em: < http://www.ncbi.nlm.nih.gov/pubmed/22770978 >.

MORGAN, J. et al. MMP-9 overexpression improves myogenic cell migration and engraftment. Muscle Nerve, v. 42, n. 4, p. 584-95, Oct 2010. ISSN 1097-4598. Disponível em: < http://www.ncbi.nlm.nih.gov/pubmed/20734311 >.

MUNTONI, F. et al. Defective glycosylation in muscular dystrophy. Lancet, v. 360, n. 9343, p. 1419-21, Nov 2002. ISSN 0140-6736. Disponível em: < http://www.ncbi.nlm.nih.gov/pubmed/12424008 >. 
NAKADA, C. et al. Cardiac-restricted ankyrin-repeated protein is differentially induced in duchenne and congenital muscular dystrophy. Lab Invest, v. 83, n. 5, p. 711-9, May 2003. ISSN 0023-6837. Disponível em: < http://www.ncbi.nlm.nih.gov/pubmed/12746480 >.

NATHAN, C. Neutrophils and immunity: challenges and opportunities. Nat Rev Immunol, v. 6, n. 3, p. 173-82, Mar 2006. ISSN 1474-1733. Disponível em: < http://www.ncbi.nlm.nih.gov/pubmed/16498448 >.

NOGUCHI, S. et al. cDNA microarray analysis of individual Duchenne muscular dystrophy patients. Hum Mol Genet, v. 12, n. 6, p. 595-600, Mar 2003. ISSN 0964-6906. Disponível em: < http://www.ncbi.nlm.nih.gov/pubmed/12620965 >.

OGAWA, T. et al. Osteoactivin upregulates expression of MMP-3 and MMP-9 in fibroblasts infiltrated into denervated skeletal muscle in mice. Am J Physiol Cell Physiol, v. 289, n. 3, p. C697-707, Sep 2005. ISSN 0363-6143. Disponível em: < http://www.ncbi.nlm.nih.gov/pubmed/16100390 >.

ORRENIUS, S.; ZHIVOTOVSKY, B.; NICOTERA, P. Regulation of cell death: the calciumapoptosis link. Nat Rev Mol Cell Biol, v. 4, n. 7, p. 552-65, Jul 2003. ISSN 1471-0072. Disponível em: < http://www.ncbi.nlm.nih.gov/pubmed/12838338 >.

PARKER, M. H.; SEALE, P.; RUDNICKI, M. A. Looking back to the embryo: defining transcriptional networks in adult myogenesis. Nat Rev Genet, v. 4, n. 7, p. 497-507, Jul 2003. ISSN 1471-0056. Disponível em: < http://www.ncbi.nlm.nih.gov/pubmed/12838342 >.

PASTORET, C.; SEBILLE, A. mdx mice show progressive weakness and muscle deterioration with age. J Neurol Sci, v. 129, n. 2, p. 97-105, Apr 1995. ISSN 0022-510X. Disponível em: < http://www.ncbi.nlm.nih.gov/pubmed/7608742 >.

PEGORARO, E. et al. SPP1 genotype is a determinant of disease severity in Duchenne muscular dystrophy. Neurology, v. 76, n. 3, p. 219-26, Jan 2011. ISSN 1526-632X. Disponível em: < http://www.ncbi.nlm.nih.gov/pubmed/21178099 >.

PETROF, B. J. et al. Dystrophin protects the sarcolemma from stresses developed during muscle contraction. Proc Natl Acad Sci U S A, v. 90, n. 8, p. 3710-4, Apr 1993. ISSN 00278424. Disponível em: < http://www.ncbi.nlm.nih.gov/pubmed/8475120 >.

PIGOZZO, S. R. et al. Revertant Fibers in the mdx Murine Model of Duchenne Muscular Dystrophy: An Age- and Muscle-Related Reappraisal. PLoS One, v. 8, n. 8, p. e72147, 2013. ISSN 1932-6203. Disponível em: < http://www.ncbi.nlm.nih.gov/pubmed/24015212 >.

PORTER, J. D. et al. Persistent over-expression of specific CC class chemokines correlates with macrophage and T-cell recruitment in mdx skeletal muscle. Neuromuscul Disord, v. 13, n. 3, p. 223-35, Mar 2003. ISSN 0960-8966. Disponível em: < http://www.ncbi.nlm.nih.gov/pubmed/12609504 >.

A chronic inflammatory response dominates the skeletal muscle molecular signature in dystrophin-deficient mdx mice. Hum Mol Genet, v. 11, n. 3, p. 263-72, Feb 2002. ISSN 09646906. Disponível em: < http://www.ncbi.nlm.nih.gov/pubmed/11823445 >.

Constitutive properties, not molecular adaptations, mediate extraocular muscle sparing in dystrophic mdx mice. FASEB J, v. 17, n. 8, p. 893-5, May 2003. ISSN 1530-6860. Disponível em: < http://www.ncbi.nlm.nih.gov/pubmed/12670877 >.

Temporal gene expression profiling of dystrophin-deficient (mdx) mouse diaphragm identifies conserved and muscle group-specific mechanisms in the pathogenesis of muscular 
dystrophy. Hum Mol Genet, v. 13, n. 3, p. 257-69, Feb 2004. ISSN 0964-6906. Disponível em: < http://www.ncbi.nlm.nih.gov/pubmed/14681298 >.

Dissection of temporal gene expression signatures of affected and spared muscle groups in dystrophin-deficient (mdx) mice. Hum Mol Genet, v. 12, n. 15, p. 1813-21, Aug 2003. ISSN 0964-6906. Disponível em: < http://www.ncbi.nlm.nih.gov/pubmed/12874102 >.

RAHIMOV, F.; KUNKEL, L. M. The cell biology of disease: cellular and molecular mechanisms underlying muscular dystrophy. J Cell Biol, v. 201, n. 4, p. 499-510, May 2013. ISSN 15408140. Disponível em: < http://www.ncbi.nlm.nih.gov/pubmed/23671309 >.

RANDO, T. A. The dystrophin-glycoprotein complex, cellular signaling, and the regulation of cell survival in the muscular dystrophies. Muscle Nerve, v. 24, n. 12, p. 1575-94, Dec 2001. ISSN 0148-639X. Disponível em: < http://www.ncbi.nlm.nih.gov/pubmed/11745966 >.

REED, P.; BLOCH, R. J. Postnatal changes in sarcolemmal organization in the mdx mouse. Neuromuscul Disord, v. 15, n. 8, p. 552-61, Aug 2005. ISSN 0960-8966. Disponível em: < http://www.ncbi.nlm.nih.gov/pubmed/16051092 >.

REED, P. W. et al. The sarcolemma in the Large(myd) mouse. Muscle Nerve, v. 30, n. 5, p. 585-95, Nov 2004. ISSN 0148-639X. Disponível em: < http://www.ncbi.nlm.nih.gov/pubmed/15389724 >.

ROSS, J. et al. Defects in glycosylation impair satellite stem cell function and niche composition in the muscles of the dystrophic Large(myd) mouse. Stem Cells, v. 30, n. 10, p. 2330-41, Oct 2012. ISSN 1549-4918. Disponível em: < http://www.ncbi.nlm.nih.gov/pubmed/22887880 >.

ROUGER, K. et al. Global/temporal gene expression in diaphragm and hindlimb muscles of dystrophin-deficient (mdx) mice. Am J Physiol Cell Physiol, v. 283, n. 3, p. C773-84, Sep 2002. ISSN 0363-6143. Disponível em: < http://www.ncbi.nlm.nih.gov/pubmed/12176734 >.

SADOULET-PUCCIO, H. M.; RAJALA, M.; KUNKEL, L. M. Dystrobrevin and dystrophin: an interaction through coiled-coil motifs. Proc Natl Acad Sci U S A, v. 94, n. 23, p. 12413-8, Nov 1997. ISSN 0027-8424. Disponível em: < http://www.ncbi.nlm.nih.gov/pubmed/9356463 >.

SHIPLEY, J. M. et al. Metalloelastase is required for macrophage-mediated proteolysis and matrix invasion in mice. Proc Natl Acad Sci U S A, v. 93, n. 9, p. 3942-6, Apr 1996. ISSN 0027-8424. Disponível em: < http://www.ncbi.nlm.nih.gov/pubmed/8632994 >.

SICINSKI, P. et al. The molecular basis of muscular dystrophy in the mdx mouse: a point mutation. Science, v. 244, n. 4912, p. 1578-80, Jun 1989. ISSN 0036-8075. Disponível em: < http://www.ncbi.nlm.nih.gov/pubmed/2662404 >.

SINGH, M. et al. Functional roles of osteoactivin in normal and disease processes. Crit Rev Eukaryot Gene Expr, v. 20, n. 4, p. 341-57, 2010. ISSN 1045-4403. Disponível em: < http://www.ncbi.nlm.nih.gov/pubmed/21395506 >.

SPENCER, M. J. et al. Helper (CD4(+)) and cytotoxic (CD8(+)) T cells promote the pathology of dystrophin-deficient muscle. Clin Immunol, v. 98, n. 2, p. 235-43, Feb 2001. ISSN 1521-6616. Disponível em: < http://www.ncbi.nlm.nih.gov/pubmed/11161980 >.

STEDMAN, $\mathrm{H}$. $\mathrm{H}$. et al. The mdx mouse diaphragm reproduces the degenerative changes of Duchenne muscular dystrophy. Nature, v. 352, n. 6335, p. 536-9, Aug 1991. ISSN 0028-0836. Disponível em: < http://www.ncbi.nlm.nih.gov/pubmed/1865908 >.

STIBER, J. A. et al. Homer modulates NFAT-dependent signaling during muscle differentiation. Dev Biol, v. 287, n. 2, p. 213-24, Nov 2005. ISSN 0012-1606. Disponível em: < http://www.ncbi.nlm.nih.gov/pubmed/16226241 >. 
Mice lacking Homer 1 exhibit a skeletal myopathy characterized by abnormal transient receptor potential channel activity. Mol Cell Biol, v. 28, n. 8, p. 2637-47, Apr 2008. ISSN 1098-5549. Disponível em: < http://www.ncbi.nlm.nih.gov/pubmed/18268005 >.

STRACKE, J. O. et al. Biochemical characterization of the catalytic domain of human matrix metalloproteinase 19. Evidence for a role as a potent basement membrane degrading enzyme. J Biol Chem, v. 275, n. 20, p. 14809-16, May 2000. ISSN 0021-9258. Disponível em: < http://www.ncbi.nlm.nih.gov/pubmed/10809722 >.

SUN, G. et al. Elevated plasma levels of tissue inhibitors of metalloproteinase-1 and their overexpression in muscle in human and mouse muscular dystrophy. J Neurol Sci, v. 297, n. 12, p. 19-28, Oct 2010. ISSN 1878-5883. Disponível em: < http://www.ncbi.nlm.nih.gov/pubmed/20655547 >.

SUZUKI, A. et al. Glycoprotein-binding site of dystrophin is confined to the cysteine-rich domain and the first half of the carboxy-terminal domain. FEBS Lett, v. 308, n. 2, p. 154-60, Aug 1992. ISSN 0014-5793. Disponível em: < http://www.ncbi.nlm.nih.gov/pubmed/1499724 $>$.

TALLANT, C.; MARRERO, A.; GOMIS-RÜTH, F. X. Matrix metalloproteinases: fold and function of their catalytic domains. Biochim Biophys Acta, v. 1803, n. 1, p. 20-8, Jan 2010. ISSN 00063002. Disponível em: < http://www.ncbi.nlm.nih.gov/pubmed/19374923 >.

TIDBALL, J. G.; VILLALTA, S. A. Regulatory interactions between muscle and the immune system during muscle regeneration. Am J Physiol Regul Integr Comp Physiol, v. 298, n. 5, p. R1173-87, May 2010. ISSN 1522-1490. Disponível em: < http://www.ncbi.nlm.nih.gov/pubmed/20219869 >.

TIDBALL, J. G.; WEHLING-HENRICKS, M. The role of free radicals in the pathophysiology of muscular dystrophy. J Appl Physiol (1985), v. 102, n. 4, p. 1677-86, Apr 2007. ISSN 87507587. Disponível em: < http://www.ncbi.nlm.nih.gov/pubmed/17095633 >.

TKATCHENKO, A. V. et al. Large-scale analysis of differential gene expression in the hindlimb muscles and diaphragm of mdx mouse. Biochim Biophys Acta, v. 1500, n. 1, p. 17-30, Jan 2000. ISSN 0006-3002. Disponível em: < http://www.ncbi.nlm.nih.gov/pubmed/10564714 >.

Identification of altered gene expression in skeletal muscles from Duchenne muscular dystrophy patients. Neuromuscul Disord, v. 11, n. 3, p. 269-77, Apr 2001. ISSN 0960-8966. Disponível em: < http://www.ncbi.nlm.nih.gov/pubmed/11297942 >.

TODA, T.; KOBAYASHI, K. Fukuyama-type congenital muscular dystrophy: the first human disease to be caused by an ancient retrotransposal integration. J Mol Med (Berl), v. 77, n. 12, p. 816-23, Dec 1999. ISSN 0946-2716. Disponível em: < http://www.ncbi.nlm.nih.gov/pubmed/10682317 >.

TONAMI, K. et al. Calpain-6 deficiency promotes skeletal muscle development and regeneration. PLoS Genet, v. 9, n. 8, p. e1003668, 2013. ISSN 1553-7404. Disponível em: < http://www.ncbi.nlm.nih.gov/pubmed/23935533 >.

TSENG, B. S. et al. Regenerated mdx mouse skeletal muscle shows differential mRNA expression. J Appl Physiol (1985), v. 93, n. 2, p. 537-45, Aug 2002. ISSN 8750-7587. Disponível em: < http://www.ncbi.nlm.nih.gov/pubmed/12133862 >.

TURK, R. et al. Muscle regeneration in dystrophin-deficient $\mathrm{mdx}$ mice studied by gene expression profiling. BMC Genomics, v. 6, p. 98, 2005. ISSN 1471-2164. Disponível em: < http://www.ncbi.nlm.nih.gov/pubmed/16011810 >. 
Common pathological mechanisms in mouse models for muscular dystrophies. FASEB J, v. 20, n. 1, p. 127-9, Jan 2006. ISSN 1530-6860. Disponível em: < http://www.ncbi.nlm.nih.gov/pubmed/16306063 >.

TURNER, P. R. et al. Increased protein degradation results from elevated free calcium levels found in muscle from mdx mice. Nature, v. 335, n. 6192, p. 735-8, Oct 1988. ISSN 0028-0836. Disponível em: < http://www.ncbi.nlm.nih.gov/pubmed/3173492 >.

TUSHER, V. G.; TIBSHIRANI, R.; CHU, G. Significance analysis of microarrays applied to the ionizing radiation response. Proc Natl Acad Sci U S A, v. 98, n. 9, p. 5116-21, Apr 2001. ISSN 0027-8424. Disponível em: < http://www.ncbi.nlm.nih.gov/pubmed/11309499 >.

UAESOONTRACHOON, $\mathrm{K}$. et al. Osteopontin deficiency delays inflammatory infiltration and the onset of muscle regeneration in a mouse model of muscle injury. Dis Model Mech, v. 6, n. 1, p. 197-205, Jan 2013. ISSN 1754-8411. Disponível em: < http://www.ncbi.nlm.nih.gov/pubmed/22917925 >.

Osteopontin and skeletal muscle myoblasts: association with muscle regeneration and regulation of myoblast function in vitro. Int J Biochem Cell Biol, v. 40, n. 10, p. 2303-14, 2008. ISSN 1357-2725. Disponível em: < http://www.ncbi.nlm.nih.gov/pubmed/18490187 >.

VAINZOF, M.; ZATZ, M. Protein defects in neuromuscular diseases. Braz J Med Biol Res, v. 36, n. 5, p. 543-55, May 2003. ISSN 0100-879X. Disponível em: < http://www.ncbi.nlm.nih.gov/pubmed/12715073 >.

VAN REEUWIJK, J. et al. POMT2 mutations cause alpha-dystroglycan hypoglycosylation and Walker-Warburg syndrome. J Med Genet, v. 42, n. 12, p. 907-12, Dec 2005. ISSN 1468-6244. Disponível em: < http://www.ncbi.nlm.nih.gov/pubmed/15894594 >.

VILLALTA, S. A. et al. Shifts in macrophage phenotypes and macrophage competition for arginine metabolism affect the severity of muscle pathology in muscular dystrophy. Hum Mol Genet, v. 18, n. 3, p. 482-96, Feb 2009. ISSN 1460-2083. Disponível em: < http://www.ncbi.nlm.nih.gov/pubmed/18996917 >.

VON MOERS, A. et al. Increased mRNA expression of tissue inhibitors of metalloproteinase-1 and -2 in Duchenne muscular dystrophy. Acta Neuropathol, v. 109, n. 3, p. 285-93, Mar 2005. ISSN 0001-6322. Disponível em: < http://www.ncbi.nlm.nih.gov/pubmed/15616792 >.

WALLACE, G. Q.; MCNALLY, E. M. Mechanisms of muscle degeneration, regeneration, and repair in the muscular dystrophies. Annu Rev Physiol, v. 71, p. 37-57, 2009. ISSN 15451585. Disponível em: < http://www.ncbi.nlm.nih.gov/pubmed/18808326 >.

WANG, L. et al. S100A4 promotes invasion and angiogenesis in breast cancer MDA-MB-231 cells by upregulating matrix metalloproteinase-13. Acta Biochim Pol, v. 59, n. 4, p. 593-8, 2012. ISSN 1734-154X. Disponível em: < http://www.ncbi.nlm.nih.gov/pubmed/23162804 >.

WANG, Y. X.; RUDNICKI, M. A. Satellite cells, the engines of muscle repair. Nat Rev Mol Cell Biol, v. 13, n. 2, p. 127-33, Feb 2012. ISSN 1471-0080. Disponível em: < http://www.ncbi.nlm.nih.gov/pubmed/22186952 >.

WARREN, G. L. et al. Chemokine receptor CCR2 involvement in skeletal muscle regeneration. FASEB J, v. 19, n. 3, p. 413-5, Mar 2005. ISSN 1530-6860. Disponível em: < http://www.ncbi.nlm.nih.gov/pubmed/15601671 >.

WAY, M. et al. Expression of the $\mathrm{N}$-terminal domain of dystrophin in E. coli and demonstration of binding to F-actin. FEBS Lett, v. 301, n. 3, p. 243-5, Apr 1992. ISSN 0014-5793. Disponível em: < http://www.ncbi.nlm.nih.gov/pubmed/1577159 >. 
WEHLING, M.; SPENCER, M. J.; TIDBALL, J. G. A nitric oxide synthase transgene ameliorates muscular dystrophy in mdx mice. J Cell Biol, v. 155, n. 1, p. 123-31, Oct 2001. ISSN 00219525. Disponível em: < http://www.ncbi.nlm.nih.gov/pubmed/11581289 >.

WU, H.; XU, G.; LI, Y. P. Atp6v0d2 is an essential component of the osteoclast-specific proton pump that mediates extracellular acidification in bone resorption. J Bone Miner Res, v. 24, n. 5, p. 871-85, May 2009. ISSN 1523-4681. Disponível em: < http://www.ncbi.nlm.nih.gov/pubmed/19113919 >.

WU, Y.; PRYSTOWSKY, M. B.; ORLOFSKY, A. Sustained high-level production of murine chemokine C10 during chronic inflammation. Cytokine, v. 11, n. 7, p. 523-30, Jul 1999. ISSN 1043-4666. Disponível em: < http://www.ncbi.nlm.nih.gov/pubmed/10419654 >.

YAHIAOUI, L. et al. CC family chemokines directly regulate myoblast responses to skeletal muscle injury. J Physiol, v. 586, n. 16, p. 3991-4004, Aug 2008. ISSN 1469-7793. Disponível em: < http://www.ncbi.nlm.nih.gov/pubmed/18566004 >.

YOSHIDA, A. et al. Muscular dystrophy and neuronal migration disorder caused by mutations in a glycosyltransferase, POMGnT1. Dev Cell, v. 1, n. 5, p. 717-24, Nov 2001. ISSN 1534-5807. Disponível em: < http://www.ncbi.nlm.nih.gov/pubmed/11709191 >.

YOSHIDA, M.; OZAWA, E. Glycoprotein complex anchoring dystrophin to sarcolemma. J Biochem, v. 108, n. 5, p. 748-52, Nov 1990. ISSN 0021-924X. Disponível em: < http://www.ncbi.nlm.nih.gov/pubmed/2081733 >.

YOSHIDA, M. et al. Dissociation of the complex of dystrophin and its associated proteins into several unique groups by n-octyl beta-D-glucoside. Eur J Biochem, v. 222, n. 3, p. 1055-61, Jun 1994. ISSN 0014-2956. Disponível em: < http://www.ncbi.nlm.nih.gov/pubmed/8026484 $>$.

YOSHIDA, T. et al. Angiotensin II inhibits satellite cell proliferation and prevents skeletal muscle regeneration. J Biol Chem, v. 288, n. 33, p. 23823-32, Aug 2013. ISSN 1083-351X. Disponível em: < http://www.ncbi.nlm.nih.gov/pubmed/23831688 >.

ZHANG, G. et al. Knockdown of S100A4 decreases tumorigenesis and metastasis in osteosarcoma cells by repression of matrix metalloproteinase-9. Asian Pac J Cancer Prev, v. 12, n. 8, p. 2075-80, 2011. ISSN 1513-7368. Disponível em: < http://www.ncbi.nlm.nih.gov/pubmed/22292654 >. 


\section{Anexos}

\section{A. Listas de genes diferencialmente expressos}

\begin{tabular}{|c|c|c|c|}
\hline \multicolumn{4}{|c|}{$D m d^{m d x}$ vs $C 57 B L 21$ dias } \\
\hline $\begin{array}{l}\text { Fold } \\
\text { Change }\end{array}$ & Symbol & Entrez Gene Name & Location \\
\hline$-1,719$ & PLAC9 & placenta-specific 9 & Other \\
\hline$-1,694$ & PLAC9 & placenta-specific 9 & Other \\
\hline$-1,694$ & PLAC9 & placenta-specific 9 & Other \\
\hline$-1,672$ & LGI1 & leucine-rich, glioma inactivated 1 & Plasma Membrane \\
\hline$-1,619$ & PTTG1 & pituitary tumor-transforming 1 & Nucleus \\
\hline$-1,564$ & TCEA3 & transcription elongation factor A (SII), 3 & Nucleus \\
\hline$-1,385$ & 4933409K07Rik & RIKEN cDNA 4933409K07 gene & Other \\
\hline$-1,370$ & 4933409K07Rik & RIKEN cDNA $4933409 K 07$ gene & Other \\
\hline$-1,338$ & METTL21C & methyltransferase like $21 \mathrm{C}$ & Other \\
\hline$-1,300$ & 4933409K07Rik & RIKEN cDNA $4933409 K 07$ gene & Other \\
\hline$-1,278$ & Gm3893 & predicted gene 3893 & Other \\
\hline$-1,278$ & Gm3893 & predicted gene 3893 & Other \\
\hline$-1,271$ & LRRC52 & leucine rich repeat containing 52 & Other \\
\hline$-1,212$ & 4933409K07Rik & RIKEN cDNA 4933409K07 gene & Other \\
\hline$-1,195$ & Gm3893 & predicted gene 3893 & Other \\
\hline$-1,139$ & KIAA0408 & KIAA0408 & Other \\
\hline$-1,093$ & 4933409K07Rik & RIKEN cDNA $4933409 K 07$ gene & Other \\
\hline$-0,998$ & LIMS2 & LIM and senescent cell antigen-like domains 2 & Cytoplasm \\
\hline 0,676 & Ahnak2 & AHNAK nucleoprotein 2 & Other \\
\hline 0,677 & ATPIF1 & ATPase inhibitory factor 1 & Cytoplasm \\
\hline 0,702 & ENO1 & enolase 1, (alpha) & Cytoplasm \\
\hline 0,703 & NAGK & $\mathrm{N}$-acetylglucosamine kinase & Cytoplasm \\
\hline 0,704 & СMTM3 & CKLF-like MARVEL transmembrane domain containing 3 & Extracellular Space \\
\hline 0,713 & NES & nestin & Cytoplasm \\
\hline 0,719 & TUBA1B & tubulin, alpha $1 b$ & Cytoplasm \\
\hline 0,724 & PSAP & prosaposin & Extracellular Space \\
\hline 0,726 & PLP2 & proteolipid protein 2 (colonic epithelium-enriched) & Cytoplasm \\
\hline 0,727 & STOM & stomatin & Plasma Membrane \\
\hline 0,73 & SMPDL3B & sphingomyelin phosphodiesterase, acid-like 3B & Extracellular Space \\
\hline 0,743 & EHD4 & EH-domain containing 4 & Plasma Membrane \\
\hline 0,744 & PHKA2 & phosphorylase kinase, alpha 2 (liver) & Cytoplasm \\
\hline 0,745 & CLN8 & $\begin{array}{l}\text { ceroid-lipofuscinosis, neuronal } 8 \text { (epilepsy, progressive with mental } \\
\text { retardation) }\end{array}$ & Cytoplasm \\
\hline 0,75 & Cbr2 & carbonyl reductase 2 & Cytoplasm \\
\hline 0,758 & REPS2 & RALBP1 associated Eps domain containing 2 & Cytoplasm \\
\hline 0,767 & CCDC23 & coiled-coil domain containing 23 & Other \\
\hline 0,771 & TPD52 & tumor protein D52 & Cytoplasm \\
\hline 0,773 & CD63 & CD63 molecule & Plasma Membrane \\
\hline 0,779 & LAYN & layilin & Plasma Membrane \\
\hline 0,779 & TUBA1B & tubulin, alpha $1 b$ & Cytoplasm \\
\hline 0,782 & LRP1 & low density lipoprotein receptor-related protein 1 & Plasma Membrane \\
\hline 0,796 & GLB1 & galactosidase, beta 1 & Cytoplasm \\
\hline 0,798 & UAP1L1 & UDP-N-acteylglucosamine pyrophosphorylase 1 -like 1 & Other \\
\hline 0,801 & CAPN6 & calpain 6 & Cytoplasm \\
\hline 0,804 & SPAG5 & sperm associated antigen 5 & Nucleus \\
\hline 0,808 & ECM1 & extracellular matrix protein 1 & Extracellular Space \\
\hline 0,816 & GLIS3 & GLIS family zinc finger 3 & Nucleus \\
\hline 0,819 & VWA5A & von Willebrand factor A domain containing $5 \mathrm{~A}$ & Nucleus \\
\hline 0,82 & SCPEP1 & serine carboxypeptidase 1 & Cytoplasm \\
\hline 0,826 & DSE & dermatan sulfate epimerase & Cytoplasm \\
\hline 0,828 & Fmn1 & formin 1 & Other \\
\hline 0,831 & ADAP2 & ArfGAP with dual PH domains 2 & Cytoplasm \\
\hline 0,831 & CASP3 & caspase 3, apoptosis-related cysteine peptidase & Cytoplasm \\
\hline 0,836 & SGOL1 & shugoshin-like 1 ( $\mathrm{S}$, pombe) & Nucleus \\
\hline 0,838 & OIP5 & Opa interacting protein 5 & Nucleus \\
\hline 0,84 & GAS7 & growth arrest-specific 7 & Cytoplasm \\
\hline 0,843 & NOX4 & NADPH oxidase 4 & Cytoplasm \\
\hline 0,843 & PYGL & phosphorylase, glycogen, liver & Cytoplasm \\
\hline 0,844 & $\mathrm{CDH} 2$ & cadherin 2 , type $1, \mathrm{~N}$-cadherin (neuronal) & Plasma Membrane \\
\hline 0,845 & FTL & ferritin, light polypeptide & Cytoplasm \\
\hline 0,845 & RASGRP4 & RAS guanyl releasing protein 4 & Cytoplasm \\
\hline 0,846 & Retnla & resistin like alpha & Extracellular Space \\
\hline 0,852 & ALDH9A1 & aldehyde dehydrogenase 9 family, member A1 & Cytoplasm \\
\hline
\end{tabular}




\begin{tabular}{|c|c|c|c|}
\hline 0,852 & GLTP & glycolipid transfer protein & Cytoplasm \\
\hline 0,853 & PPAP2C & phosphatidic acid phosphatase type $2 \mathrm{C}$ & Plasma Membrane \\
\hline 0,861 & P2RX7 & purinergic receptor $\mathrm{P} 2 \mathrm{X}$, ligand-gated ion channel, 7 & Plasma Membrane \\
\hline 0,866 & MAN2B2 & mannosidase, alpha, class $2 \mathrm{~B}$, member 2 & Cytoplasm \\
\hline 0,872 & ARL14EP & ADP-ribosylation factor-like 14 effector protein & Other \\
\hline 0,873 & POLE2 & polymerase (DNA directed), epsilon 2, accessory subunit & Nucleus \\
\hline 0,875 & TICAM2 & toll-like receptor adaptor molecule 2 & Plasma Membrane \\
\hline 0,876 & PPT1 & palmitoyl-protein thioesterase 1 & Cytoplasm \\
\hline 0,877 & LRP12 & low density lipoprotein receptor-related protein 12 & Plasma Membrane \\
\hline 0,878 & IL1RL2 & interleukin 1 receptor-like 2 & Plasma Membrane \\
\hline 0,88 & PLTP & phospholipid transfer protein & Extracellular Space \\
\hline 0,88 & SNX5 & sorting nexin 5 & Cytoplasm \\
\hline 0,881 & GPR34 & G protein-coupled receptor 34 & Plasma Membrane \\
\hline 0,891 & CENPK & centromere protein $\mathrm{K}$ & Nucleus \\
\hline 0,891 & ID2 & $\begin{array}{l}\text { inhibitor of DNA binding 2, dominant negative helix-loop-helix } \\
\text { protein }\end{array}$ & Nucleus \\
\hline 0,893 & ZNF761 & zinc finger protein 761 & Nucleus \\
\hline 0,894 & Aph1c & anterior pharynx defective $1 \mathrm{c}$ homolog (C, elegans) & Other \\
\hline 0,894 & CLCN5 & chloride channel, voltage-sensitive 5 & Plasma Membrane \\
\hline 0,898 & SERPINB8 & serpin peptidase inhibitor, clade B (ovalbumin), member 8 & Cytoplasm \\
\hline 0,9 & ABHD12 & abhydrolase domain containing 12 & Other \\
\hline 0,902 & HN1 & hematological and neurological expressed 1 & Nucleus \\
\hline 0,904 & ESYT1 & extended synaptotagmin-like protein 1 & Other \\
\hline 0,904 & MERTK & c-mer proto-oncogene tyrosine kinase & Plasma Membrane \\
\hline 0,906 & IQSEC3 & IQ motif and Sec7 domain 3 & Cytoplasm \\
\hline 0,907 & FGL2 & fibrinogen-like 2 & Extracellular Space \\
\hline 0,91 & C11orf82 & chromosome 11 open reading frame 82 & Cytoplasm \\
\hline 0,91 & IQGAP1 & IQ motif containing GTPase activating protein 1 & Cytoplasm \\
\hline 0,912 & GNPDA1 & glucosamine-6-phosphate deaminase 1 & Cytoplasm \\
\hline 0,916 & INCENP & inner centromere protein antigens $135 / 155 \mathrm{kDa}$ & Nucleus \\
\hline 0,918 & RNF149 & ring finger protein 149 & Other \\
\hline 0,92 & MPP1 & membrane protein, palmitoylated $1,55 \mathrm{kDa}$ & Plasma Membrane \\
\hline 0,92 & SDCBP & syndecan binding protein (syntenin) & Plasma Membrane \\
\hline 0,921 & HIST1H1A & histone cluster $1, \mathrm{H} 1 \mathrm{a}$ & Nucleus \\
\hline 0,921 & HSD17B12 & hydroxysteroid (17-beta) dehydrogenase 12 & Cytoplasm \\
\hline 0,922 & PRKAR2B & protein kinase, cAMP-dependent, regulatory, type II, beta & Cytoplasm \\
\hline 0,924 & ADAM12 & ADAM metallopeptidase domain 12 & Plasma Membrane \\
\hline 0,926 & IL13RA1 & interleukin 13 receptor, alpha 1 & Plasma Membrane \\
\hline 0,926 & MYBL1 & v-myb avian myeloblastosis viral oncogene homolog-like 1 & Nucleus \\
\hline 0,926 & PCNA & proliferating cell nuclear antigen & Nucleus \\
\hline 0,93 & HIST2H2BF & histone cluster $2, \mathrm{H} 2 \mathrm{bf}$ & Nucleus \\
\hline 0,93 & SAT1 & spermidine/spermine N1-acetyltransferase 1 & Cytoplasm \\
\hline 0,932 & KIF18A & kinesin family member $18 \mathrm{~A}$ & Cytoplasm \\
\hline 0,932 & PTGR1 & prostaglandin reductase 1 & Cytoplasm \\
\hline 0,934 & SRPX2 & sushi-repeat containing protein, $\mathrm{X}$-linked 2 & Cytoplasm \\
\hline 0,937 & MCM4 & minichromosome maintenance complex component 4 & Nucleus \\
\hline 0,937 & PCNA & proliferating cell nuclear antigen & Nucleus \\
\hline 0,937 & PGD & phosphogluconate dehydrogenase & Cytoplasm \\
\hline 0,938 & SLC16A7 & solute carrier family 16 (monocarboxylate transporter), member 7 & Plasma Membrane \\
\hline 0,94 & ASAH1 & $\mathrm{N}$-acylsphingosine amidohydrolase (acid ceramidase) 1 & Cytoplasm \\
\hline 0,941 & ARRB2 & arrestin, beta 2 & Cytoplasm \\
\hline 0,941 & SLC22A4 & $\begin{array}{l}\text { solute carrier family } 22 \text { (organic cation/zwitterion transporter), } \\
\text { member } 4\end{array}$ & Plasma Membrane \\
\hline 0,947 & GATM & glycine amidinotransferase (L-arginine:glycine amidinotransferase) & Cytoplasm \\
\hline 0,947 & SBNO2 & strawberry notch homolog 2 (Drosophila) & Other \\
\hline 0,948 & MELK & maternal embryonic leucine zipper kinase & Cytoplasm \\
\hline 0,949 & PDGFC & platelet derived growth factor $\mathrm{C}$ & Extracellular Space \\
\hline 0,95 & Lst1 & leukocyte specific transcript 1 & Cytoplasm \\
\hline 0,95 & PROS1 & protein S (alpha) & Extracellular Space \\
\hline 0,951 & ACER3 & alkaline ceramidase 3 & Cytoplasm \\
\hline 0,952 & FN1 & fibronectin 1 & Extracellular Space \\
\hline 0,952 & MMP3 & matrix metallopeptidase 3 (stromelysin 1, progelatinase) & Extracellular Space \\
\hline 0,953 & MYD88 & myeloid differentiation primary response 88 & Plasma Membrane \\
\hline 0,956 & TUBB2A & tubulin, beta $2 \mathrm{~A}$ class IIa & Cytoplasm \\
\hline 0,957 & NIPSNAP3B & nipsnap homolog 3B ( $C$, elegans) & Cytoplasm \\
\hline 0,96 & RAP2B & RAP2B, member of RAS oncogene family & Plasma Membrane \\
\hline 0,961 & SKAP2 & src kinase associated phosphoprotein 2 & Cytoplasm \\
\hline 0,969 & NCAPH & non-SMC condensin I complex, subunit H & Nucleus \\
\hline 0,969 & PRKCD & protein kinase $\mathrm{C}$, delta & Cytoplasm \\
\hline 0,969 & SYCE2 & synaptonemal complex central element protein 2 & Nucleus \\
\hline 0,969 & TLR6 & toll-like receptor 6 & Plasma Membrane \\
\hline 0,971 & GPR137B & G protein-coupled receptor 137B & Plasma Membrane \\
\hline
\end{tabular}




\begin{tabular}{|c|c|c|c|}
\hline 0,976 & HELLS & helicase, lymphoid-specific & Nucleus \\
\hline 0,976 & SLC29A3 & $\begin{array}{l}\text { solute carrier family } 29 \text { (equilibrative nucleoside transporter), } \\
\text { member } 3\end{array}$ & Plasma Membrane \\
\hline 0,977 & PLA2G15 & phospholipase A2, group XV & Cytoplasm \\
\hline 0,978 & RGS2 & regulator of G-protein signaling $2,24 \mathrm{kDa}$ & Nucleus \\
\hline 0,991 & FNIP2 & folliculin interacting protein 2 & Cytoplasm \\
\hline 0,993 & KIAA1644 & KIAA1644 & Other \\
\hline 1,000 & CHRND & cholinergic receptor, nicotinic, delta (muscle) & Plasma Membrane \\
\hline 1,001 & C10orf54 & chromosome 10 open reading frame 54 & Other \\
\hline 1,002 & KIF22 & kinesin family member 22 & Nucleus \\
\hline 1,002 & MFSD1 & major facilitator superfamily domain containing 1 & Other \\
\hline 1,008 & ANPEP & alanyl (membrane) aminopeptidase & Plasma Membrane \\
\hline 1,009 & HK3 & hexokinase 3 (white cell) & Cytoplasm \\
\hline 1,010 & RAB8B & RAB8B, member RAS oncogene family & Cytoplasm \\
\hline 1,014 & PTPRJ & protein tyrosine phosphatase, receptor type, J & Plasma Membrane \\
\hline 1,014 & RAB31 & RAB31, member RAS oncogene family & Cytoplasm \\
\hline 1,015 & CDKN1A & cyclin-dependent kinase inhibitor $1 \mathrm{~A}(\mathrm{p} 21, \mathrm{Cip} 1)$ & Nucleus \\
\hline 1,016 & DAB2 & Dab, mitogen-responsive phosphoprotein, homolog 2 (Drosophila) & Plasma Membrane \\
\hline 1,016 & SPC25 & SPC25, NDC80 kinetochore complex component & Cytoplasm \\
\hline 1,022 & THBS1 & thrombospondin 1 & Extracellular Space \\
\hline 1,023 & PLEKHO2 & pleckstrin homology domain containing, family $\mathrm{O}$ member 2 & Cytoplasm \\
\hline 1,026 & NPC2 & Niemann-Pick disease, type C2 & Extracellular Space \\
\hline 1,028 & UHRF1 & ubiquitin-like with PHD and ring finger domains 1 & Nucleus \\
\hline 1,029 & CLIC1 & chloride intracellular channel 1 & Nucleus \\
\hline 1,031 & CDCA3 & cell division cycle associated 3 & Cytoplasm \\
\hline 1,031 & GALC & galactosylceramidase & Cytoplasm \\
\hline 1,031 & PLD3 & phospholipase D family, member 3 & Cytoplasm \\
\hline 1,034 & ASPM & $\begin{array}{l}\text { asp (abnormal spindle) homolog, microcephaly associated } \\
\text { (Drosophila) }\end{array}$ & Nucleus \\
\hline 1,034 & ATAD2 & ATPase family, AAA domain containing 2 & Nucleus \\
\hline 1,036 & PGAM1 & phosphoglycerate mutase 1 (brain) & Cytoplasm \\
\hline 1,036 & PGAM1 & phosphoglycerate mutase 1 (brain) & Cytoplasm \\
\hline 1,038 & EDEM1 & ER degradation enhancer, mannosidase alpha-like 1 & Cytoplasm \\
\hline 1,040 & CCNE1 & cyclin E1 & Nucleus \\
\hline 1,042 & ME2 & malic enzyme 2, NAD(+)-dependent, mitochondrial & Cytoplasm \\
\hline 1,045 & ATP6V1A & ATPase, $\mathrm{H}+$ transporting, lysosomal $70 \mathrm{kDa}, \mathrm{V} 1$ subunit $\mathrm{A}$ & Plasma Membrane \\
\hline 1,047 & CDCA8 & cell division cycle associated 8 & Nucleus \\
\hline 1,047 & GALNS & galactosamine ( $\mathrm{N}$-acetyl)-6-sulfate sulfatase & Cytoplasm \\
\hline 1,048 & FGR & feline Gardner-Rasheed sarcoma viral oncogene homolog & Nucleus \\
\hline 1,049 & CLEC10A & C-type lectin domain family 10 , member A & Plasma Membrane \\
\hline 1,049 & F5 & coagulation factor V (proaccelerin, labile factor) & Plasma Membrane \\
\hline 1,056 & EFHD2 & EF-hand domain family, member D2 & Other \\
\hline 1,056 & SLC2A6 & solute carrier family 2 (facilitated glucose transporter), member 6 & Plasma Membrane \\
\hline 1,057 & UBASH3B & ubiquitin associated and $\mathrm{SH} 3$ domain containing $\mathrm{B}$ & Other \\
\hline 1,058 & $\begin{array}{l}\text { Gm13150/Znf41- } \\
\text { ps }\end{array}$ & ZNF41, pseudogene & Other \\
\hline 1,061 & S100A6 & S100 calcium binding protein A6 & Cytoplasm \\
\hline 1,063 & CKAP2L & cytoskeleton associated protein 2-like & Cytoplasm \\
\hline 1,064 & CENPI & centromere protein I & Nucleus \\
\hline 1,064 & TNFRSF11A & $\begin{array}{l}\text { tumor necrosis factor receptor superfamily, member } 11 a, \text { NFKB } \\
\text { activator }\end{array}$ & Plasma Membrane \\
\hline 1,065 & G6PD & glucose-6-phosphate dehydrogenase & Cytoplasm \\
\hline 1,067 & GDA & guanine deaminase & Cytoplasm \\
\hline 1,068 & CENPM & centromere protein $\mathrm{M}$ & Cytoplasm \\
\hline 1,070 & MRC1 & mannose receptor, $\mathrm{C}$ type 1 & Plasma Membrane \\
\hline 1,070 & TYMS & thymidylate synthetase & Nucleus \\
\hline 1,072 & Nlrp1c-ps & NLR family, pyrin domain containing $1 C$, pseudogene & Other \\
\hline 1,074 & LRRC17 & leucine rich repeat containing 17 & Extracellular Space \\
\hline 1,074 & TCF19 & transcription factor 19 & Nucleus \\
\hline 1,076 & FUCA2 & fucosidase, alpha-L- 2, plasma & Extracellular Space \\
\hline 1,078 & NAAA & $\mathrm{N}$-acylethanolamine acid amidase & Cytoplasm \\
\hline 1,078 & PLXNB2 & plexin B2 & Plasma Membrane \\
\hline 1,080 & EMP3 & epithelial membrane protein 3 & Plasma Membrane \\
\hline 1,080 & TRIP13 & thyroid hormone receptor interactor 13 & Cytoplasm \\
\hline 1,081 & ASNS & asparagine synthetase (glutamine-hydrolyzing) & Cytoplasm \\
\hline 1,082 & PDPN & podoplanin & Plasma Membrane \\
\hline 1,085 & MFSD12 & major facilitator superfamily domain containing 12 & Cytoplasm \\
\hline 1,085 & PLK4 & polo-like kinase 4 & Cytoplasm \\
\hline 1,086 & $\begin{array}{l}\text { Hist1h2ab } \\
\text { (includes others) }\end{array}$ & histone cluster $1, \mathrm{H} 2 \mathrm{ab}$ & Nucleus \\
\hline 1,089 & FUCA1 & fucosidase, alpha-L- 1, tissue & Cytoplasm \\
\hline 1,089 & NCAM1 & neural cell adhesion molecule 1 & Plasma Membrane \\
\hline
\end{tabular}




\begin{tabular}{|c|c|c|c|}
\hline 1,089 & PARP12 & poly (ADP-ribose) polymerase family, member 12 & Nucleus \\
\hline 1,091 & HMGB2 & high mobility group box 2 & Nucleus \\
\hline 1,098 & CENPN & centromere protein $\mathrm{N}$ & Other \\
\hline 1,100 & PGAM1 & phosphoglycerate mutase 1 (brain) & Cytoplasm \\
\hline 1,103 & CHAF1B & chromatin assembly factor 1 , subunit B (p60) & Nucleus \\
\hline 1,106 & DLGAP5 & discs, large (Drosophila) homolog-associated protein 5 & Nucleus \\
\hline 1,106 & STIL & SCL/TAL1 interrupting locus & Nucleus \\
\hline 1,107 & CX3CR1 & chemokine (C-X3-C motif) receptor 1 & Plasma Membrane \\
\hline 1,107 & LITAF & lipopolysaccharide-induced TNF factor & Nucleus \\
\hline 1,109 & DEPDC1 & DEP domain containing 1 & Nucleus \\
\hline 1,109 & VCAN & versican & Extracellular Space \\
\hline 1,112 & Fcrls & Fc receptor-like S, scavenger receptor & Plasma Membrane \\
\hline 1,112 & TF & transferrin & Extracellular Space \\
\hline 1,114 & FOXM1 & forkhead box M1 & Nucleus \\
\hline 1,117 & $\mathrm{Cd} 33$ & CD33 antigen & Plasma Membrane \\
\hline 1,117 & CHEK1 & checkpoint kinase 1 & Nucleus \\
\hline 1,117 & DCLRE1C & DNA cross-link repair $1 \mathrm{C}$ & Nucleus \\
\hline 1,118 & Neurl3 & neuralized homolog 3 homolog (Drosophila) & Other \\
\hline 1,118 & SMC2 & structural maintenance of chromosomes 2 & Nucleus \\
\hline 1,124 & SLFN13 & schlafen family member 13 & Nucleus \\
\hline 1,127 & FTL & ferritin, light polypeptide & Cytoplasm \\
\hline 1,128 & NPNT & nephronectin & Plasma Membrane \\
\hline 1,130 & NEIL3 & nei endonuclease VIII-like 3 ( $\mathrm{E}$, coli) & Nucleus \\
\hline 1,133 & $\mathrm{FTL}$ & ferritin, light polypeptide & Cytoplasm \\
\hline 1,137 & SKA3 & spindle and kinetochore associated complex subunit 3 & Nucleus \\
\hline 1,138 & DTL & denticleless E3 ubiquitin protein ligase homolog (Drosophila) & Nucleus \\
\hline 1,138 & TSPO & translocator protein $(18 \mathrm{kDa})$ & Cytoplasm \\
\hline 1,140 & CHRNA1 & cholinergic receptor, nicotinic, alpha 1 (muscle) & Plasma Membrane \\
\hline 1,140 & HMGB2 & high mobility group box 2 & Nucleus \\
\hline 1,144 & ANXA2 & annexin $\mathrm{A} 2$ & Plasma Membrane \\
\hline 1,144 & PIK3CG & $\begin{array}{l}\text { phosphatidylinositol-4,5-bisphosphate 3-kinase, catalytic subunit } \\
\text { gamma }\end{array}$ & Cytoplasm \\
\hline 1,146 & AIF1L & allograft inflammatory factor 1 -like & Plasma Membrane \\
\hline 1,146 & SH3BP2 & SH3-domain binding protein 2 & Cytoplasm \\
\hline 1,147 & MAN2B1 & mannosidase, alpha, class 2B, member 1 & Cytoplasm \\
\hline 1,150 & CXCL16 & chemokine (C-X-C motif) ligand 16 & Extracellular Space \\
\hline 1,155 & NRROS & negative regulator of reactive oxygen species & Other \\
\hline 1,157 & KIF15 & kinesin family member 15 & Nucleus \\
\hline 1,157 & RNH1 & ribonuclease/angiogenin inhibitor 1 & Cytoplasm \\
\hline 1,158 & $\mathrm{FTL}$ & ferritin, light polypeptide & Cytoplasm \\
\hline 1,159 & $\begin{array}{l}\mathrm{HIST} 2 \mathrm{H} 3 \mathrm{C} \\
\text { (includes others) }\end{array}$ & histone cluster 2, H3c & Nucleus \\
\hline 1,161 & FABP5 & fatty acid binding protein 5 (psoriasis-associated) & Cytoplasm \\
\hline 1,161 & $\begin{array}{l}\text { Gm13150/Znf41- } \\
\text { ps }\end{array}$ & ZNF41, pseudogene & Other \\
\hline 1,162 & CA13 & carbonic anhydrase XIII & Cytoplasm \\
\hline 1,162 & DBF4 & DBF4 homolog (S, cerevisiae) & Nucleus \\
\hline 1,164 & TNC & tenascin C & Extracellular Space \\
\hline 1,165 & FXYD5 & FXYD domain containing ion transport regulator 5 & Plasma Membrane \\
\hline 1,166 & CNDP2 & CNDP dipeptidase 2 (metallopeptidase M20 family) & Cytoplasm \\
\hline 1,166 & IQGAP2 & IQ motif containing GTPase activating protein 2 & Cytoplasm \\
\hline 1,167 & MLKL & mixed lineage kinase domain-like & Other \\
\hline 1,169 & FTL & ferritin, light polypeptide & Cytoplasm \\
\hline 1,171 & POSTN & periostin, osteoblast specific factor & Extracellular Space \\
\hline 1,172 & MCM6 & minichromosome maintenance complex component 6 & Nucleus \\
\hline 1,173 & CDK6 & cyclin-dependent kinase 6 & Nucleus \\
\hline 1,173 & PLA2G7 & $\begin{array}{l}\text { phospholipase A2, group VII (platelet-activating factor } \\
\text { acetylhydrolase, plasma) }\end{array}$ & Extracellular Space \\
\hline 1,176 & $\begin{array}{l}\mathrm{HIST} 2 \mathrm{H} 3 \mathrm{C} \\
\text { (includes others) }\end{array}$ & histone cluster $2, \mathrm{H} 3 \mathrm{c}$ & Nucleus \\
\hline 1,179 & HEXA & hexosaminidase A (alpha polypeptide) & Cytoplasm \\
\hline 1,183 & Gpr137b-ps & G protein-coupled receptor $137 \mathrm{~B}$, pseudogene & Other \\
\hline 1,185 & CLEC9A & C-type lectin domain family 9 , member $A$ & Plasma Membrane \\
\hline 1,186 & DNA2 & DNA replication helicase/nuclease 2 & Cytoplasm \\
\hline 1,186 & TUBB2B & tubulin, beta $2 \mathrm{~B}$ class IIb & Cytoplasm \\
\hline 1,188 & FABP5 & fatty acid binding protein 5 (psoriasis-associated) & Cytoplasm \\
\hline 1,188 & VASH2 & vasohibin 2 & Cytoplasm \\
\hline 1,189 & RNASEL & ribonuclease L (2',5'-oligoisoadenylate synthetase-dependent) & Cytoplasm \\
\hline 1,193 & CENPA & centromere protein $\mathrm{A}$ & Nucleus \\
\hline 1,196 & PSAT1 & phosphoserine aminotransferase 1 & Cytoplasm \\
\hline 1,201 & PTPRJ & protein tyrosine phosphatase, receptor type, J & Plasma Membrane \\
\hline 1,203 & SLC9A9 & solute carrier family 9, subfamily A (NHE9, cation proton antiporter & Cytoplasm \\
\hline
\end{tabular}




\begin{tabular}{|c|c|c|c|}
\hline & & 9), member 9 & \\
\hline 1,205 & PRIM1 & primase, DNA, polypeptide 1 (49kDa) & Nucleus \\
\hline 1,205 & RAB32 & RAB32, member RAS oncogene family & Cytoplasm \\
\hline 1,206 & HLA-B & major histocompatibility complex, class I, B & Plasma Membrane \\
\hline 1,207 & CORO2A & coronin, actin binding protein, $2 \mathrm{~A}$ & Cytoplasm \\
\hline 1,216 & ABCG1 & ATP-binding cassette, sub-family G (WHITE), member 1 & Plasma Membrane \\
\hline 1,223 & $\mathrm{ESCO} 2$ & establishment of sister chromatid cohesion $\mathrm{N}$-acetyltransferase 2 & Nucleus \\
\hline 1,223 & FRRS1 & ferric-chelate reductase 1 & Plasma Membrane \\
\hline 1,225 & $\mathrm{CD} 14$ & CD14 molecule & Plasma Membrane \\
\hline 1,225 & CTSC & cathepsin C & Cytoplasm \\
\hline 1,226 & $\begin{array}{l}\text { 9830107B12Rik } \\
\text { (includes others) }\end{array}$ & RIKEN cDNA B430306N03 gene & Other \\
\hline 1,226 & SPG21 & spastic paraplegia 21 (autosomal recessive, Mast syndrome) & Plasma Membrane \\
\hline 1,228 & HIST1H1B & histone cluster $1, \mathrm{H} 1 \mathrm{~b}$ & Nucleus \\
\hline 1,228 & STAB1 & stabilin 1 & Plasma Membrane \\
\hline 1,229 & INPP5D & inositol polyphosphate-5-phosphatase, $145 \mathrm{kDa}$ & Cytoplasm \\
\hline 1,231 & CASC5 & cancer susceptibility candidate 5 & Nucleus \\
\hline 1,232 & ADA & adenosine deaminase & Cytoplasm \\
\hline 1,232 & CTSB & cathepsin B & Cytoplasm \\
\hline 1,233 & ITGA4 & $\begin{array}{l}\text { integrin, alpha } 4 \text { (antigen CD49D, alpha } 4 \text { subunit of VLA-4 } \\
\text { receptor) }\end{array}$ & Plasma Membrane \\
\hline 1,234 & Bex1 & brain expressed gene 1 & Other \\
\hline 1,235 & PYCARD & PYD and CARD domain containing & Cytoplasm \\
\hline 1,236 & PIK3R5 & phosphoinositide-3-kinase, regulatory subunit 5 & Cytoplasm \\
\hline 1,237 & CSF2RA & $\begin{array}{l}\text { colony stimulating factor } 2 \text { receptor, alpha, low-affinity } \\
\text { (granulocyte-macrophage) }\end{array}$ & Plasma Membrane \\
\hline 1,241 & SLFN13 & schlafen family member 13 & Nucleus \\
\hline 1,242 & F7 & coagulation factor VII (serum prothrombin conversion accelerator) & Plasma Membrane \\
\hline 1,244 & P2RY12 & purinergic receptor P2Y, G-protein coupled, 12 & Plasma Membrane \\
\hline 1,245 & $\begin{array}{l}\text { Ear2 (includes } \\
\text { others) }\end{array}$ & eosinophil-associated, ribonuclease A family, member 2 & Cytoplasm \\
\hline 1,253 & DEPDC1 & DEP domain containing 1 & Nucleus \\
\hline 1,255 & A630033H20Rik & RIKEN cDNA A630033H20 gene & Plasma Membrane \\
\hline 1,256 & TIFA & TRAF-interacting protein with forkhead-associated domain & Other \\
\hline 1,259 & SLC38A1 & solute carrier family 38 , member 1 & Plasma Membrane \\
\hline 1,260 & CD300LD & CD300 molecule-like family member $\mathrm{d}$ & Plasma Membrane \\
\hline 1,263 & KIF4A & kinesin family member $4 \mathrm{~A}$ & Nucleus \\
\hline 1,263 & UBE2C & ubiquitin-conjugating enzyme $\mathrm{E} 2 \mathrm{C}$ & Cytoplasm \\
\hline 1,264 & GUSB & glucuronidase, beta & Cytoplasm \\
\hline 1,264 & NUF2 & NUF2, NDC80 kinetochore complex component & Nucleus \\
\hline 1,266 & IFI30 & interferon, gamma-inducible protein 30 & Cytoplasm \\
\hline 1,270 & GPR114 & G protein-coupled receptor 114 & Plasma Membrane \\
\hline 1,275 & $\begin{array}{l}\text { Ear2 (includes } \\
\text { others) }\end{array}$ & eosinophil-associated, ribonuclease A family, member 2 & Cytoplasm \\
\hline 1,276 & B4GALT6 & UDP-Gal:betaGlcNAc beta 1,4- galactosyltransferase, polypeptide 6 & Cytoplasm \\
\hline 1,280 & SLC25A24 & $\begin{array}{l}\text { solute carrier family } 25 \text { (mitochondrial carrier; phosphate carrier), } \\
\text { member } 24\end{array}$ & Cytoplasm \\
\hline 1,283 & Gm9733 & predicted gene 9733 & Other \\
\hline 1,290 & TMEM154 & transmembrane protein 154 & Other \\
\hline 1,293 & SAMHD1 & SAM domain and HD domain 1 & Nucleus \\
\hline 1,295 & MT1H & metallothionein $1 \mathrm{H}$ & Other \\
\hline 1,298 & CTHRC1 & collagen triple helix repeat containing 1 & Extracellular Space \\
\hline 1,298 & PLIN2 & perilipin 2 & Plasma Membrane \\
\hline 1,299 & ITGAX & integrin, alpha $\mathrm{X}$ (complement component 3 receptor 4 subunit) & Plasma Membrane \\
\hline 1,300 & Emr4 & $\begin{array}{l}\text { EGF-like module containing, mucin-like, hormone receptor-like } \\
\text { sequence } 4\end{array}$ & Plasma Membrane \\
\hline 1,302 & ALOX15 & arachidonate 15-lipoxygenase & Cytoplasm \\
\hline 1,303 & CD300LD & CD300 molecule-like family member $\mathrm{d}$ & Plasma Membrane \\
\hline 1,311 & F13A1 & coagulation factor XIII, A1 polypeptide & Extracellular Space \\
\hline 1,311 & MS4A8 & membrane-spanning 4-domains, subfamily A, member 8 & Plasma Membrane \\
\hline 1,313 & $\begin{array}{l}\text { Tmsb4x (includes } \\
\text { others) }\end{array}$ & thymosin, beta $4, X$ chromosome & Cytoplasm \\
\hline 1,314 & ANXA4 & annexin A4 & Plasma Membrane \\
\hline 1,314 & ZNF761 & zinc finger protein 761 & Nucleus \\
\hline 1,315 & AIF1 & allograft inflammatory factor 1 & Nucleus \\
\hline 1,315 & Trim30a/Trim30d & tripartite motif-containing $30 \mathrm{~A}$ & Cytoplasm \\
\hline 1,316 & HLA-DQB1 & major histocompatibility complex, class II, DQ beta 1 & Plasma Membrane \\
\hline 1,316 & PBK & PDZ binding kinase & Cytoplasm \\
\hline 1,317 & RACGAP1 & Rac GTPase activating protein 1 & Cytoplasm \\
\hline 1,318 & Cd209a & CD209a antigen & Plasma Membrane \\
\hline 1,318 & CEP55 & centrosomal protein $55 \mathrm{kDa}$ & Cytoplasm \\
\hline 1,320 & HLA-DRB1 & major histocompatibility complex, class II, DR beta 1 & Plasma Membrane \\
\hline
\end{tabular}




\begin{tabular}{|c|c|c|c|}
\hline 1,325 & CASP4 & caspase 4, apoptosis-related cysteine peptidase & Cytoplasm \\
\hline 1,325 & KIF20A & kinesin family member $20 \mathrm{~A}$ & Cytoplasm \\
\hline 1,326 & PLXNC1 & plexin $\mathrm{C} 1$ & Plasma Membrane \\
\hline 1,326 & Trim30a/Trim30d & tripartite motif-containing $30 \mathrm{~A}$ & Cytoplasm \\
\hline 1,331 & $\begin{array}{l}\text { Tmsb4x (includes } \\
\text { others) }\end{array}$ & thymosin, beta $4, x$ chromosome & Cytoplasm \\
\hline 1,335 & KIF2C & kinesin family member $2 \mathrm{C}$ & Nucleus \\
\hline 1,338 & LRRC25 & leucine rich repeat containing 25 & Other \\
\hline 1,340 & BTK & Bruton agammaglobulinemia tyrosine kinase & Cytoplasm \\
\hline 1,341 & APOE & apolipoprotein E & Extracellular Space \\
\hline 1,341 & HIST1H2AD & histone cluster $1, \mathrm{H} 2 \mathrm{ad}$ & Nucleus \\
\hline 1,342 & FOLR2 & folate receptor 2 (fetal) & Plasma Membrane \\
\hline 1,342 & NCAPG2 & non-SMC condensin II complex, subunit G2 & Nucleus \\
\hline 1,344 & SGPL1 & sphingosine-1-phosphate lyase 1 & Cytoplasm \\
\hline 1,345 & HMMR & hyaluronan-mediated motility receptor (RHAMM) & Plasma Membrane \\
\hline 1,348 & PQLC3 & PQ loop repeat containing 3 & Other \\
\hline 1,350 & BAIAP2L1 & BAI1-associated protein 2 -like 1 & Cytoplasm \\
\hline 1,350 & $\begin{array}{l}\text { Ear2 (includes } \\
\text { others) }\end{array}$ & eosinophil-associated, ribonuclease A family, member 2 & Cytoplasm \\
\hline 1,354 & GRN & granulin & Extracellular Space \\
\hline 1,362 & FAM111A & family with sequence similarity 111 , member $A$ & Other \\
\hline 1,365 & Gm4975/Sgol2 & shugoshin-like 2 (S, pombe) & Nucleus \\
\hline 1,365 & NUSAP1 & nucleolar and spindle associated protein 1 & Nucleus \\
\hline 1,367 & BUB1B & BUB1 mitotic checkpoint serine/threonine kinase B & Nucleus \\
\hline 1,368 & ASF1B & anti-silencing function $1 \mathrm{~B}$ histone chaperone & Nucleus \\
\hline 1,370 & AIM2 & absent in melanoma 2 & Cytoplasm \\
\hline 1,373 & ANXA1 & annexin A1 & Plasma Membrane \\
\hline 1,377 & IL7R & interleukin 7 receptor & Plasma Membrane \\
\hline 1,378 & KIF23 & kinesin family member 23 & Cytoplasm \\
\hline 1,380 & PTPRC & protein tyrosine phosphatase, receptor type, C & Plasma Membrane \\
\hline 1,383 & ZDBF2 & zinc finger, DBF-type containing 2 & Other \\
\hline 1,384 & ALDH3B1 & aldehyde dehydrogenase 3 family, member B1 & Cytoplasm \\
\hline 1,388 & CYBA & cytochrome b-245, alpha polypeptide & Cytoplasm \\
\hline 1,395 & $\begin{array}{l}\text { Ear2 (includes } \\
\text { others) }\end{array}$ & eosinophil-associated, ribonuclease A family, member 2 & Cytoplasm \\
\hline 1,398 & Cd52 & CD52 antigen & Other \\
\hline 1,400 & ZWILCH & zwilch kinetochore protein & Nucleus \\
\hline 1,402 & CTSZ & cathepsin Z & Cytoplasm \\
\hline 1,402 & TNFRSF1B & tumor necrosis factor receptor superfamily, member $1 \mathrm{~B}$ & Plasma Membrane \\
\hline 1,410 & ARHGAP11A & Rho GTPase activating protein $11 \mathrm{~A}$ & Cytoplasm \\
\hline 1,411 & RGS10 & regulator of G-protein signaling 10 & Cytoplasm \\
\hline 1,416 & HIST1H2BB & histone cluster $1, \mathrm{H} 2 \mathrm{bb}$ & Nucleus \\
\hline 1,421 & LILRB3 & $\begin{array}{l}\text { leukocyte immunoglobulin-like receptor, subfamily B (with TM and } \\
\text { ITIM domains), member } 3\end{array}$ & Plasma Membrane \\
\hline 1,422 & CSF2RB & $\begin{array}{l}\text { colony stimulating factor } 2 \text { receptor, beta, low-affinity } \\
\text { (granulocyte-macrophage) }\end{array}$ & Plasma Membrane \\
\hline 1,423 & Snord118 & small nucleolar RNA, C/D box 118 & Other \\
\hline 1,423 & Snord118 & small nucleolar RNA, C/D box 118 & Other \\
\hline 1,424 & ALDH1A2 & aldehyde dehydrogenase 1 family, member A2 & Cytoplasm \\
\hline 1,424 & TCIRG1 & $\begin{array}{l}\text { T-cell, immune regulator } 1, \text { ATPase, } \mathrm{H}+\text { transporting, lysosomal } \\
\text { V0 subunit A3 }\end{array}$ & Plasma Membrane \\
\hline 1,425 & Gm4951 & predicted gene 4951 & Other \\
\hline 1,428 & NCAPG & non-SMC condensin I complex, subunit G & Nucleus \\
\hline 1,428 & PEG10 & paternally expressed 10 & Nucleus \\
\hline 1,436 & $\mathrm{~F} 10$ & coagulation factor $\mathrm{X}$ & Extracellular Space \\
\hline 1,436 & RTP4 & receptor (chemosensory) transporter protein 4 & Plasma Membrane \\
\hline 1,439 & CD300LF & CD300 molecule-like family member $f$ & Plasma Membrane \\
\hline 1,439 & RBM47 & RNA binding motif protein 47 & Other \\
\hline 1,440 & AURKB & aurora kinase B & Nucleus \\
\hline 1,440 & LCP2 & $\begin{array}{l}\text { lymphocyte cytosolic protein } 2 \text { (SH2 domain containing leukocyte } \\
\text { protein of } 76 \mathrm{kDa} \text { ) }\end{array}$ & Cytoplasm \\
\hline 1,441 & SOX11 & SRY (sex determining region Y)-box 11 & Nucleus \\
\hline 1,442 & SLA & Src-like-adaptor & Plasma Membrane \\
\hline 1,447 & CENPE & centromere protein $\mathrm{E}, 312 \mathrm{kDa}$ & Nucleus \\
\hline 1,458 & TPX2 & TPX2, microtubule-associated & Nucleus \\
\hline 1,462 & UNC93B1 & unc-93 homolog B1 (C, elegans) & Cytoplasm \\
\hline 1,466 & IRF8 & interferon regulatory factor 8 & Nucleus \\
\hline 1,466 & KIAA1524 & KIAA1524 & Cytoplasm \\
\hline 1,469 & CCDC109B & coiled-coil domain containing 109B & Cytoplasm \\
\hline 1,469 & MAD2L1 & MAD2 mitotic arrest deficient-like 1 (yeast) & Nucleus \\
\hline 1,472 & SELPLG & selectin P ligand & Plasma Membrane \\
\hline 1,479 & RASSF4 & Ras association (RalGDS/AF-6) domain family member 4 & Other \\
\hline
\end{tabular}




\begin{tabular}{|c|c|c|c|}
\hline 1,480 & CD200R1L & CD200 receptor 1 -like & Plasma Membrane \\
\hline 1,480 & DCLK1 & doublecortin-like kinase 1 & Other \\
\hline 1,483 & $\mathrm{HCK}$ & hemopoietic cell kinase & Cytoplasm \\
\hline 1,484 & TNIP3 & TNFAIP3 interacting protein 3 & Other \\
\hline 1,491 & FAM105A & family with sequence similarity 105 , member $A$ & Other \\
\hline 1,491 & Slfn2 & schlafen 2 & Cytoplasm \\
\hline 1,495 & IRF5 & interferon regulatory factor 5 & Nucleus \\
\hline 1,497 & RRM2 & ribonucleotide reductase $\mathrm{M} 2$ & Nucleus \\
\hline 1,499 & ALCAM & activated leukocyte cell adhesion molecule & Plasma Membrane \\
\hline 1,499 & CASP1 & caspase 1 , apoptosis-related cysteine peptidase & Cytoplasm \\
\hline 1,501 & RENBP & renin binding protein & Other \\
\hline 1,502 & PLK1 & polo-like kinase 1 & Nucleus \\
\hline 1,505 & $\mathrm{C} 1 \mathrm{QC}$ & complement component $1, \mathrm{q}$ subcomponent, $\mathrm{C}$ chain & Extracellular Space \\
\hline 1,509 & MASTL & microtubule associated serine/threonine kinase-like & Cytoplasm \\
\hline 1,513 & NCF1 & neutrophil cytosolic factor 1 & Cytoplasm \\
\hline 1,515 & Naip2 & NLR family, apoptosis inhibitory protein 2 & Other \\
\hline 1,518 & CLEC6A & C-type lectin domain family 6 , member $A$ & Plasma Membrane \\
\hline 1,519 & CTSH & cathepsin $\mathrm{H}$ & Cytoplasm \\
\hline 1,520 & VAV1 & vav 1 guanine nucleotide exchange factor & Nucleus \\
\hline 1,521 & HLA-DQA1 & major histocompatibility complex, class II, DQ alpha 1 & Plasma Membrane \\
\hline 1,524 & CSF1R & colony stimulating factor 1 receptor & Plasma Membrane \\
\hline 1,525 & $\begin{array}{l}\text { Ifi204 (includes } \\
\text { others) }\end{array}$ & interferon activated gene 204 & Nucleus \\
\hline 1,531 & CLEC5A & C-type lectin domain family 5 , member A & Plasma Membrane \\
\hline 1,531 & KNSTRN & kinetochore-localized astrin/SPAG5 binding protein & Other \\
\hline 1,533 & GPR141 & G protein-coupled receptor 141 & Plasma Membrane \\
\hline 1,534 & RASGEF1B & RasGEF domain family, member $1 \mathrm{~B}$ & Other \\
\hline 1,538 & C1QA & complement component $1, \mathrm{q}$ subcomponent, A chain & Extracellular Space \\
\hline 1,539 & MYO5A & myosin VA (heavy chain 12 , myoxin) & Cytoplasm \\
\hline 1,540 & $\begin{array}{l}\text { 9830107B12Rik } \\
\text { (includes others) }\end{array}$ & RIKEN cDNA B430306N03 gene & Other \\
\hline 1,543 & CFP & complement factor properdin & Extracellular Space \\
\hline 1,545 & RRAD & Ras-related associated with diabetes & Cytoplasm \\
\hline 1,546 & $\mathrm{P} 2 \mathrm{RX} 4$ & purinergic receptor $\mathrm{P} 2 \mathrm{X}$, ligand-gated ion channel, 4 & Plasma Membrane \\
\hline 1,553 & CERS6 & ceramide synthase 6 & Nucleus \\
\hline 1,553 & LGALS3BP & lectin, galactoside-binding, soluble, 3 binding protein & Plasma Membrane \\
\hline 1,554 & HEXB & hexosaminidase B (beta polypeptide) & Cytoplasm \\
\hline 1,556 & DOCK2 & dedicator of cytokinesis 2 & Cytoplasm \\
\hline 1,557 & ATP8B4 & ATPase, class I, type 8B, member 4 & Other \\
\hline 1,559 & DDX60 & DEAD (Asp-Glu-Ala-Asp) box polypeptide 60 & Cytoplasm \\
\hline 1,563 & NFAM1 & NFAT activating protein with ITAM motif 1 & Plasma Membrane \\
\hline 1,564 & C1QTNF3 & $\mathrm{C} 1 \mathrm{q}$ and tumor necrosis factor related protein 3 & Extracellular Space \\
\hline 1,566 & SERPINE1 & $\begin{array}{l}\text { serpin peptidase inhibitor, clade } \mathrm{E} \text { (nexin, plasminogen activator } \\
\text { inhibitor type 1), member } 1\end{array}$ & Extracellular Space \\
\hline 1,569 & Nt5dc2 & 5'-nucleotidase domain containing 2 & Other \\
\hline 1,570 & E2F8 & E2F transcription factor 8 & Nucleus \\
\hline 1,575 & TUBB2B & tubulin, beta $2 \mathrm{~B}$ class IIb & Cytoplasm \\
\hline 1,581 & CYSLTR1 & cysteinyl leukotriene receptor 1 & Plasma Membrane \\
\hline 1,582 & PF4 & platelet factor 4 & Extracellular Space \\
\hline 1,583 & LCP1 & lymphocyte cytosolic protein 1 (L-plastin) & Cytoplasm \\
\hline 1,584 & PRR11 & proline rich 11 & Other \\
\hline 1,588 & ARL11 & ADP-ribosylation factor-like 11 & Other \\
\hline 1,588 & HGF & hepatocyte growth factor (hepapoietin A; scatter factor) & Extracellular Space \\
\hline 1,589 & CSF3R & colony stimulating factor 3 receptor (granulocyte) & Plasma Membrane \\
\hline 1,589 & MIS18BP1 & MIS18 binding protein 1 & Nucleus \\
\hline 1,594 & NPL & $\mathrm{N}$-acetylneuraminate pyruvate lyase (dihydrodipicolinate synthase) & Other \\
\hline 1,595 & CFB & complement factor B & Extracellular Space \\
\hline 1,599 & $\mathrm{HP}$ & haptoglobin & Extracellular Space \\
\hline 1,600 & Gm6377 & predicted gene 6377 & Other \\
\hline 1,600 & P4HA3 & prolyl 4-hydroxylase, alpha polypeptide III & Other \\
\hline 1,604 & SLFN13 & schlafen family member 13 & Nucleus \\
\hline 1,607 & Abcg3 & ATP-binding cassette, sub-family G (WHITE), member 3 & Plasma Membrane \\
\hline 1,611 & DHX58 & DEXH (Asp-Glu-X-His) box polypeptide 58 & Cytoplasm \\
\hline 1,613 & LY9 & lymphocyte antigen 9 & Plasma Membrane \\
\hline 1,613 & RGS18 & regulator of G-protein signaling 18 & Cytoplasm \\
\hline 1,619 & $\begin{array}{l}\text { Ifi204 (includes } \\
\text { others) }\end{array}$ & interferon activated gene 204 & Nucleus \\
\hline 1,623 & NAIP & NLR family, apoptosis inhibitory protein & Other \\
\hline 1,625 & ABCC3 & ATP-binding cassette, sub-family C (CFTR/MRP), member 3 & Plasma Membrane \\
\hline 1,626 & CDK1 & cyclin-dependent kinase 1 & Nucleus \\
\hline 1,626 & KIAA0101 & KIAA0101 & Nucleus \\
\hline 1,628 & NCF2 & neutrophil cytosolic factor 2 & Cytoplasm \\
\hline
\end{tabular}




\begin{tabular}{|c|c|c|c|}
\hline 1,629 & OAS2 & 2'-5'-oligoadenylate synthetase 2,69/71kDa & Cytoplasm \\
\hline 1,632 & KIAA0101 & KIAA0101 & Nucleus \\
\hline 1,649 & LPCAT2 & lysophosphatidylcholine acyltransferase 2 & Cytoplasm \\
\hline 1,661 & 5430435G22Rik & RIKEN CDNA $5430435 \mathrm{G} 22$ gene & Cytoplasm \\
\hline 1,661 & CD44 & CD44 molecule (Indian blood group) & Plasma Membrane \\
\hline 1,661 & SIRPA & signal-regulatory protein alpha & Plasma Membrane \\
\hline 1,663 & LAPTM5 & lysosomal protein transmembrane 5 & Plasma Membrane \\
\hline 1,665 & CXCL9 & chemokine (C-X-C motif) ligand 9 & Extracellular Space \\
\hline 1,665 & LPXN & leupaxin & Cytoplasm \\
\hline 1,667 & MYOG & myogenin (myogenic factor 4) & Nucleus \\
\hline 1,670 & CSTB & cystatin B (stefin B) & Cytoplasm \\
\hline 1,674 & PIK3AP1 & phosphoinositide-3-kinase adaptor protein 1 & Cytoplasm \\
\hline 1,677 & Phf11a/Phf11b & PHD finger protein $11 \mathrm{~A}$ & Other \\
\hline 1,679 & Nxpe5 & neurexophilin and PC-esterase domain family, member 5 & Other \\
\hline 1,683 & TIFAB & $\begin{array}{l}\text { TRAF-interacting protein with forkhead-associated domain, family } \\
\text { member B }\end{array}$ & Other \\
\hline 1,684 & CCNB2 & cyclin B2 & Cytoplasm \\
\hline 1,686 & PTPLAD2 & protein tyrosine phosphatase-like A domain containing 2 & Other \\
\hline 1,688 & GAPT & GRB2-binding adaptor protein, transmembrane & Other \\
\hline 1,688 & KIF11 & kinesin family member 11 & Nucleus \\
\hline 1,688 & MKI67 & antigen identified by monoclonal antibody Ki- 67 & Nucleus \\
\hline 1,696 & MYOF & myoferlin & Nucleus \\
\hline 1,696 & PILRA & paired immunoglobin-like type 2 receptor alpha & Plasma Membrane \\
\hline 1,699 & CCR3 & chemokine ( $\mathrm{C}-\mathrm{C}$ motif) receptor 3 & Plasma Membrane \\
\hline 1,701 & CKS2 & CDC28 protein kinase regulatory subunit 2 & Other \\
\hline 1,708 & LACC1 & laccase (multicopper oxidoreductase) domain containing 1 & Other \\
\hline 1,710 & CD300A & CD300a molecule & Plasma Membrane \\
\hline 1,719 & CAPG & capping protein (actin filament), gelsolin-like & Nucleus \\
\hline 1,720 & CXCL10 & chemokine (C-X-C motif) ligand 10 & Extracellular Space \\
\hline 1,721 & CD300LD & CD300 molecule-like family member $d$ & Plasma Membrane \\
\hline 1,727 & F630028010Rik & RIKEN cDNA F630028010 gene & Other \\
\hline 1,727 & THEMIS2 & thymocyte selection associated family member 2 & Other \\
\hline 1,728 & CD300LB & CD300 molecule-like family member b & Plasma Membrane \\
\hline 1,730 & C19orf38 & chromosome 19 open reading frame 38 & Other \\
\hline 1,733 & BCL2A1 & $\mathrm{BCL} 2$-related protein $\mathrm{A} 1$ & Cytoplasm \\
\hline 1,733 & $\begin{array}{l}\text { Hist1h2ab } \\
\text { (includes others) }\end{array}$ & histone cluster $1, \mathrm{H} 2 \mathrm{ab}$ & Nucleus \\
\hline 1,734 & CYTH4 & cytohesin 4 & Cytoplasm \\
\hline 1,735 & PRUNE2 & prune homolog 2 (Drosophila) & Other \\
\hline 1,740 & IL10RA & interleukin 10 receptor, alpha & Plasma Membrane \\
\hline 1,744 & FYB & FYN binding protein & Nucleus \\
\hline 1,748 & RUNX1 & runt-related transcription factor 1 & Nucleus \\
\hline 1,750 & TM4SF19 & transmembrane $4 \mathrm{~L}$ six family member 19 & Other \\
\hline 1,752 & LAT2 & linker for activation of $\mathrm{T}$ cells family, member 2 & Plasma Membrane \\
\hline 1,764 & ECT2 & epithelial cell transforming sequence 2 oncogene & Cytoplasm \\
\hline 1,769 & HAVCR2 & hepatitis A virus cellular receptor 2 & Plasma Membrane \\
\hline 1,771 & GPR65 & $\mathrm{G}$ protein-coupled receptor 65 & Plasma Membrane \\
\hline 1,774 & PRC1 & protein regulator of cytokinesis 1 & Nucleus \\
\hline 1,780 & ATP1A3 & ATPase, $\mathrm{Na}+/ \mathrm{K}+$ transporting, alpha 3 polypeptide & Plasma Membrane \\
\hline 1,784 & BCL2A1 & $\mathrm{BCL} 2$-related protein $\mathrm{A} 1$ & Cytoplasm \\
\hline 1,785 & SLC15A3 & solute carrier family 15 (oligopeptide transporter), member 3 & Cytoplasm \\
\hline 1,789 & GLA & galactosidase, alpha & Cytoplasm \\
\hline 1,795 & AKR1B10 & aldo-keto reductase family 1 , member B10 (aldose reductase) & Cytoplasm \\
\hline 1,799 & CKS2 & CDC28 protein kinase regulatory subunit 2 & Other \\
\hline 1,802 & Ms4a6b & membrane-spanning 4-domains, subfamily $A$, member 6B & Other \\
\hline 1,814 & CD200R1 & CD200 receptor 1 & Plasma Membrane \\
\hline 1,819 & CKS2 & CDC28 protein kinase regulatory subunit 2 & Other \\
\hline 1,823 & CD48 & CD48 molecule & Plasma Membrane \\
\hline 1,824 & IL1RN & interleukin 1 receptor antagonist & Extracellular Space \\
\hline 1,827 & Lyz1/Lyz2 & lysozyme 2 & Cytoplasm \\
\hline 1,843 & CD53 & CD53 molecule & Plasma Membrane \\
\hline 1,850 & TOP2A & topoisomerase (DNA) II alpha $170 \mathrm{kDa}$ & Nucleus \\
\hline 1,851 & MMP12 & matrix metallopeptidase 12 (macrophage elastase) & Extracellular Space \\
\hline 1,852 & MMP19 & matrix metallopeptidase 19 & Extracellular Space \\
\hline 1,863 & $\begin{array}{l}\text { Ifi204 (includes } \\
\text { others) }\end{array}$ & interferon activated gene 204 & Nucleus \\
\hline 1,865 & SH2D1B & SH2 domain containing $1 \mathrm{~B}$ & Cytoplasm \\
\hline 1,866 & P2RY6 & pyrimidinergic receptor P2Y, G-protein coupled, 6 & Plasma Membrane \\
\hline 1,867 & R3HDML & R3H domain containing-like & Other \\
\hline 1,870 & TMEM106A & transmembrane protein $106 \mathrm{~A}$ & Other \\
\hline 1,871 & BCL2A1 & $\mathrm{BCL} 2$-related protein $\mathrm{A} 1$ & Cytoplasm \\
\hline 1,873 & Gm5431 & predicted gene 5431 & Other \\
\hline
\end{tabular}




\begin{tabular}{|c|c|c|c|}
\hline 1,877 & PRUNE2 & prune homolog 2 (Drosophila) & Other \\
\hline 1,891 & FCGR2A & Fc fragment of IgG, low affinity IIa, receptor (CD32) & Plasma Membrane \\
\hline 1,892 & BST1 & bone marrow stromal cell antigen 1 & Plasma Membrane \\
\hline 1,898 & C5AR1 & complement component 5a receptor 1 & Plasma Membrane \\
\hline 1,901 & CLEC4E & C-type lectin domain family 4 , member $\mathrm{E}$ & Plasma Membrane \\
\hline 1,904 & TUBB6 & tubulin, beta 6 class $\mathrm{V}$ & Cytoplasm \\
\hline 1,905 & EMB & embigin & Plasma Membrane \\
\hline 1,907 & PTAFR & platelet-activating factor receptor & Plasma Membrane \\
\hline 1,910 & NAIP & NLR family, apoptosis inhibitory protein & Other \\
\hline 1,919 & C1QB & complement component 1 , q subcomponent, B chain & Extracellular Space \\
\hline 1,919 & $\begin{array}{l}\text { Sirpb1a (includes } \\
\text { others) }\end{array}$ & signal-regulatory protein beta $1 \mathrm{~A}$ & Plasma Membrane \\
\hline 1,951 & LILRB3 & $\begin{array}{l}\text { leukocyte immunoglobulin-like receptor, subfamily B (with TM and } \\
\text { ITIM domains), member } 3\end{array}$ & Plasma Membrane \\
\hline 1,951 & NCKAP1L & NCK-associated protein 1-like & Plasma Membrane \\
\hline 1,960 & LIPA & lipase A, lysosomal acid, cholesterol esterase & Cytoplasm \\
\hline 1,960 & SOAT1 & sterol O-acyltransferase 1 & Cytoplasm \\
\hline 1,961 & SIGLEC1 & sialic acid binding Ig-like lectin 1 , sialoadhesin & Plasma Membrane \\
\hline 1,965 & MYH8 & myosin, heavy chain 8 , skeletal muscle, perinatal & Cytoplasm \\
\hline 1,970 & PLD4 & phospholipase D family, member 4 & Extracellular Space \\
\hline 1,971 & TLR1 & toll-like receptor 1 & Plasma Membrane \\
\hline 1,973 & Pira11 & paired-Ig-like receptor A11 & Other \\
\hline 1,980 & Oasl2 & 2'-5' oligoadenylate synthetase-like 2 & Other \\
\hline 1,982 & IFIT3 & interferon-induced protein with tetratricopeptide repeats 3 & Cytoplasm \\
\hline 1,983 & ANLN & anillin, actin binding protein & Cytoplasm \\
\hline 1,985 & LGMN & legumain & Cytoplasm \\
\hline 2,005 & Clec4a1 & C-type lectin domain family 4 , member a1 & Other \\
\hline 2,005 & SPI1 & spleen focus forming virus (SFFV) proviral integration oncogene & Nucleus \\
\hline 2,008 & Lyz1/Lyz2 & lysozyme 2 & Cytoplasm \\
\hline 2,016 & OAS1 & 2'-5'-oligoadenylate synthetase $1,40 / 46 \mathrm{kDa}$ & Cytoplasm \\
\hline 2,022 & CLEC4A & C-type lectin domain family 4 , member A & Plasma Membrane \\
\hline 2,026 & CCNA2 & cyclin A2 & Nucleus \\
\hline 2,028 & S100A4 & S100 calcium binding protein $\mathrm{A} 4$ & Cytoplasm \\
\hline 2,031 & IRF7 & interferon regulatory factor 7 & Nucleus \\
\hline 2,033 & CLEC4D & C-type lectin domain family 4 , member $\mathrm{D}$ & Plasma Membrane \\
\hline 2,036 & $\begin{array}{l}\text { Ms4a4b (includes } \\
\text { others) }\end{array}$ & membrane-spanning 4-domains, subfamily $A$, member 4B & Plasma Membrane \\
\hline 2,038 & RETNLB & resistin like beta & Extracellular Space \\
\hline 2,045 & LAIR1 & leukocyte-associated immunoglobulin-like receptor 1 & Plasma Membrane \\
\hline 2,049 & TBXAS1 & thromboxane $A$ synthase 1 (platelet) & Plasma Membrane \\
\hline 2,077 & TFEC & transcription factor EC & Nucleus \\
\hline 2,087 & MS4A4A & membrane-spanning 4-domains, subfamily $A$, member $4 A$ & Other \\
\hline 2,097 & CD300C & CD300c molecule & Plasma Membrane \\
\hline 2,100 & Ccnb1/Gm5593 & cyclin B1 & Nucleus \\
\hline 2,101 & APOC2 & apolipoprotein C-II & Extracellular Space \\
\hline 2,101 & IFI27L2 & interferon, alpha-inducible protein 27-like 2 & Other \\
\hline 2,105 & CYP4F2 & cytochrome P450, family 4, subfamily F, polypeptide 2 & Cytoplasm \\
\hline 2,105 & Ifitm6 & interferon induced transmembrane protein 6 & Other \\
\hline 2,114 & ITGB2 & $\begin{array}{l}\text { integrin, beta } 2 \text { (complement component } 3 \text { receptor } 3 \text { and } 4 \\
\text { subunit) }\end{array}$ & Plasma Membrane \\
\hline 2,122 & HPSE & heparanase & Plasma Membrane \\
\hline 2,126 & SLAMF7 & SLAM family member 7 & Plasma Membrane \\
\hline 2,131 & Ccnb1/Gm5593 & cyclin B1 & Nucleus \\
\hline 2,134 & CCR1 & chemokine (C-C motif) receptor 1 & Plasma Membrane \\
\hline 2,136 & TMEM8C & transmembrane protein $8 \mathrm{C}$ & Plasma Membrane \\
\hline 2,145 & HPGDS & hematopoietic prostaglandin D synthase & Cytoplasm \\
\hline 2,167 & PCBD1 & $\begin{array}{l}\text { pterin- } 4 \text { alpha-carbinolamine dehydratase/dimerization cofactor of } \\
\text { hepatocyte nuclear factor } 1 \text { alpha }\end{array}$ & Nucleus \\
\hline 2,169 & FCGR2B & Fc fragment of IgG, low affinity IIb, receptor (CD32) & Plasma Membrane \\
\hline 2,176 & SLC37A2 & $\begin{array}{l}\text { solute carrier family } 37 \text { (glucose-6-phosphate transporter), } \\
\text { member } 2\end{array}$ & Other \\
\hline 2,190 & BUB1 & BUB1 mitotic checkpoint serine/threonine kinase & Nucleus \\
\hline 2,194 & MYO1F & myosin IF & Cytoplasm \\
\hline 2,203 & Ccnb1/Gm5593 & cyclin B1 & Nucleus \\
\hline 2,211 & $\mathrm{Ccl9}$ & chemokine ( $\mathrm{C}-\mathrm{C}$ motif) ligand 9 & Extracellular Space \\
\hline 2,226 & Olfr1372-ps1 & olfactory receptor 1372 , pseudogene 1 & Other \\
\hline 2,246 & VSIG4 & V-set and immunoglobulin domain containing 4 & Plasma Membrane \\
\hline 2,249 & $\begin{array}{l}\text { Sirpb1a (includes } \\
\text { others) }\end{array}$ & signal-regulatory protein beta $1 \mathrm{~A}$ & Plasma Membrane \\
\hline 2,252 & GLIPR1 & GLI pathogenesis-related 1 & Extracellular Space \\
\hline 2,255 & CHRNG & cholinergic receptor, nicotinic, gamma (muscle) & Plasma Membrane \\
\hline 2,266 & FCER1G & Fc fragment of IgE, high affinity I, receptor for; gamma & Plasma Membrane \\
\hline
\end{tabular}




\begin{tabular}{|c|c|c|c|}
\hline & & polypeptide & \\
\hline 2,277 & MMP8 & matrix metallopeptidase 8 (neutrophil collagenase) & Extracellular Space \\
\hline 2,296 & MYL4 & myosin, light chain 4, alkali; atrial, embryonic & Cytoplasm \\
\hline 2,331 & LY86 & lymphocyte antigen 86 & Plasma Membrane \\
\hline 2,339 & SLC11A1 & $\begin{array}{l}\text { solute carrier family } 11 \text { (proton-coupled divalent metal ion } \\
\text { transporter), member } 1\end{array}$ & Plasma Membrane \\
\hline 2,378 & ADAM8 & ADAM metallopeptidase domain 8 & Plasma Membrane \\
\hline 2,383 & MS4A14 & membrane-spanning 4-domains, subfamily A, member 14 & Other \\
\hline 2,384 & ALOX5AP & arachidonate 5-lipoxygenase-activating protein & Plasma Membrane \\
\hline 2,400 & ARG1 & arginase 1 & Cytoplasm \\
\hline 2,403 & PLAC8 & placenta-specific 8 & Nucleus \\
\hline 2,413 & ANKRD1 & ankyrin repeat domain 1 (cardiac muscle) & Cytoplasm \\
\hline 2,454 & Ms4a6c & membrane-spanning 4-domains, subfamily $\mathrm{A}$, member $6 \mathrm{C}$ & Other \\
\hline 2,473 & Chi3|3/Chi3|4 & chitinase 3-like 3 & Extracellular Space \\
\hline 2,497 & PPBP & pro-platelet basic protein (chemokine (C-X-C motif) ligand 7) & Extracellular Space \\
\hline 2,514 & TYROBP & TYRO protein tyrosine kinase binding protein & Plasma Membrane \\
\hline 2,520 & CD180 & CD180 molecule & Plasma Membrane \\
\hline 2,525 & CCR5 & chemokine (C-C motif) receptor 5 (gene/pseudogene) & Plasma Membrane \\
\hline 2,525 & CCR5 & chemokine (C-C motif) receptor 5 (gene/pseudogene) & Plasma Membrane \\
\hline 2,552 & CYBB & cytochrome b-245, beta polypeptide & Cytoplasm \\
\hline 2,575 & PLEK & pleckstrin & Cytoplasm \\
\hline 2,579 & Milr1 & mast cell immunoglobulin like receptor 1 & Plasma Membrane \\
\hline 2,593 & Clec4a3 & C-type lectin domain family 4 , member a3 & Other \\
\hline 2,612 & APOBEC1 & apolipoprotein B mRNA editing enzyme, catalytic polypeptide 1 & Cytoplasm \\
\hline 2,620 & IGSF6 & immunoglobulin superfamily, member 6 & Plasma Membrane \\
\hline 2,625 & TREM2 & triggering receptor expressed on myeloid cells 2 & Plasma Membrane \\
\hline 2,636 & DPEP2 & dipeptidase 2 & Plasma Membrane \\
\hline 2,654 & Gm5150 & predicted gene 5150 & Other \\
\hline 2,690 & FCGR1A & Fc fragment of IgG, high affinity Ia, receptor (CD64) & Plasma Membrane \\
\hline 2,698 & $\mathrm{Ccl} 8$ & chemokine (C-C motif) ligand 8 & Extracellular Space \\
\hline 2,708 & EMR1 & egf-like module containing, mucin-like, hormone receptor-like 1 & Plasma Membrane \\
\hline 2,731 & MSR1 & macrophage scavenger receptor 1 & Plasma Membrane \\
\hline 2,766 & $\begin{array}{l}\text { Ly6a (includes } \\
\text { others) }\end{array}$ & lymphocyte antigen 6 complex, locus A & Plasma Membrane \\
\hline 2,778 & Ccl6 & chemokine ( $\mathrm{C}-\mathrm{C}$ motif) ligand 6 & Extracellular Space \\
\hline 2,782 & CLEC7A & C-type lectin domain family 7 , member A & Plasma Membrane \\
\hline 2,783 & $\begin{array}{l}\text { Sirpb1a (includes } \\
\text { others) }\end{array}$ & signal-regulatory protein beta $1 \mathrm{~A}$ & Plasma Membrane \\
\hline 2,812 & MS4A7 & membrane-spanning 4-domains, subfamily A, member 7 & Other \\
\hline 2,860 & CD84 & CD84 molecule & Plasma Membrane \\
\hline 2,867 & Gp49a/Lilrb4 & leukocyte immunoglobulin-like receptor, subfamily B, member 4 & Other \\
\hline 2,930 & Wfdc17 & WAP four-disulfide core domain 17 & Other \\
\hline 2,931 & ITGAM & integrin, alpha M (complement component 3 receptor 3 subunit) & Plasma Membrane \\
\hline 2,938 & SERPINA3 & $\begin{array}{l}\text { serpin peptidase inhibitor, clade A (alpha-1 antiproteinase, } \\
\text { antitrypsin), member } 3\end{array}$ & Extracellular Space \\
\hline 2,945 & PRG4 & proteoglycan 4 & Extracellular Space \\
\hline 2,977 & CD68 & CD68 molecule & Plasma Membrane \\
\hline 2,994 & CLEC12A & C-type lectin domain family 12 , member A & Plasma Membrane \\
\hline 2,996 & TNNT2 & troponin T type 2 (cardiac) & Cytoplasm \\
\hline 3,011 & GAL & galanin/GMAP prepropeptide & Extracellular Space \\
\hline 3,060 & TIMP1 & TIMP metallopeptidase inhibitor 1 & Extracellular Space \\
\hline 3,079 & SLFN12L & schlafen family member 12 -like & Other \\
\hline 3,097 & MS4A6A & membrane-spanning 4-domains, subfamily $A$, member $6 \mathrm{~A}$ & Other \\
\hline 3,151 & MYH3 & myosin, heavy chain 3 , skeletal muscle, embryonic & Cytoplasm \\
\hline 3,180 & C3AR1 & complement component 3a receptor 1 & Plasma Membrane \\
\hline 3,181 & CTSS & cathepsin S & Cytoplasm \\
\hline 3,226 & CCR2 & chemokine (C-C motif) receptor 2 & Plasma Membrane \\
\hline 3,437 & MPEG1 & macrophage expressed 1 & Cytoplasm \\
\hline 3,486 & Gp49a/Lilrb4 & leukocyte immunoglobulin-like receptor, subfamily B, member 4 & Other \\
\hline 3,506 & CCL7 & chemokine ( $\mathrm{C}-\mathrm{C}$ motif) ligand 7 & Extracellular Space \\
\hline 3,541 & $\begin{array}{l}\text { Mup1 (includes } \\
\text { others) }\end{array}$ & major urinary protein 1 & Extracellular Space \\
\hline 3,546 & TIr13 & toll-like receptor 13 & Cytoplasm \\
\hline 3,584 & AKR1E2 & aldo-keto reductase family 1 , member E2 & Cytoplasm \\
\hline 3,626 & FCGR3A & Fc fragment of IgG, low affinity IIIa, receptor (CD16a) & Plasma Membrane \\
\hline 3,653 & LGALS3 & lectin, galactoside-binding, soluble, 3 & Extracellular Space \\
\hline 3,746 & $\begin{array}{l}\text { Mup1 (includes } \\
\text { others) }\end{array}$ & major urinary protein 1 & Extracellular Space \\
\hline 3,812 & $\begin{array}{l}\text { Mup1 (includes } \\
\text { others) }\end{array}$ & major urinary protein 1 & Extracellular Space \\
\hline 3,842 & $\begin{array}{l}\text { Mup1 (includes } \\
\text { others) }\end{array}$ & major urinary protein 1 & Extracellular Space \\
\hline
\end{tabular}




\begin{tabular}{rlll}
\hline $\mathbf{3}, \mathbf{8 5 8}$ & $\begin{array}{l}\text { Mup1 (includes } \\
\text { others) }\end{array}$ & major urinary protein 1 & Extracellular Space \\
$\mathbf{3}, \mathbf{8 6 3}$ & $\begin{array}{l}\text { Mup1 (includes } \\
\text { others) }\end{array}$ & major urinary protein 1 & Extracellular Space \\
$\mathbf{3 , 9 4 5}$ & $\begin{array}{l}\text { Mup1 (includes } \\
\text { others) }\end{array}$ & major urinary protein 1 & Extracellular Space \\
$\mathbf{3 , 9 7 2}$ & Ccl2 & chemokine (C-C motif) ligand 2 & Extracellular Space \\
$\mathbf{4 , 0 0 9}$ & $\begin{array}{l}\text { Mup1 (includes } \\
\text { others) }\end{array}$ & major urinary protein 1 \\
$\mathbf{4 , 0 5 1}$ & $\begin{array}{l}\text { Mup1 (includes } \\
\text { others) }\end{array}$ & major urinary protein 1 & Extracellular Space \\
$\mathbf{4 , 2 3 5}$ & GPNMB & glycoprotein (transmembrane) nmb & Extracellular Space \\
$\mathbf{4 , 5 7 6}$ & CCL3L1/CCL3L3 & chemokine (C-C motif) ligand 3-like 1 & Plasma Membrane \\
$\mathbf{4 , 7 2 2}$ & SPP1 & secreted phosphoprotein 1 & Extracellular Space \\
$\mathbf{4 , 9 7 0}$ & ATP6VOD2 & ATPase, H+ transporting, lysosomal 38kDa, V0 subunit d2 & Extracellular Space \\
\hline
\end{tabular}




\begin{tabular}{|c|c|c|c|}
\hline \multicolumn{4}{|c|}{ Large $^{m y d-/-}$ vs C57BL 21 dias } \\
\hline $\begin{array}{l}\text { Fold } \\
\text { Change }\end{array}$ & Symbol & Entrez Gene Name & Location \\
\hline$-2,285$ & Zfp125 & zinc finger protein 125 & Nucleus \\
\hline$-2,258$ & NXPE4 & neurexophilin and PC-esterase domain family, member 4 & Extracellular Space \\
\hline$-2,148$ & AA388235 & expressed sequence AA388235 & Other \\
\hline$-1,902$ & LARGE & like-glycosyltransferase & Cytoplasm \\
\hline 0,748 & IL7R & interleukin 7 receptor & Plasma Membrane \\
\hline 1,166 & HLA-DQA1 & major histocompatibility complex, class II, DQ alpha 1 & Plasma Membrane \\
\hline 1,309 & GLIPR1 & GLI pathogenesis-related 1 & Extracellular Space \\
\hline 1,358 & LY86 & lymphocyte antigen 86 & Plasma Membrane \\
\hline 1,447 & AIF1L & allograft inflammatory factor 1 -like & Plasma Membrane \\
\hline 1,457 & FCGR2B & Fc fragment of IgG, low affinity IIb, receptor (CD32) & Plasma Membrane \\
\hline 1,459 & Mirg & miRNA containing gene & Other \\
\hline 1,464 & ITGB2 & $\begin{array}{l}\text { integrin, beta } 2 \text { (complement component } 3 \text { receptor } 3 \text { and } 4 \\
\text { subunit) }\end{array}$ & Plasma Membrane \\
\hline 1,477 & TUBB2B & tubulin, beta 2B class IIb & Cytoplasm \\
\hline 1,516 & $\mathrm{C} 1 \mathrm{QC}$ & complement component $1, \mathrm{q}$ subcomponent, $\mathrm{C}$ chain & Extracellular Space \\
\hline 1,516 & Ms4a6c & membrane-spanning 4-domains, subfamily $A$, member $6 \mathrm{C}$ & Other \\
\hline 1,519 & Ccl9 & chemokine ( $\mathrm{C}-\mathrm{C}$ motif) ligand 9 & Extracellular Space \\
\hline 1,526 & LAIR1 & leukocyte-associated immunoglobulin-like receptor 1 & Plasma Membrane \\
\hline 1,528 & NPNT & nephronectin & Plasma Membrane \\
\hline 1,541 & CYBB & cytochrome b-245, beta polypeptide & Cytoplasm \\
\hline 1,550 & PEG10 & paternally expressed 10 & Nucleus \\
\hline 1,561 & DLK1 & delta-like 1 homolog (Drosophila) & Extracellular Space \\
\hline 1,567 & MS4A14 & membrane-spanning 4-domains, subfamily $A$, member 14 & Other \\
\hline 1,583 & Lyz1/Lyz2 & lysozyme 2 & Cytoplasm \\
\hline 1,597 & E2F8 & E2F transcription factor 8 & Nucleus \\
\hline 1,602 & CXCL10 & chemokine (C-X-C motif) ligand 10 & Extracellular Space \\
\hline 1,605 & CD300C & CD300c molecule & Plasma Membrane \\
\hline 1,637 & ITGAX & integrin, alpha $\mathrm{X}$ (complement component 3 receptor 4 subunit) & Plasma Membrane \\
\hline 1,640 & MYOG & myogenin (myogenic factor 4 ) & Nucleus \\
\hline 1,674 & C1QB & complement component 1 , q subcomponent, B chain & Extracellular Space \\
\hline 1,716 & Mirg & miRNA containing gene & Other \\
\hline 1,719 & MT1H & metallothionein $1 \mathrm{H}$ & Other \\
\hline 1,722 & Nxpe5 & neurexophilin and PC-esterase domain family, member 5 & Other \\
\hline 1,725 & Snord116 & small nucleolar RNA, C/D box 116 & Other \\
\hline 1,727 & MT1E & metallothionein $1 \mathrm{E}$ & Cytoplasm \\
\hline 1,729 & C1QTNF3 & $\mathrm{C} 1 \mathrm{q}$ and tumor necrosis factor related protein 3 & Extracellular Space \\
\hline 1,751 & FCER1G & $\begin{array}{l}\text { Fc fragment of IgE, high affinity I, receptor for; gamma } \\
\text { polypeptide }\end{array}$ & Plasma Membrane \\
\hline 1,754 & LGMN & legumain & Cytoplasm \\
\hline 1,759 & Milr1 & mast cell immunoglobulin like receptor 1 & Plasma Membrane \\
\hline 1,774 & Snord116 & small nucleolar RNA, C/D box 116 & Other \\
\hline 1,774 & Snord116 & small nucleolar RNA, C/D box 116 & Other \\
\hline 1,774 & Snord116 & small nucleolar RNA, C/D box 116 & Other \\
\hline 1,774 & Snord116 & small nucleolar RNA, C/D box 116 & Other \\
\hline 1,774 & Snord116 & small nucleolar RNA, C/D box 116 & Other \\
\hline 1,774 & Snord116 & small nucleolar RNA, C/D box 116 & Other \\
\hline 1,774 & Snord116 & small nucleolar RNA, C/D box 116 & Other \\
\hline 1,774 & Snord116 & small nucleolar RNA, C/D box 116 & Other \\
\hline 1,774 & Snord116 & small nucleolar RNA, C/D box 116 & Other \\
\hline 1,774 & Snord116 & small nucleolar RNA, C/D box 116 & Other \\
\hline 1,774 & Snord116 & small nucleolar RNA, C/D box 116 & Other \\
\hline 1,774 & Snord116 & small nucleolar RNA, C/D box 116 & Other \\
\hline 1,774 & Snord116 & small nucleolar RNA, C/D box 116 & Other \\
\hline 1,774 & Snord116 & small nucleolar RNA, C/D box 116 & Other \\
\hline 1,774 & Snord116 & small nucleolar RNA, C/D box 116 & Other \\
\hline 1,774 & Snord116 & small nucleolar RNA, C/D box 116 & Other \\
\hline 1,774 & Snord116 & small nucleolar RNA, C/D box 116 & Other \\
\hline 1,774 & Snord116 & small nucleolar RNA, C/D box 116 & Other \\
\hline 1,796 & RTL1 & retrotransposon-like 1 & Other \\
\hline 1,798 & Ifi202b & interferon activated gene 202B & Nucleus \\
\hline 1,846 & TUBB2B & tubulin, beta 2B class IIb & Cytoplasm \\
\hline 1,847 & CDKN1A & cyclin-dependent kinase inhibitor $1 \mathrm{~A}$ (p21, Cip1) & Nucleus \\
\hline 1,854 & CLEC4D & C-type lectin domain family 4 , member D & Plasma Membrane \\
\hline 1,854 & Tpsab1 & tryptase alpha/beta 1 & Nucleus \\
\hline 1,863 & RRAD & Ras-related associated with diabetes & Cytoplasm \\
\hline 1,876 & CCNA2 & cyclin A2 & Nucleus \\
\hline 1,878 & IGSF6 & immunoglobulin superfamily, member 6 & Plasma Membrane \\
\hline 1,882 & RUNX1 & runt-related transcription factor 1 & Nucleus \\
\hline 1,886 & LCN2 & lipocalin 2 & Extracellular Space \\
\hline
\end{tabular}




\begin{tabular}{|c|c|c|c|}
\hline 1,896 & MS4A4A & membrane-spanning 4-domains, subfamily $\mathrm{A}$, member $4 \mathrm{~A}$ & Other \\
\hline 1,914 & AGTR2 & angiotensin II receptor, type 2 & Plasma Membrane \\
\hline 1,916 & PLEK & pleckstrin & Cytoplasm \\
\hline 1,926 & Ccnb1/Gm5593 & cyclin B1 & Nucleus \\
\hline 1,933 & AKR1B10 & aldo-keto reductase family 1 , member $\mathrm{B} 10$ (aldose reductase) & Cytoplasm \\
\hline 1,949 & DPEP2 & dipeptidase 2 & Plasma Membrane \\
\hline 1,967 & Conb1/Gm5593 & cyclin B1 & Nucleus \\
\hline 1,974 & MMP19 & matrix metallopeptidase 19 & Extracellular Space \\
\hline 1,976 & S100A4 & S100 calcium binding protein A4 & Cytoplasm \\
\hline 1,995 & HP & haptoglobin & Extracellular Space \\
\hline 2,023 & R3HDML & R3H domain containing-like & Other \\
\hline 2,024 & Ccl8 & chemokine (C-C motif) ligand 8 & Extracellular Space \\
\hline 2,042 & CLEC7A & C-type lectin domain family 7 , member A & Plasma Membrane \\
\hline 2,043 & ADAM8 & ADAM metallopeptidase domain 8 & Plasma Membrane \\
\hline 2,044 & APOBEC1 & apolipoprotein B mRNA editing enzyme, catalytic polypeptide 1 & Cytoplasm \\
\hline 2,055 & CD84 & CD84 molecule & Plasma Membrane \\
\hline 2,095 & TUBB6 & tubulin, beta 6 class $V$ & Cytoplasm \\
\hline 2,097 & TYROBP & TYRO protein tyrosine kinase binding protein & Plasma Membrane \\
\hline 2,105 & MS4A7 & membrane-spanning 4-domains, subfamily A, member 7 & Other \\
\hline 2,106 & CLEC12A & C-type lectin domain family 12 , member A & Plasma Membrane \\
\hline 2,162 & TREM2 & triggering receptor expressed on myeloid cells 2 & Plasma Membrane \\
\hline 2,191 & MSR1 & macrophage scavenger receptor 1 & Plasma Membrane \\
\hline 2,192 & Ccl6 & chemokine (C-C motif) ligand 6 & Extracellular Space \\
\hline 2,205 & C3AR1 & complement component 3a receptor 1 & Plasma Membrane \\
\hline 2,237 & ITGAM & integrin, alpha M (complement component 3 receptor 3 subunit) & Plasma Membrane \\
\hline 2,251 & PRUNE2 & prune homolog 2 (Drosophila) & Other \\
\hline 2,268 & PRUNE2 & prune homolog 2 (Drosophila) & Other \\
\hline 2,315 & CHRNG & cholinergic receptor, nicotinic, gamma (muscle) & Plasma Membrane \\
\hline 2,317 & PRG4 & proteoglycan 4 & Extracellular Space \\
\hline 2,340 & Wfdc17 & WAP four-disulfide core domain 17 & Other \\
\hline 2,368 & CCL7 & chemokine (C-C motif) ligand 7 & Extracellular Space \\
\hline 2,395 & TMEM8C & transmembrane protein $8 \mathrm{C}$ & Plasma Membrane \\
\hline 2,430 & MYL4 & myosin, light chain 4, alkali; atrial, embryonic & Cytoplasm \\
\hline 2,464 & PCBD1 & $\begin{array}{l}\text { pterin- } 4 \text { alpha-carbinolamine dehydratase/dimerization cofactor of } \\
\text { hepatocyte nuclear factor } 1 \text { alpha }\end{array}$ & Nucleus \\
\hline 2,512 & BAIAP2L1 & BAI1-associated protein 2-like 1 & Cytoplasm \\
\hline 2,586 & Gp49a/Lilrb4 & leukocyte immunoglobulin-like receptor, subfamily B, member 4 & Other \\
\hline 2,629 & MS4A6A & membrane-spanning 4-domains, subfamily $A$, member $6 \mathrm{~A}$ & Other \\
\hline 2,647 & CTSS & cathepsin S & Cytoplasm \\
\hline 2,660 & CD68 & CD68 molecule & Plasma Membrane \\
\hline 2,678 & MPEG1 & macrophage expressed 1 & Cytoplasm \\
\hline 2,688 & TIr13 & toll-like receptor 13 & Cytoplasm \\
\hline 2,778 & ARHGAP36 & Rho GTPase activating protein 36 & Cytoplasm \\
\hline 2,820 & MYH8 & myosin, heavy chain 8 , skeletal muscle, perinatal & Cytoplasm \\
\hline 2,841 & GAL & galanin/GMAP prepropeptide & Extracellular Space \\
\hline 2,938 & ANKRD1 & ankyrin repeat domain 1 (cardiac muscle) & Cytoplasm \\
\hline 3,044 & MMP12 & matrix metallopeptidase 12 (macrophage elastase) & Extracellular Space \\
\hline 3,062 & TIMP1 & TIMP metallopeptidase inhibitor 1 & Extracellular Space \\
\hline 3,087 & VSIG4 & V-set and immunoglobulin domain containing 4 & Plasma Membrane \\
\hline 3,121 & SPP1 & secreted phosphoprotein 1 & Extracellular Space \\
\hline 3,195 & $\mathrm{Ccl} 2$ & chemokine (C-C motif) ligand 2 & Extracellular Space \\
\hline 3,211 & TNNT2 & troponin T type 2 (cardiac) & Cytoplasm \\
\hline 3,235 & Gp49a/Lilrb4 & leukocyte immunoglobulin-like receptor, subfamily B, member 4 & Other \\
\hline 3,244 & LGALS3 & lectin, galactoside-binding, soluble, 3 & Extracellular Space \\
\hline 3,288 & SERPINA3 & $\begin{array}{l}\text { serpin peptidase inhibitor, clade A (alpha-1 antiproteinase, } \\
\text { antitrypsin), member } 3\end{array}$ & Extracellular Space \\
\hline 3,343 & MYH3 & myosin, heavy chain 3 , skeletal muscle, embryonic & Cytoplasm \\
\hline 3,463 & AKR1E2 & aldo-keto reductase family 1 , member E2 & Cytoplasm \\
\hline 3,519 & CCL3L1/CCL3L3 & chemokine (C-C motif) ligand 3-like 1 & Extracellular Space \\
\hline 3,519 & GPNMB & glycoprotein (transmembrane) nmb & Plasma Membrane \\
\hline 3,684 & HAL & histidine ammonia-lyase & Cytoplasm \\
\hline 4,084 & ATP6V0D2 & ATPase, $\mathrm{H}+$ transporting, lysosomal $38 \mathrm{kDa}$, $\mathrm{V} 0$ subunit $\mathrm{d} 2$ & Cytoplasm \\
\hline 5,755 & HLA-DRA & major histocompatibility complex, class II, DR alpha & Plasma Membrane \\
\hline
\end{tabular}




\begin{tabular}{|c|c|c|c|}
\hline \multicolumn{4}{|c|}{$D m d^{m d x} /$ Large $^{m y d-/-}$ vs C57BL 21dias } \\
\hline $\begin{array}{l}\text { Fold } \\
\text { Change }\end{array}$ & Symbol & Entrez Gene Name & Location \\
\hline$-2,991$ & PRND & prion protein 2 (dublet) & Plasma Membrane \\
\hline$-2,885$ & LGI1 & leucine-rich, glioma inactivated 1 & Plasma Membrane \\
\hline$-2,868$ & PMP2 & peripheral myelin protein 2 & Cytoplasm \\
\hline$-2,221$ & HOMER2 & homer homolog 2 (Drosophila) & Plasma Membrane \\
\hline$-2,189$ & MYLK4 & myosin light chain kinase family, member 4 & Other \\
\hline$-2,125$ & LARGE & like-glycosyltransferase & Cytoplasm \\
\hline 1,404 & CXCL13 & chemokine (C-X-C motif) ligand 13 & Extracellular Space \\
\hline 1,505 & $\begin{array}{l}\text { Ifi204 (includes } \\
\text { others) }\end{array}$ & interferon activated gene 204 & Nucleus \\
\hline 1,554 & C5AR1 & complement component 5 a receptor 1 & Plasma Membrane \\
\hline 1,561 & Lyz1/Lyz2 & lysozyme 2 & Cytoplasm \\
\hline 1,561 & MS4A7 & membrane-spanning 4-domains, subfamily $A$, member 7 & Other \\
\hline 1,566 & $\mathrm{C} 1 \mathrm{QB}$ & complement component 1 , q subcomponent, B chain & Extracellular Space \\
\hline 1,578 & LGMN & legumain & Cytoplasm \\
\hline 1,612 & $\mathrm{Ccl9}$ & chemokine (C-C motif) ligand 9 & Extracellular Space \\
\hline 1,619 & S100A4 & S100 calcium binding protein A4 & Cytoplasm \\
\hline 1,653 & $\begin{array}{l}\text { Sirpb1a (includes } \\
\text { others) }\end{array}$ & signal-regulatory protein beta $1 \mathrm{~A}$ & Plasma Membrane \\
\hline 1,654 & $\begin{array}{l}\text { Ifi204 (includes } \\
\text { others) }\end{array}$ & interferon activated gene 204 & Nucleus \\
\hline 1,656 & CCNA2 & cyclin A2 & Nucleus \\
\hline 1,656 & Mirg & miRNA containing gene & Other \\
\hline 1,660 & Ccnb1/Gm5593 & cyclin B1 & Nucleus \\
\hline 1,663 & mir-154 & microRNA 494 & Cytoplasm \\
\hline 1,675 & Ms4a6c & membrane-spanning 4-domains, subfamily $A$, member $6 C$ & Other \\
\hline 1,697 & Milr1 & mast cell immunoglobulin like receptor 1 & Plasma Membrane \\
\hline 1,699 & CDKN1A & cyclin-dependent kinase inhibitor $1 \mathrm{~A}$ (p21, Cip1) & Nucleus \\
\hline 1,699 & R3HDML & R3H domain containing-like & Other \\
\hline 1,713 & CYBB & cytochrome b-245, beta polypeptide & Cytoplasm \\
\hline 1,725 & TMEM8C & transmembrane protein $8 \mathrm{C}$ & Plasma Membrane \\
\hline 1,732 & RUNX1 & runt-related transcription factor 1 & Nucleus \\
\hline 1,739 & Ccnb1/Gm5593 & cyclin B1 & Nucleus \\
\hline 1,753 & TUBB6 & tubulin, beta 6 class $\mathrm{V}$ & Cytoplasm \\
\hline 1,766 & FCGR2B & Fc fragment of IgG, low affinity IIb, receptor (CD32) & Plasma Membrane \\
\hline 1,790 & CD84 & CD84 molecule & Plasma Membrane \\
\hline 1,803 & Ccnb1/Gm5593 & cyclin B1 & Nucleus \\
\hline 1,805 & CHRNG & cholinergic receptor, nicotinic, gamma (muscle) & Plasma Membrane \\
\hline 1,816 & MMP19 & matrix metallopeptidase 19 & Extracellular Space \\
\hline 1,824 & PCBD1 & $\begin{array}{l}\text { pterin-4 alpha-carbinolamine dehydratase/dimerization cofactor of } \\
\text { hepatocyte nuclear factor } 1 \text { alpha }\end{array}$ & Nucleus \\
\hline 1,836 & TM4SF19 & transmembrane $4 \mathrm{~L}$ six family member 19 & Other \\
\hline 1,858 & HAL & histidine ammonia-lyase & Cytoplasm \\
\hline 1,860 & Mirg & miRNA containing gene & Other \\
\hline 1,863 & MT1H & metallothionein $1 \mathrm{H}$ & Other \\
\hline 1,869 & BAIAP2L1 & BAI1-associated protein 2-like 1 & Cytoplasm \\
\hline 1,879 & PRUNE2 & prune homolog 2 (Drosophila) & Other \\
\hline 1,891 & FCER1G & $\begin{array}{l}\text { Fc fragment of IgE, high affinity I, receptor for; gamma } \\
\text { polypeptide }\end{array}$ & Plasma Membrane \\
\hline 1,892 & MMP12 & matrix metallopeptidase 12 (macrophage elastase) & Extracellular Space \\
\hline 1,898 & Snord53 & small nucleolar RNA, C/D box 53 & Other \\
\hline 1,899 & EMB & embigin & Plasma Membrane \\
\hline 1,901 & FCGR3A & Fc fragment of IgG, low affinity IIIa, receptor (CD16a) & Plasma Membrane \\
\hline 1,906 & ALOX5AP & arachidonate 5-lipoxygenase-activating protein & Plasma Membrane \\
\hline 1,906 & SERPINE1 & $\begin{array}{l}\text { serpin peptidase inhibitor, clade } \mathrm{E} \text { (nexin, plasminogen activator } \\
\text { inhibitor type 1), member } 1\end{array}$ & Extracellular Space \\
\hline 1,938 & PRUNE2 & prune homolog 2 (Drosophila) & Other \\
\hline 1,944 & TREM2 & triggering receptor expressed on myeloid cells 2 & Plasma Membrane \\
\hline 1,981 & TYROBP & TYRO protein tyrosine kinase binding protein & Plasma Membrane \\
\hline 1,986 & PLEK & pleckstrin & Cytoplasm \\
\hline 1,993 & CCR1 & chemokine (C-C motif) receptor 1 & Plasma Membrane \\
\hline 1,995 & $\begin{array}{l}\text { Serpina3k } \\
\text { (includes others) }\end{array}$ & serine (or cysteine) peptidase inhibitor, clade $\mathrm{A}$, member $3 \mathrm{~K}$ & Extracellular Space \\
\hline 1,997 & LILRB3 & $\begin{array}{l}\text { leukocyte immunoglobulin-like receptor, subfamily B (with TM and } \\
\text { ITIM domains), member } 3\end{array}$ & Plasma Membrane \\
\hline 2,005 & GAL & galanin/GMAP prepropeptide & Extracellular Space \\
\hline 2,037 & RTL1 & retrotransposon-like 1 & Other \\
\hline 2,060 & ITGAM & integrin, alpha M (complement component 3 receptor 3 subunit) & Plasma Membrane \\
\hline 2,073 & MYL4 & myosin, light chain 4, alkali; atrial, embryonic & Cytoplasm \\
\hline 2,093 & C3AR1 & complement component 3a receptor 1 & Plasma Membrane \\
\hline
\end{tabular}




\begin{tabular}{|c|c|c|c|}
\hline 2,094 & DPEP2 & dipeptidase 2 & Plasma Membrane \\
\hline 2,126 & MSR1 & macrophage scavenger receptor 1 & Plasma Membrane \\
\hline 2,147 & 1700011I03Rik & RIKEN cDNA 1700011103 gene & Other \\
\hline 2,155 & MS4A4A & membrane-spanning 4-domains, subfamily $A$, member 4A & Other \\
\hline 2,204 & $\begin{array}{l}\text { ANXA8L2 (includes } \\
\text { others) }\end{array}$ & annexin A8-like 2 & Plasma Membrane \\
\hline 2,220 & ADAM8 & ADAM metallopeptidase domain 8 & Plasma Membrane \\
\hline 2,252 & CLEC4D & C-type lectin domain family 4, member D & Plasma Membrane \\
\hline 2,253 & IGSF6 & immunoglobulin superfamily, member 6 & Plasma Membrane \\
\hline 2,254 & CTSS & cathepsin S & Cytoplasm \\
\hline 2,366 & MPEG1 & macrophage expressed 1 & Cytoplasm \\
\hline 2,407 & Ccl6 & chemokine ( $\mathrm{C}-\mathrm{C}$ motif) ligand 6 & Extracellular Space \\
\hline 2,420 & Wfdc17 & WAP four-disulfide core domain 17 & Other \\
\hline 2,431 & MT1E & metallothionein $1 \mathrm{E}$ & Cytoplasm \\
\hline 2,452 & ARHGAP36 & Rho GTPase activating protein 36 & Cytoplasm \\
\hline 2,517 & MS4A6A & membrane-spanning 4-domains, subfamily $A$, member $6 \mathrm{~A}$ & Other \\
\hline 2,540 & AKR1E2 & aldo-keto reductase family 1 , member E2 & Cytoplasm \\
\hline 2,573 & Gp49a/Lilrb4 & leukocyte immunoglobulin-like receptor, subfamily B, member 4 & Other \\
\hline 2,581 & CD68 & CD68 molecule & Plasma Membrane \\
\hline 2,617 & ASPRV1 & aspartic peptidase, retroviral-like 1 & Other \\
\hline 2,744 & TIMP1 & TIMP metallopeptidase inhibitor 1 & Extracellular Space \\
\hline 2,785 & Tlr13 & toll-like receptor 13 & Cytoplasm \\
\hline 2,829 & MYH8 & myosin, heavy chain 8 , skeletal muscle, perinatal & Cytoplasm \\
\hline 2,844 & CCL7 & chemokine ( $\mathrm{C}-\mathrm{C}$ motif) ligand 7 & Extracellular Space \\
\hline 2,986 & TNNT2 & troponin T type 2 (cardiac) & Cytoplasm \\
\hline 3,035 & MYH3 & myosin, heavy chain 3, skeletal muscle, embryonic & Cytoplasm \\
\hline 3,072 & $\mathrm{Ccl} 2$ & chemokine ( $\mathrm{C}-\mathrm{C}$ motif) ligand 2 & Extracellular Space \\
\hline 3,082 & Gp49a/Lilrb4 & leukocyte immunoglobulin-like receptor, subfamily B, member 4 & Other \\
\hline 3,096 & ANKRD1 & ankyrin repeat domain 1 (cardiac muscle) & Cytoplasm \\
\hline 3,159 & LGALS3 & lectin, galactoside-binding, soluble, 3 & Extracellular Space \\
\hline 3,341 & CCL3L1/CCL3L3 & chemokine (C-C motif) ligand 3-like 1 & Extracellular Space \\
\hline 3,439 & HLA-DRA & major histocompatibility complex, class II, DR alpha & Plasma Membrane \\
\hline 3,537 & PRG4 & proteoglycan 4 & Extracellular Space \\
\hline 3,618 & RETNLB & resistin like beta & Extracellular Space \\
\hline 3,736 & GPNMB & glycoprotein (transmembrane) nmb & Plasma Membrane \\
\hline 3,935 & SPP1 & secreted phosphoprotein 1 & Extracellular Space \\
\hline 3,947 & VSIG4 & V-set and immunoglobulin domain containing 4 & Plasma Membrane \\
\hline 4,004 & LCN2 & lipocalin 2 & Extracellular Space \\
\hline 4,170 & ATP6V0D2 & ATPase, $\mathrm{H}+$ transporting, lysosomal 38kDa, V0 subunit d2 & Cytoplasm \\
\hline 4,218 & SERPINA3 & $\begin{array}{l}\text { serpin peptidase inhibitor, clade A (alpha-1 antiproteinase, } \\
\text { antitrypsin), member } 3\end{array}$ & Extracellular Space \\
\hline 4,638 & MMP8 & matrix metallopeptidase 8 (neutrophil collagenase) & Extracellular Space \\
\hline 4,708 & Chi3|3/Chi314 & chitinase 3 -like 3 & Extracellular Space \\
\hline 4,866 & Stfa2/Stfa2l1 & stefin A2 & Cytoplasm \\
\hline
\end{tabular}




\begin{tabular}{|c|c|c|c|}
\hline \multicolumn{4}{|c|}{$D m d^{m d x} /$ Large $^{m y d-/-}$ vs $D m d^{m d x}$ 21dias } \\
\hline $\begin{array}{l}\text { Fold } \\
\text { Change }\end{array}$ & Symbol & Entrez Gene Name & Location \\
\hline$-4,193$ & $\begin{array}{l}\text { Mup1 (includes } \\
\text { others) }\end{array}$ & major urinary protein 1 & Extracellular Space \\
\hline$-4,136$ & $\begin{array}{l}\text { Mup1 (includes } \\
\text { others) }\end{array}$ & major urinary protein 1 & Extracellular Space \\
\hline$-4,079$ & $\begin{array}{l}\text { Mup1 (includes } \\
\text { others) }\end{array}$ & major urinary protein 1 & Extracellular Space \\
\hline$-3,999$ & $\begin{array}{l}\text { Mup1 (includes } \\
\text { others) }\end{array}$ & major urinary protein 1 & Extracellular Space \\
\hline$-3,995$ & $\begin{array}{l}\text { Mup1 (includes } \\
\text { others) }\end{array}$ & major urinary protein 1 & Extracellular Space \\
\hline$-3,991$ & $\begin{array}{l}\text { Mup1 (includes } \\
\text { others) }\end{array}$ & major urinary protein 1 & Extracellular Space \\
\hline$-3,939$ & $\begin{array}{l}\text { Mup1 (includes } \\
\text { others) }\end{array}$ & major urinary protein 1 & Extracellular Space \\
\hline$-3,796$ & $\begin{array}{l}\text { Mup1 (includes } \\
\text { others) }\end{array}$ & major urinary protein 1 & Extracellular Space \\
\hline$-3,470$ & $\begin{array}{l}\text { Mup1 (includes } \\
\text { others) }\end{array}$ & major urinary protein 1 & Extracellular Space \\
\hline$-2,691$ & Pydc3/Pydc4 & pyrin domain containing 4 & Other \\
\hline$-2,471$ & $\begin{array}{l}\text { Ms4a4b (includes } \\
\text { others) }\end{array}$ & membrane-spanning 4-domains, subfamily $A$, member 4B & Plasma Membrane \\
\hline$-2,185$ & $\begin{array}{l}\text { Ifi204 (includes } \\
\text { others) }\end{array}$ & interferon activated gene 204 & Nucleus \\
\hline$-2,132$ & PRND & prion protein 2 (dublet) & Plasma Membrane \\
\hline$-2,068$ & NNAT & neuronatin & Plasma Membrane \\
\hline$-2,056$ & Retnla & resistin like alpha & Extracellular Space \\
\hline$-1,910$ & LARGE & like-glycosyltransferase & Cytoplasm \\
\hline$-1,877$ & IFI44 & interferon-induced protein 44 & Cytoplasm \\
\hline$-1,826$ & CXCL9 & chemokine (C-X-C motif) ligand 9 & Extracellular Space \\
\hline$-1,825$ & CD28 & CD28 molecule & Plasma Membrane \\
\hline$-1,812$ & SLAMF7 & SLAM family member 7 & Plasma Membrane \\
\hline$-1,692$ & CYP4F2 & cytochrome P450, family 4, subfamily F, polypeptide 2 & Cytoplasm \\
\hline$-1,680$ & HLA-DQB1 & major histocompatibility complex, class II, DQ beta 1 & Plasma Membrane \\
\hline$-1,672$ & A630033H20Rik & RIKEN cDNA A630033H20 gene & Plasma Membrane \\
\hline$-1,651$ & APLNR & apelin receptor & Plasma Membrane \\
\hline$-1,642$ & CCR2 & chemokine ( $\mathrm{C}-\mathrm{C}$ motif) receptor 2 & Plasma Membrane \\
\hline$-1,637$ & PMP2 & peripheral myelin protein 2 & Cytoplasm \\
\hline$-1,556$ & $\begin{array}{l}\text { Gbp6 (includes } \\
\text { others) }\end{array}$ & guanylate binding protein 6 & Cytoplasm \\
\hline$-1,541$ & HLA-B & major histocompatibility complex, class I, B & Plasma Membrane \\
\hline$-1,525$ & Fcrls & Fc receptor-like S, scavenger receptor & Plasma Membrane \\
\hline$-1,506$ & AW112010 & expressed sequence AW112010 & Other \\
\hline$-1,503$ & OAS1 & 2'-5'-oligoadenylate synthetase $1,40 / 46 \mathrm{kDa}$ & Cytoplasm \\
\hline$-1,438$ & HLA-DRB1 & major histocompatibility complex, class II, DR beta 1 & Plasma Membrane \\
\hline$-1,427$ & HLA-DMA & major histocompatibility complex, class II, DM alpha & Plasma Membrane \\
\hline$-1,425$ & Gm4841 & predicted gene 4841 & Other \\
\hline$-1,403$ & Gm5431 & predicted gene 5431 & Other \\
\hline$-1,397$ & HPSE & heparanase & Plasma Membrane \\
\hline$-1,385$ & CLEC7A & C-type lectin domain family 7 , member A & Plasma Membrane \\
\hline$-1,366$ & LGI1 & leucine-rich, glioma inactivated 1 & Plasma Membrane \\
\hline$-1,359$ & DDX60 & DEAD (Asp-Glu-Ala-Asp) box polypeptide 60 & Cytoplasm \\
\hline$-1,348$ & Klri1 & killer cell lectin-like receptor family I member 1 & Plasma Membrane \\
\hline$-1,335$ & TLR1 & toll-like receptor 1 & Plasma Membrane \\
\hline$-1,332$ & HERC6 & $\begin{array}{l}\text { HECT and RLD domain containing E3 ubiquitin protein ligase family } \\
\text { member } 6\end{array}$ & Cytoplasm \\
\hline$-1,330$ & GIMAP4 & GTPase, IMAP family member 4 & Nucleus \\
\hline$-1,318$ & MSS51 & MSS51 mitochondrial translational activator & Other \\
\hline$-1,296$ & KLRD1 & killer cell lectin-like receptor subfamily $D$, member 1 & Plasma Membrane \\
\hline$-1,282$ & LY9 & lymphocyte antigen 9 & Plasma Membrane \\
\hline$-1,281$ & 5330426P16Rik & RIKEN CDNA 5330426P16 gene & Other \\
\hline$-1,264$ & Zfp125 & zinc finger protein 125 & Nucleus \\
\hline$-1,258$ & GPR114 & G protein-coupled receptor 114 & Plasma Membrane \\
\hline$-1,226$ & 9930111J21Rik2 & RIKEN cDNA 9930111J21 gene 2 & Other \\
\hline$-1,226$ & CLEC2D & C-type lectin domain family 2 , member D & Plasma Membrane \\
\hline$-1,217$ & TNFSF10 & tumor necrosis factor (ligand) superfamily, member 10 & Extracellular Space \\
\hline$-1,194$ & PTPLAD2 & protein tyrosine phosphatase-like $\mathrm{A}$ domain containing 2 & Other \\
\hline$-1,190$ & SCIMP & SLP adaptor and CSK interacting membrane protein & Plasma Membrane \\
\hline$-1,186$ & GBP4 & guanylate binding protein 4 & Cytoplasm \\
\hline$-1,185$ & $\mathrm{H} 2-\mathrm{T} 22$ & histocompatibility $2, T$ region locus 22 & Other \\
\hline
\end{tabular}




\begin{tabular}{|c|c|c|c|}
\hline$-1,166$ & CCR3 & chemokine (C-C motif) receptor 3 & Plasma Membrane \\
\hline$-1,160$ & MS4A7 & membrane-spanning 4-domains, subfamily $A$, member 7 & Other \\
\hline$-1,154$ & NABP1 & nucleic acid binding protein 1 & Nucleus \\
\hline$-1,142$ & $\begin{array}{l}\text { Klrb1c (includes } \\
\text { others) }\end{array}$ & killer cell lectin-like receptor subfamily B member 1C & Plasma Membrane \\
\hline$-1,136$ & Abcg3 & ATP-binding cassette, sub-family G (WHITE), member 3 & Plasma Membrane \\
\hline$-1,126$ & CD48 & CD48 molecule & Plasma Membrane \\
\hline$-1,121$ & CYSLTR1 & cysteinyl leukotriene receptor 1 & Plasma Membrane \\
\hline$-1,088$ & CD47 & CD47 molecule & Plasma Membrane \\
\hline$-1,081$ & ST8SIA4 & ST8 alpha-N-acetyl-neuraminide alpha-2,8-sialyltransferase 4 & Cytoplasm \\
\hline$-1,079$ & $\begin{array}{l}\text { Zfp932 (includes } \\
\text { others) }\end{array}$ & zinc finger protein 932 & Nucleus \\
\hline$-1,069$ & MS4A14 & membrane-spanning 4-domains, subfamily A, member 14 & Other \\
\hline$-1,066$ & C5orf28 & chromosome 5 open reading frame 28 & Other \\
\hline$-1,057$ & GBP5 & guanylate binding protein 5 & Plasma Membrane \\
\hline$-1,056$ & B3GNT3 & UDP-GlcNAc:betaGal beta-1,3-N-acetylglucosaminyltransferase 3 & Cytoplasm \\
\hline$-1,050$ & MARCKS & myristoylated alanine-rich protein kinase $\mathrm{C}$ substrate & Plasma Membrane \\
\hline$-1,049$ & C1orf54 & chromosome 1 open reading frame 54 & Other \\
\hline$-1,031$ & RNPEP & arginyl aminopeptidase (aminopeptidase B) & Cytoplasm \\
\hline$-1,013$ & TMEM229B & transmembrane protein $229 \mathrm{~B}$ & Other \\
\hline$-0,98$ & Snora34 & small nucleolar RNA, H/ACA box 34 & Other \\
\hline$-0,979$ & CLEC11A & C-type lectin domain family 11 , member A & Extracellular Space \\
\hline$-0,973$ & DTX3L & deltex 3-like (Drosophila) & Cytoplasm \\
\hline$-0,963$ & Gm10808 & predicted gene 10808 & Other \\
\hline$-0,923$ & HEXB & hexosaminidase B (beta polypeptide) & Cytoplasm \\
\hline$-0,923$ & MYCT1 & myc target 1 & Nucleus \\
\hline$-0,904$ & ZNF14 & zinc finger protein 14 & Nucleus \\
\hline$-0,9$ & Clec2e & C-type lectin domain family 2 , member e & Plasma Membrane \\
\hline$-0,892$ & TLR3 & toll-like receptor 3 & Plasma Membrane \\
\hline$-0,883$ & CA8 & carbonic anhydrase VIII & Cytoplasm \\
\hline$-0,879$ & XCR1 & chemokine ( $\mathrm{C}$ motif) receptor 1 & Plasma Membrane \\
\hline$-0,877$ & PLEKHA2 & $\begin{array}{l}\text { pleckstrin homology domain containing, family A (phosphoinositide } \\
\text { binding specific) member } 2\end{array}$ & Cytoplasm \\
\hline$-0,865$ & PCP4L1 & Purkinje cell protein 4 like 1 & Other \\
\hline$-0,854$ & Rny3 & RNA, Y3 small cytoplasmic (associated with Ro protein) & Other \\
\hline$-0,853$ & TET1 & tet methylcytosine dioxygenase 1 & Nucleus \\
\hline$-0,845$ & NMI & $\mathrm{N}$-myc (and STAT) interactor & Cytoplasm \\
\hline$-0,839$ & TAF1D & $\begin{array}{l}\text { TATA box binding protein (TBP)-associated factor, RNA } \\
\text { polymerase I, } D, 41 \mathrm{kDa}\end{array}$ & Nucleus \\
\hline$-0,83$ & AS3MT & arsenic ( +3 oxidation state) methyltransferase & Cytoplasm \\
\hline$-0,827$ & SIAE & sialic acid acetylesterase & Cytoplasm \\
\hline$-0,815$ & CPXM1 & carboxypeptidase X (M14 family), member 1 & Extracellular Space \\
\hline$-0,806$ & GREM2 & gremlin 2, DAN family BMP antagonist & Extracellular Space \\
\hline$-0,789$ & Tlr11 & toll-like receptor 11 & Plasma Membrane \\
\hline$-0,78$ & SLC46A3 & solute carrier family 46 , member 3 & Extracellular Space \\
\hline$-0,777$ & MINA & MYC induced nuclear antigen & Nucleus \\
\hline$-0,765$ & NAALAD2 & $\mathrm{N}$-acetylated alpha-linked acidic dipeptidase 2 & Plasma Membrane \\
\hline$-0,758$ & SFT2D1 & SFT2 domain containing 1 & Other \\
\hline$-0,755$ & IL15 & interleukin 15 & Extracellular Space \\
\hline$-0,752$ & HEXA & hexosaminidase A (alpha polypeptide) & Cytoplasm \\
\hline$-0,749$ & SLC9A7 & $\begin{array}{l}\text { solute carrier family } 9 \text {, subfamily A (NHE7, cation proton antiporter } \\
\text { 7), member } 7\end{array}$ & Cytoplasm \\
\hline$-0,747$ & GADD45GIP1 & $\begin{array}{l}\text { growth arrest and DNA-damage-inducible, gamma interacting } \\
\text { protein } 1\end{array}$ & Nucleus \\
\hline$-0,745$ & Lipo1/Lipo4 & lipase, member $\mathrm{O} 1$ & Other \\
\hline$-0,743$ & C1QL3 & complement component 1 , q subcomponent-like 3 & Extracellular Space \\
\hline$-0,739$ & ARHGAP18 & Rho GTPase activating protein 18 & Cytoplasm \\
\hline$-0,736$ & UBE2V2 & ubiquitin-conjugating enzyme E2 variant 2 & Cytoplasm \\
\hline$-0,735$ & BCL6B & B-cell CLL/lymphoma 6, member B & Nucleus \\
\hline$-0,73$ & 9030619P08Rik & RIKEN CDNA 9030619P08 gene & Other \\
\hline$-0,723$ & BACE2 & beta-site APP-cleaving enzyme 2 & Cytoplasm \\
\hline$-0,703$ & REPS2 & RALBP1 associated Eps domain containing 2 & Cytoplasm \\
\hline$-0,691$ & SFT2D1 & SFT2 domain containing 1 & Other \\
\hline$-0,691$ & SFT2D1 & SFT2 domain containing 1 & Other \\
\hline$-0,684$ & HAUS8 & HAUS augmin-like complex, subunit 8 & Cytoplasm \\
\hline$-0,682$ & HPS5 & Hermansky-Pudlak syndrome 5 & Cytoplasm \\
\hline$-0,656$ & RWDD2B & RWD domain containing $2 \mathrm{~B}$ & Other \\
\hline$-0,639$ & 1110001A16Rik & RIKEN CDNA $1110001 \mathrm{~A} 16$ gene & Other \\
\hline$-0,61$ & KLHL28 & kelch-like family member 28 & Other \\
\hline$-0,604$ & AVEN & apoptosis, caspase activation inhibitor & Nucleus \\
\hline$-0,58$ & SPPL2A & signal peptide peptidase like $2 \mathrm{~A}$ & Plasma Membrane \\
\hline$-0,579$ & DERL2 & derlin 2 & Cytoplasm \\
\hline
\end{tabular}




\begin{tabular}{rlll}
\hline$-\mathbf{0 , 5 6 1}$ & SLC35A1 & solute carrier family 35 (CMP-sialic acid transporter), member A1 & Cytoplasm \\
$-\mathbf{0 , 4 7 4}$ & C9orf64 & chromosome 9 open reading frame 64 & Other \\
$\mathbf{0 , 7 7 9}$ & Gm10548 & ribosomal protein L29 pseudogene & Other \\
$\mathbf{0 , 8 5 3}$ & OCEL1 & occludin/ELL domain containing 1 & Other \\
$\mathbf{0 , 9 5 7}$ & $8430429 K 09 R i k$ & RIKEN CDNA 8430429K09 gene & Other \\
$\mathbf{1 , 4 4 5}$ & Snord53 & small nucleolar RNA, C/D box 53 & Other \\
$\mathbf{1 , 4 6 9}$ & CSRP3 & cysteine and glycine-rich protein 3 (cardiac LIM protein) & Nucleus \\
$\mathbf{1 , 7 8 5}$ & VSIG4 & V-set and immunoglobulin domain containing 4 & Plasma Membrane \\
\hline
\end{tabular}




\begin{tabular}{|c|c|c|c|}
\hline \multicolumn{4}{|c|}{$D m d^{m d x} /$ Large $^{m y d-/-}$ vs Large $e^{m y d-/-} 21$ dias } \\
\hline $\begin{array}{l}\text { Fold } \\
\text { Change }\end{array}$ & Symbol & Entrez Gene Name & Location \\
\hline$-1,948$ & HLA-DRA & major histocompatibility complex, class II, DR alpha & Plasma Membrane \\
\hline$-1,667$ & PMP2 & peripheral myelin protein 2 & Cytoplasm \\
\hline$-1,515$ & MSS51 & MSS51 mitochondrial translational activator & Other \\
\hline$-1,483$ & PTTG1 & pituitary tumor-transforming 1 & Nucleus \\
\hline$-1,349$ & Tpsab1 & tryptase alpha/beta 1 & Nucleus \\
\hline$-1,238$ & GLO1 & glyoxalase I & Cytoplasm \\
\hline$-1,185$ & Gsta4 & glutathione S-transferase, alpha 4 & Cytoplasm \\
\hline$-1,183$ & GLO1 & glyoxalase I & Cytoplasm \\
\hline 0,983 & APOC2 & apolipoprotein C-II & Extracellular Space \\
\hline 1,175 & Olfr1372-ps1 & olfactory receptor 1372 , pseudogene 1 & Other \\
\hline 1,243 & NXPE4 & neurexophilin and PC-esterase domain family, member 4 & Extracellular Space \\
\hline 1,290 & C10orf11 & chromosome 10 open reading frame 11 & Other \\
\hline 1,300 & PRG4 & proteoglycan 4 & Extracellular Space \\
\hline 1,345 & Snord53 & small nucleolar RNA, C/D box 53 & Other \\
\hline 1,578 & GAS5 & growth arrest-specific 5 (non-protein coding) & Other \\
\hline 3,864 & Chi313/Chi314 & chitinase 3-like 3 & Extracellular Space \\
\hline
\end{tabular}




\begin{tabular}{|c|c|c|c|}
\hline \multicolumn{4}{|c|}{$D m d^{m d x}$ vs C57BL 3 meses } \\
\hline $\begin{array}{l}\text { Fold } \\
\text { Change }\end{array}$ & Symbol & Entrez Gene Name & Location \\
\hline 1,274 & $\begin{array}{l}\text { Sirpb1a (includes } \\
\text { others) }\end{array}$ & signal-regulatory protein beta $1 \mathrm{~A}$ & Plasma Membrane \\
\hline 1,343 & Lyz1/Lyz2 & lysozyme 2 & Cytoplasm \\
\hline 1,383 & IL13RA1 & interleukin 13 receptor, alpha 1 & Plasma Membrane \\
\hline 1,391 & SLC25A24 & $\begin{array}{l}\text { solute carrier family } 25 \text { (mitochondrial carrier; phosphate carrier), } \\
\text { member } 24\end{array}$ & Cytoplasm \\
\hline 1,398 & HGF & hepatocyte growth factor (hepapoietin A; scatter factor) & Extracellular Space \\
\hline 1,402 & SIGLEC1 & sialic acid binding Ig-like lectin 1 , sialoadhesin & Plasma Membrane \\
\hline 1,402 & SIRPA & signal-regulatory protein alpha & Plasma Membrane \\
\hline 1,411 & MYO5A & myosin VA (heavy chain 12 , myoxin) & Cytoplasm \\
\hline 1,412 & APOE & apolipoprotein E & Extracellular Space \\
\hline 1,414 & Oasl2 & $2^{\prime}-5^{\prime}$ oligoadenylate synthetase-like 2 & Other \\
\hline 1,416 & CD300LD & CD300 molecule-like family member $d$ & Plasma Membrane \\
\hline 1,417 & RUNX1 & runt-related transcription factor 1 & Nucleus \\
\hline 1,423 & CSF1R & colony stimulating factor 1 receptor & Plasma Membrane \\
\hline 1,427 & IGSF6 & immunoglobulin superfamily, member 6 & Plasma Membrane \\
\hline 1,436 & CLEC4A & C-type lectin domain family 4 , member $\mathrm{A}$ & Plasma Membrane \\
\hline 1,438 & OAS1 & $2 '-5$-oligoadenylate synthetase $1,40 / 46 \mathrm{kDa}$ & Cytoplasm \\
\hline 1,443 & ITGAM & integrin, alpha $\mathrm{M}$ (complement component 3 receptor 3 subunit) & Plasma Membrane \\
\hline 1,445 & ALCAM & activated leukocyte cell adhesion molecule & Plasma Membrane \\
\hline 1,445 & GRN & granulin & Extracellular Space \\
\hline 1,448 & LPXN & leupaxin & Cytoplasm \\
\hline 1,450 & LOX & lysyl oxidase & Extracellular Space \\
\hline 1,452 & CSTB & cystatin B (stefin B) & Cytoplasm \\
\hline 1,454 & ABCG1 & ATP-binding cassette, sub-family G (WHITE), member 1 & Plasma Membrane \\
\hline 1,456 & Lyz1/Lyz2 & lysozyme 2 & Cytoplasm \\
\hline 1,457 & CD200R1 & CD200 receptor 1 & Plasma Membrane \\
\hline 1,460 & Gm5150 & predicted gene 5150 & Other \\
\hline 1,463 & MYOF & myoferlin & Nucleus \\
\hline 1,465 & B4GALT6 & UDP-Gal:betaGlcNAc beta 1,4- galactosyltransferase, polypeptide 6 & Cytoplasm \\
\hline 1,468 & HLA-DRB1 & major histocompatibility complex, class II, DR beta 1 & Plasma Membrane \\
\hline 1,470 & CYBA & cytochrome b-245, alpha polypeptide & Cytoplasm \\
\hline 1,471 & C5AR1 & complement component 5a receptor 1 & Plasma Membrane \\
\hline 1,477 & CERS6 & ceramide synthase 6 & Nucleus \\
\hline 1,483 & UNC93B1 & unc-93 homolog B1 (C, elegans) & Cytoplasm \\
\hline 1,485 & PLXNC1 & plexin $\mathrm{C} 1$ & Plasma Membrane \\
\hline 1,489 & CYTH4 & cytohesin 4 & Cytoplasm \\
\hline 1,490 & CD74 & $\begin{array}{l}\text { CD74 molecule, major histocompatibility complex, class II invariant } \\
\text { chain }\end{array}$ & Plasma Membrane \\
\hline 1,493 & MYO1F & myosin IF & Cytoplasm \\
\hline 1,495 & RGS18 & regulator of G-protein signaling 18 & Cytoplasm \\
\hline 1,496 & P2RX4 & purinergic receptor $\mathrm{P} 2 \mathrm{X}$, ligand-gated ion channel, 4 & Plasma Membrane \\
\hline 1,501 & LAPTM5 & lysosomal protein transmembrane 5 & Plasma Membrane \\
\hline 1,502 & FABP5 & fatty acid binding protein 5 (psoriasis-associated) & Cytoplasm \\
\hline 1,503 & S100A4 & S100 calcium binding protein A4 & Cytoplasm \\
\hline 1,504 & RASGEF1B & RasGEF domain family, member $1 \mathrm{~B}$ & Other \\
\hline 1,505 & SPI1 & spleen focus forming virus (SFFV) proviral integration oncogene & Nucleus \\
\hline 1,509 & SLC37A2 & $\begin{array}{l}\text { solute carrier family } 37 \text { (glucose- } 6 \text {-phosphate transporter), } \\
\text { member } 2\end{array}$ & Other \\
\hline 1,512 & FABP5 & fatty acid binding protein 5 (psoriasis-associated) & Cytoplasm \\
\hline 1,517 & TMEM106A & transmembrane protein $106 \mathrm{~A}$ & Other \\
\hline 1,527 & 5430435G22Rik & RIKEN cDNA 5430435G22 gene & Cytoplasm \\
\hline 1,534 & DOCK2 & dedicator of cytokinesis 2 & Cytoplasm \\
\hline 1,536 & CYP4F2 & cytochrome P450, family 4, subfamily F, polypeptide 2 & Cytoplasm \\
\hline 1,536 & FYB & FYN binding protein & Nucleus \\
\hline 1,547 & ITGB2 & $\begin{array}{l}\text { integrin, beta } 2 \text { (complement component } 3 \text { receptor } 3 \text { and } 4 \\
\text { subunit) }\end{array}$ & Plasma Membrane \\
\hline 1,548 & HEXB & hexosaminidase B (beta polypeptide) & Cytoplasm \\
\hline 1,555 & HLA-DQB1 & major histocompatibility complex, class II, DQ beta 1 & Plasma Membrane \\
\hline 1,562 & RGS10 & regulator of G-protein signaling 10 & Cytoplasm \\
\hline 1,563 & C1QA & complement component 1 , q subcomponent, $A$ chain & Extracellular Space \\
\hline 1,563 & MRC1 & mannose receptor, $\mathrm{C}$ type 1 & Plasma Membrane \\
\hline 1,563 & PEG3 & paternally expressed 3 & Nucleus \\
\hline 1,564 & Gm5431 & predicted gene 5431 & Other \\
\hline 1,566 & P2RY6 & pyrimidinergic receptor P2Y, G-protein coupled, 6 & Plasma Membrane \\
\hline 1,570 & SLC38A1 & solute carrier family 38 , member 1 & Plasma Membrane \\
\hline 1,572 & CAPN6 & calpain 6 & Cytoplasm \\
\hline 1,578 & Pydc3/Pydc4 & pyrin domain containing 4 & Other \\
\hline 1,582 & IL10RA & interleukin 10 receptor, alpha & Plasma Membrane \\
\hline
\end{tabular}




\begin{tabular}{|c|c|c|c|}
\hline 1,582 & LPCAT2 & lysophosphatidylcholine acyltransferase 2 & Cytoplasm \\
\hline 1,588 & CD48 & CD48 molecule & Plasma Membrane \\
\hline 1,596 & $\begin{array}{l}\text { Tmsb4x (includes } \\
\text { others) }\end{array}$ & thymosin, beta $4, \mathrm{X}$ chromosome & Cytoplasm \\
\hline 1,597 & CCR3 & chemokine (C-C motif) receptor 3 & Plasma Membrane \\
\hline 1,600 & PLEK & pleckstrin & Cytoplasm \\
\hline 1,600 & $\begin{array}{l}\text { Tmsb4x (includes } \\
\text { others) }\end{array}$ & thymosin, beta $4, X$ chromosome & Cytoplasm \\
\hline 1,601 & LY9 & lymphocyte antigen 9 & Plasma Membrane \\
\hline 1,622 & $\begin{array}{l}\text { Ifi204 (includes } \\
\text { others) }\end{array}$ & interferon activated gene 204 & Nucleus \\
\hline 1,629 & RGS1 & regulator of G-protein signaling 1 & Plasma Membrane \\
\hline 1,648 & CYBB & cytochrome b-245, beta polypeptide & Cytoplasm \\
\hline 1,653 & DPEP2 & dipeptidase 2 & Plasma Membrane \\
\hline 1,655 & Nt5dc2 & 5'-nucleotidase domain containing 2 & Other \\
\hline 1,656 & Clec4a1 & C-type lectin domain family 4 , member a1 & Other \\
\hline 1,661 & HPGDS & hematopoietic prostaglandin D synthase & Cytoplasm \\
\hline 1,662 & IFI30 & interferon, gamma-inducible protein 30 & Cytoplasm \\
\hline 1,667 & CLEC12A & C-type lectin domain family 12 , member A & Plasma Membrane \\
\hline 1,671 & HLA-DQA1 & major histocompatibility complex, class II, DQ alpha 1 & Plasma Membrane \\
\hline 1,688 & $\begin{array}{l}\text { Ifi204 (includes } \\
\text { others) }\end{array}$ & interferon activated gene 204 & Nucleus \\
\hline 1,695 & PTPRC & protein tyrosine phosphatase, receptor type, C & Plasma Membrane \\
\hline 1,709 & LCP1 & lymphocyte cytosolic protein 1 (L-plastin) & Cytoplasm \\
\hline 1,718 & LGMN & legumain & Cytoplasm \\
\hline 1,719 & $\mathrm{Bcl} 2 \mathrm{a} 1 \mathrm{c}$ & B cell leukemia/lymphoma 2 related protein A1c & Other \\
\hline 1,725 & Cd52 & CD52 antigen & Other \\
\hline 1,731 & TLR1 & toll-like receptor 1 & Plasma Membrane \\
\hline 1,738 & FCGR2A & Fc fragment of IgG, low affinity IIa, receptor (CD32) & Plasma Membrane \\
\hline 1,739 & ITGAX & integrin, alpha $\mathrm{X}$ (complement component 3 receptor 4 subunit) & Plasma Membrane \\
\hline 1,741 & DCLK1 & doublecortin-like kinase 1 & Other \\
\hline 1,742 & LAT2 & linker for activation of T cells family, member 2 & Plasma Membrane \\
\hline 1,743 & CTSH & cathepsin $\mathrm{H}$ & Cytoplasm \\
\hline 1,745 & CD300C & CD300c molecule & Plasma Membrane \\
\hline 1,749 & Gp49a/Lilrb4 & leukocyte immunoglobulin-like receptor, subfamily B, member 4 & Other \\
\hline 1,753 & HPSE & heparanase & Plasma Membrane \\
\hline 1,757 & Milr1 & mast cell immunoglobulin like receptor 1 & Plasma Membrane \\
\hline 1,757 & PLD4 & phospholipase D family, member 4 & Extracellular Space \\
\hline 1,761 & STAP1 & signal transducing adaptor family member 1 & Cytoplasm \\
\hline 1,762 & $\mathrm{C} 1 \mathrm{QC}$ & complement component 1 , q subcomponent, $\mathrm{C}$ chain & Extracellular Space \\
\hline 1,765 & CCDC141 & coiled-coil domain containing 141 & Other \\
\hline 1,768 & FCGR2B & Fc fragment of IgG, low affinity IIb, receptor (CD32) & Plasma Membrane \\
\hline 1,772 & SPP1 & secreted phosphoprotein 1 & Extracellular Space \\
\hline 1,777 & CXCL16 & chemokine (C-X-C motif) ligand 16 & Extracellular Space \\
\hline 1,779 & TYROBP & TYRO protein tyrosine kinase binding protein & Plasma Membrane \\
\hline 1,789 & TUBB2B & tubulin, beta $2 \mathrm{~B}$ class IIb & Cytoplasm \\
\hline 1,790 & TREM2 & triggering receptor expressed on myeloid cells 2 & Plasma Membrane \\
\hline 1,796 & FCGR1A & Fc fragment of IgG, high affinity Ia, receptor (CD64) & Plasma Membrane \\
\hline 1,803 & BCL2A1 & $\mathrm{BCL2}$-related protein $\mathrm{A} 1$ & Cytoplasm \\
\hline 1,812 & SLC11A1 & $\begin{array}{l}\text { solute carrier family } 11 \text { (proton-coupled divalent metal ion } \\
\text { transporter), member } 1\end{array}$ & Plasma Membrane \\
\hline 1,822 & GLIPR1 & GLI pathogenesis-related 1 & Extracellular Space \\
\hline 1,825 & GPR65 & G protein-coupled receptor 65 & Plasma Membrane \\
\hline 1,826 & SLAMF7 & SLAM family member 7 & Plasma Membrane \\
\hline 1,831 & $\mathrm{BCL} 2 \mathrm{~A} 1$ & $\mathrm{BCL} 2$-related protein $\mathrm{A} 1$ & Cytoplasm \\
\hline 1,834 & IGF2 & insulin-like growth factor 2 (somatomedin A) & Extracellular Space \\
\hline 1,845 & NCKAP1L & NCK-associated protein 1-like & Plasma Membrane \\
\hline 1,846 & ADAM8 & ADAM metallopeptidase domain 8 & Plasma Membrane \\
\hline 1,858 & TUBB6 & tubulin, beta 6 class $V$ & Cytoplasm \\
\hline 1,861 & LIPA & lipase A, lysosomal acid, cholesterol esterase & Cytoplasm \\
\hline 1,869 & FCER1G & $\begin{array}{l}\text { Fc fragment of IgE, high affinity I, receptor for; gamma } \\
\text { polypeptide }\end{array}$ & Plasma Membrane \\
\hline 1,920 & BCL2A1 & $\mathrm{BCL} 2$-related protein $\mathrm{A} 1$ & Cytoplasm \\
\hline 1,933 & SOAT1 & sterol O-acyltransferase 1 & Cytoplasm \\
\hline 1,935 & CHRNG & cholinergic receptor, nicotinic, gamma (muscle) & Plasma Membrane \\
\hline 1,938 & CLEC7A & C-type lectin domain family 7 , member A & Plasma Membrane \\
\hline 1,942 & EMB & embigin & Plasma Membrane \\
\hline 1,944 & $\mathrm{Ccl} 9$ & chemokine ( $\mathrm{C}-\mathrm{C}$ motif) ligand 9 & Extracellular Space \\
\hline 1,955 & $\begin{array}{l}\text { Ifi204 (includes } \\
\text { others) }\end{array}$ & interferon activated gene 204 & Nucleus \\
\hline 1,956 & MMP3 & matrix metallopeptidase 3 (stromelysin 1 , progelatinase) & Extracellular Space \\
\hline 1,960 & ANKRD1 & ankyrin repeat domain 1 (cardiac muscle) & Cytoplasm \\
\hline
\end{tabular}




\begin{tabular}{|c|c|c|c|}
\hline 1,966 & POSTN & periostin, osteoblast specific factor & Extracellular Space \\
\hline 1,987 & C1QB & complement component 1 , q subcomponent, B chain & Extracellular Space \\
\hline 1,994 & FCGR3A & Fc fragment of IgG, low affinity IIIa, receptor (CD16a) & Plasma Membrane \\
\hline 2,006 & CD84 & CD84 molecule & Plasma Membrane \\
\hline 2,007 & CD53 & CD53 molecule & Plasma Membrane \\
\hline 2,017 & APOBEC1 & apolipoprotein B mRNA editing enzyme, catalytic polypeptide 1 & Cytoplasm \\
\hline 2,047 & IL7R & interleukin 7 receptor & Plasma Membrane \\
\hline 2,063 & Gp49a/Lilrb4 & leukocyte immunoglobulin-like receptor, subfamily B, member 4 & Other \\
\hline 2,076 & $\begin{array}{l}\text { Mup1 (includes } \\
\text { others) }\end{array}$ & major urinary protein 1 & Extracellular Space \\
\hline 2,089 & Snord116 & small nucleolar RNA, C/D box 116 & Other \\
\hline 2,091 & MYL4 & myosin, light chain 4, alkali; atrial, embryonic & Cytoplasm \\
\hline 2,094 & CCR2 & chemokine (C-C motif) receptor 2 & Plasma Membrane \\
\hline 2,098 & CCDC141 & coiled-coil domain containing 141 & Other \\
\hline 2,100 & $\begin{array}{l}\text { Mup1 (includes } \\
\text { others) }\end{array}$ & major urinary protein 1 & Extracellular Space \\
\hline 2,130 & $\begin{array}{l}\text { Mup1 (includes } \\
\text { others) }\end{array}$ & major urinary protein 1 & Extracellular Space \\
\hline 2,139 & $\begin{array}{l}\text { Mup1 (includes } \\
\text { others) }\end{array}$ & major urinary protein 1 & Extracellular Space \\
\hline 2,151 & CXCL13 & chemokine (C-X-C motif) ligand 13 & Extracellular Space \\
\hline 2,152 & $\begin{array}{l}\text { Ms4a4b (includes } \\
\text { others) }\end{array}$ & membrane-spanning 4-domains, subfamily $A$, member 4B & Plasma Membrane \\
\hline 2,155 & $\begin{array}{l}\text { Mup1 (includes } \\
\text { others) }\end{array}$ & major urinary protein 1 & Extracellular Space \\
\hline 2,155 & $\begin{array}{l}\text { Mup1 (includes } \\
\text { others) }\end{array}$ & major urinary protein 1 & Extracellular Space \\
\hline 2,159 & $\mathrm{MT} 1 \mathrm{H}$ & metallothionein $1 \mathrm{H}$ & Other \\
\hline 2,184 & Ccl6 & chemokine (C-C motif) ligand 6 & Extracellular Space \\
\hline 2,205 & $\begin{array}{l}\text { Mup1 (includes } \\
\text { others) }\end{array}$ & major urinary protein 1 & Extracellular Space \\
\hline 2,207 & CCR5 & chemokine (C-C motif) receptor 5 (gene/pseudogene) & Plasma Membrane \\
\hline 2,207 & CCR5 & chemokine (C-C motif) receptor 5 (gene/pseudogene) & Plasma Membrane \\
\hline 2,210 & CD180 & CD180 molecule & Plasma Membrane \\
\hline 2,223 & $\begin{array}{l}\text { Mup1 (includes } \\
\text { others) }\end{array}$ & major urinary protein 1 & Extracellular Space \\
\hline 2,230 & ATP6V0D2 & ATPase, $\mathrm{H}+$ transporting, lysosomal $38 \mathrm{kDa}, \mathrm{V} 0$ subunit $\mathrm{d} 2$ & Cytoplasm \\
\hline 2,236 & Clec4a3 & C-type lectin domain family 4 , member a3 & Other \\
\hline 2,249 & MS4A14 & membrane-spanning 4-domains, subfamily $A$, member 14 & Other \\
\hline 2,276 & EMR1 & egf-like module containing, mucin-like, hormone receptor-like 1 & Plasma Membrane \\
\hline 2,279 & Ms4a6c & membrane-spanning 4-domains, subfamily $A$, member $6 \mathrm{C}$ & Other \\
\hline 2,284 & Snord116 & small nucleolar RNA, C/D box 116 & Other \\
\hline 2,284 & Snord116 & small nucleolar RNA, C/D box 116 & Other \\
\hline 2,284 & Snord116 & small nucleolar RNA, C/D box 116 & Other \\
\hline 2,284 & Snord116 & small nucleolar RNA, C/D box 116 & Other \\
\hline 2,284 & Snord116 & small nucleolar RNA, C/D box 116 & Other \\
\hline 2,284 & Snord116 & small nucleolar RNA, C/D box 116 & Other \\
\hline 2,284 & Snord116 & small nucleolar RNA, C/D box 116 & Other \\
\hline 2,284 & Snord116 & small nucleolar RNA, C/D box 116 & Other \\
\hline 2,284 & Snord116 & small nucleolar RNA, C/D box 116 & Other \\
\hline 2,284 & Snord116 & small nucleolar RNA, C/D box 116 & Other \\
\hline 2,284 & Snord116 & small nucleolar RNA, C/D box 116 & Other \\
\hline 2,284 & Snord116 & small nucleolar RNA, C/D box 116 & Other \\
\hline 2,284 & Snord116 & small nucleolar RNA, C/D box 116 & Other \\
\hline 2,284 & Snord116 & small nucleolar RNA, C/D box 116 & Other \\
\hline 2,284 & Snord116 & small nucleolar RNA, C/D box 116 & Other \\
\hline 2,284 & Snord116 & small nucleolar RNA, C/D box 116 & Other \\
\hline 2,284 & Snord116 & small nucleolar RNA, C/D box 116 & Other \\
\hline 2,284 & Snord116 & small nucleolar RNA, C/D box 116 & Other \\
\hline 2,302 & MSR1 & macrophage scavenger receptor 1 & Plasma Membrane \\
\hline 2,303 & PCBD1 & $\begin{array}{l}\text { pterin- } 4 \text { alpha-carbinolamine dehydratase/dimerization cofactor of } \\
\text { hepatocyte nuclear factor } 1 \text { alpha }\end{array}$ & Nucleus \\
\hline 2,344 & Ms4a6b & membrane-spanning 4-domains, subfamily $A$, member $6 B$ & Other \\
\hline 2,360 & Wfdc17 & WAP four-disulfide core domain 17 & Other \\
\hline 2,391 & TIMP1 & TIMP metallopeptidase inhibitor 1 & Extracellular Space \\
\hline 2,434 & CD68 & CD68 molecule & Plasma Membrane \\
\hline 2,485 & MPEG1 & macrophage expressed 1 & Cytoplasm \\
\hline 2,496 & Tlr13 & toll-like receptor 13 & Cytoplasm \\
\hline 2,503 & MS4A4A & membrane-spanning 4-domains, subfamily $A$, member $4 \mathrm{~A}$ & Other \\
\hline 2,505 & $\begin{array}{l}\text { Mup1 (includes } \\
\text { others) }\end{array}$ & major urinary protein 1 & Extracellular Space \\
\hline 2,508 & LY86 & lymphocyte antigen 86 & Plasma Membrane \\
\hline
\end{tabular}




\begin{tabular}{rlll}
\hline $\mathbf{2 , 5 2 0}$ & CCL3L1/CCL3L3 & chemokine (C-C motif) ligand 3-like 1 & Extracellular Space \\
$\mathbf{2 , 5 5 4}$ & C1QTNF3 & C1q and tumor necrosis factor related protein 3 & Extracellular Space \\
$\mathbf{2 , 5 7 6}$ & GAL & galanin/GMAP prepropeptide & Extracellular Space \\
$\mathbf{2 , 6 2 7}$ & TMEM8C & transmembrane protein 8C & Plasma Membrane \\
$\mathbf{2 , 6 5 9}$ & SERPINA3 & $\begin{array}{l}\text { serpin peptidase inhibitor, clade A (alpha-1 antiproteinase, } \\
\text { antitrypsin), member 3 }\end{array}$ & Extracellular Space \\
$\mathbf{2 , 6 6 7}$ & LGALS3 & lectin, galactoside-binding, soluble, 3 & \\
$\mathbf{2 , 7 1 8}$ & PRG4 & proteoglycan 4 & Extracellular Space \\
$\mathbf{2 , 7 2 3}$ & TNNT2 & troponin T type 2 (cardiac) & Extracellular Space \\
$\mathbf{2 , 8 1 3}$ & CTSS & cathepsin S & Cytoplasm \\
$\mathbf{2 , 8 7 4}$ & CCl8 & chemokine (C-C motif) ligand 8 & Cytoplasm \\
$\mathbf{2 , 8 9 6}$ & CCl2 & chemokine (C-C motif) ligand 2 & Extracellular Space \\
$\mathbf{2 , 9 6 8}$ & AKR1E2 & aldo-keto reductase family 1, member E2 & Extracellular Space \\
$\mathbf{3 , 0 0 2}$ & MMP12 & matrix metallopeptidase 12 (macrophage elastase) & Cytoplasm \\
$\mathbf{3 , 0 1 8}$ & MS4A7 & membrane-spanning 4-domains, subfamily A, member 7 & Extracellular Space \\
$\mathbf{3 , 1 3 9}$ & C3AR1 & complement component 3a receptor 1 & Other \\
$\mathbf{3 , 1 9 6}$ & MS4A6A & membrane-spanning 4-domains, subfamily A, member 6A & Plasma Membrane \\
$\mathbf{3 , 2 3 2}$ & MYH3 & myosin, heavy chain 3, skeletal muscle, embryonic & Other \\
$\mathbf{3 , 2 6 4}$ & GPNMB & glycoprotein (transmembrane) nmb & Cytoplasm \\
$\mathbf{3 , 2 6 7}$ & CCL7 & chemokine (C-C motif) ligand 7 & Plasma Membrane \\
\hline & & & Extracellular Space \\
\hline
\end{tabular}




\begin{tabular}{|c|c|c|c|}
\hline \multicolumn{4}{|c|}{ Large $^{m y d-/-}$ vs C57BL 3 meses } \\
\hline $\begin{array}{l}\text { Fold } \\
\text { Change }\end{array}$ & Symbol & Entrez Gene Name & Location \\
\hline$-4,312$ & $\mathrm{Ngp}$ & neutrophilic granule protein & Extracellular Space \\
\hline$-3,853$ & Ahsp & alpha hemoglobin stabilizing protein & Cytoplasm \\
\hline$-3,711$ & S100A8 & S100 calcium binding protein A8 & Cytoplasm \\
\hline$-3,586$ & IBSP & integrin-binding sialoprotein & Extracellular Space \\
\hline$-3,527$ & $\begin{array}{l}\text { Ly6a (includes } \\
\text { others) }\end{array}$ & lymphocyte antigen 6 complex, locus A & Plasma Membrane \\
\hline$-3,342$ & S100A9 & S100 calcium binding protein A9 & Cytoplasm \\
\hline$-3,310$ & $\begin{array}{l}\text { Ly6a (includes } \\
\text { others) }\end{array}$ & lymphocyte antigen 6 complex, locus $A$ & Plasma Membrane \\
\hline$-3,297$ & CA1 & carbonic anhydrase I & Cytoplasm \\
\hline$-3,267$ & LTF & lactotransferrin & Extracellular Space \\
\hline$-3,186$ & Chi3|3/Chi3/4 & chitinase 3 -like 3 & Extracellular Space \\
\hline$-3,026$ & Gypa & glycophorin A & Plasma Membrane \\
\hline$-2,957$ & LCN2 & lipocalin 2 & Extracellular Space \\
\hline$-2,927$ & PPBP & pro-platelet basic protein (chemokine (C-X-C motif) ligand 7) & Extracellular Space \\
\hline$-2,797$ & MPO & myeloperoxidase & Cytoplasm \\
\hline$-2,764$ & $\begin{array}{l}\text { Bglap (includes } \\
\text { others) }\end{array}$ & bone gamma carboxyglutamate protein & Extracellular Space \\
\hline$-2,713$ & CAMP & cathelicidin antimicrobial peptide & Cytoplasm \\
\hline$-2,662$ & SLC4A1 & solute carrier family 4 (anion exchanger), member 1 & Plasma Membrane \\
\hline$-2,080$ & LARGE & like-glycosyltransferase & Cytoplasm \\
\hline$-2,054$ & OSTN & osteocrin & Extracellular Space \\
\hline$-1,876$ & Zfp125 & zinc finger protein 125 & Nucleus \\
\hline$-1,871$ & MSTN & myostatin & Extracellular Space \\
\hline$-1,776$ & PADI2 & peptidyl arginine deiminase, type II & Cytoplasm \\
\hline$-1,699$ & SLC38A3 & solute carrier family 38 , member 3 & Plasma Membrane \\
\hline$-1,680$ & NOS1 & nitric oxide synthase 1 (neuronal) & Cytoplasm \\
\hline$-1,673$ & NXPE4 & neurexophilin and PC-esterase domain family, member 4 & Extracellular Space \\
\hline$-1,493$ & HS3ST5 & heparan sulfate (glucosamine) 3-O-sulfotransferase 5 & Cytoplasm \\
\hline 1,170 & GLIPR1 & GLI pathogenesis-related 1 & Extracellular Space \\
\hline 1,238 & CTSZ & cathepsin Z & Cytoplasm \\
\hline 1,278 & RENBP & renin binding protein & Other \\
\hline 1,284 & ANGPTL1 & angiopoietin-like 1 & Plasma Membrane \\
\hline 1,294 & CLIC1 & chloride intracellular channel 1 & Nucleus \\
\hline 1,303 & LAT2 & linker for activation of $\mathrm{T}$ cells family, member 2 & Plasma Membrane \\
\hline 1,307 & FABP5 & fatty acid binding protein 5 (psoriasis-associated) & Cytoplasm \\
\hline 1,308 & STAB1 & stabilin 1 & Plasma Membrane \\
\hline 1,309 & HLA-DQA1 & major histocompatibility complex, class II, DQ alpha 1 & Plasma Membrane \\
\hline 1,315 & PLTP & phospholipid transfer protein & Extracellular Space \\
\hline 1,317 & CD180 & CD180 molecule & Plasma Membrane \\
\hline 1,318 & CFB & complement factor B & Extracellular Space \\
\hline 1,329 & 5430435G22Rik & RIKEN cDNA 5430435G22 gene & Cytoplasm \\
\hline 1,336 & THBS4 & thrombospondin 4 & Extracellular Space \\
\hline 1,338 & TMEM106A & transmembrane protein $106 \mathrm{~A}$ & Other \\
\hline 1,352 & FABP5 & fatty acid binding protein 5 (psoriasis-associated) & Cytoplasm \\
\hline 1,353 & NPNT & nephronectin & Plasma Membrane \\
\hline 1,355 & MYOF & myoferlin & Nucleus \\
\hline 1,367 & ANXA4 & annexin A4 & Plasma Membrane \\
\hline 1,369 & LAPTM5 & Iysosomal protein transmembrane 5 & Plasma Membrane \\
\hline 1,369 & PTAFR & platelet-activating factor receptor & Plasma Membrane \\
\hline 1,385 & AIF1L & allograft inflammatory factor 1 -like & Plasma Membrane \\
\hline 1,385 & Lyz1/Lyz2 & lysozyme 2 & Cytoplasm \\
\hline 1,391 & Ms4a6c & membrane-spanning 4-domains, subfamily $\mathrm{A}$, member $6 \mathrm{C}$ & Other \\
\hline 1,401 & COL14A1 & collagen, type XIV, alpha 1 & Extracellular Space \\
\hline 1,405 & COL6A3 & collagen, type VI, alpha 3 & Extracellular Space \\
\hline 1,408 & TUBB2B & tubulin, beta 2B class IIb & Cytoplasm \\
\hline 1,414 & $\begin{array}{l}\text { Tmsb4x (includes } \\
\text { others) }\end{array}$ & thymosin, beta $4, X$ chromosome & Cytoplasm \\
\hline 1,419 & COL3Á1 & collagen, type III, alpha 1 & Extracellular Space \\
\hline 1,419 & IL13RA1 & interleukin 13 receptor, alpha 1 & Plasma Membrane \\
\hline 1,422 & COL8A1 & collagen, type VIII, alpha 1 & Extracellular Space \\
\hline 1,426 & MAP1B & microtubule-associated protein $1 \mathrm{~B}$ & Cytoplasm \\
\hline 1,429 & $\begin{array}{l}\text { Tmsb4x (includes } \\
\text { others) }\end{array}$ & thymosin, beta $4, \mathrm{X}$ chromosome & Cytoplasm \\
\hline 1,432 & $\mathrm{BCL} 2 \mathrm{~A} 1$ & $\mathrm{BCL2}$-related protein $\mathrm{A} 1$ & Cytoplasm \\
\hline 1,436 & SOAT1 & sterol O-acyltransferase 1 & Cytoplasm \\
\hline 1,437 & HPGDS & hematopoietic prostaglandin D synthase & Cytoplasm \\
\hline 1,442 & S100A4 & S100 calcium binding protein A4 & Cytoplasm \\
\hline 1,452 & $\mathrm{P} 2 \mathrm{RX} 4$ & purinergic receptor $\mathrm{P} 2 \mathrm{X}$, ligand-gated ion channel, 4 & Plasma Membrane \\
\hline
\end{tabular}




\begin{tabular}{|c|c|c|c|}
\hline 1,453 & CCDC141 & coiled-coil domain containing 141 & Other \\
\hline 1,454 & CD300C & CD300c molecule & Plasma Membrane \\
\hline 1,457 & COL6A5 & collagen, type VI, alpha 5 & Extracellular Space \\
\hline 1,477 & P2RY6 & pyrimidinergic receptor P2Y, G-protein coupled, 6 & Plasma Membrane \\
\hline 1,490 & BCL2A1 & $\mathrm{BCL} 2$-related protein $\mathrm{A} 1$ & Cytoplasm \\
\hline 1,495 & PDPN & podoplanin & Plasma Membrane \\
\hline 1,512 & APOE & apolipoprotein E & Extracellular Space \\
\hline 1,518 & CD74 & $\begin{array}{l}\text { CD74 molecule, major histocompatibility complex, class II invariant } \\
\text { chain }\end{array}$ & Plasma Membrane \\
\hline 1,523 & IFI30 & interferon, gamma-inducible protein 30 & Cytoplasm \\
\hline 1,527 & NCAM1 & neural cell adhesion molecule 1 & Plasma Membrane \\
\hline 1,532 & SLAMF7 & SLAM family member 7 & Plasma Membrane \\
\hline 1,539 & DCLK1 & doublecortin-like kinase 1 & Other \\
\hline 1,541 & ADAM8 & ADAM metallopeptidase domain 8 & Plasma Membrane \\
\hline 1,541 & IL7R & interleukin 7 receptor & Plasma Membrane \\
\hline 1,542 & AKR1B10 & aldo-keto reductase family 1 , member $\mathrm{B} 10$ (aldose reductase) & Cytoplasm \\
\hline 1,542 & CD84 & CD84 molecule & Plasma Membrane \\
\hline 1,542 & MS4A14 & membrane-spanning 4-domains, subfamily A, member 14 & Other \\
\hline 1,556 & ZDBF2 & zinc finger, DBF-type containing 2 & Other \\
\hline 1,559 & Gp49a/Lilrb4 & leukocyte immunoglobulin-like receptor, subfamily B, member 4 & Other \\
\hline 1,572 & CAPN6 & calpain 6 & Cytoplasm \\
\hline 1,582 & MSR1 & macrophage scavenger receptor 1 & Plasma Membrane \\
\hline 1,591 & SFRP1 & secreted frizzled-related protein 1 & Plasma Membrane \\
\hline 1,594 & CILP & $\begin{array}{l}\text { cartilage intermediate layer protein, nucleotide } \\
\text { pyrophosphohydrolase }\end{array}$ & Extracellular Space \\
\hline 1,599 & RGS1 & regulator of G-protein signaling 1 & Plasma Membrane \\
\hline 1,608 & CXCL16 & chemokine (C-X-C motif) ligand 16 & Extracellular Space \\
\hline 1,625 & LGMN & legumain & Cytoplasm \\
\hline 1,626 & VSIG4 & V-set and immunoglobulin domain containing 4 & Plasma Membrane \\
\hline 1,633 & ANPEP & alanyl (membrane) aminopeptidase & Plasma Membrane \\
\hline 1,636 & A930003A15Rik & RIKEN cDNA A930003A15 gene & Other \\
\hline 1,638 & FGL2 & fibrinogen-like 2 & Extracellular Space \\
\hline 1,651 & MYOG & myogenin (myogenic factor 4 ) & Nucleus \\
\hline 1,655 & $\mathrm{Ccl9}$ & chemokine (C-C motif) ligand 9 & Extracellular Space \\
\hline 1,658 & CHRNG & cholinergic receptor, nicotinic, gamma (muscle) & Plasma Membrane \\
\hline 1,662 & PRUNE2 & prune homolog 2 (Drosophila) & Other \\
\hline 1,663 & PEG3 & paternally expressed 3 & Nucleus \\
\hline 1,668 & CHRNA1 & cholinergic receptor, nicotinic, alpha 1 (muscle) & Plasma Membrane \\
\hline 1,673 & Nxpe5 & neurexophilin and PC-esterase domain family, member 5 & Other \\
\hline 1,676 & C1QA & complement component 1 , q subcomponent, A chain & Extracellular Space \\
\hline 1,677 & DPEP2 & dipeptidase 2 & Plasma Membrane \\
\hline 1,727 & SLC11A1 & $\begin{array}{l}\text { solute carrier family } 11 \text { (proton-coupled divalent metal ion } \\
\text { transporter), member } 1\end{array}$ & Plasma Membrane \\
\hline 1,728 & C1QC & complement component 1 , q subcomponent, $\mathrm{C}$ chain & Extracellular Space \\
\hline 1,763 & MFAP4 & microfibrillar-associated protein 4 & Extracellular Space \\
\hline 1,768 & CCDC141 & coiled-coil domain containing 141 & Other \\
\hline 1,775 & POSTN & periostin, osteoblast specific factor & Extracellular Space \\
\hline 1,779 & Wfdc17 & WAP four-disulfide core domain 17 & Other \\
\hline 1,786 & Clec4a3 & C-type lectin domain family 4 , member a3 & Other \\
\hline 1,788 & LIPA & lipase A, lysosomal acid, cholesterol esterase & Cytoplasm \\
\hline 1,792 & PRUNE2 & prune homolog 2 (Drosophila) & Other \\
\hline 1,798 & MS4A4A & membrane-spanning 4-domains, subfamily $A$, member $4 \mathrm{~A}$ & Other \\
\hline 1,810 & C1QB & complement component 1, q subcomponent, $\mathrm{B}$ chain & Extracellular Space \\
\hline 1,812 & EMR1 & egf-like module containing, mucin-like, hormone receptor-like 1 & Plasma Membrane \\
\hline 1,813 & CLEC7A & C-type lectin domain family 7 , member A & Plasma Membrane \\
\hline 1,816 & Tlr13 & toll-like receptor 13 & Cytoplasm \\
\hline 1,834 & $\mathrm{Ccl} 6$ & chemokine ( $\mathrm{C}-\mathrm{C}$ motif) ligand 6 & Extracellular Space \\
\hline 1,849 & MT1E & metallothionein $1 \mathrm{E}$ & Cytoplasm \\
\hline 1,854 & CDKN1A & cyclin-dependent kinase inhibitor $1 \mathrm{~A}$ (p21, Cip1) & Nucleus \\
\hline 1,865 & APOBEC1 & apolipoprotein B mRNA editing enzyme, catalytic polypeptide 1 & Cytoplasm \\
\hline 1,869 & CCL3L1/CCL3L3 & chemokine (C-C motif) ligand 3-like 1 & Extracellular Space \\
\hline 1,881 & CCDC141 & coiled-coil domain containing 141 & Other \\
\hline 1,891 & TUBB6 & tubulin, beta 6 class $\mathrm{V}$ & Cytoplasm \\
\hline 1,892 & TREM2 & triggering receptor expressed on myeloid cells 2 & Plasma Membrane \\
\hline 1,969 & RRAD & Ras-related associated with diabetes & Cytoplasm \\
\hline 1,980 & LY86 & lymphocyte antigen 86 & Plasma Membrane \\
\hline 2,011 & CCR5 & chemokine (C-C motif) receptor 5 (gene/pseudogene) & Plasma Membrane \\
\hline 2,011 & CCR5 & chemokine ( $\mathrm{C}-\mathrm{C}$ motif) receptor 5 (gene/pseudogene) & Plasma Membrane \\
\hline 2,017 & MYL4 & myosin, light chain 4, alkali; atrial, embryonic & Cytoplasm \\
\hline 2,041 & FBLN7 & fibulin 7 & Extracellular Space \\
\hline 2,055 & $\mathrm{Ccl} 2$ & chemokine ( $\mathrm{C}-\mathrm{C}$ motif) ligand 2 & Extracellular Space \\
\hline 2,059 & ITGAX & integrin, alpha $\mathrm{X}$ (complement component 3 receptor 4 subunit) & Plasma Membrane \\
\hline
\end{tabular}




\begin{tabular}{|c|c|c|c|}
\hline 2,062 & MMP19 & matrix metallopeptidase 19 & Extracellular Space \\
\hline 2,084 & CCL7 & chemokine ( $\mathrm{C}-\mathrm{C}$ motif) ligand 7 & Extracellular Space \\
\hline 2,120 & Snord116 & small nucleolar RNA, C/D box 116 & Other \\
\hline 2,172 & CCDC141 & coiled-coil domain containing 141 & Other \\
\hline 2,195 & MPEG1 & macrophage expressed 1 & Cytoplasm \\
\hline 2,216 & ANKRD1 & ankyrin repeat domain 1 (cardiac muscle) & Cytoplasm \\
\hline 2,242 & BAIAP2L1 & BAI1-associated protein 2 -like 1 & Cytoplasm \\
\hline 2,250 & Snord116 & small nucleolar RNA, C/D box 116 & Other \\
\hline 2,250 & Snord116 & small nucleolar RNA, C/D box 116 & Other \\
\hline 2,250 & Snord116 & small nucleolar RNA, C/D box 116 & Other \\
\hline 2,250 & Snord116 & small nucleolar RNA, C/D box 116 & Other \\
\hline 2,250 & Snord116 & small nucleolar RNA, C/D box 116 & Other \\
\hline 2,250 & Snord116 & small nucleolar RNA, C/D box 116 & Other \\
\hline 2,250 & Snord116 & small nucleolar RNA, C/D box 116 & Other \\
\hline 2,250 & Snord116 & small nucleolar RNA, C/D box 116 & Other \\
\hline 2,250 & Snord116 & small nucleolar RNA, C/D box 116 & Other \\
\hline 2,250 & Snord116 & small nucleolar RNA, C/D box 116 & Other \\
\hline 2,250 & Snord116 & small nucleolar RNA, C/D box 116 & Other \\
\hline 2,250 & Snord116 & small nucleolar RNA, C/D box 116 & Other \\
\hline 2,250 & Snord116 & small nucleolar RNA, C/D box 116 & Other \\
\hline 2,250 & Snord116 & small nucleolar RNA, C/D box 116 & Other \\
\hline 2,250 & Snord116 & small nucleolar RNA, C/D box 116 & Other \\
\hline 2,250 & Snord116 & small nucleolar RNA, C/D box 116 & Other \\
\hline 2,250 & Snord116 & small nucleolar RNA, C/D box 116 & Other \\
\hline 2,250 & Snord116 & small nucleolar RNA, C/D box 116 & Other \\
\hline 2,265 & IGF2 & insulin-like growth factor 2 (somatomedin A) & Extracellular Space \\
\hline 2,319 & CD68 & CD68 molecule & Plasma Membrane \\
\hline 2,363 & C1QTNF3 & $\mathrm{C} 1 \mathrm{q}$ and tumor necrosis factor related protein 3 & Extracellular Space \\
\hline 2,368 & MMP3 & matrix metallopeptidase 3 (stromelysin 1, progelatinase) & Extracellular Space \\
\hline 2,370 & TNNT2 & troponin T type 2 (cardiac) & Cytoplasm \\
\hline 2,401 & ATP6V0D2 & ATPase, $\mathrm{H}+$ transporting, lysosomal $38 \mathrm{kDa}, \mathrm{V} 0$ subunit $\mathrm{d} 2$ & Cytoplasm \\
\hline 2,442 & MS4A7 & membrane-spanning 4-domains, subfamily A, member 7 & Other \\
\hline 2,482 & GAL & galanin/GMAP prepropeptide & Extracellular Space \\
\hline 2,513 & MT1H & metallothionein $1 \mathrm{H}$ & Other \\
\hline 2,541 & LGALS3 & lectin, galactoside-binding, soluble, 3 & Extracellular Space \\
\hline 2,640 & $\mathrm{Ccl} 8$ & chemokine (C-C motif) ligand 8 & Extracellular Space \\
\hline 2,682 & MS4A6A & membrane-spanning 4-domains, subfamily $A$, member $6 \mathrm{~A}$ & Other \\
\hline 2,758 & TIMP1 & TIMP metallopeptidase inhibitor 1 & Extracellular Space \\
\hline 2,761 & TMEM8C & transmembrane protein $8 \mathrm{C}$ & Plasma Membrane \\
\hline 2,837 & CTSS & cathepsin S & Cytoplasm \\
\hline 2,854 & C3AR1 & complement component 3a receptor 1 & Plasma Membrane \\
\hline 3,005 & PCBD1 & $\begin{array}{l}\text { pterin- } 4 \text { alpha-carbinolamine dehydratase/dimerization cofactor of } \\
\text { hepatocyte nuclear factor } 1 \text { alpha }\end{array}$ & Nucleus \\
\hline 3,012 & AKR1E2 & aldo-keto reductase family 1 , member E2 & Cytoplasm \\
\hline 3,017 & MYH3 & myosin, heavy chain 3, skeletal muscle, embryonic & Cytoplasm \\
\hline 3,124 & SERPINA3 & $\begin{array}{l}\text { serpin peptidase inhibitor, clade A (alpha-1 antiproteinase, } \\
\text { antitrypsin), member } 3\end{array}$ & Extracellular Space \\
\hline 3,242 & KLK3 & kallikrein-related peptidase 3 & Extracellular Space \\
\hline 3,408 & GPNMB & glycoprotein (transmembrane) $\mathrm{nmb}$ & Plasma Membrane \\
\hline 3,493 & HAL & histidine ammonia-lyase & Cytoplasm \\
\hline 4,038 & MMP12 & matrix metallopeptidase 12 (macrophage elastase) & Extracellular Space \\
\hline 5,988 & HLA-DRA & major histocompatibility complex, class II, DR alpha & Plasma Membrane \\
\hline
\end{tabular}




\begin{tabular}{|c|c|c|c|}
\hline \multicolumn{4}{|c|}{$D_{m d^{m d x}} /$ Large $^{m y d-/-}$ vs C57BL 3 meses } \\
\hline $\begin{array}{l}\text { Fold } \\
\text { Change }\end{array}$ & Symbol & Entrez Gene Name & Location \\
\hline$-5,502$ & Ngp & neutrophilic granule protein & Extracellular Space \\
\hline$-4,207$ & Ahsp & alpha hemoglobin stabilizing protein & Cytoplasm \\
\hline$-3,898$ & S100A8 & S100 calcium binding protein A8 & Cytoplasm \\
\hline$-3,808$ & IBSP & integrin-binding sialoprotein & Extracellular Space \\
\hline$-3,627$ & Gypa & glycophorin A & Plasma Membrane \\
\hline$-3,601$ & LTF & lactotransferrin & Extracellular Space \\
\hline$-3,349$ & $\begin{array}{l}\text { Ly6a (includes } \\
\text { others) }\end{array}$ & lymphocyte antigen 6 complex, locus A & Plasma Membrane \\
\hline$-3,324$ & LCN2 & lipocalin 2 & Extracellular Space \\
\hline$-3,262$ & CA1 & carbonic anhydrase I & Cytoplasm \\
\hline$-3,235$ & S100A9 & S100 calcium binding protein A9 & Cytoplasm \\
\hline$-3,208$ & MPO & myeloperoxidase & Cytoplasm \\
\hline$-3,136$ & OSTN & osteocrin & Extracellular Space \\
\hline$-3,034$ & PPBP & pro-platelet basic protein (chemokine (C-X-C motif) ligand 7) & Extracellular Space \\
\hline$-2,868$ & $\begin{array}{l}\text { Bglap (includes } \\
\text { others) }\end{array}$ & bone gamma carboxyglutamate protein & Extracellular Space \\
\hline$-2,840$ & SLC4A1 & solute carrier family 4 (anion exchanger), member 1 & Plasma Membrane \\
\hline$-2,756$ & CAMP & cathelicidin antimicrobial peptide & Cytoplasm \\
\hline$-2,455$ & NOS1 & nitric oxide synthase 1 (neuronal) & Cytoplasm \\
\hline$-2,417$ & AMD1 & adenosylmethionine decarboxylase 1 & Cytoplasm \\
\hline$-2,397$ & AMD1 & adenosylmethionine decarboxylase 1 & Cytoplasm \\
\hline$-2,390$ & AMD1 & adenosylmethionine decarboxylase 1 & Cytoplasm \\
\hline$-2,382$ & AMD1 & adenosylmethionine decarboxylase 1 & Cytoplasm \\
\hline$-2,284$ & PADI2 & peptidyl arginine deiminase, type II & Cytoplasm \\
\hline$-2,239$ & NETO2 & neuropilin (NRP) and tolloid (TLL)-like 2 & Other \\
\hline$-2,226$ & MSTN & myostatin & Extracellular Space \\
\hline$-2,223$ & ALAS2 & aminolevulinate, delta-, synthase 2 & Cytoplasm \\
\hline$-2,169$ & AMD1 & adenosylmethionine decarboxylase 1 & Cytoplasm \\
\hline$-2,117$ & PTTG1 & pituitary tumor-transforming 1 & Nucleus \\
\hline$-2,077$ & LARGE & like-glycosyltransferase & Cytoplasm \\
\hline$-1,943$ & HS3ST5 & heparan sulfate (glucosamine) 3-O-sulfotransferase 5 & Cytoplasm \\
\hline$-1,925$ & PDE4D & phosphodiesterase 4D, cAMP-specific & Cytoplasm \\
\hline$-1,900$ & SLC38A3 & solute carrier family 38 , member 3 & Plasma Membrane \\
\hline$-1,898$ & $\mathrm{BDH} 1$ & 3-hydroxybutyrate dehydrogenase, type 1 & Cytoplasm \\
\hline$-1,856$ & ASB2 & ankyrin repeat and SOCS box containing 2 & Nucleus \\
\hline$-1,850$ & PPP1R1A & protein phosphatase 1 , regulatory (inhibitor) subunit $1 \mathrm{~A}$ & Cytoplasm \\
\hline$-1,834$ & GDAP1 & ganglioside induced differentiation associated protein 1 & Cytoplasm \\
\hline$-1,782$ & KLHL38 & kelch-like family member 38 & Other \\
\hline$-1,679$ & ASB4 & ankyrin repeat and SOCS box containing 4 & Nucleus \\
\hline$-1,660$ & LRRC14B & leucine rich repeat containing 14B & Other \\
\hline$-1,620$ & PTPN3 & protein tyrosine phosphatase, non-receptor type 3 & Cytoplasm \\
\hline 1,309 & SOX11 & SRY (sex determining region Y)-box 11 & Nucleus \\
\hline 1,313 & VAT1 & vesicle amine transport 1 & Plasma Membrane \\
\hline 1,317 & DSE & dermatan sulfate epimerase & Cytoplasm \\
\hline 1,326 & GAMT & guanidinoacetate $\mathrm{N}$-methyltransferase & Cytoplasm \\
\hline 1,327 & FYB & FYN binding protein & Nucleus \\
\hline 1,339 & TMEM176B & transmembrane protein $176 \mathrm{~B}$ & Other \\
\hline 1,353 & RASGEF1B & RasGEF domain family, member $1 \mathrm{~B}$ & Other \\
\hline 1,357 & SPI1 & spleen focus forming virus (SFFV) proviral integration oncogene & Nucleus \\
\hline 1,365 & LAYN & layilin & Plasma Membrane \\
\hline 1,377 & CD302 & CD302 molecule & Plasma Membrane \\
\hline 1,377 & GLA & galactosidase, alpha & Cytoplasm \\
\hline 1,378 & IGSF10 & immunoglobulin superfamily, member 10 & Other \\
\hline 1,378 & PEG3 & paternally expressed 3 & Nucleus \\
\hline 1,378 & Zim1 & zinc finger, imprinted 1 & Nucleus \\
\hline 1,379 & CLCN5 & chloride channel, voltage-sensitive 5 & Plasma Membrane \\
\hline 1,380 & GUSB & glucuronidase, beta & Cytoplasm \\
\hline 1,386 & CCDC80 & coiled-coil domain containing 80 & Nucleus \\
\hline 1,387 & SRPX & sushi-repeat containing protein, $\mathrm{X}$-linked & Cytoplasm \\
\hline 1,390 & CASP1 & caspase 1 , apoptosis-related cysteine peptidase & Cytoplasm \\
\hline 1,393 & LILRB3 & $\begin{array}{l}\text { leukocyte immunoglobulin-like receptor, subfamily B (with TM and } \\
\text { ITIM domains), member } 3\end{array}$ & Plasma Membrane \\
\hline 1,395 & $\mathrm{H} 19$ & $\begin{array}{l}\text { H19, imprinted maternally expressed transcript (non-protein } \\
\text { coding) }\end{array}$ & Cytoplasm \\
\hline 1,397 & BMPER & BMP binding endothelial regulator & Extracellular Space \\
\hline 1,400 & MMP14 & matrix metallopeptidase 14 (membrane-inserted) & Extracellular Space \\
\hline 1,401 & LITAF & lipopolysaccharide-induced TNF factor & Nucleus \\
\hline 1,405 & CSF2RB & $\begin{array}{l}\text { colony stimulating factor } 2 \text { receptor, beta, low-affinity } \\
\text { (granulocyte-macrophage) }\end{array}$ & Plasma Membrane \\
\hline
\end{tabular}




\begin{tabular}{|c|c|c|c|}
\hline 1,410 & Nt5dc2 & 5'-nucleotidase domain containing 2 & Other \\
\hline 1,414 & CERS6 & ceramide synthase 6 & Nucleus \\
\hline 1,417 & PLXNB2 & plexin B2 & Plasma Membrane \\
\hline 1,418 & CCDC109B & coiled-coil domain containing 109B & Cytoplasm \\
\hline 1,423 & RAB31 & RAB31, member RAS oncogene family & Cytoplasm \\
\hline 1,424 & CYBB & cytochrome b-245, beta polypeptide & Cytoplasm \\
\hline 1,433 & LCP1 & lymphocyte cytosolic protein 1 (L-plastin) & Cytoplasm \\
\hline 1,434 & VASH2 & vasohibin 2 & Cytoplasm \\
\hline 1,437 & TUBB2B & tubulin, beta $2 \mathrm{~B}$ class IIb & Cytoplasm \\
\hline 1,443 & MAN2B1 & mannosidase, alpha, class 2B, member 1 & Cytoplasm \\
\hline 1,445 & LUM & lumican & Extracellular Space \\
\hline 1,446 & MYO1F & myosin IF & Cytoplasm \\
\hline 1,447 & COL6A5 & collagen, type VI, alpha 5 & Extracellular Space \\
\hline 1,449 & RASSF4 & Ras association (RalGDS/AF-6) domain family member 4 & Other \\
\hline 1,453 & PIANP & PILR alpha associated neural protein & Other \\
\hline 1,456 & ANGPTL1 & angiopoietin-like 1 & Plasma Membrane \\
\hline 1,456 & $\begin{array}{l}\text { Ifi204 (includes } \\
\text { others) }\end{array}$ & interferon activated gene 204 & Nucleus \\
\hline 1,457 & CXCL9 & chemokine (C-X-C motif) ligand 9 & Extracellular Space \\
\hline 1,457 & FOLR2 & folate receptor 2 (fetal) & Plasma Membrane \\
\hline 1,462 & CLIC1 & chloride intracellular channel 1 & Nucleus \\
\hline 1,473 & PLAGL1 & pleiomorphic adenoma gene-like 1 & Nucleus \\
\hline 1,474 & CFB & complement factor B & Extracellular Space \\
\hline 1,476 & PROS1 & protein S (alpha) & Extracellular Space \\
\hline 1,478 & LPXN & leupaxin & Cytoplasm \\
\hline 1,479 & B4GALT6 & UDP-Gal:betaGlcNAc beta 1,4- galactosyltransferase, polypeptide 6 & Cytoplasm \\
\hline 1,479 & Cd52 & CD52 antigen & Other \\
\hline 1,484 & LAPTM5 & lysosomal protein transmembrane 5 & Plasma Membrane \\
\hline 1,490 & MFAP2 & microfibrillar-associated protein 2 & Extracellular Space \\
\hline 1,505 & TBXAS1 & thromboxane A synthase 1 (platelet) & Plasma Membrane \\
\hline 1,511 & CTSZ & cathepsin Z & Cytoplasm \\
\hline 1,512 & SLC15A3 & solute carrier family 15 (oligopeptide transporter), member 3 & Cytoplasm \\
\hline 1,516 & CD300LD & CD300 molecule-like family member $\mathrm{d}$ & Plasma Membrane \\
\hline 1,517 & GATM & glycine amidinotransferase (L-arginine:glycine amidinotransferase) & Cytoplasm \\
\hline 1,520 & LACC1 & laccase (multicopper oxidoreductase) domain containing 1 & Other \\
\hline 1,523 & CD48 & CD48 molecule & Plasma Membrane \\
\hline 1,523 & SLC25A24 & $\begin{array}{l}\text { solute carrier family } 25 \text { (mitochondrial carrier; phosphate carrier), } \\
\text { member } 24\end{array}$ & Cytoplasm \\
\hline 1,526 & CD300LD & CD300 molecule-like family member $\mathrm{d}$ & Plasma Membrane \\
\hline 1,527 & SLC9A9 & $\begin{array}{l}\text { solute carrier family } 9 \text {, subfamily A (NHE9, cation proton antiporter } \\
\text { 9), member } 9\end{array}$ & Cytoplasm \\
\hline 1,529 & SGPL1 & sphingosine-1-phosphate lyase 1 & Cytoplasm \\
\hline 1,540 & ITGB2 & $\begin{array}{l}\text { integrin, beta } 2 \text { (complement component } 3 \text { receptor } 3 \text { and } 4 \\
\text { subunit) }\end{array}$ & Plasma Membrane \\
\hline 1,541 & $\begin{array}{l}\text { Ifi204 (includes } \\
\text { others) }\end{array}$ & interferon activated gene 204 & Nucleus \\
\hline 1,543 & CAPG & capping protein (actin filament), gelsolin-like & Nucleus \\
\hline 1,544 & ANXA4 & annexin A4 & Plasma Membrane \\
\hline 1,545 & CLEC12A & C-type lectin domain family 12 , member $A$ & Plasma Membrane \\
\hline 1,548 & CTHRC1 & collagen triple helix repeat containing 1 & Extracellular Space \\
\hline 1,553 & TNFRSF1B & tumor necrosis factor receptor superfamily, member $1 \mathrm{~B}$ & Plasma Membrane \\
\hline 1,559 & PRUNE2 & prune homolog 2 (Drosophila) & Other \\
\hline 1,561 & HPSE & heparanase & Plasma Membrane \\
\hline 1,562 & HEXB & hexosaminidase B (beta polypeptide) & Cytoplasm \\
\hline 1,570 & $\begin{array}{l}\text { Ifi204 (includes } \\
\text { others) }\end{array}$ & interferon activated gene 204 & Nucleus \\
\hline 1,572 & NCAM1 & neural cell adhesion molecule 1 & Plasma Membrane \\
\hline 1,584 & MYO5A & myosin VA (heavy chain 12 , myoxin) & Cytoplasm \\
\hline 1,587 & SIRPA & signal-regulatory protein alpha & Plasma Membrane \\
\hline 1,593 & PDGFRL & platelet-derived growth factor receptor-like & Plasma Membrane \\
\hline 1,596 & IL10RA & interleukin 10 receptor, alpha & Plasma Membrane \\
\hline 1,596 & RUNX1 & runt-related transcription factor 1 & Nucleus \\
\hline 1,603 & SFRP1 & secreted frizzled-related protein 1 & Plasma Membrane \\
\hline 1,604 & ANGPTL4 & angiopoietin-like 4 & Extracellular Space \\
\hline 1,604 & Eef1a1 & eukaryotic translation elongation factor 1 alpha 1 & Cytoplasm \\
\hline 1,606 & LAIR1 & leukocyte-associated immunoglobulin-like receptor 1 & Plasma Membrane \\
\hline 1,607 & UNC93B1 & unc-93 homolog B1 (C, elegans) & Cytoplasm \\
\hline 1,610 & R3HDML & R3H domain containing-like & Other \\
\hline 1,612 & CDKN1A & cyclin-dependent kinase inhibitor $1 \mathrm{~A}$ (p21, Cip1) & Nucleus \\
\hline 1,612 & KDELR3 & $\begin{array}{l}\text { KDEL (Lys-Asp-Glu-Leu) endoplasmic reticulum protein retention } \\
\text { receptor } 3\end{array}$ & Cytoplasm \\
\hline 1,615 & CSF2RB & colony stimulating factor 2 receptor, beta, low-affinity & Plasma Membrane \\
\hline
\end{tabular}




\begin{tabular}{|c|c|c|c|}
\hline & & (granulocyte-macrophage) & \\
\hline 1,616 & Milr1 & mast cell immunoglobulin like receptor 1 & Plasma Membrane \\
\hline 1,624 & LOX & lysyl oxidase & Extracellular Space \\
\hline 1,630 & FGL2 & fibrinogen-like 2 & Extracellular Space \\
\hline 1,632 & Lyz1/Lyz2 & lysozyme 2 & Cytoplasm \\
\hline 1,634 & CYTH4 & cytohesin 4 & Cytoplasm \\
\hline 1,640 & RENBP & renin binding protein & Other \\
\hline 1,643 & CYBA & cytochrome b-245, alpha polypeptide & Cytoplasm \\
\hline 1,643 & STAB1 & stabilin 1 & Plasma Membrane \\
\hline 1,645 & EMB & embigin & Plasma Membrane \\
\hline 1,648 & AIF1L & allograft inflammatory factor 1 -like & Plasma Membrane \\
\hline 1,648 & CLEC4A & C-type lectin domain family 4 , member A & Plasma Membrane \\
\hline 1,649 & CCDC141 & coiled-coil domain containing 141 & Other \\
\hline 1,650 & CAPN6 & calpain 6 & Cytoplasm \\
\hline 1,654 & PLTP & phospholipid transfer protein & Extracellular Space \\
\hline 1,654 & SLC37A2 & $\begin{array}{l}\text { solute carrier family } 37 \text { (glucose-6-phosphate transporter), } \\
\text { member } 2\end{array}$ & Other \\
\hline 1,656 & GRN & granulin & Extracellular Space \\
\hline 1,659 & TNIP3 & TNFAIP3 interacting protein 3 & Other \\
\hline 1,662 & C5AR1 & complement component 5a receptor 1 & Plasma Membrane \\
\hline 1,662 & CSTB & cystatin B (stefin B) & Cytoplasm \\
\hline 1,667 & HGF & hepatocyte growth factor (hepapoietin A; scatter factor) & Extracellular Space \\
\hline 1,676 & CCDC141 & coiled-coil domain containing 141 & Other \\
\hline 1,680 & RGS10 & regulator of G-protein signaling 10 & Cytoplasm \\
\hline 1,689 & COL6A3 & collagen, type VI, alpha 3 & Extracellular Space \\
\hline 1,691 & CD200R1 & CD200 receptor 1 & Plasma Membrane \\
\hline 1,694 & CHRNA1 & cholinergic receptor, nicotinic, alpha 1 (muscle) & Plasma Membrane \\
\hline 1,695 & CD300LD & CD300 molecule-like family member $d$ & Plasma Membrane \\
\hline 1,699 & $\mathrm{Bcl} 2 \mathrm{a} 1 \mathrm{c}$ & $\mathrm{B}$ cell leukemia/lymphoma 2 related protein $\mathrm{A} 1 \mathrm{C}$ & Other \\
\hline 1,699 & GPR65 & G protein-coupled receptor 65 & Plasma Membrane \\
\hline 1,713 & PRUNE2 & prune homolog 2 (Drosophila) & Other \\
\hline 1,716 & RGS1 & regulator of G-protein signaling 1 & Plasma Membrane \\
\hline 1,720 & GLIPR1 & GLI pathogenesis-related 1 & Extracellular Space \\
\hline 1,723 & CPXM1 & carboxypeptidase X (M14 family), member 1 & Extracellular Space \\
\hline 1,726 & CSF1R & colony stimulating factor 1 receptor & Plasma Membrane \\
\hline 1,729 & HLA-DRB1 & major histocompatibility complex, class II, DR beta 1 & Plasma Membrane \\
\hline 1,733 & IL7R & interleukin 7 receptor & Plasma Membrane \\
\hline 1,734 & FCGR3A & Fc fragment of IgG, low affinity IIIa, receptor (CD16a) & Plasma Membrane \\
\hline 1,739 & A930003A15Rik & RIKEN cDNA A930003A15 gene & Other \\
\hline 1,740 & PTAFR & platelet-activating factor receptor & Plasma Membrane \\
\hline 1,743 & CD200R1L & CD200 receptor 1 -like & Plasma Membrane \\
\hline 1,746 & COL3A1 & collagen, type III, alpha 1 & Extracellular Space \\
\hline 1,749 & MRC1 & mannose receptor, $\mathrm{C}$ type 1 & Plasma Membrane \\
\hline 1,750 & IL13RA1 & interleukin 13 receptor, alpha 1 & Plasma Membrane \\
\hline 1,753 & TMEM106A & transmembrane protein $106 \mathrm{~A}$ & Other \\
\hline 1,755 & PLD4 & phospholipase D family, member 4 & Extracellular Space \\
\hline 1,757 & CCDC141 & coiled-coil domain containing 141 & Other \\
\hline 1,758 & Lyz1/Lyz2 & lysozyme 2 & Cytoplasm \\
\hline 1,760 & SLAMF7 & SLAM family member 7 & Plasma Membrane \\
\hline 1,767 & AW551984 & expressed sequence AW551984 & Other \\
\hline 1,769 & TM4SF19 & transmembrane $4 \mathrm{~L}$ six family member 19 & Other \\
\hline 1,774 & MYH8 & myosin, heavy chain 8 , skeletal muscle, perinatal & Cytoplasm \\
\hline 1,780 & MYOF & myoferlin & Nucleus \\
\hline 1,782 & LRRC17 & leucine rich repeat containing 17 & Extracellular Space \\
\hline 1,785 & CHRNG & cholinergic receptor, nicotinic, gamma (muscle) & Plasma Membrane \\
\hline 1,792 & NCKAP1L & NCK-associated protein 1-like & Plasma Membrane \\
\hline 1,794 & THBS4 & thrombospondin 4 & Extracellular Space \\
\hline 1,795 & PDPN & podoplanin & Plasma Membrane \\
\hline 1,798 & ALCAM & activated leukocyte cell adhesion molecule & Plasma Membrane \\
\hline 1,798 & CD53 & CD53 molecule & Plasma Membrane \\
\hline 1,802 & COL14A1 & collagen, type XIV, alpha 1 & Extracellular Space \\
\hline 1,803 & TLR1 & toll-like receptor 1 & Plasma Membrane \\
\hline 1,810 & 5430435G22Rik & RIKEN cDNA $5430435 \mathrm{G} 22$ gene & Cytoplasm \\
\hline 1,811 & HLA-DQB1 & major histocompatibility complex, class II, DQ beta 1 & Plasma Membrane \\
\hline 1,832 & CD180 & CD180 molecule & Plasma Membrane \\
\hline 1,836 & Nxpe5 & neurexophilin and PC-esterase domain family, member 5 & Other \\
\hline 1,846 & Ms4a6c & membrane-spanning 4-domains, subfamily $\mathrm{A}$, member $6 \mathrm{C}$ & Other \\
\hline 1,857 & ANPEP & alanyl (membrane) aminopeptidase & Plasma Membrane \\
\hline 1,863 & FABP5 & fatty acid binding protein 5 (psoriasis-associated) & Cytoplasm \\
\hline 1,864 & Gp49a/Lilrb4 & leukocyte immunoglobulin-like receptor, subfamily B, member 4 & Other \\
\hline 1,865 & LAT2 & linker for activation of T cells family, member 2 & Plasma Membrane \\
\hline 1,867 & P2RX4 & purinergic receptor $\mathrm{P} 2 \mathrm{X}$, ligand-gated ion channel, 4 & Plasma Membrane \\
\hline
\end{tabular}




\begin{tabular}{|c|c|c|c|}
\hline 1,868 & $\begin{array}{l}\text { Tmsb4x (includes } \\
\text { others) }\end{array}$ & thymosin, beta $4, \mathrm{X}$ chromosome & Cytoplasm \\
\hline 1,869 & FCER1G & $\begin{array}{l}\text { Fc fragment of IgE, high affinity I, receptor for; gamma } \\
\text { polypeptide }\end{array}$ & Plasma Membrane \\
\hline 1,878 & MT1E & metallothionein $1 \mathrm{E}$ & Cytoplasm \\
\hline 1,880 & FCGR1A & Fc fragment of IgG, high affinity Ia, receptor (CD64) & Plasma Membrane \\
\hline 1,885 & PEG3 & paternally expressed 3 & Nucleus \\
\hline 1,895 & CLEC6A & C-type lectin domain family 6 , member A & Plasma Membrane \\
\hline 1,895 & CTSH & cathepsin $\mathrm{H}$ & Cytoplasm \\
\hline 1,899 & APOE & apolipoprotein $\mathrm{E}$ & Extracellular Space \\
\hline 1,911 & HLA-DQA1 & major histocompatibility complex, class II, DQ alpha 1 & Plasma Membrane \\
\hline 1,914 & FABP5 & fatty acid binding protein 5 (psoriasis-associated) & Cytoplasm \\
\hline 1,917 & MYOG & myogenin (myogenic factor 4) & Nucleus \\
\hline 1,920 & BAIAP2L1 & BAI1-associated protein 2-like 1 & Cytoplasm \\
\hline 1,920 & DCLK1 & doublecortin-like kinase 1 & Other \\
\hline 1,920 & $\begin{array}{l}\text { Tmsb4x (includes } \\
\text { others) }\end{array}$ & thymosin, beta $4, X$ chromosome & Cytoplasm \\
\hline 1,946 & TYROBP & TYRO protein tyrosine kinase binding protein & Plasma Membrane \\
\hline 1,953 & CD74 & $\begin{array}{l}\text { CD74 molecule, major histocompatibility complex, class II invariant } \\
\text { chain }\end{array}$ & Plasma Membrane \\
\hline 1,978 & S100A4 & S100 calcium binding protein A4 & Cytoplasm \\
\hline 1,981 & IFI30 & interferon, gamma-inducible protein 30 & Cytoplasm \\
\hline 1,981 & LGMN & legumain & Cytoplasm \\
\hline 1,987 & BCL2A1 & $\mathrm{BCL} 2$-related protein $\mathrm{A} 1$ & Cytoplasm \\
\hline 1,988 & Fcrls & Fc receptor-like S, scavenger receptor & Plasma Membrane \\
\hline 1,999 & P2RY6 & pyrimidinergic receptor P2Y, G-protein coupled, 6 & Plasma Membrane \\
\hline 2,019 & FCGR2A & Fc fragment of IgG, low affinity IIa, receptor (CD32) & Plasma Membrane \\
\hline 2,020 & COL8A1 & collagen, type VIII, alpha 1 & Extracellular Space \\
\hline 2,021 & HPGDS & hematopoietic prostaglandin D synthase & Cytoplasm \\
\hline 2,031 & MFAP4 & microfibrillar-associated protein 4 & Extracellular Space \\
\hline 2,032 & BCL2A1 & $\mathrm{BCL} 2$-related protein $\mathrm{A} 1$ & Cytoplasm \\
\hline 2,040 & ADAM8 & ADAM metallopeptidase domain 8 & Plasma Membrane \\
\hline 2,044 & SOAT1 & sterol O-acyltransferase 1 & Cytoplasm \\
\hline 2,046 & CILP & $\begin{array}{l}\text { cartilage intermediate layer protein, nucleotide } \\
\text { pyrophosphohydrolase }\end{array}$ & Extracellular Space \\
\hline 2,051 & AKR1B10 & aldo-keto reductase family 1 , member B10 (aldose reductase) & Cytoplasm \\
\hline 2,056 & TUBB2B & tubulin, beta $2 \mathrm{~B}$ class IIb & Cytoplasm \\
\hline 2,060 & Clec4a1 & C-type lectin domain family 4 , member a1 & Other \\
\hline 2,063 & CD84 & CD84 molecule & Plasma Membrane \\
\hline 2,070 & CXCL16 & chemokine (C-X-C motif) ligand 16 & Extracellular Space \\
\hline 2,072 & $\mathrm{BCL} 2 \mathrm{~A} 1$ & BCL2-related protein A1 & Cytoplasm \\
\hline 2,073 & SLC11A1 & $\begin{array}{l}\text { solute carrier family } 11 \text { (proton-coupled divalent metal ion } \\
\text { transporter), member } 1\end{array}$ & Plasma Membrane \\
\hline 2,074 & FCGR2B & Fc fragment of IgG, low affinity IIb, receptor (CD32) & Plasma Membrane \\
\hline 2,083 & Snord53 & small nucleolar RNA, C/D box 53 & Other \\
\hline 2,089 & Ms4a6b & membrane-spanning 4-domains, subfamily $A$, member $6 B$ & Other \\
\hline 2,094 & RRAD & Ras-related associated with diabetes & Cytoplasm \\
\hline 2,116 & $\mathrm{CD} 300 \mathrm{C}$ & CD300c molecule & Plasma Membrane \\
\hline 2,138 & CCR2 & chemokine (C-C motif) receptor 2 & Plasma Membrane \\
\hline 2,139 & MSR1 & macrophage scavenger receptor 1 & Plasma Membrane \\
\hline 2,154 & CCDC141 & coiled-coil domain containing 141 & Other \\
\hline 2,190 & C1QA & complement component 1, q subcomponent, A chain & Extracellular Space \\
\hline 2,202 & DPEP2 & dipeptidase 2 & Plasma Membrane \\
\hline 2,206 & TUBB6 & tubulin, beta 6 class $\mathrm{V}$ & Cytoplasm \\
\hline 2,209 & $\mathrm{C} 1 \mathrm{QC}$ & complement component 1 , q subcomponent, $\mathrm{C}$ chain & Extracellular Space \\
\hline 2,222 & C1QB & complement component 1 , q subcomponent, $B$ chain & Extracellular Space \\
\hline 2,234 & $\mathrm{Ccl} 9$ & chemokine (C-C motif) ligand 9 & Extracellular Space \\
\hline 2,246 & Gp49a/Lilrb4 & leukocyte immunoglobulin-like receptor, subfamily B, member 4 & Other \\
\hline 2,246 & LIPA & lipase A, lysosomal acid, cholesterol esterase & Cytoplasm \\
\hline 2,265 & APOBEC1 & apolipoprotein B mRNA editing enzyme, catalytic polypeptide 1 & Cytoplasm \\
\hline 2,266 & MS4A4A & membrane-spanning 4-domains, subfamily $A$, member $4 A$ & Other \\
\hline 2,275 & MMP19 & matrix metallopeptidase 19 & Extracellular Space \\
\hline 2,280 & ZDBF2 & zinc finger, DBF-type containing 2 & Other \\
\hline 2,282 & FBLN7 & fibulin 7 & Extracellular Space \\
\hline 2,326 & Ccl6 & chemokine (C-C motif) ligand 6 & Extracellular Space \\
\hline 2,349 & MS4A14 & membrane-spanning 4-domains, subfamily $\mathrm{A}$, member 14 & Other \\
\hline 2,366 & IGF2 & insulin-like growth factor 2 (somatomedin A) & Extracellular Space \\
\hline 2,366 & TREM2 & triggering receptor expressed on myeloid cells 2 & Plasma Membrane \\
\hline 2,401 & Tlr13 & toll-like receptor 13 & Cytoplasm \\
\hline 2,448 & MYL4 & myosin, light chain 4, alkali; atrial, embryonic & Cytoplasm \\
\hline 2,516 & CLEC7A & C-type lectin domain family 7 , member A & Plasma Membrane \\
\hline 2,523 & POSTN & periostin, osteoblast specific factor & Extracellular Space \\
\hline
\end{tabular}




\begin{tabular}{|c|c|c|c|}
\hline 2,524 & Clec4a3 & C-type lectin domain family 4 , member a3 & Other \\
\hline 2,532 & $\mathrm{Ccl} 2$ & chemokine ( $\mathrm{C}-\mathrm{C}$ motif) ligand 2 & Extracellular Space \\
\hline 2,532 & PRG4 & proteoglycan 4 & Extracellular Space \\
\hline 2,536 & MT1H & metallothionein $1 \mathrm{H}$ & Other \\
\hline 2,546 & LY86 & lymphocyte antigen 86 & Plasma Membrane \\
\hline 2,562 & Wfdc17 & WAP four-disulfide core domain 17 & Other \\
\hline 2,585 & VSIG4 & V-set and immunoglobulin domain containing 4 & Plasma Membrane \\
\hline 2,591 & ANKRD1 & ankyrin repeat domain 1 (cardiac muscle) & Cytoplasm \\
\hline 2,591 & EMR1 & egf-like module containing, mucin-like, hormone receptor-like 1 & Plasma Membrane \\
\hline 2,615 & ITGAX & integrin, alpha $\mathrm{X}$ (complement component 3 receptor 4 subunit) & Plasma Membrane \\
\hline 2,667 & CCL3L1/CCL3L3 & chemokine ( $\mathrm{C}-\mathrm{C}$ motif) ligand 3-like 1 & Extracellular Space \\
\hline 2,677 & CD68 & CD68 molecule & Plasma Membrane \\
\hline 2,688 & MPEG1 & macrophage expressed 1 & Cytoplasm \\
\hline 2,738 & TMEM8C & transmembrane protein $8 \mathrm{C}$ & Plasma Membrane \\
\hline 2,763 & HAL & histidine ammonia-lyase & Cytoplasm \\
\hline 2,764 & CCR5 & chemokine (C-C motif) receptor 5 (gene/pseudogene) & Plasma Membrane \\
\hline 2,764 & CCR5 & chemokine (C-C motif) receptor 5 (gene/pseudogene) & Plasma Membrane \\
\hline 2,788 & ATP6V0D2 & ATPase, $\mathrm{H}+$ transporting, lysosomal $38 \mathrm{kDa}$, V0 subunit $\mathrm{d} 2$ & Cytoplasm \\
\hline 2,878 & $\mathrm{CCL} 7$ & chemokine ( $\mathrm{C}-\mathrm{C}$ motif) ligand 7 & Extracellular Space \\
\hline 2,929 & MMP3 & matrix metallopeptidase 3 (stromelysin 1, progelatinase) & Extracellular Space \\
\hline 2,934 & TNNT2 & troponin T type 2 (cardiac) & Cytoplasm \\
\hline 2,943 & GAL & galanin/GMAP prepropeptide & Extracellular Space \\
\hline 3,032 & SERPINA3 & $\begin{array}{l}\text { serpin peptidase inhibitor, clade A (alpha-1 antiproteinase, } \\
\text { antitrypsin), member } 3\end{array}$ & Extracellular Space \\
\hline 3,035 & LGALS3 & lectin, galactoside-binding, soluble, 3 & Extracellular Space \\
\hline 3,061 & Snord116 & small nucleolar RNA, C/D box 116 & Other \\
\hline 3,086 & C1QTNF3 & $\mathrm{C} 1 \mathrm{q}$ and tumor necrosis factor related protein 3 & Extracellular Space \\
\hline 3,164 & TIMP1 & TIMP metallopeptidase inhibitor 1 & Extracellular Space \\
\hline 3,219 & Snord116 & small nucleolar RNA, C/D box 116 & Other \\
\hline 3,219 & Snord116 & small nucleolar RNA, C/D box 116 & Other \\
\hline 3,219 & Snord116 & small nucleolar RNA, C/D box 116 & Other \\
\hline 3,219 & Snord116 & small nucleolar RNA, C/D box 116 & Other \\
\hline 3,219 & Snord116 & small nucleolar RNA, C/D box 116 & Other \\
\hline 3,219 & Snord116 & small nucleolar RNA, C/D box 116 & Other \\
\hline 3,219 & Snord116 & small nucleolar RNA, C/D box 116 & Other \\
\hline 3,219 & Snord116 & small nucleolar RNA, C/D box 116 & Other \\
\hline 3,219 & Snord116 & small nucleolar RNA, C/D box 116 & Other \\
\hline 3,219 & Snord116 & small nucleolar RNA, C/D box 116 & Other \\
\hline 3,219 & Snord116 & small nucleolar RNA, C/D box 116 & Other \\
\hline 3,219 & Snord116 & small nucleolar RNA, C/D box 116 & Other \\
\hline 3,219 & Snord116 & small nucleolar RNA, C/D box 116 & Other \\
\hline 3,219 & Snord116 & small nucleolar RNA, C/D box 116 & Other \\
\hline 3,219 & Snord116 & small nucleolar RNA, C/D box 116 & Other \\
\hline 3,219 & Snord116 & small nucleolar RNA, C/D box 116 & Other \\
\hline 3,219 & Snord116 & small nucleolar RNA, C/D box 116 & Other \\
\hline 3,219 & Snord116 & small nucleolar RNA, C/D box 116 & Other \\
\hline 3,256 & CTSS & cathepsin S & Cytoplasm \\
\hline 3,321 & PCBD1 & $\begin{array}{l}\text { pterin- } 4 \text { alpha-carbinolamine dehydratase/dimerization cofactor of } \\
\text { hepatocyte nuclear factor } 1 \text { alpha }\end{array}$ & Nucleus \\
\hline 3,355 & C3AR1 & complement component 3a receptor 1 & Plasma Membrane \\
\hline 3,370 & MS4A7 & membrane-spanning 4-domains, subfamily A, member 7 & Other \\
\hline 3,394 & MS4A6A & membrane-spanning 4-domains, subfamily $\mathrm{A}$, member $6 \mathrm{~A}$ & Other \\
\hline 3,547 & MYH3 & myosin, heavy chain 3, skeletal muscle, embryonic & Cytoplasm \\
\hline 3,552 & GPNMB & glycoprotein (transmembrane) nmb & Plasma Membrane \\
\hline 3,621 & $\mathrm{Ccl} 8$ & chemokine ( $\mathrm{C}-\mathrm{C}$ motif) ligand 8 & Extracellular Space \\
\hline 4,676 & MMP12 & matrix metallopeptidase 12 (macrophage elastase) & Extracellular Space \\
\hline 5,298 & HLA-DRA & major histocompatibility complex, class II, DR alpha & Plasma Membrane \\
\hline
\end{tabular}




\begin{tabular}{|c|c|c|c|}
\hline \multicolumn{4}{|c|}{$D m d^{m d x} /$ Large $^{m y d-/-}$ vs Dmd $d^{m d x} 3$ meses } \\
\hline $\begin{array}{l}\text { Fold } \\
\text { Change }\end{array}$ & Symbol & Entrez Gene Name & Location \\
\hline$-1,791$ & $\begin{array}{l}\text { Mup1 (includes } \\
\text { others) }\end{array}$ & major urinary protein 1 & Extracellular Space \\
\hline$-1,681$ & LARGE & like-glycosyltransferase & Cytoplasm \\
\hline$-1,592$ & $\begin{array}{l}\text { Mup1 (includes } \\
\text { others) }\end{array}$ & major urinary protein 1 & Extracellular Space \\
\hline$-1,548$ & $\begin{array}{l}\text { Mup1 (includes } \\
\text { others) }\end{array}$ & major urinary protein 1 & Extracellular Space \\
\hline$-1,512$ & $\begin{array}{l}\text { Mup1 (includes } \\
\text { others) }\end{array}$ & major urinary protein 1 & Extracellular Space \\
\hline$-1,480$ & $\begin{array}{l}\text { Mup1 (includes } \\
\text { others) }\end{array}$ & major urinary protein 1 & Extracellular Space \\
\hline$-1,465$ & $\begin{array}{l}\text { Mup1 (includes } \\
\text { others) }\end{array}$ & major urinary protein 1 & Extracellular Space \\
\hline$-1,452$ & $\begin{array}{l}\text { Mup1 (includes } \\
\text { others) }\end{array}$ & major urinary protein 1 & Extracellular Space \\
\hline$-1,443$ & $\begin{array}{l}\text { Mup1 (includes } \\
\text { others) }\end{array}$ & major urinary protein 1 & Extracellular Space \\
\hline$-1,441$ & $\begin{array}{l}\text { Mup1 (includes } \\
\text { others) }\end{array}$ & major urinary protein 1 & Extracellular Space \\
\hline$-1,313$ & Pydc3/Pydc4 & pyrin domain containing 4 & Other \\
\hline$-1,041$ & C5orf28 & chromosome 5 open reading frame 28 & Other \\
\hline$-0,94$ & B3GNT3 & UDP-GIcNAc:betaGal beta-1,3-N-acetylglucosaminyltransferase 3 & Cytoplasm \\
\hline$-0,812$ & ARNTL & aryl hydrocarbon receptor nuclear translocator-like & Nucleus \\
\hline$-0,783$ & Klri1 & killer cell lectin-like receptor family I member 1 & Plasma Membrane \\
\hline 0,59 & CCDC80 & coiled-coil domain containing 80 & Nucleus \\
\hline 0,609 & Gm266 & predicted gene 266 & Other \\
\hline 0,618 & GEM & GTP binding protein overexpressed in skeletal muscle & Plasma Membrane \\
\hline 0,638 & PER3 & period circadian clock 3 & Nucleus \\
\hline 0,658 & SRPX & sushi-repeat containing protein, $\mathrm{X}$-linked & Cytoplasm \\
\hline 0,685 & MATN2 & matrilin 2 & Extracellular Space \\
\hline 0,699 & ADCYAP1R1 & $\begin{array}{l}\text { adenylate cyclase activating polypeptide } 1 \text { (pituitary) receptor type } \\
\text { I }\end{array}$ & Plasma Membrane \\
\hline 0,711 & ANGPTL4 & angiopoietin-like 4 & Extracellular Space \\
\hline 0,721 & ENO2 & enolase 2 (gamma, neuronal) & Cytoplasm \\
\hline 0,738 & CACNA1A & calcium channel, voltage-dependent, $\mathrm{P} / \mathrm{Q}$ type, alpha $1 \mathrm{~A}$ subunit & Plasma Membrane \\
\hline 0,741 & COL15A1 & collagen, type XV, alpha 1 & Extracellular Space \\
\hline 0,799 & HLF & hepatic leukemia factor & Nucleus \\
\hline 0,805 & MFAP2 & microfibrillar-associated protein 2 & Extracellular Space \\
\hline 0,814 & NID2 & nidogen 2 (osteonidogen) & Extracellular Space \\
\hline 0,829 & SYNDIG1 & synapse differentiation inducing 1 & Plasma Membrane \\
\hline 0,847 & AEBP1 & AE binding protein 1 & Nucleus \\
\hline 0,868 & 9030619P08Rik & RIKEN cDNA 9030619P08 gene & Other \\
\hline 0,871 & COL14A1 & collagen, type XIV, alpha 1 & Extracellular Space \\
\hline 0,874 & COL8A1 & collagen, type VIII, alpha 1 & Extracellular Space \\
\hline 0,878 & PAMR1 & $\begin{array}{l}\text { peptidase domain containing associated with muscle regeneration } \\
1\end{array}$ & Extracellular Space \\
\hline 0,892 & FIBIN & fin bud initiation factor homolog (zebrafish) & Other \\
\hline 0,914 & MMP3 & matrix metallopeptidase 3 (stromelysin 1, progelatinase) & Extracellular Space \\
\hline 0,977 & AW551984 & expressed sequence AW551984 & Other \\
\hline 0,981 & COL6A6 & collagen, type VI, alpha 6 & Extracellular Space \\
\hline 0,982 & AF357355 & SnORNA AF357355 & Other \\
\hline 1,005 & PDGFRL & platelet-derived growth factor receptor-like & Plasma Membrane \\
\hline 1,018 & COL6A3 & collagen, type VI, alpha 3 & Extracellular Space \\
\hline 1,035 & CPXM1 & carboxypeptidase X (M14 family), member 1 & Extracellular Space \\
\hline 1,042 & OCEL1 & occludin/ELL domain containing 1 & Other \\
\hline 1,100 & FBLN7 & fibulin 7 & Extracellular Space \\
\hline 1,104 & DLK1 & delta-like 1 homolog (Drosophila) & Extracellular Space \\
\hline 1,108 & $\begin{array}{l}\text { Klrb1c (includes } \\
\text { others) }\end{array}$ & killer cell lectin-like receptor subfamily B member $1 \mathrm{C}$ & Plasma Membrane \\
\hline 1,149 & CILP & $\begin{array}{l}\text { cartilage intermediate layer protein, nucleotide } \\
\text { pyrophosphohydrolase }\end{array}$ & Extracellular Space \\
\hline 1,172 & Meg3 & maternally expressed 3 & Other \\
\hline 1,271 & PIANP & PILR alpha associated neural protein & Other \\
\hline 1,299 & MMP12 & matrix metallopeptidase 12 (macrophage elastase) & Extracellular Space \\
\hline 1,523 & VSIG4 & V-set and immunoglobulin domain containing 4 & Plasma Membrane \\
\hline 1,738 & Snord53 & small nucleolar RNA, C/D box 53 & Other \\
\hline
\end{tabular}




\begin{tabular}{|c|c|c|c|}
\hline \multicolumn{4}{|c|}{$D m d^{m d x} /$ Large $^{m y d-/-}$ vs Large $e^{m y d-/-} 3$ meses } \\
\hline $\begin{array}{l}\text { Fold } \\
\text { Change }\end{array}$ & Symbol & Entrez Gene Name & Location \\
\hline$-3,464$ & KLK3 & kallikrein-related peptidase 3 & Extracellular Space \\
\hline$-1,565$ & PTTG1 & pituitary tumor-transforming 1 & Nucleus \\
\hline$-1,379$ & KLK3 & kallikrein-related peptidase 3 & Extracellular Space \\
\hline 1,172 & Lyz1/Lyz2 & lysozyme 2 & Cytoplasm \\
\hline 1,406 & GAS5 & growth arrest-specific 5 (non-protein coding) & Other \\
\hline 1,480 & C10orf11 & chromosome 10 open reading frame 11 & Other \\
\hline 1,486 & NXPE4 & neurexophilin and PC-esterase domain family, member 4 & Extracellular Space \\
\hline 1,488 & SH2D1B & SH2 domain containing $1 \mathrm{~B}$ & Cytoplasm \\
\hline 1,552 & HLA-B & major histocompatibility complex, class I, B & Plasma Membrane \\
\hline 1,663 & Snord53 & small nucleolar RNA, C/D box 53 & Other \\
\hline 1,674 & RETNLB & resistin like beta & Extracellular Space \\
\hline 2,426 & Zfp125 & zinc finger protein 125 & Nucleus \\
\hline
\end{tabular}




\begin{tabular}{|c|c|c|c|}
\hline \multicolumn{4}{|c|}{$D m d^{m d x}$ vs C57BL 6 meses } \\
\hline $\begin{array}{l}\text { Fold } \\
\text { Change }\end{array}$ & Symbol & Entrez Gene Name & Location \\
\hline$-3,796$ & OSTN & osteocrin & Extracellular Space \\
\hline$-2,107$ & PTTG1 & pituitary tumor-transforming 1 & Nucleus \\
\hline$-2,104$ & LGI1 & leucine-rich, glioma inactivated 1 & Plasma Membrane \\
\hline$-2,026$ & Ces1d & carboxylesterase 1D & Cytoplasm \\
\hline$-1,970$ & PLA2G5 & phospholipase $A 2$, group $V$ & Extracellular Space \\
\hline$-1,871$ & PPP1R1A & protein phosphatase 1 , regulatory (inhibitor) subunit $1 \mathrm{~A}$ & Cytoplasm \\
\hline$-1,767$ & LRRC52 & leucine rich repeat containing 52 & Other \\
\hline$-1,755$ & FASN & fatty acid synthase & Cytoplasm \\
\hline$-1,718$ & ELOVL6 & ELOVL fatty acid elongase 6 & Cytoplasm \\
\hline$-1,656$ & ASB4 & ankyrin repeat and SOCS box containing 4 & Nucleus \\
\hline$-1,654$ & OTUB2 & OTU domain, ubiquitin aldehyde binding 2 & Other \\
\hline$-1,603$ & ALAS2 & aminolevulinate, delta-, synthase 2 & Cytoplasm \\
\hline$-1,566$ & 4933409K07Rik & RIKEN cDNA 4933409K07 gene & Other \\
\hline$-1,561$ & 4933409K07Rik & RIKEN cDNA 4933409K07 gene & Other \\
\hline$-1,538$ & PCP4L1 & Purkinje cell protein 4 like 1 & Other \\
\hline$-1,475$ & HOMER2 & homer homolog 2 (Drosophila) & Plasma Membrane \\
\hline$-1,457$ & Gm3893 & predicted gene 3893 & Other \\
\hline$-1,457$ & Gm3893 & predicted gene 3893 & Other \\
\hline$-1,444$ & MYL3 & myosin, light chain 3, alkali; ventricular, skeletal, slow & Cytoplasm \\
\hline$-1,434$ & $\begin{array}{l}\text { Orm } 1 \text { (includes } \\
\text { others) }\end{array}$ & orosomucoid 1 & Extracellular Space \\
\hline$-1,419$ & DUSP26 & dual specificity phosphatase 26 (putative) & Cytoplasm \\
\hline$-1,382$ & CYP4F22 & cytochrome $\mathrm{P} 450$, family 4 , subfamily $F$, polypeptide 22 & Extracellular Space \\
\hline$-1,360$ & MSTN & myostatin & Extracellular Space \\
\hline$-1,352$ & 4933409K07Rik & RIKEN CDNA 4933409K07 gene & Other \\
\hline$-1,351$ & Gm3893 & predicted gene 3893 & Other \\
\hline$-1,331$ & RHOU & ras homolog family member $U$ & Cytoplasm \\
\hline$-1,324$ & FGFBP1 & fibroblast growth factor binding protein 1 & Extracellular Space \\
\hline$-1,302$ & KAZALD1 & Kazal-type serine peptidase inhibitor domain 1 & Extracellular Space \\
\hline$-1,300$ & PADI2 & peptidyl arginine deiminase, type II & Cytoplasm \\
\hline$-1,298$ & PLAC9 & placenta-specific 9 & Other \\
\hline$-1,298$ & PLAC9 & placenta-specific 9 & Other \\
\hline$-1,297$ & PLAC9 & placenta-specific 9 & Other \\
\hline$-1,279$ & RASD2 & RASD family, member 2 & Cytoplasm \\
\hline$-1,270$ & 4933409K07Rik & RIKEN CDNA 4933409K07 gene & Other \\
\hline$-1,246$ & FRZB & frizzled-related protein & Extracellular Space \\
\hline$-1,242$ & HS3ST5 & heparan sulfate (glucosamine) 3-O-sulfotransferase 5 & Cytoplasm \\
\hline$-1,237$ & DGAT2 & diacylglycerol O-acyltransferase 2 & Cytoplasm \\
\hline$-1,237$ & FAM213A & family with sequence similarity 213 , member $A$ & Extracellular Space \\
\hline$-1,215$ & PRSS55 & protease, serine, 55 & Other \\
\hline$-1,176$ & ACSS1 & acyl-CoA synthetase short-chain family member 1 & Cytoplasm \\
\hline$-1,171$ & 4933409K07Rik & RIKEN cDNA $4933409 K 07$ gene & Other \\
\hline$-1,169$ & LDHB & lactate dehydrogenase $\mathrm{B}$ & Cytoplasm \\
\hline$-1,164$ & $\mathrm{BDH} 1$ & 3-hydroxybutyrate dehydrogenase, type 1 & Cytoplasm \\
\hline$-1,154$ & HOXD10 & homeobox D10 & Nucleus \\
\hline$-1,146$ & METTL11B & methyltransferase like 11B & Other \\
\hline$-1,139$ & ALPK2 & alpha-kinase 2 & Other \\
\hline$-1,139$ & EGF & epidermal growth factor & Extracellular Space \\
\hline$-1,133$ & MICAL2 & $\begin{array}{l}\text { microtubule associated monooxygenase, calponin and LIM domain } \\
\text { containing } 2\end{array}$ & Cytoplasm \\
\hline$-1,130$ & BC048679 & cDNA sequence BC048679 & Other \\
\hline$-1,127$ & $\mathrm{CDH} 4$ & cadherin 4 , type 1 , R-cadherin (retinal) & Plasma Membrane \\
\hline$-1,106$ & ASB2 & ankyrin repeat and SOCS box containing 2 & Nucleus \\
\hline$-1,098$ & LDHB & lactate dehydrogenase B & Cytoplasm \\
\hline$-1,075$ & FZD9 & frizzled family receptor 9 & Plasma Membrane \\
\hline$-1,019$ & Mrgprh & MAS-related GPR, member $\mathrm{H}$ & Plasma Membrane \\
\hline$-1,015$ & PARM1 & prostate androgen-regulated mucin-like protein 1 & Extracellular Space \\
\hline$-1,008$ & DUSP8 & dual specificity phosphatase 8 & Nucleus \\
\hline$-1,007$ & ACSS2 & acyl-CoA synthetase short-chain family member 2 & Cytoplasm \\
\hline$-1,007$ & STK40 & serine/threonine kinase 40 & Cytoplasm \\
\hline$-0,997$ & KLHL38 & kelch-like family member 38 & Other \\
\hline$-0,994$ & SLC4A4 & $\begin{array}{l}\text { solute carrier family } 4 \text { (sodium bicarbonate cotransporter), } \\
\text { member } 4\end{array}$ & Plasma Membrane \\
\hline$-0,982$ & SLC38A3 & solute carrier family 38 , member 3 & Plasma Membrane \\
\hline$-0,976$ & HNMT & histamine $\mathrm{N}$-methyltransferase & Cytoplasm \\
\hline$-0,965$ & ST8SIA5 & ST8 alpha-N-acetyl-neuraminide alpha-2,8-sialyltransferase 5 & Cytoplasm \\
\hline$-0,958$ & EPHX2 & epoxide hydrolase 2 , cytoplasmic & Cytoplasm \\
\hline$-0,929$ & CLIP4 & CAP-GLY domain containing linker protein family, member 4 & Other \\
\hline$-0,922$ & Gm4861 & predicted gene 4861 & Other \\
\hline
\end{tabular}




\begin{tabular}{|c|c|c|c|}
\hline$-0,858$ & OSBPL6 & oxysterol binding protein-like 6 & Cytoplasm \\
\hline$-0,833$ & SLC41A3 & solute carrier family 41 , member 3 & Other \\
\hline$-0,827$ & GPCPD1 & $\begin{array}{l}\text { glycerophosphocholine phosphodiesterase GDE1 homolog (S, } \\
\text { cerevisiae) }\end{array}$ & Other \\
\hline 0,675 & SNX5 & sorting nexin 5 & Cytoplasm \\
\hline 0,676 & IFT122 & intraflagellar transport 122 homolog (Chlamydomonas) & Nucleus \\
\hline 0,681 & MFAP2 & microfibrillar-associated protein 2 & Extracellular Space \\
\hline 0,694 & MDFIC & MyoD family inhibitor domain containing & Nucleus \\
\hline 0,696 & ASAH1 & $\mathrm{N}$-acylsphingosine amidohydrolase (acid ceramidase) 1 & Cytoplasm \\
\hline 0,703 & SULF2 & sulfatase 2 & Plasma Membrane \\
\hline 0,706 & IGSF10 & immunoglobulin superfamily, member 10 & Other \\
\hline 0,714 & RCN1 & reticulocalbin 1, EF-hand calcium binding domain & Cytoplasm \\
\hline 0,725 & PDGFRL & platelet-derived growth factor receptor-like & Plasma Membrane \\
\hline 0,735 & B4GALT5 & UDP-Gal:betaGlcNAc beta 1,4- galactosyltransferase, polypeptide 5 & Cytoplasm \\
\hline 0,741 & CA13 & carbonic anhydrase XIII & Cytoplasm \\
\hline 0,754 & ANXA5 & annexin A5 & Plasma Membrane \\
\hline 0,759 & DAP & death-associated protein & Cytoplasm \\
\hline 0,759 & FUCA1 & fucosidase, alpha-L- 1, tissue & Cytoplasm \\
\hline 0,761 & ARPC1B & actin related protein $2 / 3$ complex, subunit $1 \mathrm{~B}, 41 \mathrm{kDa}$ & Cytoplasm \\
\hline 0,763 & FKBP10 & FK506 binding protein $10,65 \mathrm{kDa}$ & Cytoplasm \\
\hline 0,765 & EMP1 & epithelial membrane protein 1 & Plasma Membrane \\
\hline 0,768 & TBX4 & T-box 4 & Nucleus \\
\hline 0,773 & ECM1 & extracellular matrix protein 1 & Extracellular Space \\
\hline 0,773 & GLTP & glycolipid transfer protein & Cytoplasm \\
\hline 0,773 & SDCBP & syndecan binding protein (syntenin) & Plasma Membrane \\
\hline 0,778 & MGAT2 & $\begin{array}{l}\text { mannosyl (alpha-1,6-)-glycoprotein beta-1,2-N- } \\
\text { acetylglucosaminyltransferase }\end{array}$ & Cytoplasm \\
\hline 0,779 & Sept9 & septin 9 & Cytoplasm \\
\hline 0,78 & Gm6548 & eukaryotic translation elongation factor 1 alpha 1 pseudogene & Other \\
\hline 0,782 & Fmn1 & formin 1 & Other \\
\hline 0,783 & CLCN5 & chloride channel, voltage-sensitive 5 & Plasma Membrane \\
\hline 0,788 & $\begin{array}{l}\text { Ms4a4b (includes } \\
\text { others) }\end{array}$ & membrane-spanning 4-domains, subfamily $\mathrm{A}$, member $4 \mathrm{~B}$ & Plasma Membrane \\
\hline 0,788 & PID1 & phosphotyrosine interaction domain containing 1 & Cytoplasm \\
\hline 0,789 & STEAP2 & STEAP family member 2 , metalloreductase & Plasma Membrane \\
\hline 0,79 & NPM1 & nucleophosmin (nucleolar phosphoprotein B23, numatrin) & Nucleus \\
\hline 0,793 & CD93 & CD93 molecule & Plasma Membrane \\
\hline 0,794 & IL10RB & interleukin 10 receptor, beta & Plasma Membrane \\
\hline 0,797 & CCBE1 & collagen and calcium binding EGF domains 1 & Extracellular Space \\
\hline 0,798 & PPT1 & palmitoyl-protein thioesterase 1 & Cytoplasm \\
\hline 0,799 & SCPEP1 & serine carboxypeptidase 1 & Cytoplasm \\
\hline 0,803 & ABCA1 & ATP-binding cassette, sub-family A ( $A B C 1)$, member 1 & Plasma Membrane \\
\hline 0,805 & MAGED2 & melanoma antigen family $D, 2$ & Plasma Membrane \\
\hline 0,806 & KIAA1598 & KIAA1598 & Other \\
\hline 0,81 & CD63 & CD63 molecule & Plasma Membrane \\
\hline 0,822 & CD300A & CD300a molecule & Plasma Membrane \\
\hline 0,822 & NES & nestin & Cytoplasm \\
\hline 0,823 & FSTL1 & follistatin-like 1 & Extracellular Space \\
\hline 0,824 & PDIA3 & protein disulfide isomerase family $A$, member 3 & Cytoplasm \\
\hline 0,827 & GPR114 & G protein-coupled receptor 114 & Plasma Membrane \\
\hline 0,829 & SRPX2 & sushi-repeat containing protein, $\mathrm{X}$-linked 2 & Cytoplasm \\
\hline 0,831 & P2RX7 & purinergic receptor $\mathrm{P} 2 \mathrm{X}$, ligand-gated ion channel, 7 & Plasma Membrane \\
\hline 0,833 & PLD3 & phospholipase D family, member 3 & Cytoplasm \\
\hline 0,834 & NOSTRIN & nitric oxide synthase trafficking & Cytoplasm \\
\hline 0,835 & CD80 & CD80 molecule & Plasma Membrane \\
\hline 0,835 & RRAD & Ras-related associated with diabetes & Cytoplasm \\
\hline 0,836 & VAT1 & vesicle amine transport 1 & Plasma Membrane \\
\hline 0,838 & FTL & ferritin, light polypeptide & Cytoplasm \\
\hline 0,838 & SLC29A3 & $\begin{array}{l}\text { solute carrier family } 29 \text { (equilibrative nucleoside transporter), } \\
\text { member } 3\end{array}$ & Plasma Membrane \\
\hline 0,843 & ARL11 & ADP-ribosylation factor-like 11 & Other \\
\hline 0,851 & PIP4K2A & phosphatidylinositol-5-phosphate 4-kinase, type II, alpha & Cytoplasm \\
\hline 0,856 & COL5A2 & collagen, type $\mathrm{V}$, alpha 2 & Extracellular Space \\
\hline 0,857 & CTSC & cathepsin C & Cytoplasm \\
\hline 0,86 & CTSB & cathepsin B & Cytoplasm \\
\hline 0,862 & SOX11 & SRY (sex determining region Y)-box 11 & Nucleus \\
\hline 0,864 & CD302 & CD302 molecule & Plasma Membrane \\
\hline 0,865 & Ahnak2 & AHNAK nucleoprotein 2 & Other \\
\hline 0,866 & FTL & ferritin, light polypeptide & Cytoplasm \\
\hline 0,866 & SLAMF8 & SLAM family member 8 & Extracellular Space \\
\hline 0,867 & SAT1 & spermidine/spermine N1-acetyltransferase 1 & Cytoplasm \\
\hline 0,871 & $\mathrm{FTL}$ & ferritin, light polypeptide & Cytoplasm \\
\hline
\end{tabular}




\begin{tabular}{|c|c|c|c|}
\hline 0,876 & ANXA2 & annexin $\mathrm{A} 2$ & Plasma Membrane \\
\hline 0,878 & ARL14EP & ADP-ribosylation factor-like 14 effector protein & Other \\
\hline 0,881 & SH3BP2 & SH3-domain binding protein 2 & Cytoplasm \\
\hline 0,882 & EGFR & epidermal growth factor receptor & Plasma Membrane \\
\hline 0,882 & KDELR3 & $\begin{array}{l}\text { KDEL (Lys-Asp-Glu-Leu) endoplasmic reticulum protein retention } \\
\text { receptor } 3\end{array}$ & Cytoplasm \\
\hline 0,883 & ALCAM & activated leukocyte cell adhesion molecule & Plasma Membrane \\
\hline 0,883 & GAMT & guanidinoacetate $\mathrm{N}$-methyltransferase & Cytoplasm \\
\hline 0,894 & FAM129B & family with sequence similarity 129 , member B & Cytoplasm \\
\hline 0,896 & COL14A1 & collagen, type XIV, alpha 1 & Extracellular Space \\
\hline 0,898 & Nlrp1c-ps & NLR family, pyrin domain containing $1 C$, pseudogene & Other \\
\hline 0,898 & SYTL2 & synaptotagmin-like 2 & Cytoplasm \\
\hline 0,9 & AIF1L & allograft inflammatory factor 1 -like & Plasma Membrane \\
\hline 0,902 & ABRACL & ABRA C-terminal like & Other \\
\hline 0,903 & CDK14 & cyclin-dependent kinase 14 & Nucleus \\
\hline 0,904 & CMTM3 & CKLF-like MARVEL transmembrane domain containing 3 & Extracellular Space \\
\hline 0,905 & CLEC10A & C-type lectin domain family 10 , member A & Plasma Membrane \\
\hline 0,905 & ID2 & $\begin{array}{l}\text { inhibitor of DNA binding 2, dominant negative helix-loop-helix } \\
\text { protein }\end{array}$ & Nucleus \\
\hline 0,905 & TUBB2A & tubulin, beta 2 A class IIa & Cytoplasm \\
\hline 0,907 & CD14 & CD14 molecule & Plasma Membrane \\
\hline 0,909 & FAM49A & family with sequence similarity 49 , member $A$ & Other \\
\hline 0,909 & HLA-DMA & major histocompatibility complex, class II, DM alpha & Plasma Membrane \\
\hline 0,917 & GPR34 & G protein-coupled receptor 34 & Plasma Membrane \\
\hline 0,919 & C1orf54 & chromosome 1 open reading frame 54 & Other \\
\hline 0,924 & SNORD35B & small nucleolar RNA, C/D box 35B & Other \\
\hline 0,926 & TUBB2B & tubulin, beta 2B class IIb & Cytoplasm \\
\hline 0,927 & HS6ST2 & heparan sulfate 6-O-sulfotransferase 2 & Plasma Membrane \\
\hline 0,928 & THBS4 & thrombospondin 4 & Extracellular Space \\
\hline 0,933 & MMP14 & matrix metallopeptidase 14 (membrane-inserted) & Extracellular Space \\
\hline 0,936 & ADAM19 & ADAM metallopeptidase domain 19 & Plasma Membrane \\
\hline 0,937 & LITAF & lipopolysaccharide-induced TNF factor & Nucleus \\
\hline 0,938 & Snora73a & small nucleolar RNA, H/ACA box 73a & Other \\
\hline 0,939 & TGFB1 & transforming growth factor, beta 1 & Extracellular Space \\
\hline 0,939 & TLR9 & toll-like receptor 9 & Plasma Membrane \\
\hline 0,941 & DSE & dermatan sulfate epimerase & Cytoplasm \\
\hline 0,941 & HAVCR2 & hepatitis A virus cellular receptor 2 & Plasma Membrane \\
\hline 0,946 & $\mathrm{FTL}$ & ferritin, light polypeptide & Cytoplasm \\
\hline 0,95 & CCDC109B & coiled-coil domain containing 109B & Cytoplasm \\
\hline 0,953 & BAIAP2L1 & BAI1-associated protein 2-like 1 & Cytoplasm \\
\hline 0,954 & COTL1 & coactosin-like 1 (Dictyostelium) & Cytoplasm \\
\hline 0,957 & CTHRC1 & collagen triple helix repeat containing 1 & Extracellular Space \\
\hline 0,959 & Epsti1 & epithelial stromal interaction 1 (breast) & Other \\
\hline 0,96 & CERS6 & ceramide synthase 6 & Nucleus \\
\hline 0,96 & PLEKHO2 & pleckstrin homology domain containing, family $\mathrm{O}$ member 2 & Cytoplasm \\
\hline 0,964 & SGPL1 & sphingosine-1-phosphate lyase 1 & Cytoplasm \\
\hline 0,965 & MFAP4 & microfibrillar-associated protein 4 & Extracellular Space \\
\hline 0,97 & MARCKS & myristoylated alanine-rich protein kinase $\mathrm{C}$ substrate & Plasma Membrane \\
\hline 0,972 & ACER3 & alkaline ceramidase 3 & Cytoplasm \\
\hline 0,974 & GLA & galactosidase, alpha & Cytoplasm \\
\hline 0,974 & Snora73b & small nucleolar RNA, H/ACA box 73b & Other \\
\hline 0,974 & VASH2 & vasohibin 2 & Cytoplasm \\
\hline 0,981 & BMPER & BMP binding endothelial regulator & Extracellular Space \\
\hline 0,981 & $\begin{array}{l}\text { Ifi204 (includes } \\
\text { others) }\end{array}$ & interferon activated gene 204 & Nucleus \\
\hline 0,992 & PLAU & plasminogen activator, urokinase & Extracellular Space \\
\hline 0,994 & CLEC6A & C-type lectin domain family 6 , member A & Plasma Membrane \\
\hline 0,997 & PTPRJ & protein tyrosine phosphatase, receptor type, $\mathrm{J}$ & Plasma Membrane \\
\hline 0,997 & TNIP3 & TNFAIP3 interacting protein 3 & Other \\
\hline 0,999 & INPP5D & inositol polyphosphate-5-phosphatase, $145 \mathrm{kDa}$ & Cytoplasm \\
\hline 1,000 & PAK1 & p21 protein (Cdc42/Rac)-activated kinase 1 & Cytoplasm \\
\hline 1,005 & CD109 & CD109 molecule & Plasma Membrane \\
\hline 1,007 & ABCC3 & ATP-binding cassette, sub-family C (CFTR/MRP), member 3 & Plasma Membrane \\
\hline 1,007 & TGFBI & transforming growth factor, beta-induced, $68 \mathrm{kDa}$ & Extracellular Space \\
\hline 1,008 & SERPINB6 & serpin peptidase inhibitor, clade B (ovalbumin), member 6 & Cytoplasm \\
\hline 1,012 & MYOG & myogenin (myogenic factor 4) & Nucleus \\
\hline 1,013 & ADAP2 & ArfGAP with dual PH domains 2 & Cytoplasm \\
\hline 1,016 & Zim1 & zinc finger, imprinted 1 & Nucleus \\
\hline 1,017 & CFB & complement factor B & Extracellular Space \\
\hline 1,020 & GALNT5 & $\begin{array}{l}\text { UDP-N-acetyl-alpha-D-galactosamine:polypeptide N- } \\
\text { acetylgalactosaminyltransferase } 5 \text { (GalNAc-T5) }\end{array}$ & Cytoplasm \\
\hline 1,023 & IL1RL2 & interleukin 1 receptor-like 2 & Plasma Membrane \\
\hline
\end{tabular}




\begin{tabular}{|c|c|c|c|}
\hline 1,025 & APBB1IP & $\begin{array}{l}\text { amyloid beta (A4) precursor protein-binding, family } B \text {, member } 1 \\
\text { interacting protein }\end{array}$ & Cytoplasm \\
\hline 1,025 & F13A1 & coagulation factor XIII, A1 polypeptide & Extracellular Space \\
\hline 1,026 & RAB31 & RAB31, member RAS oncogene family & Cytoplasm \\
\hline 1,031 & PI15 & peptidase inhibitor 15 & Extracellular Space \\
\hline 1,032 & FN1 & fibronectin 1 & Extracellular Space \\
\hline 1,034 & A630033H20Rik & RIKEN cDNA A630033H20 gene & Plasma Membrane \\
\hline 1,036 & PTPRJ & protein tyrosine phosphatase, receptor type, J & Plasma Membrane \\
\hline 1,037 & TCIRG1 & $\begin{array}{l}\text { T-cell, immune regulator } 1, \text { ATPase, } \mathrm{H}+\text { transporting, lysosomal V0 } \\
\text { subunit A3 }\end{array}$ & Plasma Membrane \\
\hline 1,038 & CTSZ & cathepsin Z & Cytoplasm \\
\hline 1,045 & Nxpe5 & neurexophilin and PC-esterase domain family, member 5 & Other \\
\hline 1,051 & GUSB & glucuronidase, beta & Cytoplasm \\
\hline 1,057 & PLXNC1 & plexin $\mathrm{C} 1$ & Plasma Membrane \\
\hline 1,062 & TM6SF1 & transmembrane 6 superfamily member 1 & Plasma Membrane \\
\hline 1,064 & CYSLTR1 & cysteinyl leukotriene receptor 1 & Plasma Membrane \\
\hline 1,075 & LAYN & layilin & Plasma Membrane \\
\hline 1,084 & LY9 & lymphocyte antigen 9 & Plasma Membrane \\
\hline 1,086 & CX3CR1 & chemokine (C-X3-C motif) receptor 1 & Plasma Membrane \\
\hline 1,088 & CAPG & capping protein (actin filament), gelsolin-like & Nucleus \\
\hline 1,088 & TMEM176B & transmembrane protein $176 \mathrm{~B}$ & Other \\
\hline 1,089 & PLXNB2 & plexin B2 & Plasma Membrane \\
\hline 1,091 & SH2D1B & SH2 domain containing $1 \mathrm{~B}$ & Cytoplasm \\
\hline 1,097 & Trim30a/Trim30d & tripartite motif-containing $30 \mathrm{~A}$ & Cytoplasm \\
\hline 1,098 & PDPN & podoplanin & Plasma Membrane \\
\hline 1,099 & DAB2 & Dab, mitogen-responsive phosphoprotein, homolog 2 (Drosophila) & Plasma Membrane \\
\hline 1,103 & TBXAS1 & thromboxane $A$ synthase 1 (platelet) & Plasma Membrane \\
\hline 1,106 & $\mathrm{Bcl} 2 \mathrm{a} 1 \mathrm{c}$ & B cell leukemia/lymphoma 2 related protein A1c & Other \\
\hline 1,106 & PLTP & phospholipid transfer protein & Extracellular Space \\
\hline 1,106 & RTP4 & receptor (chemosensory) transporter protein 4 & Plasma Membrane \\
\hline 1,108 & NAIP & NLR family, apoptosis inhibitory protein & Other \\
\hline 1,110 & MAP1B & microtubule-associated protein $1 \mathrm{~B}$ & Cytoplasm \\
\hline 1,111 & CYP4F2 & cytochrome P450, family 4, subfamily F, polypeptide 2 & Cytoplasm \\
\hline 1,111 & VCAN & versican & Extracellular Space \\
\hline 1,117 & CD200R1L & CD200 receptor 1-like & Plasma Membrane \\
\hline 1,119 & THEMIS2 & thymocyte selection associated family member 2 & Other \\
\hline 1,119 & ZNF761 & zinc finger protein 761 & Nucleus \\
\hline 1,124 & PTPRC & protein tyrosine phosphatase, receptor type, C & Plasma Membrane \\
\hline 1,125 & CD44 & CD44 molecule (Indian blood group) & Plasma Membrane \\
\hline 1,125 & LPCAT2 & lysophosphatidylcholine acyltransferase 2 & Cytoplasm \\
\hline 1,130 & HGF & hepatocyte growth factor (hepapoietin A; scatter factor) & Extracellular Space \\
\hline 1,131 & CD200R1 & CD200 receptor 1 & Plasma Membrane \\
\hline 1,138 & LILRB3 & $\begin{array}{l}\text { leukocyte immunoglobulin-like receptor, subfamily B (with TM and } \\
\text { ITIM domains), member } 3\end{array}$ & Plasma Membrane \\
\hline 1,139 & COL6A3 & collagen, type VI, alpha 3 & Extracellular Space \\
\hline 1,142 & PTPLAD2 & protein tyrosine phosphatase-like A domain containing 2 & Other \\
\hline 1,143 & ABCG1 & ATP-binding cassette, sub-family G (WHITE), member 1 & Plasma Membrane \\
\hline 1,145 & CHRNG & cholinergic receptor, nicotinic, gamma (muscle) & Plasma Membrane \\
\hline 1,159 & CSF2RB & $\begin{array}{l}\text { colony stimulating factor } 2 \text { receptor, beta, low-affinity } \\
\text { (granulocyte-macrophage) }\end{array}$ & Plasma Membrane \\
\hline 1,159 & FOLR2 & folate receptor 2 (fetal) & Plasma Membrane \\
\hline 1,161 & AIF1 & allograft inflammatory factor 1 & Nucleus \\
\hline 1,165 & MYH8 & myosin, heavy chain 8 , skeletal muscle, perinatal & Cytoplasm \\
\hline 1,171 & ALOX5AP & arachidonate 5 -lipoxygenase-activating protein & Plasma Membrane \\
\hline 1,171 & DOCK2 & dedicator of cytokinesis 2 & Cytoplasm \\
\hline 1,176 & LPXN & leupaxin & Cytoplasm \\
\hline 1,177 & FAM105A & family with sequence similarity 105 , member $A$ & Other \\
\hline 1,177 & SLC9A9 & $\begin{array}{l}\text { solute carrier family 9, subfamily A (NHE9, cation proton antiporter } \\
\text { 9), member } 9\end{array}$ & Cytoplasm \\
\hline 1,183 & LACC1 & laccase (multicopper oxidoreductase) domain containing 1 & Other \\
\hline 1,186 & IL13RA1 & interleukin 13 receptor, alpha 1 & Plasma Membrane \\
\hline 1,186 & TNFRSF1B & tumor necrosis factor receptor superfamily, member $1 \mathrm{~B}$ & Plasma Membrane \\
\hline 1,187 & ANPEP & alanyl (membrane) aminopeptidase & Plasma Membrane \\
\hline 1,188 & RENBP & renin binding protein & Other \\
\hline 1,189 & CYBA & cytochrome b-245, alpha polypeptide & Cytoplasm \\
\hline 1,193 & Trim30a/Trim30d & tripartite motif-containing $30 \mathrm{~A}$ & Cytoplasm \\
\hline 1,197 & B4GALT6 & UDP-Gal:betaGlcNAc beta 1,4- galactosyltransferase, polypeptide 6 & Cytoplasm \\
\hline 1,200 & CCDC141 & coiled-coil domain containing 141 & Other \\
\hline 1,201 & CD300LD & CD300 molecule-like family member $\mathrm{d}$ & Plasma Membrane \\
\hline 1,203 & COL8A1 & collagen, type VIII, alpha 1 & Extracellular Space \\
\hline 1,206 & ANXA4 & annexin A4 & Plasma Membrane \\
\hline 1,206 & SPI1 & spleen focus forming virus (SFFV) proviral integration oncogene & Nucleus \\
\hline
\end{tabular}




\begin{tabular}{|c|c|c|c|}
\hline 1,210 & SLC25A24 & $\begin{array}{l}\text { solute carrier family } 25 \text { (mitochondrial carrier; phosphate carrier), } \\
\text { member } 24\end{array}$ & Cytoplasm \\
\hline 1,219 & Gpr137b-ps & G protein-coupled receptor $137 \mathrm{~B}$, pseudogene & Other \\
\hline 1,222 & PIK3AP1 & phosphoinositide-3-kinase adaptor protein 1 & Cytoplasm \\
\hline 1,228 & EMB & embigin & Plasma Membrane \\
\hline 1,232 & MYO1F & myosin IF & Cytoplasm \\
\hline 1,234 & SIGLEC1 & sialic acid binding Ig-like lectin 1 , sialoadhesin & Plasma Membrane \\
\hline 1,238 & LCP1 & lymphocyte cytosolic protein 1 (L-plastin) & Cytoplasm \\
\hline 1,239 & CSTB & cystatin B (stefin B) & Cytoplasm \\
\hline 1,243 & CAPN6 & calpain 6 & Cytoplasm \\
\hline 1,245 & PLEKHO1 & pleckstrin homology domain containing, family $\mathrm{O}$ member 1 & Plasma Membrane \\
\hline 1,247 & Oasl2 & $2^{\prime}-5^{\prime}$ oligoadenylate synthetase-like 2 & Other \\
\hline 1,248 & RASSF4 & Ras association (RalGDS/AF-6) domain family member 4 & Other \\
\hline 1,249 & PEG3 & paternally expressed 3 & Nucleus \\
\hline 1,261 & LRRC17 & leucine rich repeat containing 17 & Extracellular Space \\
\hline 1,268 & APOE & apolipoprotein E & Extracellular Space \\
\hline 1,270 & SLFN13 & schlafen family member 13 & Nucleus \\
\hline 1,271 & $\begin{array}{l}\text { Sirpb1a (includes } \\
\text { others) }\end{array}$ & signal-regulatory protein beta $1 \mathrm{~A}$ & Plasma Membrane \\
\hline 1,271 & $\begin{array}{l}\text { Tmsb } 4 x \text { (includes } \\
\text { others) }\end{array}$ & thymosin, beta $4, \mathrm{X}$ chromosome & Cytoplasm \\
\hline 1,272 & MT1E & metallothionein $1 \mathrm{E}$ & Cytoplasm \\
\hline 1,282 & TUBB2B & tubulin, beta $2 \mathrm{~B}$ class IIb & Cytoplasm \\
\hline 1,284 & CYBB & cytochrome b-245, beta polypeptide & Cytoplasm \\
\hline 1,291 & DCLK1 & doublecortin-like kinase 1 & Other \\
\hline 1,294 & SLC37A2 & $\begin{array}{l}\text { solute carrier family } 37 \text { (glucose-6-phosphate transporter), } \\
\text { member } 2\end{array}$ & Other \\
\hline 1,296 & OAS1 & 2'-5'-oligoadenylate synthetase $1,40 / 46 \mathrm{kDa}$ & Cytoplasm \\
\hline 1,297 & Gm5431 & predicted gene 5431 & Other \\
\hline 1,298 & Lyz1/Lyz2 & lysozyme 2 & Cytoplasm \\
\hline 1,316 & RGS1 & regulator of G-protein signaling 1 & Plasma Membrane \\
\hline 1,316 & RGS10 & regulator of G-protein signaling 10 & Cytoplasm \\
\hline 1,324 & $\begin{array}{l}\text { Ifi204 (includes } \\
\text { others) }\end{array}$ & interferon activated gene 204 & Nucleus \\
\hline 1,325 & CHRNA1 & cholinergic receptor, nicotinic, alpha 1 (muscle) & Plasma Membrane \\
\hline 1,330 & CD48 & CD48 molecule & Plasma Membrane \\
\hline 1,330 & FABP5 & fatty acid binding protein 5 (psoriasis-associated) & Cytoplasm \\
\hline 1,330 & HLA-DQA1 & major histocompatibility complex, class II, DQ alpha 1 & Plasma Membrane \\
\hline 1,331 & C5AR1 & complement component 5 a receptor 1 & Plasma Membrane \\
\hline 1,333 & FABP5 & fatty acid binding protein 5 (psoriasis-associated) & Cytoplasm \\
\hline 1,333 & $\begin{array}{l}\text { Tmsb } 4 x \text { (includes } \\
\text { others) }\end{array}$ & thymosin, beta $4, \mathrm{X}$ chromosome & Cytoplasm \\
\hline 1,336 & Eef1a1 & eukaryotic translation elongation factor 1 alpha 1 & Cytoplasm \\
\hline 1,336 & HLA-DRB1 & major histocompatibility complex, class II, DR beta 1 & Plasma Membrane \\
\hline 1,338 & SIRPA & signal-regulatory protein alpha & Plasma Membrane \\
\hline 1,339 & LOX & lysyl oxidase & Extracellular Space \\
\hline 1,348 & IRF7 & interferon regulatory factor 7 & Nucleus \\
\hline 1,348 & P2RX4 & purinergic receptor $\mathrm{P} 2 \mathrm{X}$, ligand-gated ion channel, 4 & Plasma Membrane \\
\hline 1,351 & UNC93B1 & unc-93 homolog B1 (C, elegans) & Cytoplasm \\
\hline 1,352 & RUNX1 & runt-related transcription factor 1 & Nucleus \\
\hline 1,356 & SLC15A3 & solute carrier family 15 (oligopeptide transporter), member 3 & Cytoplasm \\
\hline 1,358 & CXCL16 & chemokine (C-X-C motif) ligand 16 & Extracellular Space \\
\hline 1,373 & CCDC141 & coiled-coil domain containing 141 & Other \\
\hline 1,376 & LAPTM5 & lysosomal protein transmembrane 5 & Plasma Membrane \\
\hline 1,383 & GRN & granulin & Extracellular Space \\
\hline 1,384 & LAIR1 & leukocyte-associated immunoglobulin-like receptor 1 & Plasma Membrane \\
\hline 1,384 & MYO5A & myosin VA (heavy chain 12 , myoxin) & Cytoplasm \\
\hline 1,386 & MMP19 & matrix metallopeptidase 19 & Extracellular Space \\
\hline 1,395 & Serpinb6b & serine (or cysteine) peptidase inhibitor, clade $\mathrm{B}$, member $6 \mathrm{~b}$ & Other \\
\hline 1,399 & HEXB & hexosaminidase B (beta polypeptide) & Cytoplasm \\
\hline 1,402 & Lyz1/Lyz2 & lysozyme 2 & Cytoplasm \\
\hline 1,403 & GPR65 & G protein-coupled receptor 65 & Plasma Membrane \\
\hline 1,408 & TMEM106A & transmembrane protein $106 \mathrm{~A}$ & Other \\
\hline 1,410 & FBLN7 & fibulin 7 & Extracellular Space \\
\hline 1,413 & SFRP1 & secreted frizzled-related protein 1 & Plasma Membrane \\
\hline 1,419 & FYB & FYN binding protein & Nucleus \\
\hline 1,421 & CD300LD & CD300 molecule-like family member $d$ & Plasma Membrane \\
\hline 1,424 & CD300LD & CD300 molecule-like family member $\mathrm{d}$ & Plasma Membrane \\
\hline 1,425 & AKR1B10 & aldo-keto reductase family 1 , member B10 (aldose reductase) & Cytoplasm \\
\hline 1,430 & HPSE & heparanase & Plasma Membrane \\
\hline 1,431 & HLA-DQB1 & major histocompatibility complex, class II, DQ beta 1 & Plasma Membrane \\
\hline 1,431 & Snord116 & small nucleolar RNA, C/D box 116 & Other \\
\hline
\end{tabular}




\begin{tabular}{|c|c|c|c|}
\hline 1,431 & Snord116 & small nucleolar RNA, C/D box 116 & Other \\
\hline 1,431 & Snord116 & small nucleolar RNA, C/D box 116 & Other \\
\hline 1,431 & Snord116 & small nucleolar RNA, C/D box 116 & Other \\
\hline 1,431 & Snord116 & small nucleolar RNA, C/D box 116 & Other \\
\hline 1,431 & Snord116 & small nucleolar RNA, C/D box 116 & Other \\
\hline 1,431 & Snord116 & small nucleolar RNA, C/D box 116 & Other \\
\hline 1,431 & Snord116 & small nucleolar RNA, C/D box 116 & Other \\
\hline 1,431 & Snord116 & small nucleolar RNA, C/D box 116 & Other \\
\hline 1,431 & Snord116 & small nucleolar RNA, C/D box 116 & Other \\
\hline 1,431 & Snord116 & small nucleolar RNA, C/D box 116 & Other \\
\hline 1,431 & Snord116 & small nucleolar RNA, C/D box 116 & Other \\
\hline 1,431 & Snord116 & small nucleolar RNA, C/D box 116 & Other \\
\hline 1,431 & Snord116 & small nucleolar RNA, C/D box 116 & Other \\
\hline 1,431 & Snord116 & small nucleolar RNA, C/D box 116 & Other \\
\hline 1,431 & Snord116 & small nucleolar RNA, C/D box 116 & Other \\
\hline 1,431 & Snord116 & small nucleolar RNA, C/D box 116 & Other \\
\hline 1,431 & Snord116 & small nucleolar RNA, C/D box 116 & Other \\
\hline 1,437 & MRC1 & mannose receptor, $\mathrm{C}$ type 1 & Plasma Membrane \\
\hline 1,442 & Snord116 & small nucleolar RNA, C/D box 116 & Other \\
\hline 1,444 & CILP & $\begin{array}{l}\text { cartilage intermediate layer protein, nucleotide } \\
\text { pyrophosphohydrolase }\end{array}$ & Extracellular Space \\
\hline 1,445 & COL3A1 & collagen, type III, alpha 1 & Extracellular Space \\
\hline 1,445 & Olfr1372-ps1 & olfactory receptor 1372 , pseudogene 1 & Other \\
\hline 1,447 & STAB1 & stabilin 1 & Plasma Membrane \\
\hline 1,448 & CLEC12A & C-type lectin domain family 12 , member $A$ & Plasma Membrane \\
\hline 1,449 & IL10RA & interleukin 10 receptor, alpha & Plasma Membrane \\
\hline 1,455 & CD74 & $\begin{array}{l}\text { CD74 molecule, major histocompatibility complex, class II invariant } \\
\text { chain }\end{array}$ & Plasma Membrane \\
\hline 1,458 & CD53 & CD53 molecule & Plasma Membrane \\
\hline 1,462 & CYTH4 & cytohesin 4 & Cytoplasm \\
\hline 1,463 & Forls & Fc receptor-like S, scavenger receptor & Plasma Membrane \\
\hline 1,465 & $\begin{array}{l}\text { Ifi204 (includes } \\
\text { others) }\end{array}$ & interferon activated gene 204 & Nucleus \\
\hline 1,472 & SLC11A1 & $\begin{array}{l}\text { solute carrier family } 11 \text { (proton-coupled divalent metal ion } \\
\text { transporter), member } 1\end{array}$ & Plasma Membrane \\
\hline 1,492 & $\mathrm{Nt} 5 \mathrm{dc} 2$ & 5'-nucleotidase domain containing 2 & Other \\
\hline 1,501 & BCL2A1 & BCL2-related protein A1 & Cytoplasm \\
\hline 1,504 & TYROBP & TYRO protein tyrosine kinase binding protein & Plasma Membrane \\
\hline 1,509 & BCL2A1 & $\mathrm{BCL} 2$-related protein $\mathrm{A} 1$ & Cytoplasm \\
\hline 1,509 & Milr1 & mast cell immunoglobulin like receptor 1 & Plasma Membrane \\
\hline 1,510 & CTXN3 & cortexin 3 & Other \\
\hline 1,513 & CTSH & cathepsin $\mathrm{H}$ & Cytoplasm \\
\hline 1,520 & PTAFR & platelet-activating factor receptor & Plasma Membrane \\
\hline 1,523 & ZDBF2 & zinc finger, DBF-type containing 2 & Other \\
\hline 1,525 & MYOF & myoferlin & Nucleus \\
\hline 1,525 & ТTC9 & tetratricopeptide repeat domain 9 & Extracellular Space \\
\hline 1,532 & ITGAX & integrin, alpha $\mathrm{X}$ (complement component 3 receptor 4 subunit) & Plasma Membrane \\
\hline 1,545 & RASGEF1B & RasGEF domain family, member $1 \mathrm{~B}$ & Other \\
\hline 1,549 & PEG3 & paternally expressed 3 & Nucleus \\
\hline 1,560 & ADAM8 & ADAM metallopeptidase domain 8 & Plasma Membrane \\
\hline 1,562 & BCL2A1 & $\mathrm{BCL} 2$-related protein $\mathrm{A} 1$ & Cytoplasm \\
\hline 1,562 & CSF1R & colony stimulating factor 1 receptor & Plasma Membrane \\
\hline 1,570 & FCGR3A & Fc fragment of IgG, low affinity IIIa, receptor (CD16a) & Plasma Membrane \\
\hline 1,578 & PLD4 & phospholipase $\mathrm{D}$ family, member 4 & Extracellular Space \\
\hline 1,580 & TLR1 & toll-like receptor 1 & Plasma Membrane \\
\hline 1,591 & CLEC7A & C-type lectin domain family 7 , member A & Plasma Membrane \\
\hline 1,591 & LAT2 & linker for activation of $\mathrm{T}$ cells family, member 2 & Plasma Membrane \\
\hline 1,594 & FCGR2A & Fc fragment of IgG, low affinity IIa, receptor (CD32) & Plasma Membrane \\
\hline 1,598 & FCGR2B & Fc fragment of IgG, low affinity IIb, receptor (CD32) & Plasma Membrane \\
\hline 1,600 & 5430435G22Rik & RIKEN cDNA 5430435G22 gene & Cytoplasm \\
\hline 1,603 & S100A4 & S100 calcium binding protein A4 & Cytoplasm \\
\hline 1,612 & C14orf37 & chromosome 14 open reading frame 37 & Extracellular Space \\
\hline 1,626 & FCER1G & $\begin{array}{l}\text { Fc fragment of IgE, high affinity I, receptor for; gamma } \\
\text { polypeptide }\end{array}$ & Plasma Membrane \\
\hline 1,641 & C1QA & complement component 1 , q subcomponent, A chain & Extracellular Space \\
\hline 1,648 & NCKAP1L & NCK-associated protein 1-like & Plasma Membrane \\
\hline 1,656 & $\begin{array}{l}\text { Ifi204 (includes } \\
\text { others) }\end{array}$ & interferon activated gene 204 & Nucleus \\
\hline 1,665 & LIPA & lipase A, lysosomal acid, cholesterol esterase & Cytoplasm \\
\hline 1,672 & HPGDS & hematopoietic prostaglandin D synthase & Cytoplasm \\
\hline 1,674 & FCGR1A & Fc fragment of IgG, high affinity Ia, receptor (CD64) & Plasma Membrane \\
\hline 1,676 & CD300C & CD300c molecule & Plasma Membrane \\
\hline
\end{tabular}




\begin{tabular}{|c|c|c|c|}
\hline 1,684 & LGMN & legumain & Cytoplasm \\
\hline 1,695 & IFI30 & interferon, gamma-inducible protein 30 & Cytoplasm \\
\hline 1,697 & MYL4 & myosin, light chain 4, alkali; atrial, embryonic & Cytoplasm \\
\hline 1,705 & DPEP2 & dipeptidase 2 & Plasma Membrane \\
\hline 1,706 & P2RY6 & pyrimidinergic receptor P2Y, G-protein coupled, 6 & Plasma Membrane \\
\hline 1,727 & C1QC & complement component 1 , q subcomponent, $C$ chain & Extracellular Space \\
\hline 1,728 & $\begin{array}{l}\text { Ifi204 (includes } \\
\text { others) }\end{array}$ & interferon activated gene 204 & Nucleus \\
\hline 1,734 & Ccl6 & chemokine (C-C motif) ligand 6 & Extracellular Space \\
\hline 1,734 & TUBB6 & tubulin, beta 6 class $\mathrm{V}$ & Cytoplasm \\
\hline 1,739 & IL7R & interleukin 7 receptor & Plasma Membrane \\
\hline 1,781 & SOAT1 & sterol O-acyltransferase 1 & Cytoplasm \\
\hline 1,817 & SLAMF7 & SLAM family member 7 & Plasma Membrane \\
\hline 1,819 & Clec4a1 & C-type lectin domain family 4 , member a1 & Other \\
\hline 1,819 & TREM2 & triggering receptor expressed on myeloid cells 2 & Plasma Membrane \\
\hline 1,834 & $\mathrm{Ccl} 9$ & chemokine ( $\mathrm{C}-\mathrm{C}$ motif) ligand 9 & Extracellular Space \\
\hline 1,836 & IGF2 & insulin-like growth factor 2 (somatomedin A) & Extracellular Space \\
\hline 1,892 & Gp49a/Lilrb4 & leukocyte immunoglobulin-like receptor, subfamily B, member 4 & Other \\
\hline 1,894 & ATP6V0D2 & ATPase, $\mathrm{H}+$ transporting, lysosomal 38kDa, V0 subunit d2 & Cytoplasm \\
\hline 1,899 & MT1H & metallothionein $1 \mathrm{H}$ & Other \\
\hline 1,900 & MSR1 & macrophage scavenger receptor 1 & Plasma Membrane \\
\hline 1,953 & MMP3 & matrix metallopeptidase 3 (stromelysin 1 , progelatinase) & Extracellular Space \\
\hline 1,967 & POSTN & periostin, osteoblast specific factor & Extracellular Space \\
\hline 1,970 & C1QB & complement component 1, q subcomponent, B chain & Extracellular Space \\
\hline 1,972 & CD84 & CD84 molecule & Plasma Membrane \\
\hline 1,980 & CCR2 & chemokine (C-C motif) receptor 2 & Plasma Membrane \\
\hline 2,006 & C1QTNF3 & $\mathrm{C} 1 \mathrm{q}$ and tumor necrosis factor related protein 3 & Extracellular Space \\
\hline 2,017 & TNNT2 & troponin T type 2 (cardiac) & Cytoplasm \\
\hline 2,024 & CD180 & CD180 molecule & Plasma Membrane \\
\hline 2,025 & Clec4a3 & C-type lectin domain family 4 , member a3 & Other \\
\hline 2,065 & GAL & galanin/GMAP prepropeptide & Extracellular Space \\
\hline 2,068 & Gp49a/Lilrb4 & leukocyte immunoglobulin-like receptor, subfamily B, member 4 & Other \\
\hline 2,082 & $\mathrm{Ccl} 2$ & chemokine (C-C motif) ligand 2 & Extracellular Space \\
\hline 2,090 & $\begin{array}{l}\text { Ms4a4b (includes } \\
\text { others) }\end{array}$ & membrane-spanning 4-domains, subfamily A, member 4B & Plasma Membrane \\
\hline 2,095 & TMEM8C & transmembrane protein $8 \mathrm{C}$ & Plasma Membrane \\
\hline 2,096 & APOBEC1 & apolipoprotein B mRNA editing enzyme, catalytic polypeptide 1 & Cytoplasm \\
\hline 2,101 & PRG4 & proteoglycan 4 & Extracellular Space \\
\hline 2,116 & SERPINA3 & $\begin{array}{l}\text { serpin peptidase inhibitor, clade A (alpha-1 antiproteinase, } \\
\text { antitrypsin), member } 3\end{array}$ & Extracellular Space \\
\hline 2,131 & CCL7 & chemokine (C-C motif) ligand 7 & Extracellular Space \\
\hline 2,131 & PRUNE2 & prune homolog 2 (Drosophila) & Other \\
\hline 2,142 & CCR5 & chemokine (C-C motif) receptor 5 (gene/pseudogene) & Plasma Membrane \\
\hline 2,142 & CCR5 & chemokine (C-C motif) receptor 5 (gene/pseudogene) & Plasma Membrane \\
\hline 2,161 & Ms4a6c & membrane-spanning 4-domains, subfamily $\mathrm{A}$, member $6 \mathrm{C}$ & Other \\
\hline 2,189 & Ms4a6b & membrane-spanning 4-domains, subfamily $A$, member $6 B$ & Other \\
\hline 2,213 & Tlr13 & toll-like receptor 13 & Cytoplasm \\
\hline 2,233 & LY86 & lymphocyte antigen 86 & Plasma Membrane \\
\hline 2,246 & Wfdc17 & WAP four-disulfide core domain 17 & Other \\
\hline 2,252 & PCBD1 & $\begin{array}{l}\text { pterin-4 alpha-carbinolamine dehydratase/dimerization cofactor of } \\
\text { hepatocyte nuclear factor } 1 \text { alpha }\end{array}$ & Nucleus \\
\hline 2,263 & ANKRD1 & ankyrin repeat domain 1 (cardiac muscle) & Cytoplasm \\
\hline 2,290 & GLIPR1 & GLI pathogenesis-related 1 & Extracellular Space \\
\hline 2,301 & PRUNE2 & prune homolog 2 (Drosophila) & Other \\
\hline 2,364 & EMR1 & egf-like module containing, mucin-like, hormone receptor-like 1 & Plasma Membrane \\
\hline 2,429 & MS4A4A & membrane-spanning 4-domains, subfamily $A$, member $4 \mathrm{~A}$ & Other \\
\hline 2,447 & CCL3L1/CCL3L3 & chemokine ( $\mathrm{C}-\mathrm{C}$ motif) ligand 3 -like 1 & Extracellular Space \\
\hline 2,489 & MS4A14 & membrane-spanning 4-domains, subfamily A, member 14 & Other \\
\hline 2,519 & MPEG1 & macrophage expressed 1 & Cytoplasm \\
\hline 2,530 & CD68 & CD68 molecule & Plasma Membrane \\
\hline 2,602 & LGALS3 & lectin, galactoside-binding, soluble, 3 & Extracellular Space \\
\hline 2,602 & TIMP1 & TIMP metallopeptidase inhibitor 1 & Extracellular Space \\
\hline 2,810 & $\mathrm{Ccl} 8$ & chemokine (C-C motif) ligand 8 & Extracellular Space \\
\hline 2,833 & MYH3 & myosin, heavy chain 3, skeletal muscle, embryonic & Cytoplasm \\
\hline 2,902 & CTSS & cathepsin S & Cytoplasm \\
\hline 2,952 & MS4A6A & membrane-spanning 4-domains, subfamily $A$, member $6 \mathrm{~A}$ & Other \\
\hline 2,965 & MMP12 & matrix metallopeptidase 12 (macrophage elastase) & Extracellular Space \\
\hline 3,004 & GPNMB & glycoprotein (transmembrane) nmb & Plasma Membrane \\
\hline 3,157 & MS4A7 & membrane-spanning 4-domains, subfamily A, member 7 & Other \\
\hline 3,310 & AKR1E2 & aldo-keto reductase family 1 , member E2 & Cytoplasm \\
\hline 3,421 & C3AR1 & complement component 3a receptor 1 & Plasma Membrane \\
\hline
\end{tabular}




\begin{tabular}{|c|c|c|c|}
\hline \multicolumn{4}{|c|}{ Large $^{m y d-/-}$ vs C57BL 6 meses } \\
\hline $\begin{array}{l}\text { Fold } \\
\text { Change }\end{array}$ & Symbol & Entrez Gene Name & Location \\
\hline$-3,118$ & OSTN & osteocrin & Extracellular Space \\
\hline$-2,526$ & MSTN & myostatin & Extracellular Space \\
\hline$-2,360$ & CHAC1 & ChaC, cation transport regulator homolog $1(\mathrm{E}$, coli $)$ & Cytoplasm \\
\hline$-2,342$ & METTL11B & methyltransferase like 11B & Other \\
\hline$-2,221$ & PLCD4 & phospholipase C, delta 4 & Cytoplasm \\
\hline$-1,999$ & CYP4F22 & cytochrome P450, family 4, subfamily F, polypeptide 22 & Extracellular Space \\
\hline$-1,931$ & LARGE & like-glycosyltransferase & Cytoplasm \\
\hline$-1,927$ & ASB4 & ankyrin repeat and SOCS box containing 4 & Nucleus \\
\hline$-1,887$ & OTUB2 & OTU domain, ubiquitin aldehyde binding 2 & Other \\
\hline$-1,857$ & ASB2 & ankyrin repeat and SOCS box containing 2 & Nucleus \\
\hline$-1,846$ & ST8SIA5 & ST8 alpha-N-acetyl-neuraminide alpha-2,8-sialyltransferase 5 & Cytoplasm \\
\hline$-1,734$ & VWA3B & von Willebrand factor A domain containing 3B & Other \\
\hline$-1,732$ & BEST3 & bestrophin 3 & Nucleus \\
\hline$-1,698$ & HRASLS & HRAS-like suppressor & Cytoplasm \\
\hline$-1,679$ & PDE4D & phosphodiesterase 4D, cAMP-specific & Cytoplasm \\
\hline$-1,675$ & TSPAN8 & tetraspanin 8 & Plasma Membrane \\
\hline$-1,653$ & MSS51 & MSS51 mitochondrial translational activator & Other \\
\hline$-1,643$ & ASB16 & ankyrin repeat and SOCS box containing 16 & Other \\
\hline$-1,618$ & FBP2 & fructose-1,6-bisphosphatase 2 & Cytoplasm \\
\hline$-1,606$ & KLHL38 & kelch-like family member 38 & Other \\
\hline$-1,595$ & MICAL2 & $\begin{array}{l}\text { microtubule associated monooxygenase, calponin and LIM domain } \\
\text { containing } 2\end{array}$ & Cytoplasm \\
\hline$-1,570$ & MYLK2 & myosin light chain kinase 2 & Cytoplasm \\
\hline$-1,564$ & GPCPD1 & $\begin{array}{l}\text { glycerophosphocholine phosphodiesterase GDE1 homolog (S, } \\
\text { cerevisiae) }\end{array}$ & Other \\
\hline$-1,562$ & NT5C1A & 5'-nucleotidase, cytosolic IA & Cytoplasm \\
\hline$-1,559$ & RASD2 & RASD family, member 2 & Cytoplasm \\
\hline$-1,555$ & VWA3B & von Willebrand factor $\mathrm{A}$ domain containing $3 \mathrm{~B}$ & Other \\
\hline$-1,554$ & NOS1 & nitric oxide synthase 1 (neuronal) & Cytoplasm \\
\hline$-1,543$ & PADI2 & peptidyl arginine deiminase, type II & Cytoplasm \\
\hline$-1,532$ & PHKG1 & phosphorylase kinase, gamma 1 (muscle) & Cytoplasm \\
\hline$-1,531$ & 2310015B20Rik & RIKEN CDNA 2310015B20 gene & Other \\
\hline$-1,531$ & MYLK4 & myosin light chain kinase family, member 4 & Other \\
\hline$-1,529$ & HS3ST5 & heparan sulfate (glucosamine) 3-O-sulfotransferase 5 & Cytoplasm \\
\hline$-1,525$ & LRRC14B & leucine rich repeat containing 14B & Other \\
\hline$-1,516$ & LRRC38 & leucine rich repeat containing 38 & Other \\
\hline$-1,513$ & GDAP1 & ganglioside induced differentiation associated protein 1 & Cytoplasm \\
\hline$-1,513$ & TRDN & triadin & Cytoplasm \\
\hline$-1,511$ & MC5R & melanocortin 5 receptor & Plasma Membrane \\
\hline$-1,508$ & $\mathrm{FBXO32}$ & F-box protein 32 & Cytoplasm \\
\hline$-1,493$ & TTLL7 & tubulin tyrosine ligase-like family, member 7 & Plasma Membrane \\
\hline$-1,471$ & ASB14 & ankyrin repeat and SOCS box containing 14 & Other \\
\hline$-1,467$ & GPD2 & glycerol-3-phosphate dehydrogenase 2 (mitochondrial) & Cytoplasm \\
\hline$-1,463$ & ALPK2 & alpha-kinase 2 & Other \\
\hline$-1,458$ & OSBPL6 & oxysterol binding protein-like 6 & Cytoplasm \\
\hline$-1,448$ & 2310081J21Rik & RIKEN cDNA $2310081 \mathrm{~J} 21$ gene & Other \\
\hline$-1,448$ & 2310081J21Rik & RIKEN cDNA $2310081 \mathrm{~J} 21$ gene & Other \\
\hline$-1,448$ & 2310081J21Rik & RIKEN cDNA $2310081 \mathrm{~J} 21$ gene & Other \\
\hline$-1,448$ & ASB15 & ankyrin repeat and SOCS box containing 15 & Nucleus \\
\hline$-1,437$ & VWA3B & von Willebrand factor $\mathrm{A}$ domain containing $3 \mathrm{~B}$ & Other \\
\hline$-1,433$ & C3orf43 & chromosome 3 open reading frame 43 & Other \\
\hline$-1,426$ & RXRG & retinoid $\mathrm{X}$ receptor, gamma & Nucleus \\
\hline$-1,417$ & RNF128 & ring finger protein 128 , E3 ubiquitin protein ligase & Cytoplasm \\
\hline$-1,393$ & ASB11 & ankyrin repeat and SOCS box containing 11 & Nucleus \\
\hline$-1,393$ & SLC37A4 & $\begin{array}{l}\text { solute carrier family } 37 \text { (glucose-6-phosphate transporter), } \\
\text { member } 4\end{array}$ & Cytoplasm \\
\hline$-1,385$ & DUSP26 & dual specificity phosphatase 26 (putative) & Cytoplasm \\
\hline$-1,385$ & SCN4B & sodium channel, voltage-gated, type IV, beta subunit & Plasma Membrane \\
\hline$-1,372$ & HOOK1 & hook microtubule-tethering protein 1 & Cytoplasm \\
\hline$-1,348$ & AMPD1 & adenosine monophosphate deaminase 1 & Cytoplasm \\
\hline$-1,339$ & PLA2G7 & $\begin{array}{l}\text { phospholipase A2, group VII (platelet-activating factor } \\
\text { acetylhydrolase, plasma) }\end{array}$ & Extracellular Space \\
\hline$-1,338$ & ANKRD9 & ankyrin repeat domain 9 & Other \\
\hline$-1,324$ & EEPD1 & $\begin{array}{l}\text { endonuclease/exonuclease/phosphatase family domain containing } \\
1\end{array}$ & Other \\
\hline$-1,305$ & PDZRN3 & PDZ domain containing ring finger 3 & Extracellular Space \\
\hline$-1,302$ & NR4A1 & nuclear receptor subfamily 4 , group $A$, member 1 & Nucleus \\
\hline
\end{tabular}




\begin{tabular}{|c|c|c|c|}
\hline$-1,275$ & CACNG6 & calcium channel, voltage-dependent, gamma subunit 6 & Plasma Membrane \\
\hline$-1,210$ & CNTNAP2 & contactin associated protein-like 2 & Plasma Membrane \\
\hline 1,034 & P2RX7 & purinergic receptor $\mathrm{P} 2 \mathrm{X}$, ligand-gated ion channel, 7 & Plasma Membrane \\
\hline 1,065 & EGR1 & early growth response 1 & Nucleus \\
\hline 1,087 & C14orf37 & chromosome 14 open reading frame 37 & Extracellular Space \\
\hline 1,102 & MFAP5 & microfibrillar associated protein 5 & Extracellular Space \\
\hline 1,108 & CAPG & capping protein (actin filament), gelsolin-like & Nucleus \\
\hline 1,130 & TNNT2 & troponin T type 2 (cardiac) & Cytoplasm \\
\hline 1,135 & MSR1 & macrophage scavenger receptor 1 & Plasma Membrane \\
\hline 1,135 & STEAP4 & STEAP family member 4 & Plasma Membrane \\
\hline 1,141 & ANGPTL1 & angiopoietin-like 1 & Plasma Membrane \\
\hline 1,141 & PLXNB2 & plexin B2 & Plasma Membrane \\
\hline 1,142 & MMP2 & $\begin{array}{l}\text { matrix metallopeptidase } 2 \text { (gelatinase A, } 72 \mathrm{kDa} \text { gelatinase, } 72 \mathrm{kDa} \\
\text { type IV collagenase) }\end{array}$ & Extracellular Space \\
\hline 1,142 & NOX4 & NADPH oxidase 4 & Cytoplasm \\
\hline 1,146 & OCEL1 & occludin/ELL domain containing 1 & Other \\
\hline 1,154 & HGF & hepatocyte growth factor (hepapoietin A; scatter factor) & Extracellular Space \\
\hline 1,165 & DSE & dermatan sulfate epimerase & Cytoplasm \\
\hline 1,167 & CD80 & CD80 molecule & Plasma Membrane \\
\hline 1,173 & GPX8 & glutathione peroxidase 8 (putative) & Other \\
\hline 1,181 & ITGBL1 & integrin, beta-like 1 (with EGF-like repeat domains) & Other \\
\hline 1,183 & CD300C & CD300c molecule & Plasma Membrane \\
\hline 1,191 & LAYN & layilin & Plasma Membrane \\
\hline 1,205 & LAT2 & linker for activation of T cells family, member 2 & Plasma Membrane \\
\hline 1,207 & LPXN & leupaxin & Cytoplasm \\
\hline 1,207 & MYL4 & myosin, light chain 4, alkali; atrial, embryonic & Cytoplasm \\
\hline 1,211 & ANXA4 & annexin A4 & Plasma Membrane \\
\hline 1,226 & C3 & complement component 3 & Extracellular Space \\
\hline 1,230 & SELP & selectin P (granule membrane protein $140 \mathrm{kDa}$, antigen CD62) & Plasma Membrane \\
\hline 1,233 & RASSF2 & Ras association (RalGDS/AF-6) domain family member 2 & Nucleus \\
\hline 1,239 & CMTM3 & CKLF-like MARVEL transmembrane domain containing 3 & Extracellular Space \\
\hline 1,240 & TMEM176A & transmembrane protein $176 \mathrm{~A}$ & Other \\
\hline 1,247 & CCL21 & chemokine (C-C motif) ligand 21 & Extracellular Space \\
\hline 1,247 & CCL21 & chemokine (C-C motif) ligand 21 & Extracellular Space \\
\hline 1,247 & CCL21 & chemokine ( $\mathrm{C}-\mathrm{C}$ motif) ligand 21 & Extracellular Space \\
\hline 1,247 & CCL21 & chemokine (C-C motif) ligand 21 & Extracellular Space \\
\hline 1,248 & IL1R1 & interleukin 1 receptor, type I & Plasma Membrane \\
\hline 1,251 & GRN & granulin & Extracellular Space \\
\hline 1,254 & MYOF & myoferlin & Nucleus \\
\hline 1,256 & DPEP2 & dipeptidase 2 & Plasma Membrane \\
\hline 1,257 & IGFBP4 & insulin-like growth factor binding protein 4 & Extracellular Space \\
\hline 1,258 & C1S & complement component 1 , s subcomponent & Extracellular Space \\
\hline 1,261 & MMP14 & matrix metallopeptidase 14 (membrane-inserted) & Extracellular Space \\
\hline 1,266 & $\mathrm{CFH}$ & complement factor $\mathrm{H}$ & Extracellular Space \\
\hline 1,273 & CD14 & CD14 molecule & Plasma Membrane \\
\hline 1,281 & MYO5A & myosin VA (heavy chain 12 , myoxin) & Cytoplasm \\
\hline 1,297 & COMP & cartilage oligomeric matrix protein & Extracellular Space \\
\hline 1,303 & CA13 & carbonic anhydrase XIII & Cytoplasm \\
\hline 1,304 & TMEM106A & transmembrane protein $106 \mathrm{~A}$ & Other \\
\hline 1,306 & SOAT1 & sterol O-acyltransferase 1 & Cytoplasm \\
\hline 1,308 & ITGAX & integrin, alpha $\mathrm{X}$ (complement component 3 receptor 4 subunit) & Plasma Membrane \\
\hline 1,308 & MMP19 & matrix metallopeptidase 19 & Extracellular Space \\
\hline 1,316 & PDGFRL & platelet-derived growth factor receptor-like & Plasma Membrane \\
\hline 1,328 & BMPER & BMP binding endothelial regulator & Extracellular Space \\
\hline 1,330 & TNMD & tenomodulin & Plasma Membrane \\
\hline 1,333 & C1QTNF3 & $\mathrm{C} 1 \mathrm{q}$ and tumor necrosis factor related protein 3 & Extracellular Space \\
\hline 1,333 & THBS4 & thrombospondin 4 & Extracellular Space \\
\hline 1,334 & SCN7A & sodium channel, voltage-gated, type VII, alpha subunit & Plasma Membrane \\
\hline 1,336 & CEBPA & CCAAT/enhancer binding protein (C/EBP), alpha & Nucleus \\
\hline 1,336 & LOX & lysyl oxidase & Extracellular Space \\
\hline 1,340 & CD86 & CD86 molecule & Plasma Membrane \\
\hline 1,340 & LUM & lumican & Extracellular Space \\
\hline 1,341 & LIPA & lipase A, lysosomal acid, cholesterol esterase & Cytoplasm \\
\hline 1,344 & CTSH & cathepsin $\mathrm{H}$ & Cytoplasm \\
\hline 1,349 & A530099J19Rik & RIKEN cDNA A530099J19 gene & Plasma Membrane \\
\hline 1,349 & UNC93B1 & unc-93 homolog B1 (C, elegans) & Cytoplasm \\
\hline 1,352 & CYTH4 & cytohesin 4 & Cytoplasm \\
\hline 1,352 & TMEM173 & transmembrane protein 173 & Cytoplasm \\
\hline 1,360 & $\begin{array}{l}\text { Tmsb } 4 x \text { (includes } \\
\text { others) }\end{array}$ & thymosin, beta $4, \mathrm{X}$ chromosome & Cytoplasm \\
\hline 1,363 & Gp49a/Lilrb4 & leukocyte immunoglobulin-like receptor, subfamily B, member 4 & Other \\
\hline 1,363 & Tmsb4x (includes & thymosin, beta $4, X$ chromosome & Cytoplasm \\
\hline
\end{tabular}




\begin{tabular}{|c|c|c|c|}
\hline & others) & & \\
\hline 1,365 & $\begin{array}{l}\text { Ifi204 (includes } \\
\text { others) }\end{array}$ & interferon activated gene 204 & Nucleus \\
\hline 1,366 & CCDC80 & coiled-coil domain containing 80 & Nucleus \\
\hline 1,366 & COL6A3 & collagen, type VI, alpha 3 & Extracellular Space \\
\hline 1,366 & DAB2 & Dab, mitogen-responsive phosphoprotein, homolog 2 (Drosophila) & Plasma Membrane \\
\hline 1,366 & PDPN & podoplanin & Plasma Membrane \\
\hline 1,373 & LCP1 & lymphocyte cytosolic protein 1 (L-plastin) & Cytoplasm \\
\hline 1,381 & COL8A1 & collagen, type VIII, alpha 1 & Extracellular Space \\
\hline 1,384 & DOCK2 & dedicator of cytokinesis 2 & Cytoplasm \\
\hline 1,388 & $\begin{array}{l}\text { Ifi204 (includes } \\
\text { others) }\end{array}$ & interferon activated gene 204 & Nucleus \\
\hline 1,395 & P2RY6 & pyrimidinergic receptor P2Y, G-protein coupled, 6 & Plasma Membrane \\
\hline 1,402 & PLTP & phospholipid transfer protein & Extracellular Space \\
\hline 1,412 & Epsti1 & epithelial stromal interaction 1 (breast) & Other \\
\hline 1,417 & APOE & apolipoprotein E & Extracellular Space \\
\hline 1,418 & MYH3 & myosin, heavy chain 3, skeletal muscle, embryonic & Cytoplasm \\
\hline 1,418 & UGCG & UDP-glucose ceramide glucosyltransferase & Cytoplasm \\
\hline 1,421 & ANPEP & alanyl (membrane) aminopeptidase & Plasma Membrane \\
\hline 1,425 & $\begin{array}{l}\text { Ifi204 (includes } \\
\text { others) }\end{array}$ & interferon activated gene 204 & Nucleus \\
\hline 1,432 & IGF2 & insulin-like growth factor 2 (somatomedin A) & Extracellular Space \\
\hline 1,432 & TUBB6 & tubulin, beta 6 class $\mathrm{V}$ & Cytoplasm \\
\hline 1,437 & LGMN & legumain & Cytoplasm \\
\hline 1,442 & SLC9A9 & $\begin{array}{l}\text { solute carrier family 9, subfamily A (NHE9, cation proton antiporter } \\
\text { 9), member } 9\end{array}$ & Cytoplasm \\
\hline 1,449 & TLR1 & toll-like receptor 1 & Plasma Membrane \\
\hline 1,455 & SLC7A10 & $\begin{array}{l}\text { solute carrier family } 7 \text { (neutral amino acid transporter light chain, } \\
\text { asc system), member } 10\end{array}$ & Plasma Membrane \\
\hline 1,456 & STAB1 & stabilin 1 & Plasma Membrane \\
\hline 1,460 & COL14A1 & collagen, type XIV, alpha 1 & Extracellular Space \\
\hline 1,469 & CASP4 & caspase 4, apoptosis-related cysteine peptidase & Cytoplasm \\
\hline 1,474 & CXCL16 & chemokine (C-X-C motif) ligand 16 & Extracellular Space \\
\hline 1,482 & SIGLEC1 & sialic acid binding Ig-like lectin 1 , sialoadhesin & Plasma Membrane \\
\hline 1,482 & SRPX & sushi-repeat containing protein, $\mathrm{X}$-linked & Cytoplasm \\
\hline 1,483 & S100A4 & S100 calcium binding protein A4 & Cytoplasm \\
\hline 1,486 & KRT18 & keratin 18 & Cytoplasm \\
\hline 1,488 & CSF2RB & $\begin{array}{l}\text { colony stimulating factor } 2 \text { receptor, beta, low-affinity } \\
\text { (granulocyte-macrophage) }\end{array}$ & Plasma Membrane \\
\hline 1,488 & STAP1 & signal transducing adaptor family member 1 & Cytoplasm \\
\hline 1,492 & CFD & complement factor D (adipsin) & Extracellular Space \\
\hline 1,493 & CSF1R & colony stimulating factor 1 receptor & Plasma Membrane \\
\hline 1,494 & CD48 & CD48 molecule & Plasma Membrane \\
\hline 1,497 & $\mathrm{P} 2 \mathrm{RX} 4$ & purinergic receptor $\mathrm{P} 2 \mathrm{X}$, ligand-gated ion channel, 4 & Plasma Membrane \\
\hline 1,500 & RGS10 & regulator of G-protein signaling 10 & Cytoplasm \\
\hline 1,501 & IL13RA1 & interleukin 13 receptor, alpha 1 & Plasma Membrane \\
\hline 1,505 & BCL2A1 & $\mathrm{BCL} 2$-related protein $\mathrm{A} 1$ & Cytoplasm \\
\hline 1,505 & PDE3B & phosphodiesterase 3B, cGMP-inhibited & Cytoplasm \\
\hline 1,516 & Gp49a/Lilrb4 & leukocyte immunoglobulin-like receptor, subfamily B, member 4 & Other \\
\hline 1,519 & COL3A1 & collagen, type III, alpha 1 & Extracellular Space \\
\hline 1,521 & BCL2A1 & $\mathrm{BCL2}$-related protein $\mathrm{A} 1$ & Cytoplasm \\
\hline 1,524 & SLAMF7 & SLAM family member 7 & Plasma Membrane \\
\hline 1,525 & HPGDS & hematopoietic prostaglandin D synthase & Cytoplasm \\
\hline 1,527 & RUNX1 & runt-related transcription factor 1 & Nucleus \\
\hline 1,531 & HPSE & heparanase & Plasma Membrane \\
\hline 1,544 & HLA-DQB1 & major histocompatibility complex, class II, DQ beta 1 & Plasma Membrane \\
\hline 1,546 & NCKAP1L & NCK-associated protein 1-like & Plasma Membrane \\
\hline 1,548 & RRAD & Ras-related associated with diabetes & Cytoplasm \\
\hline 1,548 & TMEM176B & transmembrane protein $176 \mathrm{~B}$ & Other \\
\hline 1,549 & HLA-DRB1 & major histocompatibility complex, class II, DR beta 1 & Plasma Membrane \\
\hline 1,550 & $\begin{array}{l}\text { Ifi204 (includes } \\
\text { others) }\end{array}$ & interferon activated gene 204 & Nucleus \\
\hline 1,559 & SVEP1 & $\begin{array}{l}\text { sushi, von Willebrand factor type A, EGF and pentraxin domain } \\
\text { containing } 1\end{array}$ & Cytoplasm \\
\hline 1,562 & C4A/C4B & complement component 4B (Chido blood group) & Extracellular Space \\
\hline 1,567 & PLD4 & phospholipase D family, member 4 & Extracellular Space \\
\hline 1,568 & TYROBP & TYRO protein tyrosine kinase binding protein & Plasma Membrane \\
\hline 1,569 & Ces1f & carboxylesterase $1 \mathrm{~F}$ & Cytoplasm \\
\hline 1,587 & PCK1 & phosphoenolpyruvate carboxykinase 1 (soluble) & Cytoplasm \\
\hline 1,589 & Ms4a6c & membrane-spanning 4-domains, subfamily $\mathrm{A}$, member $6 \mathrm{C}$ & Other \\
\hline 1,620 & APOL3/APOL4 & apolipoprotein $\mathrm{L}, 4$ & Other \\
\hline 1,628 & Cd52 & CD52 antigen & Other \\
\hline
\end{tabular}




\begin{tabular}{|c|c|c|c|}
\hline 1,634 & BCL2A1 & BCL2-related protein A1 & Cytoplasm \\
\hline 1,641 & CSF2RB & $\begin{array}{l}\text { colony stimulating factor } 2 \text { receptor, beta, low-affinity } \\
\text { (granulocyte-macrophage) }\end{array}$ & Plasma Membrane \\
\hline 1,641 & LAPTM5 & lysosomal protein transmembrane 5 & Plasma Membrane \\
\hline 1,641 & PTPRC & protein tyrosine phosphatase, receptor type, C & Plasma Membrane \\
\hline 1,647 & MS4A14 & membrane-spanning 4-domains, subfamily A, member 14 & Other \\
\hline 1,648 & Clec4a1 & C-type lectin domain family 4 , member a1 & Other \\
\hline 1,652 & Ccl9 & chemokine ( $\mathrm{C}-\mathrm{C}$ motif) ligand 9 & Extracellular Space \\
\hline 1,666 & HLA-DMB & major histocompatibility complex, class II, DM beta & Plasma Membrane \\
\hline 1,667 & COL6A5 & collagen, type VI, alpha 5 & Extracellular Space \\
\hline 1,672 & CLEC6A & C-type lectin domain family 6 , member A & Plasma Membrane \\
\hline 1,677 & TMEM8C & transmembrane protein $8 C$ & Plasma Membrane \\
\hline 1,678 & APOBEC1 & apolipoprotein B mRNA editing enzyme, catalytic polypeptide 1 & Cytoplasm \\
\hline 1,685 & CD300LD & CD300 molecule-like family member $\mathrm{d}$ & Plasma Membrane \\
\hline 1,694 & EMB & embigin & Plasma Membrane \\
\hline 1,708 & CD300LD & CD300 molecule-like family member $\mathrm{d}$ & Plasma Membrane \\
\hline 1,715 & IFI27L2 & interferon, alpha-inducible protein 27 -like 2 & Other \\
\hline 1,717 & FCGR2B & Fc fragment of IgG, low affinity IIb, receptor (CD32) & Plasma Membrane \\
\hline 1,718 & IFI30 & interferon, gamma-inducible protein 30 & Cytoplasm \\
\hline 1,721 & Ccl6 & chemokine (C-C motif) ligand 6 & Extracellular Space \\
\hline 1,722 & CCR5 & chemokine (C-C motif) receptor 5 (gene/pseudogene) & Plasma Membrane \\
\hline 1,722 & CCR5 & chemokine (C-C motif) receptor 5 (gene/pseudogene) & Plasma Membrane \\
\hline 1,723 & Fcrls & Fc receptor-like S, scavenger receptor & Plasma Membrane \\
\hline 1,724 & CFB & complement factor B & Extracellular Space \\
\hline 1,745 & MT1E & metallothionein $1 \mathrm{E}$ & Cytoplasm \\
\hline 1,752 & CD72 & CD72 molecule & Plasma Membrane \\
\hline 1,754 & PCBD1 & $\begin{array}{l}\text { pterin-4 alpha-carbinolamine dehydratase/dimerization cofactor of } \\
\text { hepatocyte nuclear factor } 1 \text { alpha }\end{array}$ & Nucleus \\
\hline 1,769 & MRC1 & mannose receptor, $\mathrm{C}$ type 1 & Plasma Membrane \\
\hline 1,779 & CCL7 & chemokine ( $\mathrm{C}-\mathrm{C}$ motif) ligand 7 & Extracellular Space \\
\hline 1,783 & CILP & $\begin{array}{l}\text { cartilage intermediate layer protein, nucleotide } \\
\text { pyrophosphohydrolase }\end{array}$ & Extracellular Space \\
\hline 1,784 & PLA2G2D & phospholipase A2, group IID & Extracellular Space \\
\hline 1,792 & HLA-DQA1 & major histocompatibility complex, class II, DQ alpha 1 & Plasma Membrane \\
\hline 1,803 & CD74 & $\begin{array}{l}\text { CD74 molecule, major histocompatibility complex, class II invariant } \\
\text { chain }\end{array}$ & Plasma Membrane \\
\hline 1,804 & IL7R & interleukin 7 receptor & Plasma Membrane \\
\hline 1,808 & Clec4a3 & C-type lectin domain family 4 , member a3 & Other \\
\hline 1,808 & Nxpe5 & neurexophilin and PC-esterase domain family, member 5 & Other \\
\hline 1,809 & CD53 & CD53 molecule & Plasma Membrane \\
\hline 1,810 & C1QA & complement component 1 , q subcomponent, A chain & Extracellular Space \\
\hline 1,815 & MS4A4A & membrane-spanning 4-domains, subfamily $A$, member $4 \mathrm{~A}$ & Other \\
\hline 1,831 & PRUNE2 & prune homolog 2 (Drosophila) & Other \\
\hline 1,852 & PRUNE2 & prune homolog 2 (Drosophila) & Other \\
\hline 1,858 & IGHM & immunoglobulin heavy constant mu & Plasma Membrane \\
\hline 1,860 & FBLN7 & fibulin 7 & Extracellular Space \\
\hline 1,861 & Mcpt4 & mast cell protease 4 & Other \\
\hline 1,870 & CD180 & CD180 molecule & Plasma Membrane \\
\hline 1,887 & BANK1 & B-cell scaffold protein with ankyrin repeats 1 & Extracellular Space \\
\hline 1,888 & CPA3 & carboxypeptidase A3 (mast cell) & Extracellular Space \\
\hline 1,903 & MFAP4 & microfibrillar-associated protein 4 & Extracellular Space \\
\hline 1,906 & C1QB & complement component 1, q subcomponent, B chain & Extracellular Space \\
\hline 1,941 & LGALS3 & lectin, galactoside-binding, soluble, 3 & Extracellular Space \\
\hline 1,942 & $\mathrm{C} 1 \mathrm{QC}$ & complement component 1 , q subcomponent, $\mathrm{C}$ chain & Extracellular Space \\
\hline 1,953 & ANKRD1 & ankyrin repeat domain 1 (cardiac muscle) & Cytoplasm \\
\hline 1,965 & MPEG1 & macrophage expressed 1 & Cytoplasm \\
\hline 1,970 & POSTN & periostin, osteoblast specific factor & Extracellular Space \\
\hline 1,980 & CCL5 & chemokine ( $\mathrm{C}-\mathrm{C}$ motif) ligand 5 & Extracellular Space \\
\hline 1,998 & EMR1 & egf-like module containing, mucin-like, hormone receptor-like 1 & Plasma Membrane \\
\hline 1,998 & IL2RG & interleukin 2 receptor, gamma & Plasma Membrane \\
\hline 2,047 & Ms4a6b & membrane-spanning 4-domains, subfamily $\mathrm{A}$, member $6 \mathrm{~B}$ & Other \\
\hline 2,057 & GLIPR1 & GLI pathogenesis-related 1 & Extracellular Space \\
\hline 2,058 & CD68 & CD68 molecule & Plasma Membrane \\
\hline 2,069 & CD3G & CD3g molecule, gamma (CD3-TCR complex) & Plasma Membrane \\
\hline 2,071 & GPNMB & glycoprotein (transmembrane) $\mathrm{nmb}$ & Plasma Membrane \\
\hline 2,085 & LY86 & lymphocyte antigen 86 & Plasma Membrane \\
\hline 2,103 & HP & haptoglobin & Extracellular Space \\
\hline 2,128 & MMP3 & matrix metallopeptidase 3 (stromelysin 1 , progelatinase) & Extracellular Space \\
\hline 2,160 & Wfdc17 & WAP four-disulfide core domain 17 & Other \\
\hline 2,189 & VSIG4 & V-set and immunoglobulin domain containing 4 & Plasma Membrane \\
\hline 2,207 & MMP12 & matrix metallopeptidase 12 (macrophage elastase) & Extracellular Space \\
\hline 2,208 & BAIAP2L1 & BAI1-associated protein 2-like 1 & Cytoplasm \\
\hline
\end{tabular}




\begin{tabular}{rlll}
\hline $\mathbf{2 , 2 2 6}$ & Snord53 & small nucleolar RNA, C/D box 53 & Other \\
$\mathbf{2 , 2 7 7}$ & SFRP1 & secreted frizzled-related protein 1 & Plasma Membrane \\
$\mathbf{2 , 3 5 1}$ & MS4A6A & membrane-spanning 4-domains, subfamily A, member 6A & Other \\
$\mathbf{2 , 3 5 1}$ & MS4A7 & membrane-spanning 4-domains, subfamily A, member 7 & Other \\
$\mathbf{2 , 3 9 0}$ & TIMP1 & TIMP metallopeptidase inhibitor 1 & Extracellular Space \\
$\mathbf{2 , 4 2 4}$ & MT1H & metallothionein 1H & Other \\
$\mathbf{2 , 4 6 4}$ & CTSS & cathepsin S & Cytoplasm \\
$\mathbf{2 , 5 5 5}$ & CXCL13 & chemokine (C-X-C motif) ligand 13 & Extracellular Space \\
$\mathbf{2 , 6 5 1}$ & C3AR1 & complement component 3a receptor 1 & Plasma Membrane \\
$\mathbf{2 , 6 5 5}$ & SERPINA3 & serpin peptidase inhibitor, clade A (alpha-1 antiproteinase, & Extracellular Space \\
& & antitrypsin), member 3 & \\
$\mathbf{2 , 9 3 2}$ & HAL & histidine ammonia-lyase & Cytoplasm \\
$\mathbf{3 , 9 3 7}$ & CCl8 & chemokine (C-C motif) ligand 8 & Extracellular Space \\
$\mathbf{4 , 2 5 6}$ & Glycam1 & glycosylation dependent cell adhesion molecule 1 & Plasma Membrane \\
$\mathbf{5 , 5 1 7}$ & HLA-DRA & major histocompatibility complex, class II, DR alpha & Plasma Membrane \\
\hline
\end{tabular}




\begin{tabular}{|c|c|c|c|}
\hline \multicolumn{4}{|c|}{$D_{m d^{m d x}} /$ Large $^{m y d-/-}$ vs C57BL 6 meses } \\
\hline $\begin{array}{l}\text { Fold } \\
\text { Change }\end{array}$ & Symbol & Entrez Gene Name & Location \\
\hline$-5,225$ & XIST & $\mathrm{X}$ inactive specific transcript (non-protein coding) & Nucleus \\
\hline$-4,007$ & OSTN & osteocrin & Extracellular Space \\
\hline$-2,338$ & METTL11B & methyltransferase like 11B & Other \\
\hline$-2,328$ & MSTN & myostatin & Extracellular Space \\
\hline$-2,266$ & ASB4 & ankyrin repeat and SOCS box containing 4 & Nucleus \\
\hline$-2,167$ & NOS1 & nitric oxide synthase 1 (neuronal) & Cytoplasm \\
\hline$-2,132$ & CYP4F22 & cytochrome P450, family 4, subfamily F, polypeptide 22 & Extracellular Space \\
\hline$-2,114$ & $\mathrm{CHAC1}$ & ChaC, cation transport regulator homolog $1(\mathrm{E}$, coli) & Cytoplasm \\
\hline$-2,096$ & PPP1R1A & protein phosphatase 1 , regulatory (inhibitor) subunit $1 \mathrm{~A}$ & Cytoplasm \\
\hline$-2,025$ & MC5R & melanocortin 5 receptor & Plasma Membrane \\
\hline$-2,015$ & LARGE & like-glycosyltransferase & Cytoplasm \\
\hline$-1,963$ & MSS51 & MSS51 mitochondrial translational activator & Other \\
\hline$-1,962$ & PTTG1 & pituitary tumor-transforming 1 & Nucleus \\
\hline$-1,914$ & PFKFB3 & 6-phosphofructo-2-kinase/fructose-2,6-biphosphatase 3 & Cytoplasm \\
\hline$-1,891$ & PLCD4 & phospholipase $\mathrm{C}$, delta 4 & Cytoplasm \\
\hline$-1,861$ & HS3ST5 & heparan sulfate (glucosamine) 3-O-sulfotransferase 5 & Cytoplasm \\
\hline$-1,858$ & ASB2 & ankyrin repeat and SOCS box containing 2 & Nucleus \\
\hline 1,264 & SULF2 & sulfatase 2 & Plasma Membrane \\
\hline 1,286 & CTSK & cathepsin $\mathrm{K}$ & Cytoplasm \\
\hline 1,289 & TGFBI & transforming growth factor, beta-induced, $68 \mathrm{kDa}$ & Extracellular Space \\
\hline 1,293 & IGSF6 & immunoglobulin superfamily, member 6 & Plasma Membrane \\
\hline 1,309 & TLR4 & toll-like receptor 4 & Plasma Membrane \\
\hline 1,310 & SCPEP1 & serine carboxypeptidase 1 & Cytoplasm \\
\hline 1,316 & CMTM3 & CKLF-like MARVEL transmembrane domain containing 3 & Extracellular Space \\
\hline 1,323 & SCN7A & sodium channel, voltage-gated, type VII, alpha subunit & Plasma Membrane \\
\hline 1,325 & CD14 & CD14 molecule & Plasma Membrane \\
\hline 1,326 & MMP2 & $\begin{array}{l}\text { matrix metallopeptidase } 2 \text { (gelatinase A, } 72 \mathrm{kDa} \text { gelatinase, } 72 \mathrm{kDa} \\
\text { type IV collagenase) }\end{array}$ & Extracellular Space \\
\hline 1,328 & PAMR1 & $\begin{array}{l}\text { peptidase domain containing associated with muscle regeneration } \\
1\end{array}$ & Extracellular Space \\
\hline 1,337 & PLXNB2 & plexin B2 & Plasma Membrane \\
\hline 1,338 & ATP8B1 & $\begin{array}{l}\text { ATPase, aminophospholipid transporter, class I, type 8B, member } \\
1\end{array}$ & Plasma Membrane \\
\hline 1,339 & $\mathrm{CFH}$ & complement factor $\mathrm{H}$ & Extracellular Space \\
\hline 1,339 & EMP3 & epithelial membrane protein 3 & Plasma Membrane \\
\hline 1,342 & CCDC80 & coiled-coil domain containing 80 & Nucleus \\
\hline 1,346 & COL6A5 & collagen, type VI, alpha 5 & Extracellular Space \\
\hline 1,348 & EGFR & epidermal growth factor receptor & Plasma Membrane \\
\hline 1,352 & SMIM3 & small integral membrane protein 3 & Other \\
\hline 1,362 & B4GALT6 & UDP-Gal:betaGlcNAc beta 1,4- galactosyltransferase, polypeptide 6 & Cytoplasm \\
\hline 1,367 & CYSLTR1 & cysteinyl leukotriene receptor 1 & Plasma Membrane \\
\hline 1,371 & $\mathrm{C} 1 \mathrm{R}$ & complement component $1, \mathrm{r}$ subcomponent & Extracellular Space \\
\hline 1,380 & ITGAM & integrin, alpha M (complement component 3 receptor 3 subunit) & Plasma Membrane \\
\hline 1,382 & LITAF & lipopolysaccharide-induced TNF factor & Nucleus \\
\hline 1,386 & C1S & complement component 1 , s subcomponent & Extracellular Space \\
\hline 1,389 & AW551984 & expressed sequence AW551984 & Other \\
\hline 1,390 & OCEL1 & occludin/ELL domain containing 1 & Other \\
\hline 1,390 & PDGFRL & platelet-derived growth factor receptor-like & Plasma Membrane \\
\hline 1,394 & CCDC141 & coiled-coil domain containing 141 & Other \\
\hline 1,395 & PEG3 & paternally expressed 3 & Nucleus \\
\hline 1,397 & PROS1 & protein S (alpha) & Extracellular Space \\
\hline 1,399 & CA13 & carbonic anhydrase XIII & Cytoplasm \\
\hline 1,399 & MFAP5 & microfibrillar associated protein 5 & Extracellular Space \\
\hline 1,403 & CAPG & capping protein (actin filament), gelsolin-like & Nucleus \\
\hline 1,405 & TNFRSF1B & tumor necrosis factor receptor superfamily, member $1 \mathrm{~B}$ & Plasma Membrane \\
\hline 1,406 & Pira11 & paired-Ig-like receptor A11 & Other \\
\hline 1,407 & $\mathrm{Bcl} 2 \mathrm{a} 1 \mathrm{c}$ & B cell leukemia/lymphoma 2 related protein A1C & Other \\
\hline 1,408 & IL1RL2 & interleukin 1 receptor-like 2 & Plasma Membrane \\
\hline 1,411 & LUM & lumican & Extracellular Space \\
\hline 1,414 & LACC1 & laccase (multicopper oxidoreductase) domain containing 1 & Other \\
\hline 1,414 & RAB31 & RAB31, member RAS oncogene family & Cytoplasm \\
\hline 1,415 & TBXAS1 & thromboxane A synthase 1 (platelet) & Plasma Membrane \\
\hline 1,419 & ITGB2 & $\begin{array}{l}\text { integrin, beta } 2 \text { (complement component } 3 \text { receptor } 3 \text { and } 4 \\
\text { subunit) }\end{array}$ & Plasma Membrane \\
\hline 1,422 & ALDH1A2 & aldehyde dehydrogenase 1 family, member A2 & Cytoplasm \\
\hline 1,425 & DSE & dermatan sulfate epimerase & Cytoplasm \\
\hline 1,428 & CCDC109B & coiled-coil domain containing 109B & Cytoplasm \\
\hline 1,429 & ECM1 & extracellular matrix protein 1 & Extracellular Space \\
\hline 1,429 & Ifi204 (includes & interferon activated gene 204 & Nucleus \\
\hline
\end{tabular}




\begin{tabular}{|c|c|c|c|}
\hline & others) & & \\
\hline 1,430 & SIRPA & signal-regulatory protein alpha & Plasma Membrane \\
\hline 1,431 & A930003A15Rik & RIKEN cDNA A930003A15 gene & Other \\
\hline 1,432 & MEDAG & mesenteric estrogen-dependent adipogenesis & Cytoplasm \\
\hline 1,433 & OSMR & oncostatin M receptor & Plasma Membrane \\
\hline 1,435 & CYBA & cytochrome b-245, alpha polypeptide & Cytoplasm \\
\hline 1,435 & FN1 & fibronectin 1 & Extracellular Space \\
\hline 1,436 & Cd52 & CD52 antigen & Other \\
\hline 1,440 & CD302 & CD302 molecule & Plasma Membrane \\
\hline 1,441 & CLEC12A & C-type lectin domain family 12 , member $A$ & Plasma Membrane \\
\hline 1,442 & $\begin{array}{l}\text { Ms4a4b (includes } \\
\text { others) }\end{array}$ & membrane-spanning 4-domains, subfamily $\mathrm{A}$, member 4B & Plasma Membrane \\
\hline 1,454 & PF4 & platelet factor 4 & Extracellular Space \\
\hline 1,457 & CYBB & cytochrome b-245, beta polypeptide & Cytoplasm \\
\hline 1,462 & GRN & granulin & Extracellular Space \\
\hline 1,463 & ALOX5AP & arachidonate 5-lipoxygenase-activating protein & Plasma Membrane \\
\hline 1,463 & FOLR2 & folate receptor 2 (fetal) & Plasma Membrane \\
\hline 1,465 & BST1 & bone marrow stromal cell antigen 1 & Plasma Membrane \\
\hline 1,466 & AIF1L & allograft inflammatory factor 1 -like & Plasma Membrane \\
\hline 1,466 & RASGEF1B & RasGEF domain family, member $1 \mathrm{~B}$ & Other \\
\hline 1,468 & LCP1 & lymphocyte cytosolic protein 1 (L-plastin) & Cytoplasm \\
\hline 1,469 & PLEKHO1 & pleckstrin homology domain containing, family $\mathrm{O}$ member 1 & Plasma Membrane \\
\hline 1,475 & IFI27L2 & interferon, alpha-inducible protein 27 -like 2 & Other \\
\hline 1,476 & UGCG & UDP-glucose ceramide glucosyltransferase & Cytoplasm \\
\hline 1,477 & CLEC4D & C-type lectin domain family 4 , member $D$ & Plasma Membrane \\
\hline 1,478 & THBS4 & thrombospondin 4 & Extracellular Space \\
\hline 1,479 & NCAM1 & neural cell adhesion molecule 1 & Plasma Membrane \\
\hline 1,481 & C14orf37 & chromosome 14 open reading frame 37 & Extracellular Space \\
\hline 1,484 & P4HA3 & prolyl 4-hydroxylase, alpha polypeptide III & Other \\
\hline 1,489 & RENBP & renin binding protein & Other \\
\hline 1,494 & TMEM176B & transmembrane protein $176 \mathrm{~B}$ & Other \\
\hline 1,495 & APOE & apolipoprotein E & Extracellular Space \\
\hline 1,495 & RGS1 & regulator of G-protein signaling 1 & Plasma Membrane \\
\hline 1,496 & TUBB2B & tubulin, beta $2 \mathrm{~B}$ class IIb & Cytoplasm \\
\hline 1,499 & ANXA1 & annexin A1 & Plasma Membrane \\
\hline 1,499 & CSTB & cystatin B (stefin B) & Cytoplasm \\
\hline 1,499 & TM6SF1 & transmembrane 6 superfamily member 1 & Plasma Membrane \\
\hline 1,503 & FCGR1A & Fc fragment of IgG, high affinity Ia, receptor (CD64) & Plasma Membrane \\
\hline 1,503 & PTPRC & protein tyrosine phosphatase, receptor type, C & Plasma Membrane \\
\hline 1,505 & TMEM173 & transmembrane protein 173 & Cytoplasm \\
\hline 1,508 & PLEK & pleckstrin & Cytoplasm \\
\hline 1,519 & ANXA4 & annexin A4 & Plasma Membrane \\
\hline 1,527 & HGF & hepatocyte growth factor (hepapoietin A; scatter factor) & Extracellular Space \\
\hline 1,530 & SLC25A24 & $\begin{array}{l}\text { solute carrier family } 25 \text { (mitochondrial carrier; phosphate carrier), } \\
\text { member } 24\end{array}$ & Cytoplasm \\
\hline 1,532 & CXCL14 & chemokine ( $\mathrm{C}-\mathrm{X}-\mathrm{C}$ motif) ligand 14 & Extracellular Space \\
\hline 1,536 & SERPINE1 & $\begin{array}{l}\text { serpin peptidase inhibitor, clade } E \text { (nexin, plasminogen activator } \\
\text { inhibitor type } 1 \text { ), member } 1\end{array}$ & Extracellular Space \\
\hline 1,537 & MCOLN2 & mucolipin 2 & Plasma Membrane \\
\hline 1,538 & CTHRC1 & collagen triple helix repeat containing 1 & Extracellular Space \\
\hline 1,540 & UNC93B1 & unc-93 homolog B1 (C, elegans) & Cytoplasm \\
\hline 1,543 & LAT2 & linker for activation of T cells family, member 2 & Plasma Membrane \\
\hline 1,549 & CFB & complement factor B & Extracellular Space \\
\hline 1,549 & CLEC10A & C-type lectin domain family 10 , member $A$ & Plasma Membrane \\
\hline 1,552 & RASSF4 & Ras association (RalGDS/AF-6) domain family member 4 & Other \\
\hline 1,561 & IL1R1 & interleukin 1 receptor, type I & Plasma Membrane \\
\hline 1,562 & COL6A3 & collagen, type VI, alpha 3 & Extracellular Space \\
\hline 1,563 & CSF2RB & $\begin{array}{l}\text { colony stimulating factor } 2 \text { receptor, beta, low-affinity } \\
\text { (granulocyte-macrophage) }\end{array}$ & Plasma Membrane \\
\hline 1,564 & PLTP & phospholipid transfer protein & Extracellular Space \\
\hline 1,565 & PTAFR & platelet-activating factor receptor & Plasma Membrane \\
\hline 1,575 & CD44 & CD44 molecule (Indian blood group) & Plasma Membrane \\
\hline 1,577 & CD180 & CD180 molecule & Plasma Membrane \\
\hline 1,582 & LAIR1 & leukocyte-associated immunoglobulin-like receptor 1 & Plasma Membrane \\
\hline 1,582 & Lyz1/Lyz2 & lysozyme 2 & Cytoplasm \\
\hline 1,582 & MYO5A & myosin VA (heavy chain 12 , myoxin) & Cytoplasm \\
\hline 1,583 & $\begin{array}{l}\text { Tmsb4x (includes } \\
\text { others) }\end{array}$ & thymosin, beta $4, X$ chromosome & Cytoplasm \\
\hline 1,583 & $\begin{array}{l}\text { Tmsb4x (includes } \\
\text { others) }\end{array}$ & thymosin, beta $4, x$ chromosome & Cytoplasm \\
\hline 1,584 & PLAC8 & placenta-specific 8 & Nucleus \\
\hline 1,587 & $\mathrm{CYTH} 4$ & cytohesin 4 & Cytoplasm \\
\hline
\end{tabular}




\begin{tabular}{|c|c|c|c|}
\hline 1,588 & CLEC10A & C-type lectin domain family 10, member $A$ & Plasma Membrane \\
\hline 1,602 & LRRC17 & leucine rich repeat containing 17 & Extracellular Space \\
\hline 1,614 & DAB2 & Dab, mitogen-responsive phosphoprotein, homolog 2 (Drosophila) & Plasma Membrane \\
\hline 1,615 & CD200R1 & CD200 receptor 1 & Plasma Membrane \\
\hline 1,615 & CD80 & CD80 molecule & Plasma Membrane \\
\hline 1,620 & SVEP1 & $\begin{array}{l}\text { sushi, von Willebrand factor type A, EGF and pentraxin domain } \\
\text { containing } 1\end{array}$ & Cytoplasm \\
\hline 1,624 & COL3A1 & collagen, type III, alpha 1 & Extracellular Space \\
\hline 1,627 & CASP1 & caspase 1 , apoptosis-related cysteine peptidase & Cytoplasm \\
\hline 1,638 & BMPER & BMP binding endothelial regulator & Extracellular Space \\
\hline 1,645 & LAYN & layilin & Plasma Membrane \\
\hline 1,649 & SPI1 & spleen focus forming virus (SFFV) proviral integration oncogene & Nucleus \\
\hline 1,651 & SRPX & sushi-repeat containing protein, $\mathrm{X}$-linked & Cytoplasm \\
\hline 1,662 & Milr1 & mast cell immunoglobulin like receptor 1 & Plasma Membrane \\
\hline 1,663 & SLC9A9 & $\begin{array}{l}\text { solute carrier family 9, subfamily A (NHE9, cation proton antiporter } \\
\text { 9), member } 9\end{array}$ & Cytoplasm \\
\hline 1,665 & HPSE & heparanase & Plasma Membrane \\
\hline 1,666 & TREM2 & triggering receptor expressed on myeloid cells 2 & Plasma Membrane \\
\hline 1,669 & LAPTM5 & lysosomal protein transmembrane 5 & Plasma Membrane \\
\hline 1,672 & IL10RA & interleukin 10 receptor, alpha & Plasma Membrane \\
\hline 1,684 & TLR1 & toll-like receptor 1 & Plasma Membrane \\
\hline 1,685 & CD200R1L & CD200 receptor 1 -like & Plasma Membrane \\
\hline 1,688 & CLEC4A & C-type lectin domain family 4 , member A & Plasma Membrane \\
\hline 1,691 & AKR1B10 & aldo-keto reductase family 1 , member B10 (aldose reductase) & Cytoplasm \\
\hline 1,694 & F13A1 & coagulation factor XIII, A1 polypeptide & Extracellular Space \\
\hline 1,694 & STAB1 & stabilin 1 & Plasma Membrane \\
\hline 1,700 & MYOF & myoferlin & Nucleus \\
\hline 1,712 & CSF2RB & $\begin{array}{l}\text { colony stimulating factor } 2 \text { receptor, beta, low-affinity } \\
\text { (granulocyte-macrophage) }\end{array}$ & Plasma Membrane \\
\hline 1,714 & HLA-DRB1 & major histocompatibility complex, class II, DR beta 1 & Plasma Membrane \\
\hline 1,714 & ТTC9 & tetratricopeptide repeat domain 9 & Extracellular Space \\
\hline 1,720 & COL14A1 & collagen, type XIV, alpha 1 & Extracellular Space \\
\hline 1,724 & CLEC7A & C-type lectin domain family 7 , member A & Plasma Membrane \\
\hline 1,736 & ANGPTL1 & angiopoietin-like 1 & Plasma Membrane \\
\hline 1,737 & CD48 & CD48 molecule & Plasma Membrane \\
\hline 1,739 & Eef1a1 & eukaryotic translation elongation factor 1 alpha 1 & Cytoplasm \\
\hline 1,743 & LILRB3 & $\begin{array}{l}\text { leukocyte immunoglobulin-like receptor, subfamily B (with TM and } \\
\text { ITIM domains), member } 3\end{array}$ & Plasma Membrane \\
\hline 1,746 & $\begin{array}{l}\text { Sirpb1a (includes } \\
\text { others) }\end{array}$ & signal-regulatory protein beta $1 \mathrm{~A}$ & Plasma Membrane \\
\hline 1,750 & RGS10 & regulator of G-protein signaling 10 & Cytoplasm \\
\hline 1,752 & NOX4 & NADPH oxidase 4 & Cytoplasm \\
\hline 1,757 & TMEM106A & transmembrane protein $106 \mathrm{~A}$ & Other \\
\hline 1,761 & SLC11A1 & $\begin{array}{l}\text { solute carrier family } 11 \text { (proton-coupled divalent metal ion } \\
\text { transporter), member } 1\end{array}$ & Plasma Membrane \\
\hline 1,766 & CCDC141 & coiled-coil domain containing 141 & Other \\
\hline 1,770 & LIPA & lipase A, lysosomal acid, cholesterol esterase & Cytoplasm \\
\hline 1,770 & MFAP4 & microfibrillar-associated protein 4 & Extracellular Space \\
\hline 1,779 & FCER1G & $\begin{array}{l}\text { Fc fragment of IgE, high affinity I, receptor for; gamma } \\
\text { polypeptide }\end{array}$ & Plasma Membrane \\
\hline 1,780 & ANPEP & alanyl (membrane) aminopeptidase & Plasma Membrane \\
\hline 1,780 & BAIAP2L1 & BAI1-associated protein 2-like 1 & Cytoplasm \\
\hline 1,787 & LOX & lysyl oxidase & Extracellular Space \\
\hline 1,791 & Snord116 & small nucleolar RNA, C/D box 116 & Other \\
\hline 1,801 & Snord116 & small nucleolar RNA, C/D box 116 & Other \\
\hline 1,801 & Snord116 & small nucleolar RNA, C/D box 116 & Other \\
\hline 1,801 & Snord116 & small nucleolar RNA, C/D box 116 & Other \\
\hline 1,801 & Snord116 & small nucleolar RNA, C/D box 116 & Other \\
\hline 1,801 & Snord116 & small nucleolar RNA, C/D box 116 & Other \\
\hline 1,801 & Snord116 & small nucleolar RNA, C/D box 116 & Other \\
\hline 1,801 & Snord116 & small nucleolar RNA, C/D box 116 & Other \\
\hline 1,801 & Snord116 & small nucleolar RNA, C/D box 116 & Other \\
\hline 1,801 & Snord116 & small nucleolar RNA, C/D box 116 & Other \\
\hline 1,801 & Snord116 & small nucleolar RNA, C/D box 116 & Other \\
\hline 1,801 & Snord116 & small nucleolar RNA, C/D box 116 & Other \\
\hline 1,801 & Snord116 & small nucleolar RNA, C/D box 116 & Other \\
\hline 1,801 & Snord116 & small nucleolar RNA, C/D box 116 & Other \\
\hline 1,801 & Snord116 & small nucleolar RNA, C/D box 116 & Other \\
\hline 1,801 & Snord116 & small nucleolar RNA, C/D box 116 & Other \\
\hline 1,801 & Snord116 & small nucleolar RNA, C/D box 116 & Other \\
\hline 1,801 & Snord116 & small nucleolar RNA, C/D box 116 & Other \\
\hline 1,801 & Snord116 & small nucleolar RNA, C/D box 116 & Other \\
\hline
\end{tabular}




\begin{tabular}{|c|c|c|c|}
\hline 1,802 & TYROBP & TYRO protein tyrosine kinase binding protein & Plasma Membrane \\
\hline 1,815 & ADAM8 & ADAM metallopeptidase domain 8 & Plasma Membrane \\
\hline 1,822 & Olfr1372-ps1 & olfactory receptor 1372, pseudogene 1 & Other \\
\hline 1,824 & FYB & FYN binding protein & Nucleus \\
\hline 1,826 & FGL2 & fibrinogen-like 2 & Extracellular Space \\
\hline 1,829 & NCKAP1L & NCK-associated protein 1-like & Plasma Membrane \\
\hline 1,839 & 5430435G22Rik & RIKEN cDNA $5430435 \mathrm{G} 22$ gene & Cytoplasm \\
\hline 1,840 & PLD4 & phospholipase D family, member 4 & Extracellular Space \\
\hline 1,843 & P2RX4 & purinergic receptor $\mathrm{P} 2 \mathrm{X}$, ligand-gated ion channel, 4 & Plasma Membrane \\
\hline 1,846 & $\mathrm{Ccl} 2$ & chemokine (C-C motif) ligand 2 & Extracellular Space \\
\hline 1,853 & LGMN & legumain & Cytoplasm \\
\hline 1,855 & VCAN & versican & Extracellular Space \\
\hline 1,856 & MYL4 & myosin, light chain 4, alkali; atrial, embryonic & Cytoplasm \\
\hline 1,865 & HLA-DQA1 & major histocompatibility complex, class II, DQ alpha 1 & Plasma Membrane \\
\hline 1,866 & CASP4 & caspase 4, apoptosis-related cysteine peptidase & Cytoplasm \\
\hline 1,867 & IFI30 & interferon, gamma-inducible protein 30 & Cytoplasm \\
\hline 1,871 & GPR65 & G protein-coupled receptor 65 & Plasma Membrane \\
\hline 1,873 & CD74 & $\begin{array}{l}\text { CD74 molecule, major histocompatibility complex, class II invariant } \\
\text { chain }\end{array}$ & Plasma Membrane \\
\hline 1,873 & CSF1R & colony stimulating factor 1 receptor & Plasma Membrane \\
\hline 1,878 & PDPN & podoplanin & Plasma Membrane \\
\hline 1,879 & IL7R & interleukin 7 receptor & Plasma Membrane \\
\hline 1,882 & IGF2 & insulin-like growth factor 2 (somatomedin A) & Extracellular Space \\
\hline 1,892 & CD300LD & CD300 molecule-like family member $d$ & Plasma Membrane \\
\hline 1,895 & $\mathrm{BCL2A1}$ & $\mathrm{BCL} 2$-related protein $\mathrm{A} 1$ & Cytoplasm \\
\hline 1,903 & CD300C & CD300c molecule & Plasma Membrane \\
\hline 1,908 & COL8A1 & collagen, type VIII, alpha 1 & Extracellular Space \\
\hline 1,909 & HLA-DQB1 & major histocompatibility complex, class II, DQ beta 1 & Plasma Membrane \\
\hline 1,913 & Fcrls & Fc receptor-like S, scavenger receptor & Plasma Membrane \\
\hline 1,914 & CD300LD & CD300 molecule-like family member $d$ & Plasma Membrane \\
\hline 1,916 & HP & haptoglobin & Extracellular Space \\
\hline 1,925 & C4A/C4B & complement component 4B (Chido blood group) & Extracellular Space \\
\hline 1,932 & SOAT1 & sterol O-acyltransferase 1 & Cytoplasm \\
\hline 1,935 & BCL2A1 & $\mathrm{BCL2}$-related protein $\mathrm{A} 1$ & Cytoplasm \\
\hline 1,938 & C5AR1 & complement component 5a receptor 1 & Plasma Membrane \\
\hline 1,965 & CLEC6A & C-type lectin domain family 6 , member A & Plasma Membrane \\
\hline 1,970 & Nxpe5 & neurexophilin and PC-esterase domain family, member 5 & Other \\
\hline 1,971 & RUNX1 & runt-related transcription factor 1 & Nucleus \\
\hline 1,991 & HPGDS & hematopoietic prostaglandin D synthase & Cytoplasm \\
\hline 1,998 & CD53 & CD53 molecule & Plasma Membrane \\
\hline 1,998 & CTSH & cathepsin $\mathrm{H}$ & Cytoplasm \\
\hline 1,999 & MSR1 & macrophage scavenger receptor 1 & Plasma Membrane \\
\hline 1,999 & S100A4 & S100 calcium binding protein A4 & Cytoplasm \\
\hline 2,005 & $\mathrm{BCL} 2 \mathrm{~A} 1$ & $\mathrm{BCL} 2$-related protein $\mathrm{A} 1$ & Cytoplasm \\
\hline 2,012 & DPEP2 & dipeptidase 2 & Plasma Membrane \\
\hline 2,012 & ITGAX & integrin, alpha $\mathrm{X}$ (complement component 3 receptor 4 subunit) & Plasma Membrane \\
\hline 2,013 & CXCL16 & chemokine (C-X-C motif) ligand 16 & Extracellular Space \\
\hline 2,024 & CD300LD & CD300 molecule-like family member $d$ & Plasma Membrane \\
\hline 2,059 & TNNT2 & troponin T type 2 (cardiac) & Cytoplasm \\
\hline 2,061 & P2RY6 & pyrimidinergic receptor P2Y, G-protein coupled, 6 & Plasma Membrane \\
\hline 2,065 & IL13RA1 & interleukin 13 receptor, alpha 1 & Plasma Membrane \\
\hline 2,070 & $\begin{array}{l}\text { Ifi204 (includes } \\
\text { others) }\end{array}$ & interferon activated gene 204 & Nucleus \\
\hline 2,087 & GAL & galanin/GMAP prepropeptide & Extracellular Space \\
\hline 2,101 & CCR2 & chemokine (C-C motif) receptor 2 & Plasma Membrane \\
\hline 2,134 & SLAMF7 & SLAM family member 7 & Plasma Membrane \\
\hline 2,141 & TUBB6 & tubulin, beta 6 class $V$ & Cytoplasm \\
\hline 2,149 & CILP & $\begin{array}{l}\text { cartilage intermediate layer protein, nucleotide } \\
\text { pyrophosphohydrolase }\end{array}$ & Extracellular Space \\
\hline 2,149 & Lyz1/Lyz2 & lysozyme 2 & Cytoplasm \\
\hline 2,155 & FCGR3A & Fc fragment of IgG, low affinity IIIa, receptor (CD16a) & Plasma Membrane \\
\hline 2,170 & EMB & embigin & Plasma Membrane \\
\hline 2,200 & Gp49a/Lilrb4 & leukocyte immunoglobulin-like receptor, subfamily B, member 4 & Other \\
\hline 2,201 & FCGR2A & Fc fragment of IgG, low affinity IIa, receptor (CD32) & Plasma Membrane \\
\hline 2,205 & APOBEC1 & apolipoprotein B mRNA editing enzyme, catalytic polypeptide 1 & Cytoplasm \\
\hline 2,205 & $\begin{array}{l}\text { Ifi204 (includes } \\
\text { others) }\end{array}$ & interferon activated gene 204 & Nucleus \\
\hline 2,216 & MRC1 & mannose receptor, C type 1 & Plasma Membrane \\
\hline 2,237 & CD84 & CD84 molecule & Plasma Membrane \\
\hline 2,247 & FBLN7 & fibulin 7 & Extracellular Space \\
\hline 2,260 & Ms4a6c & membrane-spanning 4-domains, subfamily A, member $6 \mathrm{C}$ & Other \\
\hline 2,279 & TIr13 & toll-like receptor 13 & Cytoplasm \\
\hline
\end{tabular}




\begin{tabular}{|c|c|c|c|}
\hline 2,296 & $\begin{array}{l}\text { Ifi204 (includes } \\
\text { others) }\end{array}$ & interferon activated gene 204 & Nucleus \\
\hline 2,306 & MMP19 & matrix metallopeptidase 19 & Extracellular Space \\
\hline 2,314 & C1QA & complement component 1 , q subcomponent, A chain & Extracellular Space \\
\hline 2,317 & TMEM8C & transmembrane protein $8 \mathrm{C}$ & Plasma Membrane \\
\hline 2,336 & POSTN & periostin, osteoblast specific factor & Extracellular Space \\
\hline 2,347 & CCL3L1/CCL3L3 & chemokine (C-C motif) ligand 3-like 1 & Extracellular Space \\
\hline 2,390 & $\mathrm{C} 1 \mathrm{QC}$ & complement component 1 , q subcomponent, $\mathrm{C}$ chain & Extracellular Space \\
\hline 2,391 & LY86 & lymphocyte antigen 86 & Plasma Membrane \\
\hline 2,395 & $\mathrm{C} 1 \mathrm{QB}$ & complement component 1 , q subcomponent, B chain & Extracellular Space \\
\hline 2,398 & CCL7 & chemokine (C-C motif) ligand 7 & Extracellular Space \\
\hline 2,416 & ATP6V0D2 & ATPase, $\mathrm{H}+$ transporting, lysosomal $38 \mathrm{kDa}$, V0 subunit d2 & Cytoplasm \\
\hline 2,426 & MT1E & metallothionein $1 \mathrm{E}$ & Cytoplasm \\
\hline 2,438 & RRAD & Ras-related associated with diabetes & Cytoplasm \\
\hline 2,447 & Ms4a6b & membrane-spanning 4-domains, subfamily $A$, member $6 B$ & Other \\
\hline 2,448 & PRUNE2 & prune homolog 2 (Drosophila) & Other \\
\hline 2,463 & PRUNE2 & prune homolog 2 (Drosophila) & Other \\
\hline 2,472 & Ccl9 & chemokine ( $\mathrm{C}-\mathrm{C}$ motif) ligand 9 & Extracellular Space \\
\hline 2,476 & Wfdc17 & WAP four-disulfide core domain 17 & Other \\
\hline 2,480 & MS4A14 & membrane-spanning 4-domains, subfamily A, member 14 & Other \\
\hline 2,481 & FCGR2B & Fc fragment of IgG, low affinity IIb, receptor (CD32) & Plasma Membrane \\
\hline 2,507 & CCR5 & chemokine (C-C motif) receptor 5 (gene/pseudogene) & Plasma Membrane \\
\hline 2,507 & CCR5 & chemokine (C-C motif) receptor 5 (gene/pseudogene) & Plasma Membrane \\
\hline 2,522 & Gp49a/Lilrb4 & leukocyte immunoglobulin-like receptor, subfamily B, member 4 & Other \\
\hline 2,545 & Clec4a1 & C-type lectin domain family 4, member a1 & Other \\
\hline 2,568 & SFRP1 & secreted frizzled-related protein 1 & Plasma Membrane \\
\hline 2,586 & Ccl6 & chemokine (C-C motif) ligand 6 & Extracellular Space \\
\hline 2,589 & CD68 & CD68 molecule & Plasma Membrane \\
\hline 2,606 & MPEG1 & macrophage expressed 1 & Cytoplasm \\
\hline 2,609 & C1QTNF3 & $\mathrm{C} 1 \mathrm{q}$ and tumor necrosis factor related protein 3 & Extracellular Space \\
\hline 2,647 & LGALS3 & lectin, galactoside-binding, soluble, 3 & Extracellular Space \\
\hline 2,652 & EMR1 & egf-like module containing, mucin-like, hormone receptor-like 1 & Plasma Membrane \\
\hline 2,674 & Clec4a3 & C-type lectin domain family 4, member a3 & Other \\
\hline 2,720 & PCBD1 & $\begin{array}{l}\text { pterin- } 4 \text { alpha-carbinolamine dehydratase/dimerization cofactor of } \\
\text { hepatocyte nuclear factor } 1 \text { alpha }\end{array}$ & Nucleus \\
\hline 2,764 & MMP3 & matrix metallopeptidase 3 (stromelysin 1 , progelatinase) & Extracellular Space \\
\hline 2,773 & MT1H & metallothionein $1 \mathrm{H}$ & Other \\
\hline 2,880 & PRG4 & proteoglycan 4 & Extracellular Space \\
\hline 2,893 & ANKRD1 & ankyrin repeat domain 1 (cardiac muscle) & Cytoplasm \\
\hline 2,966 & C7 & complement component 7 & Extracellular Space \\
\hline 2,969 & MYH3 & myosin, heavy chain 3, skeletal muscle, embryonic & Cytoplasm \\
\hline 2,990 & VSIG4 & V-set and immunoglobulin domain containing 4 & Plasma Membrane \\
\hline 3,054 & GPNMB & glycoprotein (transmembrane) nmb & Plasma Membrane \\
\hline 3,092 & CTSS & cathepsin S & Cytoplasm \\
\hline 3,147 & GLIPR1 & GLI pathogenesis-related 1 & Extracellular Space \\
\hline 3,175 & SERPINA3 & $\begin{array}{l}\text { serpin peptidase inhibitor, clade A (alpha-1 antiproteinase, } \\
\text { antitrypsin), member } 3\end{array}$ & Extracellular Space \\
\hline 3,179 & AKR1E2 & aldo-keto reductase family 1 , member E2 & Cytoplasm \\
\hline 3,223 & MS4A4A & membrane-spanning 4-domains, subfamily $A$, member $4 A$ & Other \\
\hline 3,274 & MS4A7 & membrane-spanning 4-domains, subfamily A, member 7 & Other \\
\hline 3,385 & TIMP1 & TIMP metallopeptidase inhibitor 1 & Extracellular Space \\
\hline 3,400 & C3AR1 & complement component 3a receptor 1 & Plasma Membrane \\
\hline 3,627 & HAL & histidine ammonia-lyase & Cytoplasm \\
\hline 3,707 & MS4A6A & membrane-spanning 4-domains, subfamily $A$, member $6 \mathrm{~A}$ & Other \\
\hline 3,726 & MMP12 & matrix metallopeptidase 12 (macrophage elastase) & Extracellular Space \\
\hline 4,330 & $\mathrm{Ccl} 8$ & chemokine ( $\mathrm{C}-\mathrm{C}$ motif) ligand 8 & Extracellular Space \\
\hline
\end{tabular}




\begin{tabular}{|c|c|c|c|}
\hline \multicolumn{4}{|c|}{$D m d^{m d x} /$ Large $^{m y d-/-}$ vs Dmd ${ }^{m d x} 6$ meses } \\
\hline $\begin{array}{l}\text { Fold } \\
\text { Change }\end{array}$ & Symbol & Entrez Gene Name & Location \\
\hline$-1,933$ & LARGE & like-glycosyltransferase & Cytoplasm \\
\hline$-1,600$ & MC5R & melanocortin 5 receptor & Plasma Membrane \\
\hline$-1,578$ & CHAC1 & ChaC, cation transport regulator homolog $1(\mathrm{E}$, coli) & Cytoplasm \\
\hline$-1,437$ & PFKFB3 & 6-phosphofructo-2-kinase/fructose-2,6-biphosphatase 3 & Cytoplasm \\
\hline$-1,391$ & PLCD4 & phospholipase $\mathrm{C}$, delta 4 & Cytoplasm \\
\hline$-1,252$ & SH3RF2 & SH3 domain containing ring finger 2 & Extracellular Space \\
\hline$-1,217$ & MSS51 & MSS51 mitochondrial translational activator & Other \\
\hline$-1,200$ & LRTM1 & leucine-rich repeats and transmembrane domains 1 & Other \\
\hline$-1,168$ & ASB15 & ankyrin repeat and SOCS box containing 15 & Nucleus \\
\hline$-1,165$ & METTL11B & methyltransferase like $11 \mathrm{~B}$ & Other \\
\hline$-1,150$ & NT5C1A & 5'-nucleotidase, cytosolic IA & Cytoplasm \\
\hline$-1,130$ & HRASLS & HRAS-like suppressor & Cytoplasm \\
\hline$-1,085$ & MYLK4 & myosin light chain kinase family, member 4 & Other \\
\hline$-1,078$ & 2310081J21Rik & RIKEN CDNA 2310081J21 gene & Other \\
\hline$-1,078$ & 2310081J21Rik & RIKEN cDNA 2310081J21 gene & Other \\
\hline$-1,078$ & 2310081J21Rik & RIKEN CDNA $2310081 \mathrm{~J} 21$ gene & Other \\
\hline$-1,049$ & 2310015B20Rik & RIKEN cDNA 2310015B20 gene & Other \\
\hline$-1,049$ & GADD45GIP1 & $\begin{array}{l}\text { growth arrest and DNA-damage-inducible, gamma interacting } \\
\text { protein } 1\end{array}$ & Nucleus \\
\hline$-1,033$ & LRRC38 & leucine rich repeat containing 38 & Other \\
\hline$-1,016$ & PLD5 & phospholipase D family, member 5 & Other \\
\hline$-0,991$ & VWA3B & von Willebrand factor $\mathrm{A}$ domain containing $3 \mathrm{~B}$ & Other \\
\hline$-0,99$ & SLC37A4 & $\begin{array}{l}\text { solute carrier family } 37 \text { (glucose-6-phosphate transporter), } \\
\text { member } 4\end{array}$ & Cytoplasm \\
\hline$-0,919$ & PHKG1 & phosphorylase kinase, gamma 1 (muscle) & Cytoplasm \\
\hline$-0,891$ & $\begin{array}{l}\text { 4930503E14Rik } \\
\text { (includes others) }\end{array}$ & RIKEN CDNA D830030K20 gene & Other \\
\hline$-0,891$ & $\begin{array}{l}\text { 4930503E14Rik } \\
\text { (includes others) }\end{array}$ & RIKEN cDNA D830030K20 gene & Other \\
\hline 0,973 & Nxpe5 & neurexophilin and PC-esterase domain family, member 5 & Other \\
\hline 1,010 & COL6A5 & collagen, type VI, alpha 5 & Extracellular Space \\
\hline 1,088 & PIANP & PILR alpha associated neural protein & Other \\
\hline 1,205 & MT1E & metallothionein $1 \mathrm{E}$ & Cytoplasm \\
\hline 1,226 & SFRP1 & secreted frizzled-related protein 1 & Plasma Membrane \\
\hline 1,300 & OCEL1 & occludin/ELL domain containing 1 & Other \\
\hline 1,344 & LYVE1 & lymphatic vessel endothelial hyaluronan receptor 1 & Plasma Membrane \\
\hline 1,392 & $\mathrm{Ccl} 8$ & chemokine ( $\mathrm{C}-\mathrm{C}$ motif) ligand 8 & Extracellular Space \\
\hline 1,507 & RRAD & Ras-related associated with diabetes & Cytoplasm \\
\hline 2,764 & VSIG4 & V-set and immunoglobulin domain containing 4 & Plasma Membrane \\
\hline 3,519 & HAL & histidine ammonia-lyase & Cytoplasm \\
\hline
\end{tabular}




\begin{tabular}{|c|c|c|c|}
\hline \multicolumn{4}{|c|}{$D m d^{m d x} /$ Large $^{m y d-/-}$ vs Large $e^{m y d} 6$ meses } \\
\hline $\begin{array}{l}\text { Fold } \\
\text { Change }\end{array}$ & Symbol & Entrez Gene Name & Location \\
\hline$-1,450$ & PTTG1 & pituitary tumor-transforming 1 & Nucleus \\
\hline 0,557 & C5AR2 & complement component 5 a receptor 2 & Plasma Membrane \\
\hline 0,585 & APOC2 & apolipoprotein C-II & Extracellular Space \\
\hline 0,617 & SMIM3 & small integral membrane protein 3 & Other \\
\hline 0,729 & MS4A14 & membrane-spanning 4-domains, subfamily A, member 14 & Other \\
\hline 0,731 & NFIL3 & nuclear factor, interleukin 3 regulated & Nucleus \\
\hline 0,753 & SLC22A4 & $\begin{array}{l}\text { solute carrier family } 22 \text { (organic cation/zwitterion transporter), } \\
\text { member } 4\end{array}$ & Plasma Membrane \\
\hline 0,764 & METTL15 & methyltransferase like 15 & Other \\
\hline 0,825 & GLIPR1 & GLI pathogenesis-related 1 & Extracellular Space \\
\hline 0,836 & ERRFI1 & ERBB receptor feedback inhibitor 1 & Cytoplasm \\
\hline 0,905 & ARL14EP & ADP-ribosylation factor-like 14 effector protein & Other \\
\hline 1,220 & Snord116 & small nucleolar RNA, C/D box 116 & Other \\
\hline 1,278 & Snord116 & small nucleolar RNA, C/D box 116 & Other \\
\hline 1,278 & Snord116 & small nucleolar RNA, C/D box 116 & Other \\
\hline 1,278 & Snord116 & small nucleolar RNA, C/D box 116 & Other \\
\hline 1,278 & Snord116 & small nucleolar RNA, C/D box 116 & Other \\
\hline 1,278 & Snord116 & small nucleolar RNA, C/D box 116 & Other \\
\hline 1,278 & Snord116 & small nucleolar RNA, C/D box 116 & Other \\
\hline 1,278 & Snord116 & small nucleolar RNA, C/D box 116 & Other \\
\hline 1,278 & Snord116 & small nucleolar RNA, C/D box 116 & Other \\
\hline 1,278 & Snord116 & small nucleolar RNA, C/D box 116 & Other \\
\hline 1,278 & Snord116 & small nucleolar RNA, C/D box 116 & Other \\
\hline 1,278 & Snord116 & small nucleolar RNA, C/D box 116 & Other \\
\hline 1,278 & Snord116 & small nucleolar RNA, C/D box 116 & Other \\
\hline 1,278 & Snord116 & small nucleolar RNA, C/D box 116 & Other \\
\hline 1,278 & Snord116 & small nucleolar RNA, C/D box 116 & Other \\
\hline 1,278 & Snord116 & small nucleolar RNA, C/D box 116 & Other \\
\hline 1,278 & Snord116 & small nucleolar RNA, C/D box 116 & Other \\
\hline 1,278 & Snord116 & small nucleolar RNA, C/D box 116 & Other \\
\hline 1,278 & Snord116 & small nucleolar RNA, C/D box 116 & Other \\
\hline 1,509 & Olfr1372-ps1 & olfactory receptor 1372 , pseudogene 1 & Other \\
\hline 1,560 & Zfp125 & zinc finger protein 125 & Nucleus \\
\hline 1,633 & PRG4 & proteoglycan 4 & Extracellular Space \\
\hline
\end{tabular}




\section{B. Classificação funcional de acordo com funções do Gene Ontology}

\begin{tabular}{|c|c|c|c|}
\hline \multicolumn{4}{|l|}{$D m d^{m d x}$ vs C57BL 21 dias } \\
\hline Termo GO & \# genes & p-valor & FDR \\
\hline GO:0009611 response to wounding & 57 & $1.26 \mathrm{E}-22$ & $2.19 \mathrm{E}-19$ \\
\hline GO:0006954 inflammatory response & 44 & $1.80 \mathrm{E}-20$ & $3.14 \mathrm{E}-17$ \\
\hline GO:0006952 defense response & 60 & $2.60 \mathrm{E}-19$ & $4.52 E-16$ \\
\hline GO:0000087 M phase of mitotic cell cycle & 34 & $2.24 \mathrm{E}-14$ & $3.90 \mathrm{E}-11$ \\
\hline GO:0005764 lysosome & 33 & 2.47E-14 & $3.25 \mathrm{E}-11$ \\
\hline G0:0000323 lytic vacuole & 33 & $2.90 \mathrm{E}-14$ & $3.82 \mathrm{E}-11$ \\
\hline GO:0007067 mitosis & 33 & 7.49E-14 & $1.30 \mathrm{E}-10$ \\
\hline GO:0000280 nuclear division & 33 & $7.49 \mathrm{E}-14$ & $1.30 \mathrm{E}-10$ \\
\hline GO:0051301 cell division & 40 & $9.26 \mathrm{E}-14$ & $1.61 \mathrm{E}-10$ \\
\hline GO:0000279 M phase & 40 & 1.17E-13 & $2.03 \mathrm{E}-10$ \\
\hline GO:0001775 cell activation & 37 & $1.70 \mathrm{E}-13$ & 2.95E-10 \\
\hline GO:0048285 organelle fission & 33 & $2.11 \mathrm{E}-13$ & $3.68 \mathrm{E}-10$ \\
\hline GO:0000278 mitotic cell cycle & 36 & $6.80 \mathrm{E}-13$ & $1.18 \mathrm{E}-09$ \\
\hline GO:0022403 cell cycle phase & 42 & 7.29E-13 & 1.27E-09 \\
\hline GO:0005773 vacuole & 33 & $1.23 \mathrm{E}-12$ & 1.62E-09 \\
\hline GO:0042330 taxis & 24 & $2.05 \mathrm{E}-12$ & $3.56 \mathrm{E}-09$ \\
\hline GO:0006935 chemotaxis & 24 & $2.05 \mathrm{E}-12$ & $3.56 \mathrm{E}-09$ \\
\hline GO:0022402 cell cycle process & 45 & $4.72 \mathrm{E}-12$ & $8.22 \mathrm{E}-09$ \\
\hline GO:0007049 cell cycle & 58 & $5.81 \mathrm{E}-12$ & $1.01 \mathrm{E}-08$ \\
\hline GO:0045321 leukocyte activation & 32 & $2.08 \mathrm{E}-11$ & 3.63E-08 \\
\hline GO:0030246 carbohydrate binding & 38 & 2.77E-11 & 4.12E-08 \\
\hline GO:0000775 chromosome, centromeric region & 23 & $4.09 \mathrm{E}-11$ & $5.38 \mathrm{E}-08$ \\
\hline G0:0002252 immune effector process & 24 & 4.77E-11 & 8.30E-08 \\
\hline GO:0044427 chromosomal part & 38 & $1.89 \mathrm{E}-10$ & 2.49E-07 \\
\hline GO:0005694 chromosome & 41 & $6.03 \mathrm{E}-10$ & 7.94E-07 \\
\hline GO:0007626 locomotory behavior & 31 & $8.86 \mathrm{E}-10$ & $1.54 \mathrm{E}-06$ \\
\hline GO:0002274 myeloid leukocyte activation & 13 & 1.01E-09 & $1.75 \mathrm{E}-06$ \\
\hline GO:0009986 cell surface & 35 & 3.27E-09 & 4.31E-06 \\
\hline GO:0002443 leukocyte mediated immunity & 18 & 8.03E-09 & $1.40 \mathrm{E}-05$ \\
\hline GO:0000779 condensed chromosome, centromeric region & 15 & $1.65 \mathrm{E}-08$ & $2.18 \mathrm{E}-05$ \\
\hline G0:0045087 innate immune response & 19 & 2.37E-08 & 4.13E-05 \\
\hline GO:0000793 condensed chromosome & 19 & $3.72 \mathrm{E}-08$ & 4.90E-05 \\
\hline GO:0001871 pattern binding & 20 & $4.52 \mathrm{E}-08$ & $6.72 \mathrm{E}-05$ \\
\hline GO:0030247 polysaccharide binding & 20 & $4.52 \mathrm{E}-08$ & $6.72 \mathrm{E}-05$ \\
\hline GO:0006909 phagocytosis & 13 & 7.17E-08 & $1.25 \mathrm{E}-04$ \\
\hline GO:0009897 external side of plasma membrane & 26 & 7.97E-08 & $1.05 \mathrm{E}-04$ \\
\hline $\begin{array}{l}\text { GO:0002460 adaptive immune response based on somatic recombination } \\
\text { of immune receptors built from immunoglobulin superfamily domains }\end{array}$ & 16 & $1.56 \mathrm{E}-07$ & $2.72 \mathrm{E}-04$ \\
\hline GO:0002250 adaptive immune response & 16 & $1.56 \mathrm{E}-07$ & 2.72E-04 \\
\hline G0:0048002 antigen processing and presentation of peptide antigen & 11 & $1.84 \mathrm{E}-07$ & $3.21 \mathrm{E}-04$ \\
\hline GO:0050778 positive regulation of immune response & 20 & $2.10 \mathrm{E}-07$ & $3.66 \mathrm{E}-04$ \\
\hline GO:0000777 condensed chromosome kinetochore & 13 & 2.52E-07 & 3.32E-04 \\
\hline GO:0019724 B cell mediated immunity & 14 & $2.66 \mathrm{E}-07$ & 4.64E-04 \\
\hline GO:0002449 lymphocyte mediated immunity & 15 & $2.71 \mathrm{E}-07$ & $4.72 \mathrm{E}-04$ \\
\hline GO:0008009 chemokine activity & 11 & 3.13E-07 & 4.66E-04 \\
\hline GO:0006323 DNA packaging & 17 & 3.37E-07 & 5.87E-04 \\
\hline GO:0042379 chemokine receptor binding & 11 & 4.09E-07 & $6.08 \mathrm{E}-04$ \\
\hline G0:0007610 behavior & 36 & 5.69E-07 & $9.90 \mathrm{E}-04$ \\
\hline GO:0050830 defense response to Gram-positive bacterium & 9 & $5.89 \mathrm{E}-07$ & 0.001026 \\
\hline $\begin{array}{l}\text { GO:0002478 antigen processing and presentation of exogenous peptide } \\
\text { antigen }\end{array}$ & 9 & 5.89E-07 & 0.001026 \\
\hline GO:0002684 positive regulation of immune system process & 24 & 7.12E-07 & 0.001239 \\
\hline GO:0006665 sphingolipid metabolic process & 13 & $1.12 \mathrm{E}-06$ & 0.001944 \\
\hline GO:0005539 glycosaminoglycan binding & 17 & $1.14 \mathrm{E}-06$ & 0.001695 \\
\hline GO:0019955 cytokine binding & 15 & $1.15 \mathrm{E}-06$ & 0.001711 \\
\hline GO:0016064 immunoglobulin mediated immune response & 13 & $1.34 \mathrm{E}-06$ & 0.002327 \\
\hline G0:0000776 kinetochore & 13 & $1.53 \mathrm{E}-06$ & 0.002011 \\
\hline
\end{tabular}




\begin{tabular}{|c|c|c|c|}
\hline G0:0045807 positive regulation of endocytosis & 10 & $1.56 \mathrm{E}-06$ & 0.002723 \\
\hline GO:0006643 membrane lipid metabolic process & 13 & $1.60 \mathrm{E}-06$ & 0.002776 \\
\hline GO:0060326 cell chemotaxis & 9 & $2.36 \mathrm{E}-06$ & 0.004111 \\
\hline GO:0030595 leukocyte chemotaxis & 9 & $2.36 \mathrm{E}-06$ & 0.004111 \\
\hline GO:0006672 ceramide metabolic process & 10 & 2.64E-06 & 0.004596 \\
\hline GO:0046649 lymphocyte activation & 22 & 2.77E-06 & 0.004825 \\
\hline GO:0019884 antigen processing and presentation of exogenous antigen & 9 & $3.21 \mathrm{E}-06$ & 0.005582 \\
\hline G0:0046519 sphingoid metabolic process & 10 & 4.30E-06 & 0.007484 \\
\hline GO:0051130 positive regulation of cellular component organization & 17 & $4.46 \mathrm{E}-06$ & 0.007767 \\
\hline GO:0048584 positive regulation of response to stimulus & 21 & $6.71 \mathrm{E}-06$ & 0.011682 \\
\hline G0:0050766 positive regulation of phagocytosis & 8 & $8.46 \mathrm{E}-06$ & 0.014724 \\
\hline GO:0007018 microtubule-based movement & 15 & $9.21 \mathrm{E}-06$ & 0.016021 \\
\hline $\begin{array}{l}\text { GO:0002495 antigen processing and presentation of peptide antigen via } \\
\text { MHC class II }\end{array}$ & 7 & 9.77E-06 & 0.016995 \\
\hline $\begin{array}{l}\text { GO:0019886 antigen processing and presentation of exogenous peptide } \\
\text { antigen via MHC class II }\end{array}$ & 7 & 9.77E-06 & 0.016995 \\
\hline G0:0046651 lymphocyte proliferation & 10 & 1.04E-05 & 0.018104 \\
\hline GO:0007059 chromosome segregation & 12 & $1.05 \mathrm{E}-05$ & 0.018234 \\
\hline G0:0070661 leukocyte proliferation & 10 & $1.28 \mathrm{E}-05$ & 0.022205 \\
\hline GO:0032943 mononuclear cell proliferation & 10 & $1.28 \mathrm{E}-05$ & 0.022205 \\
\hline GO:0050900 leukocyte migration & 10 & $1.28 \mathrm{E}-05$ & 0.022205 \\
\hline GO:0008283 cell proliferation & 24 & $1.55 \mathrm{E}-05$ & 0.02703 \\
\hline GO:0050764 regulation of phagocytosis & 8 & $1.56 \mathrm{E}-05$ & 0.027188 \\
\hline G0:0042742 defense response to bacterium & 15 & $2.01 \mathrm{E}-05$ & 0.035006 \\
\hline GO:0001817 regulation of cytokine production & 17 & $2.39 \mathrm{E}-05$ & 0.04166 \\
\hline G0:0006897 nendocytosis & 20 & $2.75 \mathrm{E}-05$ & 0.047775 \\
\hline GO:0010324 membrane invagination & 20 & $2.75 \mathrm{E}-05$ & 0.047775 \\
\hline G0:0043933 macromolecular complex subunit organization & 30 & 2.99E-05 & 0.05197 \\
\hline G0:0009617 response to bacterium & 18 & $2.99 \mathrm{E}-05$ & 0.052034 \\
\hline $\begin{array}{l}\text { GO:0002504 antigen processing and presentation of peptide or } \\
\text { polysaccharide antigen via MHC class II }\end{array}$ & 7 & 3.03E-05 & 0.0527 \\
\hline GO:0005819 spindle & 15 & $3.11 \mathrm{E}-05$ & 0.040903 \\
\hline GO:0002253 activation of immune response & 13 & $3.73 \mathrm{E}-05$ & 0.064949 \\
\hline GO:0004197 cysteine-type endopeptidase activity & 11 & $4.02 \mathrm{E}-05$ & 0.059737 \\
\hline G0:0031497 chromatin assembly & 12 & $4.90 \mathrm{E}-05$ & 0.08532 \\
\hline GO:0065004 protein-DNA complex assembly & 12 & $5.56 \mathrm{E}-05$ & 0.096707 \\
\hline GO:0030100 regulation of endocytosis & 10 & $6.32 \mathrm{E}-05$ & 0.109921 \\
\hline GO:0008201 heparin binding & 12 & $9.26 \mathrm{E}-05$ & 0.137629 \\
\hline G0:0006911 phagocytosis, engulfment & 6 & $1.08 \mathrm{E}-04$ & 0.187911 \\
\hline GO:0045576 mast cell activation & 6 & $1.08 \mathrm{E}-04$ & 0.187911 \\
\hline GO:0048534 hemopoietic or lymphoid organ development & 24 & $1.16 \mathrm{E}-04$ & 0.202227 \\
\hline G0:0065003 macromolecular complex assembly & 27 & $1.18 \mathrm{E}-04$ & 0.205511 \\
\hline G0:0030097 hemopoiesis & 22 & $1.69 \mathrm{E}-04$ & 0.293293 \\
\hline GO:0051050 positive regulation of transport & 15 & $1.85 \mathrm{E}-04$ & 0.322341 \\
\hline G0:0034622 cellular macromolecular complex assembly & 20 & $1.91 \mathrm{E}-04$ & 0.331177 \\
\hline GO:0006334 nucleosome assembly & 11 & $1.93 \mathrm{E}-04$ & 0.334921 \\
\hline G0:0016044 membrane organization & 23 & $1.93 \mathrm{E}-04$ & 0.335304 \\
\hline G0:0030593 neutrophil chemotaxis & 6 & $2.10 \mathrm{E}-04$ & 0.365353 \\
\hline GO:0002520 immune system development & 24 & $2.38 \mathrm{E}-04$ & 0.413506 \\
\hline GO:0034728 nucleosome organization & 11 & $2.70 \mathrm{E}-04$ & 0.468928 \\
\hline GO:0032993 protein-DNA complex & 11 & 3.07E-04 & 0.404202 \\
\hline G0:0000786 nucleosome & 10 & $3.21 \mathrm{E}-04$ & 0.42146 \\
\hline GO:0042098 T cell proliferation & 7 & $3.23 \mathrm{E}-04$ & 0.560544 \\
\hline GO:0034621 cellular macromolecular complex subunit organization & 21 & $3.32 \mathrm{E}-04$ & 0.577057 \\
\hline GO:0019865 immunoglobulin binding & 5 & $3.34 \mathrm{E}-04$ & 0.495046 \\
\hline GO:0019864 IgG binding & 4 & $3.50 \mathrm{E}-04$ & 0.519215 \\
\hline G0:0002764 immune response-regulating signal transduction & 9 & $3.75 \mathrm{E}-04$ & 0.651358 \\
\hline G0:0007017 microtubule-based process & 19 & $3.83 \mathrm{E}-04$ & 0.665058 \\
\hline GO:0032553 ribonucleotide binding & 86 & $4.36 \mathrm{E}-04$ & 0.64601 \\
\hline GO:0032555 purine ribonucleotide binding & 86 & $4.36 \mathrm{E}-04$ & 0.64601 \\
\hline G0:0002263 cell activation during immune response & 7 & $5.78 \mathrm{E}-04$ & 1.001411 \\
\hline G0:0002366 leukocyte activation during immune response & 7 & $5.78 \mathrm{E}-04$ & 1.001411 \\
\hline
\end{tabular}




\begin{tabular}{|c|c|c|c|}
\hline G0:0002819 regulation of adaptive immune response & 9 & $6.28 \mathrm{E}-04$ & 1.087728 \\
\hline $\begin{array}{l}\text { GO:0002822 regulation of adaptive immune response based on somatic } \\
\text { recombination of immune receptors built from immunoglobulin } \\
\text { superfamily domains }\end{array}$ & 9 & $6.28 \mathrm{E}-04$ & 1.087728 \\
\hline GO:0017076 purine nucleotide binding & 88 & $6.39 E-04$ & 0.946499 \\
\hline GO:0032675 regulation of interleukin-6 production & 7 & $6.91 E-04$ & 1.195934 \\
\hline G0:0043235 receptor complex & 11 & 7.01E-04 & 0.918893 \\
\hline GO:0003774 motor activity & 14 & 7.06E-04 & 1.045069 \\
\hline G0:0019377 glycolipid catabolic process & 4 & 7.56E-04 & 1.307507 \\
\hline GO:0046466 membrane lipid catabolic process & 5 & 7.82E-04 & 1.351511 \\
\hline GO:0030149 sphingolipid catabolic process & 5 & 7.82E-04 & 1.351511 \\
\hline GO:0019882 antigen processing and presentation & 11 & $8.08 \mathrm{E}-04$ & 1.396639 \\
\hline GO:0019956 chemokine binding & 6 & $8.24 \mathrm{E}-04$ & 1.21781 \\
\hline GO:0005874 microtubule & 20 & $9.59 \mathrm{E}-04$ & 1.25601 \\
\hline GO:0005996 monosaccharide metabolic process & 17 & $9.65 \mathrm{E}-04$ & 1.666408 \\
\hline $\begin{array}{l}\text { GO:0002824 positive regulation of adaptive immune response based on } \\
\text { somatic recombination of immune receptors built from immunoglobulin } \\
\text { superfamily domains }\end{array}$ & 7 & $9.68 \mathrm{E}-04$ & 1.670558 \\
\hline G0:0002821 positive regulation of adaptive immune response & 7 & $9.68 \mathrm{E}-04$ & 1.670558 \\
\hline GO:0050865 regulation of cell activation & 15 & 0.0010166 & 1.754599 \\
\hline GO:0007159 leukocyte adhesion & 5 & 0.0010645 & 1.836573 \\
\hline GO:0032559 adenyl ribonucleotide binding & 71 & 0.0010673 & 1.575096 \\
\hline G0:0002683 negative regulation of immune system process & 10 & 0.0011783 & 2.030931 \\
\hline GO:0002757 immune response-activating signal transduction & 8 & 0.0012058 & 2.07782 \\
\hline GO:0005524 ATP binding & 70 & 0.0012434 & 1.832762 \\
\hline GO:0001819 positive regulation of cytokine production & 9 & 0.0012487 & 2.151014 \\
\hline G0:0006333 chromatin assembly or disassembly & 12 & 0.001344 & 2.313465 \\
\hline GO:0044421 extracellular region part & 45 & 0.0013557 & 1.770944 \\
\hline G0:0042113 B cell activation & 10 & 0.0014196 & 2.441992 \\
\hline GO:0015630 microtubule cytoskeleton & 30 & 0.0014897 & 1.944338 \\
\hline GO:0030554 adenyl nucleotide binding & 73 & 0.0016086 & 2.365155 \\
\hline GO:0042060 wound healing & 12 & 0.0016762 & 2.877506 \\
\hline GO:0050670 regulation of lymphocyte proliferation & 10 & 0.0016991 & 2.916164 \\
\hline GO:0032944 regulation of mononuclear cell proliferation & 10 & 0.0016991 & 2.916164 \\
\hline G0:0002526 acute inflammatory response & 10 & 0.0018545 & 3.178854 \\
\hline GO:0070663 regulation of leukocyte proliferation & 10 & 0.0020211 & 3.459662 \\
\hline GO:0043603 cellular amide metabolic process & 7 & 0.0020294 & 3.473651 \\
\hline GO:0001883 purine nucleoside binding & 73 & 0.002044 & 2.996307 \\
\hline GO:0032680 regulation of tumor necrosis factor production & 6 & 0.0020635 & 3.531033 \\
\hline GO:0019318 hexose metabolic process & 15 & 0.00218 & 3.726959 \\
\hline G0:0060627 regulation of vesicle-mediated transport & 10 & 0.0021993 & 3.759378 \\
\hline GO:0042110 T cell activation & 12 & 0.0022207 & 3.795137 \\
\hline GO:0004896 cytokine receptor activity & 8 & 0.0022223 & 3.253642 \\
\hline GO:0000785 chromatin & 15 & 0.0022956 & 2.981606 \\
\hline GO:0051258 protein polymerization & 7 & 0.0023192 & 3.960321 \\
\hline GO:0002444 myeloid leukocyte mediated immunity & 5 & 0.0023312 & 3.980535 \\
\hline GO:0001882 nucleoside binding & 73 & 0.0023758 & 3.474685 \\
\hline GO:0005876 spindle microtubule & 5 & 0.0026042 & 3.376069 \\
\hline G0:0002694 regulation of leukocyte activation & 14 & 0.002625 & 4.471423 \\
\hline GO:0003777 microtubule motor activity & 9 & 0.0028887 & 4.209928 \\
\hline GO:0001805 positive regulation of type III hypersensitivity & 3 & 0.0034849 & 5.894722 \\
\hline GO:0001803 regulation of type III hypersensitivity & 3 & 0.0034849 & 5.894722 \\
\hline G0:0002521 leukocyte differentiation & 13 & 0.0037433 & 6.318438 \\
\hline $\begin{array}{l}\text { G0:0002768 immune response-regulating cell surface receptor signaling } \\
\text { pathway }\end{array}$ & 7 & 0.0037983 & 6.408382 \\
\hline GO:0004175 endopeptidase activity & 26 & 0.0038733 & 5.606699 \\
\hline GO:0042116 macrophage activation & 4 & 0.00409 & 6.884261 \\
\hline G0:0051249 regulation of lymphocyte activation & 13 & 0.0041916 & 7.049344 \\
\hline GO:0030888 regulation of B cell proliferation & 6 & 0.0044682 & 7.497751 \\
\hline GO:0008034 lipoprotein binding & 5 & 0.0046461 & 6.68964 \\
\hline GO:0045088 regulation of innate immune response & 7 & 0.0047568 & 7.963303 \\
\hline GO:0051015 actin filament binding & 7 & 0.0055143 & 7.892375 \\
\hline
\end{tabular}




\begin{tabular}{|c|c|c|c|}
\hline GO:0004950 chemokine receptor activity & 5 & 0.0055314 & 7.915875 \\
\hline GO:0006261 DNA-dependent DNA replication & 6 & 0.0058355 & 9.684041 \\
\hline GO:0006690 icosanoid metabolic process & 6 & 0.0058355 & 9.684041 \\
\hline GO:0030098 lymphocyte differentiation & 11 & 0.0060375 & 10.00284 \\
\hline GO:0019763 immunoglobulin receptor activity & 3 & 0.0063633 & 9.054578 \\
\hline GO:0002237 response to molecule of bacterial origin & 7 & 0.0065124 & 10.74836 \\
\hline G0:0050672 negative regulation of lymphocyte proliferation & 6 & 0.006619 & 10.9149 \\
\hline GO:0070664 negative regulation of leukocyte proliferation & 6 & 0.006619 & 10.9149 \\
\hline GO:0032945 negative regulation of mononuclear cell proliferation & 6 & 0.006619 & 10.9149 \\
\hline GO:0016042 lipid catabolic process & 12 & 0.0066947 & 11.03292 \\
\hline GO:0044430 cytoskeletal part & 42 & 0.0067486 & 8.532331 \\
\hline G0:0022610 biological adhesion & 32 & 0.0068023 & 11.20053 \\
\hline GO:0007155 cell adhesion & 32 & 0.0068046 & 11.20405 \\
\hline $\begin{array}{l}\text { GO:0050857 positive regulation of antigen receptor-mediated signaling } \\
\text { pathway }\end{array}$ & 3 & 0.0068106 & 11.21336 \\
\hline GO:0002706 regulation of lymphocyte mediated immunity & 8 & 0.0069075 & 11.36397 \\
\hline G0:0048585 negative regulation of response to stimulus & 8 & 0.006907 & 11.36397 \\
\hline GO:0002275 myeloid cell activation during immune response & 4 & 0.0071224 & 11.69726 \\
\hline GO:0005125 cytokine activity & 14 & 0.0073234 & 10.35237 \\
\hline G0:0033559 unsaturated fatty acid metabolic process & 6 & 0.0074734 & 12.23897 \\
\hline G0:0006869 lipid transport & 11 & 0.0081121 & 13.2167 \\
\hline GO:0000166 nucleotide binding & 93 & 0.008457 & 11.86248 \\
\hline GO:0009820 alkaloid metabolic process & 5 & 0.0086014 & 13.95862 \\
\hline GO:0006769 nicotinamide metabolic process & 5 & 0.0086014 & 13.95862 \\
\hline GO:0046496 nicotinamide nucleotide metabolic process & 5 & 0.0086014 & 13.95862 \\
\hline GO:0006910 phagocytosis, recognition & 4 & 0.0090247 & 14.59577 \\
\hline $\begin{array}{l}\text { GO:0002864 regulation of acute inflammatory response to antigenic } \\
\text { stimulus }\end{array}$ & 4 & 0.0090247 & 14.59577 \\
\hline GO:0002883 regulation of hypersensitivity & 4 & 0.0090247 & 14.59577 \\
\hline GO:0005044 scavenger receptor activity & 6 & 0.0091096 & 12.72103 \\
\hline G0:0032101 regulation of response to external stimulus & 10 & 0.0091973 & 14.85437 \\
\hline GO:0006873 cellular ion homeostasis & 18 & 0.0092605 & 14.94873 \\
\hline GO:0002703 regulation of leukocyte mediated immunity & 8 & 0.0102743 & 16.45085 \\
\hline GO:0007596 blood coagulation & 8 & 0.0102743 & 16.45085 \\
\hline GO:0050817 coagulation & 8 & 0.0102743 & 16.45085 \\
\hline $\begin{array}{l}\text { GO:0050664 oxidoreductase activity, acting on NADH or NADPH, with } \\
\text { oxygen as acceptor }\end{array}$ & 3 & 0.0103721 & 14.35985 \\
\hline GO:0016175 superoxide-generating NADPH oxidase activity & 3 & 0.0103721 & 14.35985 \\
\hline GO:0004563 beta-N-acetylhexosaminidase activity & 3 & 0.0103721 & 14.35985 \\
\hline GO:0051240 positive regulation of multicellular organismal process & 13 & 0.0109536 & 17.4432 \\
\hline GO:0007599 hemostasis & 8 & 0.0110698 & 17.61191 \\
\hline GO:0046479 glycosphingolipid catabolic process & 3 & 0.0110924 & 17.64454 \\
\hline $\begin{array}{l}\text { GO:0042590 antigen processing and presentation of exogenous peptide } \\
\text { antigen via MHC class I }\end{array}$ & 3 & 0.0110924 & 17.64454 \\
\hline GO:0002714 positive regulation of B cell mediated immunity & 4 & 0.0111956 & 17.79406 \\
\hline $\begin{array}{l}\text { GO:0002891 positive regulation of immunoglobulin mediated immune } \\
\text { response }\end{array}$ & 4 & 0.0111956 & 17.79406 \\
\hline G0:0002707 negative regulation of lymphocyte mediated immunity & 4 & 0.0111956 & 17.79406 \\
\hline GO:0002704 negative regulation of leukocyte mediated immunity & 4 & 0.0111956 & 17.79406 \\
\hline GO:0006739 NADP metabolic process & 4 & 0.0111956 & 17.79406 \\
\hline GO:0006259 DNA metabolic process & 25 & 0.0112844 & 17.92242 \\
\hline GO:0050864 regulation of B cell activation & 7 & 0.0113609 & 18.03288 \\
\hline GO:0050777 negative regulation of immune response & 5 & 0.0114634 & 18.18069 \\
\hline GO:0055082 cellular chemical homeostasis & 18 & 0.0118053 & 18.67183 \\
\hline GO:0016538 cyclin-dependent protein kinase regulator activity & 4 & 0.0124201 & 16.95742 \\
\hline
\end{tabular}




\begin{tabular}{|c|c|c|c|}
\hline \multicolumn{4}{|l|}{ Large $^{m y d-/-}$ C57BL vs 21 dias } \\
\hline Termo GO & \# genes & p-valor & FDR \\
\hline GO:0006955 immune response & 20 & $9.98 \mathrm{E}-12$ & $1.51 \mathrm{E}-08$ \\
\hline G0:0006935 chemotaxis & 11 & $5.08 \mathrm{E}-10$ & $7.68 \mathrm{E}-07$ \\
\hline GO:0042330 taxis & 11 & $5.08 \mathrm{E}-10$ & $7.68 \mathrm{E}-07$ \\
\hline GO:0006952 defense response & 17 & $3.22 \mathrm{E}-09$ & $4.86 \mathrm{E}-06$ \\
\hline G0:0006954 inflammatory response & 13 & $4.51 \mathrm{E}-09$ & $6.82 \mathrm{E}-06$ \\
\hline G0:0008009 chemokine activity & 7 & $4.53 \mathrm{E}-08$ & 5.57E-05 \\
\hline GO:0042379 chemokine receptor binding & 7 & 5.33E-08 & $6.56 \mathrm{E}-05$ \\
\hline GO:0009611 response to wounding & 14 & $6.61 \mathrm{E}-08$ & $9.98 \mathrm{E}-05$ \\
\hline GO:0007610 behavior & 14 & 3.93E-07 & 5.94E-04 \\
\hline GO:0007626 locomotory behavior & 11 & $9.18 \mathrm{E}-07$ & 0.001386 \\
\hline GO:0050865 regulation of cell activation & 8 & $2.82 \mathrm{E}-05$ & 0.042572 \\
\hline GO:0009986 cell surface & 11 & 2.91E-05 & 0.032251 \\
\hline GO:0005125 cytokine activity & 8 & 4.77E-05 & 0.058742 \\
\hline GO:0009897 external side of plasma membrane & 9 & 5.94E-05 & 0.065793 \\
\hline GO:0002694 regulation of leukocyte activation & 7 & 2.35E-04 & 0.354313 \\
\hline GO:0030246 carbohydrate binding & 9 & 2.77E-04 & 0.340301 \\
\hline GO:0016064 immunoglobulin mediated immune response & 5 & $4.41 \mathrm{E}-04$ & 0.663833 \\
\hline GO:0044421 extracellular region part & 15 & 4.63E-04 & 0.511459 \\
\hline GO:0001775 cell activation & 8 & 4.79E-04 & 0.721291 \\
\hline GO:0019724 B cell mediated immunity & 5 & 4.97E-04 & 0.747801 \\
\hline GO:0030247 polysaccharide binding & 6 & $6.01 \mathrm{E}-04$ & 0.737165 \\
\hline GO:0001871 pattern binding & 6 & $6.01 \mathrm{E}-04$ & 0.737165 \\
\hline GO:0050798 activated T cell proliferation & 3 & $6.53 \mathrm{E}-04$ & 0.982848 \\
\hline GO:0002252 immune effector process & 6 & 7.34E-04 & 1.103007 \\
\hline GO:0002449 lymphocyte mediated immunity & 5 & 8.98E-04 & 1.348188 \\
\hline GO:0002684 positive regulation of immune system process & 7 & 0.001094 & 1.640629 \\
\hline GO:0002250 adaptive immune response & 5 & 0.001305 & 1.953919 \\
\hline $\begin{array}{l}\text { GO:0002460 adaptive immune response based on somatic recombination } \\
\text { of immune receptors built from immunoglobulin superfamily domains }\end{array}$ & 5 & 0.001305 & 1.953919 \\
\hline GO:0051249 regulation of lymphocyte activation & 6 & 0.001336 & 1.999067 \\
\hline GO:0002443 leukocyte mediated immunity & 5 & 0.001617 & 2.415076 \\
\hline GO:0046651 lymphocyte proliferation & 4 & 0.001714 & 2.557927 \\
\hline GO:0032943 mononuclear cell proliferation & 4 & 0.001835 & 2.736303 \\
\hline G0:0070661 leukocyte proliferation & 4 & 0.001835 & 2.736303 \\
\hline GO:0050867 positive regulation of cell activation & 5 & 0.002569 & 3.811751 \\
\hline GO:0006911 phagocytosis, engulfment & 3 & 0.003173 & 4.688104 \\
\hline $\begin{array}{l}\text { GO:0019886 antigen processing and presentation of exogenous peptide } \\
\text { antigen via MHC class II }\end{array}$ & 3 & 0.003613 & 5.32177 \\
\hline $\begin{array}{l}\text { GO:0002495 antigen processing and presentation of peptide antigen via } \\
\text { MHC class II }\end{array}$ & 3 & 0.003613 & 5.32177 \\
\hline GO:0030593 neutrophil chemotaxis & 3 & 0.00408 & 5.989645 \\
\hline GO:0007155 cell adhesion & 10 & 0.004329 & 6.344899 \\
\hline GO:0022610 biological adhesion & 10 & 0.00438 & 6.416706 \\
\hline $\begin{array}{l}\text { GO:0002504 antigen processing and presentation of peptide or } \\
\text { polysaccharide antigen via MHC class II }\end{array}$ & 3 & 0.005092 & 7.423324 \\
\hline GO:0005615 extracellular space & 10 & 0.006136 & 6.591009 \\
\hline GO:0004175 endopeptidase activity & 8 & 0.007085 & 8.386001 \\
\hline GO:0050778 positive regulation of immune response & 5 & 0.007394 & 10.60733 \\
\hline $\begin{array}{l}\text { GO:0002478 antigen processing and presentation of exogenous peptide } \\
\text { antigen }\end{array}$ & 3 & 0.007424 & 10.64871 \\
\hline GO:0050766 positive regulation of phagocytosis & 3 & 0.007424 & 10.64871 \\
\hline GO:0045321 leukocyte activation & 6 & 0.008024 & 11.46022 \\
\hline GO:0050764 regulation of phagocytosis & 3 & 0.008739 & 12.42081 \\
\hline GO:0007229 integrin-mediated signaling pathway & 4 & 0.009145 & 12.96123 \\
\hline GO:0002683 negative regulation of immune system process & 4 & 0.009145 & 12.96123 \\
\hline GO:0008201 heparin binding & 4 & 0.009899 & 11.53294 \\
\hline G0:0060326 cell chemotaxis & 3 & 0.010151 & 14.28599 \\
\hline GO:0030595 leukocyte chemotaxis & 3 & 0.010151 & 14.28599 \\
\hline GO:0050670 regulation of lymphocyte proliferation & 4 & 0.010518 & 14.76477 \\
\hline GO:0032944 regulation of mononuclear cell proliferation & 4 & 0.010518 & 14.76477 \\
\hline
\end{tabular}


GO:0019884 antigen processing and presentation of exogenous antigen

$4 \quad 0.011246 \quad 15.70799$




\begin{tabular}{|c|c|c|c|}
\hline \multicolumn{4}{|l|}{$D m d^{m d x} /$ Large $^{m y d-/-}$ vs C57B/21 dias } \\
\hline Termo GO & \# genes & p-valor & FDR \\
\hline GO:0042330 taxis & 11 & $1.66 \mathrm{E}-10$ & 2.47E-07 \\
\hline GO:0006935 chemotaxis & 11 & $1.66 \mathrm{E}-10$ & 2.47E-07 \\
\hline GO:0006952 defense response & 15 & 4.31E-08 & $6.40 \mathrm{E}-05$ \\
\hline GO:0006955 immune response & 15 & 8.03E-08 & 1.19E-04 \\
\hline GO:0007626 locomotory behavior & 11 & $3.22 \mathrm{E}-07$ & 4.77E-04 \\
\hline GO:0007610 behavior & 13 & 7.93E-07 & 0.001176 \\
\hline GO:0008009 chemokine activity & 6 & 8.37E-07 & 0.001028 \\
\hline GO:0042379 chemokine receptor binding & 6 & $9.56 \mathrm{E}-07$ & 0.001175 \\
\hline GO:0009611 response to wounding & 12 & $1.25 \mathrm{E}-06$ & 0.001851 \\
\hline GO:0006954 inflammatory response & 10 & 1.91E-06 & 0.002832 \\
\hline GO:0004857 enzyme inhibitor activity & 8 & $1.31 \mathrm{E}-04$ & 0.160809 \\
\hline G0:0050865 regulation of cell activation & 7 & 1.37E-04 & 0.2036 \\
\hline GO:0030414 peptidase inhibitor activity & 7 & $1.65 \mathrm{E}-04$ & 0.202305 \\
\hline GO:0005125 cytokine activity & 7 & $1.86 \mathrm{E}-04$ & 0.228603 \\
\hline GO:0019724 B cell mediated immunity & 5 & $3.26 \mathrm{E}-04$ & 0.48348 \\
\hline GO:0030595 leukocyte chemotaxis & 4 & 3.36E-04 & 0.497399 \\
\hline GO:0060326 cell chemotaxis & 4 & $3.36 \mathrm{E}-04$ & 0.497399 \\
\hline GO:0046688 response to copper ion & 3 & $5.25 \mathrm{E}-04$ & 0.776369 \\
\hline GO:0044421 extracellular region part & 14 & 5.51E-04 & 0.614444 \\
\hline GO:0002449 lymphocyte mediated immunity & 5 & $5.93 \mathrm{E}-04$ & 0.876971 \\
\hline GO:0002250 adaptive immune response & 5 & $8.66 \mathrm{E}-04$ & 1.276954 \\
\hline $\begin{array}{l}\text { GO:0002460 adaptive immune response based on somatic recombination } \\
\text { of immune receptors built from immunoglobulin superfamily domains }\end{array}$ & 5 & $8.66 \mathrm{E}-04$ & 1.276954 \\
\hline GO:0002443 leukocyte mediated immunity & 5 & 0.001075 & 1.583165 \\
\hline GO:0002694 regulation of leukocyte activation & 6 & 0.001099 & 1.618212 \\
\hline GO:0050900 leukocyte migration & 4 & 0.001337 & 1.966572 \\
\hline $\begin{array}{l}\text { GO:0019886 antigen processing and presentation of exogenous peptide } \\
\text { antigen via MHC class II }\end{array}$ & 3 & 0.002913 & 4.236856 \\
\hline $\begin{array}{l}\text { GO:0002495 antigen processing and presentation of peptide antigen via } \\
\text { MHC class II }\end{array}$ & 3 & 0.002913 & 4.236856 \\
\hline GO:0030247 polysaccharide binding & 5 & 0.002977 & 3.595785 \\
\hline GO:0001871 pattern binding & 5 & 0.002977 & 3.595785 \\
\hline G0:0005615 extracellular space & 10 & 0.003082 & 3.392328 \\
\hline GO:0030593 neutrophil chemotaxis & 3 & 0.00329 & 4.773636 \\
\hline GO:0004175 endopeptidase activity & 8 & 0.003338 & 4.023929 \\
\hline GO:0030246 carbohydrate binding & 7 & 0.003519 & 4.237705 \\
\hline GO:0002252 immune effector process & 5 & 0.003829 & 5.534216 \\
\hline GO:0016064 immunoglobulin mediated immune response & 4 & 0.004003 & 5.779463 \\
\hline $\begin{array}{l}\text { GO:0002504 antigen processing and presentation of peptide or } \\
\text { polysaccharide antigen via MHC class II }\end{array}$ & 3 & 0.00411 & 5.929435 \\
\hline GO:0032403 protein complex binding & 4 & 0.005739 & 6.825481 \\
\hline $\begin{array}{l}\text { GO:0002478 antigen processing and presentation of exogenous peptide } \\
\text { antigen }\end{array}$ & 3 & 0.006002 & 8.547056 \\
\hline GO:0050766 positive regulation of phagocytosis & 3 & 0.006002 & 8.547056 \\
\hline GO:0051249 regulation of lymphocyte activation & 5 & 0.006139 & 8.734118 \\
\hline GO:0070011 peptidase activity, acting on L-amino acid peptides & 9 & 0.006681 & 7.904373 \\
\hline GO:0004866 endopeptidase inhibitor activity & 5 & 0.006714 & 7.94168 \\
\hline GO:0050764 regulation of phagocytosis & 3 & 0.00707 & 9.995444 \\
\hline GO:0050670 regulation of lymphocyte proliferation & 4 & 0.00779 & 10.95899 \\
\hline GO:0032944 regulation of mononuclear cell proliferation & 4 & 0.00779 & 10.95899 \\
\hline GO:0001775 cell activation & 6 & 0.008191 & 11.49153 \\
\hline GO:0070663 regulation of leukocyte proliferation & 4 & 0.008337 & 11.68434 \\
\hline GO:0008233 peptidase activity & 9 & 0.008536 & 9.994275 \\
\hline GO:0019884 antigen processing and presentation of exogenous antigen & 3 & 0.008822 & 12.32323 \\
\hline GO:0008237 metallopeptidase activity & 5 & 0.011232 & 12.95527 \\
\hline GO:0045807 positive regulation of endocytosis & 3 & 0.012839 & 17.45207 \\
\hline GO:0002274 myeloid leukocyte activation & 3 & 0.013573 & 18.35822 \\
\hline GO:0048002 antigen processing and presentation of peptide antigen & 3 & 0.013573 & 18.35822 \\
\hline GO:0050672 negative regulation of lymphocyte proliferation & 3 & 0.013573 & 18.35822 \\
\hline
\end{tabular}




\begin{tabular}{llrr}
\hline GO:0070664 negative regulation of leukocyte proliferation & 3 & 0.013573 & 18.35822 \\
\hline G0:0032945 negative regulation of mononuclear cell proliferation & 3 & 0.013573 & 18.35822 \\
\hline GO:0050867 positive regulation of cell activation & 4 & 0.014654 & 19.67655 \\
\hline GO:0004222 metalloendopeptidase activity & 4 & 0.016118 & 18.09359 \\
\hline GO:0030016 myofibril & 4 & 0.016668 & 17.1331 \\
\hline GO:0043292 contractile fiber & 4 & 0.018676 & 19.00565 \\
\hline
\end{tabular}




\begin{tabular}{|c|c|c|c|}
\hline \multicolumn{4}{|l|}{$D m d^{m d x}$ vs C57BL 3 meses } \\
\hline Termo GO & \# genes & p-valor & FDR \\
\hline GO:0006955 immune response & 40 & $1.89 \mathrm{E}-25$ & $3.04 \mathrm{E}-22$ \\
\hline GO:0006952 defense response & 33 & $6.61 \mathrm{E}-19$ & $1.06 \mathrm{E}-15$ \\
\hline G0:0006954 inflammatory response & 24 & $4.01 \mathrm{E}-17$ & $6.46 \mathrm{E}-14$ \\
\hline GO:0009611 response to wounding & 26 & $6.52 \mathrm{E}-15$ & $1.05 \mathrm{E}-11$ \\
\hline GO:0006935 chemotaxis & 16 & $2.11 \mathrm{E}-13$ & $3.40 \mathrm{E}-10$ \\
\hline GO:0042330 taxis & 16 & $2.11 \mathrm{E}-13$ & $3.40 \mathrm{E}-10$ \\
\hline GO:0001775 cell activation & 21 & $4.53 \mathrm{E}-13$ & 7.30E-10 \\
\hline $\begin{array}{l}\text { GO:0002478 antigen processing and presentation of exogenous peptide } \\
\text { antigen }\end{array}$ & 10 & $5.60 \mathrm{E}-13$ & $9.01 \mathrm{E}-10$ \\
\hline GO:0048002 antigen processing and presentation of peptide antigen & 11 & 1.07E-12 & $1.72 \mathrm{E}-09$ \\
\hline GO:0002252 immune effector process & 16 & $1.85 \mathrm{E}-12$ & 2.99E-09 \\
\hline GO:0019884 antigen processing and presentation of exogenous antigen & 10 & $4.54 \mathrm{E}-12$ & 7.30E-09 \\
\hline GO:0045321 leukocyte activation & 19 & $6.10 \mathrm{E}-12$ & $9.82 \mathrm{E}-09$ \\
\hline GO:0007626 locomotory behavior & 19 & $2.65 \mathrm{E}-11$ & 4.26E-08 \\
\hline GO:0009986 cell surface & 22 & $3.10 \mathrm{E}-11$ & $3.72 \mathrm{E}-08$ \\
\hline $\begin{array}{l}\text { GO:0019886 antigen processing and presentation of exogenous peptide } \\
\text { antigen via MHC class II }\end{array}$ & 8 & $9.14 \mathrm{E}-11$ & 1.47E-07 \\
\hline $\begin{array}{l}\text { GO:0002495 antigen processing and presentation of peptide antigen via } \\
\text { MHC class II }\end{array}$ & 8 & $9.14 \mathrm{E}-11$ & 1.47E-07 \\
\hline GO:0009897 external side of plasma membrane & 18 & $1.65 \mathrm{E}-10$ & $1.98 \mathrm{E}-07$ \\
\hline $\begin{array}{l}\text { GO:0002504 antigen processing and presentation of peptide or } \\
\text { polysaccharide antigen via MHC class II }\end{array}$ & 8 & $3.93 \mathrm{E}-10$ & $6.32 \mathrm{E}-07$ \\
\hline GO:0050778 positive regulation of immune response & 14 & $9.62 \mathrm{E}-10$ & $1.55 \mathrm{E}-06$ \\
\hline GO:0002443 leukocyte mediated immunity & 12 & $1.26 \mathrm{E}-09$ & 2.03E-06 \\
\hline G0:0050766 positive regulation of phagocytosis & 8 & 1.85E-09 & 2.97E-06 \\
\hline GO:0002684 positive regulation of immune system process & 16 & 2.13E-09 & $3.42 \mathrm{E}-06$ \\
\hline GO:0007610 behavior & 21 & 3.56E-09 & $5.73 \mathrm{E}-06$ \\
\hline GO:0050764 regulation of phagocytosis & 8 & 3.56E-09 & $5.74 \mathrm{E}-06$ \\
\hline GO:0019882 antigen processing and presentation & 11 & $1.50 \mathrm{E}-08$ & $2.42 \mathrm{E}-05$ \\
\hline GO:0045807 positive regulation of endocytosis & 8 & 3.70E-08 & 5.96E-05 \\
\hline GO:0048584 positive regulation of response to stimulus & 14 & 4.34E-08 & $6.98 \mathrm{E}-05$ \\
\hline GO:0002449 lymphocyte mediated immunity & 10 & $6.24 \mathrm{E}-08$ & $1.00 \mathrm{E}-04$ \\
\hline GO:0008009 chemokine activity & 8 & $6.78 \mathrm{E}-08$ & 8.97E-05 \\
\hline GO:0042379 chemokine receptor binding & 8 & $8.20 \mathrm{E}-08$ & $1.08 \mathrm{E}-04$ \\
\hline GO:0002250 adaptive immune response & 10 & $1.51 \mathrm{E}-07$ & 2.43E-04 \\
\hline $\begin{array}{l}\text { GO:0002460 adaptive immune response based on somatic recombination } \\
\text { of immune receptors built from immunoglobulin superfamily domains }\end{array}$ & 10 & $1.51 \mathrm{E}-07$ & 2.43E-04 \\
\hline GO:0016064 immunoglobulin mediated immune response & 9 & 2.00E-07 & 3.21E-04 \\
\hline GO:0042110 T cell activation & 11 & 2.40E-07 & 3.86E-04 \\
\hline GO:0019724 B cell mediated immunity & 9 & $2.56 \mathrm{E}-07$ & 4.12E-04 \\
\hline GO:0006911 phagocytosis, engulfment & 6 & $2.59 \mathrm{E}-07$ & 4.16E-04 \\
\hline GO:0030246 carbohydrate binding & 16 & 4.27E-07 & $5.65 \mathrm{E}-04$ \\
\hline GO:0046649 lymphocyte activation & 13 & 4.67E-07 & 7.52E-04 \\
\hline GO:0030100 regulation of endocytosis & 8 & 7.92E-07 & 0.001275 \\
\hline GO:0005764 lysosome & 13 & 8.34E-07 & 9.99E-04 \\
\hline GO:0000323 lytic vacuole & 13 & 8.85E-07 & 0.001061 \\
\hline GO:0002253 activation of immune response & 9 & $2.25 \mathrm{E}-06$ & 0.003629 \\
\hline GO:0019865 immunoglobulin binding & 5 & 2.65E-06 & 0.003513 \\
\hline GO:0005773 vacuole & 13 & $3.50 \mathrm{E}-06$ & 0.004192 \\
\hline GO:0046651 lymphocyte proliferation & 7 & 3.51E-06 & 0.005652 \\
\hline GO:0032943 mononuclear cell proliferation & 7 & 4.05E-06 & 0.006515 \\
\hline G0:0070661 leukocyte proliferation & 7 & 4.05E-06 & 0.006515 \\
\hline GO:0042098 T cell proliferation & 6 & 7.62E-06 & 0.012265 \\
\hline GO:0019864 IgG binding & 4 & 8.81E-06 & 0.011665 \\
\hline GO:0006909 phagocytosis & 7 & 8.84E-06 & 0.014226 \\
\hline GO:0045576 mast cell activation & 5 & $1.20 \mathrm{E}-05$ & 0.019364 \\
\hline GO:0060627 rregulation of vesicle-mediated transport & 8 & $1.90 \mathrm{E}-05$ & 0.030579 \\
\hline $\begin{array}{l}\text { GO:0002822 regulation of adaptive immune response based on somatic } \\
\text { recombination of immune receptors built from immunoglobulin } \\
\text { superfamily domains }\end{array}$ & 7 & $1.94 \mathrm{E}-05$ & 0.031187 \\
\hline GO:0002819 regulation of adaptive immune response & 7 & $1.94 \mathrm{E}-05$ & 0.031187 \\
\hline
\end{tabular}




\begin{tabular}{|c|c|c|c|}
\hline G0:0030593 neutrophil chemotaxis & 5 & 2.07E-05 & 0.03324 \\
\hline GO:0019955 cytokine binding & 8 & $2.28 \mathrm{E}-05$ & 0.030195 \\
\hline G0:0051130 positive regulation of cellular component organization & 9 & 3.03E-05 & 0.048709 \\
\hline GO:0001871 pattern binding & 9 & 3.42E-05 & 0.045288 \\
\hline GO:0030247 polysaccharide binding & 9 & 3.42E-05 & 0.045288 \\
\hline GO:0005125 cytokine activity & 10 & $6.39 \mathrm{E}-05$ & 0.084548 \\
\hline G0:0042742 defense response to bacterium & 8 & 1.04E-04 & 0.166819 \\
\hline G0:0002757 immune response-activating signal transduction & 6 & $1.13 \mathrm{E}-04$ & 0.181867 \\
\hline GO:0030595 leukocyte chemotaxis & 5 & $1.41 \mathrm{E}-04$ & 0.226584 \\
\hline GO:0060326 cell chemotaxis & 5 & $1.41 \mathrm{E}-04$ & 0.226584 \\
\hline GO:0008201 heparin binding & 7 & $1.53 \mathrm{E}-04$ & 0.201779 \\
\hline GO:0002764 immune response-regulating signal transduction & 6 & $1.66 \mathrm{E}-04$ & 0.267234 \\
\hline G0:0009617 response to bacterium & 9 & $1.79 \mathrm{E}-04$ & 0.288059 \\
\hline GO:0002712 regulation of B cell mediated immunity & 5 & 2.15E-04 & 0.345492 \\
\hline G0:0002889 regulation of immunoglobulin mediated immune response & 5 & $2.15 \mathrm{E}-04$ & 0.345492 \\
\hline G0:0031349 positive regulation of defense response & 6 & 2.57E-04 & 0.41337 \\
\hline $\begin{array}{l}\text { GO:0002864 regulation of acute inflammatory response to antigenic } \\
\text { stimulus }\end{array}$ & 4 & $2.61 \mathrm{E}-04$ & 0.41871 \\
\hline G0:0002883 regulation of hypersensitivity & 4 & $2.61 \mathrm{E}-04$ & 0.41871 \\
\hline G0:0006910 phagocytosis, recognition & 4 & $2.61 \mathrm{E}-04$ & 0.41871 \\
\hline GO:0001803 regulation of type III hypersensitivity & 3 & $2.96 \mathrm{E}-04$ & 0.47601 \\
\hline GO:0001805 positive regulation of type III hypersensitivity & 3 & $2.96 \mathrm{E}-04$ & 0.47601 \\
\hline G0:0002714 positive regulation of B cell mediated immunity & 4 & 3.29E-04 & 0.528734 \\
\hline $\begin{array}{l}\text { G0:0002891 positive regulation of immunoglobulin mediated immune } \\
\text { response }\end{array}$ & 4 & $3.29 \mathrm{E}-04$ & 0.528734 \\
\hline GO:0002821 positive regulation of adaptive immune response & 5 & 3.53E-04 & 0.566233 \\
\hline $\begin{array}{l}\text { GO:0002824 positive regulation of adaptive immune response based on } \\
\text { somatic recombination of immune receptors built from immunoglobulin } \\
\text { superfamily domains }\end{array}$ & 5 & 3.53E-04 & 0.566233 \\
\hline GO:0051050 positive regulation of transport & 8 & $3.59 \mathrm{E}-04$ & 0.577039 \\
\hline G0:0016044 membrane organization & 11 & $4.06 \mathrm{E}-04$ & 0.652291 \\
\hline G0:0044421 extracellular region part & 21 & $4.61 \mathrm{E}-04$ & 0.550907 \\
\hline GO:0005576 extracellular region & 35 & $4.68 \mathrm{E}-04$ & 0.558886 \\
\hline G0:0002706 regulation of lymphocyte mediated immunity & 6 & $4.76 \mathrm{E}-04$ & 0.763711 \\
\hline GO:0048534 hemopoietic or lymphoid organ development & 11 & $5.25 \mathrm{E}-04$ & 0.841086 \\
\hline GO:0019763 immunoglobulin receptor activity & 3 & $5.54 \mathrm{E}-04$ & 0.730849 \\
\hline G0:0010324 membrane invagination & 9 & $6.03 \mathrm{E}-04$ & 0.966199 \\
\hline GO:0006897 rendocytosis & 9 & $6.03 \mathrm{E}-04$ & 0.966199 \\
\hline GO:0002703 regulation of leukocyte mediated immunity & 6 & $6.70 \mathrm{E}-04$ & 1.073714 \\
\hline GO:0002673 regulation of acute inflammatory response & 4 & 7.17E-04 & 1.14769 \\
\hline G0:0002861 regulation of inflammatory response to antigenic stimulus & 4 & 7.17E-04 & 1.14769 \\
\hline $\begin{array}{l}\text { GO:0002429 immune response-activating cell surface receptor signaling } \\
\text { pathway }\end{array}$ & 5 & 7.30E-04 & 1.167993 \\
\hline GO:0002520 immune system development & 11 & 7.64E-04 & 1.22283 \\
\hline GO:0005539 glycosaminoglycan binding & 7 & $8.44 \mathrm{E}-04$ & 1.111846 \\
\hline G0:0008283 cell proliferation & 10 & $8.45 \mathrm{E}-04$ & 1.352194 \\
\hline G0:0050900 leukocyte migration & 5 & $8.75 \mathrm{E}-04$ & 1.399988 \\
\hline GO:0042277 peptide binding & 8 & $9.42 \mathrm{E}-04$ & 1.239772 \\
\hline G0:0030097 hemopoiesis & 10 & 9.47E-04 & 1.513477 \\
\hline $\begin{array}{l}\text { GO:0002768 immune response-regulating cell surface receptor signaling } \\
\text { pathway }\end{array}$ & 5 & $9.56 \mathrm{E}-04$ & 1.527222 \\
\hline GO:0032403 protein complex binding & 6 & $9.56 \mathrm{E}-04$ & 1.257745 \\
\hline GO:0050865 regulation of cell activation & 8 & $9.74 \mathrm{E}-04$ & 1.556071 \\
\hline $\begin{array}{l}\text { GO:0042590 antigen processing and presentation of exogenous peptide } \\
\text { antigen via MHC class I }\end{array}$ & 3 & $9.75 \mathrm{E}-04$ & 1.557935 \\
\hline G0:0008037 cell recognition & 5 & 0.001227 & 1.956725 \\
\hline GO:0002526 acute inflammatory response & 6 & 0.0013 & 2.072479 \\
\hline GO:0007155 cell adhesion & 15 & 0.001474 & 2.346133 \\
\hline GO:0022610 biological adhesion & 15 & 0.001499 & 2.385266 \\
\hline G0:0050830 defense response to Gram-positive bacterium & 4 & 0.0015 & 2.387309 \\
\hline GO:0002697 regulation of immune effector process & 6 & 0.00188 & 2.984256 \\
\hline G0:0005615 extracellular space & 15 & 0.00201 & 2.382234 \\
\hline GO:0050798 activated T cell proliferation & 3 & 0.002021 & 3.20358 \\
\hline
\end{tabular}




\begin{tabular}{|c|c|c|c|}
\hline G0:0032680 regulation of tumor necrosis factor production & 4 & 0.002406 & 3.803438 \\
\hline G0:0016192 vesicle-mediated transport & 13 & 0.002491 & 3.934472 \\
\hline GO:0001796 regulation of type IIa hypersensitivity & 3 & 0.002677 & 4.222595 \\
\hline GO:0001798 positive regulation of type IIa hypersensitivity & 3 & 0.002677 & 4.222595 \\
\hline GO:0001810 regulation of type I hypersensitivity & 3 & 0.002677 & 4.222595 \\
\hline GO:0002888 positive regulation of myeloid leukocyte mediated immunity & 3 & 0.002677 & 4.222595 \\
\hline GO:0002892 regulation of type II hypersensitivity & 3 & 0.002677 & 4.222595 \\
\hline GO:0002894 positive regulation of type II hypersensitivity & 3 & 0.002677 & 4.222595 \\
\hline GO:0045059 positive thymic T cell selection & 3 & 0.002677 & 4.222595 \\
\hline GO:0001817 regulation of cytokine production & 7 & 0.002726 & 4.298559 \\
\hline GO:0045060 negative thymic T cell selection & 3 & 0.003419 & 5.363555 \\
\hline GO:0050867 positive regulation of cell activation & 6 & 0.003429 & 5.379593 \\
\hline G0:0042981 regulation of apoptosis & 14 & 0.003639 & 5.699778 \\
\hline GO:0045582 positive regulation of $\mathrm{T}$ cell differentiation & 4 & 0.003934 & 6.148025 \\
\hline GO:0043067 regulation of programmed cell death & 14 & 0.004046 & 6.317672 \\
\hline G0:0010941 regulation of cell death & 14 & 0.004231 & 6.597849 \\
\hline $\begin{array}{l}\text { GO:0002866 positive regulation of acute inflammatory response to } \\
\text { antigenic stimulus }\end{array}$ & 3 & 0.004246 & 6.619455 \\
\hline GO:0002885 positive regulation of hypersensitivity & 3 & 0.004246 & 6.619455 \\
\hline G0:0043383 negative T cell selection & 3 & 0.004246 & 6.619455 \\
\hline GO:0043368 positive T cell selection & 3 & 0.004246 & 6.619455 \\
\hline GO:0002694 regulation of leukocyte activation & 7 & 0.004514 & 7.023585 \\
\hline G0:0045621 positive regulation of lymphocyte differentiation & 4 & 0.004678 & 7.269604 \\
\hline GO:0006873 cellular ion homeostasis & 9 & 0.004736 & 7.357553 \\
\hline GO:0002675 positive regulation of acute inflammatory response & 3 & 0.005155 & 7.983063 \\
\hline GO:0042613 MHC class II protein complex & 3 & 0.005429 & 6.314611 \\
\hline GO:0055082 cellular chemical homeostasis & 9 & 0.00554 & 8.554003 \\
\hline GO:0030098 lymphocyte differentiation & 6 & 0.005735 & 8.842125 \\
\hline GO:0051094 positive regulation of developmental process & 8 & 0.00574 & 8.849648 \\
\hline GO:0030217 T cell differentiation & 5 & 0.007064 & 10.78349 \\
\hline GO:0002683 negative regulation of immune system process & 5 & 0.007064 & 10.78349 \\
\hline $\begin{array}{l}\text { GO:0002863 positive regulation of inflammatory response to antigenic } \\
\text { stimulus }\end{array}$ & 3 & 0.007216 & 11.00364 \\
\hline G0:0002820 negative regulation of adaptive immune response & 3 & 0.007216 & 11.00364 \\
\hline $\begin{array}{l}\text { GO:0002823 negative regulation of adaptive immune response based on } \\
\text { somatic recombination of immune receptors built from immunoglobulin } \\
\text { superfamily domains }\end{array}$ & 3 & 0.007216 & 11.00364 \\
\hline GO:0002705 positive regulation of leukocyte mediated immunity & 4 & 0.007394 & 11.26051 \\
\hline GO:0002708 positive regulation of lymphocyte mediated immunity & 4 & 0.007394 & 11.26051 \\
\hline GO:0045597 positive regulation of cell differentiation & 7 & 0.008305 & 12.56192 \\
\hline GO:0007159 leukocyte adhesion & 3 & 0.008364 & 12.64547 \\
\hline G0:0002704 negative regulation of leukocyte mediated immunity & 3 & 0.008364 & 12.64547 \\
\hline GO:0002707 negative regulation of lymphocyte mediated immunity & 3 & 0.008364 & 12.64547 \\
\hline GO:0042108 positive regulation of cytokine biosynthetic process & 4 & 0.008468 & 12.7933 \\
\hline GO:0050801 ion homeostasis & 9 & 0.009282 & 13.93794 \\
\hline GO:0002886 regulation of myeloid leukocyte mediated immunity & 3 & 0.009588 & 14.36482 \\
\hline GO:0045061 thymic T cell selection & 3 & 0.009588 & 14.36482 \\
\hline GO:0002699 positive regulation of immune effector process & 4 & 0.010878 & 16.14319 \\
\hline GO:0045088 regulation of innate immune response & 4 & 0.010878 & 16.14319 \\
\hline GO:0030005 cellular di-, tri-valent inorganic cation homeostasis & 6 & 0.011147 & 16.5101 \\
\hline GO:0019957 C-C chemokine binding & 3 & 0.011562 & 14.26709 \\
\hline GO:0016493 C-C chemokine receptor activity & 3 & 0.011562 & 14.26709 \\
\hline GO:0045580 regulation of $\mathrm{T}$ cell differentiation & 4 & 0.012217 & 17.95133 \\
\hline $\begin{array}{l}\text { GO:0002474 antigen processing and presentation of peptide antigen via } \\
\text { MHC class I }\end{array}$ & 3 & 0.012257 & 18.00566 \\
\hline GO:0043235 receptor complex & 5 & 0.014671 & 16.2298 \\
\hline
\end{tabular}




\begin{tabular}{|c|c|c|c|}
\hline \multicolumn{4}{|l|}{ Large $^{m y d-/-}$ vs C57BL 3 meses } \\
\hline Termo GO & \# genes & p-valor & FDR \\
\hline GO:0006952 defense response & 29 & $1.74 \mathrm{E}-15$ & $2.79 \mathrm{E}-12$ \\
\hline GO:0006954 inflammatory response & 22 & $3.24 \mathrm{E}-15$ & $5.04 \mathrm{E}-12$ \\
\hline G0:0006955 immune response & 26 & 2.64E-12 & 4.14E-09 \\
\hline GO:0009611 response to wounding & 22 & $1.58 \mathrm{E}-11$ & 2.47E-08 \\
\hline GO:0044421 extracellular region part & 29 & $1.86 \mathrm{E}-09$ & $2.21 \mathrm{E}-06$ \\
\hline GO:0001871 pattern binding & 12 & 1.57E-08 & 2.09E-05 \\
\hline GO:0030247 polysaccharide binding & 12 & 1.57E-08 & 2.09E-05 \\
\hline GO:0005764 lysosome & 14 & 2.43E-08 & $2.90 \mathrm{E}-05$ \\
\hline GO:0000323 lytic vacuole & 14 & $2.60 \mathrm{E}-08$ & $3.10 \mathrm{E}-05$ \\
\hline G0:0008009 chemokine activity & 8 & $3.45 \mathrm{E}-08$ & $4.59 \mathrm{E}-05$ \\
\hline GO:0002252 immune effector process & 12 & $3.48 \mathrm{E}-08$ & 5.44E-05 \\
\hline GO:0042379 chemokine receptor binding & 8 & 4.17E-08 & $5.56 \mathrm{E}-05$ \\
\hline GO:0042330 taxis & 11 & $9.33 \mathrm{E}-08$ & $1.46 \mathrm{E}-04$ \\
\hline GO:0006935 chemotaxis & 11 & 9.33E-08 & $1.46 \mathrm{E}-04$ \\
\hline GO:0005773 vacuole & 14 & $1.22 \mathrm{E}-07$ & $1.45 \mathrm{E}-04$ \\
\hline GO:0008201 heparin binding & 9 & $6.46 \mathrm{E}-07$ & $8.61 \mathrm{E}-04$ \\
\hline GO:0005539 glycosaminoglycan binding & 10 & $6.98 \mathrm{E}-07$ & $9.29 E-04$ \\
\hline GO:0002684 positive regulation of immune system process & 13 & $6.99 \mathrm{E}-07$ & 0.001095 \\
\hline GO:0045087 innate immune response & 10 & $8.82 \mathrm{E}-07$ & 0.001381 \\
\hline G0:0031012 extracellular matrix & 15 & $2.45 \mathrm{E}-06$ & 0.002923 \\
\hline GO:0030246 carbohydrate binding & 14 & 4.23E-06 & 0.005639 \\
\hline GO:0050778 positive regulation of immune response & 10 & $6.51 \mathrm{E}-06$ & 0.010194 \\
\hline GO:0009897 external side of plasma membrane & 12 & $6.69 \mathrm{E}-06$ & 0.007964 \\
\hline G0:0005578 proteinaceous extracellular matrix & 14 & 8.34E-06 & 0.009936 \\
\hline GO:0002443 leukocyte mediated immunity & 8 & $2.36 \mathrm{E}-05$ & 0.036874 \\
\hline GO:0009986 cell surface & 13 & 5.37E-05 & 0.064012 \\
\hline GO:0048584 positive regulation of response to stimulus & 10 & 7.83E-05 & 0.122552 \\
\hline GO:0002449 lymphocyte mediated immunity & 7 & $9.01 \mathrm{E}-05$ & 0.140929 \\
\hline GO:0007626 locomotory behavior & 11 & $1.05 \mathrm{E}-04$ & 0.164891 \\
\hline G0:0002250 adaptive immune response & 7 & 1.57E-04 & 0.245953 \\
\hline $\begin{array}{l}\text { GO:0002460 adaptive immune response based on somatic recombination } \\
\text { of immune receptors built from immunoglobulin superfamily domains }\end{array}$ & 7 & 1.57E-04 & 0.245953 \\
\hline GO:0002253 activation of immune response & 7 & $1.79 \mathrm{E}-04$ & 0.280005 \\
\hline GO:0005125 cytokine activity & 9 & $1.88 \mathrm{E}-04$ & 0.250741 \\
\hline G0:0016064 immunoglobulin mediated immune response & 6 & 3.47E-04 & 0.541173 \\
\hline GO:0019724 B cell mediated immunity & 6 & 4.01E-04 & 0.626009 \\
\hline GO:0005615 extracellular space & 15 & 5.77E-04 & 0.685656 \\
\hline GO:0008034 lipoprotein binding & 4 & 7.88E-04 & 1.044859 \\
\hline GO:0005509 calcium ion binding & 18 & 0.001064 & 1.407775 \\
\hline GO:0007610 behavior & 12 & 0.001858 & 2.870625 \\
\hline G0:0070011 peptidase activity, acting on L-amino acid peptides & 14 & 0.002472 & 3.243842 \\
\hline GO:0006958 complement activation, classical pathway & 4 & 0.002939 & 4.504668 \\
\hline G0:0008233 peptidase activity & 14 & 0.003552 & 4.630036 \\
\hline GO:0006873 cellular ion homeostasis & 9 & 0.003777 & 5.75327 \\
\hline GO:0042742 defense response to bacterium & 6 & 0.003895 & 5.927219 \\
\hline GO:0050829 defense response to Gram-negative bacterium & 3 & 0.003946 & 6.002889 \\
\hline GO:0004175 endopeptidase activity & 11 & 0.004001 & 5.200792 \\
\hline GO:0009617 response to bacterium & 7 & 0.004131 & 6.275413 \\
\hline GO:0042592 homeostatic process & 14 & 0.004175 & 6.341493 \\
\hline GO:0055082 cellular chemical homeostasis & 9 & 0.004427 & 6.712002 \\
\hline $\begin{array}{l}\text { GO:0002455 humoral immune response mediated by circulating } \\
\text { immunoglobulin }\end{array}$ & 4 & 0.004575 & 6.928933 \\
\hline GO:0048002 antigen processing and presentation of peptide antigen & 4 & 0.004575 & 6.928933 \\
\hline GO:0030414 peptidase inhibitor activity & 7 & 0.004616 & 5.978063 \\
\hline $\begin{array}{l}\text { GO:0002541 activation of plasma proteins involved in acute } \\
\text { inflammatory response }\end{array}$ & 4 & 0.004957 & 7.485393 \\
\hline GO:0006956 complement activation & 4 & 0.004957 & 7.485393 \\
\hline GO:0030169 low-density lipoprotein binding & 3 & 0.005627 & 7.242112 \\
\hline
\end{tabular}




\begin{tabular}{lrrr|}
\hline GO:0004857 enzyme inhibitor activity & 8 & 0.005668 & 7.292829 \\
\hline GO:0019725 cellular homeostasis & 10 & 0.005978 & 8.960542 \\
\hline GO:0050801 ion homeostasis & 9 & 0.007476 & 11.08524 \\
\hline GO:0002526 acute inflammatory response & 5 & 0.007748 & 11.4663 \\
\hline GO:0006693 prostaglandin metabolic process & 3 & 0.007781 & 11.51221 \\
\hline GO:0006692 prostanoid metabolic process & 3 & 0.007781 & 11.51221 \\
\hline GO:0030005 cellular di-, tri-valent inorganic cation homeostasis & 6 & 0.009575 & 13.9846 \\
\hline GO:0008283 cell proliferation & 8 & 0.009999 & 14.56016 \\
\hline GO:0019886 antigen processing and presentation of exogenous peptide & 3 & 0.010132 & 14.73913 \\
antigen via MHC class II & 3 & 0.010132 & 14.73913 \\
GO:0002495 antigen processing and presentation of peptide antigen via & & & \\
MHC class II & 6 & 0.01279 & 18.25421 \\
\hline GO:0051249 regulation of lymphocyte activation & 6 & 0.013511 & 19.18386 \\
\hline GO:0055066 di-, tri-valent inorganic cation homeostasis & 6 & 0.013873 & 16.98126 \\
\hline GO:0004866 endopeptidase inhibitor activity & & \\
\hline
\end{tabular}




\begin{tabular}{|c|c|c|c|}
\hline \multicolumn{4}{|l|}{$D_{m d^{m d x}} /$ Large $^{m y d-/-}$ vs C57B/3 meses } \\
\hline Termo GO & \# genes & p-valor & FDR \\
\hline GO:0006955 immune response & 45 & $1.66 \mathrm{E}-21$ & $2.74 \mathrm{E}-18$ \\
\hline GO:0006952 defense response & 41 & $7.15 E-19$ & $1.18 \mathrm{E}-15$ \\
\hline GO:0006954 inflammatory response & 29 & $3.83 \mathrm{E}-17$ & $6.30 \mathrm{E}-14$ \\
\hline GO:0009611 response to wounding & 32 & $1.00 \mathrm{E}-14$ & $1.64 \mathrm{E}-11$ \\
\hline GO:0002252 immune effector process & 19 & 2.03E-12 & 3.34E-09 \\
\hline GO:0005764 lysosome & 22 & $5.48 \mathrm{E}-12$ & $6.79 \mathrm{E}-09$ \\
\hline GO:0000323 lytic vacuole & 22 & $6.11 \mathrm{E}-12$ & 7.57E-09 \\
\hline $\begin{array}{l}\text { GO:0002478 antigen processing and presentation of exogenous } \\
\text { peptide antigen }\end{array}$ & 10 & $4.73 \mathrm{E}-11$ & $7.78 \mathrm{E}-08$ \\
\hline GO:0005773 vacuole & 22 & 7.53E-11 & $9.34 \mathrm{E}-08$ \\
\hline GO:0048002 antigen processing and presentation of peptide antigen & 11 & $1.42 \mathrm{E}-10$ & 2.34E-07 \\
\hline GO:0009986 cell surface & 26 & 1.57E-10 & 1.94E-07 \\
\hline GO:0002443 leukocyte mediated immunity & 15 & $1.66 \mathrm{E}-10$ & 2.73E-07 \\
\hline $\begin{array}{l}\text { GO:0019884 antigen processing and presentation of exogenous } \\
\text { antigen }\end{array}$ & 10 & $3.72 \mathrm{E}-10$ & $6.12 \mathrm{E}-07$ \\
\hline G0:0009897 external side of plasma membrane & 21 & $6.21 \mathrm{E}-10$ & 7.71E-07 \\
\hline GO:0030246 carbohydrate binding & 23 & $2.16 \mathrm{E}-09$ & 2.99E-06 \\
\hline G0:0006935 chemotaxis & 15 & 2.61E-09 & $4.29 \mathrm{E}-06$ \\
\hline GO:0042330 taxis & 15 & 2.61E-09 & 4.29E-06 \\
\hline $\begin{array}{l}\text { GO:0002495 antigen processing and presentation of peptide antigen } \\
\text { via MHC class II }\end{array}$ & 8 & $2.85 \mathrm{E}-09$ & 4.70E-06 \\
\hline $\begin{array}{l}\text { GO:0019886 antigen processing and presentation of exogenous } \\
\text { peptide antigen via MHC class II }\end{array}$ & 8 & $2.85 \mathrm{E}-09$ & 4.70E-06 \\
\hline GO:0002449 lymphocyte mediated immunity & 13 & $3.32 \mathrm{E}-09$ & $5.46 \mathrm{E}-06$ \\
\hline GO:0019724 B cell mediated immunity & 12 & 7.13E-09 & 1.17E-05 \\
\hline GO:0044421 extracellular region part & 39 & 7.72E-09 & $9.58 \mathrm{E}-06$ \\
\hline GO:0002250 adaptive immune response & 13 & $1.08 \mathrm{E}-08$ & 1.77E-05 \\
\hline $\begin{array}{l}\text { GO:0002460 adaptive immune response based on somatic } \\
\text { recombination of immune receptors built from immunoglobulin } \\
\text { superfamily domains }\end{array}$ & 13 & $1.08 \mathrm{E}-08$ & 1.77E-05 \\
\hline $\begin{array}{l}\text { GO:0002504 antigen processing and presentation of peptide or } \\
\text { polysaccharide antigen via MHC class II }\end{array}$ & 8 & $1.21 \mathrm{E}-08$ & $1.98 \mathrm{E}-05$ \\
\hline GO:0002684 positive regulation of immune system process & 18 & 4.61E-08 & 7.59E-05 \\
\hline GO:0050778 positive regulation of immune response & 15 & 4.69E-08 & 7.72E-05 \\
\hline GO:0030247 polysaccharide binding & 14 & $6.03 \mathrm{E}-08$ & 8.34E-05 \\
\hline GO:0001871 pattern binding & 14 & $6.03 \mathrm{E}-08$ & 8.34E-05 \\
\hline G0:0016064 immunoglobulin mediated immune response & 11 & $6.64 \mathrm{E}-08$ & $1.09 \mathrm{E}-04$ \\
\hline GO:0008009 chemokine activity & 9 & 7.31E-08 & $1.01 \mathrm{E}-04$ \\
\hline GO:0007626 locomotory behavior & 19 & 7.48E-08 & $1.23 \mathrm{E}-04$ \\
\hline GO:0042379 chemokine receptor binding & 9 & $9.08 \mathrm{E}-08$ & $1.26 \mathrm{E}-04$ \\
\hline GO:0031012 extracellular matrix & 22 & $1.30 \mathrm{E}-07$ & $1.62 \mathrm{E}-04$ \\
\hline GO:0045087 innate immune response & 13 & $1.70 \mathrm{E}-07$ & $2.80 \mathrm{E}-04$ \\
\hline GO:0005578 proteinaceous extracellular matrix & 21 & $3.06 \mathrm{E}-07$ & 3.79E-04 \\
\hline GO:0001775 cell activation & 18 & 5.93E-07 & $9.75 \mathrm{E}-04$ \\
\hline GO:0045321 leukocyte activation & 17 & $6.13 \mathrm{E}-07$ & 0.001009 \\
\hline GO:0005539 glycosaminoglycan binding & 12 & $1.08 \mathrm{E}-06$ & 0.001494 \\
\hline GO:0050766 positive regulation of phagocytosis & 7 & $1.42 \mathrm{E}-06$ & 0.00234 \\
\hline GO:0019882 antigen processing and presentation & 11 & $1.48 \mathrm{E}-06$ & 0.00243 \\
\hline GO:0048584 positive regulation of response to stimulus & 15 & 2.21E-06 & 0.003642 \\
\hline GO:0050764 regulation of phagocytosis & 7 & 2.43E-06 & 0.003995 \\
\hline GO:0006911 phagocytosis, engulfment & 6 & $2.92 \mathrm{E}-06$ & 0.004812 \\
\hline GO:0007610 behavior & 22 & 3.07E-06 & 0.005054 \\
\hline GO:0008201 heparin binding & 10 & 3.99E-06 & 0.005518 \\
\hline GO:0019955 cytokine binding & 10 & $6.51 \mathrm{E}-06$ & 0.008992 \\
\hline GO:0002253 activation of immune response & 10 & 1.09E-05 & 0.017929 \\
\hline GO:0019865 immunoglobulin binding & 5 & $1.48 \mathrm{E}-05$ & 0.020494 \\
\hline G0:0045807 positive regulation of endocytosis & 7 & $1.63 \mathrm{E}-05$ & 0.026828 \\
\hline GO:0019864 IgG binding & 4 & 3.24E-05 & 0.044706 \\
\hline GO:0045576 mast cell activation & 5 & $8.22 \mathrm{E}-05$ & 0.13512 \\
\hline GO:0006909 phagocytosis & 7 & $1.38 \mathrm{E}-04$ & 0.227226 \\
\hline GO:0030100 regulation of endocytosis & 7 & $1.93 \mathrm{E}-04$ & 0.31747 \\
\hline
\end{tabular}




\begin{tabular}{|c|c|c|c|}
\hline G0:0004857 enzyme inhibitor activity & 13 & $3.00 \mathrm{E}-04$ & 0.413259 \\
\hline GO:0005509 calcium ion binding & 27 & 3.35E-04 & 0.462117 \\
\hline GO:0002526 acute inflammatory response & 8 & $3.53 \mathrm{E}-04$ & 0.578677 \\
\hline GO:0005125 cytokine activity & 11 & 3.81E-04 & 0.525182 \\
\hline mmu04610:Complement and coagulation cascades & 8 & $4.51 \mathrm{E}-04$ & 0.490364 \\
\hline GO:0001803 regulation of type III hypersensitivity & 3 & $7.89 \mathrm{E}-04$ & 1.289702 \\
\hline GO:0001805 positive regulation of type III hypersensitivity & 3 & 7.89E-04 & 1.289702 \\
\hline GO:0030595 leukocyte chemotaxis & 5 & $9.06 \mathrm{E}-04$ & 1.480175 \\
\hline GO:0060326 cell chemotaxis & 5 & $9.06 \mathrm{E}-04$ & 1.480175 \\
\hline GO:0002883 regulation of hypersensitivity & 4 & 0.00109 & 1.778783 \\
\hline $\begin{array}{l}\text { GO:0002864 regulation of acute inflammatory response to antigenic } \\
\text { stimulus }\end{array}$ & 4 & 0.00109 & 1.778783 \\
\hline GO:0006910 phagocytosis, recognition & 4 & 0.00109 & 1.778783 \\
\hline G0:0019763 immunoglobulin receptor activity & 3 & 0.001313 & 1.798554 \\
\hline GO:0030414 peptidase inhibitor activity & 10 & 0.001337 & 1.831229 \\
\hline G0:0006958 complement activation, classical pathway & 5 & 0.001361 & 2.216706 \\
\hline GO:0006692 prostanoid metabolic process & 4 & 0.001371 & 2.23191 \\
\hline GO:0006693 prostaglandin metabolic process & 4 & 0.001371 & 2.23191 \\
\hline GO:0001503 0ssification & 8 & 0.001754 & 2.8468 \\
\hline GO:0005615 extracellular space & 20 & 0.001811 & 2.224417 \\
\hline GO:0006959 humoral immune response & 6 & 0.001836 & 2.977772 \\
\hline G0:0001817 regulation of cytokine production & 9 & 0.002018 & 3.269594 \\
\hline $\begin{array}{l}\text { GO:0002822 regulation of adaptive immune response based on somatic } \\
\text { recombination of immune receptors built from immunoglobulin } \\
\text { superfamily domains }\end{array}$ & 6 & 0.00216 & 3.494475 \\
\hline GO:0002819 regulation of adaptive immune response & 6 & 0.00216 & 3.494475 \\
\hline GO:0031349 positive regulation of defense response & 6 & 0.002336 & 3.775268 \\
\hline G0:0060627 regulation of vesicle-mediated transport & 7 & 0.002356 & 3.807399 \\
\hline $\begin{array}{l}\text { GO:0002455 humoral immune response mediated by circulating } \\
\text { immunoglobulin }\end{array}$ & 5 & 0.002441 & 3.94102 \\
\hline GO:0030593 neutrophil chemotaxis & 4 & 0.00247 & 3.987568 \\
\hline GO:0002444 myeloid leukocyte mediated immunity & 4 & 0.00247 & 3.987568 \\
\hline GO:0004197 cysteine-type endopeptidase activity & 6 & 0.002491 & 3.387938 \\
\hline $\begin{array}{l}\text { GO:0042590 antigen processing and presentation of exogenous } \\
\text { peptide antigen via MHC class I }\end{array}$ & 3 & 0.002572 & 4.149468 \\
\hline GO:0005044 Scavenger receptor activity & 5 & 0.002664 & 3.618838 \\
\hline $\begin{array}{l}\text { GO:0002541 activation of plasma proteins involved in acute } \\
\text { inflammatory response }\end{array}$ & 5 & 0.002711 & 4.368527 \\
\hline GO:0006956 complement activation & 5 & 0.002711 & 4.368527 \\
\hline GO:0042110 T cell activation & 8 & 0.002927 & 4.708211 \\
\hline G0:0002673 regulation of acute inflammatory response & 4 & 0.002929 & 4.711217 \\
\hline GO:0002861 regulation of inflammatory response to antigenic stimulus & 4 & 0.002929 & 4.711217 \\
\hline GO:0050801 ion homeostasis & 13 & 0.003204 & 5.1439 \\
\hline GO:0060348 bone development & 8 & 0.00322 & 5.168596 \\
\hline GO:0042592 homeostatic process & 20 & 0.003336 & 5.349029 \\
\hline GO:0016485 protein processing & 7 & 0.003538 & 5.664905 \\
\hline GO:0008034 lipoprotein binding & 4 & 0.003607 & 4.86962 \\
\hline GO:0010324 membrane invagination & 10 & 0.003772 & 6.028104 \\
\hline G0:0006897 endocytosis & 10 & 0.003772 & 6.028104 \\
\hline G0:0006873 cellular ion homeostasis & 12 & 0.0038 & 6.072333 \\
\hline G0:0051130 positive regulation of cellular component organization & 8 & 0.003874 & 6.186881 \\
\hline G0:0051605 protein maturation by peptide bond cleavage & 6 & 0.004149 & 6.611846 \\
\hline G0:0070011 peptidase activity, acting on L-amino acid peptides & 19 & 0.004171 & 5.612142 \\
\hline GO:0046649 lymphocyte activation & 10 & 0.004184 & 6.666291 \\
\hline GO:0004175 endopeptidase activity & 15 & 0.004486 & 6.023174 \\
\hline GO:0055082 cellular chemical homeostasis & 12 & 0.004635 & 7.359412 \\
\hline GO:0051604 protein maturation & 7 & 0.004861 & 7.704132 \\
\hline GO:0050900 leukocyte migration & 5 & 0.005197 & 8.216305 \\
\hline GO:0051050 positive regulation of transport & 8 & 0.005948 & 9.349813 \\
\hline GO:0051015 actin filament binding & 5 & 0.006111 & 8.121077 \\
\hline G0:0032403 protein complex binding & 6 & 0.006251 & 8.299744 \\
\hline G0:0008233 peptidase activity & 19 & 0.006412 & 8.504691 \\
\hline G0:0030005 cellular di-, tri-valent inorganic cation homeostasis & 8 & 0.006447 & 10.09536 \\
\hline
\end{tabular}




\begin{tabular}{|c|c|c|c|}
\hline G0:0001796 regulation of type IIa hypersensitivity & 3 & 0.006973 & 10.87556 \\
\hline GO:0001798 positive regulation of type IIa hypersensitivity & 3 & 0.006973 & 10.87556 \\
\hline GO:0001810 regulation of type I hypersensitivity & 3 & 0.006973 & 10.87556 \\
\hline GO:0002894 positive regulation of type II hypersensitivity & 3 & 0.006973 & 10.87556 \\
\hline $\begin{array}{l}\text { GO:0002888 positive regulation of myeloid leukocyte mediated } \\
\text { immunity }\end{array}$ & 3 & 0.006973 & 10.87556 \\
\hline G0:0002892 regulation of type II hypersensitivity & 3 & 0.006973 & 10.87556 \\
\hline G0:0001501 skeletal system development & 12 & 0.007258 & 11.29513 \\
\hline G0:0002757 immune response-activating signal transduction & 5 & 0.007692 & 11.93144 \\
\hline GO:0007584 response to nutrient & 6 & 0.008036 & 12.4316 \\
\hline G0:0030097 hemopoiesis & 11 & 0.008321 & 12.84541 \\
\hline GO:0004896 cytokine receptor activity & 5 & 0.009179 & 11.96246 \\
\hline GO:0032680 regulation of tumor necrosis factor production & 4 & 0.009425 & 14.42756 \\
\hline GO:0055066 di-, tri-valent inorganic cation homeostasis & 8 & 0.010119 & 15.40914 \\
\hline G0:0002764 immune response-regulating signal transduction & 5 & 0.010176 & 15.48885 \\
\hline GO:0048872 homeostasis of number of cells & 7 & 0.010555 & 16.02019 \\
\hline GO:0004866 endopeptidase inhibitor activity & 8 & 0.010741 & 13.86093 \\
\hline GO:0055080 cation homeostasis & 9 & 0.010771 & 16.32143 \\
\hline GO:0019725 cellular homeostasis & 13 & 0.0108 & 16.36175 \\
\hline $\begin{array}{l}\text { GO:0002866 positive regulation of acute inflammatory response to } \\
\text { antigenic stimulus }\end{array}$ & 3 & 0.010968 & 16.59534 \\
\hline G0:0002885 positive regulation of hypersensitivity & 3 & 0.010968 & 16.59534 \\
\hline GO:0001516 prostaglandin biosynthetic process & 3 & 0.010968 & 16.59534 \\
\hline GO:0046457 prostanoid biosynthetic process & 3 & 0.010968 & 16.59534 \\
\hline GO:0031667 response to nutrient levels & 7 & 0.011446 & 17.25539 \\
\hline G0:0030003 cellular cation homeostasis & 8 & 0.012441 & 18.61466 \\
\hline GO:0002712 regulation of B cell mediated immunity & 4 & 0.012622 & 18.86072 \\
\hline G0:0002889 regulation of immunoglobulin mediated immune response & 4 & 0.012622 & 18.86072 \\
\hline GO:0042613 MHC class II protein complex & 3 & 0.012745 & 14.713 \\
\hline G0:0002675 positive regulation of acute inflammatory response & 3 & 0.013263 & 19.72221 \\
\hline GO:0002694 regulation of leukocyte activation & 8 & 0.013293 & 19.76333 \\
\hline GO:0030169 low-density lipoprotein binding & 3 & 0.015615 & 19.54409 \\
\hline G0:0030141 secretory granule & 7 & 0.017582 & 19.7544 \\
\hline
\end{tabular}




\begin{tabular}{|c|c|c|c|}
\hline \multicolumn{4}{|l|}{$D m d^{m d x}$ vs C57BL 6 meses } \\
\hline Termo GO & \# genes & p-valor & FDR \\
\hline GO:0006955 immune response & 52 & $6.53 \mathrm{E}-21$ & $1.11 \mathrm{E}-17$ \\
\hline GO:0006954 inflammatory response & 35 & 1.17E-18 & $1.99 \mathrm{E}-15$ \\
\hline GO:0006952 defense response & 46 & $2.96 \mathrm{E}-17$ & $5.04 \mathrm{E}-14$ \\
\hline GO:0009611 response to wounding & 39 & 7.44E-16 & $1.32 \mathrm{E}-12$ \\
\hline GO:0005764 lysosome & 27 & $3.92 \mathrm{E}-13$ & $5.02 \mathrm{E}-10$ \\
\hline GO:0000323 lytic vacuole & 27 & $4.48 \mathrm{E}-13$ & $5.74 \mathrm{E}-10$ \\
\hline GO:0002252 immune effector process & 21 & $8.05 \mathrm{E}-12$ & 1.37E-08 \\
\hline GO:0005773 vacuole & 27 & $9.69 \mathrm{E}-12$ & $1.24 \mathrm{E}-08$ \\
\hline $\begin{array}{l}\text { GO:0002478 antigen processing and presentation of exogenous } \\
\text { peptide antigen }\end{array}$ & 11 & $3.00 \mathrm{E}-11$ & $5.10 \mathrm{E}-08$ \\
\hline GO:0009986 cell surface & 32 & $3.70 \mathrm{E}-11$ & 4.74E-08 \\
\hline GO:0002443 leukocyte mediated immunity & 17 & $1.51 \mathrm{E}-10$ & 2.56E-07 \\
\hline GO:0048002 antigen processing and presentation of peptide antigen & 12 & $1.94 \mathrm{E}-10$ & 3.29E-07 \\
\hline GO:0002274 myeloid leukocyte activation & 12 & $1.94 \mathrm{E}-10$ & 3.29E-07 \\
\hline $\begin{array}{l}\text { GO:0019884 antigen processing and presentation of exogenous } \\
\text { antigen }\end{array}$ & 11 & $3.11 \mathrm{E}-10$ & $5.29 \mathrm{E}-07$ \\
\hline $\begin{array}{l}\text { GO:0002495 antigen processing and presentation of peptide antigen } \\
\text { via MHC class II }\end{array}$ & 9 & 7.56E-10 & $1.28 \mathrm{E}-06$ \\
\hline $\begin{array}{l}\text { GO:0019886 antigen processing and presentation of exogenous } \\
\text { peptide antigen via MHC class II }\end{array}$ & 9 & $7.56 \mathrm{E}-10$ & $1.28 \mathrm{E}-06$ \\
\hline GO:0002449 lymphocyte mediated immunity & 15 & $1.55 \mathrm{E}-09$ & $2.63 \mathrm{E}-06$ \\
\hline GO:0019724 B cell mediated immunity & 14 & $2.08 \mathrm{E}-09$ & 3.53E-06 \\
\hline GO:0009897 external side of plasma membrane & 24 & $2.25 \mathrm{E}-09$ & $2.88 \mathrm{E}-06$ \\
\hline GO:0030246 carbohydrate binding & 28 & $2.50 \mathrm{E}-09$ & $3.61 \mathrm{E}-06$ \\
\hline $\begin{array}{l}\text { GO:0002504 antigen processing and presentation of peptide or } \\
\text { polysaccharide antigen via MHC class II }\end{array}$ & 9 & 4.18E-09 & 7.10E-06 \\
\hline GO:0044421 extracellular region part & 49 & $5.81 \mathrm{E}-09$ & 7.44E-06 \\
\hline GO:0002250 adaptive immune response & 15 & 6.07E-09 & 1.03E-05 \\
\hline $\begin{array}{l}\text { GO:0002460 adaptive immune response based on somatic } \\
\text { recombination of immune receptors built from immunoglobulin } \\
\text { superfamily domains }\end{array}$ & 15 & 6.07E-09 & $1.03 \mathrm{E}-05$ \\
\hline GO:0002684 positive regulation of immune system process & 22 & $1.06 \mathrm{E}-08$ & $1.79 \mathrm{E}-05$ \\
\hline GO:0016064 immunoglobulin mediated immune response & 13 & 1.57E-08 & 2.67E-05 \\
\hline GO:0006935 chemotaxis & 16 & $2.59 \mathrm{E}-08$ & 4.39E-05 \\
\hline GO:0042330 taxis & 16 & $2.59 \mathrm{E}-08$ & 4.39E-05 \\
\hline GO:0045321 leukocyte activation & 22 & $3.11 \mathrm{E}-08$ & $5.29 \mathrm{E}-05$ \\
\hline GO:0045807 positive regulation of endocytosis & 10 & 4.87E-08 & 8.27E-05 \\
\hline GO:0001775 cell activation & 23 & $5.12 \mathrm{E}-08$ & $8.71 \mathrm{E}-05$ \\
\hline GO:0050764 regulation of phagocytosis & 9 & $5.31 \mathrm{E}-08$ & $9.01 \mathrm{E}-05$ \\
\hline GO:0031012 extracellular matrix & 27 & 7.72E-08 & 9.89E-05 \\
\hline GO:0050778 positive regulation of immune response & 17 & 8.47E-08 & $1.44 \mathrm{E}-04$ \\
\hline GO:0005578 proteinaceous extracellular matrix & 26 & 1.37E-07 & $1.76 \mathrm{E}-04$ \\
\hline GO:0007626 locomotory behavior & 22 & $1.40 \mathrm{E}-07$ & $2.39 \mathrm{E}-04$ \\
\hline GO:0030100 regulation of endocytosis & 11 & 2.31E-07 & $3.92 \mathrm{E}-04$ \\
\hline GO:0050766 positive regulation of phagocytosis & 8 & $5.50 \mathrm{E}-07$ & 9.35E-04 \\
\hline GO:0006911 phagocytosis, engulfment & 7 & $5.76 \mathrm{E}-07$ & 9.79E-04 \\
\hline GO:0051130 positive regulation of cellular component organization & 15 & 7.49E-07 & 0.001273 \\
\hline GO:0030247 polysaccharide binding & 15 & $1.01 \mathrm{E}-06$ & 0.001461 \\
\hline GO:0001871 pattern binding & 15 & 1.01E-06 & 0.001461 \\
\hline GO:0019955 cytokine binding & 12 & 4.01E-06 & 0.005791 \\
\hline GO:0019882 antigen processing and presentation & 12 & $4.51 \mathrm{E}-06$ & 0.007657 \\
\hline GO:0048584 positive regulation of response to stimulus & 17 & $5.84 \mathrm{E}-06$ & 0.00992 \\
\hline GO:0005539 glycosaminoglycan binding & 13 & $9.00 \mathrm{E}-06$ & 0.013002 \\
\hline GO:0006909 phagocytosis & 9 & 1.37E-05 & 0.023304 \\
\hline GO:0060627 regulation of vesicle-mediated transport & 11 & $1.89 \mathrm{E}-05$ & 0.032176 \\
\hline GO:0007610 behavior & 25 & 2.07E-05 & 0.035142 \\
\hline GO:0005509 calcium ion binding & 39 & $2.54 \mathrm{E}-05$ & 0.036616 \\
\hline GO:0006897 endocytosis & 16 & $2.80 \mathrm{E}-05$ & 0.04754 \\
\hline GO:0010324 membrane invagination & 16 & 2.80E-05 & 0.04754 \\
\hline GO:0002819 regulation of adaptive immune response & 9 & $3.76 \mathrm{E}-05$ & 0.063868 \\
\hline GO:0002822 regulation of adaptive immune response based on somatic & 9 & 3.76E-05 & 0.063868 \\
\hline
\end{tabular}




\begin{tabular}{|c|c|c|c|}
\hline GO:0050801 ion homeostasis & 20 & $4.58 \mathrm{E}-05$ & 0.077795 \\
\hline GO:0048770 pigment granule & 11 & $5.38 \mathrm{E}-05$ & 0.068963 \\
\hline GO:0042470 melanosome & 11 & 5.38E-05 & 0.068963 \\
\hline GO:0042110 TT cell activation & 12 & $7.02 \mathrm{E}-05$ & 0.119301 \\
\hline GO:0019865 immunoglobulin binding & 5 & 7.13E-05 & 0.102938 \\
\hline GO:0055080 cation homeostasis & 15 & $8.65 \mathrm{E}-05$ & 0.146957 \\
\hline GO:0002526 acute inflammatory response & 10 & $9.43 \mathrm{E}-05$ & 0.160163 \\
\hline GO:0019864 IgG binding & 4 & 1.07E-04 & 0.15433 \\
\hline GO:0006873 cellular ion homeostasis & 18 & 1.09E-04 & 0.184833 \\
\hline GO:0002706 regulation of lymphocyte mediated immunity & 9 & $1.12 \mathrm{E}-04$ & 0.189768 \\
\hline G0:0033559 unsaturated fatty acid metabolic process & 7 & $1.50 \mathrm{E}-04$ & 0.253766 \\
\hline GO:0055082 cellular chemical homeostasis & 18 & $1.50 \mathrm{E}-04$ & 0.254486 \\
\hline GO:0002253 activation of immune response & 10 & $1.50 \mathrm{E}-04$ & 0.255376 \\
\hline GO:0016044 membrane organization & 18 & $1.79 \mathrm{E}-04$ & 0.303663 \\
\hline GO:0008009 chemokine activity & 7 & $1.79 \mathrm{E}-04$ & 0.258444 \\
\hline G0:0002703 regulation of leukocyte mediated immunity & 9 & $1.89 \mathrm{E}-04$ & 0.321316 \\
\hline GO:0030003 cellular cation homeostasis & 13 & 1.95E-04 & 0.330767 \\
\hline GO:0042379 chemokine receptor binding & 7 & $2.08 \mathrm{E}-04$ & 0.299706 \\
\hline GO:0051050 positive regulation of transport & 12 & $2.24 \mathrm{E}-04$ & 0.379628 \\
\hline GO:0030005 cellular di-, tri-valent inorganic cation homeostasis & 12 & $2.55 \mathrm{E}-04$ & 0.432912 \\
\hline GO:0009617 response to bacterium & 13 & $2.64 \mathrm{E}-04$ & 0.446909 \\
\hline GO:0050777 negative regulation of immune response & 6 & $2.69 \mathrm{E}-04$ & 0.456834 \\
\hline GO:0045576 mast cell activation & 5 & 3.01E-04 & 0.510158 \\
\hline GO:0001501 skeletal system development & 18 & $3.10 \mathrm{E}-04$ & 0.525829 \\
\hline GO:0001817 regulation of cytokine production & 12 & $3.51 \mathrm{E}-04$ & 0.594308 \\
\hline GO:0019725 cellular homeostasis & 20 & $3.54 \mathrm{E}-04$ & 0.600276 \\
\hline GO:0032943 mononuclear cell proliferation & 7 & 4.09E-04 & 0.692968 \\
\hline GO:0070661 leukocyte proliferation & 7 & 4.09E-04 & 0.692968 \\
\hline GO:0042592 homeostatic process & 28 & $4.16 \mathrm{E}-04$ & 0.705382 \\
\hline GO:0046649 lymphocyte activation & 14 & $4.58 \mathrm{E}-04$ & 0.775834 \\
\hline GO:0008201 heparin binding & 9 & $5.23 \mathrm{E}-04$ & 0.752799 \\
\hline GO:0055066 di-, tri-valent inorganic cation homeostasis & 12 & $5.33 \mathrm{E}-04$ & 0.902527 \\
\hline G0:0002712 regulation of B cell mediated immunity & 6 & $5.42 \mathrm{E}-04$ & 0.916244 \\
\hline GO:0002889 regulation of immunoglobulin mediated immune response & 6 & $5.42 \mathrm{E}-04$ & 0.916244 \\
\hline GO:0008283 cell proliferation & 16 & $5.76 \mathrm{E}-04$ & 0.973574 \\
\hline GO:0045059 positive thymic T cell selection & 4 & $6.11 \mathrm{E}-04$ & 1.032486 \\
\hline GO:0048878 chemical homeostasis & 20 & 7.61E-04 & 1.284615 \\
\hline GO:0005770 late endosome & 7 & 7.81E-04 & 0.995428 \\
\hline GO:0042742 defense response to bacterium & 10 & $8.26 \mathrm{E}-04$ & 1.394172 \\
\hline GO:0002697 regulation of immune effector process & 9 & $9.04 \mathrm{E}-04$ & 1.525404 \\
\hline GO:0042277 peptide binding & 12 & 9.39E-04 & 1.348093 \\
\hline GO:0002821 positive regulation of adaptive immune response & 6 & $9.81 \mathrm{E}-04$ & 1.65435 \\
\hline $\begin{array}{l}\text { GO:0002824 positive regulation of adaptive immune response based on } \\
\text { somatic recombination of immune receptors built from immunoglobulin } \\
\text { superfamily domains }\end{array}$ & 6 & $9.81 \mathrm{E}-04$ & 1.65435 \\
\hline GO:0006690 icosanoid metabolic process & 6 & $9.81 \mathrm{E}-04$ & 1.65435 \\
\hline GO:0045621 positive regulation of lymphocyte differentiation & 6 & $9.81 \mathrm{E}-04$ & 1.65435 \\
\hline GO:0002764 immune response-regulating signal transduction & 7 & 0.00115 & 1.936581 \\
\hline GO:0043368 positive T cell selection & 4 & 0.001265 & 2.127187 \\
\hline G0:0006672 ceramide metabolic process & 6 & 0.001281 & 2.154117 \\
\hline GO:0051094 positive regulation of developmental process & 14 & 0.001317 & 2.214395 \\
\hline GO:0004896 cytokine receptor activity & 7 & 0.001369 & 1.959831 \\
\hline GO:0001805 positive regulation of type III hypersensitivity & 3 & 0.001543 & 2.589663 \\
\hline GO:0001803 regulation of type III hypersensitivity & 3 & 0.001543 & 2.589663 \\
\hline GO:0046519 sphingoid metabolic process & 6 & 0.001643 & 2.755163 \\
\hline GO:0042613 MHC class II protein complex & 4 & 0.001681 & 2.132755 \\
\hline GO:0050830 defense response to Gram-positive bacterium & 5 & 0.00169 & 2.832903 \\
\hline G0:0002683 negative regulation of immune system process & 8 & 0.001742 & 2.919024 \\
\hline GO:0002696 positive regulation of leukocyte activation & 9 & 0.00194 & 3.24659 \\
\hline GO:0016023 cytoplasmic membrane-bounded vesicle & 22 & 0.00195 & 2.470007 \\
\hline
\end{tabular}




\begin{tabular}{|c|c|c|c|}
\hline G0:0030097 hemopoiesis & 15 & 0.001954 & 3.268288 \\
\hline G0:0050867 positive regulation of cell activation & 9 & 0.002202 & 3.677437 \\
\hline G0:0043062 extracellular structure organization & 11 & 0.002261 & 3.774124 \\
\hline GO:0031988 membrane-bounded vesicle & 22 & 0.002317 & 2.927887 \\
\hline G0:0045597 positive regulation of cell differentiation & 12 & 0.002332 & 3.889508 \\
\hline GO:0006633 fatty acid biosynthetic process & 8 & 0.002515 & 4.18862 \\
\hline GO:0046651 lymphocyte proliferation & 6 & 0.002584 & 4.30204 \\
\hline GO:0004197 cysteine-type endopeptidase activity & 7 & 0.002766 & 3.922066 \\
\hline G0:0006910 phagocytosis, recognition & 4 & 0.002864 & 4.756795 \\
\hline $\begin{array}{l}\text { GO:0002864 regulation of acute inflammatory response to antigenic } \\
\text { stimulus }\end{array}$ & 4 & 0.002864 & 4.756795 \\
\hline GO:0002883 regulation of hypersensitivity & 4 & 0.002864 & 4.756795 \\
\hline G0:0006665 sphingolipid metabolic process & 7 & 0.002871 & 4.767513 \\
\hline GO:0002694 regulation of leukocyte activation & 11 & 0.002877 & 4.777629 \\
\hline GO:0019763 immunoglobulin receptor activity & 3 & 0.0029 & 4.107963 \\
\hline $\begin{array}{l}\text { G0:0045356 positive regulation of interferon-alpha biosynthetic } \\
\text { process }\end{array}$ & 3 & 0.003039 & 5.040554 \\
\hline GO:0045354 regulation of interferon-alpha biosynthetic process & 3 & 0.003039 & 5.040554 \\
\hline G0:0046456 icosanoid biosynthetic process & 5 & 0.003117 & 5.166267 \\
\hline GO:0032680 regulation of tumor necrosis factor production & 5 & 0.003117 & 5.166267 \\
\hline GO:0050865 regulation of cell activation & 11 & 0.003158 & 5.232202 \\
\hline $\begin{array}{l}\text { GO:0002768 immune response-regulating cell surface receptor } \\
\text { signaling pathway }\end{array}$ & 6 & 0.003179 & 5.26697 \\
\hline G0:0006643 membrane lipid metabolic process & 7 & 0.00337 & 5.575462 \\
\hline GO:0042098 T cell proliferation & 5 & 0.003572 & 5.898849 \\
\hline G0:0006636 unsaturated fatty acid biosynthetic process & 5 & 0.003572 & 5.898849 \\
\hline GO:0002714 positive regulation of B cell mediated immunity & 4 & 0.003584 & 5.918366 \\
\hline $\begin{array}{l}\text { GO:0002891 positive regulation of immunoglobulin mediated immune } \\
\text { response }\end{array}$ & 4 & 0.003584 & 5.918366 \\
\hline GO:0002704 negative regulation of leukocyte mediated immunity & 4 & 0.003584 & 5.918366 \\
\hline G0:0002707 negative regulation of lymphocyte mediated immunity & 4 & 0.003584 & 5.918366 \\
\hline GO:0006692 prostanoid metabolic process & 4 & 0.003584 & 5.918366 \\
\hline GO:0006693 prostaglandin metabolic process & 4 & 0.003584 & 5.918366 \\
\hline G0:0048585 negative regulation of response to stimulus & 7 & 0.003643 & 6.013883 \\
\hline G0:0032535 regulation of cellular component size & 11 & 0.003956 & 6.513222 \\
\hline GO:0044459 plasma membrane part & 59 & 0.004202 & 5.251727 \\
\hline GO:0045061 thymic T cell selection & 4 & 0.004404 & 7.226513 \\
\hline GO:0048872 homeostasis of number of cells & 9 & 0.00441 & 7.235363 \\
\hline GO:0051015 actin filament binding & 6 & 0.004602 & 6.445852 \\
\hline G0:0002757 immune response-activating signal transduction & 6 & 0.004654 & 7.621095 \\
\hline $\begin{array}{l}\text { GO:0042590 antigen processing and presentation of exogenous } \\
\text { peptide antigen via MHC class I }\end{array}$ & 3 & 0.004989 & 8.147063 \\
\hline GO:0002237 response to molecule of bacterial origin & 6 & 0.005088 & 8.302882 \\
\hline G0:0002366 leukocyte activation during immune response & 5 & 0.005202 & 8.480779 \\
\hline GO:0002263 cell activation during immune response & 5 & 0.005202 & 8.480779 \\
\hline G0:0048534 hemopoietic or lymphoid organ development & 15 & 0.005383 & 8.763919 \\
\hline GO:0016192 vesicle-mediated transport & 21 & 0.005391 & 8.776909 \\
\hline GO:0003779 actin binding & 15 & 0.005417 & 7.546563 \\
\hline G0:0051251 positive regulation of lymphocyte activation & 8 & 0.005761 & 9.350809 \\
\hline G0:0032675 regulation of interleukin-6 production & 5 & 0.005839 & 9.472732 \\
\hline GO:0045582 positive regulation of $\mathrm{T}$ cell differentiation & 5 & 0.005839 & 9.472732 \\
\hline GO:0032649 regulation of interferon-gamma production & 5 & 0.005839 & 9.472732 \\
\hline GO:0051249 regulation of lymphocyte activation & 10 & 0.00589 & 9.551018 \\
\hline G0:0015629 actin cytoskeleton & 13 & 0.005964 & 7.377513 \\
\hline GO:0008610 lipid biosynthetic process & 15 & 0.006076 & 9.838781 \\
\hline G0:0030414 peptidase inhibitor activity & 11 & 0.006239 & 8.643484 \\
\hline GO:0002673 regulation of acute inflammatory response & 4 & 0.007509 & 12.02103 \\
\hline G0:0002861 regulation of inflammatory response to antigenic stimulus & 4 & 0.007509 & 12.02103 \\
\hline GO:0044243 multicellular organismal catabolic process & 4 & 0.007509 & 12.02103 \\
\hline G0:0045860 positive regulation of protein kinase activity & 9 & 0.007657 & 12.24399 \\
\hline GO:0030217 T cell differentiation & 7 & 0.00783 & 12.50391 \\
\hline G0:0002520 immune system development & 15 & 0.008137 & 12.96301 \\
\hline G0:0030198 extracellular matrix organization & 8 & 0.008461 & 13.44514 \\
\hline
\end{tabular}




\begin{tabular}{|lrrr|}
\hline GO:0004857 enzyme inhibitor activity & 13 & 0.008598 & 11.72667 \\
\hline GO:0044420 extracellular matrix part & 8 & 0.008637 & 10.51758 \\
\hline GO:0010876 lipid localization & 9 & 0.009199 & 14.53373 \\
\hline GO:0031349 positive regulation of defense response & 6 & 0.009638 & 15.1743 \\
\hline GO:0031410 cytoplasmic vesicle & 23 & 0.00976 & 11.80752 \\
\hline GO:0016049 cell growth & 5 & 0.00981 & 15.42445 \\
\hline GO:0033674 positive regulation of kinase activity & 9 & 0.010053 & 15.77567 \\
\hline GO:0002698 negative regulation of immune effector process & 4 & 0.010142 & 15.90523 \\
\hline GO:0045359 positive regulation of interferon-beta biosynthetic process & 3 & 0.010163 & 15.93471 \\
\hline GO:0032647 regulation of interferon-alpha production & 3 & 0.010163 & 15.93471 \\
\hline GO:0045357 regulation of interferon-beta biosynthetic process & 3 & 0.010163 & 15.93471 \\
\hline GO:0045619 regulation of lymphocyte differentiation & 6 & 0.010355 & 16.21162 \\
\hline GO:0005044 scavenger receptor activity & 5 & 0.010876 & 14.61097 \\
\hline GO:0001503 0ssification & 8 & 0.010893 & 16.9819 \\
\hline GO:0008034 lipoprotein binding & 4 & 0.01091 & 14.65388 \\
\hline GO:0030199 collagen fibril organization & 4 & 0.011635 & 18.03487 \\
\hline GO:0045058 T cell selection & 4 & 0.011635 & 18.03487 \\
\hline GO:0031982 vesicle & 23 & 0.01237 & 14.74032 \\
\hline GO:0051347 positive regulation of transferase activity & 9 & 0.012442 & 19.16354 \\
\hline GO:0001530 lipopolysaccharide binding & 3 & 0.012754 & 16.92333 \\
\hline GO:0002708 positive regulation of lymphocyte mediated immunity & 5 & 0.01287 & 19.75769 \\
\hline GO:0002705 positive regulation of leukocyte mediated immunity & 5 & 0.01287 & 19.75769 \\
\hline GO:0004175 endopeptidase activity & 18 & 0.013962 & 18.37983 \\
\hline
\end{tabular}




\begin{tabular}{|c|c|c|c|}
\hline \multicolumn{4}{|l|}{ Large $^{m y d-/-}$ vs C57BL 6 meses } \\
\hline Termo GO & \# genes & p-valor & FDR \\
\hline GO:0006955 immune response & 41 & $1.81 \mathrm{E}-19$ & $2.96 \mathrm{E}-16$ \\
\hline GO:0006954 inflammatory response & 29 & $3.98 \mathrm{E}-18$ & $6.52 \mathrm{E}-15$ \\
\hline GO:0006952 defense response & 35 & $4.32 \mathrm{E}-15$ & 7.09E-12 \\
\hline G0:0044421 extracellular region part & 45 & 2.13E-14 & 2.61E-11 \\
\hline GO:0009611 response to wounding & 30 & $4.72 \mathrm{E}-14$ & 7.73E-11 \\
\hline G0:0002252 immune effector process & 19 & 4.77E-13 & 7.82E-10 \\
\hline G0:0002684 positive regulation of immune system process & 22 & $4.26 \mathrm{E}-12$ & $6.98 \mathrm{E}-09$ \\
\hline GO:0045087 innate immune response & 16 & $5.94 \mathrm{E}-11$ & 9.73E-08 \\
\hline GO:0050778 positive regulation of immune response & 17 & 1.99E-10 & 3.25E-07 \\
\hline GO:0002253 activation of immune response & 14 & 4.47E-10 & 7.32E-07 \\
\hline $\begin{array}{l}\text { GO:0019886 antigen processing and presentation of exogenous } \\
\text { peptide antigen via MHC class II }\end{array}$ & 8 & $1.58 \mathrm{E}-09$ & 2.59E-06 \\
\hline $\begin{array}{l}\text { GO:0002495 antigen processing and presentation of peptide antigen } \\
\text { via MHC class II }\end{array}$ & 8 & $1.58 \mathrm{E}-09$ & $2.59 \mathrm{E}-06$ \\
\hline GO:0016064 immunoglobulin mediated immune response & 12 & $2.08 \mathrm{E}-09$ & 3.40E-06 \\
\hline $\begin{array}{l}\text { GO:0002541 activation of plasma proteins involved in acute } \\
\text { inflammatory response }\end{array}$ & 10 & $2.15 \mathrm{E}-09$ & 3.53E-06 \\
\hline GO:0006956 complement activation & 10 & 2.15E-09 & 3.53E-06 \\
\hline GO:0048584 positive regulation of response to stimulus & 18 & 2.79E-09 & $4.58 \mathrm{E}-06$ \\
\hline GO:0019724 B cell mediated immunity & 12 & 2.94E-09 & $4.82 \mathrm{E}-06$ \\
\hline GO:0006959 humoral immune response & 11 & $6.28 \mathrm{E}-09$ & $1.03 \mathrm{E}-05$ \\
\hline $\begin{array}{l}\text { GO:0002504 antigen processing and presentation of peptide or } \\
\text { polysaccharide antigen via MHC class II }\end{array}$ & 8 & $6.71 \mathrm{E}-09$ & $1.10 \mathrm{E}-05$ \\
\hline GO:0002443 leukocyte mediated immunity & 13 & $8.18 \mathrm{E}-09$ & $1.34 \mathrm{E}-05$ \\
\hline GO:0030246 carbohydrate binding & 21 & 1.09E-08 & $1.49 \mathrm{E}-05$ \\
\hline G0:0031012 extracellular matrix & 22 & $1.22 \mathrm{E}-08$ & $1.50 \mathrm{E}-05$ \\
\hline GO:0002449 lymphocyte mediated immunity & 12 & $1.63 \mathrm{E}-08$ & 2.67E-05 \\
\hline GO:0009897 external side of plasma membrane & 18 & $1.91 \mathrm{E}-08$ & $2.35 \mathrm{E}-05$ \\
\hline $\begin{array}{l}\text { GO:0002478 antigen processing and presentation of exogenous } \\
\text { peptide antigen }\end{array}$ & 8 & $3.10 \mathrm{E}-08$ & $5.08 \mathrm{E}-05$ \\
\hline GO:0005578 proteinaceous extracellular matrix & 21 & $3.25 \mathrm{E}-08$ & 3.99E-05 \\
\hline $\begin{array}{l}\text { GO:0002455 humoral immune response mediated by circulating } \\
\text { immunoglobulin }\end{array}$ & 9 & $3.74 \mathrm{E}-08$ & $6.13 \mathrm{E}-05$ \\
\hline G0:0051605 protein maturation by peptide bond cleavage & 11 & 4.07E-08 & $6.68 \mathrm{E}-05$ \\
\hline G0:0002250 radaptive immune response & 12 & 4.76E-08 & 7.80E-05 \\
\hline $\begin{array}{l}\text { GO:0002460 adaptive immune response based on somatic } \\
\text { recombination of immune receptors built from immunoglobulin } \\
\text { superfamily domains }\end{array}$ & 12 & 4.76E-08 & $7.80 \mathrm{E}-05$ \\
\hline GO:0016485 protein processing & 12 & $9.85 \mathrm{E}-08$ & $1.61 \mathrm{E}-04$ \\
\hline $\begin{array}{l}\text { GO:0019884 antigen processing and presentation of exogenous } \\
\text { antigen }\end{array}$ & 8 & $1.41 \mathrm{E}-07$ & $2.30 \mathrm{E}-04$ \\
\hline GO:0051604 protein maturation & 12 & 1.93E-07 & $3.16 \mathrm{E}-04$ \\
\hline GO:0006958 complement activation, classical pathway & 8 & $2.36 \mathrm{E}-07$ & $3.86 \mathrm{E}-04$ \\
\hline GO:0009986 cell surface & 20 & $2.48 \mathrm{E}-07$ & 3.05E-04 \\
\hline GO:0002526 acute inflammatory response & 11 & 3.47E-07 & $5.69 \mathrm{E}-04$ \\
\hline GO:0005539 glycosaminoglycan binding & 12 & $3.98 \mathrm{E}-07$ & $5.46 \mathrm{E}-04$ \\
\hline G0:0008009 chemokine activity & 8 & $6.59 E-07$ & 9.03E-04 \\
\hline GO:0006935 chemotaxis & 12 & 7.09E-07 & 0.001162 \\
\hline GO:0042330 taxis & 12 & 7.09E-07 & 0.001162 \\
\hline GO:0048002 antigen processing and presentation of peptide antigen & 8 & 7.30E-07 & 0.001197 \\
\hline GO:0042379 chemokine receptor binding & 8 & 7.94E-07 & 0.001088 \\
\hline G0:0030247 polysaccharide binding & 12 & $1.28 \mathrm{E}-06$ & 0.001752 \\
\hline GO:0001871 pattern binding & 12 & $1.28 \mathrm{E}-06$ & 0.001752 \\
\hline GO:0008201 heparin binding & 10 & $1.75 \mathrm{E}-06$ & 0.002392 \\
\hline G0:0006508 proteolysis & 36 & 4.34E-06 & 0.007113 \\
\hline GO:0001775 cell activation & 16 & 4.61E-06 & 0.007558 \\
\hline GO:0045321 leukocyte activation & 15 & $5.56 \mathrm{E}-06$ & 0.00911 \\
\hline GO:0042110 T cell activation & 11 & $9.55 \mathrm{E}-06$ & 0.015658 \\
\hline GO:0005764 lysosome & 13 & $2.01 \mathrm{E}-05$ & 0.02475 \\
\hline G0:0000323 lytic vacuole & 13 & $2.13 E-05$ & 0.026189 \\
\hline GO:0019955 cytokine binding & 9 & $2.48 \mathrm{E}-05$ & 0.033923 \\
\hline
\end{tabular}




\begin{tabular}{|c|c|c|c|}
\hline G0:0046649 lymphocyte activation & 13 & $3.13 \mathrm{E}-05$ & 0.051281 \\
\hline GO:0005509 calcium ion binding & 27 & $6.42 \mathrm{E}-05$ & 0.087874 \\
\hline G0:0007626 locomotory behavior & 14 & $6.58 \mathrm{E}-05$ & 0.107844 \\
\hline G0:0070011 peptidase activity, acting on L-amino acid peptides & 22 & $6.75 \mathrm{E}-05$ & 0.092346 \\
\hline GO:0005773 vacuole & 13 & 7.65E-05 & 0.094128 \\
\hline GO:0008233 peptidase activity & 22 & $1.22 \mathrm{E}-04$ & 0.167414 \\
\hline G0:0044243 multicellular organismal catabolic process & 5 & $1.28 \mathrm{E}-04$ & 0.209569 \\
\hline GO:0005125 cytokine activity & 11 & $1.70 \mathrm{E}-04$ & 0.232046 \\
\hline GO:0004175 endopeptidase activity & 17 & $1.95 \mathrm{E}-04$ & 0.2672 \\
\hline GO:0019882 antigen processing and presentation & 8 & $3.28 \mathrm{E}-04$ & 0.536891 \\
\hline GO:0032963 collagen metabolic process & 5 & 3.49E-04 & 0.570835 \\
\hline GO:0008283 cell proliferation & 13 & $3.58 \mathrm{E}-04$ & 0.585163 \\
\hline G0:0006957 complement activation, alternative pathway & 4 & 3.70E-04 & 0.605091 \\
\hline G0:0046651 lymphocyte proliferation & 6 & 3.93E-04 & 0.64269 \\
\hline GO:0042613 MHC class II protein complex & 4 & $4.01 \mathrm{E}-04$ & 0.492476 \\
\hline $\begin{array}{l}\text { G0:0044259 multicellular organismal macromolecule metabolic } \\
\text { process }\end{array}$ & 5 & 4.14E-04 & 0.676665 \\
\hline GO:0032943 mononuclear cell proliferation & 6 & 4.40E-04 & 0.718221 \\
\hline GO:0070661 leukocyte proliferation & 6 & $4.40 \mathrm{E}-04$ & 0.718221 \\
\hline G0:0044236 multicellular organismal metabolic process & 5 & 5.69E-04 & 0.928819 \\
\hline GO:0042098 T cell proliferation & 5 & 7.61E-04 & 1.240754 \\
\hline GO:0004896 cytokine receptor activity & 6 & $8.68 \mathrm{E}-04$ & 1.181617 \\
\hline G0:0048534 hemopoietic or lymphoid organ development & 13 & 0.001116 & 1.812904 \\
\hline G0:0007610 behavior & 16 & 0.001189 & 1.931115 \\
\hline GO:0045582 positive regulation of $\mathrm{T}$ cell differentiation & 5 & 0.001276 & 2.071195 \\
\hline G0:0045621 positive regulation of lymphocyte differentiation & 5 & 0.001608 & 2.602749 \\
\hline GO:0002520 immune system development & 13 & 0.001684 & 2.725192 \\
\hline GO:0030574 collagen catabolic process & 4 & 0.001941 & 3.134901 \\
\hline GO:0050865 regulation of cell activation & 9 & 0.002452 & 3.944572 \\
\hline GO:0008034 lipoprotein binding & 4 & 0.002717 & 3.656687 \\
\hline GO:0050870 positive regulation of $\mathrm{T}$ cell activation & 6 & 0.003091 & 4.947369 \\
\hline G0:0050867 positive regulation of cell activation & 7 & 0.004137 & 6.569195 \\
\hline GO:0005770 late endosome & 5 & 0.004612 & 5.530158 \\
\hline G0:0030097 hemopoiesis & 11 & 0.004669 & 7.383602 \\
\hline G0:0045597 positive regulation of cell differentiation & 9 & 0.004933 & 7.786222 \\
\hline G0:0001817 regulation of cytokine production & 8 & 0.004994 & 7.878112 \\
\hline G0:0051094 positive regulation of developmental process & 10 & 0.005057 & 7.974798 \\
\hline G0:0030217 T cell differentiation & 6 & 0.005665 & 8.892451 \\
\hline GO:0045580 regulation of $\mathrm{T}$ cell differentiation & 5 & 0.00573 & 8.989501 \\
\hline GO:0050863 regulation of $\mathrm{T}$ cell activation & 7 & 0.005732 & 8.991735 \\
\hline GO:0045059 positive thymic T cell selection & 3 & 0.005917 & 9.270054 \\
\hline G0:0051249 regulation of lymphocyte activation & 8 & 0.006041 & 9.455113 \\
\hline GO:0045060 negative thymic T cell selection & 3 & 0.007533 & 11.65739 \\
\hline GO:0005771 multivesicular body & 3 & 0.007945 & 9.34973 \\
\hline GO:0002694 regulation of leukocyte activation & 8 & 0.008618 & 13.22702 \\
\hline GO:0043368 positive T cell selection & 3 & 0.009324 & 14.23422 \\
\hline G0:0043383 negative T cell selection & 3 & 0.009324 & 14.23422 \\
\hline G0:0002819 regulation of adaptive immune response & 5 & 0.009859 & 14.99033 \\
\hline $\begin{array}{l}\text { GO:0002822 regulation of adaptive immune response based on somatic } \\
\text { recombination of immune receptors built from immunoglobulin } \\
\text { superfamily domains }\end{array}$ & 5 & 0.009859 & 14.99033 \\
\hline GO:0019221 cytokine-mediated signaling pathway & 5 & 0.009859 & 14.99033 \\
\hline G0:0030414 peptidase inhibitor activity & 8 & 0.010106 & 12.9853 \\
\hline G0:0002697 regulation of immune effector process & 6 & 0.010406 & 15.75667 \\
\hline GO:0045619 regulation of lymphocyte differentiation & 5 & 0.011128 & 16.7592 \\
\hline G0:0001914 regulation of T cell mediated cytotoxicity & 3 & 0.011284 & 16.97379 \\
\hline GO:0030169 low-density lipoprotein binding & 3 & 0.012903 & 16.2933 \\
\hline GO:0008237 metallopeptidase activity & 8 & 0.013776 & 17.30144 \\
\hline GO:0005044 scavenger receptor activity & 4 & 0.015628 & 19.40211 \\
\hline
\end{tabular}




\begin{tabular}{|c|c|c|c|}
\hline \multicolumn{4}{|l|}{$D_{m d^{m d x}} /$ Large $^{m y d-/-}$ vs C57B/ 6 meses } \\
\hline Termo GO & \# genes & p-valor & FDR \\
\hline GO:0006955 immune response & 53 & $9.85 E-29$ & $1.62 \mathrm{E}-25$ \\
\hline GO:0006954 inflammatory response & 35 & 2.73E-23 & $4.50 \mathrm{E}-20$ \\
\hline GO:0006952 defense response & 46 & $4.10 E-23$ & $6.75 \mathrm{E}-20$ \\
\hline GO:0009611 response to wounding & 40 & 7.99E-22 & $1.32 \mathrm{E}-18$ \\
\hline GO:0030246 carbohydrate binding & 30 & $6.03 \mathrm{E}-15$ & 8.32E-12 \\
\hline GO:0045087 innate immune response & 20 & $9.39 \mathrm{E}-15$ & $1.55 \mathrm{E}-11$ \\
\hline GO:0002252 immune effector process & 21 & $1.71 \mathrm{E}-14$ & $2.82 \mathrm{E}-11$ \\
\hline GO:0030247 polysaccharide binding & 19 & 7.70E-13 & 1.07E-09 \\
\hline GO:0001871 pattern binding & 19 & $7.70 \mathrm{E}-13$ & 1.07E-09 \\
\hline GO:0050778 positive regulation of immune response & 20 & $8.56 \mathrm{E}-13$ & $1.41 \mathrm{E}-09$ \\
\hline G0:0002684 positive regulation of immune system process & 23 & $3.31 \mathrm{E}-12$ & 5.44E-09 \\
\hline GO:0044421 extracellular region part & 46 & 4.69E-12 & 5.84E-09 \\
\hline GO:0009986 cell surface & 28 & $1.44 \mathrm{E}-11$ & $1.79 \mathrm{E}-08$ \\
\hline GO:0002443 leukocyte mediated immunity & 16 & $1.46 \mathrm{E}-11$ & $2.41 \mathrm{E}-08$ \\
\hline GO:0005539 glycosaminoglycan binding & 17 & $1.56 \mathrm{E}-11$ & 2.17E-08 \\
\hline GO:0002449 lymphocyte mediated immunity & 15 & $2.03 E-11$ & 3.34E-08 \\
\hline GO:0006935 chemotaxis & 17 & $2.68 \mathrm{E}-11$ & 4.41E-08 \\
\hline GO:0042330 taxis & 17 & $2.68 \mathrm{E}-11$ & 4.41E-08 \\
\hline GO:0019724 B cell mediated immunity & 14 & 3.61E-11 & 5.95E-08 \\
\hline $\begin{array}{l}\text { GO:0002478 antigen processing and presentation of exogenous } \\
\text { peptide antigen }\end{array}$ & 10 & $5.12 \mathrm{E}-11$ & 8.44E-08 \\
\hline $\begin{array}{l}\text { GO:0002460 adaptive immune response based on somatic } \\
\text { recombination of immune receptors built from immunoglobulin } \\
\text { superfamily domains }\end{array}$ & 15 & $8.35 \mathrm{E}-11$ & 1.37E-07 \\
\hline GO:0002250 adaptive immune response & 15 & $8.35 E-11$ & 1.37E-07 \\
\hline GO:0002253 activation of immune response & 15 & $1.16 \mathrm{E}-10$ & 1.91E-07 \\
\hline GO:0048002 antigen processing and presentation of peptide antigen & 11 & $1.55 \mathrm{E}-10$ & $2.56 \mathrm{E}-07$ \\
\hline GO:0009897 external side of plasma membrane & 22 & $2.25 \mathrm{E}-10$ & 2.80E-07 \\
\hline GO:0048584 positive regulation of response to stimulus & 20 & $2.29 \mathrm{E}-10$ & 3.78E-07 \\
\hline GO:0016064 immunoglobulin mediated immune response & 13 & $3.82 \mathrm{E}-10$ & $6.29 \mathrm{E}-07$ \\
\hline $\begin{array}{l}\text { GO:0019884 antigen processing and presentation of exogenous } \\
\text { antigen }\end{array}$ & 10 & $4.03 \mathrm{E}-10$ & $6.64 \mathrm{E}-07$ \\
\hline GO:0031012 extracellular matrix & 26 & $5.83 \mathrm{E}-10$ & 7.25E-07 \\
\hline GO:0001775 cell activation & 22 & 7.14E-10 & $1.18 \mathrm{E}-06$ \\
\hline GO:0005578 proteinaceous extracellular matrix & 25 & $1.35 \mathrm{E}-09$ & $1.68 \mathrm{E}-06$ \\
\hline $\begin{array}{l}\text { GO:0019886 antigen processing and presentation of exogenous } \\
\text { peptide antigen via MHC class II }\end{array}$ & 8 & 3.04E-09 & $5.00 \mathrm{E}-06$ \\
\hline $\begin{array}{l}\text { GO:0002495 antigen processing and presentation of peptide antigen } \\
\text { via MHC class II }\end{array}$ & 8 & 3.04E-09 & 5.00E-06 \\
\hline GO:0008201 heparin binding & 13 & 4.13E-09 & 5.74E-06 \\
\hline GO:0002526 acute inflammatory response & 13 & 7.80E-09 & $1.28 \mathrm{E}-05$ \\
\hline GO:0019955 cytokine binding & 13 & $8.20 \mathrm{E}-09$ & $1.14 \mathrm{E}-05$ \\
\hline $\begin{array}{l}\text { GO:0002504 antigen processing and presentation of peptide or } \\
\text { polysaccharide antigen via MHC class II }\end{array}$ & 8 & $1.28 \mathrm{E}-08$ & 2.11E-05 \\
\hline GO:0045321 leukocyte activation & 19 & 2.24E-08 & 3.69E-05 \\
\hline GO:0050766 positive regulation of phagocytosis & 8 & $5.90 \mathrm{E}-08$ & $9.72 \mathrm{E}-05$ \\
\hline GO:0008009 chemokine activity & 9 & $8.21 \mathrm{E}-08$ & $1.14 \mathrm{E}-04$ \\
\hline GO:0007626 locomotory behavior & 19 & $8.58 \mathrm{E}-08$ & $1.41 \mathrm{E}-04$ \\
\hline GO:0042379 chemokine receptor binding & 9 & $1.02 \mathrm{E}-07$ & $1.41 \mathrm{E}-04$ \\
\hline GO:0050764 regulation of phagocytosis & 8 & $1.13 \mathrm{E}-07$ & $1.85 \mathrm{E}-04$ \\
\hline GO:0005764 lysosome & 16 & $1.10 \mathrm{E}-06$ & 0.001373 \\
\hline GO:0045807 positive regulation of endocytosis & 8 & $1.11 \mathrm{E}-06$ & 0.001828 \\
\hline GO:0000323 lytic vacuole & 16 & $1.19 \mathrm{E}-06$ & 0.001474 \\
\hline GO:0019882 antigen processing and presentation & 11 & $1.60 \mathrm{E}-06$ & 0.002638 \\
\hline $\begin{array}{l}\text { GO:0002541 activation of plasma proteins involved in acute } \\
\text { inflammatory response }\end{array}$ & 8 & $1.67 \mathrm{E}-06$ & 0.002758 \\
\hline GO:0006956 complement activation & 8 & 1.67E-06 & 0.002758 \\
\hline GO:0006959 humoral immune response & 9 & 2.61E-06 & 0.004296 \\
\hline G0:0045576 mast cell activation & 6 & 3.06E-06 & 0.005034 \\
\hline GO:0006911 phagocytosis, engulfment & 6 & $3.06 \mathrm{E}-06$ & 0.005034 \\
\hline GO:0005773 vacuole & 16 & $6.03 E-06$ & 0.007499 \\
\hline
\end{tabular}




\begin{tabular}{|c|c|c|c|}
\hline GO:0006958 complement activation, classical pathway & 7 & $8.00 \mathrm{E}-06$ & 0.013184 \\
\hline GO:0007610 behavior & 21 & $1.25 \mathrm{E}-05$ & 0.020659 \\
\hline GO:0019865 immunoglobulin binding & 5 & 1.57E-05 & 0.021832 \\
\hline GO:0004896 cytokine receptor activity & 8 & $1.85 \mathrm{E}-05$ & 0.025658 \\
\hline $\begin{array}{l}\text { GO:0002455 humoral immune response mediated by circulating } \\
\text { immunoglobulin }\end{array}$ & 7 & 2.04E-05 & 0.03364 \\
\hline GO:0030100 regulation of endocytosis & 8 & $2.15 E-05$ & 0.035332 \\
\hline GO:0005615 extracellular space & 25 & $2.75 E-05$ & 0.034236 \\
\hline GO:0005509 calcium ion binding & 30 & $2.78 \mathrm{E}-05$ & 0.038617 \\
\hline GO:0019864 IgG binding & 4 & 3.38E-05 & 0.046951 \\
\hline GO:0060326 cell chemotaxis & 6 & 6.99E-05 & 0.115089 \\
\hline GO:0030595 leukocyte chemotaxis & 6 & $6.99 \mathrm{E}-05$ & 0.115089 \\
\hline GO:0032680 regulation of tumor necrosis factor production & 6 & 6.99E-05 & 0.115089 \\
\hline GO:0004175 endopeptidase activity & 19 & $7.71 \mathrm{E}-05$ & 0.106975 \\
\hline GO:0051605 protein maturation by peptide bond cleavage & 8 & $9.31 \mathrm{E}-05$ & 0.153275 \\
\hline GO:0005125 cytokine activity & 12 & $9.59 \mathrm{E}-05$ & 0.132921 \\
\hline GO:0001817 regulation of cytokine production & 11 & $1.01 \mathrm{E}-04$ & 0.166609 \\
\hline GO:0016485 protein processing & 9 & 1.17E-04 & 0.19231 \\
\hline GO:0042110 T cell activation & 10 & 1.27E-04 & 0.208508 \\
\hline GO:0030593 neutrophil chemotaxis & 5 & $1.45 \mathrm{E}-04$ & 0.237852 \\
\hline GO:0006909 phagocytosis & 7 & $1.45 \mathrm{E}-04$ & 0.238893 \\
\hline GO:0002673 regulation of acute inflammatory response & 5 & $1.83 \mathrm{E}-04$ & 0.301782 \\
\hline GO:0051604 protein maturation & 9 & 1.84E-04 & 0.302172 \\
\hline GO:0051130 positive regulation of cellular component organization & 10 & $1.86 \mathrm{E}-04$ & 0.30621 \\
\hline GO:0050865 regulation of cell activation & 11 & 2.61E-04 & 0.429373 \\
\hline $\begin{array}{l}\text { GO:0002822 regulation of adaptive immune response based on somatic } \\
\text { recombination of immune receptors built from immunoglobulin } \\
\text { superfamily domains }\end{array}$ & 7 & 3.06E-04 & 0.503343 \\
\hline GO:0002819 regulation of adaptive immune response & 7 & 3.06E-04 & 0.503343 \\
\hline GO:0046649 lymphocyte activation & 12 & $3.28 \mathrm{E}-04$ & 0.538487 \\
\hline GO:0031349 positive regulation of defense response & 7 & 3.38E-04 & 0.554781 \\
\hline GO:0070011 peptidase activity, acting on L-amino acid peptides & 22 & 3.43E-04 & 0.47525 \\
\hline G0:0060627 regulation of vesicle-mediated transport & 8 & $4.32 \mathrm{E}-04$ & 0.709783 \\
\hline G0:0001819 positive regulation of cytokine production & 7 & 5.34E-04 & 0.876414 \\
\hline G0:0008233 peptidase activity & 22 & 5.97E-04 & 0.825834 \\
\hline GO:0046651 lymphocyte proliferation & 6 & $6.03 E-04$ & 0.987943 \\
\hline G0:0070661 leukocyte proliferation & 6 & $6.73 \mathrm{E}-04$ & 1.10251 \\
\hline GO:0032943 mononuclear cell proliferation & 6 & $6.73 \mathrm{E}-04$ & 1.10251 \\
\hline GO:0050900 leukocyte migration & 6 & $6.73 \mathrm{E}-04$ & 1.10251 \\
\hline GO:0001803 regulation of type III hypersensitivity & 3 & 8.03E-04 & 1.314313 \\
\hline GO:0001805 positive regulation of type III hypersensitivity & 3 & 8.03E-04 & 1.314313 \\
\hline GO:0008283 cell proliferation & 13 & $8.22 \mathrm{E}-04$ & 1.346079 \\
\hline GO:0002694 regulation of leukocyte activation & 10 & 0.001027 & 1.677601 \\
\hline GO:0042098 T cell proliferation & 5 & 0.001079 & 1.762313 \\
\hline $\begin{array}{l}\text { GO:0002864 regulation of acute inflammatory response to antigenic } \\
\text { stimulus }\end{array}$ & 4 & 0.001119 & 1.827151 \\
\hline GO:0002883 regulation of hypersensitivity & 4 & 0.001119 & 1.827151 \\
\hline GO:0006910 phagocytosis, recognition & 4 & 0.001119 & 1.827151 \\
\hline GO:0002757 immune response-activating signal transduction & 6 & 0.00112 & 1.828354 \\
\hline GO:0002237 response to molecule of bacterial origin & 6 & 0.00123 & 2.007462 \\
\hline GO:0004857 enzyme inhibitor activity & 12 & 0.001233 & 1.697124 \\
\hline GO:0019763 immunoglobulin receptor activity & 3 & 0.001352 & 1.860096 \\
\hline GO:0050867 positive regulation of cell activation & 8 & 0.001396 & 2.274358 \\
\hline GO:0002714 positive regulation of B cell mediated immunity & 4 & 0.001407 & 2.292214 \\
\hline $\begin{array}{l}\text { GO:0002891 positive regulation of immunoglobulin mediated immune } \\
\text { response }\end{array}$ & 4 & 0.001407 & 2.292214 \\
\hline GO:0006692 prostanoid metabolic process & 4 & 0.001407 & 2.292214 \\
\hline GO:0006693 prostaglandin metabolic process & 4 & 0.001407 & 2.292214 \\
\hline GO:0002712 regulation of B cell mediated immunity & 5 & 0.001407 & 2.29299 \\
\hline GO:0002889 regulation of immunoglobulin mediated immune response & 5 & 0.001407 & 2.29299 \\
\hline GO:0030414 peptidase inhibitor activity & 10 & 0.001481 & 2.036135 \\
\hline GO:0051050 positive regulation of transport & 9 & 0.00154 & 2.506122 \\
\hline
\end{tabular}




\begin{tabular}{|c|c|c|c|}
\hline G0:0032101 regulation of response to external stimulus & 8 & 0.001564 & 2.545253 \\
\hline G0:0002764 immune response-regulating signal transduction & 6 & 0.001611 & 2.621225 \\
\hline G0:0032760 positive regulation of tumor necrosis factor production & 4 & 0.001737 & 2.823402 \\
\hline $\begin{array}{l}\text { GO:0002824 positive regulation of adaptive immune response based on } \\
\text { somatic recombination of immune receptors built from immunoglobulin } \\
\text { superfamily domains }\end{array}$ & 5 & 0.002262 & 3.661576 \\
\hline GO:0002821 positive regulation of adaptive immune response & 5 & 0.002262 & 3.661576 \\
\hline GO:0006690 icosanoid metabolic process & 5 & 0.002262 & 3.661576 \\
\hline GO:0050727 regulation of inflammatory response & 6 & 0.002429 & 3.926664 \\
\hline $\begin{array}{l}\text { GO:0042590 antigen processing and presentation of exogenous } \\
\text { peptide antigen via MHC class I }\end{array}$ & 3 & 0.002618 & 4.226717 \\
\hline GO:0004197 cysteine-type endopeptidase activity & 6 & 0.002658 & 3.625762 \\
\hline GO:0051249 regulation of Iymphocyte activation & 9 & 0.00266 & 4.292808 \\
\hline G0:0033559 unsaturated fatty acid metabolic process & 5 & 0.0028 & 4.514167 \\
\hline GO:0005044 scavenger receptor activity & 5 & 0.002812 & 3.83198 \\
\hline G0:0002861 regulation of inflammatory response to antigenic stimulus & 4 & 0.003004 & 4.834859 \\
\hline GO:0042277 peptide binding & 9 & 0.003077 & 4.186237 \\
\hline GO:0004866 endopeptidase inhibitor activity & 9 & 0.00321 & 4.36356 \\
\hline GO:0002697 regulation of immune effector process & 7 & 0.003306 & 5.309154 \\
\hline GO:0008034 lipoprotein binding & 4 & 0.003762 & 5.094849 \\
\hline GO:0010324 membrane invagination & 10 & 0.003996 & 6.382244 \\
\hline GO:0006897 rendocytosis & 10 & 0.003996 & 6.382244 \\
\hline G0:0002706 regulation of lymphocyte mediated immunity & 6 & 0.004309 & 6.866794 \\
\hline GO:0043235 receptor complex & 7 & 0.004396 & 5.332982 \\
\hline $\begin{array}{l}\text { GO:0002429 immune response-activating cell surface receptor } \\
\text { signaling pathway }\end{array}$ & 5 & 0.004516 & 7.183962 \\
\hline GO:0042108 positive regulation of cytokine biosynthetic process & 5 & 0.004927 & 7.814547 \\
\hline GO:0050798 activated T cell proliferation & 3 & 0.00538 & 8.50249 \\
\hline G0:0045357 regulation of interferon-beta biosynthetic process & 3 & 0.00538 & 8.50249 \\
\hline GO:0045359 positive regulation of interferon-beta biosynthetic process & 3 & 0.00538 & 8.50249 \\
\hline $\begin{array}{l}\text { GO:0002768 immune response-regulating cell surface receptor } \\
\text { signaling pathway }\end{array}$ & 5 & 0.005825 & 9.175193 \\
\hline GO:0002696 positive regulation of leukocyte activation & 7 & 0.005891 & 9.273776 \\
\hline G0:0002703 regulation of leukocyte mediated immunity & 6 & 0.005911 & 9.303375 \\
\hline GO:0001530 lipopolysaccharide binding & 3 & 0.006062 & 8.090957 \\
\hline G0:0032403 protein complex binding & 6 & 0.006651 & 8.844176 \\
\hline GO:0001796 regulation of type IIa hypersensitivity & 3 & 0.007096 & 11.06789 \\
\hline GO:0001798 positive regulation of type IIa hypersensitivity & 3 & 0.007096 & 11.06789 \\
\hline GO:0001810 regulation of type I hypersensitivity & 3 & 0.007096 & 11.06789 \\
\hline $\begin{array}{l}\text { GO:0002888 positive regulation of myeloid leukocyte mediated } \\
\text { immunity }\end{array}$ & 3 & 0.007096 & 11.06789 \\
\hline GO:0002892 regulation of type II hypersensitivity & 3 & 0.007096 & 11.06789 \\
\hline G0:0002894 positive regulation of type II hypersensitivity & 3 & 0.007096 & 11.06789 \\
\hline GO:0002683 negative regulation of immune system process & 6 & 0.008336 & 12.88024 \\
\hline GO:0046456 icosanoid biosynthetic process & 4 & 0.009658 & 14.77333 \\
\hline GO:0050670 regulation of lymphocyte proliferation & 6 & 0.010291 & 15.6663 \\
\hline GO:0032944 regulation of mononuclear cell proliferation & 6 & 0.010291 & 15.6663 \\
\hline G0:0042060 wound healing & 7 & 0.010556 & 16.03793 \\
\hline GO:0006636 unsaturated fatty acid biosynthetic process & 4 & 0.010687 & 16.22098 \\
\hline GO:0002885 positive regulation of hypersensitivity & 3 & 0.011159 & 16.87638 \\
\hline $\begin{array}{l}\text { G0:0002866 positive regulation of acute inflammatory response to } \\
\text { antigenic stimulus }\end{array}$ & 3 & 0.011159 & 16.87638 \\
\hline GO:0001516 prostaglandin biosynthetic process & 3 & 0.011159 & 16.87638 \\
\hline GO:0046457 prostanoid biosynthetic process & 3 & 0.011159 & 16.87638 \\
\hline GO:0042116 macrophage activation & 3 & 0.011159 & 16.87638 \\
\hline G0:0070663 regulation of leukocyte proliferation & 6 & 0.011377 & 17.17798 \\
\hline G0:0006508 proteolysis & 28 & 0.011594 & 17.47776 \\
\hline G0:0042613 MHC class II protein complex & 3 & 0.013983 & 16.0684 \\
\hline
\end{tabular}




\section{Parecer do Comitê de Ética}

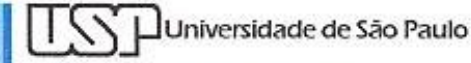 \\ in Instituto \\ 1) de Biociências}

OF.CEUA/IB/014/2014

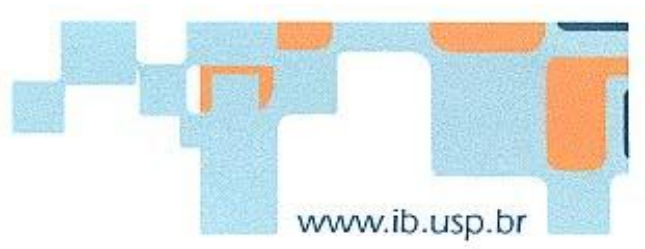

São Paulo, 21 de março 2014

Prezada Senhora,

Dirijo-me a V.Sa. para informar que a Comissão de Ética no Uso de Animais do IB (CEUA), em reunião realizada no dia 20 de março de 2014, APROVOU o Projeto "Identificação e estudo de genes diferencialmente expressos em modelos murinos de distrofia muscular", Protocolo 200/2014, de sua responsabilidade (Colaboradora: Camila de Freitas Almeida).

A pesquisadora responsável deverá comunicar a esta Comissão qualquer alteração e/ou intercorrência que houver durante a realização da pesquisa.

Lembramos que deverão ser apresentados os relatórios anuais ou final, conforme modelo disponivel no link desta Comissão.

Atenciosamente,

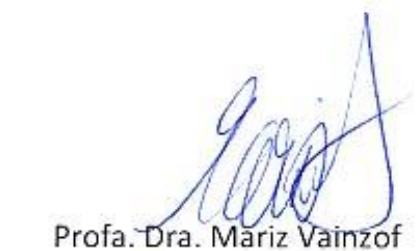

Coordenadora da Comissão de Ética no

Uso de Animais do IB (CEUA)

IIma. Sra.

Profa. Dra. MARIZ VAINZOF

Departamento de Genética e Biologia Evolutiva - IB 